\title{
NATIONAL HEALTH INSURANCE
}

\section{MEDICAL RESEARCH COMMITTEE SERIES}

\section{MILK AND ITS \\ HYGIENIC RELATIONS}

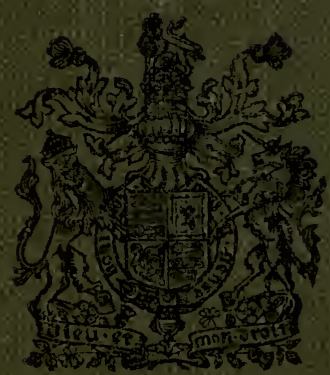




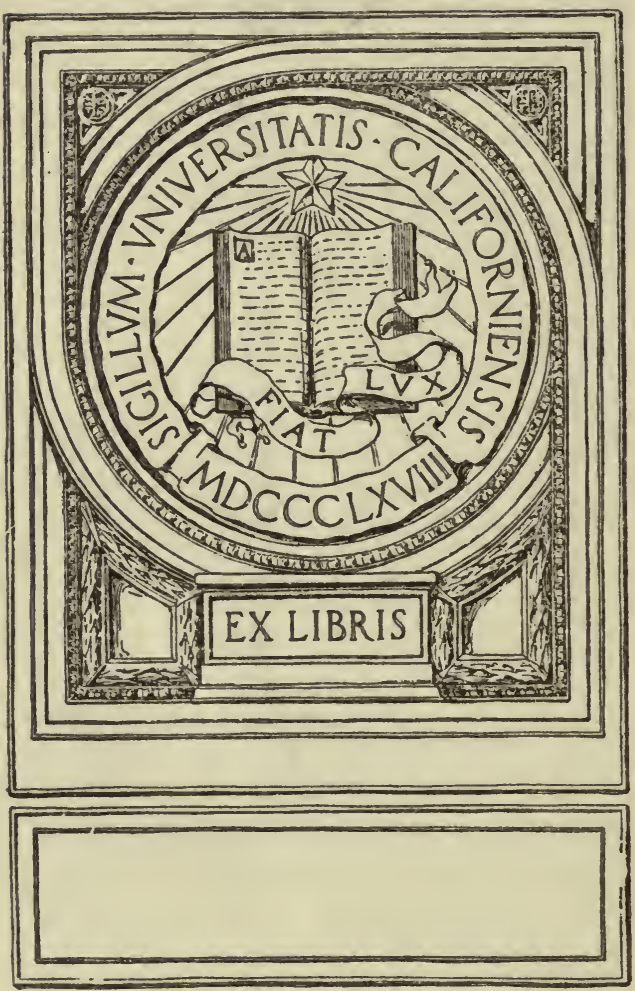



Digitized by the Internet Archive in 2007 with funding from Microsoft Corporation 


\section{MILK AND ITS HYGIENIC RELATIONS}





\section{I L K}

\section{AND ITS HYGIENIC RELATIONS}

BY

JANET E. LANE-CLAYPON, M.D., D.SC. (LOND.)

ASSISTANT MEDICAL INSPECTOR UNDER

THE LOCAL GOVERNMENT BOARD

PUBLISHED UNDER THE DIRECTION OF THE MEDICAL RESEARCH COMMITTEE (NATIONAL HEALTH INSURANCE)

WITH 8 PLATES AND DIAGRAMS IN THE TEXT

LONGMANS, GREN, AND CO. 39 PATERNOSTER ROW, LONDON FOURTH AVENUE \& 3OTH STREET, NEW YORK BOMBAY, CALCUTTA, AND MADRAS 



\section{PREFACE}

THE Medical Research Committee are charged with the administration of the Research Fund which has become available under the provisions of the National Insurance Act, for the advancement of medical knowledge by research. It falls to their duty, therefore, in the application of that Fund, to aid, to initiate, and to organise the work of scientific enquiry along available lines of advance, towards the enlargement of our powers of preserving health and of diminishing disease.

Among the plans for research which the Committee formulated at the beginning of their work, the subject of Milk, in its relations to public health, was naturally included. The study of milk is from its nature what has been called a 'borderland subject,' and has attracted enquiry by workers employing the widely different technical methods of chemistry, of physiology, of bacteriology, of agricultural science, and of clinical medicine. The results of this work have been published separately in the technical archives and journals devoted to those special branches of science, and these publications are dispersed widely through the literatures of many different languages. To the workers in any one field the bibliography of his own subject is familiar, or at least easily accessible, but in the case of a subject not falling wholly within the customary boundaries of a conventional scientific field, it is a matter of difficulty involving great expenditure of time and labour to secure a general view of the state of knowledge as it exists at any given moment.

Such a general view, however, of present knowledge and of its" basis in gathered evidence is a necessary preliminary to the proper organisation of fresh researches, and the Medical Research Committee accordingly invited Dr. Janet Lane-Claypon, who had

$$
3324
$$


earlier made valuable reports upon certain portions of the subject to the Local Government Board, to assist them in collecting the available scientific evidence upon the hygienic relations of milk from all the best sources of information, however widely scattered. By the courtesy of the Local Government Board, the services of Dr. Lane-Claypon were made available for this work, and in due time its results were before the Committee.

It seemed to the Committee that this collection and critical summary of the published work upon the subject was likely to be valuable to many of those engaged in research work connected with it, and no less valuable to those concerned with the administrative questions which centre round the problems of milk and its proper treatment as a food. They have accordingly arranged for its publication, and in doing this they have endeavoured to secure that it shall be made available at the lowest price compatible with efficiency of production.

It has further been the hope of the Committee that the treatment of her material by Dr. Lane-Claypon has been such as to allow those ignorant of scientific technology to appreciate the chief positions which knowledge has gained in this matter, and that for this reason the book may have added value in bringing the illumination given by scientific work to those who are responsible for the formation of public opinion and for the determination of administrative action.

Medical Research Committee,

15 Buckingham Street, Strand,

LoNDON, W.C.

January 12, г916. 


\section{CONTENTS}

CHAPTER PAGE

I. AUTHOR'S INTRODUCTION . . . . . . I

II. ON the General Composition of Milk • • • 4

III. On the ORganic Constituents of Milk . . . 30

IV. ON the InoRganic Constituents of Milk . . 48

V. On the so-Called 'Biological Properties' of Milk.

A. The Ferments or Enzymes . . . . 63

VI. On the so-Called 'Biological Properties' of Milk (continued). B. The Substances CONCERNED IN THE Production of ImMunity . . . . . 108

VII. On the Cellular Content of Milk . . . I3o

VIII. ON BREast-FeEding . . . . . . . . 147

IX. ON the Nutritive Value of Boiled Milk of the SAME SPEcies . . . . . . . . . I6I

X. Experimental Data upon the Nutritive Value of Raw and BoIled Milk as a Food for the Young of DifFERENT SPECIES . . . . . .

XI. Clinical Data on the Nutritive Value of Raw and BoIled Cows' Milk as a Food for Infants . 187

XII. ON DRIEd MILK AS A Food For Infants • • . 206

XiII. On the Alleged Production of Barlow's Disease AND RICKETS BY THE USE OF HEATED MILK FOR INFANTS . . . . . . . . 216

XIV. Changes Occurring in Milk as a Result of the APPLICATION OF Heat . • • • • •

XV. On the Presence in Milk of certain Organisms liable to cause Disease, with Notes on MilkBORNE EPIDEMICS • • • • . • 244

XVI. Notes on the Sources of the Contamination of Milk 265

XVII. ON the Production of Milk as far as Possible FREE FROM CONTAMINATION • . . • . 270

XVIII. ON THE TYPES OF BACTERIA COMMONLy FOUND IN Milk AND THEIR THERMAL DEATH-POINTS $\quad \cdot \quad 283$ vii 
XIX. ON the Methods COMMONLY USED IN THE HeATING OF MILK

XX. On the Presence of Pathogenic Bacteria in Butter AND Cheese

\section{APPENDICES}

TO CHAPTER

VIII. A. As to the Development of the Mammary FuncTION

B. ON the SUBSEQUENT DEVELOPMENT OF THE ORGANISM in Relation to the Method of Feeding in Early LIFE

C. On the Preservation of Human Milk

XI. D. Tables and Additional Data Relating to the Berlin Material

XII. F. ON the Methods employed in the Desiccation of MILK .

XVII. G. Notes on the Grading of Milk .

XIX. H. ON MEthods used for the Destruction of Bacteria in Milk without the Application of Heat INDEX

\section{LIST OF PLATES}

PLATE

I. I. Showing a Fairly Typical Field with VARIETIES OF CELLS.

2. Showing Individual Cell Types .

II. I. Short Chains of Streptococci

2. Long Chains of Streptococci

III. THE SAME (from Ernst's Textbook of Milk Hygiene).

IV. Milking Shed, as described in Text .

V. Milking Machine • • • .

Vi. Bottling Plant. The Cooler is shown ABOVE THE APPARATUS FOR BOTTLING. The MilK passes STRAight FROM THE COOLER TO THE TANK PLACED ABOVE THE BOtTles

asteurising Plant, showing Supply

Tank and Heating Apparatus to the RIGHT, WITH COOLER ABOVE; ALSO Bottling ARrangements

VIII. Showing the Method Used in Electrical. 


\section{I L K}

\section{AND ITS HYGIENIC RELATIONS}

\section{CHAPTER I}

\section{AUTHOR'S INTRODUCTION}

THE hygienic aspect of the milk supply of this country has been before the public for some years and has been much discussed.

Although at first sight the problem may seem to be a simple one, its study opens up such a variety of intricate questions, and the number of issues arising is so great, that it is difficult to form a well-balanced judgment.

The position is rendered more difficult by the fact that most of the research work which has been undertaken in order to elucidate the problems of milk, is to be found in foreign periodicals, of which only a few are in the English language, the majority being in either French or German. Moreover, many of these periodicals are difficult of access to readers in this country.

As a result it has been almost impossible even for the scientific worker to obtain a clear view of the position without great expenditure of both time and labour.

The primary aim of this book is to present a survey of the existing knowledge upon such aspects of the milk question as hitherto has been inaccessible or difficult to obtain by most of those desiring it.

The material which might properly be included under the title of the book is so voluminous as to be unwieldy. Attention has therefore been concentrated mainly upon those branches of the subject which have received less attention from other authors. Even with this object in view it was by no means easy to decide which of the numerous questions should be included in the survey, but, so far as possible, only material directly related to the hygienic or nutritional aspects of milk has been 
considered. Subjects not directly connected with these aspects have either been omitted or have been accorded only brief mention.

It seemed desirable for the sake of clarity to give some account of the general composition of the only two varieties of milk which are used as a food in considerable quantity in this country-that is, human and cows' milk.

It is hoped that the dreariness of the figures giving the average composition of milk may have been slightly relieved by a discussion of the causes of variation in composition, known at present rather to agriculturists than to hygienists.

The chapters following that on the general composition of milk contain, it is believed, material which has not hitherto found its way into English text-books. The literature on the subjects of these chapters has been given as completely as possible, and the so-called 'Biological Properties' have been dealt with fully. The great and wholly unmerited importance which has frequently been attached to some of these properties (e.g. the ferments), and the general ignorance of the value to the young of the same species, of certain other properties of colostrum, appeared to justify the devotion to them of considerable space.

After considering the composition of human and cows' milk as fully as appeared to be necessary, it was decided to deal first with the supply of human milk under the heading of breast-feeding. Until recently much of the most useful knowledge upon this important subject had been published in foreign literature. In direct sequence to this subject comes the question of the nutritive value of the boiled milk of the same species as a food for both infants and calves, and this again leads directly to a consideration of the nutritive value of the milk (raw and heated) of a foreign species, that is, to the artificial feeding of infants and young animals.

The experimental data upon this important subject have been fully dealt with, and opinions or statements unsupported by fact have been excluded.

Details as to the methods of infant feeding have been omitted except for an occasional reference, since it is not only outside the lines of this work, but also because precise data are so frequently lacking in the papers upon this subject.

It seemed impossible to ignore altogether the question of milk production, and of commercial methods of treating milk. These have, however, been dealt with as briefly as was felt to be consistent with a clear presentment of the subject.

The great variety of the branches of knowledge which it has been necessary to bring under review render it almost impossible for any one writer to be personally conversant with them all; this must inevitably lead to some unevenness of treatment, which it is hoped may receive the indulgence of the reader.

The book is intended to appeal both to the expert and to the person without technical knowledge. In the endeavour to simplify 
the subjects, a summary has, on the suggestion of the Committee, been prefixed to each chapter.

These summaries are as far as possible free from technical terms, and contain in many cases explanatory notes upon the more technical side of the subject-matter of the chapter which follows. It is hoped, nevertheless, that the chapters have for the most part been so presented as to be intelligible after perusal of the summary to those with slight knowledge of the subject.

A few of the papers referred to in the bibliography have been inaccessible, but nearly all have been read by the writer.

On some questions it is believed that the bibliography relating to original work is complete, but this would have been impossible to accomplish in regard to those parts of the subject in which opinions and discussions form the main literature. Moreover, on some questions the literature is too voluminous to permit of a complete set of references. In such cases the main research papers have been referred to, and any research worker can, it is believed, obtain full references from an investigation of the works quoted. It may perhaps not be out of place to mention the magnificent library belonging to the Patent Office, which is especially valuable for periodicals dealing with agricultural and 'borderland ' subjects.

The appendices which have been prepared deal with special extensions of the work discussed in some of the chapters It was felt that although the subject-matter might be of interest, it was hardly of sufficient general importance to include in the chapter whose contents corresponded most closely to the appendix in question.

I have pleasure also in acknowledging my indebtedness to the Controller of H.M. Stationery Office, by whose kind permission the diagrams relating to the work of Prof. Delépine, Dr. Savage, and of myself are reproduced; also to Prof. Delépine, Dr. Savage, Dr. David Forsyth, Mr. Wilfred Buckley, and the Liverpool Corporation, for permission to reproduce diagrams and plates relating to different subjects.

I am also deeply indebted to Prof. Hewlett and Mr. Reiss, for being so kind as to supply me with microscopical slides, from which the drawings on the plates of cells and streptococci in milk are taken. 


\section{SUMMARY OF CHAPTER II}

\section{ON THE GENERAL COMPOSITION OF MILK}

ALL classes of mater als which are necessary to maintain life are represented in milk. The relative amounts of these vary greatly in the milk of different species, and differences are also found in the chemical composition of the members of different classes of foodstuffs.

Of the three main classes of food-stuffs, two-protein and fat-are represented in milk by more than one variety of the class. These constituents vary in different species, both in the percentage amount present and in their chemical composition.

In considering the chemical composition of milk with any degree of accuracy, the milk of each species must be dealt with separately. It is proposed here to deal only with human milk and with cows' milk, since this latter milk is the most usual form of food for children who are unable to obtain human milk or who have been weaned.

Pröscher showed many years ago that the milk of each species was adjusted so as to contain a suitable proportion of such substances as were needed for the young of that species. When the young animal was born in a state of relative maturity, the milk contained a high proportion of protein-and conversely.

It is difficult to compare the condition of the young of different species at birth as regards maturity or immaturity, but the young of the human species, especially compared with the calf, can safely be regarded as relatively immature at birth.

In this chapter only the proportions of the classes of foodmaterials will be considered, and the changes in composition occurring at different periods of lactation, or from other causes.

Average Composition of Cows' Milk and of Human Milk.It will be shown in the course of this chapter that there is no exact standard for the composition of the milk of any species, but it will be convenient to consider the average composition of a number of samples. The figures given below have been obtained by various investigators : 


\begin{tabular}{|c|c|c|c|c|c|c|c|c|}
\hline \multirow{2}{*}{-} & \multicolumn{2}{|c|}{ Protein } & \multicolumn{2}{|c|}{ Fat } & \multicolumn{2}{|c|}{ Sugar } & \multicolumn{2}{|c|}{ Ash } \\
\hline & $\underset{\text { Milk }}{\text { Human }}$ & $\begin{array}{l}\text { Cows' } \\
\text { Milk }\end{array}$ & $\underset{\text { Milk }}{\text { Human }}$ & $\begin{array}{l}\text { Cows' } \\
\text { Milk }\end{array}$ & $\underset{\text { Milk }}{\text { Human }}$ & $\begin{array}{l}\text { Cows' } \\
\text { Milk }\end{array}$ & $\underset{\text { Milk }}{\text { Human }}$ & $\begin{array}{l}\text { Cows' } \\
\text { Milk }\end{array}$ \\
\hline & Per cent. & Per cent. & Per cent. & Per cent. & Per cent. & Per cent. & Per cent. & Per cent. \\
\hline $\begin{array}{l}\text { Munk and Uffel- } \\
\text { mann }\end{array}$ & $2 \cdot I$ & - & $3 \cdot 4$ & - & $5 \cdot 0$ & - & 0.2 & - \\
\hline Kōnig & $2 \cdot 3$ & - & 3.5 & - & $6 \cdot 2$ & - & $0 \cdot 3$ & - \\
\hline Heubner . & I.03 & 3.50 & $4^{\circ} \cdot 07$ & 3.50 & $7 \cdot 03$ & $5 \cdot 0$ & 0.21 & 0.07 \\
\hline $\begin{array}{l}\text { Camerer and } \\
\text { Söldner }\end{array}$ & $I \cdot 27$ & - & 3.91 & - & $6 \cdot 52$ & - & 0.22 & - \\
\hline Meigs . & $\mathrm{I} \cdot 04$ & $3 \cdot 02$ & $4 \cdot 28$ & $3 \cdot 7$ & $7 \cdot 4$ & $4 \cdot 9$ & o.roI & $0.4^{8}$ \\
\hline Bamberg & - & - & $3 \cdot 1$ & - & $6 \cdot 69$ & - & 0.215 & - \\
\hline
\end{tabular}

Great variations occur, however, and Meigs and Marsh and Kirchner give the averages below:

\begin{tabular}{|c|c|c|c|c|c|c|c|c|}
\hline & \multicolumn{2}{|c|}{ Protein } & \multicolumn{2}{|c|}{ Fat } & \multicolumn{2}{|c|}{ Sugar } & \multicolumn{2}{|c|}{ Ash } \\
\hline & $\underset{\text { Milk }}{\text { Human }}$ & $\begin{array}{l}\text { Cows' } \\
\text { Milk }\end{array}$ & $\underset{\text { Milk }}{\text { Human }}$ & $\begin{array}{l}\text { Cows' } \\
\text { Milk }\end{array}$ & $\underset{\text { Milk }}{\text { Human }}$ & $\begin{array}{l}\text { Cows' } \\
\text { Milk }\end{array}$ & $\begin{array}{c}\text { Human } \\
\text { Milk }\end{array}$ & $\begin{array}{l}\text { Cows' } \\
\text { Milk }\end{array}$ \\
\hline $\begin{array}{l}\text { Meigs and Marsh } \\
\text { Kirchner. }\end{array}$ & $\begin{array}{l}\text { Per cent. } \\
0 \cdot 7-\mathrm{I} \cdot 5\end{array}$ & $\begin{array}{l}\text { Per cent. } \\
2 \cdot 5-4 \cdot 0 \\
2 \cdot 3-5 \cdot 65\end{array}$ & $\begin{array}{c}\text { Per cent } \\
2-4 \\
-\end{array}$ & $\begin{array}{c}\text { Per cent. } \\
2-4 \\
0 \cdot 8-8 \cdot 0\end{array}$ & $\begin{array}{c}\text { Per cent. } \\
6-7.5 \\
\end{array}$ & $\begin{array}{c}\text { Per cent. } \\
3 \cdot 5-5 \\
3 \cdot 0-6 \cdot 0\end{array}$ & Per cent. & $\int_{0.6-0.9}^{\text {Per cent. }}$ \\
\hline
\end{tabular}

The variations are thus considerable, but, generally speaking, cows' milk contains more protein and more salts or ash than human milk. Human milk contains much more sugar, while the amount of fat is fairly equal. It is probable that in reality the average fat content of human milk is higher than that of cows', although it is more difficult to obtain a sample of the milk in such a manner as to ensure a correct result. It is well known that the milk of certain breeds of cows is ' richer' than others. This term relates mainly to the fat content, although some variation also occurs in the amount of protein.

Changes in the Composition of Milk occurring at different Stages of Lactation.-The milk given by all species of mammalia in the early days after parturition is very different in composition from that given later. The milk of this period is known as colostrum, and the colostral characteristics persist for different periods in different species, and to some extent also in different members of the species.

By the end of the first month, however, the colostral characteristics have disappeared, and the milk will have the average composition, so far as such an average composition of milk exists. The most pronounced colostral characters have usually ceased by about the fourth or fifth day after parturition. 
Colostrum is a more viscid fluid than the later milk. Some of the constituents of milk are present in higher proportion, and certain properties are possessed by milk in the early days of lactation which are not found later. These are considered in the chapters dealing with the constituents or properties concerned.

The protein and the salt content are higher in colostrum than in the later milk. Some observers find that there is rather more fat in colostrum than in the later milk, but this appears not to be a constant feature. The number of cells found in colostrum is frequently higher than in later milk.

The composition of the colostrum of cows is hardly material to the present purpose, as it is not used for infants and is not a marketable commodity. Generally, the divergences in composition of colostrum from that of average milk are similar to those occurring in human milk.

There is no doubt that colostrum is of primary importance to the young animal, and there is no way of replacing it. An infant deprived of the colostrum of its mother must endeavour, not always with success, to make up later the disadvantage under which it has laboured at the start.

Practical difficulties are encountered in obtaining samples of human colostrum for estimation. The infant can usually succeed in obtaining an appreciable amount of colostrum before it is possible to obtain any artificially, since suckling almost certainly empties the gland more completely than is otherwise possible. The differences in fat content between the milk at the beginning and end of suckling are very considerable, and this renders the estimation of the fat of colostrum unreliable.

The essential differences between colostrum and average milk are given below :

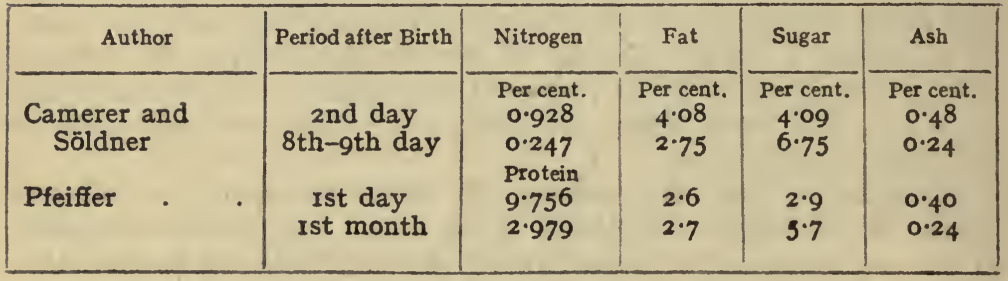

Fairly similar figures are given by other authors.

The figures for the fat content are very variable, which can probably be accounted for by the difficulty of obtaining an average sample.

As lactation proceeds changes tend to appear in the composition of the milk. In human milk both the protein and the salts tend to fall, whereas in cows' milk both tend to rise. It is not unlikely that this difference can be accounted for by the fact that cows 
kept for milking are usually pregnant during the later months of lactation.

Cows' milk, therefore, does not appear to undergo any loss of nutritive value towards the end of lactation, but in women there is a tendency for this to occur.

Milk in Relation to Diet.-Much work has been done upon this subject, though many of the statements which have been made with regard to it are not based upon fact.

Fundamentally the question is one of the mode of action of the mammary gland, and must be considered in relation to the quality and quantity of the food, both upon the total amount and upon the individual constituents of the milk.

I. Quantity of Food. - When the total amount of food taken falls below the minimal daily requirements of the organism, either as a whole or in any one of the necessary constituents, the milk tends rather to decrease in total amount, than to show a deficit of that particular constituent which is supplied in insufficient quantity in the diet.

This is illustrated by the work of Woll, who found that the milk of cows which were receiving too short an allowance of food decreased in amount.

Fingerling found that goats receiving a diet in which there was too little lime and phosphorus gave less milk until a sufficient amount of these substances was restored.

Any factor acting disadvantageously on the general health or economy of the organism tends to produce a fall in the amount of milk given. This applies also to the human species.

2. Addition of Special Substances to the Food.-Numerous attempts have been made to increase special constituents of the milk by giving additional amounts of these constituents in the dietary, both of cows and of women.

One or two observers have claimed a partial success, but the most careful observations show that no appreciable increase in any one constituent can be obtained by its addition to the food, even in large quantities. This has been attempted for fat and sugar, and for combinations of lime, iron, and phosphorus. The experiments are considered fully in the chapters dealing with these constituents.

The amount of fat produced varies greatly with the same cow at different times.

Variations in the Fat Content.-The fat content is low in the milk obtained when the gland is full. As milking proceeds, the fat content rises and is highest in the end-milk, or strippings. In estimating the total percentage of fat in either human or cows' milk it is essential that a sample of the milk given in the whole period of milking should be taken.

The fat content also varies within the twenty-four hours, being apparently highest towards mid-day. 


\section{CHAPTER II}

THE GENERAL COMPOSITION OF MILK

A. The Average Composition of Human and Cows' Milk.-The composition of milk is such a well-worn subject that it would not be unreasonable to believe that complete information was available. Definite information upon the composition of the milk of numerous species is given in many text-books upon milk, and this information has been gradually accepted.

Recent investigations have shown, however, that there is no precise composition which can be assigned to the milk of any species. A figure giving the average composition of a number of samples can be obtained, but a considerable degree of variation is exhibited in the figures of the different samples. In addition to the divergence in composition due to individual differences in the members of the species, great variations occur in several of the constituents from other causes. Such causes are-the period of lactation, the condition of the gland, whether full or nearly empty at the time of taking the sample. Further, in cows the breed exercises an important influence on the amount of certain constituents of the milk.

Although the composition of milk does not show a constant figure, it is useful as a foundation from which to consider the variations, which will be referred to later.

In this chapter only known chemical substances will be considered. The less tangible bodies, sometimes known as the "biological properties,' will be dealt with separately in Chapters V. and VI. The cells and the cell content of milk will also be considered later.

It will be convenient to consider the chemical composition of human milk and cows' milk at the same time. The main differences in composition of average samples of human and cows' milk respectively as obtained by various observers for certain of the main constituents of the milk are shown below:

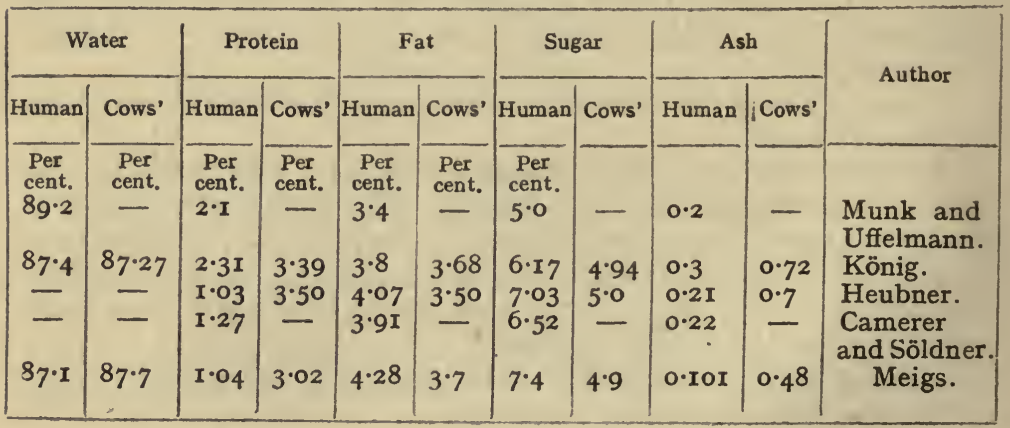


In later analyses Meigs and Marsh give the amounts of fat, lactose, and protein in the second month of lactation (that is, when the colostral period is over and the milk may be considered to be of average composition) as follows:-

Fat, from 2-4 per cent., both for human milk and cows' milk.

Lactose, from 6-7.5 per cent. for human and 3.5-5 per cent. for cows' milk.

Protein, from $0 \cdot 7-I^{\prime} 5$ per cent. for human and $25^{\circ}-4^{\circ} 0$ per cent. for cows' milk.

Further estimations of the average amount of some constituents of human milk are given by the following authors:

\begin{tabular}{|c|c|c|c|c|}
\hline Authors & . & Fat & Nitrogen & Sugar \\
\hline $\begin{array}{l}\text { Pfeiffer } \\
\text { Camerer } \\
\text { Schlossmann }\end{array}$ & $\dot{.}$ & $\begin{array}{l}\text { Per cent. } \\
3 \cdot I I \\
3 \cdot 6 I \\
4 \cdot 83^{1} \\
3 \cdot 47\end{array}$ & $\begin{array}{c}\text { Per cent. } \\
0.31 \\
0.19 \\
0.25 \\
0.26\end{array}$ & $\begin{array}{c}\text { Per cent. } \\
6 \cdot 30 \\
6.66 \\
6.95 \\
7 \cdot 14\end{array}$ \\
\hline
\end{tabular}

Schloss, who took the total milk given in twenty-four hours by eight different women and the mixed milk of fifteen to sixteen wet-nurses on two separate occasions, obtained the following figures :

\begin{tabular}{|c|c|c|c|c|c|}
\hline \multicolumn{2}{|c|}{ Constituent. } & & Average of 8 Women & $\underset{(x)}{\text { Mixed }}$ & $\underset{(2)}{\text { Mixed }}$ \\
\hline $\begin{array}{l}\text { Fat . } \\
\text { Nitrogen } \\
\text { Ash. }\end{array}$ & $\dot{.}$ & : & $\begin{array}{l}\text { Per cent. } \\
3.78 \\
0.1847 \\
0.1839\end{array}$ & $\begin{array}{l}\text { Per cent. } \\
4.02 \\
0.1904 \\
0.1912\end{array}$ & $\begin{array}{l}\text { Per cent. } \\
3.58 \\
0.1897 \\
0.1828\end{array}$ \\
\hline
\end{tabular}

Bamberg, taking samples of milk expressed from the gland before and after the feeding of the infant, and then mixed together, so as to secure as far as possible a fair sample, obtained the following average figures for human milk:

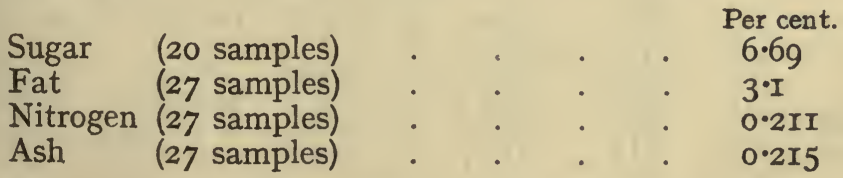

Very considerable differences occur in the constituents of the ash of the two varieties of milk, which will be dealt with later.

It is not necessary to consider all the data given by numerous

1 Difference due to more first milk being taken in collecting the second sample. 
authors regarding the average composition of cows' milk. Much information upon this subject will be found in numerous text-books.

The variations found in the composition of different milk samples is well illustrated by the figures obtained by Kirchner, who gives the range in percentage composition of the samples examined :

\begin{tabular}{|c|c|c|c|c|c|c|}
\hline Water. & - & . & • & & from & $83-90$ \\
\hline Fat & - & - & . & • & ", & $0.8-8 \cdot 0$ \\
\hline Caseinogen & . & - & . & . & ," & $2 \cdot 0-4 \cdot 5$ \\
\hline Albumin & $\cdot$ & • & $\cdot$ & - & ," & $0.2-0.8$ \\
\hline Lacto-proteir & - & - & - & - & , & $0.08-0.35$ \\
\hline Lactose & . & · & - & - & ," & $3 \cdot 0-6 \cdot 0$ \\
\hline Ash & . & - & - & . & ," & $0.6-0.9$ \\
\hline
\end{tabular}

These results show the impossibility of adopting any set of figures as a standard for the composition of cows' milk. Doubtless some of the extreme figures are attributable to certain causes which are considered below.

The average composition of cows' milk is affected by the breed of the cow, although the individual variations which occur between the composition of the milk of different cows of the same breed are sometimes as great as those which may reasonably be attributed to the breed of the cow. Eckles and Roscoe Shaw studied in detail the effect of breed on the percentage of the main constituents. The food ration was kept constant, and samples were taken over practically the whole period of lactation. The same series of investigations was also available to show the variations in composition due to the stage of lactation and to the individual cow. These latter results will be considered later.

Samples of the daily milk were preserved with formalin, and the estimations carried out once a week. It is impossible here to attempt to reproduce more than a few of the figures obtained by these investigators. The following table gives a summary of the variations in the composition of milk in Jerseys, Holsteins, and Shorthorns, there being three cows in each series:

\begin{tabular}{|c|c|c|c|c|c|}
\hline Breed & Fat & Sugar & Total N. & Total Solids & Solids not Fat \\
\hline $\begin{array}{l}\text { Jerseys } \\
\text { Holsteins } \\
\text { Shorthorns }\end{array}$ & $\begin{array}{c}\text { Per cent. } \\
4.95 \\
3.09 \\
3.73\end{array}$ & $\begin{array}{c}\text { Per cent. } \\
4.87 \\
4.51 \\
4.99\end{array}$ & $\begin{array}{c}\text { Per cent. } \\
0.57 \\
0.46 \\
0.53\end{array}$ & $\begin{array}{c}\text { Per cent. } \\
34 \cdot 6-34 \cdot 7 \\
26 \cdot 7-27 \cdot 3 \\
27 \cdot 7-31 \cdot 7\end{array}$ & $\begin{array}{l}\text { Per cent. } \\
9 \cdot 15 \\
8 \cdot 2 \\
9 \cdot 1\end{array}$ \\
\hline
\end{tabular}

Very considerable variations occur, more especially in the fat samples, even when the average estimations are in four-weekly periods. In the Holsteins the fat content was below 3 per cent. and above 5 per cent. in the Jerseys in several averages. 
Sugar appears to have a remarkably constant percentage both among different breeds and among individuals of the breed.

The authors carried out numerous researches into the nature of the fat, and concluded that no variations occurred in the meltingpoint of the fat which could be attributed to the breed of the cow.

Eckles has shown that yearly variations occur in the amount of fat in cows' milk.

It would appear that there are no data as to the differences in composition of human milk, as a result of difference of race, although such differences may quite likely exist.

B. Variations in Composition due to the Period of Lactation.It is well known that the milk given in the early days after parturition is different in quality from the milk of later periods ; also that alterations occur upon the approach of cessation of lactation, and owing to disease.

All these points require consideration, and it will be convenient to consider first of all the general trend of the changes occurring as the period of lactation passes on; then to consider the special composition of the milk in the early days after parturition. The question of disease will be dealt with briefly.

The alterations in special constituents of the ash due to the period of lactation will be dealt with under the appropriate headings.

Human Milk. - Comprehensive investigations were made by Pfeiffer in I 895 and by Schlossmann in I900 upon the alterations in human milk due to the period of lactation. Pfeiffer's figures are as follows:

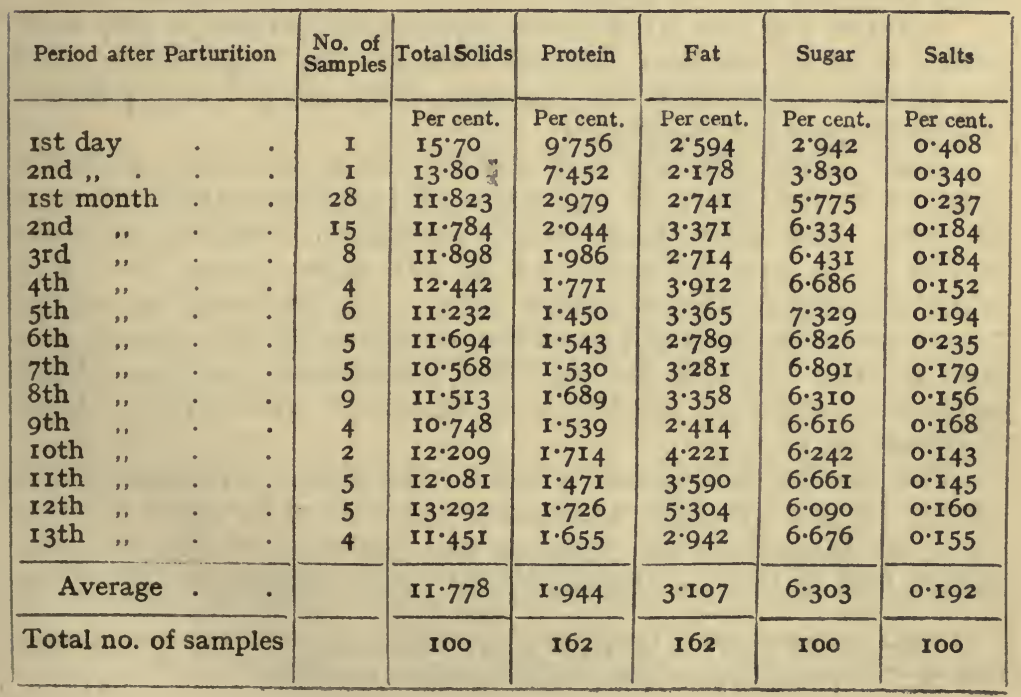


Schlossmann obtained figures for the milk of a large number of women by taking a sample of the milk expressed from the opposite gland from that at which the child was feeding. The average results obtained were as follows:

\begin{tabular}{|c|c|c|c|c|c|c|}
\hline \multicolumn{3}{|c|}{ Days after Confinement } & & \multirow{2}{*}{$\begin{array}{c}\text { Fat } \\
\text { Per cent. } \\
4 \cdot 23\end{array}$} & \multirow{2}{*}{$\begin{array}{c}\text { Nitrogen } \\
\begin{array}{c}\text { Per cent. } \\
0.29\end{array}\end{array}$} & \multirow{2}{*}{$\begin{array}{c}\text { Sugar } \\
\begin{array}{c}\text { Per cent } \\
6.95\end{array}\end{array}$} \\
\hline 9th and 10 & oth & . & & & & \\
\hline IIth-2oth & . & - & & 4.63 & 0.29 & 6.89 \\
\hline 2 Ist-3oth & . & . & & $4 \cdot 53$ & $0.3 I$ & $6 \cdot 77$ \\
\hline 3 Ist-4oth & - & - & & $5 \cdot 00$ & 0.24 & 6.97 \\
\hline 4Ist-5oth & . & - & & $5 \cdot 4 I$ & 0.28 & $6 \cdot 80$ \\
\hline 5Ist-6oth & . & - & & $4 \cdot 62$ & 0.25 & $7 \cdot 28$ \\
\hline 6 Ist-7oth & - & - & & $4 \cdot 69$ & 0.23 & $6 \cdot 94$ \\
\hline 7rst-rooth & - & . & & $5 \cdot 39$ & 0.20 & 6.79 \\
\hline Iorst-I 4oth & . & - & & $5 \cdot 10$ & 0.20 & $6 \cdot 94$ \\
\hline I 4Ist-200th & - & - & & $\begin{array}{c}4.02 \\
\text { or }\end{array}$ & 0.21 & $6 \cdot 89$ \\
\hline Over 20oth & $\cdot$ & - & & $\begin{array}{l}4 \cdot 74^{1} \\
5 \cdot 55\end{array}$ & 0.21 & $7 \cdot 33$ \\
\hline
\end{tabular}

The figures in these tables show that there is a general tendency for the amount of nitrogen to fall during lactation. The figures for fat and sugar, although showing some variations, do not exhibit any decided alteration in relation to the period after parturition.

Bamberg, in the course of other investigations, found the same tendency for the nitrogen content to fall during lactation.

Towards the end of lactation certain properties of the early period tend to reappear, but as these do not appreciably affect the chemical composition of the milk, they will not be considered in this chapter (see Chap. VI.).

Cores' Milk.-Eckles and Roscoe Shaw obtained elaborate data as to the effect of the stage of lactation upon the milk of cows. The estimations were commenced approximately one month after parturition except in one case-Jersey cow (c)where the first sample was taken later. The figures given are too numerous to quote, and it has been necessary for the present purpose to take only the first and last four-weekly averages of the estimations obtained for the more important constituents. These are given on p. 13 .

The intermediate figures, which are not given here, show a slight drop in the nitrogen figures in the early months of lactation, followed by a corresponding rise towards the cessation of the function. Eckles and Shaw also compared the total amount of milk given

2 This second figure is obtained if the results given by the milk of three women in whom lactation had nearly ceased, are omitted. 
with the variations in the various constituents, and represented the results graphically. One of these diagrams is given on p. I4. It shows the drop in the total amount of milk towards the end

Jersey Cows

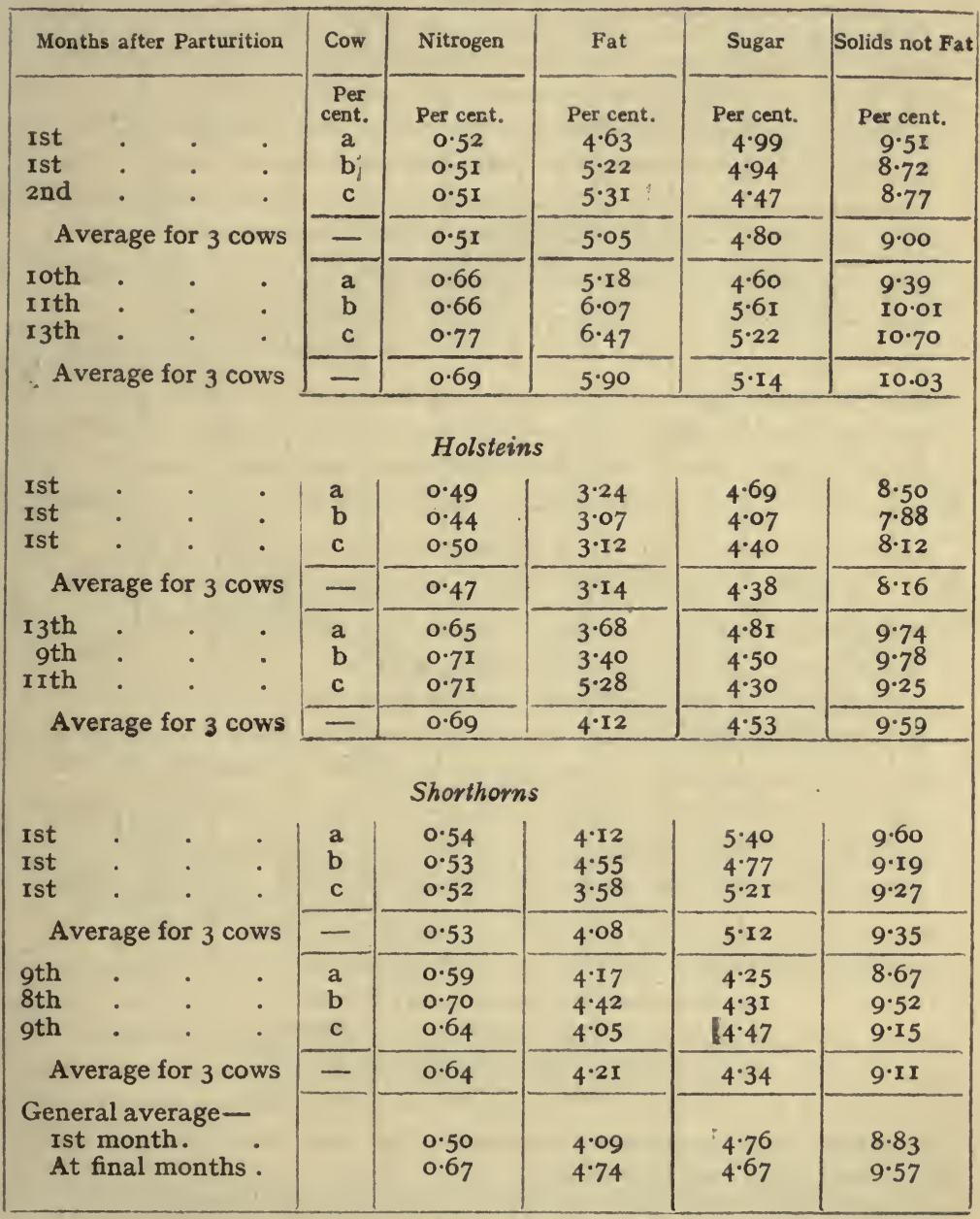

of lactation and the accompanying rise in certain of the constituents. The ratio of the protein nitrogen to the total nitrogen was found to be fairly constant throughout. This final tendency to a rise in the total nitrogen is the reverse of that found 
in the case of human milk. It is not unlikely that the explanation of this apparent divergence may be found in the fact that

Diagram showing Variation in Yield andl Composition of Milk from One Cow, the estimations shown representing the average on each 4-weekly period.

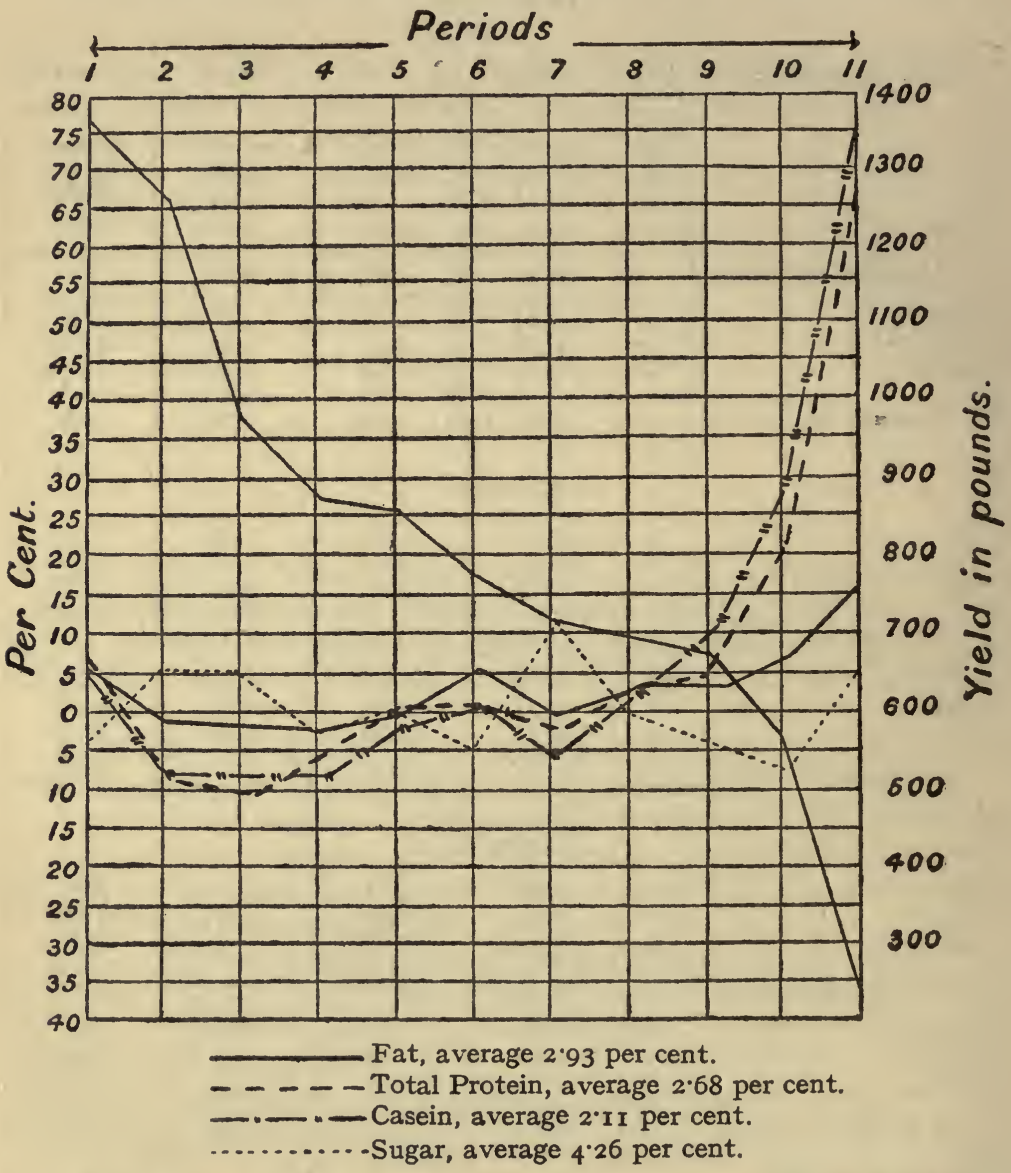

The milk yield in pounds is shown by the plain line falling gradually throughout the period of lactation.

The curves showing the changes in composition are arranged to show the percentage rise or fall above the average percentage for each constituent, which is represented by the zero line.

these cows were all pregnant in the later months of lactation. Samples taken from five cows who were farrow showed little alteration in the constituents of the milk taken at the same 
periods after parturition. It is possible that the mammary gland may act to a slight extent as an excretory organ, when there is a surplus of waste substances circulating in the blood stream.1 This condition will be the case in the later months of pregnancy at all events, and probably occurs in the early months. In this case the slight rise in nitrogen may be partly, if not wholly, accounted for. It would appear that no observations upon the metabolism of pregnant cows are available. Investigations upon the metabolism of pregnancy and lactation have been carried out upon women by Mellanby, and upon dogs by Murlin and by Dienes. For further details and additional literature, reference should be made to these authors. Detailed discussion of this subject is outside the scope of the present work.

Medical literature contains much discussion upon the desirability or otherwise of weaning an infant should pregnancy supervene. The general opinion appears to tend in the direction that weaning is not necessary unless the health of the mother should require it.

The practical side of the question may be regarded as having been settled long ago by farmers, since the very great majority of cows which provide the milk-supply of the country are allowed to become pregnant usually within a few weeks (sometimes rather later) of parturition.

The rise in the non-fatty solids may perhaps be accounted for by the same suggestion as in the case of the rise of nitrogen.

The sugar content is extremely constant throughout the whole period of lactation.

The increase in the fat is so slight that in view of the general wide variations in fat content, it hardly calls for discussion.

The ash content of cows' milk in relation to the period of lactation was exhaustively examined by Trunz in two cows. He found that no definite alterations in the salt content could be detected, although generally there was a slight fall in the first weeks, which rose again towards the end of the tenth month.

Variations in the composition of milk in relation to the amount of milk given will be considered in dealing with the individual constituents.

C. Composition of Milk in the Early Days after Parturition (Colostrum).- The value of colostrum to the young animal of the same species would appear to be very great. Naturally-fed infants and calves each receive the colostrum of their own species, but the colostrum of the cow is not a marketable product, and, as far as I am aware, there is no record of its having been supplied to infants as a food.

The composition of colostrum is, however, a matter of considerable intrinsic interest, and a brief digression upon this subject

$1 C p$. Engel and Murschhauser, p. 42 . 
will not be out of place. Only the chemical constituents will be considered in this chapter.

The colostrum of the cow appears to show the same type of change from the average sample as in the human species. As it is not used for infants, it will be sufficient to quote a few figures, confining the discussion more definitely to the composition of human colostrum.

König gives the following figures for the percentage composition of cows' colostrum :

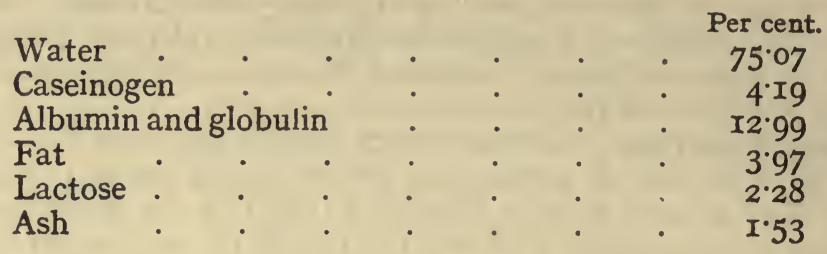

The protein figures are of especial interest if they are compared with the work on the biological aspect of the milk-proteins which is considered later.

Engel and Dennemark investigated the milk of three cows. They found that the physical characteristics of colostrum were most marked in the first three days, and during this period marked differences in the distribution of the nitrogen occurred. If milk fever supervened, the peculiar distribution of nitrogen was maintained over a longer period.

These authors give the following figures:

\begin{tabular}{|c|c|c|c|c|}
\hline a & & a & At First & Falling by 35 th Day to \\
\hline $\begin{array}{l}\text { Fat. } \\
\text { Total N. } \\
\text { N. in whey } \\
\text { N. in casein }\end{array}$ & $\begin{array}{l}\dot{.} \\
\dot{.} \\
\text {. }\end{array}$ & $\begin{array}{ll}\cdot & \cdot \\
\cdot & \cdot \\
. & . \\
. & .\end{array}$ & $\begin{array}{l}\text { Per cent. } \\
4.65 \\
2.8375 \\
2.1662 \\
0.6713\end{array}$ & $\begin{array}{l}\text { Per cent. } \\
2 \cdot 70 \\
0.4667 \\
0.0902 \\
0.3764\end{array}$ \\
\hline
\end{tabular}

The figures given by Sassenhagen for the fat content of colostrum show variations extending between $I \cdot I$ per cent. and $3^{\cdot} 6$ per cent.in one case 7.8 per cent. The fat estimations were only an incidental part of the work, and it is not advisable to lay any stress upon them, as it is not stated that the samples were average mixed samples. Taken with the figures already given, they show, however, that the fat content of colostrum does not appear to exceed that of the later milk, and that it is equally, if not more, variable.

Capobianco, who deals fully with the literature upon this matter, finds that the osmotic pressure of colostrum is above the figure usually given for average milk. 
Human Colostrum.-The estimation of the composition of human colostrum is rendered difficult in view of the relatively small amount which is present in the gland. It is not possible to obtain more than a small fraction of the total amount of milk produced, for purposes of analysis. The gland is not in working order, expression of milk is painful, and the breast-pump, at all times an insufficient method of obtaining the end milk, is of little assistance at this juncture. It is probable that the infant obtains a good deal more milk than can possibly be removed by artificial means ; further, as the end milk is the richest in fat, it is almost certain that the food value available for the infant will exceed that suggested by the published estimates of the average composition of colostrum. Langstein, Rott, and Edelstein say that in their experiments the child was usually able to obtain Io to I5 grammes of milk at a period when it was impossible for any to be expressed for estimation.

The following figures are given by Camerer and Söldner ( $\mathrm{I}$ ) for the values of colostrum:

\begin{tabular}{|c|c|c|c|c|c|}
\hline Period & & Nitrogen & Fat & Sugar & Ash \\
\hline $\begin{array}{l}26 \text { th to 5ist hour } \\
56 \text { th to } 6 \text { rst } \\
5 \text { th to 6th day } \\
\text { 8th to 9th ". }\end{array}$ & $\begin{array}{ll}\cdot & \bullet \\
: & \cdot \\
: & \cdot\end{array}$ & $\begin{array}{c}\text { Per cent. } \\
0.928 \\
0.508 \\
0.327 \\
0.247\end{array}$ & $\begin{array}{c}\text { Per cent. } \\
4.08 \\
3 \cdot 92 \\
2 \cdot 89 \\
2 \cdot 75\end{array}$ & $\begin{array}{c}\text { Per cent. } \\
4 \cdot 09 \\
5 \cdot 48 \\
5 \cdot 75 \\
6 \cdot 75\end{array}$ & $\begin{array}{c}\text { Per cent. } \\
0.48 \\
0.4 I \\
0.34 \\
0.24\end{array}$ \\
\hline
\end{tabular}

Zuckmayer gives figures for the nitrogen and ash in the early days, in average samples taken from twenty-six women, viz.: $0 \cdot 26$ per cent. for nitrogen and 0.20 per cent. for ash, between the third and eighth days. Bailey and Murlin give rather different figures for five samples taken, as below:

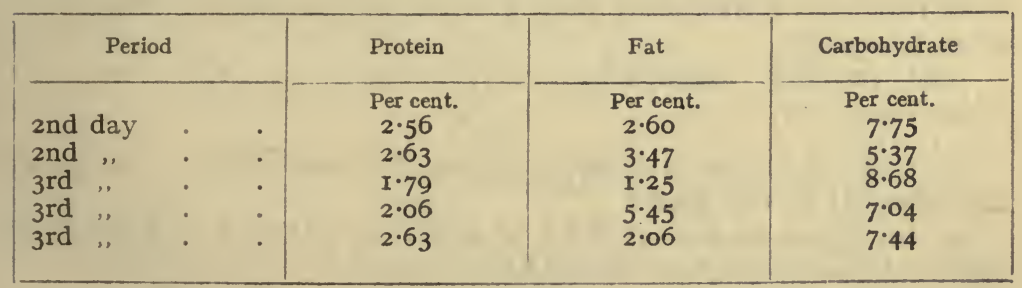

The extreme variation in the last three sets of figures, especially in the fat, raises a doubt whether the specimens were really average ones, more especially as the authors appear to have experienced some difficulty in obtaining samples. The method employed is 
not stated, nor the amount of milk obtained naturally by the children.

The ash of human colostrum was estimated by Birk, and compared with the ash of normal milk obtained by Camerer and Söldner, Bunge, and others.

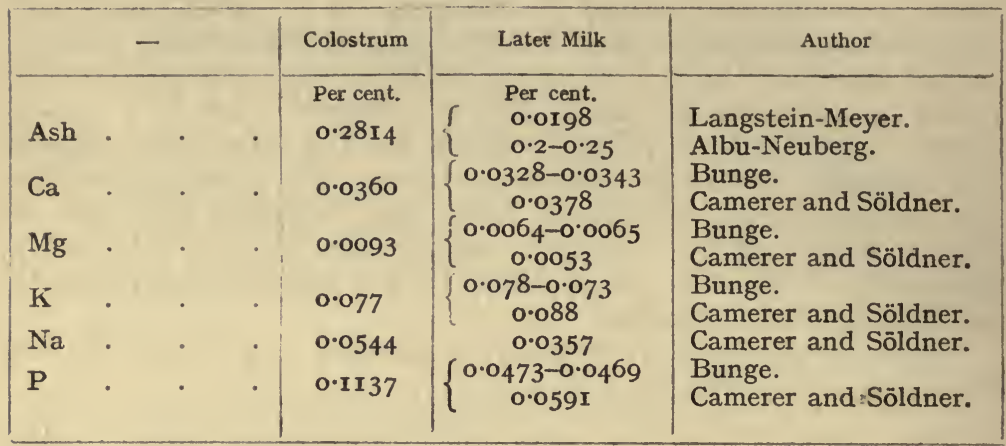

The total ash is much higher in colostrum than in later milk, and the most striking differences lie in the sodium and phosphorus content.

The main chemical differences between colostrum and later milk appear to consist in the increased content of nitrogen and certain constituents of the ash. Fat and sugar are little, if at all, higher than in later milk, and may be lower. ${ }^{1}$

The value of colostrum as a food for the new-born child is a question of great interest. The loss of weight which occurs in infants after birth has been investigated by numerous observers, with more or less satisfactory results. The cause of the loss does not appear at all certain, and the investigation of the food value of colostrum was a necessary step towards attainment of knowledge upon this point.

The problem essentially resolves itself into the two considerations :-

I. Does the loss of weight denote an insufficient amount of nourishment in the food?

2. Is it due to loss of fluid or of waste material? Must it in any case be regarded as detrimental, or not?

In order to obtain an answer to the first part of the problem investigations have been made as to the food requirements of a new-born child. Many difficulties are encountered in this work.

${ }^{1} \mathrm{Cp}$. Pfeiffer's figures on $\mathrm{p}$. II for first and second days after parturition. 
The heat value of the food taken can only be ascertained approximately, owing to the difficulty of obtaining all the colostrum except by suckling, and to the fact that the colostrum cannot be used both for estimation and as a food for the infant.

Langstein, Rott, and Edelstein endeavoured to avoid some-nf these difficulties by expressing some milk before and after feeding, and mixing the samples thus obtained. If the total amount of milk available is known and the heat value of an average sample is ascertained, a reasonable approximation may be arrived at as to the calories available for the infant.

Langstein and his colleagues took samples from eight cases, and concluded that all colostrum did not have the same heat value. They divided the results obtained into two classes, of which the heat value per litre of milk for Group I. (of rich colostrum) is given as:

\section{Day}

$$
\begin{aligned}
& \text { I } \\
& 2 \\
& 3 \\
& 4 \\
& 5 \\
& 6 \\
& 7
\end{aligned}
$$

Calories per Litre.

$\begin{array}{rr}\text {. } & \text { I } 480 \\ . & \text { II80 } \\ . & 810 \\ . & 730 \\ . & 700 \\ . & 675 \\ . & 650\end{array}$

In Group II. (poor colostrum) there was little difference in caloric value as compared with that of the later days.

Birk studied the metabolism of two children, one of whom was fed naturally from birth, with colostrum passing to later milk, while the other received no colostrum, but was fed by a wet-nurse in a later stage of lactation. Although the first child lost weight in the usual way, it showed a positive balance for nitrogen and salts; the other child showed a negative balance for nitrogen and several saline constituents, viz. :-

\begin{tabular}{|c|c|c|}
\hline - & Child I & Child II \\
\hline $\begin{array}{l}\mathrm{N}_{2} \\
\mathrm{Ash} \\
\mathrm{CaO} \\
\mathrm{MgO} \\
\mathrm{K}_{2} \mathrm{O} \\
\mathrm{Na}_{2} \mathrm{O} \\
\mathrm{P}_{2} \mathrm{O}_{5}\end{array}$ & $\begin{array}{l}\text { Gms. Per cent. } \\
+.9513 \\
+\mathrm{I} .6366 \text { or } 56.4 \\
+0.2691 \text { or } 72.5 \\
+0.0955 \text { or } 70.1 \\
+0.7911 \text { or } 62.9 \\
+0.5599 \text { or } 45.4 \\
+\mathrm{I} .1700 \text { or } 79.3\end{array}$ & $\begin{array}{l}\text { Gms. } \\
-.3461 \\
+0.2360 \\
+0.1700 \\
-0.0036 \\
-0.0230 \\
+0.0545 \\
-0.1258\end{array}$ \\
\hline
\end{tabular}

The percentage retention of the salts is interesting, and the 
figures show the loss suffered by the infant when deprived of colostrum.

It seems doubtful whether the loss in total weight is detrimental when the weight begins to rise again within a few days after birth. Griffith and Gittings found that the loss of weight after birth could be prevented by giving the child additional human milk during - the first day or two, but that after a few weeks no advantage could be detected in these infants over those in whom loss of weight had been allowed to occur.

Murlin and Bailey concluded that there was not enough food value in colostrum. The calculation upon which this conclusion is based is not clear, but it is not material for the present purpose. Having decided that nature was a delinquent in regard to the provision of food for the early days of an infant's life, these observers prepared percentage feeds of cows' milk to supplement the deficiency. They found that 'supplementary feeding of new-born infants from the first day forward with a formula somewhat resembling colostrum in composition, diminished the initial loss of weight, accelerated the return to birth weight, and had no unfavourable effects.' It is not stated which of the three advantages is considered the greatest-possibly the last.

A full résumé of the literature upon the loss of weight in the early days of life is given by Pies.

Further questions relating to colostrum are dealt with in Chapters III. and VI.

D. The Influence of Diet.-The investigations and results which have been detailed above, lead without further observation to the conclusion, that the composition of the milk is independent of the constituents of the food within very wide limits.

Carlyle and Woll show that to some extent the fat production appears to vary independently of the amount of food.

Thus in one cow (Bessie) as compared with another cow (Dolly), it was found that:

Bessie, in I900-190I, produced $42.64 \mathrm{lbs}$. of butter-fat more than in I899-I900, but her food cost $\$ 5.42$ less than in that year.

Dolly, in the year I899-I900, produced $302 \mathrm{lbs}$. of butter-fat against $98 \mathrm{lbs}$. in the preceding year, and her food cost \$I.I less.

The experiments carried out by Woll with what was found to be an insufficient supply of food, showed an appreciable fall in the total milk produced, but the fat-ratio appeared to be little affected, although the total fat fell.

Woll quotes figures from Holtsmark to show that up to a certain point an increase in the amount of milk can be obtained by increasing the food-supply of cows, as shown by the following figures : 


\begin{tabular}{|c|c|c|c|}
\hline Food Units & $\begin{array}{c}\text { Milk in } \\
\text { Kg. }\end{array}$ & $\begin{array}{c}\text { Kg. of Milk } \\
\text { per Ioo } \\
\text { Food Units }\end{array}$ & $\begin{array}{c}\text { Increase in } \\
\text { Milk Production } \\
\text { per 500 Food Units }\end{array}$ \\
\hline & 923 & $61 \cdot 5$ & - \\
2000 & 1424 & $71 \cdot 2$ & 501 \\
2500 & 1813 & $72 \cdot 5$ & 389 \\
3000 & 2131 & $71 \cdot 0$ & 318 \\
3500 & 2399 & $68 \cdot 5$ & 268 \\
4000 & 2632 & $65 \cdot 8$ & 233 \\
4500 & 2837 & $63 \cdot 1$ & 205 \\
\hline
\end{tabular}

The increase in the amount of milk produced may evidently cease to be profitable to the farmer, owing to the greater cost of the food required to produce it.

Koning found that poor food caused a fall in the fat-content and in the 'solids not fat.' The addition of even 200 gms. of sodium chloride to the food gave no increase of chlorides in the milk.

Kohn showed that a somewhat higher fat-content was obtained when goats were partly fed on the meadows, instead of with dried food only. The ash also rose somewhat with meadow feeding.

Engel and Plaut found that the milk of a nursing woman is reduced if there is insufficient fat in the diet, but that increasing the fat in the food did not increase the fat in the milk.

Allemann endeavoured to alter the composition of the milk by alteration in the food given, but without success. The addition of large quantities of salt to the food was not successful in causing a rise of salt-content in the milk. When, however, saltpetre was used in large quantities, traces of this could be detected in the milk. The fact that traces of the abnormal salt were found in the milk is of interest in connection with the work of Engel and Murschhauser. ${ }^{1}$

When certain important constituents of the food fall below the physiological limit, the amount of milk secreted is reduced. This would appear to be due to a physiological mechanism, designed to prevent undue depletion of the organism.

Thus Fingerling found that when goats were fed on a diet poor in calcium and phosphorus, a fall both in the amount of the constituents and of the total milk occurred. This drop commenced when a certain degree of depletion had been reached consequent on the reduction in intake of these constituents. On restoring the calcium and phosphorus the secretion returned to normal.

Cathcart and Paton, in the course of experiments undertaken to determine the source of lactose in milk, fed a goat on a diet calculated to reduce the carbohydrate taken, and administered phloridzin to remove the store of glycogen. The amount of milk given fell very rapidly-also the ash-content-but in two instances the fatcontent rose. At one period the secretion of milk almost stopped. 
The addition of salts to the food, with the view of increasing the output of a particular constituent, has been frequently attempted, but with no appreciable success, although some observers claim to have produced an effect. These will be dealt with under their several headings in Chap. IV.

Attempts have also been made to determine some degree of correlation between the various constituents of the milk. Thus, Schloss believes that there is a relationship between the nitrogen and the ash. Bamberg, however, finds none. Engel finds a relationship between the amount of milk and the fat; this is denied by Helbich (2). So far no distinct relationship between any of the constituents has been shown to exist, although this may obtain in a few isolated cases.

E. Differences in Composition in Milk at Different Stages of Emptying the Gland.-Agriculturists have long been aware of the great rise in fat-content which occurs towards the end of milking. It is entirely unnecessary to quote numerous authors in support of this, but it may be of interest to mention a few. (The last portion of the milk is known as the 'strippings,' the first portion as 'first milk,' while the rest is termed ' middle milk.')

Jensen, in the course of experiments conducted for another purpose, gives the following figures:

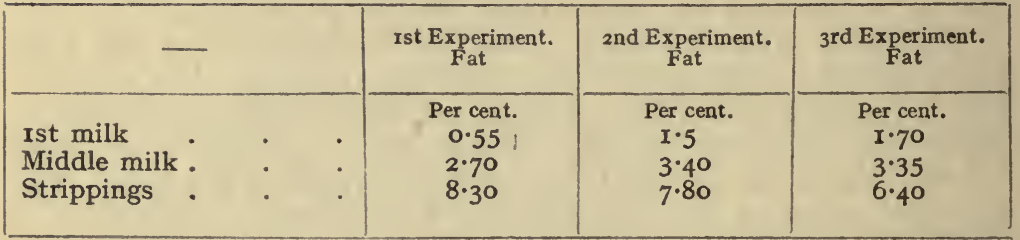

Eckles and Shaw (3) show that the fat alone is involved in the difference of composition obtained from twelve samples for six different cows :

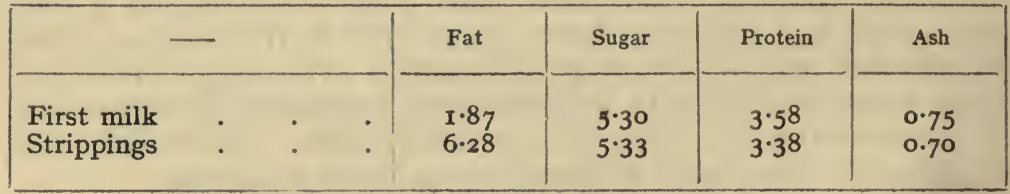

Similar results were obtained by Wellmann on calves. $\mathrm{He}$ inserted a tube in the side of the cesophagus of a calf and took samples of the milk obtained by the calf from the gland.

The calf did not appear to be inconvenienced by the tube after the first day or so. Four sets of estimations were made with varying intervals between the feeds. Alternate half-litres were 
taken as samples in each case. Wellmann obtained the following figures:

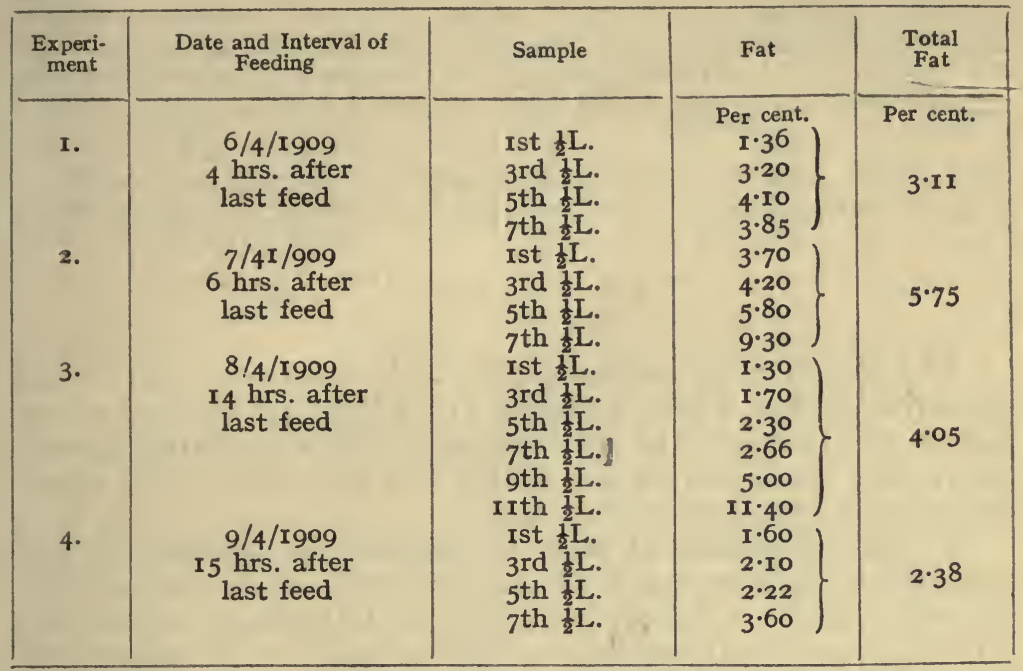

Further analyses were made of the first and last samples in Experiments 3 and 4 as follows:

\begin{tabular}{|c|c|c|c|c|c|c|c|c|}
\hline $\begin{array}{c}\text { Experi- } \\
\text { ment }\end{array}$ & Sample & Saliva & Water & Solids & Protein & Fat & Ash & $\begin{array}{l}\text { Solids } \\
\text { not Fat }\end{array}$ \\
\hline 4. & $\left\{\begin{array}{l}\text { Ist } \frac{1}{2} \mathrm{~L} . \\
\text { I Ith } \frac{1}{2} \mathrm{~L} . \\
\text { Ist } \frac{1}{2} \mathrm{~L} . \\
7 \text { th } \frac{1}{2} \mathrm{~L} .\end{array}\right.$ & $\begin{array}{c}\text { Per cent } \\
\text { II } \cdot 3 \\
7 \cdot 9\end{array}$ & $\begin{array}{l}\text { Per cent } \\
88 \cdot 7 \\
80 \cdot 65 \\
89 \cdot 66 \\
88 \cdot 92\end{array}$ & $\begin{array}{l}\text { Per cent. } \\
\text { I I. } 23 \\
\text { I } 9.35 \\
\text { IO } 34 \\
\text { I I } 08\end{array}$ & $\begin{array}{l}\text { Per cent } \\
3.22 \\
3.07 \\
2.93 \\
2.89\end{array}$ & $\begin{array}{r}\text { Per cent. } \\
I \cdot 45 \\
I I \cdot 45 \\
I \cdot 73 \\
3 \cdot 60\end{array}$ & $\begin{array}{c}\text { Per cent. } \\
- \\
0.53 \\
0.72 \\
0.78\end{array}$ & $\begin{array}{l}\text { Per cent } \\
9 \cdot 70 \\
7 \cdot 90 \\
7 \cdot .68 \\
7 \cdot 4^{8}\end{array}$ \\
\hline
\end{tabular}

Human Milk.-Söldner gives the following figures :

\begin{tabular}{|c|c|c|c|c|c|c|c|}
\hline Day after & Parturition & Portion & Milk & Nitrogen & Fat & Sugar & Ash \\
\hline \multirow{4}{*}{ I 7 th } & \multirow{3}{*}{ - } & Ist & In gms. & $\begin{array}{l}\text { Per cent. } \\
0.18\end{array}$ & $\begin{array}{l}\text { Per cent. } \\
\text { I } 7 r\end{array}$ & $\begin{array}{c}\text { Per cent. } \\
5.50\end{array}$ & $\begin{array}{c}\text { Per cent. } \\
0.46\end{array}$ \\
\hline & & 2nd & $33 \cdot 3$ & O.I 5 & 2.77 & 5.70 & 0.32 \\
\hline & & 3 rd & $57 \cdot 3$ & $0 \cdot 13$ & $4 \cdot 54$ & $5 \cdot 07$ & 0.28 \\
\hline & & Ist & $48 \cdot 3$ & 0.14 & I.94 & 6.82 & 0.22 \\
\hline \multirow{3}{*}{67 th } & \multirow[t]{3}{*}{. } & 2nd & $30 \cdot 3$ & 0.14 & 3.07 & $9 \cdot 92$ & 0.23 \\
\hline & & $3 \mathrm{rd}$ & $40 \cdot I$ & 0.17 & $4 \cdot 5^{8}$ & $5 \cdot 87$ & $0.2 I$ \\
\hline & & Ist & $39 \cdot 6$ & O.I 7 & $1 \cdot 23$ & $5 \cdot 97$ & 0.16 \\
\hline \multirow[t]{2}{*}{ 93rd } & \multirow[t]{3}{*}{ - } & 2nd & $37 \cdot 9$ & 0.14 & $2 \cdot 50$ & 6.03 & 0.24 \\
\hline & & 3rd & $4 I \cdot 9$ & 0.14 & $4 \cdot 6 I$ & $6 \cdot 43$ & 0.24 \\
\hline \multirow{3}{*}{ II 8 th } & & Ist & $30 \cdot 0$ & 0.17 & $2 \cdot 54$ & $5 \cdot 17$ & 0.23 \\
\hline & \multirow[t]{2}{*}{. } & 2nd & $22 \cdot 5$ & $0 \cdot 16$ & 3.98 & $5 \cdot 17$ & 0.25 \\
\hline & & 3 rd : & $3 x \cdot 8$ & 0.17 & $7 \cdot 20$ & $5 \cdot 17$ & 0.25 \\
\hline
\end{tabular}


Schlossmann also gives figures as below :

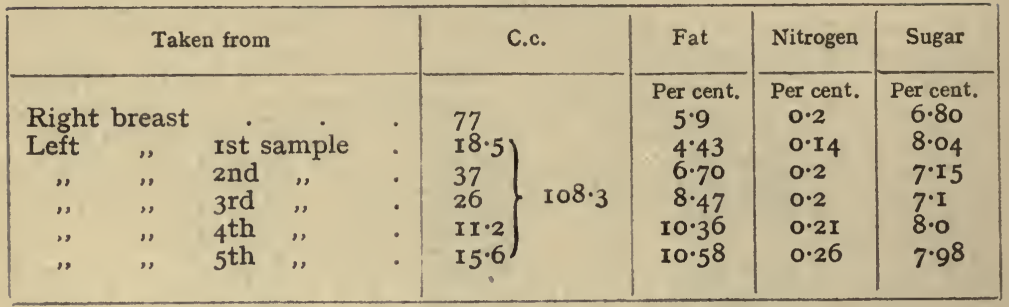

The figures need no comment. They show the futility of fat estimation unless a mixed sample of all the milk secreted at one time is obtained, and the great importance from a nutritive standpoint that the infant should obtain the end milk in the gland; otherwise it loses much of the fat.

F. The Composition of Milk in Relation to Amount of Milk Produced.-The constancy in the percentage of certain constituents of the milk, which has already been shown to be the case, suggests that no fixed amount of these substances is secreted in the twenty-four hours, but that the daily output varies roughly with the total milk produced. Special attention has been devoted to this point by Bamberg, who found that the differences in composition of human milk were due to the individual women, and did not arise from the secretion of varying amounts of milk. This holds good even with a greatly increased milk production.

Bamberg took samples before and after the child had been fed, so as to obtain a medium sample. The analysis of a number of samples showed that the percentage amount of protein, sugar, and total ash are all independent of the amount of milk produced. Bamberg also includes fat in the list, but this is not in accordance with results obtained by other observers. ${ }^{1}$

G. The Effect of Different Intervals of Milking.-The effect produced on the amount of milk given by a wet-nurse by altering the intervals of feeding, was studied by Helbich (2), and is dealt with in Chap. VIII.

Eckles and Shaw (3) carried out a study of the alterations in composition of cows' milk due to a change in the intervals of milking, and obtained the figures shown on p. 25.

It is usually believed that the low fat-content frequently found in the morning milk of cows is due to the longer interval elapsing between the evening and morning, than between the morning and evening milking. Eckles and Shaw's (3) figures, however, show considerable variations in fat-content where, as throughout these

${ }^{1} C p$. below, pp. $4^{2-43}$, on variation in fat-contents. 
studies, the length of interval is kept constant. This is referred to in considering the fat-content alone. ${ }^{1}$

Variations in the Fat-content during the Twenty-four Hours.The work of Eckles and Shaw (3) in relation to the intervals of milking shows that the fat-content was highest in the Io A.M. milking, and these authors state generally that the fat-content was usually highest about midday.

This appears to be also the case for the human species. Helbich (2) took careful analyses of mixed samples of milk obtained from a

Milking Twice Daily.

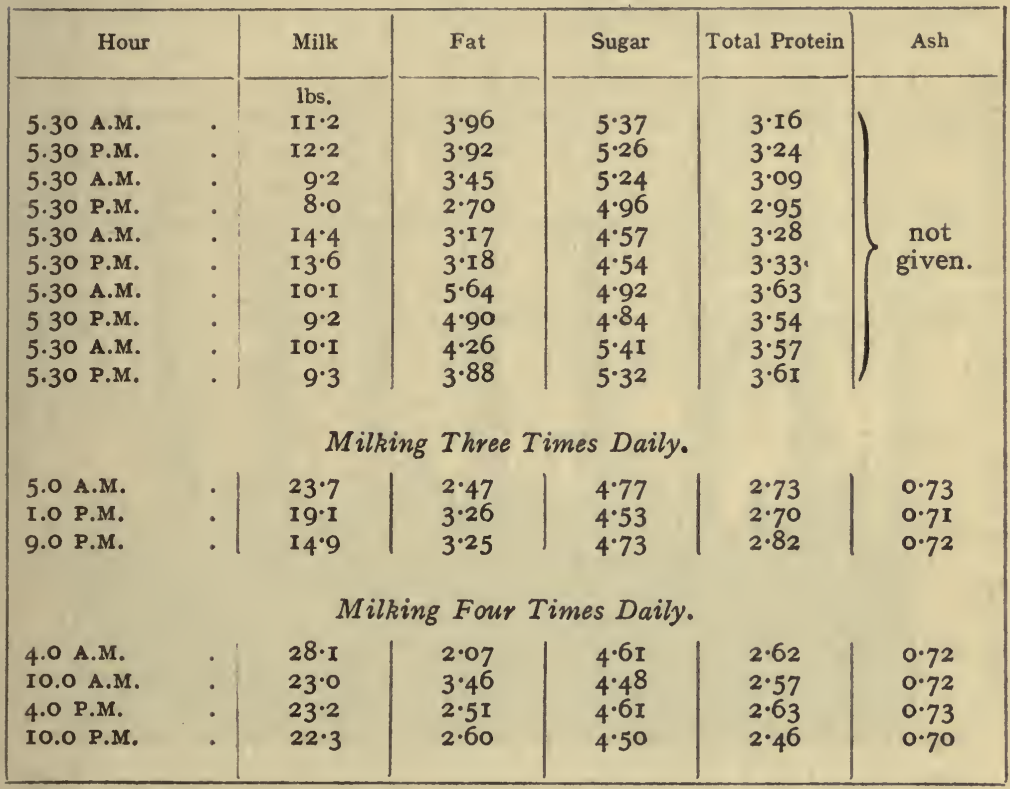

lactating woman at four-hourly intervals during the day, with an eight-hourly interval at night. The results of one of the sets of experiments are shown in the diagram given on p. 26 .

The fat-content was in each case highest at ro A.M. in this experiment, but in several of the others it was highest at 2 P.M., while the milk yield was greatest at the first feed-i.e. after an eight-hourly interval.

The results of these investigations are very interesting, but no explanation can as yet be given.

1 See p: 43, and also the figures on p; 23 obtained by Wellmann with different intervals of feeding: 
$H$. Notes on the Chemical Composition of Milk as Affected by possible Disease of the Gland.-The work of several of the investigators already quoted has shown that a deficiency of nutriment or other unsatisfactory condition of health may lead to a diminution either in the total milk supply or, under certain circumstances, to the derrease in certain constituents of the milk, usually, however, the former.

The work of several observers who were considering the possible

Diagram showing the Amount of Milk and the Fat-content of each Feed. on eight consecutive days. (After Helbich.) $)^{1}$

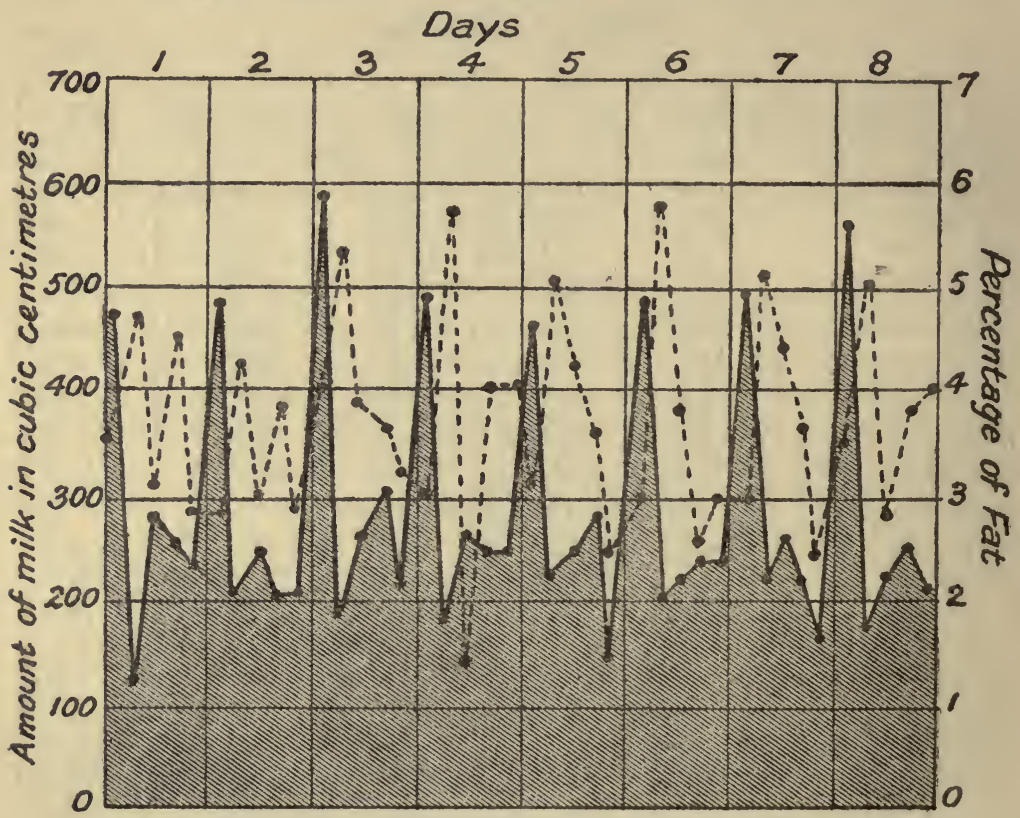

The shaded part represents the amount of milk given, and the dotted line the percentage of fat, on each occasion. The intervals were four-hourly during the day, with an eight-hour one at night:

disease of one or more quarters of the udder, shows that circumstances may arise in which the milk from one quarter may show a marked decrease in the amount of lactose accompanied by an increase in the nitrogen, and possibly alterations in the other constituents.

Thus Hewlett, Revis, and Villar in I9Io, in the course of investigations carried out upon the cellular content of milk, showed that in a number of cases where a high cell-content was obtained, there was an abnormally low content of lactose. This was sometimes accompanied by an increase in the total protein present. In 
several of such instances no disease or unsatisfactory condition of the quarter of the udder could be detected clinically.

Seel, in I9II, analysed the milk from thirty-four cows where one or more quarters of the udder were inflamed. He found certain differences between the milk of the abnormal quarter, and also showed that the milk, even from the apparently healthy quarters, showed similar differences. The chief alterations which occurred were a marked reduction in the amount of lactose present, as also in the chlorides. There was usually a reduction of fat in the affected quarter, while the fat-content of the healthy quarters of the same udder showed a tendency to rise. There was also a general rise in the albumen-content from all the quarters, and some rise in the phosphorus-content in the milk secreted by the apparently healthy parts.

In cases of cows definitely suffering from mastitis there appeared to be some rise in the total ash-content. No constant divergence between the normal and abnormal quarters of the udder was, however, obtained. Seel considers these differences sufficiently important to be of use in aiding diagnosis of disease of the udder.

The alterations in composition of the milk arising from definite disease of the gland is not pertinent to the present discussion. When disease is well established, it can usually be detected in the altered appearance of the milk. Such milk should not be used as a food, but should be discarded.

\section{REFERENCES IN Chapter II}

Albu-Neuberg, Physiol. u. Pathol. des Mineralstoffwechsels, 1906.

Allemann, Schweizer Milchzeit, r911, Nos.67,71, 72, 74. Also ref. Milchw Zentralb., r912, p. ro5.

BaIly and Murlin, 'The Energy Requirements of the New-born,' Proc. Soc. Exp. Biol., New York, I9I4, xi. I09; Amer. Journ. Biol., I915, lxxi. 526.

BAMBERG, "Zur Physiologie der Lactation, mit besonderer Berücksichtigung der chemischen Zusammensetzung der Frauenmilch milchreicher Frauen und des Einfluss der Menstruation,' Zeit f. Kinderh. I913, vi. 424.

BrRk, 'Beiträge zur Physiologie des neugeborenen Kindes,' Monats. $f$. Kinderh. I9I0, ix. 595 .

Bunge. Quoted by Albu-Neuberg, Phys. u. Path. des Minevalstoffwechsels, 1906.

CAMERER AND SöldNER. (I) 'Analysen der Frauenmilch, Kuhmilch u. Stutenmilch,' Zeit. f. Biol. 1896, xxxiii. 535. (2) 'Die Bestandtheile der Frauenmilch und Kuhmilch, Zeit. f. Biol. 1898, xxxvi. 277.

Capobianco, 'Sur la Pression osmotique du Colostrum et duLait,' Arch. ital. de Biol. I912, lviii. 177.

Carlyle and Woll, 'Studies in Milk Production,' Agric. Exp. Station, Wisconsin, 1903-4, Bull. 102.

Cathcart and Paton, "On the Production of Lactose in the Mammary Gland,' Journ. of Physiol. I9I I, xliii. I79.

DENNEMARK. See Engel and Dennemark.

DIENEs, "Beitrag zur Kenntnis des Stoffwechsels in der Schwangerschaft und der Lactation,' Biochem. Zeit. I913, lv. I24.

EckLES, "Jahreszeitliche Schwankungen des prozentischen Fettgehaltes in Kuhmilch,' Milchw. Zentralb. r909, v. 488. 
Eckles and Roscoe Shaw, (I) 'The Influence of the Stage of Lactation on the Composition and Properties of Milk,' Bureau of Animal Industry, Bull. I 55. (2) 'The Influence of Breed and Individuality on the Composition and Properties of Milk,' Bureau of Animal Industry, Bull. I 56. (3) 'Variations in the Properties and Composition of Milk from the individual Cow.' Bureau of Animal Industry, I913, Bull. I57.

Edelstern. See Langstein, Rott, and Edelstein.

ENGEL, 'Ueber einige Fragen der Frauenmilchsecretion, insbesondere über die Secretion des Milchfettes,' Arch. f. Kinderh, I910, liii. 24 I.

ENGel aND DENNEMARK, 'Ueber den Uebergang des Kolostrums in die Milch, insbesondere über das Verhalten der stickstofthaltigen Körper, Zeit. f. physiol. Chem. I9I2, lxxvi. 148. Also Ref. Milchw. Zentralb. I912, p. 532.

ENGEL aND MURschmauser, 'Zusammensetzung der Frauenmilch bei Nephritis,' Zeit. f. physio!. Chem. I9I I, Ixxiii. Ior. Also Ref. Milchw. Zentralb. I912, p. 438 .

ENGel and Plaut, Art und Menge des Fettes in der Nahrung stillender Frauen und die Wirkung seiner Entziehung auf das Milchfett,' Mün. Med. Wochensch. 1906, lv. II 58.

Fingerling, 'Beiträge zur Verwertung von Kalk-u.-Phosphorsäureverbindungen durch den tierischen Organismus,' Landwirtsch. Versuchsstat. IgI $I, \mathrm{lxxv}$. $\mathrm{I}$.

GrtTINGs. See Griffith and Gittings.

Griffith and Girtings, 'The Weight of Breast-fed Infants,' Arch. of Ped. May, I907.

HelBICH, (I) Bedarf es des physiologischen Reizes zur Anregung und Erhaltung der Laktation?' Monats. f. Kinderh. I9r I, x. 39r. (2) 'Die Variationen der Milchmenge und ihre Beziehungen zum Fettgehalt,' Monats. f. Kinderh. rgI r, x. 649.

HeuBner, 'Ueber Kuhmilch als Säuglingsnahrung,' Berl. klin. Wochensch. I 894, Xxxi. 84r.

Hewletr, Revis, and Villar, 'Cellular Elements in Milk, II,' Journ. of Hyg. Igro, x. 56

Jensen, 'De l'Origine des Catalases et Réductases du Lait de Vache,' Rev. gen. du Lait, r906, vi. 33, 56, 85 .

KIRCHNER, Handbuch der Milchwirtschaft, r891, p. 6.

KöNIG, Chemische Zusammensetzung der menschlichen Nahrungs- und Genussmittel, Berlin, I889.

KонN, 'Die Beeinflüssung der Zusammensetzung der Ziegenmilch durch Stallhaltung,' Deutsch. Tier. Wochensch. I913, xxi. 49.

Koning, 'Abweichungen in der Zusammensetzung der Milch,' Milchw. Zentralb. I9ro, vi. 675 .

LANGSTEIN-MEYER, Säuglingsernährung und Säuglingsstoffwechsel, Wiesbaden, I9IO.

Langstein, Rotr, and Edelstein, 'Der Nahrwert des Colostrums,' Zeit. f. Kinderh. orig. r913, vii. 210.

MARSH. See Meigs and Marsh.

Mergs, Milk Analysis and Infant Feeding, Philadelphia, 1885, pp. 34, 36.

Mrigs and Marsh, 'The Comparative Composition of Human Milk and of Cows' Milk,' Journ. of Biol. Chem. I913, xvi. 147.

Mellanby, 'The Metabolism of Lactating Women,' Proc. Roy. Soc. B., I9r 3 , Ixxxvi. 88.

MUNK AND UFFELMAN, Ernährung des gesunden $u$. kranken Menschens, Wien and Leipzig, r887, p. 269.

MurLIN, 'Qualitative Effects of Pregnancy on the Protein Metabolism of the Dog,' Amer. Journ. of Physiol. r9I I, xxviii. 422.

Murlin. See Baily and Murlin.

MurschHauser. See Engel and Murschhauser.

Paton. See Cathcart and Paton. 
Pfeiffer, ' roo Analysen von ausgebildeter menschlicher Milch.' Verhand. d. Gesellsch. f. Kinderh. I895, xi. I26.

Pres, 'Zur Physiologie des Neugeborenen. Ueber die Dauer, die Grösse und den Verlauf der physiologischen Abnahme,' Monats. f. Kinderh. I9Io, ix. 514 .

Plaut. See Engel and Plaut.

Pröscher. (See Summary of Chapter II.), 'Die Beziehung der Wachsthumsgeschwindigkeit des Säuglings zur Zusammensetzung der Milch bei verschiedenen Säugethiere,' Zeit. f. Physiol. Chem. I898, xxiv. 285.

Revis. See Hewlett, Revis, and Villar.

Rort. See Langstein, Rott, and Edelstein.

SASSENHAGEN, 'Ueber die biologische Eigenschaften der Kolostral- und Mastitis-Milch,' Arch. f. Kinderh. I9ro, liii. 281.

Schross, "Die Chemische Zusammensetzung der Frauenmilch auf Grund neuer Analysen,' Monats. f. Kinderh. orig. I910, ix. 636. Also Ref. Milchw. Zentralb. I912, pp. I72, 7 I9.

Schlossmann, 'Zur Frage der natürlichen Säuglingsernährung,'Arch. $f$. Kinderh. 1900, xxx. 288, and I902, xxxiii. 338.

SEEL, 'Vergleichende Untersuchungen der Milch bei Enterentzündungen der Kühe,' Zeit. Unters. Nahr.- u. Genussm. Igrı, xxi. I29. Also Ref. Milchw. Zentralb. r912, p. 217.

Shaw. See Eckles and Shaw.

Söldner, 'Analysen der Frauenmilch,' Zeit. f. Biol. I896, xxxiii. 43. See also Camerer and Söldner.

Trunz, 'Ueber die Mineralischen Bestandteile der Kuhmilch und ihre Schwan. kungen im Verlaufe einer Laktationsperiode,' Zeit. f. physiol. Chem. I $903-4$, xl. 263.

UFFELMANN. See Munk and Uffelmann.

Villar. See Hewlett, Revis, and Villar.

Wellmans, "Untersuchungen über die Zusammensetzung der durch das Kalb gesäugten Kuhmilch,' Milchw. Zentralb. I9II, vii. 304 .

Woll, 'The Relation of Food to the Production of Milk and Butter-fat by Dairy Cows,' Agric. Exp. Station, Wisconsin, r903-04, Bull. I16.

Worl. See Carlyle and Woll.

ZuckMAYer, "Ueber die Frauenmilch der ersten Laktationszeit und den Einfluss eines Kalk- und Phosphorsäure Zulage auf ihre Zusammensetzung,' Arch. f. d. ges. Physiol. I9r 4, clviii. 209. 


\section{SUMMARY OF CHAPTER III \\ ON THE ORGANIC CONSTITUENTS OF MILK}

I. The Proteins.- The amount of protein present in milk varies with different species. The protein-content of cows' milk is from two to two and a half times as great as that of human milk.

Two proteins (possibly three) are found in milk-caseinogen and lact-albumin. Small amounts of lacto-globulin are probably also found. The separation of caseinogen and lact-albumin from milk can be accomplished without difficulty. Caseinogen is precipitated by acetic acid, or by half saturation with ammonium sulphate, and by other reagents which do not affect the albumin. The separation of caseinogen and of a possible lacto-globulin is more difficult, since caseinogen partakes of the nature of a globulin, and tends therefore to be precipitated by the same reagents. Those investigators who have used chemical methods have differed in their views as to the presence of a true globulin, mainly on these grounds.

Later work undertaken with biological methods renders it fairly certain that this third protein is present in milk, although in small quantities. From a nutritional standpoint it can almost certainly be neglected, but biologically it is probably of considerable importance.

The term ' whey-protein' is frequently applied to the protein of milk apart from caseinogen. This term will include the lactalbumin and the globulin, since caseinogen alone is affected by the curdling with rennet.

The excess of protein in cows' milk over human milk is mainly due to the larger amount of caseinogen. Lact-albumin appears to be present in human milk in rather larger amount than in cows' milk, although the absolute amount is less than that of the caseinogen.

Caseinogen contains a good deal of phosphorus, and is combined also with calcium. Lact-albumin is stated to contain a higher percentage of sulphur than caseinogen. Slight differences in composition are obtained between the caseinogen of cows' milk and that of human milk.

There is no reason to suppose that the proteins of cows' milk 
differ sufficiently from those of human milk to be the detrimental factor in artificial feeding - at least after the early days of life. ${ }^{1}$

The Biological Relationship of the Milk-proteins. - The relationship of proteins is difficult, if not impossible, to establish by chemical methods, but the methods which have been discovered by workers on immunity enable much accurate information upon this point to be obtained.

Three methods have been used in establishing the relationship of the milk-proteins.

I. The precipitin method.

2. The method of complement deviation.

3. Anaphylactic methods.

The precipitin method is based upon the fact that if a foreign protein is injected into an animal, the organism reacts and forms a substance capable of precipitating further amounts of the original protein injected.

For instance, when milk or when solutions of the different proteins of milk or of blood are injected into an animal of another species the tissues of that animal respond to the invasion of the foreign substance by producing another substance which is capable of precipitating or throwing out of solution the invading or injected protein. The precipitation of the foreign substance renders it harmless to the organism, and is the method employed by the body to protect itself against the invasion of proteins which do not harmonise with those of the animal concerned. If the blood of an animal which has been injected with milk or milk proteins is collected, the serum thus obtained has the power, when mixed with a solution of the proteins which were injected, of precipitating these proteins. The reaction thus obtained is visible to the naked eye, and when the precipitate is formed it is known that special substances (precipitins) have been present in the serum. Moreover, it has been shown that these precipitins are capable not only of throwing out of solution the substances (antigens) as a result of whose injection the precipitin was formed, but they can also precipitate, at least partially, the proteins in the blood or milk of animals having a near relationship. In fact, the strength of the reaction affords proof of the nearness or otherwise of the inter-relationship of different classes of animals.

The application of this method has shown (I) that the proteins of human and cows' milk are biologically dissimilar, so that the milk proteins must be regarded as 'foreign' for the human infant ; (2) that in both cows' milk and human milk caseinogen and lactalbumin are separate bodies, since a caseinogen-anti-serum will not react fully with lact-albumin, and vice versa ; and (3) that the albumin of milk and the albumin of the blood are biologically identical, in both cows and women.

${ }^{1} C p$. Chap. VI: for work on this latter point: 
The principle of the method of complement deviation is somewhat elaborate and more sensitive. It has been used mainly by Bauer working alone and with Engel. These authors have confirmed and extended the results obtained by the precipitin methods. Further, it has been shown (I) that both human and cows' milk contain lacto-globulin, more being present in human milk than in cows' milk. Although present only in small amounts, this body acts as a powerful exciter of reactions when injected into the body.

(2) That the albumin and the globulin in the milk of both species are biologically identical with those bodies in the blood of that species.

(3) That albumin and globulin are more closely related to one another than to caseinogen.

(4) That caseinogen is, however, more closely related to globulin than to albumin.

Confirmatory although less extensive results have been obtained by the third method, that of anaphylaxis.

The Proteins of Colostrum.-The protein content of colostrum is higher than that of the later milk. The above methods have been used to show that the proteins of colostrum and of later milk are identical, and that the albumin and globulin of milk are identical with these bodies in the blood. There is some uncertainty as to whether the caseinogen or the whey-protein (albumin and globulin) predominates. Probably both are present in greater amount than in later milk, but the whey-protein is further increased relatively to the caseinogen.

The identity of the proteins of the blood and of whey, which has been shown by the above methods, raises important questions. It is difficult to avoid the conclusion that the proteins of whey are derived directly from the blood by filtration. Caseinogen, however, must be formed by the gland, either by a modification of the bloodprotein or it must be derived from the gland cells.

Bauereisen points out, and this has also been shown by other authors, that we must regard the colostral period as being the transition stage for the infant from that period when it was nourished directly by the blood of its mother, to the subsequent period when it depends upon its own alimentary tract for nourishment. The protein constituents of whey and of blood are practically identical : the method of administration constitutes the main difference. In the transition period, extending immediately after birth up to the end of the colostral period, that is, probably until about the fourth or fifth day (when the colostral characteristics cease to be marked), a different mechanism of absorption appears to be employed by nature. This method has for its object the tiding over of the infant from the intrauterine period to the period when it is dependent upon its own digestive juices, and it seems that the proteins of the colostrum can be absorbed by the infant from its alimentary canal without undergoing any marked changes, whereas later, after the 
colostral period, the proteins must be broken down, and the products thus obtained be absorbed by the infant. It is difficult to afford a direct proof of this statement, but indirect and convincing proof is afforded by the fact that the mechanism which is concerned with the production of immunity appears to be intimately attached to the protein constituents of the blood. It will be shown more fully in another chapter that these properties are present in the milk, presumably attached to the proteins, and that during the early days they can be transferred to the infant and can be found in the infant's circulation. Had the proteins been subjected to digestion along ordinary lines, the properties connected with immunity would almost certainly have been destroyed. Hence the assumption that these substances have been absorbed directly into the infant's body. This absorption does not, however, take place after the first few days of life.

2. On the Fats of Milk.-The percentage of fat in milk has been considered in the preceding chapter. The composition of fat in the milk of different species varies considerably, being composed of different fatty acids. It would not appear necessary to enter upon these differences in composition, since no evidence has been adduced which renders it of importance from the nutritional standpoint, and the investigations upon the subject are not numerous. The amount of fat given has been shown to vary considerably in the twenty-four hours.

3. Sugar.-The carbohydrate found in milk is lactose. This substance is present in greater amount in human milk than in cows' milk.

\section{CHAPTER III}

\section{THE ORGANIC CONSTITUENTS OF MILK}

IN the preceding chapter the different classes of chemical substances present in milk have been considered as a whole. This general aspect is, however, not sufficiently precise for the present purpose, and it will be necessary to devote attention to the individual organic and inorganic substances comprised in the general classes. The organic substances fall into the three main classes of food-stuffs-proteins, carbohydrates, and fats-and will be dealt with in the present chapter under these headings, the inorganic constituents being considered in the following chapter.

I. The Proteins and Nitrogen-containing Substances. - The discovery of methods for the separation of the proteins of blood and of egg-white were applied to milk by various observers. An account of the development of this line of research is given by 
Schryver, to whose book reference should be made for additional information.

It was found that such separation could be effected by the addition of salts, certain proteins falling out of solution with different salts or with a different concentration of the salt. The two main classes of protein obtained by this means are termed globulin and albumin, the globulin being the more easily precipitated.

The application of these methods to milk showed that at least two proteins were present in this fluid. Of these two bodies one was found to belong to the globulin and the other to the albumin group. These substances are known as caseinogen and lactalbumin. Caseinogen is not a true globulin, although it has certain of the properties of the substances of this class. It contains phosphorus, and is probably present in milk as caseinogenate of calcium. ${ }^{1}$

When milk is clotted by means of rennet, caseinogen becomes altered and is known as casein. Caseinogen can be removed from milk by various methods, leaving the rest of the protein in solution.

Hammarsten thought that a true globulin substance (lactoglobulin) was present in milk in addition to caseinogen, and other investigators have agreed with him. Sebelien (1885) found that a precipitation of lacto-globulin could be obtained when Hammarsten's method was used, but he gives reasons for doubting whether this can be regarded as a separate substance of globulin type. Halliburton was unable to obtain any evidence of the presence of lacto-globulin.

It is impossible here to consider fully the literature upon this question, but it seems likely that a third protein body (of globulin type) is present in milk; normally, however, it occurs in very small quantities. More recently the application of biological methods has appeared to confirm this view, and the amount of lacto-globulin in colostrum appears to be appreciable.

The small amounts of this substance which have been found in milk render it of comparatively minor importance from the nutritional standpoint, and it is very commonly classed with lact-albumin under the term ' whey-protein.' This term includes the proteins other than caseinogen, which alone of the proteins present in milk is coagulated by the action of rennet.

On the Amount of Caseinogen and Lact-albumin in Milk.The amount of caseinogen present in cows' milk is much greater than that in human milk, and the higher total protein content of cows' milk may be assigned to this fact.

Numerous estimations have been made of the caseinogen in both cows' and human milk, and the figures are given in text- 
books dealing with physiological chemistry. The estimations show a considerable degree of variation, but 3 per cent. appears to be an average round figure for the caseinogen of cows' milk, while for human milk I per cent. may be taken as a fair average. In both cases, however, considerable variations both above and below these figures are found.

The published estimations of lact-albumin are less numerous than those of caseinogen. The amounts of albumin in human and cows' milk do not differ very widely, although it is usually greater in human than in cows' milk. Broadly, in human milk there appears to be about 0.5 per cent. albumin, the tendency being for the figure to be higher. In cows' milk 0.5 per cent. is given by some observers as the figure for albumin, but, as a whole, it tends to be rather lower.

Lehmann stated that in human milk $29^{\circ} 4$ per cent. of the total protein was albumin, or 0.5 per cent. in the milk, while 70.6 per cent. of the total protein was caseinogen, which equals $I \cdot 2$ per cent. in the milk. In cows' milk 9 per cent. of the protein was albumin, or 0.3 per cent. in the milk, while 9I per cent. of the total protein was present in the form of caseinogen, or 3 per cent. in the original milk.

The relative proportions of caseinogen and albumin are given by Schlossmann, who, estimating the total nitrogen content of human milk and its distribution on the twenty-fifth day after parturition, assigned 35 per cent. of the nitrogen to the albumin and $4 \mathrm{I}$ per cent. to the caseinogen.

The same author, in another paper dealing with cows' milk, gives the percentage amount of the three proteins as follows:
Caseinogen
Lacto-globulin
$3 \cdot 185$ per cent.
0.I54 per cent.
Lact-albumin 0.374 per cent.

He found great resemblance between the albumin and the globulin, and considers that for nutritional purposes the latter may be neglected.

Sidler assigns 43 per cent. of the total nitrogen in human milk to caseinogen and 42 per cent. to the whey-proteins, the remainder being non-protein nitrogen.

The relatively high nitrogen content of milk during the colostral period has already been considered, and occurs both in human and cows' colostrum. There seems little doubt that colostrum contains a higher percentage of caseinogen and whey-proteins than later milk, but the evidence upon the amounts of these present at this period is not conclusive, wide variations being obtained by different authors. ${ }^{1}$

The work of Bauer $(I, 3)$ and of Bauereisen on biological lines renders it likely that there is also a relatively higher proportion of whey-proteins in colostrum than in later milk.

${ }^{1} \mathrm{Cp}$. also Edlefsen and Sebelien. 
The large amount of caseinogen present in cows' milk as compared with human milk, has, until the last few years, formed a prominent feature of the voluminous literature upon infant-feeding. It is probable that this has been the determining factor in the question of the dilution of cows' milk for infants, since average cows' milk contains less sugar and fat than human milk.

Any general discussion upon the digestibility of cows' caseinogen for infants would be beyond the scope of the present work, but a few points may be considered.

The numerous papers published both in America and Germany in recent years show no reason to suppose that the infant cannot digest cows' caseinogen. The so-called 'casein' curd of infants' stools has been shown not to be due to casein, but to the salts of fatty acids.

Finkelstein reviewed the factors which at various times have been regarded as the detrimental element in artificial feeding. He says : 'Improved clinical observations, the metabolism experiments, and the comparative researches upon the fat of cows' and human caseinogen in the infant's intestine have concordantly demonstrated that the disturbance must have its origin in other circumstances than in the harmful casein residue' (schädliche Kaseinrest).

In this country little research work has been carried out upon this matter. Cameron, however, reviewing the whole question, says, 'The disturbances of protein digestion are, generally speaking, secondary to fermentative dyspepsia. Although all that we know of the chemistry of infantile digestion and much accurate clinical observation point to this conclusion, it is often authoritatively taught that the protein of cows' milk is the most frequent source of trouble, and that which most commonly causes vomiting and colic,' and 'Evidence that diarrhœa and colic are caused by abnormal protein digestion is not forthcoming. In the stools of an infant fed upon cows' milk there are always present, in more or less abundance, white curd-like masses of soaps, formed by the combination of the fatty acids derived from the food with calcium and magnesium. These whitish curd-like masses of soap have much the appearance of undigested casein curds of milk, and their presence accounts for the frequent description of the stools by mothers and nurses as "undigested." ' Bauer (6) finds that true casein curds do sometimes occur in infants" stools, but he says that they occur only when the children are fed on raw cow's milk, disappearing when the milk given has been heated. This is also stated by Brennemann.

From the hygienic standpoint it would not appear necessary to deal any further with the differences in the protein content of human and cows' milk. In colostrum the whole question assumes an important biological aspect, which will be considered below.

The Chemical Composition of Caseinogen and Lact-albumin.Several investigations into the chemical composition both of 
caseinogen and of lact-albumin have been made, especially into that of the former body. In view, however, of the minimal nutritional importance of these minor differences, a detailed account will not be given.

The main differences between the two bodies lie in the content of sulphur and phosphorus. Caseinogen contains a considerable amount of phosphorus, which is perhaps somewhat higher in cows' than in human caseinogen. On the other hand, human caseinogen appears to contain more sulphur than cows' caseinogen. Lactalbumin of both species contains a higher proportion of sulphur than the caseinogen of the corresponding species.

The figures given by different observers, although showing slight divergences in the amounts of the elements found, are yet sufficiently concordant for it to be unnecessary to give many quotations. The figures below may be taken as giving the values sufficiently accurately:

\begin{tabular}{|c|c|c|c|c|}
\hline \multirow{2}{*}{ - } & \multicolumn{2}{|c|}{ Caseinogen } & \multicolumn{2}{|c|}{ Lact-albumin } \\
\hline & Cows' & Human & Cows' & Human \\
\hline $\begin{array}{l}\mathrm{C} \\
\mathrm{H} \\
\mathrm{N} \\
\mathrm{S} \\
\mathrm{P}\end{array}$ & $\begin{array}{c}\text { Per cent. } \\
52.69 \\
6.8 \mathrm{I} \\
15.65 \\
0.832 \\
0.877 \\
\text { After } \\
\text { Raudnitz }\end{array}$ & $\begin{array}{c}\text { Per cent. } \\
52.24 \\
7.32 \\
14.97 \\
1.12 \\
0.68 \\
\text { After } \\
\text { Engel (3) }\end{array}$ & $\begin{array}{c}\text { Per cent. } \\
52 \cdot 19 \\
7 \cdot 18 \\
15 \cdot 77 \\
1 \cdot 73 \\
- \\
\text { After } \\
\text { Sebelien }\end{array}$ & $\begin{array}{c}\text { Per cent. } \\
47.91 \\
7.00 \\
14.74 \\
1.65 \\
\text { After } \\
\text { Engel (3) }\end{array}$ \\
\hline
\end{tabular}

The results obtained by Langstein and Edelstein should also be compared.

The amount of calcium present in combination with caseinogen is variously given, and a general figure is difficult to obtain from the literature. Raudnitz appears to put the figure at something over I per cent. of calcium oxide $(\mathrm{CaO})$ in caseinogen, but his remarks are not very precise.

There is no doubt that a large part of the total calcium present in milk is in combination with caseinogen.

The differentiation of cows' milk and human milk assumes a practical value in foreign hospitals where human milk is purchased at a high rate for the feeding of sickly infants. There is evidently a great temptation on the part of the nursing woman to add a little cows' milk to her own and sell at the higher rate.

Bauer (4) and Bacchi have independently shown that the milks can be differentiated by a simple colour reaction.

On the Interrelationship between the Proteins of the Milk and their Relationship to those of the Blood. - The researches 
into the chemical composition of the milk proteins were made for the most part in the last thirty years of the nineteenth century. Several observers ( $c p$. Eugling and Menozzi and Musso) believed, as a result of chemical analysis and methods of precipitation, that the albumin of milk and of blood were identical. A little later the idea seems to have been abandoned with some emphasis, probably owing to the rise of the physico-chemical school of physiologists. The difficulties of establishing the identity of any two proteins by purely chemical means are manifestly immense, and the relationship of the proteins in milk and blood has been investigated in the present century by other methods. These methods have been evolved by workers on immunity, and have led to the discovery of most interesting facts concerning the proteins of milk.

These facts are of importance in relation to the transference of immunity by suckling from mother to child, and will be considered in some detail.

The first step was made by Bordet (I899), who showed that if an animal was injected with milk of another species, the serum of this animal, when withdrawn from the body, was found to have acquired the property of precipitating the milk of the species which had been used for injecting. Such a serum is known as a lactoserum, and the reaction as the 'precipitin' reaction. Practically, the phenomenon means that when a foreign protein is injected into the body, a reaction occurs on the part of the organism which enables it to throw this protein out of solution should occasion arise. This occasion is made to arise artificially by removing the serum and mixing it in a test-tube with some of the protein originally used. The substances which are capable of giving rise to this reaction on the part of the body are known as ' antigens.' The reaction is not absolutely specific for the one species, but may occur with the protein of a closely related species. For the present purpose the complication of allied species need not be considered, since there is no question that the proteins of the bovine and of the human species are 'foreign' to one another. This specificity of human and cows' milk was shown by Rosenau and Anderson, using the method of anaphylaxis, and has been confirmed by numerous investigators.

Hamburger (I9OI) showed that an anti-serum for ox blood would also precipitate milk, and that a lacto-serum for cows' milk would produce a precipitation with ox blood-serum. These observations showed a very close relationship between the proteins of blood and those of milk. Hamburger carried his observations yet further, and found that the proteins of milk could be differentiated; a lactoserum prepared by the injection of caseinogen will precipitate caseinogen, but not lact-albumin, and vice versa. All the results were not in complete accordance but they were sufficiently definite to show that, biologically, caseinogen and lact-albumin 
are separate bodies. Bauer (I) believes that the partial discrepancies in Hamburger's work can be attributed to the method employed.

Hamburger's work was confirmed by Schlossmann and Moro, who showed, by means of the precipitin reaction, that the proteins of cows' milk must be regarded as 'foreign ' to those of the human species, and that the caseinogen and lact-albumin in the milk of each species are distinct bodies. They found, further, that lact-albumin was biologically identical with the albumin of the blood. Small amounts of lacto-globulin were obtained from cows' milk, but Schlossmann ( $I$ ) considers that from the nutritional standpoint this body may be safely neglected. The amount is very small, and it resembles albumin so closely as not to require separate consideration for infant feeding. Schlossmann $(I, 2)$ considers that as the albumins of blood and of milk are identical substances, the albumin in milk can readily be, and probably is, absorbed directly by the infant in the early days of life. ${ }^{1}$

A few years later (I908) Bauer (2) showed that much finer differentiation of proteins could be obtained by using the method of ' complement deviation.' This method has been mainly used by him in his subsequent extensive investigations in this direction.

The work of Bauer (5) and of his pupil Kollmeyer shows that caseinogen must be placed biologically in a class by itself.

The differentiation between the caseinogen and the wheyprotein of the same species was more marked than that between the caseinogen of the cow and of the goat. On the other hand, lact-albumin anti-sera, both of cows' milk and of human milk, reacted with the serum-protein of the corresponding species, and seemed to show the biological identity of the whey- and serum-proteins.

Using this method, which is more sensitive than the precipitin method, Bauer (2) and (3) obtained no reaction between a lactoserum obtained by the injection of cows' milk, and ox-serum. He attributes this to the large amount of casein present, which body does not react with blood-serum.

Bauereisen, using the precipitin method, showed the biological identity between the whey-protein and the proteins of the blood, and placed caseinogen somewhat apart from these in its biological properties. He considers that the whey-proteins of colostrum can be absorbed directly by the infant and form part of the blood protein.

Bauer and Engel (I9II) undertook further comprehensive investigations into the relationship of the milk-proteins, using the method of complement deviation.

The caseinogen was separated out first by the acetic acid method of Engel (I). This was filtered off and the filtrate subjected to half saturation with ammonium sulphate. This treatment precipitated 
a further amount of protein (globulin), which the observers believe is a true lacto-globulin. The albumin remaining in the fluid was obtained either by the addition of acetic acid or by complete saturation with ammonium sulphate. The authors found that, contrary to cows' milk, in human milk the yield of globulin was much greater than that of albumin; in fact the amount of this last was so small that it was impossible to obtain a suitable solution for experimentation.

The results of these authors leave no doubt that these three proteins in cows' milk are biologically distinct bodies, of which globulin, although present in smaller amounts, appears to be the stronger antigen, producing a stronger anti-serum. At the same time there is a clear relationship between the three proteins; albumin and globulin are more nearly connected to one another than to caseinogen, and caseinogen resembles globulin more than it does albumin. This applies to both varieties of milk, with the reservation that human albumin was not used.

The following tables show:

I. The relation of the three proteins, and

2. The potency of the globulin in producing anti-sera, although the actual amount of globulin in the whey of cows' milk is less than the albumin.

\section{TABLE I}

Showing the hamolysis obtained by the action of O'I c.c. of cores' caseinogen anti-serum with 0.5 per cent. protein solution of the following substances (complement deviation method used).

Cows' Milk

\begin{tabular}{|c|c|c|c|c|}
\hline Dilution & Caseinogen & Globulin & Albumin & Whey \\
\hline $\begin{array}{l}\text { Per cent. } \\
\text { I/4 } \\
\text { I } / 8 \\
\text { I } / I 6 \\
I / 32 \\
I / 64 \\
I / I 28 \\
I / 256 \\
I / 5 I 2 \\
I / I 024 \\
I / 2048 \\
0\end{array}$ & $\begin{array}{c}0 \\
0 \\
o \\
0 \\
0 \\
0 \\
0 \\
\text { moderate } \\
\text { almost } \\
\text { complete } \\
\text { complete } \\
\text {,, }\end{array}$ & $\begin{array}{c}\text { o } \\
\text { o } \\
? \\
? \\
\text { trace } \\
\text { slight } \\
\text { moderate } \\
\text { well-marked } \\
\text { complete } \\
\text { ", }\end{array}$ & $\begin{array}{c}\text { o } \\
\text { o } \\
\text { ? } \\
\text { moderate } \\
\text { well-marked } \\
\text { complete } \\
\text { ", } \\
\text { ", } \\
\text { ", } \\
\text {," }\end{array}$ & $\begin{array}{c}0 \\
o \\
o \\
o \\
\text { trace } \\
\text { moderate } \\
\text { almost } \\
\text { complete } \\
\text { complete } \\
\text { ", } \\
\text { ", }\end{array}$ \\
\hline
\end{tabular}




\section{TABLE II}

Showing the hamolysis obtained by the action of O.I c.c. of cows' whey anti-serum on a 0.32 per cent. protein solution of

\section{Cows' Milk}

\begin{tabular}{|c|c|c|c|c|}
\hline Dilution & Whey & Globulin & Albumin & Caseinogen \\
\hline $\begin{array}{l}\quad I \\
I / 2 \\
I / 4 \\
I / 8 \\
I / I 6 \\
I / 32 \\
I / 64 \\
I / I 28 \\
I / 256 \\
I / 512 \\
I / 1024 \\
I / 2048 \\
I / 4096 \\
0\end{array}$ & $\begin{array}{c}- \\
o \\
o \\
0 \\
o \\
0 \\
0 \\
o \\
o \\
\text { slight } \\
\text { well-marked } \\
\text { complete } \\
\text { ", }\end{array}$ & $\begin{array}{c}- \\
o \\
o \\
o \\
o \\
o \\
0 \\
o \\
\text { o } \\
\text { moderate } \\
\text { complete } \\
\text {," } \\
\text {," }\end{array}$ & $\begin{array}{c}\overline{\text { o }} \\
\text { o } \\
0 \\
0 \\
0 \\
\text { o } \\
? \\
? \\
\text { moderate } \\
\text { well-marked } \\
\text { complete } \\
\text {," } \\
\text {, }\end{array}$ & $\begin{array}{c}\text { o } \\
\text { o } \\
\text { o } \\
\text { slight } \\
\text { moderate } \\
\text { well-marked } \\
\text { almost } \\
\text { complete } \\
\text { complete } \\
\text { ", } \\
\text { ", } \\
\text { ", } \\
\text { ", } \\
\text { ", }\end{array}$ \\
\hline
\end{tabular}

The high power of globulin to form anti-sera is of considerable interest in view of the fact that the anti-toxins in the serum are known to be attached to the globulin fraction. Bauer and Engel showed further that the albumin and globulin obtained from milk and from serum are respectively biologically identical.

Caseinogen is found in no other tissue-fluid, and stands apparently in a class by itself.

The differentiation of the proteins of milk have been investigated by means of anaphylactic methods by Besredka and Heuner. Besredka found that with whole milk the toxic constituent was the caseinogen, and that sensitivity was not always produced by injecting whey. Heuner, working under Bauer, confirmed the differentiation of the three proteins, and also the relationships already mentioned.

The Proteins of Colostrum.-Fully as much work has been carried out upon the biological relation of the proteins of colostrum, as upon those of later milk.

Kollmeyer, Bauereisen, and Bauer and Engel, using the methods above described, have all reached the same fundamental conclusion, namely, that the proteins of colostrum are biologically identical with those of later milk, and the whey-proteins of colostrum, as of later milk, are biologically indistinguishable from those of the serum.

Bauereisen believed that the anti-serum obtained by the injection 
of colostrum was essentially a whey-protein anti-serum, owing to the predominance in the colostrum of these proteins.

Kollmeyer and Bauer and Engel all agree as to the marked relative increase in the albumin-globulin bodies in colostrum as compared with later milk.

Langer (I907) obtained a more powerful anti-serum by injecting colostrum than by using later milk. He does not appear to have distinguished between the different antigens in colostrum, but his observations can be explained by the work of the above authors. König's figures for the protein content of colostrum, given on p. I6, are of much interest in connection with the investigations just quoted.

The value of colostrum from the nutritive standpoint has already been considered, and its importance in the question of immunity will be considered in Chap. VI.

Some experiments have also been carried out in order to ascertain the effect (if any) of heat upon the power of the milk protein to produce anti-sera and anaphylaxis. These are dealt with in Chap. XIV.

Wroblewski described another protein in cows' milk which he termed 'opalisin.' The presence of this body has, however, not been confirmed, and is denied by Eufinger.

Meigs and Marsh described a further nitrogenous body in milk, but this also has not been confirmed.

Some non-protein nitrogen undoubtedly occurs in milk, and its nature has been studied by several observers. Rietschel believes that urea accounts for the bulk of the non-protein nitrogen.

An isolated observation and of interest has been made by Engel and Murschhauser $(I, 2)$. These observers found that urea appeared in the milk of an eclamptic woman. They subsequently succeeded in obtaining evidence of a rise of non-protein nitrogen in the milk of a healthy woman, who was fed on considerable amounts of urea. They suggest that the mammary gland may have a slight excretory function when waste material is present in excess in the blood.

Fat.-It has been shown in the preceding pages that no precise figure can be given for the fat content of milk. Even when a sample of the whole milk obtained at one time is taken, the figure holds only for that particular occasion.

The work both of Hunnaeus and of Aurnhammer on human milk shows that considerable individual differences in the average amount of fat given in twenty-four hours may occur. Hunnaeus says the figure varies from 4 per cent. to 5 per cent. for the twentyfour hours, and Aurnhammer gives 4.5 per cent. to 5.5 per cent., but these are averages only, the actual figures showing a greater range.

Aurnhammer finds that the total amount of fat given in the twenty-four hours by each individual is fairly constant, and that it does not increase with an increase in the amount of milk given. 
Engel (Igro) believes that an inverse ratio exists between the amount of milk and the amount of fat. He made estimations of the fat in the milk of a number of wet-nurses whose total output of milk was known. Some of the data given bear out Engel's contention, but any very general deduction upon the relationship of the amount of milk to the fat content is hardly justifiable from his figures.

Helbich (IgII), who carried out careful investigations upon the fat content in relation to the total amount of milk given at each feed, was unable to trace any relationship between the two. The diagram on p. 26 shows the results of one set of observations made by him, and the others are on the same lines. The fat content was usually lowest in the morning, rising considerably at one of the next feeds. In the diagram the ro A.M. feed gave the highest percentage of fat, but this was not found in all the experiments.

This is in general harmony with the observation of Eckles and Shaw on the variation in fat content of cores' milk due to different intervals of milking. They state that the milk about midday usually had the highest fat content. ${ }^{1}$

The average fat content of human milk is higher than that of cows' milk, although in the case of the cow variations due to breed, \&c., may raise the level to that of human milk. Great individual variations also occur in both cases, as well as differences from other causes dealt with on pp. 22-26.

A great deal of work has been done on the composition of the fat of both human and cows' milk, but there is no evidence to show that such differences in composition as may occur have any bearing upon the health of either infants or adults, and the subject will not be considered here.

Reference may be made to the work of Arnold on human fat, where references to the literature upon this point, both for human and cows' milk, are also given. Eckles and Shaw give elaborate data upon the fat of cows' milk, with literature.

Attempts have been made to produce an increased fat content in the milk by feeding on fat. Engel and Plaut found that increasing the fat in the food, even considerably, did not enable any appreciable increase in the fat content to be detected in the milk of a normally-nourished woman. If the intake of fat is below the amount required for the usual metabolism, the amount of fat in the milk is reduced. ${ }^{2}$ These results are in agreement with those obtained in numerous investigations upon other constituents of milk. Similar work relating to the sugar content is given on the next page, and that relating to the inorganic constituents in the next chapter.

The experiments conducted by Woll on the amount of butterfat produced by cows in relation to their food are of great interest. Cows fed on a food which is below the minimal physiological require- 
ments give a low amount of milk, the quantity rising again when the physiological requirements are fulfilled. Above this, however, although high feeding may produce an increase both in the amount of milk and in the butter-fat, this rise is in no way proportional to the increased amount of food. This has been considered in greater detail on pp. 20,21 .

The presence of lecithin in milk has been investigated by several authors, with positive results. Stocklasa says that I litre of cows' milk contains from 0.90 to $I \cdot I 3$ gramme of lecithin, and the same amount of human milk contains from $x^{\prime} 70$ to $I \cdot 86$ gramme. ${ }^{1}$

There is no evidence as to the nutritional value of lecithin in milk.

Sugar.-The figures already quoted for the sugar content of cows' milk and human milk hardly require amplifying.

In spite of the use of different methods of estimation of the sugar, fairly concordant results have been obtained.

There seems no doubt that the sugar content of cows' milk is much below that of human milk. Lust, using the colorimetric method, has confirmed the figures for human milk; and Antenrieth and Funk, using the same method, found the average amount to be $7 \cdot x$ per cent.

The sugar content appears to be hardly affected by the period of lactation or by the composition of the dietary, so long as the dietary is sufficient for the needs of the organism.

The experiments of Cathcart and Paton, already quoted, show that when the body is artificially depleted of glucose, the milk supply falls, and also the sugar content.

Lust endeavoured to raise the lactose content of the milk by feeding nursing women with large amounts of dextrose and other sugars. In a few cases a very slight rise was noted, which might perhaps be attributed to the additional amount taken. No distinct alteration in the content of lactose was, however, obtained.

This absence of effect due to increasing the amount in the food is in harmony with the work on other constituents considered later under the several headings.

It appears from the work of Porcher, Cathcart and Paton, and others, that the sugar in the milk is synthesised in the gland itself from the carbohydrate present in the blood. This subject is, however, beyond the scope of the present work.

\section{REFERENCES IN CHAPTER III}

\section{The Organic Constituents of Milk}

Anderson. See Rosenau and Anderson.

AUtenRIETh AND FUnK, 'Ueber eine kolorimetrische Bestimmung des Milchzuckers im Harn und in der Milch,' Münch. med. Wochensch. I9II, lix. I7I 7 .

${ }^{1} \mathrm{Cp}$. also Schmidt-Mülheim and Bordas and Racgkowsky. 
ARnold, 'Frauenmilchfett,' Zeit. Unters. Nahr-u. Genussm. 1912, xxiii. 433. Ref. Milchw. Zentralb. r913, p. 45.

AUrnhammer, 'Ueber die Beziehung zwischen Milchproduktion und Fettgehalt der Milch,'Arch. $f$. Kinderh. 1909, li. I6r.

Bauer. (I) 'Die Biologie der Milch,' Evgeb. d. inn. Med., v. I83. (2) 'Ueber biologische Milchdifferenzierung,' Münch. med. Wochensch. 1908, lv. 847. (3) 'Die Biologie des Kolostrums,' Verh. d. Gesellsch. f. Kinderh. 1909. Deutsch. med. Wochensch. 1909, No. 38. (4)'Ueber eine Reaktion zur Unterscheidung von Kuh- und Frauenmilch,' Monats. $f$. Kinderh. I 912 , orig. xi. 474. (5) 'Ueber den Artcharakter der Milcheiweisskörper,' Berl. klin. Wochensch. I910, No. x8. (6) 'Ueber den Befund von Kuhmilchkasein in Säuglingsstählen,' Monats. f. Kinderh. Orig. II., x. I9r.

BACCHI, "Reazioni cromatiche differenziati fra Latte di Donna e Latte di Vacca,' Liguria Med. Genova, I913, vii. 25.

BAUER AND ENGEL, 'Ueber die chemische und biologische Differenzierung der drei Eiweisskörper in der Kuh- und Frauen-milch,'Biochem. Zeit. I9II, xxxi. 60 .

BAutreisen, 'Die Beziehungen zwischen dem Eiweiss der Frauenmilch und dem Serumeiweiss von Mutter und Kind,' Arch.f. Gyn. x910, xc. 349.

BesRedka, 'De l'Anaphylaxie lactique (sixième mémoire),' Ann. de l'Inst. Pasteur, r909, xxiii. I66.

BORDAS AND RACGKOWSKY, 'Influence de l'âge du Lait sur l'Erreur en Acide phosphorique,' La Semaine Méd. I902, xxii. 277.

Bordrt, 'Le Mécanisme de l'Agglutination,'Ann. de l'Inst. Pasteur, I899, xiii. 225.

Brennemann, ' Boiled versus Raw Milk,' Journ. of Amer. Med. Assoc. 1913, lx. 575.

CAMERON, Diet and Disease in Infancy, Chapter IX. Churchill, London, I9I5.

Cathcart and Paton, ' On the Mode of Production of Lactose in the Mammary Gland,' Journ. of Physiol. I9I I, xlii. I79.

ECKLES AND SHAW, "The Influence of Breed and Individuality on the Composition and Properties of Milk,' Bureau of Animal Industry, Bull. ${ }_{56} 6$.

Edelstern. See Langstein and Edelstein.

EDIEFSEN, 'Ueber die Hauptunterschiede zwischen Kuhmilch und Frauenmilch,' Münch. med. Wochensch. r9or, xlviii. 7 .

ENGEL. (I) 'Vergleichende Untersuchung über den Verhalt der Frauenmilch zu Säure und Lab,' Biochem. Zeit. I908, xiii. 89. (2) 'Ueber einige Fragen der Frauenmilchsecretion insbesondere über die Secretion des Milchfettes,' Arch. f. Kinderh. 1910, liii. 24I. (3) 'Die Frauenmilch,' Sommerfeld's Handbuch der Milchkunde, p. 787.

ENGEL. See Bauer and Engel.

ENGel and MURSchHauser. (I) 'Zusammensetzung der Frauenmilch bei Nephritis,' Zeit.f. physiol. Chem. I9I r, lxxiii. Ior; Ref. Milchw. Zentralb. I9I2, p. 438. (2) "Ueber den Einfluss des Harnstoffs auf das Blut und die Milch stillender Frauen,' Zeit. $f$. physiol. Chem. I9I I, Ixxiii. I3I.

Engel and Plaur, 'Art und Menge des Fettes in der Nahrung stillender Frauen und die Wirkung seiner Entziehung auf das Milchfett,' Münch. med. Wochensch. 1906, lv. I 58 .

Eufinger. Quoted by Bauer and Engel, Biochem. Zeit. I9II, xxxi. 6r.

Eugling. Quoted by Sebelien in Zeit f. physiol. Chem. 1885, ix. 445 ; Forschungen auf dem Gebiete der Viehhaltung, I.

Finkelstern, Lehrbuch der Säuglingskrankheiten, Part II. Division 2, p. 23I. Berlin, I9I I.

Funk. See Antenrieth and Funk.

Halliburton, 'The Proteids of Milk,' Journ. of Physiol. 189o, xi. 448.

HAMBURGER, 'Biologisches über die Eiweisskörper der Kuhmilch und über Säuglingsernährung;' Wiener Klin. Wochensch. 1901, p. 1202. 
Hammarsten. (I) 'Zur Frage, ob das Casein ein einheitlicher Stoff sei,' Zeit. f. physiol. Chem. 1882-3, vii. 227. (2) 'Ueber die Anwendbarkeit des Magnesiumsulfates zur Trennung und quantitativen Bestimmung von Serumalbumin und Globulinen,' Zeit. f. physiol. Chem. 1883-4, viii. 467 .

HelBICH, 'Die Variationen der Milchmenge und ihre Beziehungen zum Fettgehalt,' Monats. f. Kinderh. I9I I, x. 649.

Hempel, 'Die Milchuntersuchungen Prof. Dr. Julius Lehmann's,' Pflüger's Arch. 1894, lvi. 558.

HEUNER, 'Untersuchungen zur Biologie der Milch mittels der anaphylaktischen Methode,' Arch. f. Kinderh. I9I I, lvi. 358.

HunNaEus, 'Ueber den Kalkgehalt der Frauenmilch,' Biochem. Zeit. 1909, xxii. 442 .

KolLMEYER, ' Ueber die biologische Differenzierung von Milch und Milcheiweisskörper,' Zeit. f. Biol. I9Io, liv. 64.

LANGER, 'Zur Resorption des Colostrums,' Verh. $d$ Gesellsch. f. Kinderh. Dresden, 1907, p. 70.

LANGSTEIN AND EDELSTEIN, 'Ueber die Einheitlichkeit des Frauenmilchkaseins,' Jahrb. f. Kinderh. I910, lxxii. Ergänzungsheft, p. I6.

Lehmann. See Hempel.

LUST, 'Ueber den Milchzucker der Frauenmilch,' Monats. f. Kinderh. I913, xi. 236.

MARSH. See Meigs and Marsh.

MEIGS AND MARSH, 'The Comparative Composition of Human Milk and of Cows' Milk,' Journ. of Biol. Chem. 1913, xvi. 147.

Mrnozzi and Musso. Quoted by Sebelien in Zeit. f. physiol. Chem. x885, ix. 445: Forschungen auf dem Gebiete der Viehhaltung, i. Part 3.

Moro. See Schlossmann and Moro.

MURSCHHAUSER. See Engel and Murschhauser.

Musso. See Menozzi and Muso.

W. A. OsBorne, 'Caseinogen and its Salts,' Journ. of Physiol. I9oI-2, xxvii. 398.

Paton. See Cathcart and Paton.

Plaut. See Engel and Plaut.

Porcher, 'Ueber die Entstehung des Milchzuckers,' Biochem. Zeit. Igro, xxiii. 370.

RACGKOWSKY. See Bordas and Racgkowsky.

RAUDNITZ, 'Allgemeine Chemie der Milch,' Sommerfeld's Handbuch der Milchkunde, p. 165 .

RIETSCHEL, 'Uber den Reststickstoff der Frauenmilch,' Jahrb. f. Kinderh. 1906, lxiv. I25.

Rosenau AND ANDERson, 'Studies upon the Phenomenon of Anaphylaxis,' Lab. of Hyg. Washington, Bulls. 36,45 , and 50.

Schlossmann. (I) 'Ueber die Eiweissstoffe der Milch und die Methode ihrer Trennung,' Zeit. f. physiol. Chem. 1896, xxii. 197. (2) 'Ueber einige bedeutungsvolle Unterschiede zwischen Frauenmilch und Kuhmilch, 1898.'

Schlossmann and Moro, ' Zur Kenntnis der Arteigenheit der verschiedene Eiweisskörper der Milch,' Münch. med. Wochensch. 1903, xiv. 597.

SchMIDT-MÜLHEIM, 'Ueber das Vorkommen von Cholesterin in der Kuhmilch,' Pflüger's Arch. 1883, xxx. 379.

Schryver, 'The General Characters of the Proteins,' pp. 8-10. Series of Monographs on Biochemistry. London, I909.

SEbELIEN. (I) 'Beitrag zur Kenntnis der Eiweisskörper der Kuhmilch, Zeit. f. physiol. Chem. 1885, ix. 445. (2) 'Studien über die analytische Bestimmungsweise der Eiweisskörper mit besonderer Rücksicht auf die Milch,' Zeit.f. physiol. Chem. I889, xiii. I35.

SIDLER, 'Untersuchungen über die gebräuchlichsten in der Schweiz fabrikmässig hergestellten Milchpräparate, etc.,' Arch. f. Hyg. 1903, xlvii. 327. 
SHaw. See Eckles and Shaw.

Stocklasa, 'Zur Kenntnis des Phosphors in der Frauen- und Kuhmilch,' Zeit $f$. physiol. Chem. 1897, xxiii. 343 .

Woll, 'Relation of Food to the Production of Milk and Butter-fat by Dairy Cows,' Agric. Exp. Station, Wisconsin, 1903, Bull. Ir6.

WroblewsKI, 'Ein neuer eiweissartiger Bestandteil der Milch,' Zeit. f. physiol. Chem. 1898-9, xxvi. 308. 


\section{SUMMARY OF CHAPTER IV}

\section{ON THE INORGANIC CONSTITUENTS OF MILK}

THE inorganic constituents of milk have formed the subject of considerable investigation. As a whole, it appears that the amount of the various salts which are present in cows' milk is greater than the amount of the corresponding substance in human milk. The chief exception has been shown to be iron. Recent investigations conducted upon the amount of this mineral present in the milk of women and of cows, leave little room for doubt that the iron content of human milk is from two to three times as great as that of cows' milk.

The calcium content of milk has attracted much attention because it was supposed that a deficiency of calcium in the milk might be the cause of rickets. Although this possibility cannot be absolutely set aside, the numerous investigations which have been carried out show that there is no definite relationship between the occurrence of rickets and the amount of calcium which is found in the mother's milk in the case of breast-fed children.

Numerous experiments have been carried out with a view to determining whether it was possible to increase the content of any particular salt in milk by the addition of this material to the foodstuff. The results obtained cannot be regarded as showing this possibility to any appreciable extent, although one or two observers claim to have produced a small increase in the amount present. The withdrawal, however, of any particular inorganic constituent found in the milk from the dietary produces an undoubted effect. The content of this substance in the milk is not reduced, at any rate appreciably, the organism depleting itself to maintain the normal percentage of this substance in the mammary secretion. As soon, however, as such depletion would injure the organism the supply of milk is reduced and the output of the constituents correspondingly decreased, thus preventing depletion of the maternal organism. On restoring to the dietary the required amount of the inorganic constituent, the amount of milk produced returns to its former level. 


\section{CHAPTER IV}

\section{ON THE INORGANIC CONSTITUENTS OF MILK}

Total Ash.-A large number of figures dealing with the total ash have already been given in the preceding sections.

The ash content of cows' milk is in all cases considerably higher than that of human milk, so that the infant which is artificially fed on undiluted cows' milk does not suffer from lack of total ash. Variations appear in the amount found by various authors, especially among the earlier workers, but in no case does the variation obliterate the marked difference between the total amounts of ash in the two classes of milk.

Although there can be no doubt that all the inorganic materials present are needed for the life of the organism, certain of the constituents have received much closer investigation than others. The sodium, potassium, magnesium, \&c., have been estimated both for cows' and for human milk, by Bunge, Camerer and Söldner, and others, and many of the figures have already been given. ${ }^{1}$

More detailed investigations have been carried out on the calcium, iron, and phosphorus content of both human and cows' milk, and in view of the importance of these constituents, it will be necessary to consider them in detail under separate headings.

Iron.-The iron content of milk is a subject of much importance and of considerable interest.

The investigations made by the earlier workers give results which are so different from one another as to leave the reader of their papers in some degree of despair.

The chief source of discrepancy lies in the difficulty of securing an accurate estimation of the minute quantities of iron that are present. Until a few years ago the methods used necessitated a preliminary desiccation and ashing of large quantities of fluid, and any error was accentuated owing to the very small amounts found.

The colorimetric method of recent years has produced much more satisfactory results. Soxhlet states that it is correct to within Io per cent., which, although a high percentage of error, is comparatively immaterial on the minute quantities concerned.

The fact of primary importance to be decided is whether cows' milk contains as much iron as human milk, and if not, how great the deficit, and whether this can be repaired.

A very interesting account of the history of the work upon

1 See p. 18. 
the iron content of human milk and of cows' milk, together with original investigations upon the subject, has been given by Soxhlet (I9I2). He deals with the theory of Bunge $(2,3,4)$, who believed -and the belief was supported by his pupils-that the infant came into the world with a store of iron in the liver upon which it drew for its development. The iron in the food was apparently not considered of much account. Bunge $(I, 2)$ stated that human milk contained $4 \mathrm{mg}$. per litre, or 0.0004 per cent. of ferrous oxide $\left(\mathrm{Fe}_{2} \mathrm{O}_{3}\right)$. Soxhlet shows that this amount is more than enough to provide the iron required for the child as based upon the estimated requirements made by Camerer. There is, therefore, no need to call upon the iron which is deposited in the liver from the broken-up red corpuscles.

The simplest method of demonstrating the wide variations in iron content obtained by various authors will be to tabulate the results in chronological order, subsequently dealing individually with the more important papers.

Human Milk

\begin{tabular}{|c|c|c|}
\hline & $\mathrm{Fe}, \mathrm{O}$, in Mgms. per Litre & Percentage Amount \\
\hline $\begin{array}{l}\text { Bunge }(x) \\
\text { Abderhalden }(\mathbf{r}, 2) \\
\text { Camerer and Söldner }(\mathrm{r}) \\
\text { Glikin } \\
\text { Bahrdt andEdelstein }(\mathrm{x}) \\
\text { Soxhlet }\end{array}$ & $\begin{array}{c}4 \cdot 0 \\
8 \cdot 0 \\
2 \cdot 2-I \cdot 0 \\
7 I \cdot I \\
I \cdot 77 \\
I \cdot 6\end{array}$ & $\begin{array}{c}0.0004 \\
0.0008 \\
0.00022-0.0001 \\
0.00711 \\
0.000177 \\
0.00016\end{array}$ \\
\hline & Cows' Milk & \\
\hline 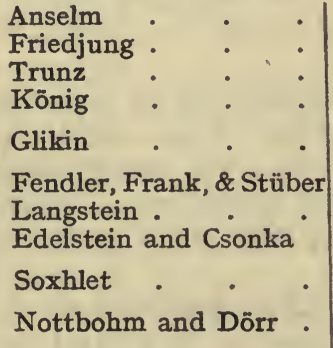 & $\begin{array}{c}0.875-I \cdot 2 \\
I \cdot 2-2.6 \\
0.32-0.51 \\
0.5-6.7 \\
68.0-98 \cdot 4 \\
\text { Average } 81 \cdot 2 \\
4.0-12.0 \\
0.3-0.7 \\
0.4-0.7 \\
0.25-1.2 \\
\text { Average } 0.6 \\
0.3-0.7\end{array}$ & \begin{tabular}{ll}
0.0000875 & -0.000125 \\
0.00012 & -0.00026 \\
0.000032 & -0.000051 \\
0.00005 & -0.00067 \\
0.0068 & -0.00984 \\
0.00812 & \\
0.0004 & -0.0012 \\
0.00003 & -0.00007 \\
0.00004 & -0.00007 \\
0.000025 & -0.00012 \\
\multicolumn{1}{c}{ Average 0.00006} \\
$0.00003-0.00007$
\end{tabular} \\
\hline
\end{tabular}

The later results show that human milk contains about $I \cdot 6$ to $\mathrm{I} \cdot 7 \mathrm{mgm}$. of ferrous oxide $\left(\mathrm{Fe}_{2} \mathrm{O}_{3}\right)$ per litre, or from three to four times as much as cows' milk, which contains from 0.3 to 0.7 mgm. of ferrous oxide $\left(\mathrm{Fe}_{2} \mathrm{O}_{3}\right)$ per litre.

Some variations occur in the iron content in relation to the period of lactation. 
Human Milk-Camerer and Söldner ${ }^{1}$ obtained the following figures :-

\begin{tabular}{|c|}
\hline $\mathrm{k}$ \\
\hline iddle period \\
\hline
\end{tabular}

Soxhlet obtained a number of samples at different periods of lactation, and gives the following results:

\begin{tabular}{|c|c|}
\hline $\begin{array}{l}4^{\text {th to }} 7 \text { th day ( } 7 \text { samples) } \\
\text { together with } 5 \text { weeks (I sample) } \\
\text { Period unknown (2 samples) }\end{array}$ & $\begin{array}{l}\mathrm{I} \cdot 2-2 \cdot 2 \mathrm{mgm} . \\
\text { average } \mathrm{I} \cdot 7 \mathrm{mgm} . \\
\mathrm{I} \cdot 3-\mathrm{I} \cdot 6\end{array}$ \\
\hline Later period (7th month) (I sample) & 1.5 \\
\hline
\end{tabular}

Although some samples in the early days have a lower iron content than others, there seems to be a tendency for the content to fall towards the end of lactation.

Cows' Milk.-Trunz found some tendency for the iron content to rise towards the end of lactation in one cow investigated, but not in the other. The figures obtained varied greatly on different days in the milk of the same cow. Thus in one cow the content varied from 0.019 to 0.045 gramme per kilo, the greater number of estimation being about $0^{\circ} 03$ gramme per kilo.

In the other cow the amount found varied from 0.009 to 0.023 gramme per kilo, the majority of the estimations being just below 0.02 gramme per kilo.

Nottbohm and Dörr (19I3) found a tendency for the iron content to rise towards the end of lactation. There is considerable variation in the amounts of iron given by different cows. The occurrence of mastitis appears to lead to an increase in the iron content and to simulate the condition of the end period of lactation.

The varying tendencies exhibited by human and cows' milk in their iron content as regards the period of lactation has already been shown to occur in the case of nitrogen and applies also to the lime content.

Langstein, and subsequently Edelstein and Csonka, state that the iron content of milk increases on keeping, and they believe that this is due to the passing into solution of small amounts of iron from the cans. No experimental evidence has, however, been brought forward to control this statement.

Edelstein and Csonka used Lachs and Friedenthal's method of estimation. They took milk from individual cows, milked straight into the glass; also mixed milk from the dairy at the

${ }^{1} C p$. also Camerer. 
Kaiserin-Auguste-Viktoria-Haus, from Bolle's dairy, and from the Viktoria Park dairy, with the following results :

\section{Kaiserin-Auguste-Viktoria-Haus.}

I. Direct into glass

2. Mixed milk
0.263-0.694 mg. per litre

. 0.64, 0.92, I.005 mg. per litre

Bolle's Dairy.

I. Direct into glass .

2. Mixed milk
. 0.35-I.o mg. per litre

I. I2-I.53 mg. per litre

Viktoria Park Dairy.

I. Direct into glass . . . 0.25-I'2 mg. per litre

These very considerable variations do not appear to be fully explained. The authors make no mention of the period of lactation at which the various samples of milk were taken.

Langstein (I9II) suggests that this increase in the iron content of the milk by the iron derived from the vessels (if this really occurs) may not be of any use to the infants, as the iron may not be assimilable.

The work of Krasnogorsky (1906) supports this supposition. Krasnogorsky investigated the iron metabolism of several infants fed naturally and on goats' milk. Several days were allowed to elapse after the commencement of the dietary before the estimations were begun, and when the same child was used for two sets of experiments, a considerable interval occurred between the experiments.

The following table summarises the general outline of the work:

\begin{tabular}{|c|c|c|c|c|}
\hline & 1. & $\begin{array}{c}\text { Amount of } \\
\text { Iron taken in } \\
\text { Mgms. }\end{array}$ & Absorbed & Retained \\
\hline $\begin{array}{l}\text { Infants fed on } \\
\text { Infants fed on } \\
\text { goats' milk }\end{array}$ & $\begin{array}{l}\text { human milk. } \\
\text { Raw } \\
\text { Boiled for ro mins } \\
\text { Boiled for } 20 \text { mins. }\end{array}$ & $\begin{array}{l}\left\{\begin{array}{l}7.05 \\
5.63 \\
4.24 \\
7.18\end{array}\right. \\
\left\{\begin{array}{l}3.86 \\
3.92\end{array}\right. \\
\left\{\begin{array}{l}3.44 \\
3.96\end{array}\right. \\
3.33\end{array}$ & $\begin{array}{c}\text { Per cent. } \\
88.09 \\
80.64 \\
74.06 \\
77.58 \\
12.18 \\
19.64 \\
24.71 \\
43.69 \\
30.93\end{array}$ & $\begin{array}{c}\text { Per cent. } \\
80.28 \\
75 \cdot 67 \\
72 \cdot 17 \\
72.98 \\
3.89 \\
13.27 \\
22.09 \\
35.10 \\
27.03\end{array}$ \\
\hline
\end{tabular}

These figures demonstrate the immense superiority of the milk of the same species as regards the power of absorption and retention of the iron.

A few experiments were also carried out on iron metabolism 
in rather older children fed with egg-yolk and spinach. About 59 per cent. to 70 per cent. of the iron was absorbed, and 55 per cent. to 70 per cent. retained. Ferratin was also tried, and it was found that about 23 per cent. was retained.

Langstein investigated the iron metabolism of two breast-fed infants in the early weeks of life, one being twelve weeks and the other eight weeks old.

He found that the first child retained about $0.255 \mathrm{mg}$. per day, and the second child $0 \cdot 188 \mathrm{mg}$. per day. Hence there is no need for a store of iron in the body to provide for growth.

Further work by Langstein and Edelstein also showed a positive iron balance in the early days of life. They obtained samples of the mother's milk, and accurate information as to the amount taken by the infant. A positive balance of 32 to 39 per cent. of the total intake in the early days of life, and of about $4 \mathrm{I}$ per cent. in the second week, was found.

It seems evident that the milk of the species contains the amount of iron necessary for growth.

Some experiments have been carried out in order to ascertain whether the iron content of milk can be raised by the addition of iron to the food of cows.

It appears that at one period, evidently before the year I902, a German firm advertised an article called 'Eisenzucker.' This substance, when added to the food in sufficient quantities, was said to increase greatly the iron content of the milk, and to render the milk highly valuable for cases of anæmia, \&c. The precise iron content which could be obtained was stated to be 0.0842 per cent. of ferrous oxide.

Giordani (I902) states that the injection of this substance into goats and rabbits caused an increase in the iron content of the milk, which was more than doubled in some cases. He found an accompanying slight reduction in the total milk output, but no change in the other constituents.

Mai (Igro) undertook feeding experiments with 'Eisenzucker.' The method used for the iron estimation is only claimed to be relatively accurate, but Mai obtained no evidence of a rise in iron content, unless a rise of $0^{\circ} 000 \mathrm{I} \mathrm{gm}$. per cent. on two occasions can be counted as an increase due to feeding. The substance itself was found to be the pharmacopœial preparation known as Ferrum Oxydatum Saccharatum. Mai states that the dairy on whose behalf the work was carried out informed the proprietor of the failure of the preparation, and powder was then offered to the dairyman with the suggestion that it should be added directly to the milk.

Soxhlet also carried out feeding experiments on cows, using large quantities of 'Eisenoel' and of hæmoglobin. A rise of O. I mg. per litre occurred, which might be attributed to the feeding, but he concludes that alterations in iron content of the milk cannot be obtained by feeding with iron compounds. 
The conclusions which may be drawn appear to be:

I. That human milk contains about three to four times as much iron as cows' milk.

2. That there is sufficient iron in human milk for the needs of the infant.

3. That the iron content of cows' milk cannot be increased by feeding with iron compounds.

Calcium.-Much work has been done upon the calcium content both of human and cows' milk, but the standpoint from which the investigations have been undertaken are somewhat different. In dealing with human milk, attention has been directed towards ascertaining the amount of lime present, and endeavouring to compare this amount with the calcium requirement of the young child. It seemed possible that a study of the calcium content of human milk might throw light upon the occurrence of rickets in breast-fed children.

In cows' milk the investigations on the general calcium content have not been extensive; efforts appear to have been directed mainly towards the percentage distribution of calcium-that is, the amount present in organic and inorganic combination respectively.

The distribution of the calcium content of milk-that is, its combination with either organic or inorganic substances-is not a problem which affects the present work. The normal infant or young animal can probably avail itself of the calcium present in the milk, whatever the form of the calcium.

The work upon the calcium content of human milk carried out by the earlier authors has been carefully summarised by Bahrdt and Edelstein (2) in IgIO, and it will only be necessary to refer anyone interested in the full details to the paper by these authors.

The work of Hunnaeus (Igog) may be mentioned before considering that of Bahrdt and Edelstein.

Hunnaeus studied the calcium content of human milk in relation to the stage of lactation, and other points. He found the calcium content for the same woman varied very little.

I. In five samples of milk taken in the morning and evening, the amount varied between 0.046 per cent. and $0.035 \mathrm{I}$ per cent.

2. In six samples of milk taken as first milk and as end milk, the figures lay between $0^{\circ} 046$ to 0.038 per cent., the content for the first milk being rather higher than that for the end milk.

3. Samples taken from twelve women in the first month of lactation showed rather more variation, the figures varying from 0.0518 to 0.0332 per cent.

4. No variation occurred in the total calcium output in the milk of the same woman on different consecutive days, although in the later months of lactation there is a tendency for the total amount to decrease. This is shown in the following table: 


\begin{tabular}{|c|c|c|c|}
\hline Wet-nurse & $\begin{array}{l}\text { Month after } \\
\text { Parturition }\end{array}$ & $\mathrm{CaO}$ Content & Difference \\
\hline I & $\left\{\begin{array}{l}\text { Ist } \\
\text { 2nd }\end{array}\right.$ & $\begin{array}{l}\text { Per cent. } \\
0.0482 \\
0.0466\end{array}$ & $\begin{array}{l}\text { mgs. } \\
I \cdot 6\end{array}$ \\
\hline 2 & $\left\{\begin{array}{l}2 \mathrm{nd} \\
3 \mathrm{rd}\end{array}\right.$ & $\left.\begin{array}{l}0.0444 \\
0.0432\end{array}\right\}$ & $I \cdot 2$ \\
\hline 3 & $\left\{\begin{array}{l}\text { Ist } \\
\text { 3rd } \\
\text { th }\end{array}\right.$ & $\left.\begin{array}{l}0.0475 \\
0.0410\end{array}\right\}$ & $\begin{array}{l}6 \cdot 5 \\
3 \cdot 1\end{array}$ \\
\hline 4 & $\left\{\begin{array}{l}\text { Ist } \\
3 \text { rd } \\
4 \text { th }\end{array}\right.$ & $\left.\begin{array}{l}0.0381 \\
0.0518 \\
0.0486 \\
0.0465\end{array}\right\}$ & $3 \cdot 2$ \\
\hline 5 & $\left\{\begin{array}{l}4 \text { th } \\
5 \text { th } \\
6 \text { th }\end{array}\right.$ & $\left.\begin{array}{l}0.0425 \\
0.0402 \\
0.0378\end{array}\right\}$ & $\begin{array}{l}2 \cdot 3 \\
2 \cdot 4\end{array}$ \\
\hline 6 & $\left\{\begin{array}{l}3 \text { rd } \\
5 \text { th } \\
7 \text { th }\end{array}\right.$ & $\left.\begin{array}{l}0.0379 \\
0.0372 \\
0.0367\end{array}\right\}$ & $\begin{array}{l}0.7 \\
0.5\end{array}$ \\
\hline 7 & $\left\{\begin{array}{l}7_{\text {th }} \\
\text { roth }\end{array}\right.$ & $\left.\begin{array}{l}0.045^{2} \\
0.0423\end{array}\right\}$ & $2 \cdot 9$ \\
\hline
\end{tabular}

5. Feeding experiments, where the mother was fed with calcium lactate and calcium phosphate to the amount of I gm. per diem, showed no increase in the calcium in the milk. Further, the removal of milk from the dietary of the mother, thus decreasing appreciably the amount of calcium taken, did not effect any reduction in the calcium content of the milk.

These observations suggest that the variation in the calcium content of the milk of individual women is as great as variations from other causes.

Bahrdt and Edelstein (Igro) prepared a comprehensive table of the values obtained by previous observers in a large number of samples of human milk. It is unnecessary to quote the tables fully here ; it may be stated generally that great divergences in the calcium content evidently occur between the milk of individual women.

Among the mothers of healthy children the variations extend from between $0^{\circ} 08$ per cent. and 0.028 per cent., or between 300 and 400 per cent. difference. The average amount was found by them to be 0.042 per cent., a figure which is about one-third higher than the usual average given. With these great individual differences the figure for the average amount is of little practical value. Further, a table was prepared showing the lime content of the milk of a number of mothers having rickety children. In this series the figures varied between 0.04646 per cent. and 0.019 per cent. As many of the mothers in the second series were in the eleventh to thirteenth month of lactation, the low figures may be to some extent due to the late stage of lactation. The addition 
of calcium to the food of the nursing mother was found to be entirely without effect upon the lime content of the milk.

The authors conclude that there is no general connection between the appearance of rickets in children and the calcium content of the mother's milk.

Dibbelt (I) claims to have obtained a rise in the calcium content of milk by feeding with various forms of calcium compounds $\mathrm{He}$ investigated the milk of three women and obtained the following figures:

I. Before feeding with calcium After 7 days on Dr. Wattenberg's Ca milk .

2. Before feeding with calcium After 7 days on 5 gms. di-calcium phosphate per diem .

3. Before feeding with calcium. After feeding as in 2. .

Per cent. $\mathrm{CaO}$

These observations have not been confirmed by later investigators.

Schabad examined the lime content of samples of milk taken both at the beginning and at the end of emptying the gland. The figures confirm the observations of Hunnaeus, since the individual differences between the milk of different women are shown to be greater than between the first and end milk: the content of the first milk is, however, rather higher than that of the end milk.

Schabad gives the average calcium content as 0.042 per cent. for the mothers of healthy children (forty-nine cases), and 0.039 per cent. for the mothers of rickety children (twenty-two cases). Schabad found that the organic constituents appear to be higher in the milk of mothers having rickety children, and he compared the lime content with the total caloric value. As a result of the raised amount of organic constituents, the actual proportion of lime to the caloric value of the milk is lowered, although the actual amount of calcium may not be very low. Addition of lime to the mother's food has no effect on the calcium content of her milk.

The figures obtained by Schloss showed an average of 0.038 per cent. in a number of samples taken both as mixed milk from fifteen to sixteen wet-nurses and in the milk of a number of individual women. Bamberg gives an average of 0.0439 per cent. from twenty-five samples.

The question of appreciably influencing the lime content of human milk has received further attention from Zuckmayer. This worker fed twenty-six women with large amounts of calcium in the form of tricalcol or tricalcium phosphoretted casein, which was added to their food. Of the twenty-six women, twelve received the calcium for ten days after confinement only, and fourteen received it for from two months to sixteen days before confinement as well as afterwards. 
The average figures obtained were as follows:

\begin{tabular}{|c|c|c|c|c|}
\hline- & Total Ash & $\mathrm{CaO}$ & Varying from & $\mathrm{P}_{2} \mathrm{O}_{8}$ \\
\hline $\begin{array}{l}\text { After confinement only } \\
\text { Before and after confinement }\end{array}$ & $\begin{array}{l}\text { Per cent. } \\
0.1983 \\
0.217\end{array}$ & $\begin{array}{l}\text { Per cent. } \\
0.0352 \\
0.0387\end{array}$ & $\begin{array}{c}\text { Per cent. } \\
0.032-0.043 \\
0.029-0.049\end{array}$ & $\begin{array}{l}\text { Per cent. } \\
0.340 \\
0.349\end{array}$ \\
\hline
\end{tabular}

The calcium content of human milk evidently varies within very wide limits, although usually at about $0.04 \mathrm{mg}$. per Ioo c.c. of milk. The content of the milk of each individual is approximately constant, although there is a tendency to fall in the later months of lactation.

Dibbelt (2), taking figures obtained by Thomas for the total ash of infants, concluded that the child frequently had to grow on a deficit of calcium in the early months. He regards this as a physiological arrangement to secure the transference of lime salts from the interior parts of long bone to the outer parts, a transference which has long been known to occur and which appears to be necessary for growth. He believes that 04 to 05 per cent. of calcium is sufficient for the infant, so that the needs of the child would therefore appear to be met in the majority of cases. The amount taken in will also clearly be dependent upon the amount of milk taken, which has been shown to vary very considerably with different children. ${ }^{1}$

Several authors have endeavoured to trace a connection between the output of calcium and other constituents of the milk, chiefly in relation to fat.

Hoobler studied the metabolism of a child of nine months on low, medium, and high fat diets, i.e. 2 .I per cent., 4 per cent., and 5.4 per cent. of fat respectively. In low fat feeding calcium was withdrawn from the body, more calcium being found in the fæces than was present in the food. In high fat feeding $54^{\circ} 57$ per cent. of the calcium was retained. The greatest nitrogen and phosphorus intake occurred with a medium fat diet.

Some relationship appears to exist between the calcium, nitrogen, and phosphorus. Schloss and Frank, studying the metabolism of children in the early stages of rickets, found that there was a high but rather unsteady nitrogen retention, but a bad retention of calcium and phosphorus. The addition of fat to the food, in the form of cod liver oil, led to an increased nitrogen output, but steadied the nitrogen balance. The addition of calcium phosphate raised the calcium balance and increased the retention of phosphorus.

Aschenheim finds that in infants taking a normal diet with sufficient fat, calcium is excreted in the fæces only, but when the 
diet has less than the normal amount of fat, calcium appears also in the urine.

These observations suggest that there is some degree of antagonism between a high nitrogen retention and a high retention of calcium : the latter is encouraged by a high fat diet, but not the former. Work on the treatment of rickets by cod liver oil seems to show that one of the main advantages of this drug is to bring about an improved calcium retention. ${ }^{1}$ A discussion of this matter would be beyond the scope of this work.

Comparatively little work has been carried out on the total calcium content of cows' milk.

The relationship of calcium to caseinogen has already been considered in Chap. III.

The amount of calcium in cows' milk is many times higher than that in human milk.

Trunz (I904) investigated the composition of the ash of cows' milk. He used the milk of two cows throughout a period of ten and twelve months respectively. He made separate estimations of the calcium combined with caseinogen and of the calcium present in the form of salts. The total calcium content appears to be about 0.I8 to 0.I9 per cent., a slight fall to about 0.I54 per cent. occurring after the colostral period. The amount appearing as salts, i.e. not bound to caseinogen, is given as 0.13 per cent. to 0.14 per cent., with a drop to 0.12 per cent. in the early months. Raudnitz gives 0.2 per cent. as the figure for lime content of cows' milk.

The calcium which is present in the form of salts is probably mainly combined with phosphorus and with citric acid. A considerable amount of work has been done upon these salts in milk, but is outside the scope of this work.

Phosphorus.-It may reasonably be assumed that, as with the other constituents of the milk, the milk of each species, with respect to phosphorus, is specially adapted for the young of that species.

From the public health aspect, the phosphorus content of milk does not appear to be as important as the content of other constituents, since the phosphorus content of cows' milk is greatly in excess of that in human milk, so that the human infant fed on cows' milk receives a plentiful supply of phosphorus.

The phosphorus is present in several forms-in caseinogen, as salts, and also in lecithin.

Siegfried states that in cows' milk 6 per cent. of the total phosphorus is combined with caseinogen, and in human milk $4 \mathrm{I}^{\circ} 5$ per cent., this latter milk containing relatively little inorganic phosphorus. The high lecithin content found in human milk by Stocklasa has already been mentioned.

${ }^{1} \mathrm{Cp}$. Schabad and Sorochowitsch and others. 
Bunge $(\mathrm{I})$ gives the percentage of phosphoric anhydride $\left(\mathrm{P}_{3} \mathrm{O}_{8}\right)$ in the ash of human milk as $2 \mathrm{I} \cdot 3$ of the whole, that for cows' milk being 24.75 . As, however, the total ash of cows' milk is much larger than that of human milk, the total quantity of phosphorus is correspondingly greater.

Trunz gave figures for the $\mathrm{P}_{2} \mathrm{O}_{5}$ content of cows' milk in the two cows whose milk was studied by him. Both cows showed a slight fall of phosphorus in the milk after the colostral period, rising again towards the end of lactation. The figures given show an approximate distribution as follows:

\begin{tabular}{|c|c|c|c|}
\hline & $\begin{array}{c}\text { Total } \\
\text { Phosphorus }\end{array}$ & $\begin{array}{l}\text { Phosphorus in } \\
\text { Caseinogen }\end{array}$ & $\begin{array}{l}\text { Phosphorus in } \\
\text { Salts }\end{array}$ \\
\hline $\begin{array}{l}\text { Colostrum } \\
\text { After } 3-4 \text { weeks the }\end{array}$ & 0.2867 & 0.0593 & $0 \cdot 1774$ \\
\hline lowest figures were & 0.19 & 0.039 & 0.1420 \\
\hline Rising again to & 0.24 & 0.06 & 0.1767 \\
\hline
\end{tabular}

Raudnitz gives the figure for the phosphorus in cows' milk as 0.24 per cent. and for human milk 0.05 per cent.

Schloss, ${ }^{1}$ working with human milk, obtained the values of :

0.040 per cent. as the average figure for eight women, and 0.044 per cent.

and 0.038 per cent. respectively for the two mixed samples,

or an average of $0.04 \mathrm{I}$ per cent.

Zuckmayer obtained a slightly lower value for the average of a large number of samples, namely, $0^{\cdot} 034^{8}$ per cent. $^{1}$

Glikin gives values for the distribution of the phosphorus in milk, in especial relation to the lecithin content ; but this is beyond the scope of the present work.

Fingerling (I) fed goats on phosphorus-containing substanceslecithin, phytin, casein, nuclein, nucleic acid, and di-sodium phosphate. No increase was obtained in the phosphorus content, nor of the ash of the milk, nor was there any rise in the total amount of milk given. This agrees with the work of Zuckmayer on pp. $56-57$.

Fingerling concludes, however, that these substances may be used to make up the requisite amount of phosphorus in the food in the case of an animal giving a large quantity of milk and consequently in danger of losing too much phosphorus. The other experiments by this worker (2), quoted on P. 2I, show that when the total phosphorus intake is decreased below the physiological limit

1 For details compare p. 9. 
of health, the amount of milk falls-the mechanism being one of protection to prevent undue depletion of the organism owing to output of this constituent in the milk.

It has been stated that phosphates are excreted in the urine of infants suffering from digestive disturbances, and that the amount excreted varies with the degree of the disturbance. The literature is not very extensive, but it is beyond the scope of this work.

Recent work by Kaminer and Mayerhofer, and by Knox and Tracy, suggests that the normal breast-fed infant does not excrete phosphates in the urine, but that phosphates tend to appear with alteration of food or with digestive disturbances. Knox and Tracy agree that bottle-fed children excrete more phosphorus in the urine than breast-fed children. The literature on the subject is discussed by these authors.

\section{REFERENCES IN CHAPTER IV}

\section{The Inorganic Constituents of Milk}

AbDeRHALden. (I) 'Die Beziehung der Wachsthumsgeschwindigkeit des Säuglings zur Zusammensetzung der Milch, etc.,' Zeit. f. physiol. Chem. 1899, xxvii. 408. (2) Lehrbuch der Physiologie, 1906, p. 395.

Anselm, ' Ueber den Eisengehalt der Milch,' Zentralb. f. inn. Med. I895, xvi.

AschenHeim, 'Beitrag zum Fett in Stickstoffwechsel beim Säugling,' Jahrb. f. Kinderh. I913, Ixxvii. 505.

BAHRDT AND EDEISTEIN. (I) 'Ein Beitrag zur Kenntniss des Eisengehalts der Frauenmilch, und seine Beziehung zur Säuglingsanämie,' Zeit. $f$. Kinderh. I9II, i. I82. (2) 'Das Kalkgehalt in der Frauenmilch,' Jahrb. f. Kinderh. I9I0, lxxii, 'Ergängzungsheft,' p. I6.

BAMBerg, 'Zur Physiologie der Lactation mit besonderer Berücksichtigung der chemischen Zusammenhang der Frauenmilch milchreicher Frauen und des Einfluss der Menstruation,' Zeit. $f$. Kinderh. I913, vi. 424.

Bunge. (I) 'Der Kali-, Natrium- und Chlorgehalt der Milch,' Zeit. f. Biol. I874, X. 295 and 305. (2) 'Ueber die Aufnahme des Eisens in den Organismus des Säuglings,' Zeit. f. physiol. Chem. I889, xiii. 399. (3) 'Weitere Untersuchungen über die Aufnahme des Eisens in den Organismus des Säuglings,' Zeit. f. physiol. Chem. I892, xvi. I73. (4)'Ueber den Eisengehalt der Leber,' Zeit. f. physiol. Chem. I892, xvii. 78.

CAMERER, 'Mitteilung über den Eisengehalt der Frauenmilch,' Zeit. $f$. Biol. I904-5, xlvi. 371 .

CAMERER AND SöLDNER, 'Die Aschenbestandteile des neugebornen Menschen und der Frauenmilch,' Zeit. f. Biol. 1903, xliv. 6r.

Csonka. See Edelstein and Csonka.

Drbbelt. (I) 'Die Pathogenere der Rachitis,' Avb. a. d. Gebiete der pathologischen Anatomie u. Bakt. aus dem pathol. Inst. Tübingen, 1908, ht. 3 . (2) 'Die physiologische Bedeutung des Kalkhungers bei Brustkindern im ersten Lebensjahre,' Berl. klin. Wochensch. I9II, xlvi. 2062.

DörR. See Nottbohm and Dōrr.

EDELSTEIn AND v. Csonka, 'Ueber den Eisengehalt der Kuhmilch,' Biochem. Zeit. I9I2, xxxviii. I4.

Edeistein. See Bahrdt and Edelstein, and Langstein and Edelstein. 
Fendler, Frank and Stüber, 'Eisenbestimmungen in der Milch,' Zeit. f. Nahr-u. Genussm. I910, xix. 369.

FINGERLING. (I) 'Einfluss organischer und anorganischer Phosphorverbindungen auf die Milchsekretion,' Bioch. Zeit. I9I2, xxxix. p. 239. (2) 'Beiträge zur Verwertung von Kalk- und Phosphorsäureverbindungen durch den tierischen Organismus,' Landwirtsch. Versuchs. I9II, lxxv. I ; Ref. Milchw. Centralb. 1912, p. ro5.

Frank. See Schloss and Frank, and Fendler, Frank, and Stüber.

Friedenthal. See Lachs and Friedenthal.

FRIEDJUNG, 'Ueber den Eisengehalt der Frauenmilch,' Molkeveizeit, Igor, p. 245 .

GroRDANI, 'Beitrag zum Studium der medikamentösen Milchproduktion : "die Eisenmilch," Rev. mens. Mal. de l'Enfance, I902; Ref. Münch. med. Wochensch. 1902, xlix. I977.

GlikıN, "Ueber den Lecithin- und Eisengehalt in der Kuh- und Frauenmilch, Biochem. Zeit. I909, xxi. 348.

Hoobler, 'Nitrogen and Mineral Salt Metabolism,' Med. and Surg. Reports, Presbyterian Hosp. I9I2, ix. I65.

Hunnaeus, 'Ueber den Kalkgehalt der Frauenmilch,' Biochem. Zeit. I909, xxii. 442 .

Kaminer and MAYERHOFer, 'Ueber den klinischen Wert der Bestimmung des anorganischen Phosphors im Harne unnatürlich ernährter Säuglinge,' Zeit.f. Kinderh. I9I3, viii. 24.

KNOX AND TRACY, "A Contribution to our Knowledge of the Excretion of Phosphates in Infancy,' Amer. Journ. Dis. Children, 1914, vii. 409.

KöNIG, Chemische Zusammensetzung der menschlichen Nahrungs-, und Genussmittel. (Quoted by Camerer and Söldner, Zeit. f. Biol. r896, xxxiii. 43.)

KRASNOGORSKY, ' Ueber die Ausnützung des Eisens bei Säuglingen,' Jahrb. $f$. Kinderh. I906, lxiv. 651.

LACHS AND FRIEDENTHAL, 'Die Bestimmung des Eisens auf colorimetrischem Wege,' Bioch. Zeit. I9I I, xxxii. I30.

LANGSTEIN, 'Das Eisen bei der natürlichen und künstlichen Ernährung des Säuglings,' Jahrb.f. Kindevh. Igr I, Ixxiv. 536.

Langstein AND Edelstein, 'Der Eisenhaushalt im Säuglingsalter,' Verh. d. Gesellsch. f. Kinderh., Wien, I913, p. 3.

MAI, 'Ueber sogenannte Eisenmilch,'Zeit. f. Nahr- u. Genussm. 1910, xix. 2 I. MAYERHOFER. See Kaminer and Mayerhofer.

Nоттвонм AND DöRR, 'Ueber den Eisengehalt der Kuhmilch,' Zeit. f. Nahru. Genussm. I9I 4, xxviii. $4 \mathrm{I} 7$.

RAUDNITZ, Schlossmann-Pfaundler's Handbuch der. Kinderheilkunde, I910, 2nd Edit. i. 133

Schabad, "Der Kalkgehalt der Frauenmilch. Zur Frage der ungenügenden Kalkzufuhr als Ursache der Rachitis,' Jahrb. f. Kinderh. I9I I, lxxiv. 5 II.

Schabad AND Sorochowitz, 'Die Behandlung der Rachitis mit Lebertranemulsion,' Monats. f. Kinderh. I9II, x. I2.

Schross, 'Die chemische Zusammensetzung der Frauenmilch auf Grund neuer Analysen,' Monats. f. Kinderh. I9I0, ix. 636; Ref. Milchw. Zentralb. I9I2, pp. I72, 7 I9.

Schloss AND FRANK, "Tricalciumphosphat als Knochenbilder beim menschlichen Säugling,' Biochem. Zeit. I9I4, lx. 378.

Siegrried, 'Zur Kenntnis des Phosphors in den Frauen- und Kuhmilch,' Zeit. f. physiol. Chem. I896, xxii. 575.

SöldNER. See CAMERER.

SoRochowitz. See Schabad and Sorochowitz.

Soxhlet, 'Ueber den Eisengehalt der Frauen- und Kuhmilch' Münch. med. Wochensch. I9I2, xxviii. I 529.

Stocklasa, 'Zur Kenntnis des Phosphors in der Frauen- und Kuhmilch,' Zeit.f. physiol. Chem. 1897, xxiii. 343 . 
StÜber. See Fendler, Frank, and Stüber.

Tномаs, "Ueber die Zusammensetzung von Hund und Katze während der ersten Verdoppelungsperioden des Geburtsgewichtes,' Arch. f. Anat. $u$. Physiol. I9I I, p. 9.

Tracy. See Knox and Tracy.

TRUNz, Die mineralischen Bestandteile der Kuhmilch und ihre Schwankungen im Verlaufe einer Laktationsperiode,' Zeit. f. physiol. Chem. 1903-4, xl. 263.

ZUCKMAYER, 'Ueber die Frauenmilch der ersten Laktationszeit und den Einfluss einer Kalk- und Phosphorsäurezulage auf ihre Zusammensetzung,' Pfüger's Arch. I914, clviii. 209. 


\section{SUMMARY OF CHAPTER V}

THE SO-CALLED 'BIOLOGICAL PROPERTIES' OF MILK

\section{A. The Ferments or Enzymes}

A GREAT deal has been written and spoken about the ferments or enzymes in milk, and many writers have attributed great importance to the presence of these substances. It will be of interest to consider briefly how the discussion upon this question has arisen.

Before the beginning of the present century physicians do not appear to have taken much interest in the question, although a considerable amount of work had already been done by numerous chemists. In the year I900, Professor Escherich, of Vienna, at that time one of the foremost physicians for children's diseases, sought to account for the difference in progress made by infants fed on boiled cows' milk as compared with breast-fed babies, by suggesting that milk contained certain 'properties' which were destroyed by boiling and which might be of value for the infant. It may be remarked here, that boiled milk is almost universally used on the Continent, since raw milk, even though carefully collected, is not considered a safe food for infants. This idea, once started, opened up a very wide field of investigation and occupied the attention of a number of observers for many years. Recently, the literature on the medical side has decreased in amount, and the interest appears to have slackened considerably. The investigations are, however, still continued by dairymen for purposes which are not directly connected with the feeding of infants, and which will be alluded to briefly in this chapter.

The discovery in milk of a considerable number of ferments has led a number of people to describe milk as a 'living substance,' and to credit milk with powers which investigation has not substantiated. Before dealing in detail with the ferments which are found in milk, a few preliminary considerations are necessary.

It must be remembered that milk is a secretion produced by the mammary gland, and its production is on analogous lines with the secretion of saliva by the salivary glands. The knowledge which we possess of secretory processes in general shows that although each 
gland manufactures certain chemical substances differing in composition from those manufactured by other organs, the secretion also contains traces of waste products which have passed out from the bloodvessels in small amounts, so that the secretion also contains some substances which have been derived from the blood by filtration. Every living cell contains ferments, and every animal organism depends for its existence upon the action of ferments. Digestion, leading to the assimilation of digested food-stuffs, and the interchange of nutritive material-in fact, most of the processes connected with the metabolism or life of a cell-are due directly or indirectly to the action of ferments. This being the case, it is unreasonable to suppose that ferments do not exist in every part of the body. There is considerable variation in concentration of the ferments, but the fluids of the body, practically without exception, contain ferments of one kind or another.

As far as is at present known, each ferment performs one action, and one action only-that is to say, it is adapted for working upon and effecting an alteration in one particular chemical substance only. A ferment which will attack a fatty substance has no effect whatever upon a substance belonging to the class of starches or sugars. Each ferment, therefore, is said to be 'specific' in its activity. Evidently there must be a great number of ferments, each of which fulfils its own part in the life of the animal organism.

Ferments are produced by animal cells and by bacteria. Actions identical in their effects with those due to certain ferments are also caused by certain metals, when these are in colloidal form. Thus spongy platinum will break up hydrogen peroxide, with the evolution of oxygen, in the same way that this substance is split by the ferment catalase, which is found in the blood and in the tissues.

Ferments are present in every cell of the mammary gland. It is known that these cells break down and disintegrate in the course of milking and of milk production, since portions of cells can always be found, together with intact cells, in the sediment from any sample of milk. It is impossible to suppose, therefore, that ferments would not be found in the milk owing to the presence of these portions of disintegrated cells. Moreover, the blood and lymph, carrying the nutritive substances to the cells of the mammary gland, contain ferments and, as in the case of the other secretory glands, traces of substances find their way through from the blood and lymph into the secretion of the gland, in this case into the milk.

There is abundant evidence to show that ferments of various kinds are present in milk, and that these ferments differ, both in quantity and also in quality, in the milk of different species. In addition to the ferments derived from the gland itself, ferments are frequently introduced after the milk has been collected. This is due to the presence of bacteria in the milk, the bacteria having been derived from the air or from the cow herself, or from other 
sources of contamination since milking. The bacteria which are present are capable of producing different varieties of ferments in considerable quantities. Evidently, if investigations are being made into the ferments which are present in milk as such, it is essential that the presence of ferments due to subsequent bacterial action should be eliminated. This consideration did not, however, receive due attention among the earlier observers, and in a large number of instances the milk used for investigation was collected with no special precautions, and the bacterial content, which was probably considerable, was not taken into account. In some cases the observers appear to have been conscious of a defect in their investigations, and endeavoured to kill the bacteria by . introducing antiseptics before they proceeded with their investigations upon the presence of ferments. This method, although it may have been successful in killing the bacteria, did not remove the ferments which had been manufactured by them before they were killed.

A great many investigations have been carried out with a view to discovering a method of detecting whether milk had been boiled prior to being sold. In I898, when the campaign against tuberculosis in cattle was commenced in Denmark, regulations were issued for compulsory pasteurisation, in order to limit the spread of tubercular disease by means of milk. It was necessary to provide a test which would ensure the fulfilment of the prescribed pasteurisation, and such a test was based upon the presence in milk of a ferment which gave a specific colour reaction. This ferment, now known as peroxidase, gives a peculiar grey-blue colour when treated with paraphenylene-diamine and hydrogen peroxide. If the milk has been boiled, this reaction is modified or destroyed. Storch, who first worked out this reaction, believed that it was reliable for differentiating between milk which had been heated to $80^{\circ} \mathrm{C}$, and above, and milk which had not been heated to so high a temperature. This reaction, about which more will be said later, is very generally known as Storch's reaction or test.

Efforts have also been made to utilise a colour reaction produced by a ferment for estimating the number of bacteria present. A considerable number of bacteria have the property of ' reducing' methylene blue. By their action, they slightly alter the chemical composition of this substance, and the colour completely disappears, the milk to which this substance has been added becoming white.

Efforts have been made to utilise the ferment action of milk for yet another purpose, namely, to discover the presence of milk from a diseased cow when the milk from such a cow has been added to a general milk supply. A different ferment, catalase, has been investigated in connection with this matter, and is one which acts upon hydrogen peroxide with the evolution of oxygen in the form of gas. This gas can be collected over the surface of the milk, and 
the amount given off by a known quantity of milk can be estimated. The reaction has not proved extremely reliable, since this ferment is also readily formed by a number of the bacteria which may have gained access to the milk after its collection, and also to the fact (which will be considered in detail later) that diseased conditions of the udder do not universally produce a rise in the content of this ferment in milk. The literature, therefore, is concerned with the ferments in milk in connection with several different matters. In this work the main consideration must be directed to the presence of ferments from the point of view of the nutrition of the infant or young animal, although it will be impossible to omit some consideration of the other aspects.

On the Possible Value to Infants of the Ferments present in Milk.-. There are two ways in which ferments in milk might be useful to the infant. They might either assist in the digestion of the food material contained in the milk after it has been taken by the infant, or they might conceivably act as subsidiary agents in connection with the digestive processes, although not themselves directly concerned. In view of the specificity of ferments, the first point, namely, the digestion of the substances in milk itself, is evidently concerned only with such ferments as are capable of attacking and altering the various food materials present in the milk. These have been shown in the previous chapter to consist of nitrogenous substances, or proteins, of carbohydrate, or sugar, and of fatty substances. Inorganic constituents do not require consideration, from this point of view. We are, therefore, first concerned with the investigation of the presence of such ferments as can attack the organic substances, and afterwards with those having a possible subsidiary action.

Proteolytic Ferments, i.e. those acting on Proteins.-Various observers have carried out work upon this matter, but in several cases the milk was not free from bacteria at the time of investigation. Proteolytic ferments are produced by a considerable number of bacteria, hence when these latter are present it cannot be assumed that the milk itself contained these ferments. The earliest investigations were carried out in connection with the ripening of cheese by Babcock and Russell (I897). The work of these observers is chiefly interesting as being the earliest observations upon this point, but in view of the fact that the milk was not free from bacteria, they do not call for detailed consideration here. Further information is given in Chap. V. No subsequent observer found any marked proteolytic action in milk, although several observers obtained evidence of the breaking down of a small portion of the protein when the experiments were carried out over a prolonged period. For the present purpose such experiments are of comparatively little interest, because milk, when taken by the infant, is digested within a few hours after it enters the body, so that experiments conducted over a period exceeding a few hours cannot 
be regarded as of any value. Investigations carried out by myself, in which experiments were conducted with bacterial-free milk over a period of twenty-four hours, gave no indications of proteolytic action in milk.

Grimmer, who has carried out much work upon many aspects of milk, has more recently investigated the ferments present in the mammary gland itself. He examined the resting and active glands of a number of animals, and found that a small amount of proteolytic activity occurred when the gland, carefully prepared for experiment, was allowed to stand and to undergo auto-digestion. The action was more marked in the active gland, but in no case was the action strong enough to affect any foreign protein introduced-that is, it was only able to act upon the protein of the gland itself. There seems some possibility of another ferment being present in the active gland which has the power of breaking down simpler substances (polypeptides) derived from proteins. Grimmer states that the presence of these ferments in the gland itself is doubtless due to the necessity for the production of milk protein from the proteins of the gland itself.

As concerning the proteolytic action in milk itself, after reviewing the literature, he comes to the conclusion that the proteolytic action of milk, if present at all (upon which, he says, the evidence is not very conclusive), is so small that it cannot be regarded as being worthy of any serious consideration as an aid to digestion in the infant.

Fat-splitting or Lipolytic Ferments. - Experimentation upon the presence of a lipase in milk is not easy, and the number of investigations carried out have not been large.

Experiments on Human Milk. - It appears fairly certain that human milk does contain a ferment capable of splitting fatty substances. This action, however, is said to be insufficient to show any action upon fat contained in the milk itself, and is only demonstrable when fatty substances are added to the milk. As a whole, two substances have been used for this purpose, monoand tri-butyrin, and some evidence has been obtained of the splitting of this substance by human milk. The most important investigations have been those of Davidsohn, who has made some interesting observations. Davidsohn added a few drops of tributyrin to fresh human milk, and found that, after gently shaking for a few minutes, a peculiar smell, that of butyric acid, was produced. He showed that the action of this ferment was connected with the phenomenon of surface tension in the milk, the surface tension being reduced by the action of the ferment. This action is not observed in milk unless tributyrin be added to the milk. He found the ferment both in the whole milk and in the whey, and showed that its action was of a similar type to the fat-splitting ferment present in the blood. There seems no reason to doubt that this ferment is derived from the blood stream, and passes into the milk by a process of 
filtration. It is present in much smaller amounts in the milk than in the blood.

Experiments on Cows' Milk.-One or two of the earlier observers have stated that cows' milk contained a fat-splitting ferment. This has not been confirmed by later observers. Davidsohn, when using cows' milk, was unable to obtain the above-mentioned reaction for human milk.

Ferments acting on Sugar.-Some observations have been carried out with a view to ascertaining whether milk contained a ferment capable of acting on the sugar in milk, i.e. lactose. The investigations are accompanied by considerable experimental difficulties in determining a change of a small order in the quantity of sugar present. The older observers, who worked with milk containing bacteria, believed that they obtained evidence of some action upon the sugar. So many bacteria are capable of fermenting milk-sugar that unless the milk is absolutely germ-free, the disappearance of a small quantity of this sugar cannot be regarded as necessarily due to an action in the milk as such. Lactose, when acted upon by the ferment lactase, is split up into two molecules of different sugars, namely, one molecule of galactose and one of glucose. This action is known to take place very readily in the alimentary canal of the infant. It has been shown by Aders Plimmer that lactase is present in the alimentary canal of young animals at birth, and in some species of animals even before birth, in considerable amounts, and will rapidly convert the lactose into the simpler sugars, which are then absorbed for the use of the organism.

Lactase, if present at all in milk, is present only in infinitesimal quantities, and it is more likely that it is entirely absent, and that such disappearance of lactose as has been observed, has been due to bacterial action. Since the sugar becomes converted to the simpler sugars within a very short period of its being taken by the infant, no physiological value can be attributed to the possibility of. minute traces of lactase in the milk.

Briefly, it may be said that cows' milk does not contain ferments capable of aiding the digestion of the substances in milk itself, to an appreciable extent. One of the ferments is present in larger amounts in human milk than in cows' milk, but even here the effect upon digestion in the infant must be regarded as negligible. The presence of these ferments is almost certainly to be accounted for by filtration from the blood, or as a result of the breaking down of the cells of the gland itself.

On the Presence of Oxidising Ferments.-Reference has already been made to a ferment whose presence has been used to detect previous heating of the milk. This ferment is known as peroxidase, because it acts on substances known as peroxides. The literature upon this ferment is extensive.

The first observations upon the presence of this ferment appear 
to have been made in the year 1868 by Klebs, since when there has been a continuous succession of papers dealing with one aspect or another of its activity. For many years it was believed that there were two ferments present in milk, both acting as oxidising agents - that is, they were both capable of increasing the amount of oxygen in certain substances, but had slightly different actions. This belief appears to have been due to the fact that different reactions were obtained according as the test solution had been allowed to stand for some time before using or not.

The method of testing for this ferment which was first used, was to add guaiacum tincture to milk. In certain cases the milk at once turned blue. In others this blue reaction was only brought about after hydrogen peroxide had also been added. It seems clear as a result of later observations that the difference arose from the fact that when guaiacum tincture is allowed to stand, a substance develops in it which can take the part of hydrogen peroxide and produce the blue colour at once without the addition of this substance. Guaiacum tincture is not so much used at the present time, since Storch, whose investigations have already been alluded to, discovered that a more reliable reaction was obtained when the substance known as para-phenylene-diamine was used, instead of the guaiacum tincture. It has already been mentioned that this reaction results in the formation of a grey-blue coloration in the milk. A number of other substances are now used to replace or act as supplementary tests to the para-phenylenediamine. Many of these substances strike extremely brilliant colours in the milk, and are believed by many to be equally reliable. In this country, however, the peroxidase test appears to be most usually carried out with para-phenylene-diamine, and this method will be regarded as the recognised one in the following remarks.

On the Presence of Peroxidase in Cows' Milk. - This ferment appears to be universally present in cows' milk. It is also widely distributed throughout the entire animal and vegetable kingdoms, being found in a very great number of vegetable tissues as well as in most animal tissues. It is present in blood in considerable quantities; in fact, a common test for the presence of blood is the test above alluded to, with guaiacum tincture. The desirability of possessing a reliable test for milk which has been heated is so evident as to need no further consideration. It applies equally in countries where the regulations demand that market milk shall be pasteurised, and in those, such as this country, where milk is expected to be sold in a raw condition.

Although this test does show roughly whether milk has been previously heated or not, it is not absolutely reliable. The disappearance of the colour reaction after the milk has been boiled is somewhat variable and depends upon the length of time of heating, the temperature to which the milk has been raised, and the rate at which the heating has been carried out. These con- 
siderations, influencing the effect of the reaction, have not been taken into due consideration. As a result, there is a great deal of discrepancy between the observations of the numerous investigators who have dealt with this subject. Some assert that heating to $75^{\circ} \mathrm{C}$., the temperature which was believed by Storch to be sufficient to prevent the reaction occurring, is inadequate. Others state that $70^{\circ} \mathrm{C}$. is sufficient if the milk be kept at this temperature for half an hour, and so on. Where the length of time of heating and the temperature to which the milk has been raised are unknown, and the reaction not very marked, difficulty is likely to arise in determining whether the milk can be considered to have been heated or not.

Further, where the dairyman desires that it should not be known that the milk has been heated, the addition of a small proportion of raw milk causes the reaction to return, and unless full precautions are taken, and a considerable series of observations carried out, the observer may be entirely deceived as to the presence of a large amount of heated milk. In spite of these drawbacks, however, no other method appears to be available for determining whether milk has been heated or not.

Much controversy has arisen in regard to the chemical mechanism which produces this reaction in milk. For some years past a discussion has been proceeding between several German dairy chemists as to the true state of affairs in regard to this substance. It is stated on the one hand that the reaction is not due to a ferment at all, and that it depends for its production upon the reaction of the milk, which must be alkaline for the production of this reaction; also that, even having due regard to the alkalinity, the presence of iron is instrumental in bringing it about. The opposite statement is that this reaction is a true ferment action inasmuch as, although it does depend upon the alkalinity of the milk, it is only in part dependent upon the reaction, and depends also upon the physical condition of the protein present in the milk. If the protein is in any way altered, the reaction is not produced, although the milk may be of the necessary alkalinity.

A number of observers have dealt with the relationship of this reaction to the presence of iron. It seems probable that it is connected with the presence of iron in colloidal form, and possibly also of manganese. This presents no difficulty when considered in relation to milk, since it has already been shown that iron is constantly present in milk, and the investigations which have been made show that the amount of iron present in cows' milk, although small, is quite sufficient to produce this reaction. Infinitesimally small quantities of manganese have also been found in the ash of milk by several observers. The full mechanism of this reaction is even now not entirely understood, but for the present purpose no difficulty is presented.

On the Presence of Peroxidase in Human Milk.-Numerous 
observers have investigated the peroxidase reaction in human milk with varying results. In some cases peroxidase has been stated to be present; in others no trace of it has been detected. It seems reasonable to suppose that when present it is present only in small quantities, and that frequently it is entirely absent in human milk. Some observers (Spolverini, Marfan and Gillet, Friedjung and Hecht) believed that the ferment is more constantly present in colostrum than in the later milk, and that its presence is probably due to the leucocytes, which are more numerous in colostrum than later. But even in colostrum no reaction was obtained in a certain number of cases. Friedjung and Hecht examined I74 samples of milk, and found the reaction to be negative in II4 cases. Some observers have failed to detect any peroxidase in the samples of milk examined by them, and have consequently believed that it was absent in human milk.

Efforts have been made to trace an effect upon the progress of the infant according as peroxidase was present in the milk of its mother or not. These have been entirely unsuccessful, no difference being detectable in the progress of the infants.

Summary of the Position in regard to Peroxidase in Milk.-It appears that peroxidase is constantly present in cows' milk, but that its presence is extremely inconstant in human milk. There is no reason to believe that it has any effect upon nutrition. The fact of its frequent absence in human milk would in any case tend to the belief that its effect was negligible.

Reductases, or Reducing Ferments.-The presence of these substances has caused as much discussion as that connected with the previous ferment, peroxidase. The early investigators discovered that the bright blue coloration, produced on the addition of methylene blue in small quantities to milk, frequently disappears if the milk is incubated, the milk becoming quite white. It was noticed that the time required for the colour to disappear varied considerably in different samples of milks. The disappearance of the colour is due to chemical changes which take place in the methylene blue. It is not necessary for the present purpose to enter into a long account of the reduction of methylene blue alone. It is now universally admitted that this reaction is brought about solely by the bacteria which have obtained access to the milk after milking. Efforts have been made to utilise this reaction to standardise the number of bacteria present and to enable an estimate to be arrived at of the " goodness ${ }^{2}$ or otherwise, of the milk for purposes of sale. But this is not a satisfactory procedure, since only certain strains of bacteria will effect this reduction, and no indication is given of the number of bacteria present which do not decolorise methylene blue. This reaction is frequently known as the direct reductase reaction.

In I902 Schardinger published a paper in which he showed that milk, when quite fresh, did not reduce methylene blue alone, but 
would do so when a small amount of formalin was added to the methylene blue solution. This solution, which is now very generally known by the name of its discoverer, Schardinger, is also referred to as the F.M.B. solution (that is, formalin-methylene-blue solution), and the reaction as the F.M.B. reaction, and this term will be used here. It is also known as the indirect reductase reaction.

The literature upon the Schardinger reaction is now nearly as extensive as that of the other ferments in milk. This reaction, which appears to be usually present in cows' milk, occurs only during the first few hours after milking. If the milk is quite fresh, the methylene blue will be reduced by the F.M.B. solution. After some twelve hours this reaction is no longer given, but is gradually replaced by the direct reduction of methylene blue owing to the presence of bacteria. Some observers have stated that the F.M.B. reaction is also bacterial, but this appears not to be the case, since it has been definitely found in milk obtained free from bacteria. This ferment cannot be regarded as having any influence upon nutrition. It acts only when formalin has been added to the milk, and therefore would not act at all in the stomach of an infant. Moreover, its action is entirely destroyed in an acid medium such as that of the infant's stomach. Further, by the time cows' milk has been brought to the infant, the reaction, even in the presence of formalin and an alkaline medium, will be no longer shown. The investigations which have been carried out have failed to detect this reaction in human milk, thus again accentuating the absence of value of this ferment from a nutritional standpoint.

On the Presence of Catalase. - The ferment which is known by this name has the power of splitting hydrogen peroxide with the evolution of oxygen. A vast aınount of work has been carried out upon the presence and origin of this ferment in milk, and, as already mentioned, efforts have been made to obtain a standard for the amount of catalase present, so that excess of this substance could be taken as denoting a pathological condition of the milk.

Catalase in Cores' Milk.-As a result of much investigation, it appears that catalase is universally present in cows' milk, although the amount of this ferment which is present, varies within considerable limits. Catalase is present in most tissues, and is found in large quantities in the blood. It is also formed by a great number of bacteria. These two last sources of catalase at once give possible origins of catalase in milk. It may be present either as a result of filtration from the blood, or may be the result of bacterial contamination of the milk after it has been collected. In market milk this latter source provides the greater part of the catalase content of the milk.

In order to determine the catalase content of milk as it leaves the udder, it is necessary to investigate the milk immediately after it has been collected. The milk should be free from bacteria. 
Several methods have been used for the estimation of the gas (oxygen) evolved as a result of the action of this ferment upon hydrogen peroxide, when added to milk. Some of the methods are fairly reliable, others appear to be less so. It is necessary for the apparatus to be shaken constantly or at very frequent intervals, if an approximately accurate estimate of the total gas evolved is to be obtained. Some of the methods do not provide for this.

The amount of oxygen collected from milk collected free from bacteria is very small, although somewhat variable. It has been shown by various authors ${ }^{1}$ that the catalase rises with the cream, and that if separate estimations be made of the oxygen evolved from the first milk, middle milk, and strippings, the content gradually rises as the end of milking is reached.

Rullmann, and Harden and Lane-Claypon, working on sterile milk, found that small quantities of oxygen were evolved even when there was no evidence of any bacteria present in the milk. Rullmann's results showed that in the first hour practically no gas at all was evolved, but that after eighteen to twenty-four hours the amount obtained from 20 c.c. of milk varied between 0.2 and 3.6 c.c. Harden and Lane-Claypon obtained larger quantities in a few cases, but much variation in the amount evolved was shown.

This brief summary of the large amount of work which has been carried out, which is described more fully in Chap. V, shows that catalase is present in milk which is uncontaminated by bacteria, in variable but always in small amounts. It is not known whether catalase plays any part at all in nutritional processes. It has been suggested by several authors that the almost universal presence of catalase in tissues has for its object the immediate splitting up of any peroxide which might be formed, which substances are believed to be detrimental to the life of the cells. It is difficult to attribute any importance to the small quantities of catalase present in fresh milk, especially when compared with the large amounts present in the blood. It is almost certain that the catalase present in the milk from a healthy gland, is derived from the blood by the process of filtration. Additional proof of this is afforded by the fact that in diseased conditions of the udder or in the later stages of lactation, when the milk assumes more of the characteristics of serum, the catalase content tends to be increased.

On Catalase in Human Milk.-Numerous investigations have been conducted as to the presence of catalase in human milk. There is a general concensus of opinion that catalase is present, but the amounts show great variations, both from day to day in the same woman, and between different women. As a whole, it is probably present in larger amounts when the gland is working feebly, owing to the poor health of the mother, and at the beginning

${ }^{1} \mathrm{Cp}$. Reiss, Jensen, and others. 
of lactation. No nutritional value has been attributed to it by any observer.

Two other ferments have been the subject of considerable investigations which do not belong either to the ferments acting upon substances present in milk, nor have they been used for commercial or public purposes. These ferments are amylase, which acts upon starch, converting it into dextrin, and salolase, which acts upon salol, converting it into phenol, and salicylic acid. It is difficult to imagine that either of these substances can play any part in the nutrition of the infant.

Amylase.-There is no starch in milk, but amylase is present in considerable quantities in the blood, and it is most probable that it is present in milk as a result of filtration.

Another source of this ferment may be the mammary gland, since Grimmer obtained evidence of its presence in his experiments on gland tissue, even in those animals where little or no amylase was found in the milk.

A considerable number of observers have investigated the presence in both cows' milk and human milk of a ferment capable of splitting starch into simpler bodies.

Amylase in Human Milk. - Human milk appears to possess the capacity of splitting starch, all observers being agreed upon this point. The amount of starch which can be converted within a period of a few hours is not large, although the action is quite definite. It has long been known that amylase is present in the blood, and it is probable that the presence of this ferment in milk is due to filtration through from the blood itself.

Amylase in Cows' Milk.-There is some difference of opinion among investigators in regard to the presence of amylase in cows' milk. A number of observers have entirely failed to find any evidence of this ferment in the milk of this animal. When found, it is present only in small quantities. Thus Giffhorn, in I9IO, found that Ioo gms. of milk will decompose from $0 I$ to $25 \mathrm{gm}$. of starch. In experiments carried out by myself upon cows' milk, it appeared that Io c.c. of cows' milk were capable of splitting from .00I to $002 \mathrm{gm}$. of starch in three hours in an incubator kept at a temperature of $37^{\circ} \mathrm{C}$. Evidently, therefore, the strength of this ferment in cows' milk is so small as to be insignificant, and, moreover, the digestive juices are much richer in amylase than is milk.

Salolase.-This substance has not so far been found in cows' milk, but it has been almost universally found in human milk by those who have investigated its presence. There is some doubt as to its true nature, since certain observers have stated that the reaction is still present after the milk has been boiled, which would not be the case were the reaction produced by an enzyme. It is difficult to postulate any value for this property of human milk in the nutrition of the infant, since salol is not present in milk nor in the infant's stomach. If it is not due to a ferment, it must 
be regarded as a property of milk which, if of any value, will emphasise the necessity for breast-feeding, but, since it is absent in cows' milk, can play no part in the nutrition of the infant fed artificially on cows' milk.

The following table summarises the facts dealt with in the preceding pages :

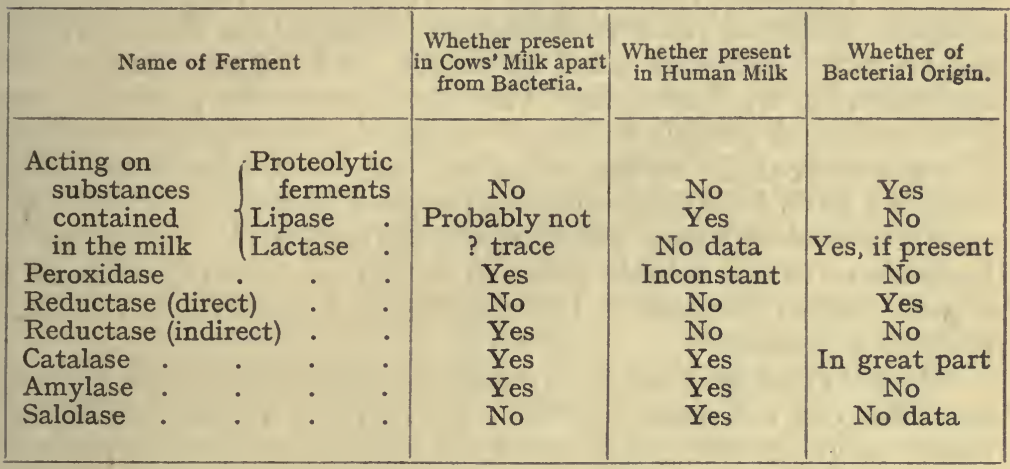

\section{CHAPTER V}

THE SO-CALLED 'BIOLOGICAL PROPERTIES' OF MILK

\section{A. The Ferments or Enzymes}

THE literature upon the subject-matter of this chapter would fil ${ }^{1}$ many volumes. Many authors have dealt with the different varieties of enzymes present, and have investigated the mechanism of their actions. Much of the literature, however, is concerned with other aspects arising out of the occurrence of the ferments, such as the detection of the heating of milk, the presence of disease in the udder of the cow, or of the number of bacteria present in the milk. All these aspects will need to be considered, although some will be briefly dealt with.

The ferments which have been found in milk can be placed under two main headings: I, those which might act upon the foodstuffs present in milk, thus aiding its digestion, and 2 , those which might assist in the oxidising and reducing processes in the body. The former group will be considered first.

The ferments which might act upon substances present in milk will fall into the following groups :

(I) Proteolytic.

(2) Lipolytic.

(3) Lactase. 
Proteolytic Ferments. In Cows' Milk.-A fair number of investigations have been carried out with a view to ascertaining whether proteolytic enzymes were present in milk. Prolonged investigations were carried out by Babcock, Vivian and Russell $(I, 2,3,4)$ (I898 and I899), by Freudenreich (I900), and by Boekout and De Vries (I, 2) (I899-I90I), all of which were more directly connected with the ripening of cheese than with proteolytic enzymes in milk as such. Babcock and his collaborators collected the milk carefully, but no initial bacterial count was made, and the milk was at once treated with an antiseptic. The experiments were carried out over prolonged periods (weeks or months), the amount of soluble nitrogen present at the beginning and end of the experiment being used as a basis for determining the presence of proteolytic enzymes.

Freudenreich (I900), who sterilised the milk with ether, obtained no increase in the soluble nitrogen within one month, although a slight increase occurred if the experiment was carried over more prolonged periods.

Boekout and De Vries $(I, 2)$ found that cheese made from pasteurised milk did not ripen, and that the increase of soluble nitrogen which occurs is very small compared with that which occurs with cheese made from raw milk. Bacteria appear to have been present in both forms of milk, and they conclude that the proteolytic activity observed was due to the action of bacteria.

Babcock and Russell $(x, 2)$ obtained evidence of the formation of albumoses and peptone, but they point out that the products of proteolytic activity, which were ammonia, amides, and peptones are suggestive rather of bacterial than of enzyme action.

Moro (3) (I9O2) carried out investigations of the action of milk upon fibrin suspended in this fluid. $\mathrm{He}$ obtained evidence of traces of proteolytic activity, but the milk was not known to be free from bacteria.

Zaitschek (I904) was unable to demonstrate any degree of proteolytic activity other than such as might be within the limits of experimental error. The small amount of activity found by Moro is probably due to the same fact.

A. J. J. Vandevelde (r), working both alone and with De Waele and Sugg, used milk which was not sterile, but to which acetoneiodoform solution was added. The experiments were carried out over fairly long periods, in no case less than five days, and some evidence of proteolytic activity was found. The degree of action was, however, very variable.

In none of these observations was initially sterile milk used, and there is no evidence to show that the proteolytic activity was not due to bacteria present in the milk. The addition of antiseptics does not preclude this possibility, since, although the bacteria themselves may be killed by the antiseptic, yet between the time of milking and the time of their death they may conceivably have produced proteolytic enzymes, which are not destroyed by antiseptics. 
The work of Spolverini (I) and Snyder may also be consulted.

Experiments undertaken by me for a report to the Local Government Board failed to show any evidence of the presence of proteolytic action in the milk. The milk was collected by a milking tube, and was free from bacteria; 50 c.c. of milk was incubated for 24-26 hours at $37^{\circ} \mathrm{C}$. The protein was subsequently precipitated and a portion of the filtrate examined for soluble nitrogen. Controls were also used. In no case was any increase of soluble nitrogen obtained as a result of the incubation.

In Human Milk. - The same remarks as to the presence of bacteria in the milk of cows are applicable here. The earlier observers, Spolverini (I, 2) (I902), Moro (3) (I902), Friedjung and Hecht (I903), stated that proteolytic activities were to be found in human milk. The milk, however, does not appear to have been free from bacteria.

Zaitschek was unable to detect any proteolytic activity in human milk, as was also Austin, who worked upon the milk of twenty-one women in different states of health. Austin obtained no hydrolysis of protein even after fourteen to sixteen days, and he concludes(I) that there is no evidence of auto-digestion of human milk, at least under the conditions appertaining to such digestion in organ tissues, and (2) that the digestive disturbances of infants fed upon human milk can have no relation to such an enzyme, as the milk of both healthy and sick women was examined.

Müller and Jochmann investigated the presence of proteolytic activity in colostrum expressed from the breast both before and after the birth of the child. They used a nutrient medium, consisting of blood, serum, and bouillon, in Petri dishes, the evidence of proteolytic activity being shown by any impairment of surface. These authors found that there was constant evidence of proteolytic activity in the fluid expressed in the last two months of pregnancy and in the early days after birth, but that this subsequently fell very rapidly, being small after the first few days and generally absent by the eleventh day. They believe that this action is due to the colostrum corpuscles. In view of the probability that some of the colostrum corpuscles are leucocytes, there is no difficulty in supposing that this ferment is present in colostrum, since leucocytes are known to show proteolytic activity.

Grimmer (I) investigated the presence of proteolytic ferments in the resting and active gland of a number of animals. He found that some degree of auto-digestion does take place in the tissue. He does not suggest the possibility of this action being bacterial in nature, and believes that it is present in the cells of the gland. The action was at all times too weak to have any effect upon foreign proteins, and was less marked in the resting gland than in the active gland. He also showed the presence of an ereptase which was capable of splitting polypeptides, with tyrosin as one of the products. 
The general evidence as to the presence of proteolytic enzymes in human or cows' milk tends to show that such enzymes are not present, except possibly in colostrum. The only reliable work is evidently that where the milk has been collected initially free from bacteria, in view of the presence of bacteria in the fluid examined.

A few authors believe that, apart from enzymes acting upon protein substances in milk, there is another enzyme acting on polypeptides. But here again, the milk used for the purpose of experiment was not initially sterile, but was treated with antiseptics.

Wohlgemuth and Strich found evidence of the hydrolysis of glycyl-tryptophane when this substance was added to both human and cows' milk, as also did Warfield for human milk.

Grimmer (5) thinks it possible that this ferment may occur only in the active gland, and that some degree of activity in the splitting of polypeptides, which was obtained by him in the resting gland, may be due to an additional proteolytic action, since the breakdown products obtained were different. The value of such a ferment, if it exists at all, is probably negligible, especially in view of the absence of proteolytic ferments in the milk itself.

Lipolytic Ferments. On the Presence of Lipase in Cows' Milk.Spolverini, (I, 2) Luzzati and Biolchini (I902), also Marfan and Gillet (I902), found that cows' milk was capable of splitting monobutyrin into butyric acid and glycerine. The action Marfan and Gillet found to be specific for this substance ; oil was not acted upon at all, nor other compounds of butyrin.

Moro (3) (I902) found that cows' milk had the power of splitting olive oil. The method used by him is not, however, sufficiently accurate to be convincing, the presence of fatty acid being tested for by the formation of an emulsion when alkali was added.

Leperre (I904) was unable to trace any decrease in fat content even after several weeks, the other constituents of the milk being, however, altered in quantity.

A. J. J. Vandevelde (2) (I907) determined the acidity of the milk as a test for the formation of fatty acids. The milk was treated with the acetone-iodoform mixture used by him, and after incubation was distilled. No change in the acidity of the distillate could be detected even after several weeks.

On the Presence of Lipase in Human Milk.-Spolverini, Luzzati, and Biolchini, also Marfan and Gillet, all found monobutyrinase in human milk.

Friedjung and Hecht (I903) also found the same, but did not investigate the presence of an autolytic lipase.

Hippius (I905), using Mankowsky's reagent for the detection of the presence of fatty acids, believed that human milk was capable of splitting olive oil. This reaction was destroyed by heating to $64^{\circ} \mathrm{C}$.

Davidsohn (I) found that the surface tension was reduced in 
human milk on standing, the reduction being more marked when the milk was put to stand in the cold. He attributes this phenomenon to the action of a lipase, and confirmed his results by using the stalagmometric method, which depends upon the number of drops falling per minute. Davidsohn points out that this phenomenon fits well with Ellenbeck's remarks upon the development of a stable haemolysin in human milk when this milk is allowed to stand in the cold. Neuberg and Reichert had previously shown that haemolysins and immune sera had lipolytic activities. It seems, therefore, that there is a connection between the lipase and an apparent haemolytic activity of milk. The presence of lipase in blood and in serum has been shown by Rona and Michaelis, and has been further investigated by Bauer, and also by Davidsohn (2).

Samelsohn found a strong lipolytic activity in the blood of infants of from two months to two years of age. The ferment was capable of splitting tributyrin. Less activity was shown by the blood of two atrophic children than by that of healthy children. It may probably be regarded as established that the ferment in blood and that in the milk are identical, although the amount present in the milk is very much less than that in the blood. The ferment probably reaches the milk by filtration.

On the Presence of Lactase and Glycolytic Ferments in Milk.Spolverini (I902) found evidence of glycolysis present in all the milks examined by him; Zaitschek, however (I904), found no change in reducing power on incubation, except in the case of bacterial contamination, and he hence considered that Spolverini's results must have been due to this cause.

Stocklasa (I904) prepared a ferment solution from milk by means of alcoholic precipitation, which he considered had lactosesplitting power. The milk used was not initially sterile, but was preserved by means of antiseptics; 50 c.c. of a 40 per cent. solution of lactose was used for each experiment, and the amount of lactose lost varied from $\cdot 32-\cdot 68$ gramme. The experiments were carried out over from three to five days, at $37^{\circ} \mathrm{C}$.

A. J. J. Vandevelde (3) (I908) believed that he had evidence of the presence in milk of a glycolytic ferment. The milk was not initially sterile, but was disinfected by means of iodoform and acetone. The amount of lactose present was estimated both by the polarimeter and by Fehling's method. There was no increase in reducing power, so that the lactose was not split into dextrose and galactose. The fluids used were found to be bacterial-free as a result of the addition of the disinfecting agent. Vandevelde carried his experiments over prolonged periods, and the amount of sugar lost, even after many months, was inconsiderable, and only occurred in the acetone-iodoform samples. The samples preserved with formol showed no change, or so little as to be negligible. Thus- 


\begin{tabular}{|l|c|c|c|}
\hline & After 27 days. & After 155 days. & After 429 days \\
\cline { 1 - 1 } Milk sterilised by heat . & Lactose per cent. & Lactose per cent. & Lactose per cent. \\
Milk and formol . & 4.63 & 4.76 & 4.50 \\
Milk and acet.-iod. & 4.63 & 4.63 & $4.3 \mathrm{r}$ \\
& 4.06 & 2.22 & 1.86 \\
\hline
\end{tabular}

In another case, after treatment with antiseptics, there was a decrease of 0.362 per cent. of lactose in three years and five months.

This work of Stocklasa's and Vandevelde's is open to the objection that the milk was not obtained free from bacterial contamination, but was only rendered sterile afterwards. The varieties of bacteria which will ferment lactose are very numerous, and it is, therefore, not unlikely that traces of ferment action might occur in the solution in presence of the bacteria killed by means of the antiseptics.

The only value that lactase in milk could have for the infant, must consist in the ferment acting with some rapidity upon the lactose within the first few hours. For this purpose the twentyseven days of Vandevelde's experiment have no significance, especially in view of the very small amount of sugar decomposed.

It was shown by Aders Plimmer (I906) that lactase is present in the alimentary canal at birth, and in some animals just before birth, in considerable amount, compared with which the strength of ferment obtained in milk by Stocklasa and Vandevelde fades into complete insignificance. Various authors have also detected lactase in the alimentary canal of new-born infants. ${ }^{1}$ Even if a ferment of the strength found by these observers is present in milk collected free from bacterial contamination, it is difficult to believe that it could have any biological value whatever. For this reason it will not be considered any further.

The Second Group of ferments will now be considered.

On the Presence of Oxidising Ferments in Milk.-The presence of an oxidising body in cows' milk was first mentioned by Klebs (I868). In the work by subsequent observers the action now known to be due to the ferment catalase appears to have been confused with that of the ferment now known as peroxidase. Babcock and Russell $(I, 2)$ demonstrated the presence of the two reactions, but believed that they were both manifestations of proteolytic activity. These authors worked with a ferment solution prepared by them from milk. The failure to differentiate between these two reactions led to considerable confusion in the work of the earlier observers. Raudnitz ( $\mathrm{I}$ ) in I898 stated his belief that the two reactions were due to separate bodies, and this was further conclusively shown by Loew (I) (I9OI) and Neumann-Wender (I) in I903.

${ }^{1} \mathrm{Cp}$. Ibrahim. 
After it had been shown that catalase and peroxidase were separate ferments, further difficulties arose because the reaction with guaiacum tincture was found to show two different phases. Some milks gave the reaction at once on the addition of guaiacum tincture, while in other cases it was necessary to add hydrogen peroxide, and for some time it was considered that these different phases were due to two different enzymes, one of which reacted directly with guaiacum tincture and the other did not. Numerous authors have investigated this question from varying standpoints, and there seems no doubt, at the present time, that the reactions are due to the same body. Where the reaction is given directly with milk and guaiacum tincture it is due to the formation of a peroxide or some similar substance in the guaiacum solution, so that the reaction occurs without the addition of the hydrogen peroxide. It has been found that this substance is present in guaiacum tincture which has been allowed to stand for a prolonged period, or has been exposed to the action of certain chemical substances. Thus Kowalewsky showed that the reaction occurred without addition of $\mathrm{H}_{2} \mathrm{O}_{2}$, when old guaiac tincture, which had stood in the light, was used. Bourquelot showed that the addition of hydrogen peroxide to the tincture produced the same result. Further confirmatory work has been carried out by NeumannWender ( $I, 2)$, Arnost, Waentig (I), and Siegfeld (I). Bach and Chodat have also reached the same conclusion, although using somewhat different terminology, and Moore and Whitley, working with vegetable extracts and also with milk, have shown the same. It seems, therefore, evident that only one ferment is concerned in the reaction with guaiacum tincture.

The work of Storch has already been referred to fully in the summary of this chapter, and in practical work Storch's method of using para-phenylene-diamine is more generally used than that with guaiacum tincture. The latter, in relation to milk, is now chiefly of historical interest.

In addition to Storch's method, a large number of other substances have been used by different authors to demonstrate the presence of this ferment. One of the better-known solutions is that prepared by Rothenfüsser, who used the hydrochloride of para-phenylene-diamine and also a mixture of guaiacol and paraphenylene-diamine. For further reference to the reagents employed, see Arnold and Menzel, Glage, v. Itallie, Weber, Wirthle, Zink, Chlopin, Utz $(2,3,4)$, Siegfeld (I), Kastle and Porch.

On the Presence of Peroxidase in Milk. Cow's' Milk.-No observer has failed to detect the presence of peroxidase in cows' milk, even when the milk is collected with such care that it is sterile. $C p$. Rullmann (4), and Harden and Lane-Claypon.

Human Milk.-Raudnitz (I) (I898) failed to obtain the peroxidase reaction with human milk using guaiacum and hydrogen peroxide; and he showed that this was not due to any inhibitory 
body, since when human milk was added to cows' milk the reaction with the cows' milk took place just as easily. He found, however, that human colostrum was active, and that the active substance was precipitated with the globulin fraction. It may be mentioned that in respect of this last point, Raudnitz found the same for cows' milk.

Moro (3) (I902), using the oxidation of salicylic aldehyde as a measure of the oxidising power, obtained negative results with human milk.

Spolverini $(2,3)$ (I902 and 1904) found a weak reaction with human milk, and showed that it became stronger if the milk assumed the character of colostrum. He believed that the ferment was attached to the leucocytes.

Nordmann (I902) published a case of a child who was fed upon the breast of a mother who was suffering from mastitis. The infant did not thrive, and on testing the milk it was found to be negative to Storch's reagent. Three samples of milk taken from other women gave a positive reaction, and Nordmann apparently attributed the infant's lack of progress to the absence of peroxidase. This paper produced a reply from Thiemich (I903), who showed that the presence of peroxidase is altogether uncertain. $\mathrm{He}$ examined the milk of a large number of women attending the Breslauer Klinik, and found that whilst it was usually present it was very inconstant.

Marfan and Gillet (I902) found that the reaction is present in colostrum, but disappears as the gland gets into full work; if, however, the gland is allowed to become less active, then the peroxidase again appears, and with it the leucocytes ; the peroxidase reaction may, however, appear rather earlier than the leucocytes. They found further that if milk giving the peroxidase reaction be examined under the microscope, on the addition of guaiacum and hydrogen peroxide, the area around the nucleus of the polymorpho-nuclear leucocytes became blue. The fluid around also showed a faint bluish tinge, so that, apparently, the substance can pass out.

Gillet, carrying this work further, showed that the presence of peroxidase is due to leucocytes, and that it is found both in the fluid and in the sediment of centrifuged milk.

He also examined the milk from a large number of women, and found, as Thiemich did, that the reaction was extremely uncertain; it varied even in the milk from the two breasts.

Friedjung and Hecht (Ig03), working on the milk from a large number of women, found that the reaction was negative in II4 out of 174 samples of milk examined, and varied greatly in intensity when present. As a whole the reaction was more marked in colostral milk, but it was often absent even there.

Jolles (1904) was so entirely unable to detect the presence of peroxidase in human milk that he suggested that the test should 
be 'used as a means of distinguishing cows' milk from human milk.

Kastle and Porch (I908) found the results of the peroxidase reaction very uncertain with human milk, even with the addition of their sensitiser trikresol ; the colostral stage appeared to have, as a whole, greater activity than the later milk.

Mechanism of the Peroxidase Reaction.-Much work has been done upon the mechanism of the peroxidase reaction. Peroxidase is present throughout the animal and vegetable kingdom, but has not been found as a result of bacterial action. ${ }^{3}$ The mechanism of this action has aroused the attention not only of dairy chemists but also of botanists and biological chemists. Solutions have been prepared by several investigators from plants and from milk, and there is strong evidence that all these solutions contain small quantities of iron and possibly also traces of manganese. The iron is said to be present in colloidal form, and Sarthou $(I, 3)$ showed that the reaction can be brought about when the solution contains as small an amount as 0002 per cent. of iron. ${ }^{2}$ Other investigators, who have incidentally confirmed the results obtained by the above authors, have shown that the reaction was of the same nature as that of a metallic sol and that, although the solution was inactivated by boiling, it could be reactivated by appropriate methods, such as the addition of platinsol, or by projecting milk in a fine jet at a high pressure on to an agate plate, or by the addition of pumice. ${ }^{8}$ Röhman and Shmamine believe that iron and other salts, as also certain organic bodies, have an affinity for hydrogen peroxide, to which they become attached. They believe that this probably occurs also with organic peroxides, and that this method of action may account for the action of the iron in the peroxidase reaction.

Some discussion has occurred between Grimmer $(2,3,4,6)$ and $\operatorname{Kooper}(I, 2,3,4)$ and Hesse and $\operatorname{Kooper}(I, 2,3)$ in regard to the method of action of the peroxidase in milk. Kooper and Hesse worked with Rothenfüsser's reagent, and believed that the reaction was dependent upon the alkalinity of the milk. Grimmer did not agree with this suggestion, and believed that the reaction was produced by a ferment, and that this ferment was connected with the albumin fraction of the protein in milk. The discussion has been continued for a considerable period, and neither of the authors appears to be convinced by the arguments of the other. Grimmer agrees that the reaction is affected by the alkalinity or acidity of the milk before boiling, but that it depends in reality upon the denaturalisation of the albumin.

Several observers have investigated the possibility of this reaction being due to bacteria present in the milk, but all have

${ }^{1} \mathrm{Cp}$. Fred and others.

${ }^{2} C p$. also Bertrand $(\mathrm{r}, 2)$, Van der Haar, Moore and Whitley.

${ }^{3} \mathrm{Cp}$. Engler and Wohler, Bordas and Touplain, and Meyer. 
failed to obtain the reaction in bacterial cultures so far investigated, although it was shown by Jensen to be present inside the cells of Oidium Lactis and Penicillium Glaucum. ${ }^{1}$

A good deal of work has been done in order to ascertain which of the constituents of the milk was primarily concerned with the reaction. Observers are to some extent divided in their opinion as to whether the caseinogen or the albumin is primarily concerned, but it would appear that the latter is the one most probably connected with the production of this effect. Thus Klebs, Raudnitz $(2,3,4)$, Barthel (I), Bordas and Touplain $(I, 2)$ believed that caseinogen was concerned in the peroxidase reaction, while Kowalewsky believed that it was connected with lactalbumin. Monvoisin found the reaction positive in the filtrate obtained after saturation with magnesium sulphate. Meyer showed that the reaction was not given by caseinogen alone, but that a positive reaction was obtained with cream from centrifuged milk as well as with the milk remaining behind, and also slightly with the sediment. Kooper (I) did not obtain the peroxidase reaction with cream, and Sames showed that the reaction was strongest in the first milk (that poorest in cream) and was often absent in the strippings (that richest in cream.) Sames also showed that the reaction was probably connected with the albumin fraction. Grimmer (I) showed that a solution prepared by saturating whey with ammonium sulphate, and subsequently dissolving the precipitate thus obtained, gave a strong peroxidase reaction.

The Effect of Heat upon the Peroxidase Reaction. - In using this reaction for the purpose of detecting the previous heating of milk, it is necessary to know at what temperature this reaction ceases to be given. The numerous observations upon this point are by no means concordant. It is not possible to deal in detail with the various results obtained, but the accompanying table, compiled in great measure from the tables given by Waentig (2) (I907) and van Eck (I9II), will show the most essential points. It illustrates the great difficulty of deciding upon the precise temperature at which the reaction ceases to be given, and therefore the exact temperature to which the milk may be considered to have been heated.

Van Eck (IgII) arranged a series of test-tubes containing varying amounts of raw and sterilised milk. (The sterilised milk was heated to $100^{\circ} \mathrm{C}$. for half an hour.) The series ranged from $9^{\circ} 9$ c.c. sterilised milk and $I$ c.c. raw, to 8 c.c. raw and 2 c.c. sterilised. After adding equal amounts of the reagent (Storch's test was used), these tubes formed a scale of colour which was used for each experiment as a standard colour scale, the colour depending upon the amount of fresh milk-that is, upon the amount of ferment present in each tube.

He then took some of the same milk and heated it gradually in a water-bath fitted with a stirrer, and, taking samples at different

${ }^{1} \mathrm{Cp}$. also Bellei. 
temperatures and intervals, he compared them with the standard colour scale for that experiment.

Using the values thus obtained, he found that the reaction followed the law for monomolecular reactions, and that the equation $\mathrm{K}=\frac{\mathrm{I}}{\mathrm{T}} \log _{e} \frac{a}{a-x}$ (where $\mathrm{K}=\mathrm{a}$ constant, and $a=$ concentration at time $\mathrm{O}, x=$ concentration at time $\mathrm{T}$ ), was true, and that hence the reaction was monomolecular in type. The effect evidently depends upon the length of time over which the heat is maintained,

\section{Table showing the Inactivation-point for Peroxidase, after different A uthors.}

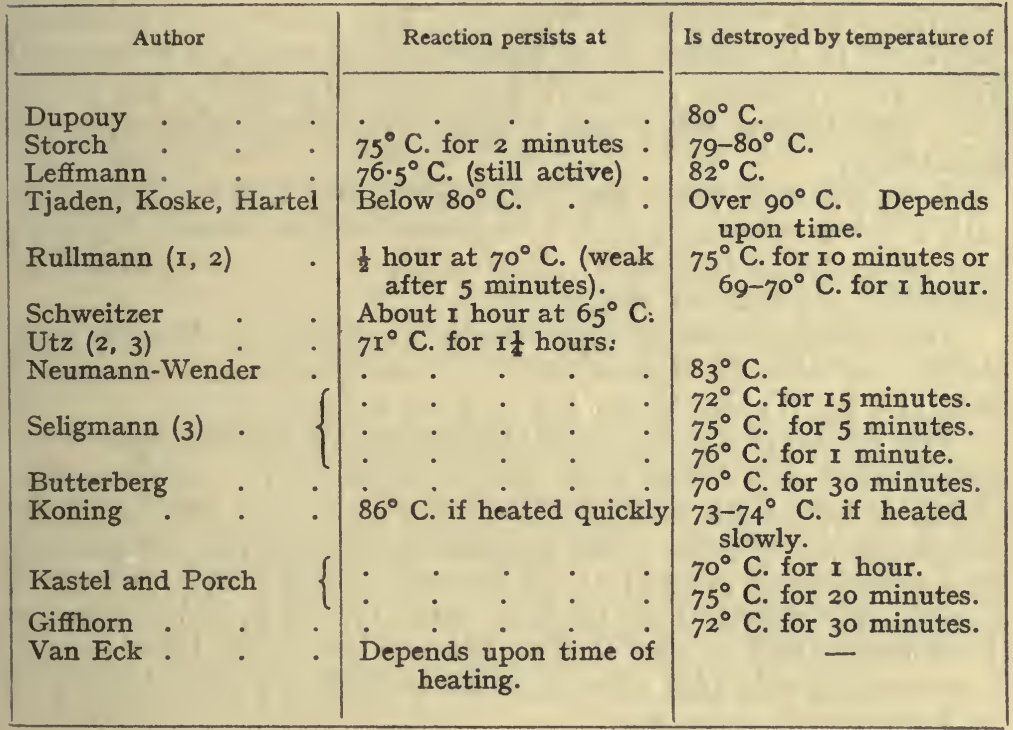

and van Eck points out that it is impossible with any one test to discover both the temperature and the length of time of heating.

There is no means of testing the amount of peroxidase present in milk; van Eck's work deals with the disappearance of such amounts of peroxidase as are present in the particular sample of milk considered, and not with absolute quantities. Further, the test for peroxidase can readily be restored to heated milk by the addition of a small amount of raw milk, if the presence of the reaction is required.

On the Presence of Reducing Ferments in Milk.-The reductases are bodies whose action consists in bringing about the chemical reduction of a given substance. 
Their action is most easily detected if the substance used changes colour as a result of the reduction. For this reason methylene blue has been found satisfactory, and has been largely, although not exclusively, used in the investigation of the presence of these ferments in milk. Methylene blue has been used alone-in which case, if it is reduced, the ferment or body causing such reduction is known as a 'direct reductase.' It has also been used with formalin, and the resulting reduction is said to be brought about by an ' indirect reductase.' This last body has also been called ' aldehydecatalase,' 'aldehyde-reductase,' 'formaldehydase,' and it has also been suggested by $\operatorname{Bach}(I, 2)$ that, following the general type of nomenclature, ' redukase 'would be more appropriate. Further, inasmuch as the reaction was first discovered by Schardinger (I), it is often known as 'Schardinger's reaction,' and on the assumption that the body is a ferment it is known as 'Schardinger's ferment.' These two reactions are most frequently denoted by the letters M.B. (methylene blue) and F.M.B. (formalin-methylene-blue) respectively.

In addition to these two substances some authors have dealt with a third reducing agent, hydrogenase, which converts sulphur into sulphuretted hydrogen. This action will be considered after the direct and indirect reductases.

The reducing power of milk was shown in 1897 by Vaudin using indigo, and also by Neisser and Wechsberg (I900) for methylene blue, and by Wynter Blyth (IgOI) using litmus.

The literature dealing with the reducing ferments began on a considerable scale about I902, and since this date a vast number of papers have been published dealing with various aspects of the reducing power of milk. The question has been further complicated by a considerable amount of controversy, which cannot be said to be altogether closed at the present time. It will probably simplify the consideration of the various issues which have been studied in connection with this class of bodies in milk, if a short history of the literature be given first.

Schardinger (I) in I 902 published his first paper on the reducing properties of milk. He showed that when milk was quite fresh it did not reduce methylene blue unless formalin was added to the solution. The solution used by him for this test was made up of:

5 c.c. saturated solution of methylene blue,

5 c.c. formalin,

Igo c.c. water,

and is known generally as Schardinger's reagent or solution. Schardinger concluded that (I) either an aldehyde substance was necessary for the reduction of the methylene blue, which was ordinarily formed gradually in the milk by the action of bacteria, being replaceable in the early stages by formaldehyde or some other 
similar substance, or (2) that the reaction was due to the "living protoplasm' of the bacteria. He believed the latter to be a more likely explanation.

This latter view was also that of Cathcart and Hahn, who in the same year had demonstrated the power of many bacteria to reduce methylene blue, and who believed that the property was probably attached to the protoplasm of the cell.

Schardinger's reaction was most marked at a temperature of $45^{\circ}-50^{\circ} \mathrm{C}$., the colour usually disappearing within thirty minutes after incubation.

Schardinger's work showed that it was likely there were two separate actions in milk connected with the reduction of methylene blue. Schardinger himself believed that this reduction could be used as a means for detecting the difference between raw and boiled milk. For a time, work upon the reduction of methylene blue was concentrated upon this latter point, but no decisive result was obtained. Gradually the work turned more particularly upon the cause of the two reactions of methylene blue, and it was shown by numerous observers that Schardinger's reaction was probably due to a ferment, the reduction of methylene blue alone being due to bacteria.

Another series of observations was concerned with endeavouring to utilise the reduction of methylene blue alone, as a method of estimating the number of bacteria present. The efforts, however, resulted in failure.

On the Differentiation between Direct and Indirect Reductase.-A number of investigators have followed up Schardinger's original paper in regard to the differentiation between the reaction with F.M.B. in fresh milk and the reaction with M.B.alone, in milk which has been kept for some hours.

Smidt (I) showed that there were three factors in milk which could bring about the reduction of methylene blue (he appears to have regarded this action as a catalytic one).

These three factors were:-

I. Lactose, or other substances which became alkaline on boiling,

2. Ferments, and

3. Bacteria.

Smidt showed that fresh milk a few hours after milking gave a positive reaction with Schardinger's reagent but not with methylene blue alone. The reaction with formalin-methylene blue was weakened by heating to $70^{\circ} \mathrm{C}$. and destroyed by heating to $75^{\circ} \mathrm{C}$. for twenty minutes. He considered this reaction to be due to a ferment which he called aldehyde-catalase.

The rate of reduction of methylene blue alone, depended upon the number of bacteria present and was in direct relation to it. 
$\mathrm{He}$ also showed that lactose in alkaline solution at $45^{\circ}-50^{\circ} \mathrm{C}$. gives decolorisation in a few minutes, and methylene blue is reduced when milk is boiled for about fifteen minutes, provided the dye is added at boiling temperature or before boiling.

He therefore considered that the reaction with formalin-methylene-blue was different in origin from that with methylene blue alone.

In effect Smidt's views have been almost universally acknowledged to be correct, although a vast amount of labour has been bestowed upon the subject since his paper appeared.

Following Smidt's work, Seligmann $(2,4)$ endeavoured to show that both reactions were due to bacteria, but his results as regards the F.M.B. reaction have not been confirmed by subsequent workers.

Jensen showed that numerous organisms commonly present in milk can produce a direct reductase. He found that really pure milk did not reduce M.B., but only F.M.B. Koning's investigations also showed the same, as did those of Butterberg and Brand. Similar results were also obtained by Oppenheimer and Sommerfeld. The observations of Oppenheimer showed that when milk is fresh and has been carefully collected so as to be free from bacterial contamination, F.M.B. is reduced within fifteen minutes at $50^{\circ} \mathrm{C}$. and within seven and a quarter minutes at $70^{\circ} \mathrm{C}$. The rate of reduction was found to have no connection with the bacterial content.

Sommerfeld, Barthel $(3,4,5)$ and Schroeter endeavoured to obtain a relationship between the rate of reduction of methylene blue alone and the number of bacteria present. The matter was also dealt with by Jensen, and results have been tabulated by Barthel (5) and are given below. No relationship is shown between the reduction time and the bacteria present.

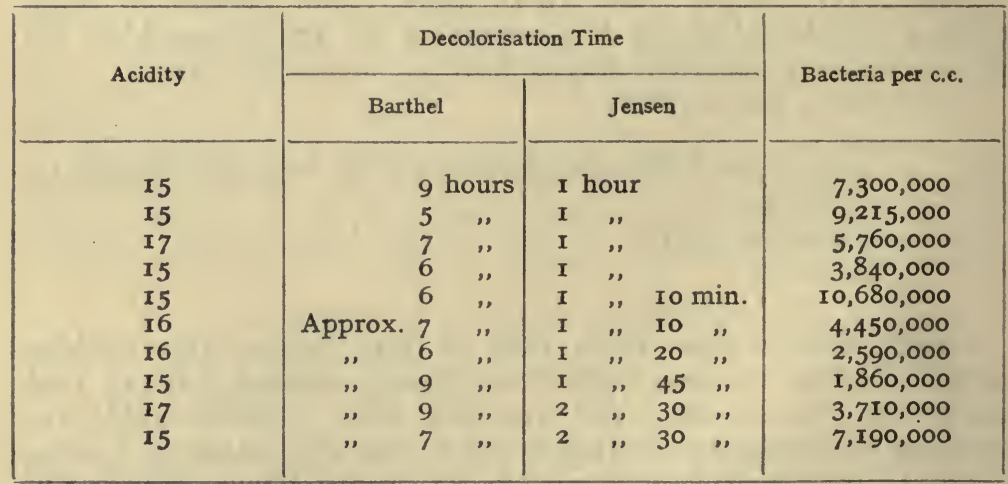

Fred investigated the reducing power of twenty-two strains of bacteria found in milk. Of the twenty-two used, twenty-one 
showed reducing power for methylene blue. He considers that if reduction occurs in

Less than 3 hours the milk is of poor quality.

In $3-7$ hours the milk is of fair quality.

In over 7 hours the milk is of good quality.

Reduction in less than one hour, i.e. a quarter or half an hour, denotes a bacterial content of fifteen to twenty millions; if the period is over seven hours the content will be less than one million per c.c.

Bertin-Sans and Ganjoux (2) were unable to establish any relationship between the reduction time and the bacterial content. Their results, however, agree generally with those of Fred, as they consider that milk which reduces M.B. in a quarter of an hour must be regarded as bad, and pasteurised milk should not effect reduction in less than seven hours.

Schardinger's Reaction.-The importance of a reliable test for boiled milk in contradistinction to raw milk has already been pointed out, and it has been shown that the peroxidase reaction has been largely used for this purpose. Evidently, when the boiled milk can have the property upon which the test rests restored by some artificial means after it has been boiled, the value of the test is almost at once negatived.

Utz pointed out that the results obtained with Schardinger's reagent depended upon the alkalinity of the milk. Milk, when fresh, has an alkaline reaction, but stale milk having an acid reaction did not give the F.M.B. test. $\operatorname{Utz}(2,3)$, however, showed that the reduction could be restored even in sour milk by the addition of an alkali. If this is the case, evidently Schardinger's test cannot be regarded as a reliable one for the previous boiling of milk.

The matter was further considered by Siegfeld (2), who believed it to be unreliable, and by Rullmann $(2,5)$, who believed that the reaction was positive even after the milk had been heated to $68^{\circ} \mathrm{C} .1$

Several later observers have dealt with the restoration of the Schardinger reaction by the addition of alkali and also by the addition of an iron solution to milk which has been boiled. Brand showed that the addition of alkali, even to raw milk, aids the F.M.B. reaction, which cannot be reproduced in boiled milk by this means. Koning confirmed these results, but showed further that the addition of lactose to sterilised or boiled milk is capable of restoring the F.M.B. reaction.

Römer and Sames showed that even when milk has ceased to give Schardinger's reaction it will at once do so if a small amount of I per cent. solution of ferrous sulphate be added. The reaction, however, is negative if the ferrous sulphate has been previously

${ }^{1} C p$. also Utz (5), Schardinger (2). 
boiled. The solution alone does not reduce F.M.B. in water solution.

Wedemann showed that the milk of goats (which has been found by numerous observers to contain no ferment capable of reducing the F.M.B. solution) will give reduction on the addition of alkali in sufficient quantities to be alkaline to lackmus or on the addition of ferrous sulphate. He confirmed the presence of this ferment in cows' milk.

Rullmann $(3,4)$ showed that formic acid could replace formaldehyde in the reduction of the F.M.B. reaction. He first showed that the addition of lactose to soda had an appreciable effect in reducing the time required for reduction both of M.B. and of F.M.B. in boiled or sterilised milk. He also showed that lactose alone does not produce this effect.

Rullmann also carried out a number of investigations relating to the restoration of the reaction in boiled milk or sterilised milk. $\mathrm{He}$ concludes that there is a substance present in milk which is capable of bringing about the reduction of Schardinger's reagent at $45^{\circ}-50^{\circ} \mathrm{C}$. apart from bacteria, and that this substance is probably a ferment; that reduction of the same reagent can also be brought about at higher temperatures by substances present in milk, i.e. lactose and salts, which probably assist in the reduction of the reagent at the lower temperature. The presence of a ferment which reduces Schardinger's reagent, in milk obtained free from bacteria, first shown by Rullmann, was confirmed by Harden and Lane-Claypon.

Burri and Kursteiner carried out prolonged observations upon the Schardinger reaction, and they confirmed the belief of previous authors that the reaction is due to the presence of a ferment whose action can be simulated by the addition of alkali or ferrous sulphate. They suggest the name 'formaldehydase' for the ferment concerned. They believe that the length of time required for reduction depends upon the presence or absence of oxygen, being prolonged when oxygen is present and curtailed when oxygen is removed. Burri and Schmid had also shown in IgII that milk of a lower bacterial content, I0,000 to 30,000 per c.c., shows a reduction in the time required for the Schardinger reaction if it is cooled to $12^{\circ} \mathrm{C}$. or boiled before testing. The authors connected this alteration in reduction time with changes occurring in the fat globules on cooling, described by Burri and Nussbaumer.

Lagane ( $\mathrm{I}$ ) found this ferment present in cows' milk unless the cow is in poor health or unless she had not been milked recently. The blue colour reappeared after reduction in from two to four hours, being more rapid when there is a greater exposure of the surface to the air. This seems to harmonise with the findings of Burri and Kursteiner. Lagane showed that the sediment gave no reduction, the reaction depending upon the fat. The 
phenomenon disappears with boiling and is reduced in power by heating for fifteen minutes at $80^{\circ} \mathrm{C}$.

If the milk is allowed to stand after the colour has returned, this will again disappear owing to the development of bacterial activity.

On the Constituents of the Milk which are concerned in the F.M.B. Reaction.-Various investigations have been made concerning the relation of indirect reductase to fat or to leucocytes. Generally, there appears to be agreement in regard to the relation between the ferment and fat globules. Seligmann $(2,4)$ showed this in I905-6, and was confirmed by Jensen, who gives results shown in the following table:

\begin{tabular}{|c|c|c|c|c|c|}
\hline Milk & & & Bacteria per c.c. & $\begin{array}{l}\text { Fat Content } \\
\text { per cent. }\end{array}$ & $\begin{array}{l}\text { Reduction Time } \\
\text { of F.M.B. }\end{array}$ \\
\hline Ist Experiment : & & & & & \\
\hline First milk & 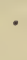 & . & 16,000 & $\cdot 55$ & $\begin{array}{l}\text { Not in three } \\
\text { hours. }\end{array}$ \\
\hline Middle milk & . & • & $4^{80}$ & $2 \cdot 70$ & $120 \mathrm{~min}$. \\
\hline $\begin{array}{l}\text { Strippings } \\
\text { 2nd Experiment : }\end{array}$ & . & . & 360 & $8 \cdot 30$ & $15 \ldots$ \\
\hline First milk & . & . & 3,200 & I. 5 & $90 \quad$, \\
\hline Middle milk & . & . & 2,800 & $3 \cdot 40$ & $75 \quad$, \\
\hline $\begin{array}{l}\text { Strippings } \\
\text { 3rd Experiment : }\end{array}$ & . & . & 360 & $7 \cdot 80$ & $14 \quad$, \\
\hline First milk & - & • & - & $I \cdot 70$ & I05 ", \\
\hline Middle milk & - & . & - & $3 \cdot 35$ & $80 \ldots$ \\
\hline Strippings & . & . & - & $6 \cdot 40$ & I6 ", \\
\hline
\end{tabular}

Brand believed that the ferment was only in part attached to the cream, since some action was obtained in the milk after the cream had been removed. Monvoisin, on different grounds, did not believe that it was attached exclusively to the fat globules. Koning stated that colostrum reduced F.M.B. more slowly than ordinary milk, while Smidt (2) agreed with the previous observers who had shown that the reductase for F.M.B. goes up in the cream on centrifuging, and cannot be washed away from it.

Sassenhagen finds that the F.M.B. reaction is not given by colostrum, but may be obtained in the later colostral period with centrifuged cream.

Mechanism of the Indirect Reductase Reaction.-The consideration of the mechanism of this reaction falls outside the scope of the present work. Investigations by Bredig and Sommer, Bach $(I, 2)$, Paal and Gerum suggest that the action of this ferment in milk is probably identical with that of the metallic sols. Further details are given in my report to the Local Government Board, New Series, 76. 
On the Presence of Reductases in Human Milk.-The amount of work which has been done upon the reducing substances in human milk is small, but enough has been done to obtain reliable information in this direction. It is much easier to obtain human milk free from any great degree of bacterial contamination than cows' milk, although the amount obtained is small.

Gillet (1902), using Abelous and Girard's method of testing for reduction by the conversion of nitrates to nitrites, obtained negative results.

Hecht (I904), who worked exclusively with human milk, obtained reduction of methylene blue alone, in from one to two days, but he was not sure that his samples were sterile, and does not appear to have controlled them by plating out. The time of reduction is entirely in accord with the reduction by bacteria, and by no other agency. In one case where special precautions were taken to ensure sterility no reduction was obtained. Reduction was stopped by a temperature of from $60^{\circ}-80^{\circ} \mathrm{C}$. Above this temperature reducing powers again appeared on prolonged heating, presumably due to the lactose.

Hecht does not appear to have used Schardinger's reagent, and his results were most probably due to bacterial growth.

Rullmann (2), Smidt (I), Koning and Sassenhagen, using Schardinger's reagent, obtained negative results with human milk.

Hydrogenase in Cows' Milk.-There remains one more substance to consider under the heading of reducing bodies, namely hydrogenase, or that ferment which has the property of forming sulphuretted hydrogen from sulphur.

The literature is not inconsiderable, and the results are quite conclusive. In I89I Rösing, in the course of his researches into the production of $\mathrm{H}_{2} \mathrm{~S}$ from egg-white, found that if sulphur was added to milk it was sometimes possible to obtain the reaction for sulphuretted hydrogen; the result was, however, sometimes negative.

Raudnitz (3) (I902) in his excellent résumé of the literature deals briefly with the question of hydrogenase, and states that he himself had not been able to detect $\mathrm{H}_{2} \mathrm{~S}$ in milk on the addition of sulphur; the same was also stated by Schardinger (I902).

Utz (I) (I903) obtained $\mathrm{H}_{2} \mathrm{~S}$ from milk on the addition of sulphur after prolonged boiling.

Hoeffter (I904), like Rösing, found that fresh milk sometimes gave reduction of sulphur; the negative samples, however, also reduced after they had been incubated for one or two days. The addition of antiseptics prevented this development, and as a result of these and of other experiments, he concludes that the development of $\mathrm{H}_{2} \mathrm{~S}$ in milk upon the addition of sulphur, is bacterial in origin.

Jensen (I906) also came to the same conclusion.

Brüning (I906) did not detect hydrogenase in fresh milk, but 
he found that if fresh milk was inoculated with stale milk $\mathrm{H}_{2} \mathrm{~S}$ appeared on the addition of sulphur. He considered that B. coli was especially active in the production of $\mathrm{H}_{2} \mathrm{~S}$ from sulphur.

Rullmann (4), using milk which was obtained sterile by means of the milking-tube, was unable to detect hydrogenase in any case. He concluded that the formation of sulphuretted hydrogen from sulphur was bacterial in origin.

Catalase.-The ferment to which this name is given has the property of splitting hydrogen peroxide with the evolution of molecular oxygen, after the equation

$$
2 \mathrm{H}_{2} \mathrm{O}_{2}=2 \mathrm{H}_{2} \mathrm{O}+\mathrm{O}_{2} \text {. }
$$

The early investigators did not differentiate catalase from the other ferment-actions noticed by them, but observations of Bach and Chodat, confirmed by Neumann-Wender (I), showed definitely that catalytic activity was separate from the other ferment actions.

The use of hydrogen peroxide for the preservation of milk was suggested by Buddé, and the process so introduced is known as buddisation. This process was investigated by Chick, who worked upon the presence of catalase in milk in order to test the value of hydrogen peroxide as a preservative. Chick showed that milk had the power of splitting hydrogen peroxide, but that the addition of fairly large amounts of this reagent removed this power. Concurrently with the disappearance of the reaction, the milk became sterile owing to the bacteria being destroyed. She showed further that when milk, which had been rendered approximately sterile by boiling, received the addition of a small amount of raw milk, the capacity for splitting hydrogen peroxide gradually returned. These facts pointed to the production of catalase by bacteria present in the milk, but did not preclude the presence of catalase in the milk apart from that produced by bacteria.

Method of Estimation of Catalase.-The amount of catalase present in milk is estimated by ascertaining the amount of hydrogen peroxide which is split by the enzyme, as measured by the amount of oxygen evolved. It is necessary to shake the apparatus used at frequent intervals, or a correct estimation of the oxygen is not obtained. Evidently also precautions must be taken to equalise the pressure inside and outside the apparatus.

Various authors have designed different methods for the estimation of catalase. For the most part I0, I5, or 20 c.c. of milk have been employed, to which 3 or 5 c.c. of a weak solution of hydrogen peroxide have been added. Many observers use a 3 per cent. solution of the peroxide; others have used a weaker solution.

The apparatus is usually kept in a water-bath, and the experiment does not extend over a prolonged period. Descriptions of the methods used will be found in the papers by Koning, Burri 
and Staub, Gerber and Ottiker, Kooper $(2,3)$, Harden and LaneClaypon.

Kooper showed that the results obtained by the different apparatus were not identical, and he endeavoured to obtain a correction factor for the different methods, but without appreciable success.

In dairy produce Lobeck's apparatus ${ }^{1}$ appears to be the most widely used. The disadvantage of this apparatus lies in the absence of facilities for adequate shaking, which tends to give inaccurate results. For ordinary dairy purposes the estimation need only be correct within certain limits, but it is doubtful how far the dairyman, in this country at any rate, places any reliance upon the estimation of catalase in determining the quality of the milk.

Sources of the Catalase found in Cows' Milk. -The estimations of the catalase content of milk showed that the amount of catalase increased when the milk was kept. Chick's work, already referred to, had indicated bacteria as a probable source of catalase in milk. Several observers have investigated the formation of catalase by bacteria, and have shown that a large number of these organisms produce this enzyme in the course of their growth.

Seligmann $(I, 2,4)$ isolated from milk a strain of cocci which produce large quantities of catalase on being cultured. Koning showed that bacteria will produce catalase, and found, further, that these bacteria would not produce peroxidase, and hence deduced that catalase and peroxidase were different enzymes. Jensen found that a number of organisms would produce catalase. Sarthou (2), Kooper $(I, 2)$, and Faitelowitz all showed that the catalase content of milk increases with the age of the milk, and they believed that this was due to the formation of catalase by bacteria.

Sarthou showed that catalase was formed if, after heating, the milk was inoculated with a lactic-acid-forming organism, and Kooper found that milk collected initially with full precautions against bacterial contamination had a lower content of catalase. If, however, such carefully collected milk was contaminated by the addition of a small piece of solid excreta, the catalase content rose very greatly. Further, he showed that catalase could be produced in boiled milk, if such milk was inoculated with raw milk.

The increase of catalase in milk can be inhibited by the addition of antiseptics, which are well known to prevent the growth of bacteria. Faitelowitz used chloroform and formalin for demonstrating this fact, and Barthel (3) and Smidt (2), working independently, showed that although the milk was rendered sterile by antiseptics, catalase was still present, and they believed that probably there was some other source of this enzyme, apart from bacteria. The milk used by these observers is not stated to have been germ-free.

In order to establish the presence of any original catalase

$1 \mathrm{Cp}$. Gerber and Ottiker. 
in milk, it is necessary to collect samples free from bacteria. This was carried out in the first place by Rullmann (IgII) and later by Harden and Lane-Claypon. The results obtained by these observers leave little doubt that even when there are no bacteria present, as shown by growth on culture media, or when bacteria are present in such small numbers as to be negligible, tracesof catalase are present in most samples.

Rullmann (4) used twenty samples of milk, and gives the following figures for the oxygen evolved :

After I hour $\quad \cdot \quad$. Nil, or only a trace.
After I2-I8 hours $\quad \cdot \quad \cdot 0 \cdot 2-3.8$ c.c.
After I8-24 hours $\quad \cdot \quad \cdot 0 \cdot 3-3.6$ c.c.

Milk which was not entirely free from bacteria showed the presence of rather more catalase when investigated over longer periods, than in the case of the sterile samples.

The results obtained by Harden and Lane-Claypon showed considerable variation in even the sterile samples of milk. Using 50 c.c. of milk, they obtained amounts varying from 3.7 to $6 \cdot 0$ c.c. of oxygen when the time was less than four hours-in several cases less than one hour.

There can be little doubt that there are two sources of origin for the catalase in cows' milk, but the greater part of the catalase in ordinary market milk is of bacterial origin.

Efforts have been made to connect the catalase with one of the constituents of milk, and the investigations of several observers show that the cream is richer in catalase than other parts of the milk. The catalase, however, has been found to be easily removed from the cream by washing, so that it seems unlikely that the catalase is an integral property of the fat globules. ${ }^{1}$ The figures given by Jensen upon this matter are interesting and show also the absence of relationship between the bacteria present in small numbers and the amount of catalase.

\begin{tabular}{|c|c|c|c|c|}
\hline- & & $\begin{array}{c}\text { Fat Content } \\
\text { per cent. }\end{array}$ & Bacteria per c.c. & $\begin{array}{l}\text { Oxygen from } \\
\text { ro c.c. Milk }\end{array}$ \\
\hline \multicolumn{5}{|l|}{ Cow I : } \\
\hline First milk & . $\quad$. & .55 & I 60,000 & trace \\
\hline Middle milk & $\dot{0}$ & $2 \cdot 70$ & 480 & .5 c.c \\
\hline Strippings & $\dot{.}$ & $8 \cdot 30$ & 360 & $2 \cdot 0$ C.c \\
\hline \multicolumn{5}{|l|}{ Cow $2:$} \\
\hline First milk & . & $I \cdot 5$ & 3,200 & .5 c.c. \\
\hline Middle milk & . $\quad$. & $3 \cdot 4$ & 2,800 & I.O c.c. \\
\hline Strippings & - $\quad$. & $7 \cdot 8$ & 360 & I.5 c.c. \\
\hline
\end{tabular}

${ }^{1} C p$. Reiss, Heygendorff and Meurer, Moyer. 
Other observers consider there may be some connection between the leucocytes and the amount of catalase, but this cannot be considered as definitely proven. ${ }^{1}$

Catalase in Human Milk.-Catalase appears not to be universally present in human milk although it has been found in small quantities in the majority of samples examined. Friedjung and Hecht found that while great variety in amount was exhibited, the amount being always small, the general average was increased in milk having colostral characteristics or in the last portions of milk taken from the gland, i.e. in that which is richest in fat. V. d. Velden believed there was some degree of relationship between the cell content and the catalase, while the Tordays, working together, believed that the catalase content depended in some measure upon the health of the mother, being less when the mother was in good health. All observers, however, agree that wide variations exist in the amount of catalase present, and clinically no relationship has been able to be traced between the nutrition of the infant and the amount of catalase present in the milk of its mother.

For further information the work of Raudnitz (1), Luzzati and Biolchini, Marfan and Gillet, Friedjung and Hecht, Jolles, Bier, van der Velden and E. and A. Torday should be compared.

On the Amount of Catalase as determining the Quality of the Milk.-Efforts have been made to establish a standard for the amount of catalase which should be regarded as normal, or the amount which should be regarded as rendering milk unfit for use, the catalase content being taken as denoting the presence of certain definite numbers of bacteria. No exact standard has been reached, although such have been recommended by numerous observers, and several authors agree upon the standard which should be observed.

Raudnitz (4) (I903) showed that the amount of catalase present in milk was very variable, as did also Koning. Lam, using ro c.c. of milk and 5 c.c. of I per cent. $\mathrm{H}_{2} \mathrm{O}_{2}$, considered that if more than from 0.3 to I c.c. of oxygen were evolved the milk was not good. Gerber and Ottiker, using 9 c.c. of milk and 3 c.c. of I per cent. $\mathrm{H}_{2} \mathrm{O}_{2}$, gave the standard which might be allowed as from 2.5 to 3 c.c. of oxygen. If this amount was exceeded they believed that there was probably a considerable amount of dirt in the milk or that the cow was diseased. Heygendorff and Meurer, and Schroeter were unable to obtain any satisfactory standard which could be used for the number of bacteria present. The irregularity of the figures is shown by Schroeter, who gives the following:

$\begin{array}{ccc}\text { Bacterial Count } & \text { Sediment Figure } & \text { Oxygen given off } \\ \text { II, } 775,000 & \cdot 25 & 6.5 \text { c.c. } \\ \text { I2,000,000 } & -3 & 2.25 \text { c.c. }\end{array}$

${ }_{1} C p$. Jensen, Barthel (x), Bertin-Sans and Ganjoux (I). 
Variations in Catalase Content.-The content of catalase is greatly increased in inflammatory conditions of the udder, and Kooper (3) believes that differences may be detected between the breed of cows and the catalase content of milk. There is, further, a general consensus of evidence to show that the catalase content of milk increases when the gland is nearly 'dry,' and also probably in colostrum. It appears, therefore, that when the gland is commencing or ceasing its activity, or when there is inflammation, the amount of catalase is usually increased.

In view of the very large amount of catalase present in blood, it is unlikely that no trace of this enzyme would be found in the milk, more especially when the blood supplied to the gland is probably increased or when the milk supply is running short. For further detailed information upon this subject compare the work of Bier, Giffhorn, Gerber and Ottiker, Spindler, Koning, and Bertin-Sans and Ganjoux (I).

On the Presence of Amylase.-The action of amylase is to break down starch or amylum into simpler substances. It appears that starch is not converted by this enzyme to a further stage than maltose, and that unless this medium be acid (Mellanby and Woolley) it remains for the most part in the stage of dextrins.

Amylase has been shown to be present in milk, and it is probable that in this medium starch is not split further than dextrin. The difficulties, however, of estimating the end point of this reaction in milk are very great, since it is almost impossible to detect the formation of minute quantities of maltose.

Amylase in Cores' Milk.-Investigators are not unanimous upon the presence of amylase in cows' milk, and it does not appear that it is present in more than very small quantities in the milk of this species.

Spolverini (I902) was unable to obtain evidence of the presence of amylase in cows' milk, but Zaitschek (I904) found evidence of amylolytic activity in all the samples of milk examined by him. $\mathrm{He}$ estimated the amount of starch hydrolysed by weighing the increase of reducing sugar which occurred during incubation, the sugar being calculated as maltose.

Koning (I906) showed that certain bacteria were capable of producing amylase, but he believed that the action found by him in cows' milk was not due to bacterial contamination. He collected the milk with the greatest care and the investigations were carried out over short periods only. He found that about $\cdot 0{ }^{5}$ to $\cdot 02 \mathrm{gm}$. of starch was decomposed by roo c.c. of milk in half an hour. The first and middle milks were richer in amylase than the strippings, but any increase in strength beyond that given was regarded by him as pathological. The activity was destroyed by heating the milk for forty-five minutes at $68^{\circ} \mathrm{C}$.

Giffhorn found that roo c.c. of milk would decompose from -or to $.25 \mathrm{gm}$. of starch, the amount of enzyme present being increased 
in pathological conditions of the udder. He found that the enzyme action was destroyed by heating to $65^{\circ} \mathrm{C}$. for thirty minutes.

Wohlgemuth and Strich were unable to obtain evidence of the presence of amylase in cows' milk. They showed that in the dog, if the pancreatic duct was tied while the animal was in full lactation, the amylase content of the blood and subsequently of the milk and of the urine increased. The content of the blood was always higher than that of the milk.

Lane-Claypon carried out investigations upon the amylase content of sterile cows' milk collected by means of a collecting tube. Amylase was found in each experiment, but the amount present was small. Ten c.c. of milk were incubated at $37^{\circ} \mathrm{C}$. for from three to four hours with known quantities of starch, the reaction to iodine being tested at the end of the experiment. It was found that the ro c.c. of the milk used were able to split from oor to .002 gramme of starch in three hours at $37^{\circ} \mathrm{C}$.

Amylase in Human Milk.-There appears to be universal agreement among observers in regard to the presence of amylase in human milk. Investigations were carried out by $\operatorname{Moro}(\mathrm{I}, 2,3)$, Luzzati and Biolchini, Nobécourt and Sévin, Spolverini, Friedjung and Hecht, Zaitschek, Hippius, Wohlgemuth and Strich. All these observers obtained positive results, although different methods were used. The amount present appears to be greater than has been detected in cows' milk, but no precise figures are given by any of the authors.

Lagane (2) (IgI3) showed that the action of amylase in human milk was greatly increased by the addition of hydrogen peroxide. Amylolytic activity was also found when hydrogen peroxide was added to growing heads of barley. These barley heads contained no amylase but a large amount of peroxidase. Lagane therefore suggests that the increased activity is due not to a direct action of the amylase but to a side action on the peroxidase, which is also frequently present in human milk. He believed that with the addition of hydrogen peroxide the starch was split to a further stage than dextrin and that some maltose was formed. He failed to obtain any action with either raw cows' milk or goats' milk, even with the addition of hydrogen peroxide.

It seems therefore that amylase is usually present in human milk, and has also been found in cows' milk, although not in every case. It is probable that as amylase is known to be present in the blood $^{1}$ the amylase in milk occurs as the result of filtration.

On the Presence of a Salol-splitting Ferment in Cows' Milk and in Human Milk.-The discovery by Nobécourt and Merklen in I9or, that milk was capable of splitting salol into phenol and salicylic acid, has received a good deal of attention, and has been confirmed by numerous later observers.

${ }^{1} \mathrm{Cp}$. Achard and Clerc, Lepine, Bial, Senter, Kastle and Amoss, v. Itallie, Wohlgemuth and Strich. 
The evidence is not quite in agreement as to the presence of this substance in cows' milk, although every observer who has studied its presence in human milk is convinced that the reaction is always obtained.

Moro (3) (I902) believed that the reaction is not affected by boiting, but there is some doubt whether it is due to ferment action.

Other observers ${ }^{1}$ believed that the reaction of the fluid played a part in the production of the reaction, while Rullmann (4) (I9II), using initially sterile cows' milk, was unable to detect any salolase and concluded that the reaction, when found, is due to the presence of bacteria.

For further information reference can be had to Spolverini (2), Luzzati and Biolchini, Friedjung and Hecht, Pozzi-Escot, A. J. J. Vandevelde (2), Grimmer (I), and Usener.

In view of the absence of salol in both cows' and human milk the splitting of this substance by human milk does not appear to be of any importance for the present work.

Short résumés of the work of most of the authors referred to throughout this chapter will be found in my report to the L.G.B., New Series, No. 76 .

On an Increase in the Ferment Content of Milk in Abnormal Conditions. - There is evidence to show that certain of the ferments normally present in milk as a result of filtration through from the blood stream, are increased in conditions which are connected with an abnormal condition of the gland and possibly also of the cow. Such conditions arise towards the end of lactation, when the milk assumes a character frequently approximating to that of serum, and also in conditions of inflammation of the udder, or mastitis.

Thus Köstler believed that a high catalase content in freshly collected milk denoted illness of the cow. He pointed out, however, that a high content in fresh milk must not be confused with the catalase content of milk which had been allowed to stand, when the catalase would probably be due to bacterial action.

Sassenhagen found a more powerful reaction with Schardinger's reagent when mastitis was present than was the case in ordinary milk.

Vollrath investigated the ferment content of milk from fiftyfour cows, some of whom had disease of the udder, others being the victims of a general malady. He found, generally, no change in the amount of peroxidase present, but there was frequently a definite rise in the amount of reductase and catalase. This occurred in cases also of foot-and-mouth disease. This author does not consider that the change in the ferment content is sufficiently definite to admit of a diagnosis of the presence of disease.

Trommsdorff also investigated the presence of ferments in cases of acute and chronic mastitis. He agrees that the alteration

${ }^{1} \mathrm{Cp}$. Desmoulières, Miele and Willem. 
in the ferment content cannot be regarded as a reliable test of the presence of disease.

Gratz and Maray, investigating conditions of mastitis in relation to the ferment content, showed that the reductase content, as measured by the time required for reduction of the F.M.B. solution, was very variable, and could not be regarded as a reliable aid in the diagnosis of mastitis. The time of the reaction was frequently prolonged with colostral milk.

Ullmann found that the catalase content was usually raised in conditions of mastitis, but he pointed out that the alteration in content appeared to depend rather more upon the alteration in the nature of the secretion than on the actual clinical condition of the udder. The peroxidase content of milk in mastitis he found to be variable. Sometimes an increase was obtained, sometimes a decrease, and evidence of the presence of peroxidase might even be absent. Reduction of the F.M.B. solution might also be absent, while the amount of diastase present was variable. Accompanying these changes there was usually a rise in the alkalinity of the milk.

Montius investigated the milk of cows suffering from foot and mouth disease. He found that unless the udder itself was affected a rise of ferment content was not present. Should, however, an increase in catalase be obtained, this was probably indicative of commencing disease of the udder, and was, he considered, secondary to the primary disease. Stetter also found a rise in ferment content in diseased conditions of the udder.

These facts, although somewhat indefinite, denote that in conditions where the gland tissue is affected, so as to admit of increased exudation from the blood to the lumen of the gland tubules even in a small degree, there will be a tendency for a rise in the content of catalase and possibly of other ferments which are present in the blood.

\section{REFERENCES IN ChAPTER V}

\section{The Enzymes of Milk}

ACHARD AND Clerc, 'Variations pathologiques du Pouvoir amylolytique du Sérum sanguin,' Compt. Rendus Soc. de Biol. I901, iii. 708.

Amoss. See Kastle and Amoss.

ARnold AND MENzel, 'Die Guajakprobe in der Praxis,' Zeit. f. Fleisch-u. Milchhygiene, 1902, p. 205.

Arnost, 'Die Guajak Reaktion der Milch,' Zeit. f. Unters. Nahr- und Genussm. I905, X. 538.

Austin, 'The Proteolytic Enzyme of Human Milk,' Journ. of Med. Research, I908, xix. 309.

BABCOCK AND Russell. (I) 'Unorganised Ferments of Milk,'Agric. Exp.

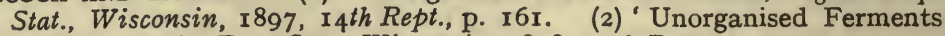
of Milk,' Agric. Exp. Stat., Wisconsin, I898, I 5 th Rept., p. 177.

Babcock, Russell, ANd Vivian. (I) 'Properties of Galactase-a Digestive Ferment of Milk,' Agric. Exp. Stat., Wisconsin, 1898, I 5 th Rept., p. 79. 
(2) 'Distribution of Galactase in Cows' Milk,' Agric. Exp. Stat., Wisconsin, 1898, 15th Rept., p. 87. (3) 'Distribution of Galactase in Different Species of Mammalia,' Agric. Exp. Stat., Wisconsin, I898, I $5^{\text {th }}$ Rept., p. 93. (4) "The Action of Proteolytic Ferments on Milk, with special Reference to Galactase, the Cheese-ripening Enzyme,' Agric. Exp. Stat., Wisconsin, 1899 , I6th Rept., p. 157.

BACH. (I) 'Zur Kenntnis der Reduktionsfermente. I. Ueber das Schardinger-Enzym (Perhydridase)' Biochem. Zeit. I9I I, xxxi. 443.

- Zur Kenntnis der Reduktionsfermente. II. Reduktion der Nitrate durch das System Perhydridase-Aldehyd-Wasser,' Biochem. Zeit. IgII, xxxiii. 282.

BACH AND CHODAT, 'Untersuchungen über die Rolle der Peroxyde in der Chemie der lebenden Zellen. VIII. Ueber die Wirkungsweise der Peroxydase,' Ber. d. Chem. Gesellsch. I904, xxxvii. I342-48; also Biochem. Zentralb. 1903.

Barthel. (I) Quoted in Milchztg. I899, xxviii. 487 ; (2) 'La Destruction de la Peroxydase du Lait par $\mathrm{H}_{2} \mathrm{O}_{2}$ à $50^{\circ} \mathrm{C}$.' Rev. gén. du Lait, I907, vi. 534 . (3) 'Reduktaseprobe bei Milch,' Zeit. f. Unters. Nahr-u. Genussm. r9o8, xv. 385. (4) 'Die Reduktaseprobe,' Milchztg. I9ro, xxxix. 25. (5)

'Die Reduktaseprobe,' Zeit.f. Unters. Nahr-u. Genussm. I9I I, xxi. 5 I3.

BAUER, 'Ueber das fettspaltende Ferment des Blutserums bei krankhaften Zuständen,' Wien. klin. Wochensch. I9I2, xxv. I376.

Beller, 'Intorno ad una speziale Reazione del Latte,' Giornale della Soc. Ital. di Igiene, 1904, xxvi. 52 ; Ref. Zentralb. f. Bakt. II. I904, xii. 548.

Bertin-Sans and Ganjoux. (I) 'Les Catalases du Lait de Vache: Leur signification au point de vue de la valeur hygienique du lait,' Rev. d'Hyg. et de Pol.San. I912, xxxiv. 1020. (2) 'Les Reductases du I.ait de V ache,' Rev. d'Hyg. I9I4, xxxvi. 258.

BERTRAND. (I) 'Sur l'Intervention du Manganese dans les Oxydations provoquées par la Laccase,' Compt. Rendus, 1897, cxxiv. 1032. (2) 'Sur l'Action oxydant des Sels manganeux et sur la Constitution chemique des Oxydases,' Compt. Rendus, I897, cxxiv. I355.

BIAL, 'Ueber die diastatische Wirkung des Blut- u. Lymph-Serums,' Pflüger's Arch. I892, lii. I37.

Bier, 'Ueber die Katalase in der Milch,' Maly's Tierch. I905, xxxv. 230.

BrolchinI AND Luzzati, 'Ueber die Anwesenheit einiger löslichen Fermente in der Milch.' Given at the 4 th Congress of Ital. Ped. in Florence, I901. Ref. Arch. f. Kinderh. I902, xxxiii. 460.

BoeKhout AND DE VRIES. (I) 'Ueber die Reifungsprozess der Edamer Kase,' Zentralb. $f$. Bakt. II. I899, v. 304. (2) Zentralb. f. Bakt. I901, vii. 8 I 7.

Bordas and Touplain. (I) 'Sur les Diastases du Lait,' Compt. Rendus, I9o9, cxlviii. 1057. (2) 'Contribution à l'Étude des Reactions dues à l'État colloidal du Lait cru,' Compt. Rendus, I9ro, cl. $34 \mathrm{I}$.

BRAND, 'Ueber die praktische Bedeutung der Reduktionsfähigkeit der Milch,' Münch. med. Wochensch. 1907, liv. i. 821 .

BREDIG AND SOMMER, 'Anorganische Fermente und die SchardingerscheReaktion,' Zeit. $f$. physik. Chemie, I910, lxx. 34.

BRÚnIng, 'Ueber das Verhalten des Schwefels zur Milch,' Zeit.f. exp. Path. u. Ther. 1906, iii. 157 .

BURRI AND KURSTEINER, ' Zur Klärung der Anschauungen über die reduzierenden Eigenschaften der Kuhmilch,' Milchw. Zentralb. 1912, viii. 40, 68, IOI, I34, I68 (5 papers).

BuRRI AND Nussbaumer, 'Ueber Oberflächenspannungs und ViscositätsBestimmungen der Kuhmilch unter Verwendung des Traubeschen Stalagmometers,' Bioch. Zeit. I909, xxii. 90.

BURRI AND SCHMID, "Die Beeinflussung der sogenannten Schardinger Reaktion durch die Kühlung der Milch," Biochem. Zeit. I9I I, xxxvi. 376.

BurRI AND STAUB, ' Ein neuer Apparat zur Bestimmung der Milch Katalase, Zert. f. Unters. Nahr-u. Genussm. I909, xvii. 88. 
Butterberg, 'Zur Untersuchung der pasteurisierten Milch,' Zeit. f. Unters. Nahr- $u$. Genussm. I906, xi. 377 .

CATHCART AND HahN, 'Ueber die reduzierenden Wirkungen der Bakterie,' Avch. f. Hyg. 1902, xliv. 295.

CHrck, 'Sterilisierung von Milch durch Wasserstoffsuperoxyd,' Zentralb. $f$. Bakt. II. I901, vii. 705.

Chlopin, 'Ein neues Reagens auf Ozon,' Zeit.f. Unters. Nahr-u. Genussm. I902, v. 504 .

Chodat. See Bach and Chodat.

Clerc. See Achard and Clerc.

Davidsohn. (I) 'Neue Methode zur Unterscheidung von Frauenmilch und Kuhmilch, zugleich ein Beitrag zum Studien des lipolytischen Milchferments,' Zeit.f. Kinderh. I913, orig. viii. I4. (2) 'Beitrag zum Studium der Magenlipase,' Biochem. Zeit. I913, xlix. 249.

Desmoulikeres, 'Sur le Ferment du Salol contenu dans certains Laits,' Journ. de Pharm. Chim. I903, xvii. 232; and Compt. Rendus, I903, cxxxvii. 337.

Dupouy, 'Moyen de différencier le Lait cru du Lait bouilli,' Journ. de Pharm. I903, xvii. 483 .

VAN ECK, 'Ueber da's Verhalten der Kuhmilchperoxydase beim Erhitzen, Zeit.f. Unters. Nahr-u. Genussm. I9I I, xxii. 393.

EllenBeck, 'Zur Hoemolyse der Frauenmilch,' Verhand. d: Gesellsch. $f$. Kinderh. Münster, 1912, p. 63; Jahrb. d. Kinderh. I912, lxxvi. 443.

ENGLER AND WöHLER, 'Pseudocatalytische Sauerstoffübertragung,' Zeit. f. anorg. Chem. I902, xxvii. I.

FaIrelowitz, "Zur Kenntnis der Katalase in Milch, und deren Bedeutung für die Milchkontrolle,' Milchw. Zentralb. I910, vi. 299, 36r, 420.

FRED, 'A Study of the Quantitative Reduction of Methylene Blue by Bacteria found in Milk, and the Use of this Stain in determining the Keeping Quality of Milk,' Centralb. f. Bakt. II. I9I2, xxxv. I7.

FREUDENREICH, 'Ueber das in der Milch vorhandene unorganisierte Ferment, die sogenannte Galactase,' Zentralb. f. Bakt. II. I900, vi. 332 ; and Milchztg. I900 xxix. 245.

FRIEDJung AND Hecht, 'Ueber Katalase und Fermentwirkung der Milch,' Arch. f. Kinderh. I903, xxxvii. 346.

Ganjoux. See Bertin-Sans and Ganjoux.

Gerber and OtTIKer, 'Zur Katalase Bestimmung der Milch,' Milchw. Zentralb. I9ro, vi. 3 I6.

Gerum. See Paal and Gerum.

GIFFHORN, 'Untersuchungen über Enzyme in der Kuhmilch,' Inaug. Dissert. Hannover, I909; Ref. Rev. gèn. du Lait. I9I I, viii. No. 22.

Gillet, 'Le Ferment oxydant du Lait,' Journ. de Physiol. et de Path. gen. I 902, p. 439.

Gillet. See Marfan and Gillet.

GlaGe, 'Die Guajakprobe in der Praxis,' Zeit. f. Fleisch-u. Milch-Hygiene, I90I, p. I62.

GRATZ AND MARAY, 'Vergleichende Untersuchungen über die Brauchbarkeit der Katalase, Reduktase und Leucocytenprobe zur Erkennung von Mastitismilch,' Milchw. Zentralb. I9I2, pp. 225, 257.

Grimmer. (I) 'Beiträge zur Kenntnis der Enzyme der Milchdruse,' Milchw. Zentralb. I9Io, vi. I42. (2) 'Zur Kenntnis der Milchperoxydase,' Milchw. Zentralb. I9I1, vii. 295. (3) 'Liegt den Erscheinungen der sog. Peroxydase ein Ferment zugrunde?' Zeit. f. Unters. Nahr-u. Genussm. I9I I, xv. 676. (4) "Bemerkungen zu der Arbeit von W. D. Kooper, "Untersuchungen über die Katalase," etc.,' Milchw. Zentralb. I9II, xvii. 3 I4 and I712. (5) "Beiträge zur Kenntnis der Fermente der Milchdrüse und der Milch,' Biochem. Zeit. I913, liii. 429. (6) 'Peroxydase der Milch,' Zeit. Unters. Nahr-u. Genussm. 1913, xxv. 85 .

VAN DER HAAR, "Untersuchungen über Pflanzen-peroxydasen. I. Eine 
neue Methode der Peroxydase-Gewinnung. II. Die Hedera Peroxydase. Ein Gluco-proteide,' Ber. d. d. chem. Gesellsch. I910 (2), xliii. 132x and 1327.

HAHN. See Cathcart and Hahn.

HaRden AND LANE-Claypon, 'Occurrence of Ferments in the Sterile Milk collected by Milking-Tube from Cows and Goats,' Journ. of Hyg. I9I2, xii. I 43 .

Нвснт, 'Die Reduktion als Lebensfunktion der Milch,' Arch. f. Kinderh. I904, xxxviii. 349 .

Hеснт. See Friedjung and Hecht.

Hertel. See Tjade, Koshe and Hertel

HEYGendoRfF AND MeURer, 'Zur Katalasebestimmung,' Milchw. Zentralb. I910, vi. 529.

Hippius, 'Biologisches zur Pasteurisierung,' Jahrb. f. Kinderh. I905, 1xi. 365.

HoefFTer, "Ueber die Wirkung des Schwefels auf Eiweisskörper. II. Das Verhalten der Sekrete gegen Schwefel,'Beitr. der chem. Physiol. u. Path. I904, v. 213.

IBRAHIM, 'Neuere Forschungen über die Verdauungs-Physiologie des Säuglingsalters,' Verh. d. Gesell. f. Kinderh. Köln. 1908, p. 2 I.

v. Itallie, 'Sur les Catalases du Sang,' Compt. Rendus Soc. de Biol. r9o6, lx. 148 .

Jensen, 'De l'Origine des Catalases et Reductases du Lait de Vache,' Rev. gén. du Lait. 1906, vi. 33, 56, 85.

Jochmann. See Müller and Jochmann.

Jolles, 'Beiträge zur Kenntnis der Frauenmilch'' Zeit. f. Biol. r904, xlv. 248 .

Kastle AND Amoss, "Variations in the Peroxidase Activity of the Blood in Health and Disease,' Bull. 3I, Hygienic Lab., Washington.

Kastle AND PoRCH, "The Peroxidase Reaction of Milk,' Journ. of Biol. Chem. r908, iv. 30r.

Krebs, 'Die Pyrogene Substanz,' Zentralb. f. med. Wissen. r868, p. 4 I 7

KonING, 'Biologische und biochemische Studien über Milch. V. Die Enzyme,' Milchw. Zentralb. I906, ii. 5I7, 53I; and 1907, iii. 4I, 53.

Kooper. (I) 'Beitrag zur Kenntnis der Oxydasen und Reduktasen der Kuhmilch,' Zeit.f. Unters. Nahr-u.Genussm. I9I0, xx. 565: (2) 'Erwiderung auf die Bemerkungen von Dr. Grimmer, etc,' Milchw. Zentralb. rgrI, vii. 4II. (3) 'Untersuchungen über die Katalase,' Milchw. Zentralb. I9r I, vii. 264. (4) 'Sind Alkalinität u. Peroxydase der Milch identische Begriffe?' Zeit. Unters. Nahr-u. Genussm. I91 2, xxiii. I.

KOOPER AND HESSE. (I) "Methoden des Nachweises einer stattgehabter Erhitzung von Milch und Molkereiprodukten, speziell in der Butter,' Milchw. Zentralb. x910, x. 4I2, 468: (2) 'Liegt den Erscheinungen der sog. Peroxydase ein Ferment zugrunde?' Zeit. f. Unters. Nahr- $u$. Genussm. I9I I, xxi. 385. (3) 'Peroxydase,' ibid. I912, xxiv. 301.

Koske. See Tjaden, Koske, and Hertel.

KöstLER, 'Katalaseprobe und Gäreduktaseprobe,' $24^{\text {te }}$ Jahresb. der Bernischen Molkereischule in Rulti-Zollikofen, rgro.

Kowalewsky, 'Ueber das Verhalten der Milch zum Guajakharz,' Zentralb. d. med. Wissen. 189o, pp. 145, 162; Rev. de Sciences méd. I 891, xxxviii. 45.

Kursteiner. See Burri and Kursteiner.

LAGANE. (I) Le Pouvoir réducteur des Laits (non-microbiens) dans la Série Animale,' Rev. d'Hyg. I9I4, xxxvi. 222. (2) 'Action de l'Eau oxygénée sur l'Amylase du Lait de Femme,' Compt. Rendus, I9I3, clvi. I94I.

LAM, 'Die Prüfung der Marktmilch,' Maly's Tierch, I906, xxxvi. 232.

LANE-Claypon. (I) "Report to the L.G.B. upon the "Biological Properties" of Milk, both of the Human Species and of Cows, considered in special relation to the feeding of infants,' New Series, No. 76, r9r3.

Lane-Claypon. (2) See Harden and Lane-Claypon. 
LefrmanN, 'Note on the Test for Distinguishing Boiled from Unboiled Milk,' Analyst. I898, p. 85 .

LEPERRE. Quoted by Vandevelde, Nat. on Geneesk. Congress, Antwerp. r 904.

LEPINE, 'Entstehung und Verbreitung des tierischen Zuckerfermentes,' Ber. d. d. Sachs. Gesellsch. d. Wissen. 1870.

Lozw. (r) 'Catalase: A New Enzyme of General Occurrence, with special Reference to the Tobacco Plant,' U.S. Dept. of Agriculture, Washington, I90I, Rept. 68. (2) 'Eine Bemerkung ẗber Katalase,' Zeit. f. Biol. I902, xliii. 256.

Luzzari. See Biolchini and Luzzati.

MARAY. See Gratz and Maray.

Marfan and Gillex, 'Ueber zwei Fermente der Milch,' Monats. f. Kinderh. I902, i. 57.

Mellanby and Woolley, "The Ferments of the Pancreas. Pt. V. The Carbohydrate Ferments of Pancreatic Juice,' Journ. of Physiol. I9I 5 , xlix. 246.

Menzel. See Arnold and Menzel.

Merklen. See Nobécourt and Merklen.

Meurer. See Heygendorff and Meurer.

Meyer, J., 'Bemerkungen über die Fermente der Milch,'Avb. a. d. kaiserl. Gesundheitsamt, I9ro, xxxiv. II 5.

Michaelis. See Rona and Michaelis.

Miele and Willem, 'A propos d'une Diastase lactique dédoublant le Salol,' Compt. Rendus, I903, cxxxvii. $\mathrm{r} 35$.

Montıus, 'Die Milch, Maul- und Klauenseuche kranker Kühe,' Milchw. Zentralb. I9r4, Heft iii. p. 85.

Monvorsin, ' Sur quelques Diastases du Lait,' Rev. gén du Lait, 1907, vi. 265

MOORE AND Whitley, 'The Properties and Classification of the Oxidising Enzymes, etc.,' Biochem. Journ. I909, iv. I36.

MORO. (I) 'Untersuchungen über diastatisches Enzym in den Stühlen von Säuglingen und in der Muttermilch,'Jahrb. d. Kinderh. 1898 , xlvii. 342. (2) 'Zur Charakteristik des diastatischen Enzymes in der Frauenmilch,' Jahrb. d. Kinderh. 1900, lii. 524. (3) 'Die Fermente der Milch,' Jahrb. d. Kinderh. I902, lvi. 36r.

MUller AND JochmanN, "Ueber den Nachweis eines eiweissverdauendes Fermentes im menschlichen Kolostrum,' Münch. med. Wochensch. 1906, p. 2002.

NeIsser aND Wechsberg, 'Ueber eine neue einfache Methode zur Beobachtung von Schädigungen lebenden Zellen,' Münch. med. Wochensch. I900, xlvii. I26I.

NeUberg aNd Reichert, 'Lipolyse Agglutination und Hoemolyse,' Münch. med. Wochensch. 1907, xxxv. 1725 .

Neumann-Wender. (I) 'Die Enzyme der Milch,' Oesterr. chem. Ztg. I903, vi. I. (2) 'Der Mechanismus der Guajak-Reaktion,' Oesterr. chem. Ztg. I904, vii. 532.

Nobecourt and Merklen, ' Un Ferment du Lait de Femme et du Lait d'ânesse,' Rev. mens. des Mal. de l'Enfance, rgor.

NoBtcourt and Stevin, 'Le Ferment amylolytique chez les Nourrices et les Vaches laitières,' Bull. de la Soc. de Péd. de Paris, I902, iv. 20

NoRdMaNN, 'Ueber einen positiven chemischen Befund bei Unverträglichkeit der Muttermilch,' Monats. f. Geburts. u. Gyn. I902, xv. I52.

Nussbaumer. See Burri and Nussbaumer.

OPPENHEIMER, 'Weiteres zur Schardinger'schen Reduktionsprobe, Arb. a. d. Inst. exp. Therap., Frankfurt, I998, iv. 75.

OtTIKer. See Gerber and Ottiker.

PAAL AND GERUM, Ber d. d. chem. Gesellsch. I908, xli. 805.

Plimmer, Aders, ' On the Presence of Lactase in the Intestines of Animals, etc.,' Journ. of Physiol. 1906, xxxv. 20.

Porch. See Kastle and Porch. 
Pozzi-Escor, 'Dédoublement diastasique du Salol,' Compt. Rendus, I903, cxxxvi., May IIth.

RaUdnitz. (I) 'Ueber die sogenannte Ferment-Reaktion der Milch,' Centralb. $f$. Physiol. r898, xii. 790. (2) 'Beiträge zur Kenntnis der oxydativen Fermente und der Superoxydasen,' Zeit.f. Biol. r9or, xlii. 91 ; (3) 'Sammelreferate,' Monats. f. Kinderh. 1902, i. 338. (4) Ergebnisse der Physiologie, r903, ii. pt. I, p. 274.

ReIss, 'Die Katalase der Milch,' Zeit. f. klin. Med. I905, lvi. I.

Röhmann and Shmamine, 'Ueber komplexe Verbindungen von Ferrosalzen, Wasserstoffsuperoxyd und Eiweisstoffen, ein Beitrag nach der Beteiligung des Eisens an biologischen Oxydationen,' Biochem. Zeit. rgr2, xlii. 235.

RöMER AND SAMES, 'Beiträge zur Schardinger'schen Reaktion der Kuhmilch,' Zeit. $f$. Unters. Nahr-u. Genussm. rgro, xx. I.

RösING, Untersuchungen über die Oxydation von Eiweiss in Gegenwart von Schwefel,' Inaug. Dissert. Rostock, r89r.

Rona AND Michaelis, 'Ester und Fettspaltung im Blute und Serum,' Biochem. Zeit. I9II, xxxi. 345 .

RothenfÚsser, "Ueber dẹ Nachweis von Fermenten unter besondere Berücksichtigungen der Milch,' 'Zeit. Unters. Nahr- u. Genussm. I908, xvi. 63.

Rullmann. (I) 'Ueber Pasteurisieren und Sterilisieren der Milch im allgemein, etc.,' Zeit. Unters. Nahr-u. Genussm. I903, vi. 603. (2) 'Ueber Reaktionen des oxydierenden Enzymes der Kuh- u. Frauenmilch,' Zeit. f. Unters. Nahr. u. Genussm. I904, vii. 8I. (3) 'Die Schardinge'rscheReaktion der Milch,' Biochem. Zeit. I9I I, xxxii. 446. (4) 'Ueber den Enzym- und Streptokkoken-Gehalt aseptischgewonnener Milch,'Arch. f. Hyg. rgr I, lxxiii. 8I ; (5) "Vorläufige Mitteilungen über Römer's Arbeit: "Zur Schardinger-Reaktion der Kuhmilch," Biochem. Zeit. I9I3, xlviii. I52.

Russell. See Babcock, Russell, and Vivian, and Babcock and Russell.

SAMELSOHN, 'Ueber Fettspaltung im Säuglingsblut,' Zeit. f. Kinderh., ror2, iv. 205 .

SAMES, "Ueber einige Farbenreaktionen zur Unterscheidung der Erhitzten von der rohen Milch,' Milchw. Zentralb. I9Io, vi. 462.

SAMES. See Römer and Sames.

Sarthou. (I) 'Du Rôle que paraît jouer le Fer dans la Schinoxydase,' Journ. de Pharm. I900, ii. 583. (2) 'Sur la Présence d'une Anaeroxydase et d'une Catalase dans le Lait de Vache,' Journ. de Pharm. I909, xxx. 350 ; Compt. Rendus, r909, cxlix. 809; and r9ro, cl. Ir9. (3) 'Rôle du Fer dans les Phénomenes d'Oxydation. Oxydases artificielles à Base de Fer,' Journ. de Pharm. I9I I, iii. 49.

SASSENHAGEN, "Ueber die biologischen Eigenschaften der Kolostral- und Mastitis-Milch,' Arch. f. Kinderh. r9ro, vol. liii. 28r.

SCHARDINGER. (I) 'Ueber das Verhalten der Kuhmilch gegen Methylenblau und seine Verwendung zur Unterscheidung von ungekochter und gekochter Milch,' Zeit. f. Unters. Nahr-u. Genussm. I902, v. III3. (2) 'Einige Bemerkungen zu den mir im Laufe des Jahres 1903 bekannt geworden Veröffentlichungen, etc.,' Chem. Ztg. I904, xxviii. 704; and Zeit. f. Nahr-u. Genussm. 1905, p. 556.

Sснмгд. See Burri and Schmid.

SCHROETER, "Vergleichende Prüfung bacteriologischer und biochemischer Methode zur Beurteilung der Milch,' Zentralb. f. Bakt. II. I9II, xxxii. $\mathbf{r} \mathbf{r}$.

SchweItzer, 'Milchhygienische Studien,' Centralb. f. Bakt. II. I903, x. 50r, 565.

Seligmann. (I) 'Ueber den Einfluss einiger Aldehyde, besonders des Formalins, auf die Oxydationsfermente der Milch, etc.' Zeit. f. Hyg. 1905, 1. 97. (2) 'Ueber den Nachweis stattgehabter Erhitzung der 
Milch' Zeit. f. anger. Chemie, 1906, xix. r540. (3) 'Ueber die Reduktase der Kuhmilch,' Zeit.f. Hyg. r906, lii. I6r. (4) Zeit.f. Hyg. I908, lviii. I.

Senter, 'Das Wasserstoffsuperoxyd-zersetzende Enzym des Blutes,' Zeit. f. physik. Chemie, 1903, xliv. 257.

Siegfeld. (I) 'Ueber den Nachweis einer Erhitzung der Milch,' Mi!chztg: I901, p. 772. (2) 'Nachweis einer Erhitzung der Milch,'Zeit. f. angew. Chemie, r903, xvi. 764 .

Smidt. (I) 'Ueber die Fähigkeit der Milch, Methylenblau zu reduzieren,' Hyg. Rund. 1904, xiv. II37. (2) 'Ueber die sogenannte Reduktase der Milch,'Arch. f. Hyg. I908, lviii. 313.

SNYDER, 'The Digestive Action of Milk,' Agric. Exp. Stat., Minnesota, I904, I2th Annual Rept.

SOMMERFEID, P., 'Die Frage der reduzierenden Eigenschaften der Milch,' Hyg. Centralb. 1908, iv. I.

Spindler, 'Beiträge zur Kenntnis der Milchkatalase,' Biochem. Zeit. Igrr, xxx. 384 .

Spolverini. (I) 'Sui Fermenti del Latte, etc.,' Il Policlinico, I902, viii. 707. (2) Rev. d'Hyg. et de Méd. inf. 1902, i. Nos. 3 and 4. (3) 'Le Ferment oxydant du Lait,' Rev. d'Hyg. el de Méd. inf. 1904, ii. No. 2.

Staub. See Burri and Staub.

StetTer, "Ueber Katalase- und Reduktase-bestimmung von Kuhmilch in der Praxis und über Beziehungen zwischen Katalase und Reduktase einerseits und spezifischem Gewichte, Fett und Azidität andererseits," Milchw. Zentralb. r9I4, Heft xiv. 369.

STOcklASA, 'Ueber die Isolierung gärungserregender Enzyme aus Kuh- und Frauenmilch,' Arch. f. Hyg. 1904, 1. I65.

STORCH, 'Eine Methode zur Unterscheidung von pasteurisierten und nichtpasteurisierten Milch,' Ber. des Versuchst. d. K. Vet. u. Landb. Hochs., Kopenhagen. Milchztg. I898, xxvii. 374. Ref. Zeit. Unters. Nahr-u. Genussm. I899, ii. 239 .

STRICH. See Wohlgemuth and Strich.

SugG. See Vandevelde, de Waele, and Sugg.

Thremich, 'Ueber die Stor'sche Reaktion der Frauenmilch,' Monats. f. Geb. u. Gyn. I903, xvi. 32 .

Tjaden, Koske, and Hertel, 'Zur Frage der Erhitzung der Milch, mit besonderen Berücksichtigung der Molkereien,' Arb. a. d. kaiserl. Gesundh. I90I, Xviii. 2 I9.

TORDAY, A., "Der Einfluss physikalischer und chemischer Faktoren auf die Katalase der Frauenmilch,' Maly's Tierch. 1907, xxxvii. 264.

TORDAY, A. and E., ' Ueber die Katalase der Frauenmilch,' Jahrb. d. Kinderh. I908, lxvii. 277.

Touplarn. See Bordas and Touplain.

TROMmsDorfF, 'Zur Frage der reduzierenden Eigenschaften der Milch und der Schardinger'schen Reaktion,' Zentralb. f. Bakt. I. I909, xlix. 29 I.

UlimanN, 'Milch euterkranker Kühe und ihr Enzymgehalt,' Milchw. Zentralb. I913, 392. Dissert. Stuttgart, ror2.

UTz. (I) 'Entsteht beim Kochen der Milch Schwefelwasserstoff ?' Milchztg. I903, xxxii. 354. (2) 'Der Nachweis einer Erhitzung der Milch,'Zeit. f. angew. Chemie, r903, xvi. 871. (3) Weitere Beiträge zum Nachweis von gekochter und ungekochter Milch,' Milchztg. I903, xxxii. 4 I 7 . (4) 'Zur Untersuchung von roher und gekochter Milch,' Milchztg. I903, xxxii. 594; also Milchztg. 1902, p. I45; and 1903, p. 129; and Oesterr. chem. Ztg. I904, p. 916. (5) Ueber Reaktionen des oxydierenden Enzyms der Kuh- u. Frauenmilch,' Oesterr. chem. Zeit. 1904, vii. 389, 533 ; and Zeit.f. Unters. Nahr-u. Genussm. 1905, ix. 556.

UsEnER, "Ueber ein salolspaltendes Ferment in der Frauenmilch und dessen Einfluss bei Salolmedication,' Zeit. $f$. Kinderh. I9I2, orig. v. p. 43 I.

A. J. J. VANDEvelde. (I) 'Untersuchungen über die Proteolyse der Milch,' Bull. Soc. chim. de Belg., xxi. 434 ; also ref. Maly, 1907, xxxvii. 
295! (2) 'Nouvelles Recherches sur les Ferments solubles du Lait,' Memoires couronnées de l'Acad. sc. de Belg. I907. (3) 'Ueber Milchzucker zerstörende Enzyme in der Milch,' Biochem. Zeit. I908, xi. 6r.

A. J. J. VANDEVel.ne, dF WAele, AND SUGg, 'Ueber proteolytische Enzyme der Milch,' Hofmeister's Beiträge, I904, v. 57 I.

VAudIN, 'Beurteilung der Frische der Milch durch Indigolösung,' Rep. de Pharm. I897, p. 538 ; ref. Maly, I897, p. 232.

v. D. VeldeN, 'Die " Katalase" der Frauenmilch,' Biochem. Zeit. I907, iii. 403.

Vivian. See Babcock, Russell, and Vivian.

VollRath, 'Untersuchungen über den Einfluss äusserer und innerer Krankheiten auf den Enzymgehalt der Kuhmilch,' Milchw. Centrulb. 1912, p. 747 ; Inareg. Dissert. Stuttgart, I9I2.

DE VRIES. See Boekhout and De Vries.

DE WAELE. See Vandevelde, de Waele, and Sugg.

Waentig. (I) 'Die Peroxydase Reaktion der Kuhmilch, etc.,'Arb. a. d. kaiserl. Gesundh 1907, xxvi. 464. (2) 'Literatur Ubersicht betr. die Veränderungen der Kuhmilch beim Erhitzen,' Arb. a. d. kaiserl. Gesundh. I907, xxvi. 582.

WARFIELD, 'A Peptide-splitting Enzyme in Woman's Milk,' Journ. of Med. Research, I9II, Xxv. 235.

WEBER, 'Arnold's Guajakprobe zur Unterscheidung roher und gekochter Milch,' Milchatg. I902, pp. 657,673 .

WechSBERG. See Neisser and Wechsberg.

WedemanN, 'Ueber die Schardingersche Formaldehyd-Methylenblau Reaktion und einige andere Fermentreaktionen bei Ziegenmilch,' Biochem. Zeit. I91 4, 1x. 330.

Whitley. See Moore and Whitley.

Willem. See Miele and Willem.

Wirthle, 'Ein neues Verfahren zum Nachweis von gekochter und ungekochter Milch,' Chem. Ztg. I903, p. 432.

WoHLer. See Engler and Wöhler.

Wohlgemuth aND STRICh, 'Untersuchungen über die Fermente der Milch und über deren Herkunft,' Sitzungsber. d. k. preuss. Akad. der Wissensch., Berlin, I9I0, i. 250.

Woolley. See Mellanby and Woolley.

Wynter Blyth, 'The Detection and Estimation of Preservatives in Milk,' Analyst. I901, xxv. 128.

ZaITSCHEK, "Vergleichende Untersuchungen über den Gehalt an eiweissund stärkelösenden Enzymen verschiedener Milcharten,' Pflüger's Arch. I904, civ. 539 .

ZINK, Milchatg. I903. 


\section{SUMMARY OF CHAPTER VI}

ON THE SO-CALLED 'BIOLOGICAL PROPERTIES' OF MILK (continued)

\section{B. The Substances concerned in the Production OF IMMUNITY}

THE subject-matter of this chapter forms the basis of one of the most interesting, but at the same time one of the most difficult, phases in the hygienic aspect of the milk question.

The transference of immunity from one generation to another has been the subject of investigation for a number of years, in fact ever since the problem of immunity began to be studied. The first phase in the investigations was directed towards ascertaining, if possible, whether such immunity as might be found to be conferred was conferred before or after birth. In the present work the condition of the fœtus as regards immunity is only indirectly of importance, since it evidently has no relation to milk.

The early investigators studied the inheritance of immunity from three possible points of view: (I) Through the father, (2) through the mother before birth, and (3) through suckling. As a result of these investigations it appears that no immunity is conferred by the father, while there is some divergence of opinion in regard to the possible conferring of immunity through the mother before birth, the bulk of the evidence being definitely against this occurrence. The third line of investigation is the one with which this present work is chiefly concerned.

The production of immunity in any organism is not a simple matter, but involves many complex considerations. Everyone is aware that certain diseases once contracted by an individual confer immunity from further attacks. Moreover, the difference in the tendency to contract diseases between different individuals is a matter of common knowledge. Some species of animals are more liable to certain diseases than are other species, while others again are entirely immune from diseases to which further varieties of animals fall a ready prey.

A very great amount of work has been carried out in order to discover what mechanisms are at work in the animal organism, which account for these remarkable phenomena. Although these in- 
vestigations have provided us with a considerable amount of information of great interest, and have enlarged our knowledge sufficiently to enable great advances to be made in the prevention of disease, there are still many points which await elucidation. Even where sufficient knowledge has been acquired to be of immense benefit to the community, the precise reactions which are necessary in the body before an individual can be put in a position to resist disease, are to a large extent obscure.

In order that immunity may be conferred by the mother upon her offspring, she must herself possess immunity to the particular disease or organism which may be under consideration. It has been found more convenient by the majority of investigators who were engaged upon the study of inheritance of immunity, to render the mother immune to certain well-known diseases and to study subsequently in the offspring any transference of immunity to this disease. Immunity to a disease thus artificially imposed upon the mother is known as acquired immunity. E.g. vaccination imparts an acquired immunity to smallpox. A person who has once suffered from scarlet fever and other diseases does not usually contract the disease a second time.

Where an individual or a species possesses immunity to any particular disease without any manipulation being required, such immunity is spoken of as natural immunity. ${ }^{1}$

In addition to these two types of immunity there is yet a third type, known as passive immunity. This form is transitory, and the mechanism employed for its production is different from that of either acquired or natural immunity. ${ }^{2}$ It will be shown later that the form of immunity which may be acquired by suckling when the mother herself possesses either natural or acquired immunity, is passive immunity.

One of the methods employed by the animal organism for protecting itself against the invasion of foreign substances has already been referred to in Chap. III, where it was shown that the injection of a foreign protein produces a reaction of the body tending to throw out of solution the invading substance. Analogous methods are employed by the body to deal with invading microorganisms. Substances are produced which are capable of disintegrating the bacteria, or which may act by first of all throwing the bacteria into clumps, that is by agglutinating them, and subse-

1 For example, pigeons enjoy a practical immunity to the bacillus of human tuberculosis, and rats show a high resistance to anthrax.

2 Passive immunity is conveyed when an antitoxin found in the body of one animal in response to a stimulus (acquired immunity) is injected into the body of another, for the purpose of neutralising a toxin already present, or to act as a temporary defence against a possible invasion of micro-organisms producing the toxin. Thus where a wound has become infected with material containing the organism of tetanus, an injection of tetanus antitoxin neutralises the toxins formed and gives the body time to develop its own protective mechanism. 
quently killing them. Similar methods are employed by the body to defend itself against the presence of red corpuscles belonging to another animal when these are injected. This last method forms a convenient one for investigating many of the problems connected with immunity. The reaction of the body to these different materials is a complex one, more than one substance being involved in the extermination of the invading bacteria or red corpuscles, but to consider this more fully would be beyond the scope of the present work. Each animal organism possesses a certain degree of immunity to the invasion of other substances, differing considerably in different species, and also slightly between different members of the same species.

The numerous experiments which have been carried out upon milk show that whatever 'protective' substances may be present in the blood of the mother will pass out in the milk.

During the colostral period there is a higher content of these substances than in later milk. In view of the connection of these properties with protein, this fact is in accordance with the high protein and antigen content of colostrum compared with that of later milk.1

Famulener found that the immune substances in colostrum were actually present in higher amount than in the blood.

After the colostral period is passed the amount of the protective substances found in the milk is generally greatly reduced. Where, however, the immunity in the mother is of the passive variety, induced by the injection of an antitoxin, the amount present in the milk will depend upon the amount in the blood.

No precise ratio has been determined between the content of these substances in the blood and in the milk, but it has been found to vary in strength in the milk between $\frac{1}{10}$ to $\frac{1}{30}$ that of the blood.

There seems no doubt that the absorption of unchanged protein must take place from the alimentary canal of the infant in the early days of life. The properties connected with the production of all forms of immunity are known to be attached to the proteins and to be almost certainly destroyed by digestion. The blood of the young of a mother who has been immunised, does not at birth contain the immune substances possessed by its mother. These, however, are found after suckling has been established, although it has been shown that only a portion of the total amount present in the milk has been absorbed by the young animal as a result of suckling.

If antitoxin be used, the amount present in the milk can be estimated. The corresponding amount can easily be added to the milk of an unimmunised mother and fed to a control animal, but in this case it is found that the amount absorbed is less than 
when the antitoxin has been received through the mother. This is attributed to the nature of the protein to which the antitoxin is attached. When it is added directly to the milk it will probably be attached to a protein which is 'foreign' to the suckling animal under investigation. It appears that although some absorption of 'foreign' protein does occur, it is absorbed in smaller amount than the 'native' protein of the mother's milk.

Direct absorption of protein does not occur later than the first few days after birth, except in some cases where the condition of the alimentary canal is abnormal. This may be the case in general disturbances, and can also be induced artificially.

Many of the investigations upon the transference of immunity by means of suckling have been carried out with antitoxin, with the results which have just been mentioned. Experiments have also been carried out in order to determine the occurrence in milk of those bodies normally present in the blood of adult animals, which are concerned with the production of immunity.

The factors concerned in hæmolysis have been found to be present in colostrum. One of these (amboceptor) is only found in the first two to three days, the other (complement) persists for a few days longer. Some authors have found evidence of the presence of this factor in later milk. There is a good deal of evidence tending to show that the reaction used to demonstrate the presence of complement depends upon other factors.

There has been a good deal of discussion upon the power of milk to destroy bacteria. Some observers have even regarded it as a sufficient protection against infection through milk. These claims can in no way be substantiated as a result of investigations and as further evidenced by the occurrence of epidemics, which have been traced indubitably to milk. A decrease in the number of colonies of bacteria found, on plating out milk, has undoubtedly been shown to occur after milking. After a few hours, however, this phenomenon is not exhibited, and even when it has occurred in the early hours the number of colonies at the end of twentyeight hours does not suggest any permanent decrease in the number of bacteria. It appears probable that the diminution in colonies is due to the agglutination or clumping together of several bacteria, which, as the agglutinating power wears off, again separate and begin to multiply vigorously.

Our knowledge upon the transference of immunity by suckling demonstrates the immense value to the young of the colostrum of its mother, and emphasises the need for breast-feeding. 


\section{CHAPTER VI}

\section{THE SO-CALLED 'BIOLOGICAL PROPERTIES' OF MILK (continued)}

\section{$B$. The Substances concerned in the Production}

\section{OF IMMUNITY}

On the Presence of Substances concerned in Hæmolysis.-A good deal of work has been carried out in order to determine whether either of the hæmolytic factors-complement or amboceptor or both-were normally present in milk. For the investigation of this matter it is necessary to use an appropriate system.

The earliest investigations, which were carried out by Pfaundler and Moro (I), showed evidence of the presence of complement in cows' milk. The system used by these observers consisted of guinea-pigs' corpuscles + inactive ox serum,

+ raw milk.

This system is known to be a suitable one on the supposition that the complement contained in milk will be identical with that present in ox blood.

Shortly afterwards Kopf, working in Schlossmann's laboratory under Bauer, and using the same system, was unable to detect the presence of complement in ordinary milk, although he obtained evidence of its presence in colostrum.

Sassenhagen and Bauer showed, further, that complement is easily demonstrable in milk of a cow suffering from mastitis, and they believed that this test formed a useful method of diagnosing the presence of mastitis before clinical observation was able to detect the presence of this trouble.

Investigations carried out by myself in Igo8 led me to believe that complement was normally present in cows' milk. The condition of the cows from which the samples of milk used by me were obtained was, however, not known, and it is not unlikely that had this information been forthcoming the presence of the complement found by me might have been explained on lines in agreement with the work of other authors.

Sassenhagen in IgIo showed that complement is regularly present in colostrum, and that it disappears from the milk with the disappearance of the colostral characteristics. The evidence above obtained by Sassenhagen and by Sassenhagen and Bauer was confirmed in IgII by Bernard Schmidt, who, using the method of the above authors, found complement to be present in colostrum and also in milk from a cow suffering from mastitis. He was unable to obtain evidence of the presence of complement in ordinary milk with the usual hæmolytic system, but traces could sometimes be shown to be present, when an immune serum of high potentiality was used. 
Lenzen also found complement constantly present in the milk of cows suffering from mastitis. More recently evidence has been obtained by Moser and by Kobele, who showed also that the complement content is the same throughout the milking, there being no difference between the early milk and the strippings.

Human Milk.-The investigations on the presence of complement in human milk are not conclusive, and it does not appear that human colostrum has been subjected to any investigation from this point of view.

Cattaneo (I905) believed that he had obtained evidence of complement in human milk, but Frey pointed out later that Cattaneo's results were probably due to a technical flaw.

Other observers, notably Pfaundler and Moro (2), Bauer (2), Noeggerath and Kolff, have investigated the presence of complement in human milk, using a similar system to that used when dealing with cows' milk.

Moro and Pfaundler (2) believed that there was an inhibitory effect preventing hæmolysis, due to some alteration of the red corpuscles. Bauer (2) agreed as to the inhibitory effect, but believed that it was not due to the cause assigned by these authors. Moro and Pfaundler, and Noeggerath and Kolff, although they failed to detect the presence of complement in human milk, were able to obtain traces of hæmolysis in some cases, when using a strong immune serum.

The presence of amboceptor has not been demonstrated in ordinary milk, either in cows' milk or in human milk, but Kobele found amboceptor was present somewhat inconstantly in colostrum up to the second or third day, but it did not persist as long as complement, which was present up to about the fifth day.

In addition to the work above described upon the presence of complement in human and cows' milk, investigations have been carried out which suggest that the hæmolytic action which has been obtained by certain authors, is possibly not due to the presence of hæmolytic factors as such. Thus, there is some evidence to show that milk which gives no indication of the presence of complement immediately after being withdrawn from the gland does show evidence of the presence of this substance when the milk is kept in the cold. ${ }^{1}$

Hewlett and Revis $(I, 2)$ carried out some experiments upon the presence of complement in the milk from separate cows and in mixed milk. They found it more frequently present in the early and later stages of lactation, or in a condition of mastitis, than in ordinary milk. When present, the reaction does not occur with all hæmolytic systems, even though these systems are of considerable sensitiveness, and they suggest that the reaction is not that of a true complement. These authors also find that milk exercises a stimulating effect upon hæmolytic action, the extent of which

${ }^{1} C p$. Ellenbeck and Bauer (3). 
depends upon the amount of the amboceptor which is added to form part of the hæmolytic system. They consider that this may account for some of the divergent results obtained by different investigators.

Schmidt found that the complement present in serum is inactivated by shaking, but that reactivation can be obtained by various methods.

The evidence so far obtained shows that complement and sometimes amboceptor are present in the colostrum of cows, and that complement tends to reappear towards the end of lactation or in conditions of mastitis. In ordinary milk, if present at all, it is present in such small quantities that it can only occasionally be detected by using a very sensitive system.

It may be recalled here that in considering the presence of lipase in milk it was shown by Davidsohn, that the surface tension was reduced on standing in the cold, which effect he believed was attributable to the action of lipase. It is possible that this phenomenon is also closely connected with the hæmolysis, of which evidence is found when milk is allowed to stand in the cold. The occurrence of hæmolysis is known to be connected with surface tension, and it is therefore very probable that there is a connection between any hæmolytic activity which is shown by milk after it has been drawn from the gland, and the presence of lipase. In any case there seems no doubt that such hæmolytic action as may be found, must be due to the filtration through from the blood of the substance concerned. Colostrum partakes more of the nature of serum than does later milk, while towards the end of lactation milk assumes a different physical appearance and may even show certain of the characteristics of serum. This may also occur in mastitis, but will depend upon the degree of inflammation which is present.

On the Presence of Bactericidal and Agglutinating Substances. -Numerous investigations have been carried out upon the bactericidal power of milk, and statements have been made based upon what appears to be an exaggerated view of the bactericidal action of milk.

There would seem to be little doubt that there is some degree of bactericidal activity in milk, if this activity be judged merely by the decreasing number of colonies which grow when the milk is plated out. The power, however, does not last more than a few hours after the milk has been drawn, and it has been shown that, probably, the apparent bactericidal activity is in reality due to the agglutination of numbers of the bacteria, which thus reduces the numbers of colonies on the plates.

Investigations upon the action of milk on cholera bacilli have been carried out by a number of authors. ${ }^{1} \quad$ The object of certain

1 See Wolffhugel and Riedel, Kitasato, Heim, Uffelmann, Friedreich, Basenau, Weigmann, Hesse, and Fokker. 
of these investigations was to show that milk which was infected by the cholera organism might safely be drunk, because the bactericidal power of milk would be sufficient to destroy the organism. The investigations as a whole appear to show that the organism died only as soon as the milk became sour.

A great number of organisms grow very readily in milk, although there is some evidence to show that certain organisms survive at the expense of other strains which die out fairly rapidly in the milk. ${ }^{1}$

Conn and Stocking showed that during the first few hours after milking there was an apparent decrease in the total number of bacteria which was most rapid during the first three hours. This decrease in total numbers was accompanied by a rapid increase in the number of acid-forming bacteria, which not only increased absolutely, but also in proportion to the total organisms present. The following table gives some idea of the results obtained by these workers :

\begin{tabular}{|c|c|c|c|c|}
\hline Time after Milking & Total Bacteria & Acid-forming & Liquefying & $\begin{array}{l}\text { Per cent. of } \\
\text { Acid-forming }\end{array}$ \\
\hline $\begin{array}{l}\text { Fresh } \\
\text { Three hours. } \\
\text { Six hours } \\
\text { Nine hours . } \\
\text { Twelve hours }\end{array}$ & $\begin{array}{r}\text { Per c.c. } \\
12,550 \\
12,250 \\
19,650 \\
56,900 \\
114,250\end{array}$ & $\begin{array}{c}\text { Per c.c. } \\
1,250 \\
2,000 \\
2,250 \\
20,250 \\
68,400 \\
\text { (Practically } \\
\text { all B.A. Lact.) }\end{array}$ & $\begin{array}{l}\text { Per c.c. } \\
200 \\
200 \\
800 \\
550 \\
1,900\end{array}$ & $\begin{array}{l}10 \\
16 \\
23 \\
36 \\
60\end{array}$ \\
\hline
\end{tabular}

Many observers have failed to obtain evidence of any bactericidal power of milk. ${ }^{2} \quad$ Klimmer, Sommerfeld, and Kolle used cultures of B. Coli or B. Typhosus for their investigations. Cozzolino found some evidence of inhibition of bacterial growth both with human and cows' milk.

Koning investigated the numbers of bacteria present in the same sample of milk both directly after milking, and at later stages. He obtained evidence of an initial decrease in the number of bacteria, which was most marked in milk collected as far as possible free from bacterial contamination, being less marked in dirty milk. He found the optimum temperature to be $37^{\circ} \mathrm{C}$. The decrease in the number of bacteria was not shown in milk which had been previously boiled, and persisted in raw milk for a longer period if the milk was kept cool. He believed that milk contained substances inhibitory to the growth of bacteria, which were probably derived from the blood.

2 $C p$. Schottelius, Moro (3), Klimmer, Sommerfeld, Kolle. 
Rullmann and Trommsdorff agreed with Koning, and showed that the inhibitory effect upon ordinary bacterial flora persisted almost throughout the first day even at room temperature. The inhibitory effect was increased in mastitis.

The majority of observers who have compared the rate of growth of bacteria in raw and boiled milk believe that the inhibitory effect is destroyed by boiling, and that bacteria grow more readily in milk which has been previously boiled than they do in raw milk. ${ }^{1}$

Myer Coplans showed that the inhibition was exhibited for six hours after milking, at $20^{\circ} \mathrm{C}$., partial inhibition persisting for some hours longer. If the milk was kept at blood heat, the inhibition only lasted for one hour, partial inhibition lasting for from two to six hours after milking. At $0^{\circ} \mathrm{C}$. the inhibition persisted for twenty-four hours.

Rosenau and McCoy (I908) showed (see table below) that the apparent bactericidal effect, as shown by a decrease in the number of colonies obtained on plating out, which occurred in fresh milk was probably due to agglutination of the bacteria, since it could be shown to be entirely absent if the agglutinated masses of bacteria were broken up before the milk was plated out.

\begin{tabular}{|c|c|c|c|c|c|c|}
\hline \multirow{3}{*}{-} & \multicolumn{6}{|c|}{ Bacteria per Loopful } \\
\hline & \multirow{2}{*}{$\begin{array}{l}\text { At } \\
\text { Once }\end{array}$} & \multirow{2}{*}{ Hours } & \multirow{2}{*}{ Hours } & \multirow{2}{*}{$\begin{array}{l}6 \frac{1}{2} \\
\text { Hours }\end{array}$} & \multicolumn{2}{|c|}{$8 t$ Hours } \\
\hline & & & & & $\begin{array}{l}\text { Moderate } \\
\text { Shaking }\end{array}$ & $\begin{array}{c}\text { Mixed with } \\
\text { Pipette }\end{array}$ \\
\hline B. Typhosus raw milk & $I, 880$ & $x, 380$ & $I, 060$ & $\mathrm{I}, 480$ & $I, 980$ & 12,200 \\
\hline ," boiled ," & 2,120 & 4,020 & $\begin{array}{l}a . b . \\
800,000\end{array}$ & a. & a. & a. \\
\hline $\begin{array}{cc}\text { one drop } \\
\text { typhoid } \\
\text { serum added }\end{array}$ & 2,100 & 2,040 & 1,920 & 2,300 & $I, 260$ & $\begin{array}{l}a . b . \\
20,000\end{array}$ \\
\hline " boiled. & 2,280 & 2,360 & 7,020 & 6,480 & 10,860 & $\begin{array}{l}a . b . \\
60,000\end{array}$ \\
\hline $\begin{array}{l}\text { B. Typhosus in broth, } \\
\text { serum added. }\end{array}$ & $\mathbf{1 , 8 3 0}$ & 970 & 2,920 & 9,180 & I I , I60 & $\begin{array}{l}a . b . \\
100,000\end{array}$ \\
\hline Organisms in milk alone & o & I & 2 & 2 & 2 & 46 \\
\hline
\end{tabular}

$$
\text { a. = Innumerable. }
$$

b. = About.

The decrease occurred only in the first six to eight hours after milking, and was not found in boiled milk or in milk heated to $80^{\circ} \mathrm{C}$. It was not effected by freezing, but was hindered by dilution. The action was specific, since it was not the same for different species of bacteria, nor was it the same in different milks, or even in different samples from the same animal. They also showed

$1 C p$. St. John and Pennington, Moro (3), Myer Coplans. 
that the agglutinating and therefore the inhibitory effect could be apparently restored by adding a drop of typhoid agglutinating serum, as shown in the table on the previous page.

The breaking up of the clumps was accomplished by drawing the milk up and down a fine pipette pressed against the bottom of the vessel.

The milk was almost germ-free, and the samples after inoculation were kept at $37^{\circ} \mathrm{C}$.

The effect of agglutination was also shown by Bub, working on colostrum. Bub obtained evidence of some inhibition upon the ordinary flora of milk at a temperature of from $15^{\circ}-18^{\circ} \mathrm{C}$., the action being less marked at $37^{\circ} \mathrm{C}$. If the milk was well shaken before plating for the bacterial count, no inhibition was detected, although the count was higher in boiled milk than in raw. The organisms used were B. Coli, B. Paratyphosus and B. Pyocyaneus.

\begin{tabular}{|c|c|c|c|}
\hline 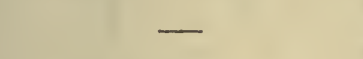 & $\begin{array}{c}\text { No. at Once } \\
\text { after Inoculation }\end{array}$ & $\begin{array}{l}\text { No. after } 6 \text { Hours } \\
\text { (Moderate Shaking) }\end{array}$ & $\begin{array}{l}\text { No. after } 6 \text { Hours } \\
\text { (Strong Shaking) }\end{array}$ \\
\hline B. Coli in raw milk & $\mathrm{I}, \mathrm{I} 84$ & 8,120 & 49,000 \\
\hline , sterilised. & $I, I 45$ & $2,000,000$ & - \\
\hline B. Parat. in raw milk & 6,342 & 3,873 & 57,000 \\
\hline " sterilised . & 6,480 & Infinite & - \\
\hline B. Pyocyaneus in raw milk. & II, 870 & I 7,760 & Infinite \\
\hline sterilised. & $x_{5}, 084$ & Infinite & - \\
\hline
\end{tabular}

Other observations which have been carried out by Much, Bartelli, Gutseit and Kleinschmidt are for the most part on similar lines to those already considered and confirmatory of the results already obtained.

Bartelli believed that the inhibition was due to the gradual development of acidity in the milk owing to the growth of the lactic acid organisms. If the milk was kept cool during the period of inhibition, then the acidity did not rise and no inhibition occurred.

Sassenhagen carried out a number of experiments with the colostrum and later milk of both cows and goats. He considers that the results show bactericidal power in the milk, which is more marked in colostrum than in later milk. The table on p. II8 has been compiled from the results given by Sassenhagen, but the figures hardly bear out the claims for any marked power for destroying bacteria.

In some experiments, drops of a culture of B. Coli were added. The milk was in all cases collected with aseptic precautions, and in some of the work the milk was heated to inactivate the complement (which he showed was present in colostrum) in order to eliminate the bactericidal effect. The figures obtained at four hours after milking in the experiments with colostrum justify to 


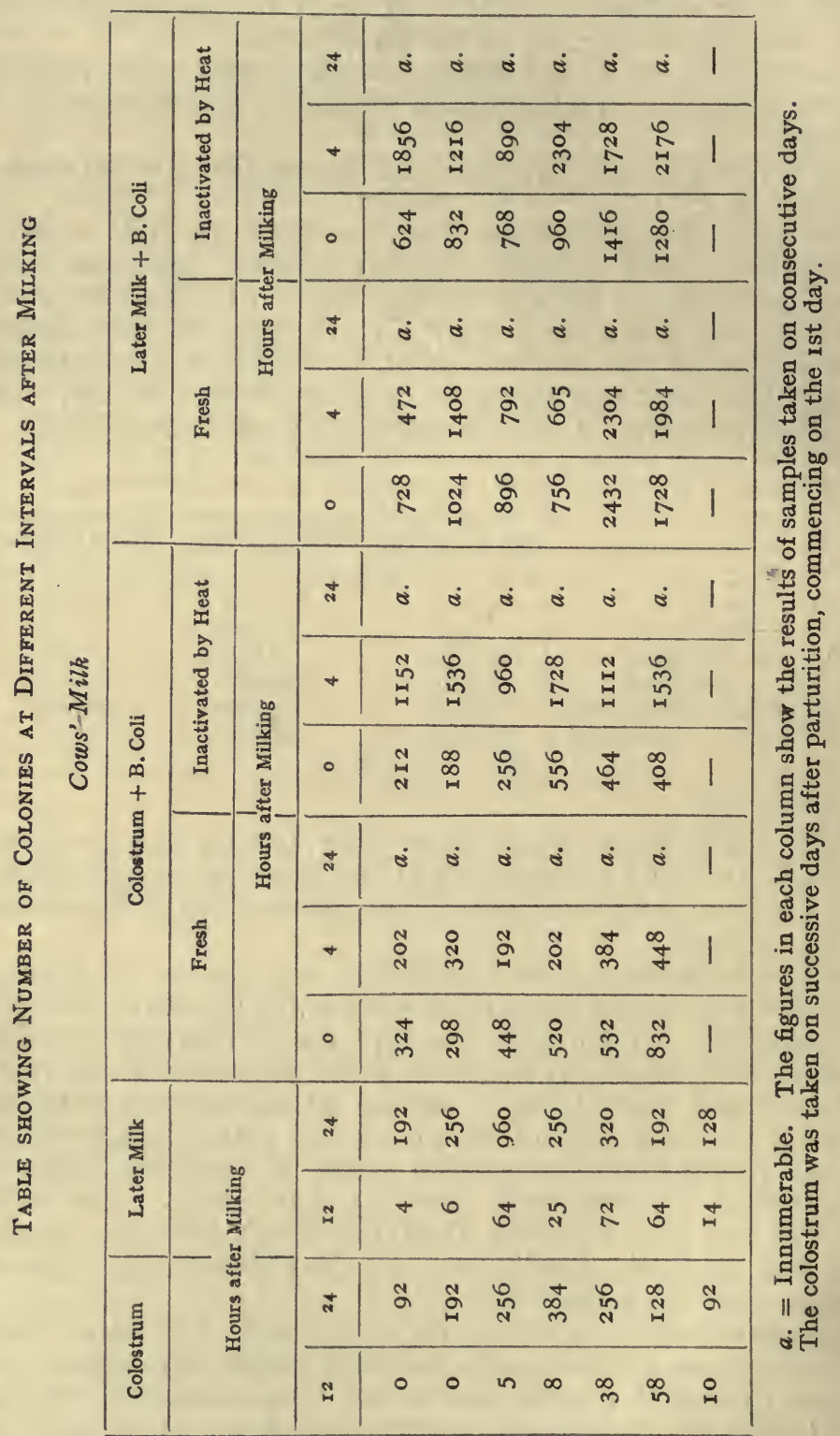


some extent the claims as to bactericidal power, but the effect appears to have completely worn off at a later stage, when all the samples to which $\mathrm{B}$. Coli had been added gave a bacterial count too high to estimate.

The results could readily be interpreted as due to the agglutinating power which is known to be present in fresh milk and which has already been considered.

The probability that it is the agglutination of the bacteria which is one of the prime factors in producing the decrease in bacteria during the early hours after milking, receives confirmatory evidence from the investigations of those who have studied the presence of agglutinins in milk. Thus Kraus (Igor) found that artificial agglutinins, if present in the blood, were passed out into the milk. Langer showed that the agglutinating power of colostrum is greater than that of the later milk, and von Zubrzycki and Wolfsgruber found that hæmagglutinins were present in colostrum, but that only traces could be detected later, the reaction being most marked in the first two or three days. These authors showed that the agglutinins were present for a longer period in primiparous women than in multiparous.

Tunnicliffe (IgI2) showed that the opsonic power of milk for streptococci, staphylococci, and tubercle was greater in colostrum than in later milk. The streptococcus phagocytic index for serum, in one woman whose milk was investigated, was 0.8 in the serum and 0.18 in the colostrum.

The work upon the presence of bactericidal substances or agglutinins in human milk and in colostrum is neither very extensive nor are the results very convincing. Clinical evidence has been obtained of the presence of agglutinins in the milk of women suffering from typhoid fever. For further details of work compare Honigmann, Moro $(2,4,7)$, Cozzolino, Klimmer, Schenk, Noeggerath and Kolff, Kleinschmidt.

Summarising the question of bactericidal power possessed by raw milk, it appears that there is some evidence of decrease in the number of bacteria during the first few hours after milking, as shown by the methods of plating out. It is not unlikely, however, that this is apparent rather than real, and is due to the agglutination of the bacteria by agglutinins present in the milk. The inhibitory power which is present depends for its persistence upon the temperature at which the milk is kept, but in ordinary circumstances would not appear to last for more than twelve hours after the milk has been drawn. As milk is seldom delivered to the customer within twelve hours after milking, the bactericidal power of milk from the point of view of infant hygiene may be neglected.

The presence in ordinary milk of factors concerned in hæmolysis is probably in itself a matter of comparatively little importance. The same is almost certainly true of the bactericidal or agglutinating 
effect. The real interest of their presence lies in the insight thus obtained into the mode of action of the mammary gland. There can be no doubt that these substances are derived from the blood stream and pass out into the milk.

Greater amounts of these substances are present in colostrum, and the fact that the hæmolytic factors are found only during the colostral period, or at such other periods when the gland function is in some degree abnormal, adds weight to this point.

The Production of Passive Immunity by Suckling.-The passage of substances concerned in the production of immunity from the blood to the milk, has been widely studied. For this purpose it has been found easier to immunise the mother, or inject a known antitoxin, whose presence both in the blood and in the milk could be readily detected. In some cases the relative strength of the antitoxin in the blood and in the milk was examined, and also the effect on the milk of raising the antitoxin content of the blood.

The results obtained have shown conclusively that whatever properties are possessed by the blood of the mother are possessed also by the milk, although to a lesser degree. These properties are known to be attached to the proteins, and there is a good deal of evidence to show that they are destroyed in the alimentary canal when the protein undergoes digestion. ${ }^{1}$

Hence, when the digestive functions of the child are established after birth, the immune properties present in the milk are destroyed, and they then possess only the actual food-value of the protein to which they are attached.

The possibility of the absorption of protein without digestion in the early days of life has been mentioned in Chapter III, where the identity of the whey-proteins with those of the blood was shown. If this occurs, it would be likely that any immune properties possessed by the mother's blood would be absorbed by the infant directly, until such time as the digestive functions have sufficiently developed to destroy the protein-complex.

Numerous experiments have been conducted upon these lines, and all show that the above proposition holds good.

The early experiments were carried out by workers who were investigating the transmission of immunity from the parent to the offspring. Ehrlich found that when a mother was rendered immune to abrin, ricin, robin or tetanus, this immunity was transferred to her young by means of suckling. The immunity thus conferred lasted for about a month. By the third month of life it was much reduced, and shortly afterwards it disappeared entirely. The animals used by him were mice.

Hamburger (2), working on somewhat similar lines, showed definitely that this immunity was transferred by suckling. He Bauer.

$1 C p$. Michaelis and Oppenheimer, Pick and Obermeyer, Sacconaghi and 
also used mice which were immune to ricin. After the birth of the young, one of the mothers which had been immunised was allowed to suckle young mice from a normal mother, and another immunised mother was allowed to suckle her own young. Immunity to ricin was found in the young of both series and in an approximately equal degree, thus showing that the immunity had been transferred by suckling.

Experiments on these lines demonstrate the fundamental fact of the transference of immune properties from the mother to the young animal by means of the milk. This fact carries with it the necessity for the absorption of the immune properties by the young animal, and as has already been pointed out, it is necessary for such absorption to be carried out without prior digestion of the protein substances to which the immune properties are attached.

Two considerations arise consequent upon this fact: (x) The length of time for which such absorption can last after birth, and (2) the amount of immune substances thus absorbed. This second consideration will evidently depend upon the amount of such immune substance present in the milk. The majority of the observations upon these matters have been carried out with antitoxins of one kind or another. The length of time after birth during which absorption can take place directly, varies in different animals, but would not appear to be longer than a few days under normal circumstances.

Römer (I) worked with diphtheria antitoxin, which he injected into a pregnant mare shortly before parturition. After parturition antitoxin could be detected in the milk in a strength of about $\frac{1}{10}$ of that in the mother's blood. At the time of birth no antitoxin could be detected in the blood of the foal, but after birth it appeared, and the amount continued to rise until about the twelfth day, after which the content of antitoxin in the foal's blood gradually sank. Later injections of antitoxin into the mother produced a corresponding rise in the antitoxin content of the milk, but did not prevent the continued fall of antitoxin content in the foal's blood. Evidently this experiment implies that absorption of antitoxin took place during the first few days after birth, but that although there may be a higher antitoxin content in the milk at a later date, no such absorption occurs.

Confirmatory results were also obtained by Hamburger (2), who found that if a kid twelve days old was fed by a mother who had been injected with tetanus antitoxin very little absorption took place. Working with Sperk and using the precipitin method for the detection of protein, Hamburger failed to obtain evidence of absorption of protein in a calf of three days old, or in infants of from five weeks to thirteen weeks old, to whom horse serum was given. Evidently the children were above the age at which such absorption would be likely to occur, and the work is somewhat complicated 
by the use of a 'foreign' protein. The absorption of 'foreign' protein by animals fed on this material within a few days after birth is considered later. Similar results involving certain points which will be considered immediately, were also obtained by Much and Römer and by Much and Happich.

Famulener immunised pregnant goats to the red corpuscles of the sheep, and showed that a passive immunity to sheep's corpuscles was obtained by suckling. $\mathrm{He}$ also demonstrated the presence of the immune substances in the colostrum, and found that the content of these bodies was sometimes actually higher in colostrum than in the blood of the mother. If the immunisation of the mother was only commenced after parturition ${ }^{1}$ no immunity was conferred by suckling, although the immune substances could be detected in the milk, but in smaller amounts than were found in the colostrum in the first experiments. These experiments also show that absorption takes place only in the early days after birth.

The amount of absorption which occurs as a result of suckling is not an entirely simple matter. The antitoxin which is injected into the mother is usually derived from an animal of a different species. For example, tetanus antitoxin may be derived from the horse and injected into the mother in the form of horse serum. This horse serum, when injected into the mother, will evidently enter the blood stream, and, except in the case of a mare, the question arises whether it passes out in the milk attached to the protein of the horse serum or not. The results so far obtained seem to show that there is probably a transference of the immune properties from the horse serum, which formed the vehicle for the supply of antitoxin in the mother's blood, to the protein of the species which was injected.

The amount absorbed by suckling appears to depend upon whether the immune properties are attached to the 'foreign' protein or to the protein of the same species. This has been demonstrated by the following experiment.

Much and Römer injected tetanus antitoxin derived from a horse, into a cow, before parturition. The calf was fed from birth with the milk of its mother, the amount of antitoxin in the milk being estimated, as also the amount in the calf's serum. It was found that about $\frac{1}{20}$ of the amount of antitoxin present in the milk was absorbed by the calf. If, instead of allowing the calf to suckle from an immunised mother, the same amount of antitoxin which had been found to be present in the milk of the immunised mother was mixed with the milk in the form of horse-antitoxin and fed to the calf, the absorption which occurred amounted only to $\frac{1}{200}$ (or ten times as little as in the former case) of the amount

1 Several days are required for the production of immunity in the mother, so that immune substances would not appear in the milk until some days after the commencement of immunisation. 
present in the milk. They found further that if the calf was allowed to suckle an immunised mother, beginning at the fifth day after birth, only about $\frac{1}{2000}$ of the total amount of antitoxin present in the milk was absorbed.

Almost identical results were obtained by Much and Happich in a case of a woman who had received tetanus antitoxin on the day before, and four days after, the confinement. The blood of the infant born the day after the first injection contained no antitoxin. The amount of antitoxin present in the milk was estimated and the amount which subsequently appeared in the infant's blood. It was found that in the first four days after birth the child had absorbed by suckling about $\frac{1}{4}$ of the total amount of antitoxin which was present in the milk. Between the fourth and eighth day only $\frac{1}{12}$ of the total antitoxin present was absorbed. Using the milk from a normal woman, the observers added an amount of antitoxin obtained from a horse which corresponded to the amount present in the former experiment. In this case they found that about $\frac{1}{64}$ was absorbed within the first six days after birth and about $\frac{1}{192}$ was absorbed between the fourth and the eighth days after birth. In this work experiments were carried out to determine whether there was any evidence of horse protein in the milk of the mother, that is to say, whether the antitoxin passed out in the milk attached to the proteins of the horse serum, or had been transferred to the proteins of the mother. No evidence of the presence of horse serum in the milk could be obtained either by the precipitin reaction or by the method of complement deviation.

These results were confirmed by further similar experiments upon rabbits.

Hamburger (I) did not, however, agree with the interpretation of Much and his collaborators. He injected lactating rabbits with tetanus antitoxin obtained from the horse, and stated that horse antitoxin could be demonstrated in milk by the ordinary precipitin test. Also he stated that evidence of the 'foreign' protein which must have been absorbed from the milk by suckling, could be obtained in the blood of the young animal, by injecting the blood into mice and ascertaining the presence of an antigen. The amount of ' foreign' protein present in the blood of the young was only about $\frac{1}{400}$ of that found in the milk.

Further experiments have been carried out by Römer (I) and Römer and Sames (I) (Ig09) which confirmed the results previously obtained by these investigators. It would not appear necessary to consider these in any further detail, since the results were similar to those previously considered.

It seems evident that 'foreign' protein can be absorbed by the suckling animal in the early days of life, but that the absorption proceeds on a very much smaller scale than in the case of a native protein. Thus Ganghofner and Langer, using the precipitin method, 
found that egg-white was absorbed by young animals during the first few days of life:

In puppies up to the sixth day,

In kittens up to the eighth day,

In rabbits up to the seventh day,

and was already negative in goats at the eighth day. They believed that a longer period must be allowed for infants. The investigation, however, of Salge (I) tends to show that the direct absorption of protein in infants ceases after about four days. The work also of Langer, Bauer (I), Vaillard, Kraus and Bauereisen should also be compared for the question of absorption in the early days of life.

On the Possible Direct Absorption of Protein after the Early Days of Life.-A considerable amount of work has been carried out by different observers with a view to ascertaining under what conditions protein could be absorbed directly from the alimentary canal in later life. Some of the work has been undertaken in the endeavour to administer diphtheria by means of the alimentary canal instead of by injection. ${ }^{1}$ There is evidence that a protein can be absorbed directly in abnormal conditions of the alimentary canal. Thus Ganghofner and Langer and also Uhlenhuth found that when very large amounts of proteins were given some degree of absorption took place. The same result was obtained by Mayerhofer and Pribram, who rendered the intestines somewhat abnormal before giving the protein, and also by Van Alstyne and Grant, using a Thierry-Vella fistula.

Investigations have also been carried out upon the absorption of ' foreign' protein by children who were in an unsatisfactory state of health. Moro $(5,6)$ examined the blood of twenty-three cases of children who were veryill, or who had just died, for the presence of foreign protein, by means of the precipitin method. $\mathrm{He}$ found a positive reaction in three cases. Using the method of complement deviation in seven cases, he found four were positive. It is probable, if not certain, that the condition of the intestine in these cases was abnormal and had admitted of the passage of the protein.

More recent investigations both by Lust and by Hahn are confirmatory of the above results, and show that it is only in comparatively few cases that absorption of 'foreign' protein occurs unchanged. Hahn found that in only five cases out of twenty-three-and in two of these the result was doubtful-was any evidence of the absorption of antitoxin obtained by the alimentary canal, and this only in children who were very ill and where large doses had been given.

Lust found that in a few cases where there was severe intestinal disturbance some absorption took place, egg-white being more

$1 C p$. McKlintock and King. 
easily absorbed than ox serum. He found that even where the condition was such as to allow of the passage of a ' foreign ' protein, recovery was still possible.

Some observers have believed that the 'foreign' protein of cows' milk, of which a small portion is probably absorbed by the infant, was actually detrimental, but the evidence upon this point cannot be regarded as entirely conclusive. ${ }^{1}$

At birth the young animal appears to have no capacity for providing its own resistance to the invasion of foreign substances or organisms. This capacity develops gradually during the early months of life, apparently about the sixth month in breast-fed children, and about the fifty-third day in young rabbits. ${ }^{2}$ Artificially-fed children appear to develop this capacity rather earlier. A greater strain is thrown initially upon the organism, leading, when this initial strain has been overcome, to the rather earlier development of a protective mechanism. The strain on the artificially-fed child is referred to in Chap. X, where the generally lower weight of artificially-fed babies during the early weeks of life as compared with breast-fed ones, is shown.

Investigations by Moro $(I, 3)$ and Salge show that greater natural properties of immunity are possessed by the breast-fed child than by the artificially-fed one. This subject is beyond the scope of the present work, but further information can be obtained in the papers by Halban, Halban and Landsteiner, Bertarelli, and Gewin. There can be no doubt of the extreme value to the young animal of the colostrum of its species. It is stated that in some species the young do not survive if deprived of this form of nourishment, and there can be no doubt that the artificially-fed human infant, although it does not die, and may even show no outwardly detrimental effects from early artificial feeding, leads a much more precarious existence than its fellow who has received its natural food after birth.

\section{References in Chapter VI}

\section{Immunity}

VAN ALSTYNE AND GRANT, 'Absorption of Albumin without Digestion,' Journ. of Med. Research, 19I I, xxv. 399.

BARTELli, ' Beitrag zum Studium der Bakteriozidine der Milch,' Milchw. Zentralb. I909, v. 462.

BASENAU. (I) Arch.f. Hyg. I895, xxiii. 44, I 77 .

BAUER. (I) "Ueber die Durchgängigkeit des Magendarmkanals für Eiweiss und Immunkörper, etc.', Arch. f. Kinderh. 1905, xlii. 399. (2) 'Ueber biologische Milchdifferenzierung,' Münch. med. Wochensch. 1908, lv. 847. (3) 'Zur Biologie der Milch,' Verh. d. Gesellsch. f. Kinderh. I909, p. 56.

BAUER AND SASSENHAgen, ' Ein neues Verfahren zum Nachweis der MastitisMilch,' Med. Klinik. 1909, p. I927.

${ }^{1} C p$. Salge' (2) and Moll.

${ }^{2} \mathrm{Cp}$. Gewinn and Ossimin. 
Bauereisen, 'Die Beziehungen zwischen dem Eiweiss der Frauenmilch und dem Serumeiweiss von Mutter und Kind,' Arch. f. Gyn. I9Io, xc. 349 .

BERTARELII, 'Ueber aktive und passive Immunisation der Neugeborenen und Säuglinge auf dem Wege der Verdauungs-organe,' Zentralb. f. Bakt. 1905, xxxix. 285.

BuB, 'Besitzt die Colostral-Milch bacterizide Eigenschaften ?' Zentralb. f. Bakt. I9Io, Abt. II, Orig. xxvii. 32 I.

Cattaneo, La Pediatria, 1905, p. 488 . Quoted by Frey.

Conn and Esten, "The Comparative Growth of Different Species of Bacteria in Normal Milk,' Storrs' Agric. Exp. Station, Connecticut, I901, p. I3.

Conn and Stocking, 'Studies on the so-called Germicidal Action of Milk,' Rev. gén. de Lait, 1902-3, ii. 265, 298.

Coplans, MYer, ' On some Vital Properties of Milk,' Lancet, r907, II, I074

Cozzolino, 'Ueber die Vegetation von B. Coli Commune, etc.,' Arch. f. Kinderh. I902, xxxiii. 405.

Davidsohn, "Neue Methode zur Unterscheidung von Frauenmilch und Kuhmilch zugleich ein Beitrag zum Studium des lipolytischen Milchfermentes,' Zeit. f. Kinderh. I9I3, viii. I4.

Ellenbeck, 'Zur Hämolyse der Frauenmilch,' Verh. d. Gesellsch. Kinderh. Münster, p. 63; Jahrb. d. Kinder. I912, lxxvi. 443.

EнRLICH, 'Ueber Immunität durch Vererbung und Säugung,' Zeit. f. Hyg. I892, xii: I83:

Esten. See Conn and Esten.

Famulener, 'On the Transmission of Immunity from Mother to Offspring, Journ. of Inf. Dis. I912, x. 332.

FoKKER, 'Ueber Bakterienvernichtende Eigenschaften der Milch,' Zeit. $f$. Hyg. I 890 , ix. 4I.

FREY, 'Haemolysiert die Frauenmilch?' Münch. med. Wochensch. 1907, lii. 1782 .

FRIEDRICH, 'Beiträge zum Verhalten der Cholera Bakterien auf Nahrungsund Genussmittel,' $A v b$. a. d. K. Gesunds. I893, viii. 465.

Ganghofner and LANGer, "Ueber die Resorption Genuiner Eiweiss in Magendarmkanal Neugeborener Tiere und Säuglinge,' Münch. med. Wochensch. 1904, li. 1497.

GewiN, 'Zur Frage des Ambozeptorgehaltes des Säuglinges Blutes,' Zeit. f. Immunität. I909, i. 613 .

Grant. See Van Alstyne and Grant.

Gutzeir, "Ueber die angebliche Vermehrung der Bakterien in der Milch durch mechanische Einwirkung,' Milchw. Zentralb. I9II, vii. I93.

HAHN, 'Die Durchlässigkeit des Magendarmkanals ernährungsgestörter Säuglinge für anheterologisches Eiweiss gebundenes Antitoxin,' Jahrb. f. Kinderh. I913, Ixxvii. 405.

HALBAN, 'Agglutinationsversuche mit mütterlichen und kindlichem Blute,' Wiener klin. Wochensch. I900, xiii. 545.

HALBAN AND LANDSTEINER, "Ueber Unterschiede des fötalen und mütterlichen Blutserums, etc.,' Münch. med. Wochensch. I902, p. 473.

HAMBuRger. (I) 'Ueber Eiweissresorption bei der Ernährung,' Jahrb. $f$; Kinderh. 1907, lxv. Ergänzungsheft I 5. (2) 'Ueber Antitoxin und Eiweiss,' Münch. med. Wochensch. 1907, vol. liv. I. 254 .

Hamburger and SPERK, "Biologische Untersuchungen über EiweissResorption vom Darm aus,' Wiener klin. Wochensch. I904, p. 64I.

HAPPICH. See Much and Happich.

HEIM, - Ueber das Verhalten der Krankheits-Erreger der Cholera . . . in Milch,'Arb. a. d. K. Gesundh. 1899, v. 294.

Hesse, 'Beziehungen zwischen Kuhmilch u. Cholerabazillen,' Zeit. f. Hyg. I 894 , xvii. 238.

Hewlett AND Revis. (I) "On the Presence of so-called "Complement" in Milk,' Journ. of Hyg. I9I4, xiv. 48r. (2) 'On a Complement-stimulating Substance in Cows' Milk,' Journ. of Hyg. I9I 5, xv. I. 
HonigmanN, 'Bakteriologische Untersuchungen über Frauenmilch,' Zeit. f. Hyg. I893, xiv. 207.

KInG. See Mc lintock and King.

Kitasato, 'Das Verhalten des Cholerabakterien in der Milch,' Zeit. f. Hyg. I 889 , v. 492.

Kleinschmidt, 'Die Bakteriozidine in Frauen- und Kuhmilch,' Monats. $f$. Kinderh. I91 I, x. 254.

Klimmer, 'Besitzt die unerhitzter Milch baktericide Eigenschaften?' Arch. f. Kinderh. 1903, xxxvi. I.

Kовеце, 'Untersuchungen über die haemolytsche Wirkung der Kolostralmilch der Kuh,' Centralb. f. Bakt. I. Ixi. 56r ; Ref. Milchw. Zentralb. I912, p. 465 .

KoLFF. See Noeggerath and Kolff.

KolLE, 'Milchhygienische Untersuchungen,' Klin. Jahrb. 1905, xiii. 3 I9.

Konrng, 'Biologische und biochemische Studien über die Milch,' Milchw. Zentralb. r905, i. $49,97,215,289,337$.

KopF, 'Haptine in Rinderserum und in der Rindermilch,' Zeit. f. Hyg. I909, lxiii. 291.

KRAUS, "Ueber das Vorkommen der Immunhaemagglutine und ImmunHämolysine in der Milch,' Wiener klin. Wochensch. I901, p. 737.

LANE-Claypon, 'On the Presence of Hæmolytic Factors in Milk,' Journ. of Path. I908.

LANDSTEINER. See Halban and Landsteiner.

LANGER, 'Zur Resorption des Colostrums,' Gesellsch.f. Kinderh., Dresden, 1907:

LANGER. See Ganghofner and Langer.

LENzen, 'Ueber die Bedeutung und den praktischen Wert der gebräuchlichsten Untersuchungsmethoden der Milch,' Leipzig, I9Ir. (Quoted by Kobele.)

Lusr, 'Die Durchlässigkeit des Magendarmkanals für heterologes Eiweiss bei ernährungsgestörten Säuglingen,' Jahrb. f. Kinderh. I913, Ixxvii. 243,383 .

MAYERHofer and PRIBRAm, ' Zur Frage der Durchlässigkeit der Darmwand, etc.,' Zeit. f. exp. Path. $u$. Ther. I9ro, vii. 247.

McClintock AND KING, 'The Oral Administration of Antitoxin,' Journ. of Inf. Diseases, r9o6, iii. 70r ; and 1909, vi. 46.

McCoy. See Rosenau and McCoy.

MICHAElis AND OPPENhEIMER, 'Ueber die Immunität gegen Eiweisskörper, Arch.f. Anat. u. Phys. r902, Suppl., p. 336.

Mol,, 'Ueber das Verhalten des jugendlichen Organismus gegen artfremdes Eiweiss,' Verh. d. Gesellsch. f. Kinderh. 1907.

Moro, (I) 'Biologische, Beziehungen zwischen Milch und Serum,'Wiener klin. Wochensch. I901, p. I073: (2) Ibid., Jahrb. f. Kinderh. I901, liv. 675. (3) Ibid., Arch. f. Kinderh. I902, xxxiii. 435. (4) 'Untersuchungen über die Alexine der Milch und des kindlichen Blutserums,' Jahrb. f. Kinderh. 1902, Iv. 397. (5) 'Kuhmilchpracipitine im Blut

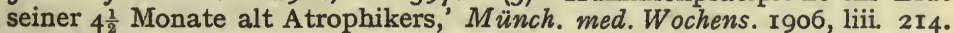
(6) 'Weitere Untersuchungen über Kuhmilchpräzipitine im Säuglingsblut,' Münch. med. Wochens. 1906, liii. 2383. (7) 'Ueber das bakteriolytische Alexine der Milch,' Zeit. f. exp. Path u. Ther. I907, iv. 470.

MORO. See Pfaundler and Moro.

Moser, 'Untersuchungen über die hämolytische Wirkung der Mastitismilch,' Centralb. f. Baht. Abt. I. I912, lxv. 269.

Much, ' Ueber Bakteriezidine in Perhydridasemilch,' Münch. med. Wochensch. I908, 1v. 384 .

MUCH AND HAPPICH, 'Ueber die antitoxische Funktion und Eiweiss,' Münch. med. Wochensch. 1907, liv. 2589.

Much AND Römer, 'Antitoxine und Eiweiss,' Jahrb. f. Kinderh. I9o6, lxiii. 684 .

NoEgGeratH, 'Serologishe Untersuchungen zur Theorie der Säuglingsernährung,' Gesell. f. Kinderh. Salzburg, r909. 
NOeggerath and KolfF, 'Ueber das Komplement der Frauenmilch,' Jahrb. f. Kinderh. 1909, 1xx. 701 .

OBERMEYER. See Pick and Obermeyer.

OpPenheImer. See Michaelis and Oppenheimer.

Ossimin, 'Zur Frage über den Einfluss von künstlicher Ernährung auf biologische Eigenschaften des Organismus in dessen frühen Alter,' Arch. f. Kinderh. I913, lix. 98.

Pennington. See St. John and Pennington.

Pfaundler AND Moro. (I) 'Ueber hämolytische Substanzen der Milch,' Zeit. f. exp. Path. $u$. Ther. 1907, iv. 551. (2) 'Ueber haemolytisches Komplement in der Frauenmilch,' Münch. med. Wochensch. 1908, No. 20.

Pick AND OBermeyer, 'Biologisch-chemische Studien über das Eiklar,' Wiener. klin. Rund. 1902, No. I5.

Pribram. See Mayerhofer and Pribram.

REDEL. See Wolffhügel and Redel.

RöMER. (I) 'Untersuchungen über Antitoxine-Uebertragung, etc.,' Berl. klin. Wochensch. I90I, xxxviii. II50. (2) 'Ueber die intestinale Resorption von Serumantitoxin und Milchantitoxin'' Zeit. f. Immunitätf. I909, Orig. i. I7I.

RÖMER. See Much and Römer.

RöMER AND SAMES. (I) 'Beiträge zur antitoxischer Immunisierung auf intestinalem Wege,' Zeit. f. Immunitätf. I909, iii. 49. (2) 'Ueber die Haltbarkeit heterologen Antitoxine im Organismus,' Zeit. f. Immunitätf. I9I0, Abt. I, Orig. iv. 270.

Rosenau And McCoy, 'The Germicidal Properties of Milk,' Journ. of Med. Research, I908, xviii. I65.

Rullmann and TrommsdoRfF, 'Milchhygienische Untersuchungen,' Arch. f. Hyg. I906, lix. 224.

Sacconaghi, 'Ueber die Präzipitine der Verdauungsprodukte,' Zeit. f. klin. Med. 1904, li. 189.

St. John and Pennington, "The Relative Rate of Growth of Milk Bacteria in Raw and Pasteurised Clean Milk,' Journ. of Inf. Diseases, I907, iv. 467.

SALGE. (I) 'Immunisierung durch Milch,' Jahrb. f. Kinderh. I 905, Ixi. 486. (2) 'Ueber den Durchtritt des Antitoxins durch die Darmwand des Menschlichen Säuglings,' Jahrb. d. Kinderh. 1904, lx. I.

SAmEs. See Römer and Sames.

SASSENHAGEN, 'Ueber die biologischen Eigenschaften der Kolostral- und Mastitis-Milch,'Arch. f. Kinderh. I910, vol. liii. 28 r.

Sassenhagen. See Bauer and Sassenhagen.

ScheNK, 'Untersuchungen über das biologische Verhalten des mütterlichen und kindlichen Blutes und über Schützstoffe der normalen Milch,' Monats. f. Geb. u. Gyn. I904, xix. I59, 344, 568.

Schmidt, BerNaRd, 'Ueber Milchhämolyse,' Arch.f. Kinderh. I9I I, lvi. 342.

Schмid, 'Studies on the Inactivation of Complement by Shaking,' Journ. of $\mathrm{Hyg}$. I9I 4 , xiv. $4 \mathrm{I} 7$.

Schotrelius, 'Ueber das Wachsthum der Diphtherie-Bacillen in Milch,' Centralb. f. Bakt. I896, xx. 897 .

SOMMERFELD, P., : Besitzen die löslichen Eiweisskörper der Milch spezifische " baktericide Eigenschaften ?' Centralb. f. Bakt. I904, Orig. xxxvii. 7 I6.

SPERK. See Hamburger and Sperk.

Stocking. See Conn and Stocking.

TROMMSDORFF. See Rullmann.

TUNNICLIFFE, 'The Content of Antibodies of Normal Human Colostrum and Milk,' Journ. of Inf. Diseases, 1912, xi. 347.

Uffelmann, 'Beiträge zur Biologie des Cholerabacillus,' Berl. klin. Wochensch. I892, xxix. I209.

Uhlenhuth, 'Neuer Beitrag zum spezifischen Nachweis von Eiweiss auf biologischem Wege,' Deutsch. med. Wochensch. 1900, No. 46.

VaIllard, 'Hérédité de l'Immunité acquise,' Ann. de l'Inst. Pasteur, 1896, x. 65 . 
Weigmann, 'Ueber das Verhalten von Cholerabacillen in Milch,' Milchztg. I894, xxxi. 49r.

WolfFHỨGEl AND REDEL, 'Die Vermehrung der Bakterien in Wasser,'Arb. a. d. K. Gesundh. 1886, i. 470.

WOLFSGRUBER. See von Zubrzycki and Wolfsgruber

VON ZUBRZYCKI AND WOLFSCrRUBER, "Normale Hämagglutinine in der Frauenmilch und ihr Ubergang auf das Kind,' Deutsch. med. Wochensch. I913, xxxix. 2 I0. 


\section{SUMMARY OF CHAPTER VII}

\section{ON THE CELLULAR CONTENT OF MILK}

THE presence of cells in milk has been known for many years. They form a normal constituent of the milk obtained from healthy cows under satisfactory conditions. It is a question whether the number of cells which are present may enable a determination to be made of the condition of the cow or of the cow's udder at the time of milking, i.e. whether healthy or not. If the enumeration of cells could be utilised for such a purpose, it would evidently be necessary to ascertain within what limits the number of cells found could be regarded as normal, and whether the boundary line denoting pathological conditions could be defined. Further, it would be necessary to ensure the use of an accurate method of estimation of the number of cells present.

Several methods have been suggested and used for estimating the cellular content of milk. The most usual methods have been to take a small quantity of milk, place it in small tubes, and centrifugalise for a definite period. The supernatant fluid is then drawn off and the sediment investigated. This may be done either by removing the whole of the sediment and making films of it, which is known as the 'smeared sediment' method, or the supernatant fluid may be removed down to a certain point, the volume of sediment being noted. This volume of sediment is then stained and the cells counted in an ordinary blood-counting apparatus.

Recently it has been stated that more accurate counts are obtained when the milk is not previously centrifugalised but when the counts are made direct from milk which has been thoroughly mixed. Objections have been raised to the centrifuging of milk on the ground that a large number of the cells are caught up with the cream, becoming entangled in the meshes of the fat globules. The cream being removed with the supernatant fluid after centrifugalising, a large number of the cells are removed with it, and do not enter into the count subsequently made. This error is said to amount to about 12 per cent. of all the cells, but it is probable that considerable variations exist in the number of cells thus caught up and removed from the fluid used for the estimation. 
It has also been shown by numerous observers that the cell count is greatly increased when the milk is raised before centrifugalising, to a temperature of about $70^{\circ} \mathrm{C}$. It is believed that this preliminary heating destroys some of the agglutinating properties known to occur in milk, and that in some way it modifies the fat globules, rendering them unable to entangle and carry up the cells.

In relation to the fallacies apparently shown when milk is centrifugalised or is not heated before the estimations are made, it is contended that the percentage loss is probably approximately equal in all the samples examined. In considering the cellular content of milk from an individual cow, although the absolute content may not be accurately estimated, yet the differences will remain the same in all the estimations : thus any marked rise in cellular content would, it is believed, be readily noted although the absolute number might not be obtained.

In view of the defects in the methods which have been employed, it seems probable that many of the recorded cell-counts in milk are not accurate. There seems, moreover, little doubt that the differences between the cellular content of the milk of individual healthy cows is greater than the inaccuracies which may reasonably be attributed to the methods used. It would seem impossible to fix any figure as the normal cellular content of milk; the variations found are too great.

The attention of most observers has been directed towards determining at what figure the cell count could be considered to be abnormally large, and whether such an abnormal count could be directly associated with diseased conditions of the cow or of the udder. It appears that no such direct association can be found, and that the cell count frequently fluctuates from day to day between figures which might be regarded as either normal or abnormal. No factors have been found to account for such change in many of the instances.

If disease were present it is probable that a high cell count would be accompanied by other changes. It has been shown already, in dealing with the presence in milk of ferments and of immune substances, that the content of these rises appreciably in early inflammatory disease of the udder. Several observers claim to have established a connection between an increased cell content and the presence of an undue number of bacteria, chiefly streptococci, in milk. Observations connecting the ferment content and the immune substance content with that of streptococci or other organisms, and also with the high cell content in the milk, do not appear to have been made. It would seem, however, that there is sufficient evidence of the connection between a high cell content and the presence of a large number of streptococci to render further examination advisable, if the cell count should reach a figure which may reasonably be regarded as abnormal.

A method of estimating leucocytes or white blood corpuscles 
in milk was formulated by Trommsdorff. In this method the cells were not counted, but the depth of the layer obtained after centrifuging was noted. It was believed that an increase in the depth of the layer over what was believed to show a normal cell content denoted disease of the udder.

Later investigations as to the value of this method as the sole means of diagnosis tend rather to show that no one method of investigation can satisfactorily establish the presence of disease of the udder as shown in the milk. A high cell content alone may not denote any pathological condition, but when associated either with many streptococci or with an increased ferment or immune-substance content of the milk, there is increased probability, amounting perhaps when well marked to a certainty, of the presence of udder trouble. The application of these methods will evidently provide useful information, only when applied to the milk obtained either from one cow or from a comparatively small number of cows. In mixed milk or in market milk, the milk from one unhealthy udder, even though when examined alone it should show a very high cell icontent or a high content of the factors above considered, will pass undetected when mixed with a larger quantity of milk, since there will be much dilution of the excess substance or substances. Even where suspicion has been shown to attach to three or four cows only, it has been necessary to obtain milk separately from the individual cows, and frequently also from the individual quarters of the udder, in order to locate the site of the disease.

The work of Bauer, Sassenhagen, and others ${ }^{1}$ shows that changes may occur in the milk before any evidence of inflammatory condition can be detected clinically in the udder. The udder trouble was sometimes only detected several days after changes had been found in the milk. Admitting for the moment that discovery of such changes in milk obtained from an apparently healthy udder denoted the onset of early mastitis, it is doubtful whether such a discovery affords a method of practical value in dealing with an ordinary milk supply. It is evidently impossible to estimate separately either the bacterial content or the ferment content or the cell content of the milk of each cow at sufficiently frequent intervals to be able to eliminate a cow suffering from early mastitis.

The real value of such tests would appear to lie in the aid afforded in the detection of disease in a cow whose milk had probably been the source of disease in human beings, such disease having been traced to the milk from a special farm, and, by a process of elimination, to a particular cow. In such cases, however, it is probable that some evidence of a pathological condition would be obtained as a result of careful veterinary examination. The tests mentioned become extremely valuable as confirmatory evidence of early disease of the udder, and may lead to a more 
minute clinical examination being made of a suspected cow than would perhaps otherwise have been the case. A veterinary surgeon, when called upon to examine a large herd of cows, would be assisted by having his attention drawn to one or more suspected cows, and would be able to devote more care to the examination of these animals than he would be able to bestow on all the animals in the herd.

The nature of the cellular elements present in milk has been the subject of much investigation both by histologists and by sanitarians. The histologist is concerned with the origin of the cells in relation to the function of the gland. He wishes to know whether the cells found in milk are derived from the gland itself or whether they come from the blood and lymph. If they come from the gland, the presence of a large number of cells in milk would denote a very high degree of activity on the part of the gland tissue. If, on the other hand, they come from the blood, it then becomes a matter of interest to know why a large number of cells from the blood should be present in milk, whether they have strayed into the lumen of the gland and been thrown out in the process of secretion, whether they can be regarded as denoting an abnormal condition, or whether they should be regarded as providing nutriment for the suckling animal.

The sanitarian is mainly concerned to determine whether the cells present in the milk are healthy or not. The origin of the cells is important to him, because if they should be shown to be derived from the blood, when they are present in large quantities, it might be supposed that they were of the nature of pus cells, that is, that they were dead leucocytes which had been killed in the attempt to resist bacterial infection in the gland.

It must be admitted that at the present time opinions are not agreed upon this question. There is no means of distinguishing satisfactorily between dead and living leucocytes. Moreover, the cells of the mammary gland, of which a number undoubtedly would occur in milk, resemble very closely certain varieties of leucocytes. It is impossible here to consider at any length the structure of the different cells which are present in milk, but the main classes into which they can be placed may be mentioned. There would appear to be general agreement as to the presence of three main classes of cells: (I) Large uninucleated cells, (2) multinucleated cells, (3) small uninucleated cells. These are present in different proportions in different samples of milk examined. Pictures of the cells in these three classes are shown in the plate facing $\mathrm{p}$. 136 . In addition a considerable number of other cells occur, but in small numbers.

Great differences of opinion appear to arise round the second class of cells, namely, the multinucleated. Some observers ${ }^{1}$ 
consider that they are the ordinary type of polymorphonuclear leucocytes which are found universally in the blood stream. These cells, as is well known, are the scavengers of the blood and destroy bacteria which gain access to the organism. Hewlett considers that they cannot be leucocytes because he has not obtained any evidence of amœboid movement on examining these cells, and he has not noted any phagocytosis as shown by the presence of bacteria in the cells. Other observers report the presence of bacteria in the bodies of these cells, which leads them to the belief that the cells are derived from the blood stream and are the ordinary polymorphic variety of leucocytes. If these cells are the scavenging cells of the body, their number should rise in any pathological condition of the udder.

The work upon the relative numbers of the different varieties of cells found in milk when there is a high cell count, and possibly some inflammatory condition, is rather fragmentary and not very conclusive. At the present time it does not seem possible to decide the origin of the cells, but it is not unlikely that the kind of cell may differ in the milk of different species.

\section{CHAPTER VII}

\section{ON THE CELLULAR CONTENT OF MILK}

THE presence of cells in normal milk has long been known. Interest arises out of this fact mainly on two grounds. There is evidently a physiological side which is concerned with the origin of these cells and their function, and another one relating to public health. It has been suggested that the number of cells present might give an indication of the condition of the gland, i.e. whether healthy or not. This implies the necessity for using a method whereby the number of cells can be accurately estimated.

The two questions are difficult to separate completely. It is not proposed here to deal at any length with the nature of the cells found in milk, since to do so would involve a consideration of the physiology and histology of the gland, which must be regarded as somewhat outside the scope of the present work. Neither the origin nor the function of these cells has as yet been definitely determined. It is possible that precise information may never be arrived at, since it is not at all unlikely that the origin will differ somewhat in different conditions

The Nature of the Cellular Elements present in Milk.The discussion which has arisen round the cellular elements of milk has been mainly concerned in endeavouring to decide 
whether the bulk of the cells are derived from the epithelium of the gland or whether they must be regarded as white corpuscles, which have exuded from the tissues and from the blood stream.

Czerny ( 1890 ) investigated the colostrum corpuscles of human milk and believed that the cells were in reality leucocytes, whose function was to remove such fat globules as had not been passed out in the milk, and to transfer them from the mammary gland to the nearest lymph gland. He did not regard them as excretory material. Czerny injected milk into the dorsal lymph sac of a frog and found that the fat globules were taken up by the leucocytes and carried away. Further experiments carried out on women, and also on a cat and on a rabbit, strengthened his belief in the carrying power of these leucocytes. He believed that when the gland function becomes upset, leucocytes pass through in increasing amounts. He found in a cat investigated, that the lymph glands nearest to the mammary gland were full of the same type of leucocyte as those found in the milk, and, in fact, could not be distinguished microscopically from the colostrum corpuscles. Czerny appears to regard these cells as normal leucocytes, of the large uninuclear variety.

Winkler divided the cells present in milk into several groups. $\mathrm{He}$ believed that the majority of them were derived from the epithelium of the gland. Such cells often appeared to be multinucleated, but were, he believed, not blood corpuscles. These views are also held by Hewlett, Villar and Revis, who examined the varieties of cells present in a large number of milk samples. These investigators divided the cells into the following classes: (I) Large uninucleated cells, (2) multinucleated cells, (3) small uninucleated cells-these classes forming the main mass of cells present : in addition they described small numbers of eosinophile cells, some larger cells with vacuolated protoplasm, and other cells whose characteristics were indeterminate. These authors regard the vacuolated cells, which were of large size, as " probably fat-bearing' cells. No phagocytosis was observed. No amœboid movement in any of the cells was noticed. It seems possible that these vacuolated cells of Hewlett may correspond to the cells described by Czerny, although Hewlett does not himself make any statement upon this subject. See Plate I. facing next page.

Berka examined cells in human milk, and considers that the cells are lymphocytes of the large uninuclear variety. He believes that as these cells begin to disintegrate the nucleus takes on a polymorphic appearance, thus resembling the usual polymorphic leucocyte. He states that these cells are amœboid, and considers therefore that they are not of epithelial origin. Moreover, in examining sections of the active gland, mitoses are not seen in the cells lying in the secretion which would, he thinks, be the case if the cells found in milk were derived mainly 
from the epithelium of the gland. He agrees with Czerny that these cells are capable of taking up fat globules which have not been excreted and of conveying them to the nearest lymph gland. He believes that in other animals the colostral cells are probably polymorphic leucocytes.

Gratz and Maray considered that the cells from the milk of cows were mostly of the type of polymorphic leucocytes, though colostrum corpuscles, presumably derived from the gland epithelium, were also present. The number of polymorphic cells increased in conditions of mastitis.

Thomas examined the cells present in milk and believed that they consisted of polymorphic leucocytes and of large mononuclear cells which had phagocytic powers. Granular cells were also present which resembled epithelial cells in their appearance.

Without going further into the question of the origin of these cells, it may be reasonably concluded that a proportion of the cells found in milk is likely to be derived from the gland tissue. All active tissues of a glandular character tend to throw off a certain number of cells as a result of their activity, these cells presumably being dead or dying when cast off. Further, it is only reasonable to suppose that a number of leucocytes will be present in normal milk. The mammary gland has a large blood supply, and it has already been shown that a comparatively free filtration of salts and other substances takes place from the blood vessels to the lumen of the gland. Moreover, a high degree of cellular activity, which must be a normal condition of the active gland throughout the whole period of lactation, suggests in itself that there will be present in the whole gland tissue considerable numbers of white corpuscles of various forms.

Savage examined the cells in the milk from the several quarters of some cows which had one quarter affected by inflammatory conditions. The most prominent variety of cells seems to have been the large uninucleated type, although sometimes there appears to have been excess of the multinucleated cells. Savage calls these cells 'leucocytes,' i.e. he considers they are derived from the blood. Hewlett and his co-workers think that in cases of a high cell count, even where there may be some inflammation, there is an increase in the multinuclear cells, but they do not consider that such cells are 'pus' cells in the usual meaning of the term.

The increased number of cells found in colostrum does not afford any difficulty. It is known that before the gland function is actively developed in the production of milk, the lumen of the tubules is crowded with cells. These cells must evidently first be cleared out of the gland with the early colostrum secreted.

Practically, the point at issue from the public health aspect is at what stage the number of cells found in the milk, and the variety of such cells, must be regarded as passing from the normal cell con- 

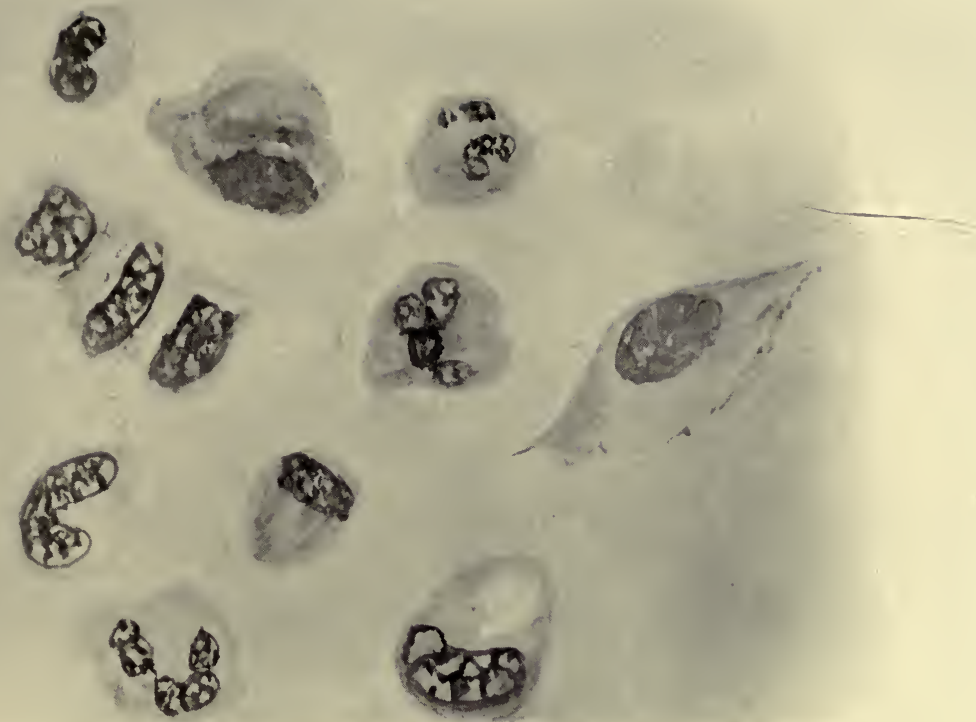

r.-Showing a fairly typical field with varieties of cells.
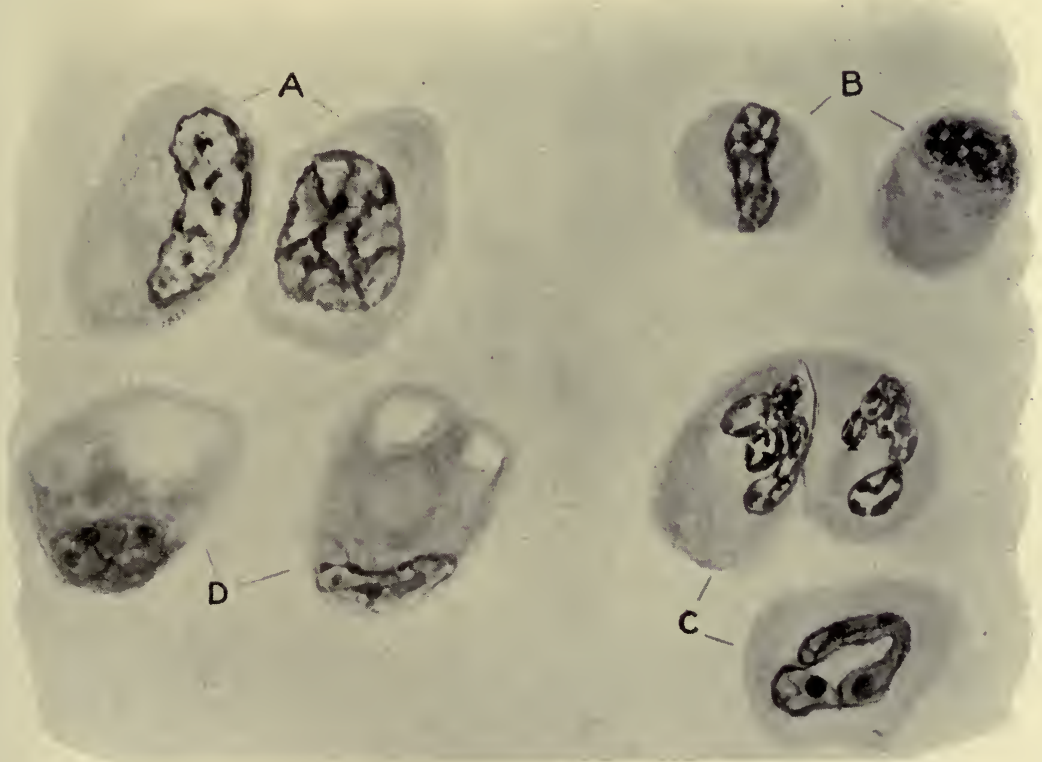

2.-Showing individual cell types.

A.-Large uninucleated cells. C.-Multinucleated cells.

B.-Small uninucleated cells.

D.-Vacuolated cells. 

tent to that attending the presence of inflammatory or other diseased condition of the gland. This at once leads to a consideration of the methods which have been employed for enumerating the total number of cells present in milk.

On the Methods of Estimating the Cellular Content of Milk.It is evidently important that the method of estimating the cell content of milk should be accurate if deductions are to be drawn from the number of cells found. The difficulties met with are, however, considerable, and preliminary manipulations are necessary before the number of cells present can be estimated.

Stokes (I897) was the first investigator to deal with a method of estimating the cells in milk. His method consisted in centrifuging Io c.c. of milk for ten minutes in a tube. He then removed the fat and supernatant liquid and examined a loopful of the sediment spread over an area of $\mathrm{I}$ sq. $\mathrm{cm}$. on a glass cover slip. The film thus made was stained with methylene blue and examined with an oil immersion lens. The cells in ten fields were counted and the average count per field obtained. When the number of leucocytes exceeded ten per field, it was customary to regard the milk as containing an abnormal number of cells and as unfit for use. It is now generally admitted that this method of Stokes cannot be regarded as sufficiently accurate.

Stewart (I905) introduced a modification of this method. He used I c.c. of milk in a small glass tube, of which the lower end was closed with a rubber plug. The tube was then centrifuged for ten minutes and the rubber plug carefully drawn out from the tube, the sediment upon it being smeared over an area of I sq. $\mathrm{cm}$. on a cover slip. This was then stained and the number of cells found in ten fields counted. As a result of practice it was customary to regard the number as excessive when the count exceeded twenty-three cells per field.

Doane and Buckley introduced another method. This consisted in taking ro c.c. of milk in a glass tube which was marked off in cubic centimetres. After centrifuging for ten minutes, the fat and supernatant liquid down to the I c.c. mark were removed. Stain was then applied to this remaining cubic centimetre and a drop of the mixture placed in a Thoma-Zeiss apparatus and the number of leucocytes per c.c. determined. Using this method, it was estimated that cells were present in excess when the figure for those counted showed a rate of more than 500,000 per c.c. of milk.

A different form of test was introduced by Trommsdorff in I906. This method does not involve microscopical examination. Trommsdorff prepared small centrifuge tubes of which the lower end was drawn out into the form of a capillary tube and graduated. The graduations were arranged to show the volumes of sediment per litre. He usually took 5 c.c. of milk, or for a general test Io c.c. might be utilised. When, after centrifuging, more than one volume per litre of sediment was found, suspicion of excess of 
cells should, he considered, arise. If the volume reached two per litre, then mastitis was almost certainly present, as diagnosed by an increased number of cells present. Trommsdorff says that the dirt will be found at the bottom of the tube, and can be readily differentiated from the leucocytes lying upon it owing to the fact that these latter present a creamy colour in contradistinction to the greyish aspect of the actual dirt. The employment of this method suggested by Trommsdorff has led to a considerable degree of discussion. Evidently, if it can be regarded as reliable, it supplies a simple method which can be used by persons not sufficiently skilled to be capable of dealing with any microscopic test. It has been objected that the capillary tube may become blocked by dirt, and thus present an inaccurate reading. On the other hand, it is claimed that there is no difficulty in reading off the leucocyte content even should this occur. Trommsdorff himself regards his test as reliable only where milk from one cow is used, such milk including that obtained from all four quarters of the udder. The test is not claimed to be reliable for mixed milk, since here the total increase in cell content owing to disease in one or only a few of the cows from whom the milk is derived, is distributed through such a large quantity of milk as hardly to raise appreciably the total cell content.

The value of this test has been fully discussed by Ruhm, who considers it useful for the discovery of mastitis or other disease of the udder in individual cows, but when suspicion is aroused in a sample of mixed milk further investigations of a microscopical character should be carried out. He does not consider that the test is sufficiently accurate for any judicial proceedings to be undertaken consequent upon the discovery of a high volume of leucocytes.

Ernst appears to regard Trommsdorff's test as of considerable value in determining the presence of mastitis-milk with a view to further detailed examination.

Criticisms on this method have also been raised by Schuppius and Revis. Sassenhagen, using this method with the milk of cows suffering from mastitis, obtained as a rule an increase in the depth of the cellular deposit. He considers, however, that the test is not nearly so reliable as the presence of complement in a case of suspected mastitis.

A somewhat different method was introduced by Savage, who centrifugalised I c.c. of milk in a tube, the lower end of which was drawn out to a smaller diameter than that of the main tube. Toison's fluid was added directly to the milk, which was then centrifuged at $I 800$ revolutions per minute. After centrifuging, the cream was shaken up with a clean glass rod to disentangle such cells as had risen with it. The tubes were then again centrifuged for ten minutes. The cream and fluid were then removed down to the I c.c. mark at the bottom of the tube. The cells in the fluid of this remaining cubic centimetre were then counted by means of the 
Thoma-Zeiss apparatus. The leucocyte count was found to be extremely variable, extending from 40,000 to over $\mathrm{I}, 000,000$ per c.c. Savage also investigated the cell content of milk at different stages of milking -in the fore-milk,middle milk, and strippings respectively. $\mathrm{He}$ found that the middle milk usually showed the lowest count.

Russell and Hoffmann (I907) used the Doane-Buckley method for counting the cells, but they showed that better results were obtained when the milk was previously heated to $70^{\circ} \mathrm{C}$. before centrifuging. Even then, however, great variations in the cell content were obtained, and they did not feel able to fix any standard within which the cell content could be considered to be normal. They considered, however, that a high cell content was suggestive of some trouble of the udder, although this trouble might no longer be active. The figures found by them varied to between 4000 and $I, 000,000$ cells per c.c.

Campbell (I909) used the Doane-Buckley method, but after centrifuging removed the supernatant liquid only to the fifth or sixth mark. The tube was then filled up to the Io c.c. mark with distilled water and recentrifuged. This was repeated until the upper surface of the liquid was transparent, when the supernatant fluid was removed down to the I c.c. mark. This remaining c.c. of sediment was thoroughly mixed, and the cells contained in it counted by means of a blood-counting apparatus. Campbell states that washing the cells several times before staining removed the fat globules more satisfactorily, and that no precipitate was obtained from the stain.

Campbell also compared the results obtained by using the methods of Stokes, Stewart, Doane and Buckley, and Trommsdorff on the same samples of milk. The investigations carried out by Campbell in regard to the difference in the counts obtained when the milk was previously heated (as recommended by Russell and Hoffmann), and when the heating was omitted, are most striking. $\mathrm{He}$ has also investigated the cellular content of the fore-milk, middle milk, and strippings, with heat and without heat, and some characteristic findings are given in the following table:

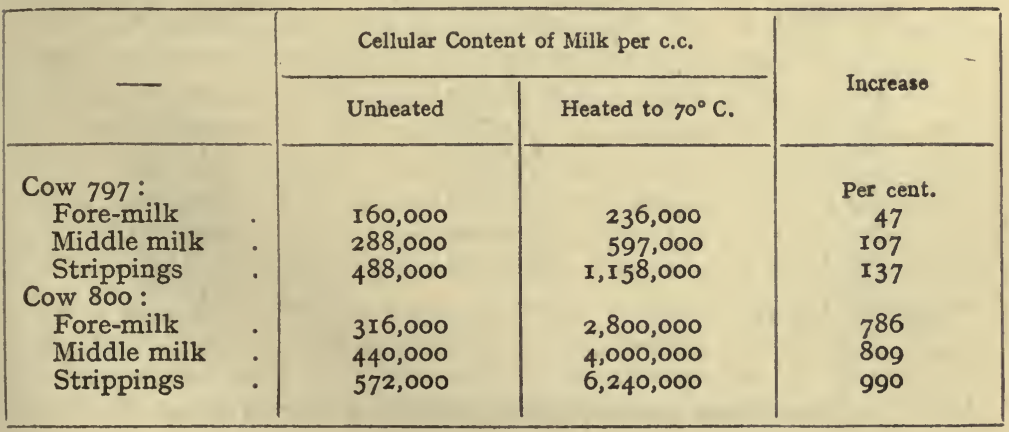


These figures were obtained from milk taken directly from the cow. Out of forty-two samples examined, in two cases only was a decrease in the number of cells obtained as a result of heating. In all the other cases an increase was observed, which varied from I2 per cent. (one sample only) to I360 per cent. increase in the number of cells observed in the heated samples over the unheated.

Similar results were obtained in the case of market milk, the average increase per cent. being, however, considerably higher as a result of heating, than in the case of the milk from a single cow.

Campbell also showed that the analytical error is much smaller in samples of milk which have been heated to $70^{\circ} \mathrm{C}$. than in unheated samples. A number of examinations are given, of which the following may be taken as typical :

\begin{tabular}{|c|c|c|c|c|c|}
\hline \multicolumn{3}{|c|}{ Unheated } & \multicolumn{3}{|c|}{ Heated } \\
\hline $\begin{array}{l}\text { Ist Exam- } \\
\text { ination }\end{array}$ & $\begin{array}{c}\text { 2nd Exam- } \\
\text { ination }\end{array}$ & Variation & $\begin{array}{l}\text { Ist Exam- } \\
\text { ination }\end{array}$ & $\begin{array}{l}\text { 2nd Exam- } \\
\text { ination }\end{array}$ & Variation \\
\hline Number & Number & Per cent. ${ }^{1}$ & Number & Number & Per cent. ${ }^{1}$ \\
\hline 41,000 & 102,000 & $59 \cdot 9$ & 548,000 & 592,000 & $7 \cdot 4$ \\
\hline 85,000 & 64,000 & 24.7 & 612,000 & 632,000 & $3 \cdot \mathrm{I}$ \\
\hline 46,000 & 70,000 & $34^{\circ} \cdot 2$ & 626,000 & 600,000 & $4 \cdot I$ \\
\hline 72,000 & 42,000 & $4 I \cdot 6$ & 636,000 & 608,000 & 4.4 \\
\hline 21,000 & 96,000 & $78 \cdot 1$ & 580,000 & 608,000 & $4 \cdot 6$ \\
\hline 23,000 & 58,000 & $60 \cdot 1$ & 616,000 & 604,000 & $1 \cdot 9$ \\
\hline 73,000 & 60,000 & $17 \cdot 8$ & 664,000 & 648,000 & $2 \cdot 4$ \\
\hline
\end{tabular}

Campbell showed further, in a number of experiments, that the temperature to which the milk is raised has a marked effect upon the number of leucocytes found. Thus in one sample the following counts were obtained :

\begin{tabular}{|c|c|c|}
\hline Temperature & $\begin{array}{c}\text { Number of Cells per c.c. } \\
\text { Sample I }\end{array}$ & $\begin{array}{c}\text { Number of Cells per c.c. } \\
\text { Sample 2 }\end{array}$ \\
\hline $15^{\circ} \mathrm{C}$. & 78,000 & 18,000 \\
$30^{\circ} \mathrm{C}$. & 84,000 & 44,000 \\
$40^{\circ} \mathrm{C}$. & 144,000 & 78,000 \\
$50^{\circ} \mathrm{C}$. & 154,000 & 120,000 \\
$60^{\circ} \mathrm{C}$. & $1,120,000$ & 139,000 \\
$70^{\circ} \mathrm{C}$. & $1,600,000$ & 158,000 \\
$80^{\circ} \mathrm{C}$. & $-640,000$ & 360,000 \\
$90^{\circ} \mathrm{C}$. & - & 670,000 \\
$100^{\circ} \mathrm{C}$. for $15^{\circ}$ & - & 630,000 \\
\hline
\end{tabular}

1 The smaller number is used as the basis in each case. 
When milk is heated for a second time no appreciable further increase in the cell content was found, viz:

\begin{tabular}{|c|c|c|c|c|c|}
\hline \multirow{2}{*}{ - } & & \multicolumn{2}{|c|}{ Ist Examination } & \multicolumn{2}{|c|}{$\begin{array}{l}\text { 2nd Examination (after Cooling at } \\
15^{\circ} \mathrm{C} \text {. for } 24 \text { Hours) }\end{array}$} \\
\hline & & Unheated & Heated to $70^{\circ} \mathrm{C}$ & $\begin{array}{l}\text { Heated and } \\
\text { Cooled }\end{array}$ & $\begin{array}{l}\text { Heated Second } \\
\text { Time to } 70^{\circ} \mathrm{C} \text {. }\end{array}$ \\
\hline $\begin{array}{c}\text { Sample } \\
\text { ", } \\
\text { ", }\end{array}$ & $\begin{array}{l}I \\
2 \\
3 \\
4\end{array}$ & $\begin{array}{r}\text { Per c.c. } \\
30,000 \\
208,000 \\
76,000 \\
96,000\end{array}$ & $\begin{array}{c}\text { Per c.c. } \\
430,000 \\
380,000 \\
222,000 \\
256,000\end{array}$ & $\begin{array}{c}\text { Per c.c. } \\
416,000 \\
440,000 \\
208,000 \\
208,000\end{array}$ & $\begin{array}{c}\text { Per c.c. } \\
404,000 \\
346,000 \\
200,000 \\
270,000\end{array}$ \\
\hline
\end{tabular}

He suggests that this fact might be utilised in determining whether milk had been previously heated or not.

The increased leucocyte count obtained by Russell and Hoffmann was believed by them to be due to alterations in the fat globule clusters. They state that milk when heated for ten minutes to $60^{\circ} \mathrm{C}$. exhibits a great reduction in the creaming-power, which reduction appears to be due to the breakdown of the fat clusters. In rising to the surface these fat globules ordinarily entangle with them many leucocytes. When the fat-globule clusters are broken down by heat they are no longer capable of enmeshing the leucocytes as they rise in the milk on centrifuging. Campbell agrees with this explanation of the results obtained by heating milk, and believes also that the leucocytes settle more freely with the sediment as a result of becoming disintegrated from the fat globules due to the effect of heat. In unheated milk he believed that only a small proportion of the leucocytes settle with the sediment.

Prescott and Breed (Igro) investigated further methods for the estimation of the cell content of milk, and believed that accurate results can only be obtained when the milk is used without centrifuging. They compared the methods in which the sediment is used and the results obtained when milk is used without previous manipulation.

The method employed by them was as follows : A small quantity of milk (O•OI c.c.), which has been carefully mixed but not centrifugalised, is spread on an area of definitely known extent ( $\mathrm{I} \mathrm{sq.} \mathrm{cm}$.). The film is allowed to dry and the fat removed by washing with alcohol. The film is then stained with methylene blue and the cells counted. It is desirable to count Ioo fields at random. Each cell found will represent 5000 cells per c.c. in the milk. These authors show that any method which involves the use of the centrifuge is very inaccurate, since a great number of the cells go up in the cream and many also lie in the fluid just below the cream. Only from 2.5-50 per cent. of the cells are found in the sediment as a result of centrifuging, and the variations obtained are too great 
to render the method reliable. The cell-count obtained by the use of the direct method was much higher than that obtained in the same sample of milk by the use of the other methods. These authors believe that the average number of cells present in milk is probably not less than I,500,000 per c.c.

Hewlett, Villar and Revis used about six drops of formalin to 60 to 70 c.c. of milk before centrifuging, prior to staining, and to subsequent counting of the cells. They state that they compared this method with the heating method suggested by Russell and Hoffmann and found that the two methods gave very similar results. They suggest that the action is due to a disruptive effect on the clusters of cells themselves, and consider it possible that heat or formalin break down aggregations of cells by destroying some agglutinating property rather than by an action upon the fat clusters. The destruction of the agglutinating substance would thus produce a more even distribution of the cells and cause an apparent numerical increase. They add that the carrying power of fat globules not only for cells but also for blood, bacteria, etc., may be broken down by either heat or formalin.

These authors have also carried out investigations upon the best fluid to use for washing the cells.

Ross (IgI2) heated the milk investigated by him for cellular content to $100^{\circ}-\mathrm{I} 20^{\circ} \mathrm{F}$. Ten c.c. of the milk was then centrifuged and the sediment content kept at I c.c. The sediment was then stained and the cells counted in the usual manner.

The Cellular Content in Relation to Certain other Factors.The great irregularity of the cellular content of samples of milk from apparently normal cows has been shown in the preceding pages in connection with the methods of estimation. Some of the variations may perhaps be due to experimental error, but it is likely that there are normally very wide variations between the cell content of different samples of milk. Several investigators have endeavoured to ascertain the possible relationship between the cell content and other factors, such as the stages of lactation and an unhealthy condition of the gland, also minor factors, such as fat content and reaction of the milk.

Stages of Lactation.-There is some diversity of opinion as to whether the cellular content is higher in colostrum than in later milk.

Gratz and Maray believe that there is frequently no increase in leucocytes in colostral milk.

Savage investigated a large number of samples of milk from individual cows. In regard to the period of lactation he was unable to trace any relationship with the leucocyte count, except in the case of cows which were also pregnant, when the number of cells tended to rise towards the end of lactation. The diminution of the amount of milk given was found to be associated with a rise in the number of leucocytes, and the less the amount of milk yielded, the 
higher the number of leucocytes found. Savage also investigated the varieties of leucocytes in the number of the estimations of total cellular content made by him. In definite pathological conditions the number of leucocytes was greatly increased, and there was a tendency for a high leucocyte count to persist in conditions of old trouble which was no longer active. This continued high cell count after the subsidency of inflammation has been pointed out by several observers who have investigated the cell content of milk. ${ }^{1}$

Hewlett, in the course of numerous investigations upon the cell content of the milk from a large number of cows, examined the milk from several cows in the later stages of lactation. In three cases no rise of cell content was obtained, and the cows were found to be non-pregnant. In a number of other cases the cell content was found to be high, but no connection could be traced either with the stage of lactation or with any unsatisfactory condition of the udder.

Ross found no apparent relationship between the cell content and the amount of milk produced or with the fat content. Great variations were found between the different cows and also in the milk of the same cow at different times. As a whole, the cell content was higher in the strippings than in the middle milk, which itself showed a higher cell content than the first milk. This agrees with the findings of Campbell quoted above. Ross believed that as a rule the cell content was higher in colostrum than in later milk, and was greatly increased in any inflammatory condition of the udder.

Frick investigated the cell content in relation to the reaction of the milk, using Trommsdorff's method. Colostrum having an increased acidity over normal milk, was associated with a high leucocyte count. The leucocyte count of the later milk of cows depended upon whether the cow was pregnant or not. In the former case Frick obtained a reduced acidity of the milk and a raised leucocyte count. In the case of non-pregnant cows no change in the acidity or the leucocyte count from that of normal milk was found.

Presence of Disease.-There is very general agreement on the part of observers as to the rise in cell content which occurs in mastitis, although all are not agreed that a rise in cell content necessarily denotes mastitis. The results given above show that a high cell content may occur under numerous conditions which are not associated with mastitis. This disease in cows is caused by various bacteria, but in many instances is due to an infection from some form of streptococcus. Hence, if a high cell count is found to be associated with the presence of streptococcus, the suggestion that the two are connected and are diagnostic of mastitis is not an

1 Cp. Hastings and Hoffmann, Hewlett, Villar and Revis, also Russell and Hoffmann. 
unreasonable one. This view has been adopted by a number of workers, but not by all.

Bergey (3) (r907), using Trommsdorff's method, believed that milk very generally contained leucocytes and streptoccoci. Should the content of both cells and streptococci rise together, this was diagnostic of a condition of mastitis. When this occurs he believes that an indurated area can usually be detected in the udder.

Gminder and also Frick and Miller believed that in conditions of mastitis, leucocytes were present in excess together with streptococci, while Savage obtained no definite relationship between the presence of a high cell count and streptococci.

Gratz and Maray, and Seibold consider that there are no streptococci in the milk obtained from a healthy cow, but this view is not borne out by the observations of numerous other workers. Thus streptococci were obtained in milk collected from cows who were entirely healthy as far as could be ascertained clinically by Bergey $(I, 2)$ and Rosenow. There is, further, abundant evidence that the milk which is in the teats when milking is commenced contains bacteria, some of which may be streptococci. ${ }^{1}$

Hewlett has also given cases where streptococci were found in the milk, and that in the case of a cow who 'ran her milk.' The presence of streptococci was accompanied by a high cell content, but no disease which could be described as mastitis of an acute or suppurative type was found.

Lewis does not consider that any standard of cells is possible as a means of diagnosing disease, even when there are clumps of cells, unless these are definitely polymorphonuclear or eosinophile cells, either with or without the accompaniment of streptococci. $\mathrm{He}$ agrees with Campbell and Ross, quoted above, that there are usually more cells in the strippings than in the rest of the milk. The work of Rullmann, Pennington and Roberts may also be compared.

It has been suggested by numerous authors that the organisms found in the first milk have gained access to the inside of the teat from the exterior. Streptococci are readily found on the udder, and there is no difficulty in supposing that they occur also on the outside of the teats and probably are able to pass some way up the ducts.

The whole question of cell content and its relation to the presence of streptococci was carefully investigated in America by the New York Milk Committee, and in IgI2 they reported their considered opinion. No more recent work has appeared to alter the opinions there expressed. The Committee say:

'No method has yet been accepted for accurately distinguishing between the pus cells and other cells that may be in the milk that do not have an origin in inflammatory 
conditions. Some regard noticeably clumped cells as indicating pus, stating that upon proper incubation all such clumpings may be found to be accompanied by chain-forming streptococci. Others regard all polymorphonuclear neutrophilic cells as pus. Most, however, at the present time fail to recognise any method of clearly distinguishing pus from tissue cells.

'A general consensus of opinion has been reached that a high cell count should not alone condemn milk, although it is a matter for suspicion. The cell count varies with the same cow upon different days and it may be increased by simply manipulating the udders. ... A high cell count accompanied by streptococci apparently always indicates udder troubles. In many cases these have been followed up to the dairy, and where this has been done it is almost always possible to find the source in some cow suffering from some trouble in its udder.'

The report of the Committee indicates that all cases of high cell count accompanied by streptococci should be regarded with suspicion. Many observers, however, do not go so far, and are disposed to require an investigation of the variety of the strain of streptococcus present. The question of the pathogenicity of strains of streptococci is considered in Chap. XV.

\section{References in Chapter VII}

Cellular Content

Bergey. (I) 'The Prevalence of Streptococci in Cows' Milk,' Amer. Med. Igor, i. I22. (2) 'Source and Nature of Bacteria in Milk,' Penna. Dept. of Agric., Bull. 125, 1904. (3) "The Leucocyte and Streptococcus Content of Cows' Milk,' Univ. of Pennsylvania, Philad., Med. Bull. No. 7 ; Ref. Münch. med. Wochens. 1907, 2398.

BERKA, 'Untersuchungen über menschliches Kolostrum,' Virchow's Arch., I9II, CCV. 59.

BREED. See Prescott and Breed.

BuCKLEy. See Doane and Buckley

CAMPBELL, 'Leucocytes in Milk,' Bureau of Animal Industry, r909, Bull. Ir 7:

Czerny, 'Ueber das Kolostrum,' Prager med. Wochensch. I890, pp. 40r, 4 I6.

DoANe AND Buckley, ' Leucocytes in Milk and their Significance,' Maryland Agric. Exp. Station, 1905, Bull. 102, p. 205.

ERNST, 'Ueber Milchstreptokokken und streptokokken Mastitis,' Monats. $f$. Tierheilk. $1909, \mathrm{xx} .4^{\mathrm{I}} 4$, and $\mathrm{xxi} .55$.

FREUDENREICH, "Ueber die Bakterien im Kuheuter und ihre Verteilung in den verschiedenen Partien des Melkens,' Centralb. f. Bakt. Abt. 2, I904, xiii. $281,407$.

FrICK, Einfluss der Leukocytenzahl und der Entzündungsprodukte auf die Reaktion der Milch,' Milchw. Zentralb. r913, p. 392.

GMINDER, 'Untersuchungen über Mastitisstreptokokken und ihre Differenzierung von saprophytischen Streptokokken;' Centralb. f. Bakt. orig. I9I2, lxiii. I 52 .

Gratz AND MARAy, 'Vergleichende Untersuchungen über die Brauchbarkeit der Katalase, Reduktase und Leucozytenprobe zur Erkennung von Mastitismilch,' Milchw. Zentralb. I912, pp. 225, 257. 
Hastings and Hofrmann, 'Bacterial Content of Milk of Individual Animals,' Centralb. f. Bakt. Abt. 2, I909-10, xxv. 465.

Hewletr, ' On the Nature of the Cellular Elements Present in Milk, Part IV,' Journ. of Hyg. I9I3, xiii. 87.

Hewletr AND Revis, "A Re-investigation on the Nature of the Cellular Elements present in Milk,' Lancet, I9I5, p. 855 .

Hewlett, Villar, and Revis. ( $\mathrm{I}$ ) 'On the Nature of the Cellular Elements Present in Milk,' Journ. of Hyg. 1907, vii. 271. (2) Ibid. Journ. of Hyg. I9I0, x. 56.

Horfmann. See Russell and Hoffmann, and Hastings and Hoffmann.

LEwIs, 'The Cell Content of Milk,' Amer. Journ. of Diseases of Children, r9r3, vi. 225.

MARAy. See Gratz and Maray.

MILleR, 'The Significance of Leucocytes and Streptococci in Milk,' Journ: of Comp. Pathol. and Therap. I909, xxii. 34.

NEw YoRk, "Report of the Commission on Milk Standards appointed by the New York Milk Committee,' Public Health Dept., Washington, Rept. No. 78 , 1912.

Pennington and Roberts, "The Significance of Leucocytes and Streptococci in the Production of a High-grade Milk,' Journ. of Inf. Diseases, 1908, v. 72 .

PRescotT AND BReED, 'Determination of the Number of Body-cells in Milk,' Journ. of Inf. Diseases, I9ro, vii. 632 .

Revis, 'The Examination of Milk for Dirt and Leucocytes,' Journ. of Roy. Inst. of Public Health, I908, xvi. 734.

Revis. See Hewlett and Revis, and Hewlett, Villar, and Revis.

RoBerts. See Pennington and Roberts.

Rosenow, 'A Study of Streptococci from Milk,' Journ. of Inf. Diseases, I $912-13$, xi. 338 .

Ross, 'The Cell Content of Milk,' Journ. of Inf. Diseases, I9I2, x. 7 .

RUнм, 'Die Milchleucozytenprobe (Milcheiterprobe) nach Trommsdorff, Zeit.f. Fleisch-u. Milchhygiene, 1909, xix. 210, $243,277$.

RullmaNN, "Ueber den Enzym- u. Streptokokkengehalt aseptisch entnommener Milch,' Arch. f. Hyg. I9I I, lxxiii. 8I.

Russell aNd Hoffmann, "Distribution of Cell Elements in Milk and their Relation to Sanitary Standards,' Wisconsin Agric. Exp. Station, 1907, p. 231 ; Journ. of Inf. Diseases, IgII, viii. Suppt. 3, p. 63.

SAssenHAGEN, "Ueber biologische Eigenschaften der Kolostral- und Mastitismilch,' Inaug. Dissert. Bern. r 910 ; and Arch. f. Kinderh. I910, liii. 281.

SAVAGE. (I) 'Report on Bacterial Studies of Milk from Healthy and Diseased Cows,' Report of the Medical Officer to L.G.B. 1906-7, Appendix B., No. 4.

(2) 'Streptococci and Leucocytes in Milk,' Journ. of Hyg. 1906, vi. 123.

SchuppIUs, 'Die Milchleukozytenprobe nach Trommsdorff,' Arch. f. Hyg. I907, Ixii. 137 .

SEIBOLD, 'Ueber den Keimgehalt unter aseptischen Kautelen gewonnener Milch und dessen Bedeutung für die Praxis,' Centralb. f. Bakt. orig. Abt. I, I9I0, lv. 301 .

STEWART, 'Methods employed in the Examination of Milk by City Health Authorities,' Amer. Med. I905, ix. 486.

STOKEs, Med. News, I $897,1 \times x i .45$.

Thомas, 'Zur Biologie der Colostrumkörperchen,' Zeit. f. Kinderh. rgr3, viii. orig. 291 .

TrommsdorFF, 'Die Milchleukozytenprobe,' Berl. klin. Wochensch. I906, No. 15; 1909, No. 4 ; Münch. med. Wochensch. 1906, No. I2.

Villar. See Hewlett, Villar, and Revis.

Winkler, 'Die Milchbildung und die Mikroscopische Milchprüfung,' Zeit. d. landwirtsch. Versuchwesen in Oesterreich. 1908, p. 562. 


\section{SUMMARY OF CHAPTER VIII}

\section{BREAST-FEEDING}

IT is not easy to present a concise summary of the work which has been carried out upon breast-feeding, the importance of which it is difficult to over-estimate. The evidence brought forward gives no support to the statements which have been made to the effect that the capacity for lactation is decreasing among women. Where care is exercised and adequate attention paid to the necessary details, the glands can in nearly all cases be brought into the required degree of activity.

Experience both in this country and in other countries shows the advantage of allowing sufficient interval to elapse between the times of feeding. There is abundant evidence to show that the activity of the mammary gland depends greatly upon the stimulus which it receives. Where high demands are made upon it, a much greater amount of milk is secreted, and vice versa. The output of milk is affected when the food-supply of the mother falls below the physiological limit.

\section{CHAPTER VIII}

\section{BREAST-FEEDING}

THE investigations which have been made in many countries into the causes of the infantile death-rate have revealed a close connection between the number of infants who are breast-fed and the number who survive the first year of life. Setting aside the other factors affecting infant life, the naturally-fed infant has a greatly superior chance of surviving than its artificially-fed brother. During the latter part of the nineteenth century a decrease appears to have occurred in the amount of breast-feeding. This has been attributed by some writers to a decrease in the capacity of the female of 
the human species for the fulfilment of the function of lactation. Bunge, as a result of investigations carried out by questionnaires to a number of doctors in Switzerland, believed that the period of lactation was becoming shortened. It appears probable that the period over which lactation extended in earlier times was considerably longer than that which is now customary. Even if this is correct, it does not necessarily follow that the duration of capacity for lactation has undergone a change. No reliable records as to the state of infant mortality in previous centuries are available, and it is not unlikely that the period of lactation was more prolonged than was really advisable. In some districts in this country at the present time, many women continue to suckle their babies until well on into the second year of life, often with unsatisfactory results both to mother and child. The present unnatural conditions of life may tend to produce detrimental effects upon a large number of individual women, but it is hardly likely that the capacity of the race for lactation has as yet been appreciably affected.

In this chapter the advisability of breast-feeding will be assumed. It remains to consider the present state of knowledge "as to the best methods to secure the possibility of breast-feeding. Bunge's work referred to above was subject to some degree of misinterpretation, many readers believing that he considered the function of lactation to be on the decline. This, as has been mentioned above, is not precisely the point of view to which Bunge was led as the result of his investigations.

The movement for the preservation of infant life and health which spread over a large part of Europe and in America with astonishing rapidity during the last quarter of a century, has thrown a flood of light upon the whole question of breast-feeding. The institutions which have been established for the welfare of mothers and infants differ in their methods according to the characteristics of the country in which they are found. All, however, have assisted in providing data upon this subject, and the results obtained, although differing in certain points of detail, have been fundamentally confirmatory of one another.

Two main points will be considered in this chapter: (I) The existing capacity for the function of lactation in the human species, and (2) the period of lactation.

I. The Capacity for Lactation.-There can be little doubt that with few exceptions lactation can be established in every woman. Increased experience has shown that the difficulties which exist in a certain proportion of cases can be satisfactorily surmounted in nearly every instance. In foreign institutions where wetnurses are frequently used it is recognised that there are fairly wide variations between the extent of the capacity for lactation in different women, yet it is exceptional to find cases where this cannot be established. Budin (I) says: 'Every woman 
I deliver must suckle while in hospital. When she leaves the clinic she is usually both willing and able to nurse.' Thiemich says: 'It happens so rarely that the breast of a lying-in woman gives no secretion that it plays no part in practice. . . Sometimes it may be 48 hours after birth before practically any colostrum can be pressed out of the breast, and yet after a little while the secretion of milk reaches a satisfactory height, if the child is put to the breast regularly and sucks strongly.' 1 On February 5, I9I4, Professor Pinard stated to the French Academy of Medicine that out of I2,000 cases of confinement which had occurred in the hospitals in Paris in the previous five months, there had been none in which lactation had not been possible. $\mathrm{He}$ added that he regarded a lying-in woman who had no milk as being an abnormal person.

An important factor appears to lie in the infant itself. The response of the gland varies with the stimulus given to it by suckling, and if the infant be feeble the stimulus may not be great enough adequately to establish the function of lactation, which is thus retarded. This difficulty, unless overcome, will probably lead to the abandonment of breast-feeding. The /strength of stimulus can easily be improved either by temporarily supplementing the feeding or by allowing a stronger child to supply the necessary increased stimulus. ${ }^{2}$

There is no reason to suppose that the capacity for the establishment of lactation among Englishwomen is less than that among the women of countries quoted above. The information as to the method of feeding which is obtained in numerous towns throughout this country by the municipal health visitors shows that it is by no means unusual to find that 80 per cent. or more of the women nurse their babies for at least the first fortnight after birth, within which period the visit by the health visitor is paid. ${ }^{3}$ The figures given do not show the extent of the capacity for breast-feeding, as some mothers have already put the child on the bottle, before the advent of the health visitor, in spite of the presence of plenty of milk in the gland. Further, there are some women who make no effort to secure the establishment of lactation, as they do not wish to suckle the baby. If the value of natural feeding were realised it can hardly be doubted that the capacity for breastfeeding would be found to be practically universal among the women of England. Thus the Inspector of Midwives for Northamptonshire says :

- The important matter of breast-feeding has been kept well before the midwives, and, from inquiries made, I find that out of I854 live births occurring in their practice, I799 were breast-fed

$1 C p$. also Engel (I).

$2 C p$. Rietschel, Cameron, and others. others.

${ }^{3}$ Cp. Annual Report of M.O.H. for Newcastle, Coventry, and many 
while the midwife was in attendance, but I am sorry to say in many instances this has been given up for the bottle when the midwife has ceased her visits.' 1

And the Medical Officer of Health for St. Helens says :

- A high percentage (97 per cent.) of infants were breast-fed at the time of the first visit, but there is reason to believe that this is discontinued within a short period.' '

These instances might be multiplied many times, but enough evidence has probably been brought forward to show that the capacity for lactation may still be regarded as universally present in the female of the human species.

2. The Period of Lactation.-It is frequently stated that, although lactation may be established, it is not possible to maintain it for the necessary period. This statement has led many persons to the belief that the capacity for sustained lactation is decreasing among women.

It may be at once admitted that on the surface there appears to be some truth in this statement. Inquiry and investigation show, however, that where due regard is paid to the requirements of the gland the difficulties are apparent rather than real, and can in almost all cases be removed.

The knowledge which has been obtained as to the functions of the human mammary gland has come almost entirely from countries outside our own. The chief cause of this is probably to be found in the more common use of wet-nurses in foreign countries, especially in institutions for sick children.

It is curious that in considering this matter so little attention has been paid to the method of action of the mammary glands of lower animals, more especially to that of the humble cow. There has, however, been no lack of readiness to rely upon the organ of this animal instead of attempting to ascertain why it was, that the gland of the cow continued to give milk and that of the human species did not do so. The functions of the various organs are fundamentally similar throughout the animal kingdom, and knowledge gained as to the functions of an organ in one species can frequently be applied to that of the human species.

It is a matter of common knowledge to the dairy farmer, that unless the udder be emptied at each milking, and unless the milkings take place at sufficiently frequent intervals, the cow will no longer give her full quantity of milk, and will in fact soon cease to give milk altogether.

The growth of the movement for 'clean milk' in America led to the introduction of the milking machine for cows. It was found at first that the machine did not empty the udder and that the cows ceased to give milk much sooner than would have been the

1 R.A., Co. M.O.H., I9I 2, pp. 48, 49.

${ }^{2}$ A.R., I9I 4, p. 418. 
case had they been milked by hand. This proved a source of considerable financial loss to the farmers.

The same causes operate in the human species in reducing the period of lactation.

Unless the gland is emptied completely the functions will not be maintained. The child should not be fed so frequently that it is not hungry when fed. Unless it is hungry it will probably not empty the gland. The practice of feeding a baby every two hours during the day and every four hours at night during the early months is unfortunately still too common in this country.

The work of Leven and Barratt, and also of Tobler and Bogen, upon the time required for digestion in the infant's stomach, suggests that this organ is seldom emptied in less than two hours after a meal, hence there is no rest for the stomach of the infant which is fed every two hours. These authors found that the progress of digestion in the infant's stomach could be studied with the X-rays without the addition of bismuth to the food. Various quantities of milk, both human and cows' milk, were given to the infants in the amounts and dilutions which are generally employed in the feeding of infants. It is an interesting point that in both sets of observations a high fat content was found to lengthen the time required for digestion.

It is well known that the end milk of the cow contains the bulk of the fat. This is also the case in human milk ( $c p$. Chap. II, pp. 23-24). Hence the child who is fed too frequently to be hungry not only does not give the full physiological stimulus to the gland, but obtains only a fraction of the available fatty portion of the food.

Frequent feeding will therefore have a deleterious effect both on the infant and on the milk supply, tending to cause both a shortened period of lactation and to induce unsatisfactory nutritive conditions in the child owing to a deficiency of fat. A vicious circle is thus set up which leads to weaning, as the mother usually becomes convinced that the child is not satisfied with her milk. Night-feeding is also detrimental to the mother, as it prevents her from receiving the restful sleep which she needs.

Numerous observers have investigated the amounts of milk given by a mother during the whole period of lactation. ${ }^{1}$ It is found that the amount given gradually increases during the early weeks, remaining practically constant until just before the end of lactation. Diagram 3 (see next page) shows (I) the rise and maintenance of the quantity of milk given, together with the weight charts of the children, and (2) that good weight charts may be shown by children taking different quantities of milk. There is clearly a considerable power of adaptation between the needs of the individual child and the function of the breast. 


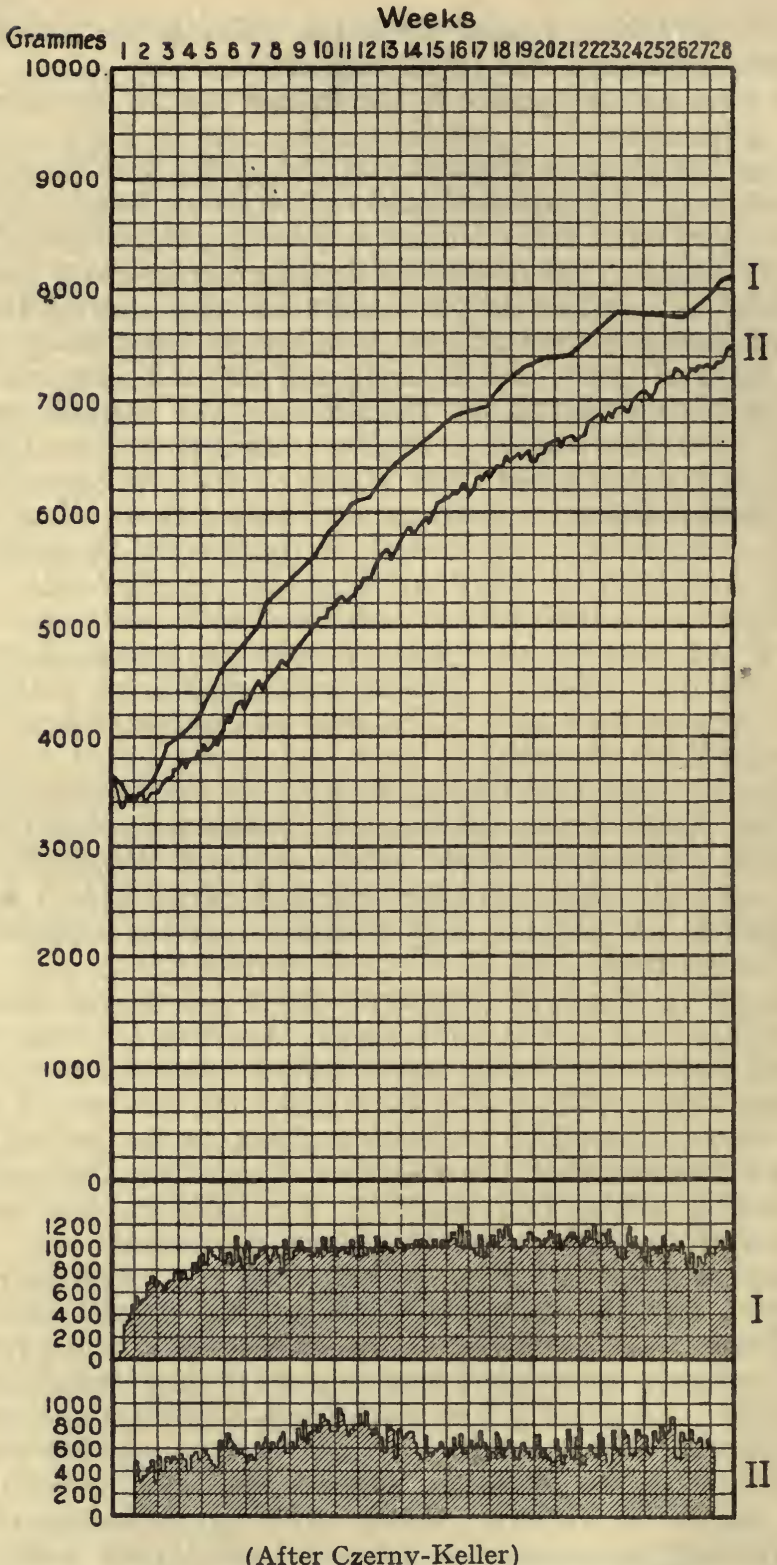

(After Czerny-Keller)

DIAGRAM 3.-The numerals I and II placed against the curves correspond respectively to those below. These latter show the grammes of milk taken each day by each of the two children. 
Observations made by Forsyth in this country show very similar conditions. The table given below shows the gradual rise in the

\begin{tabular}{|c|c|c|c|c|c|}
\hline Week & $\begin{array}{c}\text { Total Weekly } \\
\text { Consumption }\end{array}$ & Daily Average & $\begin{array}{c}\text { Average Size } \\
\text { of Feed }\end{array}$ & Largest Feed & Smallest Feed \\
\cline { 3 - 6 } & c.c. & c.c. & c.c. & c.c. & c.c. \\
\hline 2 & 750 & 250 & 28 & 55 & 7 \\
3 & 3620 & 517 & 57 & 125 & 7 \\
4 & 3025 & 461 & 46 & 125 & 7 \\
5 & 3290 & 470 & 46 & 100 & 13 \\
6 & 4305 & 615 & 66 & 100 & 30 \\
7 & 4215 & 602 & 65 & 110 & 40 \\
& 4595 & 685 & 77 & 185 & 35 \\
\hline
\end{tabular}

amount of milk taken during the early weeks of life, and also the great irregularity in the quantities taken at each feed; and

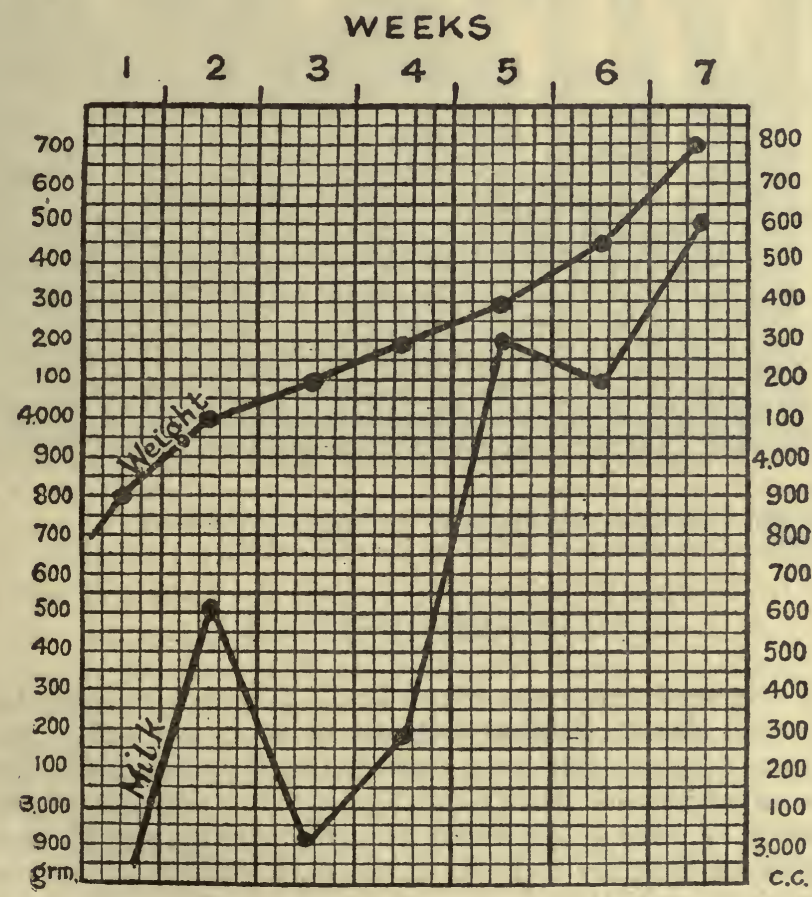

DIAGRAM 4.-Showing the average amount of milk and the weight in grammes of the child of the above table in the first seven weeks after birth.

Diagram 4 illustrates very markedly the facts just referred to in connection with Diagram 3, namely, that there is no direct 
proportion between the rate of growth and the amount of milk taken.

The Response to an Increased Stimulus.-Several investigators have shown that the amount of milk given by the gland can be increased by increasing the demand upon it. Budin showed that if a wet-nurse was called upon to feed more than one child, her milk increased in amount; and, up to a certain limit, varied with the number of children she was feeding. Similar results were shown by Schlossmann, and more recently by Brodsky and also by Aurnhammer. In order to demonstrate this the following diagram

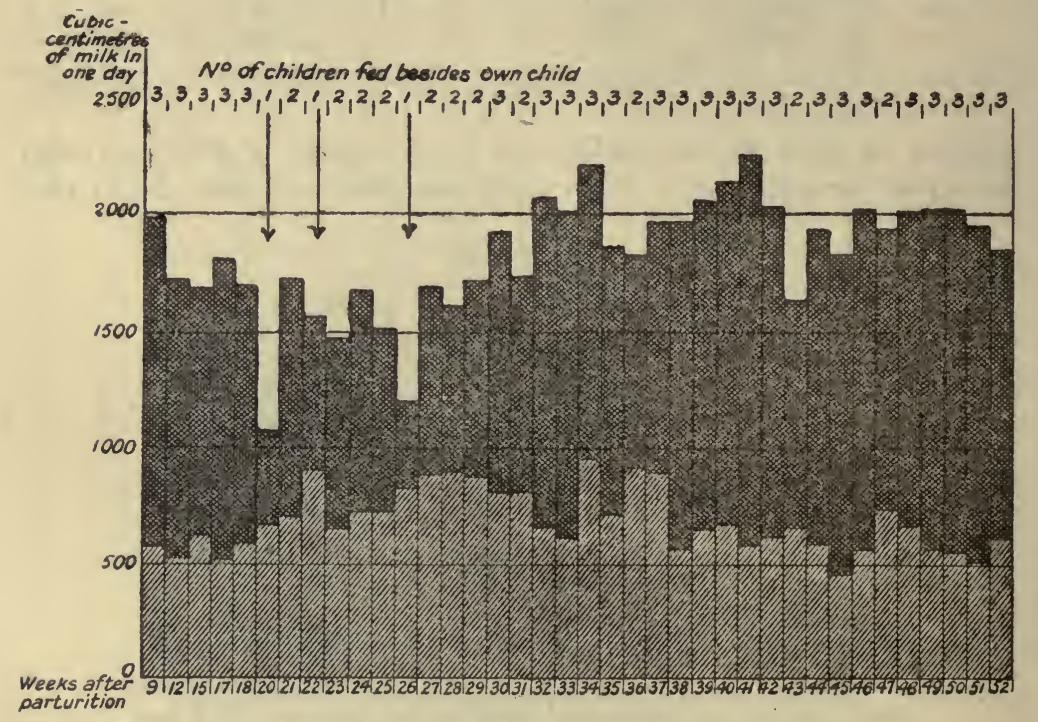

VIm Shows amount taken by wet-nurse's own child.

Shows amount taken by the other children.

DIAGRAM 5.-Showing the relationship between the amount of milk given and the number of children fed.

has been prepared from one set of Budin's figures. Other figures by Budin and also by Schlossmann are given in Appendix A.

Diagram 5 shows the very remarkable response made by the gland to an additional stimulus. The marked temporary drop in the quantity of milk given which occurred on two occasions when the number of children fed was reduced is extremely interesting. Birk also deals with the increased response of the gland to the demand put upon it, and points out that care should be taken to avoid overtaxing the strength of the mother.

Some interesting points in connection with the intervals of feeding were also ascertained by Helbich. This observer obtained 
the total amount of milk given at different intervals by a nursing mother. The amount of milk given was ascertained partly by mechanical removal and partly by weighing the infant before and after suckling, by which method the amount taken by the infant is given. The figures thus obtained were added and showed the total amount given at each occasion. The diagram below has been prepared to show these points, and is taken from Helbich's figures.

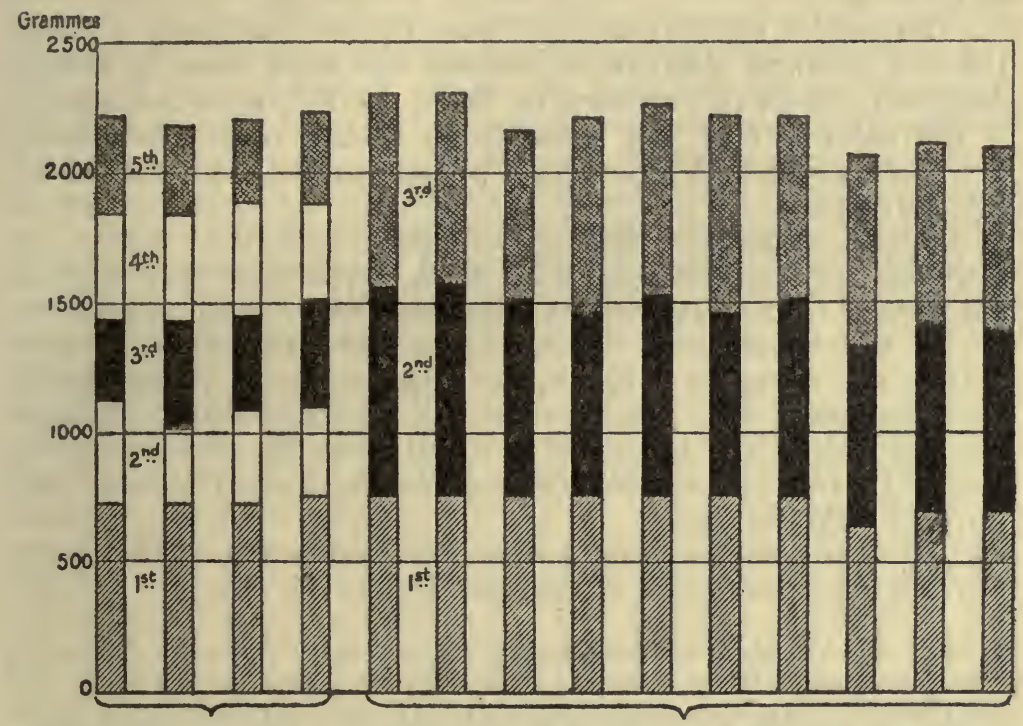

DIAGRAM 6.-Showing the effect of the intervals of feeding on the amount of milk obtained after each interval.

Each column shows the total amount of milk given each day. The divisions in each column show the amounts given at each occasion when the gland was emptied.

With five periods of suckling in the twenty-four hours, i.e. four hours in the daytime and eight hours at night, the amount given in the morning greatly exceeded the others. When, however, the intervals were made equal, that is eight hourly, the amounts of milk given on each occasion became approximately equal.

On the fifth day of the experiment the procedure was altered and the milk was withdrawn three times a day at eight-hourly intervals, namely, at 5.30 A.M., I.30 P.M., and 9.30 P.M. The result was three large, almost equal, amounts of milk, the total of which equalled the quantity obtained daily under the former conditions.

It is interesting to note that while the secretion was well maintained for six and a half months when the removal of milk was made five times in the day, it began to fall off slightly after three 
weeks when removal was only practised three times a day. This fact is of considerable importance in connection with mixed feeding. Mixed feeding, i.e. giving both human and cows' milk to the same infant at the same period of life, is now universally accepted as greatly superior to artificial feeding alone. The practical difficulty, however, is that just referred to, namely, that when the gland is only emptied two or three times in the day the secretion tends to decrease.

The greater equality in the amount given which results from the less frequent intervals of feeding has been recently further demonstrated in this country by $\mathrm{H}$. $\mathrm{K}$. Waller, who showed that if the child is only fed three times in the twenty-four hours the amounts become more equal (in one case I4, I2, and II oz. respectively).

General experience has shown that mechanical means for emptying the mammary gland are much less effective than suckling the infant. The last portions of the milk cannot easily be removed by the usual apparatus, which will, however, remove the greater portion of the supply. Hence, the gland subjected to mechanical emptying only, will usually cease to produce milk." Helbich, however, with care, succeeded in maintaining the function of the gland in several wet-nurses for many weeks, when the breast was emptied artificially only.

Out of the numerous cases described in detail by Helbich, two will provide illustrations of the main results:

Case A.-The child was ten days old when it came under observation for this experiment. It then weighed 1900 grammes (rather over 4 lbs.). The child was too weak to obtain the milk from the breast, and the milk was, therefore, drawn off artificially. The child died a fortnight later. The mother was then instructed to draw off the milk with the breast-pump. The daily amount of milk, which at the beginning of the period of observation was about 300400 grammes, rose to about 800 grammes before the child died, and continued to rise gradually until ro weeks later it had reached a fairly constant level of 1300 grammes.

$C$ ase $B$.- The child was fourteen days old when the observations were commenced, and was too weak to obtain sufficient nourishment by suckling. At first the amount of milk which could be obtained artificially from the breast amounted only to a few grammes in the day. A week later the child died, and the daily amount of milk given had then reached 300-400 grammes in all, including that taken by the child. Artificial removal of the milk was continued, but for about five weeks did not exceed 400-500 grammes a day. It then gradually rose, and in the next five or six weeks reached about I300 grammes, a maximum of I 500 grammes being attained later. The amount remained at about 1400 grammes until the patient left the hospital, the milk having been withdrawn artificially for 21 weeks.

So far, in considering the function of lactation, it has been assumed that satisfactory conditions were provided for the maternal organism, upon which the gland depends for its blood supply. It is essential that the food supply for the mother should be sufficient and suitable. Remarks are frequently found upon the value of 
various special foods or substances in the production of milk. The available evidence is to the effect that no special influence upon the secretion of milk is exercised by any one particular substance directly.

What is really essential is that there should be a sufficient amount of food taken, which must contain a sufficiency of the materials essential for the daily life of the maternal organism, i.e. there must be enough protein, fat, carbohydrate, salts and water. Schlossmann in I90o quoted several cases which had come into his practice where the wet-nurses had a plentiful supply of milk while in the institution. Here the food was ample, reasonably varied, perhaps rather coarse, but what each woman was accustomed to in her own home. On being sent as wet-nurse to a private house, a woman not infrequently lost her milk. Inquiry showed that although sufficient food was provided, frequently of a highly nutritious kind, it was not such as the woman liked. In consequence she would not eat it, and the milk supply failed after a short period. When she returned to the institution the milk supply was restored.

A considerable amount of work has been carried out upon the relation of the amount of milk secreted by cows to special constituents of the food. This has already been considered in Chaps. II and IV, where it was shown that unless any particular constituent of the food is decreased beyond the physiological limit for the organism the amount of milk given by the gland is not affected. When the amount of any essential constituent falls below the physiological limit, the supply also falls.

It would seem that the milk given by cows can be to some extent increased by an additional amount of food, and that if the food-supply is diminished below the physiological limit, the amount of milk produced falls off. Conversely, if the amount of food-stuff is increased, it is possible to increase the amount of milk to some degree, although the increase is not proportional to the amount of food given. ${ }^{1}$ This subject is also dealt with by Claus, who showed that a decrease in the food reduces the amount of milk given, and he suggests that the expense of the additional food might be greater than the value of the corresponding milk produced, and that it might pay farmers better to give less food and obtain rather less milk.

It is probable that many cases of failure of lactation in women have been caused by the absence of proper nourishment for the mother. The experience which has been gained at institutions, where dinners for nursing mothers are provided, is to the same effect. The published figures available from these dining centres are somewhat fragmentary and for the most part too few in number for considerable stress to be laid upon the experience obtained 
from any one centre. Where, however, although each centre is individually small, the experience runs along identical lines, some reliance may be placed upon the general results obtained. It is the opinion of the officers who supervise the work at these centres that the provision of an adequate food-supply for the mother almost invariably enables breast-feeding to be maintained, mothers who have previously been unable to feed their children being able to do so without difficulty when provided with sufficient food of a suitable nature. Moreover, in many instances, where the milk-supply was becoming apparently short, it has been completely regained, and lactation continued up to the ninth month.

No special foods or substances are either indicated or contraindicated. The health of the mother must be maintained. Where this is affected owing to the idiosyncrasy of the individual for any particular food-stuff, that food-stuff should be avoided-that is all.

Birk considers the question of an increased output, obtained as a result of increasing the number of children fed, in relation to the health of the mother. He found that where several infants were fed by one mother, the amount of energy taken in, in the food of the mother, might not be sufficient. In several cases investigated by him he found that the residual energy available for the mother, after deducting the energy given off in the milk, was below that usually considered sufficient for health. He thinks the question probably does not arise when only one child is fed, but in other cases he suggests that attention should be paid to the energy requirements of the mother, especially to the inorganic salts in the food.

Bamberg, however, does not take quite the same view, and regards the output of milk as to some degree controlled by a selfregulating mechanism. He estimated the heat value of the food taken and of the milk given out by several women who were suckling more than one child. In several cases he found that there was not enough difference between the two values to provide the theoretical amount of calories per kilogram of body-weight for the mother. These women, however, appeared to be quite well, did a fair amount of work, and did not lose weight. These practical points appear to outweigh the theoretical question of calories needed, and led him to the conclusion that the total output of milk was regulated so as not unduly to deplete the maternal organism.

Budin's tables ${ }^{1}$ show that a considerable supply of milk may be given for sixty-four weeks, and this has already been referred to as occurring in this country. General experience, and considerations arising out of the composition of milk after about the eighth month of lactation, fixes the length of lactation at from six to nine months, the longer period being a very usual one. 
In the series of 300 breast-fed infants whose records were examined by me for the purpose of a report to the Local Government Board, where all the babies had been fed on the breast up to the age of four months, it was found that 52 out of the 300 had been weaned between the ages of four and six months (some possibly for other reasons than the failure of the milk), but that the great majority were not weaned until nine months of age. The weight charts, however, suggested that although the supply was sufficient for the needs of the infant, the optimum rate of growth was not secured in all cases for the full period of nine months. See Chap. XI.

It is stated, however, by Finkelstein, Schlossmann (2), Engel (2), and others that there is practically no limit to the period of lactation of a good wet-nurse, and that the breast will continue to secrete a good quantity of milk so long as the stimulus of suckling is supplied. It is doubtful how far this can be considered generally applicable to the mother of a family, the conditions in institutions being of a somewhat unusual nature.

Later Effects of Breast-feeding.-The later results of breastfeeding as compared with artificial feeding have not been adequately investigated.

The question of rickets in relation to breast-feeding will be considered in Chap. XIII.

The low mortality among breast-fed infants during the first year of life, as compared with that among the artificially-fed infants, has been so fully demonstrated that it is unnecessary to deal with the matter here. Further information may be obtained in Chap. XIV of the Supplement to the 42nd Report of the Medical Officer of the Local Government Board. (See under Newsholme.)

The health of breast-fed children after the period of infancy is considered briefly in Appendix B.

\section{References in Chapter Vili and Appendices}

\section{Breast-Feeding}

Aurnhammer, 'Ueber die Beziehung zwischen Milchproduktion und Fettgehalt der Milch,' Arch. f. Kinderh. I 909, li. I6r.

BAMBERG, ' Zur Physiologie der Lactation mit besonderer Berücksichtigung der chemischen Zusammenhang der Frauenmilch milchreicher Frauen und des Einfluss der Menstruation,' Zeit. f. Kinderh. 1913, vi. 424.

BARRATT. See Leven and Barratt.

BIRK, 'Zur Frage der Ernährung stillender Frauen,' Münch. med. Wochensch. Igr I, lviii. I665.

BOGEN. See Tobler and Bogen.

BRODSKY, 'Beobachtungen über die Lactation der Ammen,' Arch. f. Kinderh. I914, lxiii. 16r.

Budin. (I) The Nursling," p. I56. (2) The Nursling, Appendices II and III, Pp. 166-172. English translation. 
BUNGE, 'Die zunehmende Unfähigkeit der. Frauen zu stillen,' München, I 909. CAMERON, "On the Causes of the Failure of Women to Nurse their Infants at the Breast,' Lancet, I9I3, ii. 9II.

Claus, Mitteilungen des landwirtschaftlichen Instituts der Universität Leipzig, I9I I, Heft Io. Quoted by Grimmer, Milchw. Zentralb, I91 2, p. I05.

Coventry. See Annual Report of M.O.H., I9I3, p. 44; and also other years.

Czerny-Keller. Des Kindes Ernährung, etc.

ENGEL. (I) Grundriss der Säuglingskunde, p. 59, Wiesbaden, I9I2. (2) Schlossmann and Pfaundler's Handbuch der Kinderheilkunde.

Finkelstern, Die Waisensäuglinge Berlins, Berlin, I904.

Forsyth, 'Breast-feeding,' Lancet, I913, i. I656.

HELBICH, ' Bedarf es des physiologischen Reizes zur Anregung und Erhaltung der Laktation ?' Monats. f. Kinderh. I9I I, x. 391 .

LANE-Claypon, Report to the L.G.B. upon the Available Data in Regard to the Value of Boiled Milk as a Food for Infants and Young Animals, New Series, No. 63, I912.

Leven and Barratt, 'L'Estomac du Nourisson,' Presse Médicale I906, No. 63, p. 503 .

NewCASTLE, Annual Report of M.O.H., I913, p. 52 ; and also other years.

Newsholme, Supplement of the 42 nd Annual Report to the L.G.B.,' I9ro.

Northamptonshire, Annual Report of Co. M.O.H., I912, pp. $48,49$.

Pinard, Bull. de l'Acad. de Méd. I9I4, lxxiii. 234.

Rietschel, ' Zur Technik der Ernährung der Brust-Kinder,' Jahrb. f. Kinderh. I912, lxxv. 403 and 601 .

St. Helens, Annual Report of M.O.H., r9I 4, p. 218.

Schlossmann. (I) 'Zur Frage der natürlichen Säuglingsernährung,'Arch. f. Kinderh. 1900, xxx. 324. (2) 'Ueber die Leistungsfähigkeit der weiblichen Brustdrüse,' Monats. f. Geb. u. Gyn. I903, xvii. II3I.

Tobler AND Bogen, 'Ueber die Dauer der Magenverdauung der Milch und ihre Beeinflussung durch verschiedene Faktoren,' Monats. $f$. Kinderh. 1908-9, vii. I 2

ThIемich, Feer's Handbuch der Kinderheilkunde, pp. 32, 34.

WALlER, 'Breast-feeding,' Lancet, I9I 5, p. I I 5. 


\section{SUMMARY OF CHAPTER IX}

IT may appear at first sight that it would always be superfluous to boil the milk for the young of the same species. This procedure may, however, be necessary in special cases, where there is danger of disease in the mother becoming transmitted to the offspring through the milk.

Human Milk.-In this country the question of boiling human milk may be said not to arise, but in other countries where wetnurses are used, it becomes a matter of considerable importance. It is well known that hereditary disease can be transmitted by suckling. A mother suffering from syphilitic disease can infect the healthy child of another woman, if she suckles it. This danger is perhaps the most prominent difficulty in connection with wetnursing. It is sometimes almost impossible to be certain that the wet-nurse is free from this disease, and the first positive information upon this matter may arise from the occurrence of the disease in the child she has suckled. In order to avoid this danger, it is not uncommon in countries where wet-nurses are extensively used in institutions and among the richer classes, to instruct the wet-nurse to express from the breast any milk for other children beside her own child. This milk is then boiled before being used. Boiling removes the danger of the transmission of the disease, but the possible loss of nutritive value by this procedure must be taken into consideration. Very few detailed investigations are available upon this point, and in such cases as have been published the data are not sufficiently extensive for any precise decision to be arrived at. In actual practice the procedure has been comparatively frequently carried out, and although no precise statistics are available upon the subject, it is generally believed by those who have had most experience upon this matter, that little, if any, impairment of nutritive value is produced by boiling the milk.

Cows' Milk.-The problem of the nutritive value of boiled cows' milk as a food for calves is one of practical importance to the agriculturist. It is of special importance in those countries where the sale of tuberculous milk is universally prohibited and the pro- 
hibition strictly enforced. Under these circumstances the milk of tuberculous cows is useless as a market commodity in its raw state, and it becomes a matter of considerable financial importance to the farmer to be informed what he can do in order to obtain some return for the milk produced by tuberculous cows.

The problem has been attacked practically in Denmark under the direction of Professor Bang, of Copenhagen. Here the milk of tuberculous cows is boiled and is then fed to their calves, with results which are said to be entirely satisfactory. Unfortunately, precise data upon this point are not available.

Valuable work along this line has also been carried out by Hittcher, whose work shows the value of an adequate and suitable salt content in the food. He emphasises the importance of carrying out experiments over a sufficiently long period, and also of taking into consideration the age of the animal. Growth is more rapid in the early weeks than later, and much confusion may arise unless this fact is recognised, especially when the amount of food taken in relation to the body weight, and the increase in body weight, have to be considered. The amount of food required in the feeding of animals is a matter of extreme importance to the farmer, and may just make the difference between financial loss and gain. Hittcher's experiments show that, with the addition of salt, boiled milk appears to be better utilised by the calves than raw milk. It seems clear from the work in Denmark and from Hittcher's experiments that calves may be fed quite satisfactorily upon the boiled milk of their tuberculous mothers.

\section{CHAPTER IX}

ON THE NUTRITIVE VALUE OF BOILED MILK OF THE SAME SPECIES

1. Human Milk.-The experiments which have been made upon the use of boiled human milk are not numerous. In this country no experiments have been performed, and, as wet-nurses are not used, little practical value attaches to the whole matter.

The work hitherto undertaken in other countries has been mainly carried out on individual children, which renders it difficult to survey the investigations briefly. The results are somewhat varied, partly, no doubt, owing to the different conditions under which the experiments were conducted. The work, the greater part of which was originally prepared by me for a report to the L.G.B., is therefore necessarily given in considerable detail.

Moro (I902) describes two cases of weakly children who received first of all the breast, and were then fed upon the expressed milk, which had been boiled for ten minutes. The children showed a 
markedly inferior gain in weight upon the boiled human milk, to that which they exhibited upon the breast milk.

The average gain in weight noted was as follows:-

In case I:-

In fourteen days on the breast the average gain was $26 \frac{1}{2}$ grammes per day.

In eight days on the bottle with raw human milk the average gain was 37 grammes per day.

In ten days on boiled human milk the figure was 9.9 grammes per day.

In case II :-

In seven days the average gain on the breast was I 4 grammes per day.

In five days on raw human milk in a bottle it was 20 grammes per day.

In seven days on boiled human milk it was 9 grammes per day.

It would be unwise to base any assertions upon two experiments, but as far as the experiments go, it would appear that some of the value of the human milk is lost by boiling. It is curious that both children showed a greatly increased average gain per day, when fed upon the human milk in a bottle as compared with the breast, and this rather suggests that they were getting more actual food in the shape of a larger quantity of milk. It might be that different results would have been obtained if the milk had not been boiled for as long a time as ten minutes. Moro attributes the effect produced to a loss of the so-called 'protective substances' of the milk.

L. F. Meyer (I906), in the course of his 'Exchange' experiments, where three children were fed first upon human whey and the protein of cows' milk, and then upon cows' milk and the protein of human milk, found that if the human whey was boiled the good results obtained with the first mode of feeding were greatly reduced. As, however, the experiment was only carried out over a very few days, and was an isolated one, it cannot be taken as proving that substances necessary for health are lost by the boiling of milk.

It would appear also that Meyer himself does not lay much stress upon this experiment, since in his book (I9IO) in conjunction with Langstein he says, "clinical observations could not show any advantage of raw cows' milk over boiled, and recent experiments have also shown that the boiling of human milk does not cause any deterioration of its nutritive value.'

Potpeschnig (1907) carried out some work with a view to ascertaining whether these same hypothetical substances said to have a protective function were injured by heating to $60^{\circ} \mathrm{C}$., this being the temperature to which $\mathrm{v}$. Behring considered that milk might safely be heated without undergoing any loss of nutritive value. 
Two children, both premature, were fed at the breast of a wet-nurse until it was evident that they were doing well, and the weight-curve showed a daily satisfactory increase. This was for a period of three days. The children then received the milk after it had been expressed and kept cool, all aseptic precautions being taken. Both children showed a transient loss of weight, but in a few days the weight curve again began to rise, and showed a steady increase. This period lasted five days.

The expressed milk was now heated to $60^{\circ} \mathrm{C}$. for half an hour, and was then stored in the cold room for use as required. The period of this form of feeding lasted seventeen days, and the weightcurve showed a steady rise throughout the entire period, nor could a disturbance of any kind be detected. After this, the wet-nurses being no longer available, the children received boiled cows' milk, and the weight-curves continued to rise just as steadily as with the boiled human milk.

The author considers that these children are no criterion, since they did as well upon boiled cows' milk as upon human milk, and thus he says were evidently capable of manufacturing their own 'protective substances.' The basis for this stätement is hardly satisfactory.

E. Müller (I908) carried out a very interesting experiment upon a child under his care. This baby was premature and weakly, and was twenty-five days old when it came under his treatment. The child was first of all put upon the breast of a wet nurse, and made very little progress, the average gain in weight being 12 grammes per day. The baby was therefore put upon a diet of raw human whey and raw cow' fat and casein; this feeding was continued for five days, during which time the child gained weight at the rate of 4.4 grammes per day. The author considered this increased gain in weight due to the increase of protein material in the food. Next it received cows' whey and human fat and casein, both raw, for lourteen days, but the results obtained were not similar throughout the period. For the first five days the child made good progress and put on weight at the rate of 33 grammes per day, but during the last nine days it only gained 30 grammes in the whole period. There was also a tendency to diarrhœa. It was then put back upon human whey and cows' casein and fat, and again made good progress, gaining I 7 grammes per day for three days. The human whey was now boiled and mixed with the cows' casein and fat, and the child gained in weight at the rate of 15 grammes per day for thirty-three days. It would seem, therefore, that no harm was done to the nutritive properties of the human whey by boiling.

Müller points out that the upholders of the theory of "protective substances' in milk all agree that these are present in the whey; hence this case in which he fed a weakly child with success upon boiled whey (in which presumably these same substances, if present, were destroyed) is of considerable interest. 
Finkelstein mentions that he fed six babies upon boiled mother's milk, and found that they did not do so well as upon the raw human milk, and concludes therefore that the milk of the same species loses some of its value by boiling; in contradistinction to that of a foreign species. He does not give any data upon this point.

The most numerous cases I have been able to discover are those of Professor Thiemich of Magdeburg. They are unfortunately as yet unpublished, although the data are available, but Professor Thiemich was so kind as to give permission to me to quote his experiences for the purpose of my report to the L.G.B. $\mathrm{He}$ furnished me with a short report of his results, as follows: 'In my wards the milk of all the new wet-nurses is given boiled only, until Wasserman's and Stern's reactions ${ }^{1}$ have been carried out.

'If it happens, as it frequently does, that one or other of the reactions is positive or doubtful, and there is no detectable evidence of specific trouble in either mother or child, I sometimes keep the wet-nurse for many months, and during the whole of this period her milk is only given boiled. I may add that in the case of an infant living with its parents which requires a wet-nurse or human milk for " allaitement mixte" it is only in very exceptional cases that I allow actual suckling. Otherwise only expressed and boiled milk, human milk, is given by the bottle in suitable quantities. Similarly the milk of a feverish wet-nurse is boiled, not because of the risk of the direct passage of any organisms in the milk, but because of the possibility of outside contamination of the milk.

- On this system I have now seen a great number of children improve just as well upon boiled human milk, as happens with raw human milk.

- In a smaller number of cases raw and boiled human milk have been given alternately and systematically for various periods of days and we ks with the same result, namely, that no difference could be detected.'

The data are not extensive, and while no decisive pronouncement can be made upon the subject there is considerable evidence that no marked impairment in nutritive value is produced by boiling human milk.

2. Cows' Milk.-The evidence as to the nutritive value of boiled cows' milk for calves is of a very similar nature to that in the case of human milk.

Th detailed experiments have with one notable exception (Hittcher) all been on a very small number of calves. Where, as in Denmark, the experiment has been conducted upon a large scale, no precise data are available. An account of the investigations is given in chronological order.

The first work appears $t$ be that by Gerlach, who found that calves fed upon boiled milk from birth did not do well after

1 Stern's reaction is a modification of Wassermann's, and apparently sometimes clears up a doubtful diagnosis obtained by Wassermann's method. 
about four days. All trouble ceased; however, after the addition of sodium chloride, and the calves did excellently upon the boiled milk. After about a year, calves fed by this method again began to do badly, and it was ascertained that the salt had been omitted. These facts are very interesting, especially in conjunction with the experiments of Hittcher, recorded below.

The experiments of Price, and of Doane and Price in America, certainly point to there being a disadvantage in the sterilisation of cows' milk. This food produced diarrhœa in some of the calves used.

Calves were also fed upon raw, boiled or pasteurised milk and sterilised milk, by Price, who found that the calves fed upon raw milk did the best. Four calves were used, and were fed for three days at a time upon the different forms of milk. Sterilised milk produced scouring in three out of the four calves. This milk was heated to $190^{\circ} \mathrm{F}$. for half an hour.

No data are given as to the age of the calf or the amount of milk given.

One of the calves was found to digest the sterilised milk as well as the other forms of milk.

H. H. Dean carried out some work upon calves fed upon raw and pasteurised skim milk. He used four calves; two were fed for the first four weeks of the experiment upon raw, and two upon pasteurised milk. After a week's interval the feeding was reversed, and those which had received raw milk now received pasteurised milk and vice versa. The calves also received other food. The weights of the calves and the weight of food taken were recorded. Dean concluded that no difference between the two kinds of feeding could be detected, and recommended the pasteurising of skim milk before it is given to calves.

A successful campaign has been waged in Denmark against tuberculosis, under the auspices of Prof. Bang of Copenhagen, by the simple process of boiling the milk of tuberculous cows before giving it to the calves. Unfortunately no data as to the weight or rate of growth of the calves during the course of the feeding with boiled milk are available. I am informed by Prof. Bang that the method has now been applied in many hundreds of cases, and has been found to be entirely satisfactory. The calves are taken away from the tuberculous mother at birth, and are fed for two days upon raw cows' milk, after which they receive the milk of their tuberculous mother, either boiled or raised to a temperature of $80^{\circ} \mathrm{C}$.

Hittcher has carried out some important work upon the value of boiled and raw cows' milk as a food for calves, with and without the addition of certain salts. He first ascertained which salts would restore to boiled milk the property of clotting with rennet. He then performed a series of experiments in the course of which seventy-two calves were fed upon raw and boiled milk, 
to which, in many cases, one of these salts had been added. Full data are given, and the results tabulated. The table which is given below shows not only the weights of the calves, but also the solids contained in the milk taken, and the amount of milk taken by the calves of each series, in order to put on I kilo. of bodyweight.

Some of the experiments were carried out over a period of ten weeks and others over a period of fifteen weeks.

Hittcher's table cannot be summarised ; it must be studied for itself in detail. He has arranged it so that there is an ascending series of figures under the heading of the amount of milk required to produce one kilogram of increase of body-weight.

If this be taken as the main criterion of the nutritive value of any food-stuff, then the striking fact appears that the addition of salts is of much greater importance than the question as to whether the milk is given raw or boiled. It is difficult to assess the precise value of the figures in the other columns in comparing the results of each

\section{Table of Results obtained by Hittcher}

\begin{tabular}{|c|c|c|c|c|c|c|}
\hline \multicolumn{2}{|c|}{ Calves } & \multirow{3}{*}{ Food given } & \multirow{3}{*}{$\begin{array}{l}\text { Kilos of } \\
\text { Milk re- } \\
\text { quired to } \\
\text { Produce } \\
\text { I Kilo. of } \\
\text { Body- } \\
\text { weight }\end{array}$} & \multicolumn{2}{|c|}{ Daily Increase } & \multirow{3}{*}{$\begin{array}{l}\text { Daily } \\
\text { Food in } \\
\text { per cent. } \\
\text { of Body- } \\
\text { weight } \\
\text { (in Kilo- } \\
\text { grams) }\end{array}$} \\
\hline$\dot{z}$ & T & & & & & \\
\hline 号 & $\dot{\mathrm{z}}$ & & & In & Per cent. & \\
\hline 9 & 3 & Boiled milk and $\mathrm{Ca}_{3}\left(\mathrm{PO}_{4}\right)_{2}$ & 8.87 & 775 & $\mathrm{r} 6 \mathrm{I} \cdot 4$ & $I \cdot 36$ \\
\hline Io & 3 & Raw milk and formalin & $10 \cdot 16$ & 702 & 126.6 & $\mathrm{I} \cdot 32$ \\
\hline 8 & 3 & Boiled milk and $\mathrm{Ca}_{2} \mathrm{H}_{2}\left(\mathrm{PO}_{4}\right)_{2}$ & $10.2 I$ & 687 & $142 \cdot 5$ & $\mathrm{I} \cdot 45$ \\
\hline 7 & 5 & Raw milk and $\mathrm{NaCl}$. & $10 \cdot 2 I$ & 866 & I $19 \cdot 3$ & $I \cdot 315$ \\
\hline 3 & 6 & Boiled milk and $\mathrm{NaCl}$. & 10.45 & 803 & $120 \cdot 1$ & I.3I 7 \\
\hline 2 & 7 & Boiled milk alone & 10.82 & 790 & I 19.5 & $\mathrm{I} \cdot 38$ \\
\hline $\mathbf{I}$ & 6 & Raw milk alone & $\mathbf{I} \mathbf{I} \cdot \mathbf{I} \mathbf{I}$ & $798 \cdot 5$ & $127 \cdot 6$ & I. 45 \\
\hline 5 & 6 & Boiled milk and $\mathrm{Ca}$ citrate & I $1 \cdot 66$ & 697 & IIO.I & $\mathbf{I} \cdot 38$ \\
\hline 12 & 4 & Raw milk and $\mathrm{CaCO}_{3}$ & $12 \cdot 08$ & 863 & $182 \cdot 3$ & I.93 \\
\hline 6 & 6 & Boiled milk and $\mathrm{CaH}_{4}\left(\mathrm{PO}_{4}\right)_{2}$. & $12 \cdot 17$ & 675 & 103.6 & $I \cdot 40$ \\
\hline 4 & 6 & Boiled milk and $\mathrm{CaCl}_{2}$ & I2.59 & 644 & $107 \cdot 1$ & $I \cdot 44^{8}$ \\
\hline I I & 6 & Boiled milk and $\mathrm{CaCO}_{3}$ & $13 \cdot 13$ & 876 & $15 \mathrm{I} \cdot 7$ & $I \cdot 92$ \\
\hline
\end{tabular}

series with one another. If the amount of milk required to produce one kilogram increase in body-weight in Groups $I$ and 2 is considered, it is then seen that less boiled milk is required than raw milk; that is, the boiled milk would appear to be more nutritious.

Owing, however, to the paucity of data dealing with the amount of milk required to give an increase of one kilogram of body-weight, it has been necessary to take the gain in absolute weight, as the criterion of nutritive value. Upon this basis, if the Groups I and 2 , and 7 and 3 , be examined, then there appears to be some 
advantage in favour of the raw milk over the boiled milk of the same species.

The age of the calf is shown to be of great importance in dealing with the nutritive value of the food. Thus a group of four calves which received raw milk and chalk required 9.01 kilos. of milk in order to put on I kilo. of body-weight in the first five weeks of life, and required 14.99 kilos. of milk for the same increase in body-weight on the second five weeks of life.

If these two periods are taken together, then I2.08 kilos. of milk are required for I kilo. increase of body-weight.

Another set of six calves which were fed upon boiled milk and chalk required 13.23 kilos. of milk during the first period of five weeks and 13.25 kilos. for the second period, in order to add I kilo. to their body-weight.

The net results of both periods show a slight difference in favour of the raw milk, but Hittcher justly points out how great the error might have been in drawing deductions from either period taken alone.

The table given by Hittcher, which is reproduced above in full, shows that the addition of salts is a more important factor than the actual boiling of the milk. The kilos. of milk are calculated from the values of total solids obtained by actual analysis, on the basis of milk containing II.5 per cent. of solids.

The salt content of the inilk is evidently of great importance. If the addition of salts to mother's milk can bring about such striking differences, then that difference in salt content, which is known to exist between the milks of different species of animals, may reasonably be expected to play an important part in the nutritive value of the milk of a foreign species.

Hittcher justly emphasises the impurtance of conducting experiments over a long period of time, and of estimating daily the solid value of the food taken, and not merely taking the weight of liquid milk given.

A single experiment was made on boiled goat's milk as a food for kids by Brüning in I906. This will be considered with the experiments in Chap. $\mathrm{X}$.

It would appear that the salt content is of far greater importance than any effect which can be produccd by boiling. Babick (1912) says that common salt should be added to the food of milking cows. If this is not done, he finds that at varying periods after commencement of lactation the cow shows signs of ill-health, loss of appetite, rough coat, loss of weight, and decreased milk supply. The more milk is given by the cow, the greater the effect produced. Common salt speedily restores the cow to health.

Dammann (IgI2) carried out an experiment with raw milk and milk kept at $100^{\circ} \mathrm{C}$. for an hour. Three calves were uscd; ( $\mathrm{I}$ ) and (2) received the heated milk and (3) raw milk. The experiment extended over two months. During the first month only milk was 
given; during the second month hay and groats were added. All the calves put on weight, but calf (2) died suddenly of tympanitis. The results are shown in the following table:

\begin{tabular}{|c|c|c|c|c|}
\hline \multirow{2}{*}{\multicolumn{2}{|c|}{ Date }} & \multicolumn{3}{|c|}{ Weights of Calves in lbs. approximately ${ }^{3}$} \\
\hline & & Calf $(\mathrm{r})$ & Calf (2) & Calf (3) \\
\hline $24 / 1 / 12$ & . & 100 & 62 & 82 \\
\hline $28 / 2 / 12$ & . & I37 & 95 & $\mathrm{II}_{4}$ \\
\hline $27 / 3 / 12$ & - & 172 & Died suddenly & 149 \\
\hline \multicolumn{2}{|c|}{ Increase } & 72 & 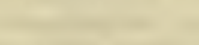 & 67 \\
\hline
\end{tabular}

No evidence of either rickets or Barlow's disease could be found in either (I) or (2). The author concludes that heating would not affect the milk. The evidence points to little if any loss of nutritive value of the milk being produced by boiling.

Work by Grosser ${ }^{2}$ suggests that the effect of heating milk may differ with the milk of different species. He shows that the salt content of human milk is more affected by heating than that of cows' milk.

\section{REFERENCES IN CHAPTER IX}

\section{Boiled Milk of the same Species}

BABICK, Einfluss gewöhnlichen Salzes auf Milchproduktion und Gesundheit der Kühe. Ref. Milchw. Zentra!b. I9I 2, p. 32.

BANG, The Fight against Tuberculosis in Denmark. (In French.) Geneva, 1895.

BRUNING, 'Vergleichende Studien über den Werth der natürlichen und künstlichen Säuglingsernährung bei Tieren,' Wiener klin. Rundschau, 1904, xxvii. 481, 503, 521, 539, 556; Zeit.f. Tiermed. 1906, x 198, 277.

DammanN, 'Aufzucht der Kälber mit roher und erhitzter Milch,' Deutsch. Tierärzt. Wochensch. 19I2, xx. 397 ; Milchw. Zentralb. 1913, p 13.

DEAn, 'Pasteurised versus Raw Skim Milk for Calves,' Report of the Ontario Dept. of Agric. r 898, i. 66.

DOANE AND PRICE, Maryland Agric. Exp. Stat., Bulletin 77, IgOI; Zeit. $f$ Unters. Nahr-u. Genussm. Ig03.

Finkelstein, 'Die rohe Milch in der Säuglingsernährung.' Therap. Monats. October 1907.

GERLACH, 'Verfütterung von gekochter Milch an Kälber,' Landwirtsch. Presse, I90I, xxviii. 160.

1 The original paper gives the figures in lbs. (German), which is approximately the same as lbs. avoirdupois.

2 See Chap. XIV. 
Grosser,' Ueber den Einfluss des Kochens auf das physikalisch-chemische Verhalten von Frauenmilch, Kuhmilch und Buttermilch,' Biochem. Zeit. I9r3, xlviii. 427.

Hirrcher, 'Kälberfütterungsversuche,' Landwirtsch. Jahrb. I909.

LANE-CIAYPON, Report to the L.G.B. upon the Available Data in Regard to the Value of Boiled Milk as a Food for Infants and Young Animals, New Series, No. 63, I9I2.

LANGSTEIN-MEYER, Säuglingsernährung und Säuglingsstoffwechsel, Wiesbaden, I9ro.

MEYER, L. F.,'Beitrag zur Kenntnis der Unterschiede zwischen Frauenund Kuhmilch-ernährung,' Monats. f. Kinderh. I906, v. 361.

MEYER. See Langstein-Meyer.

MORO, 'Die Fermente der Milch,' Jahrb. f. Kinderh. 1902, lvi. 391.

MUller, E.,' Beiträge zur Frage der natürlichen Schutzstoffe in der Frauenmilch,' Berl. klin. Wochensch. 1908, p. 1058.

PotPEschNIG, 'Ernährungsversuche an Säuglinge mit erwärmter Milch,' Münch. med. Wochens. I907, xxvii. 1326.

PrICE, "The Comparative Digestibility of Raw, Pasteurised, and Sterilised Milk,' New York Med. Journ. 1904, Ixxix. 405.

PrICE. See Doane and Price. 


\section{SUMMARY OF CHAPTER X}

EXPERIMENTAL DATA UPON THE NUTRITIVE VALUE OF RAW AND BOILED MILK AS A FOOD FOR THE YOUNG OF DIFFERENT SPECIES

THE utilisation of boiled milk, in contradistinction to raw milk, as a food for infants and young animals has formed the subject of much discussion and of a considerable amount of experimentation. The experiments have been conducted upon a variety of animals, and results have been obtained which aid in the general question of the feeding of infants. At the same time there are many difficulties connected with animal experimentation upon this subject, which must be afforded due consideration in forming an estimate of the value of the work carried out.

Difficulties in Connection with Animal Experiments.-Although it may appear that the simplest method of arriving at a satisfactory conclusion in regard to the nutritive value of boiled milk, as opposed to raw, would be by experimentation upon animals, certain circumstances arise which markedly vitiate the value of such work. It has already been pointed out that the composition of milk of different species varies very greatly. Hence in the first place, in determining the animal to be used for the purpose of experimentation and the kind of milk which is to be given, the composition of the milk should be considered so as to ensure, if possible, some degree of similarity of composition between the milk of the species itself and of the milk to be used for the purpose of feeding.

Serious practical difficulties, however, occur in obtaining samples of the milk of certain species for use in feeding experiments. For instance, certain species are extremely difficult to milk. They appear to have the power to some extent of refusing to yield milk if they so wish.

It has been shown in Chap. II that in order to obtain an average sample, especially an average fat sample, it is necessary that the gland should be completely emptied and an estimation made of the mixed sample. In the case of some animals this is impossible. so that the estimations are probably not accurate. Even if the precise composition were known it would be difficult to 
find the milk of two species which is sufficiently similar in composition for these differences not to require consideration.

These differences in composition have led many people to believe that goats' milk, which is nearer in composition to that of human milk, should, theoretically speaking, be preferable for infants to cows' milk.

Condition of Young Animals at Birth.-The condition of young animals when born into the world varies within very wide limits. Some are born comparatively mature, while in others the striking feature is the immaturity of condition at birth. Guinea-pigs, for instance, are active almost at once after birth. During the first few hours they are found to be capable of eating almost anything that they can find in their cage. They receive mother's milk for a short time only, and at no period are they entirely dependent upon their mother. Throughout their existence, from birth onwards, they take vegetable substances as well as mother's milk. On the other hand, such animals as kittens and rabbits are born in a condition in which they are entirely dependent upon their mother for care and for sustenance in the way of milk. Evidently the needs of organisms in such varied conditions of maturity must be different.

It is to some extent irrelevant to compare, for instance, the nutritive value of raw and boiled cows' milk upon guinea-pigs with a view to ascertaining the value of this food for infants.

Rate of Growth. - The rate of growth of most young animals is much more rapid than that of the human infant. Adult life is reached more rapidly. Animals such as rats and mice are mature in a very few weeks from the time of their birth, and are capable of bringing families into the world within two or three months of their own birth. Compared with that of the human infant, who is dependent for its existence upon milk for a considerable number of months after birth, the development of these animals offers no parallel conditions.

Additional Experimental Difficulties.-Several additional experimental difficulties arise. It is well known that where only one or two animals can be secured for experiment, the margin of error is extremely great. Should one of them die, the experiment is practically valueless. It is not easy, however, to secure a large number of animals of exactly the same age. Hence many observers have been obliged either to work with an unduly small number of animals, or they have found it necessary to utilise animals whose ages, although roughly similar, were not identical. In animals whose dependence upon the mother for nutriment is reckoned only in days, evidently a few days or a week's difference of age may destroy the value of the experiment.

These remarks show that too much reliance must not be placed upon animal experimentation when it is desired to obtain evidence relating to the nutritive value of food for infants. At the same 
time, taken altogether, they may suffice to show sufficiently well the general nutritive value, and to serve as supporting evidence when taken in conjunction with clinical data.

Of recent years experimentation on animals has practically ceased, but it is of interest to consider such work as has been accomplished before proceeding with the clinical data.

One advantage is undoubtedly presented by animal experimentation in connection with the present problem. Clinicians are very frequently predisposed in favour of raw or of boiled milk for their patients. In these circumstances they hesitate to employ any other variety of milk, since they only desire to utilise what they believe to be the best form of nourishment. In animal experimentation, however, it is possible to feed groups of animals over the same period upon both raw and boiled milk, and to compare the results obtained either with one another or with the results obtained by breast-feeding alone. Hence in the animal experiments it is usual to find the experiments carried out in two or three series worked simultaneously, whereas in the clinical work this is not the case.

Experiments upon Guinea-pigs.-In spite of the difficulties considered above in regard to the feeding of guinea-pigs with milk, a considerable number of experiments have been carried out. These experiments have added to our knowledge of desirable foods for guinea-pigs, and have incidentally offered some evidence in regard to utilisation of cows' milk for infants. There seems little doubt, however, that guinea-pigs cannot live on a milk diet only, the addition of vegetable substances being necessary. Only one observer has stated that he was able to keep guinea-pigs alive on milk alone, and his investigations have not been confirmed, nor have satisfactory data upon the subject been published.

The most conclusive experiments have demonstrated the importance of breast-milk, even in the case of young guinea-pigs, who cannot live on milk only.

As regards the use of raw or boiled cows' milk, no marked difference in the nutritive value could be detected. As a whole, however, the boiled milk appeared to have given more favourable results than the raw milk.

Experiments on Rats and Mice.-Experiments were conducted by Keller on mice fed upon raw milk and upon boiled milk. Keller was unable to detect any difference in the nutritional condition of the sets of animals.

Experiments were carried out by myself on rats, the animals being fed upon raw and boiled milk of the finest quality; an additional series of rats were fed upon dried milk. These investigations are open to the objections which have already been pointed out generally in regard to animal experimentation. With this reservation, no difference could be detected between the raw and the boiled milk series, although some slight advantage appeared in those fed on dried milk. 
Experiments on Rabbits.-These have been carried out by several observers, but young rabbits appear to thrive no better upon cows' milk than do young guinea-pigs. This is probably owing to the great difference in composition between rabbits' milk and cows' milk, as some reduction in the mortality was obtained when cream and sugar were added to the milk.

Experiments on Dogs.-A considerable amount of work has been carried out on puppies in order to ascertain any differences which may exist between the nutritive value of raw and boiled cows' milk. It appeared that in every instance the breast-fed puppies were very greatly superior to any of the artificially-fed ones at the end of the experiments, which lasted a considerable time in each case. As regards the series of artificially-fed animals, the gain in weight in relation to the food was either almost identical or showed a slightly higher figure for the dogs fed on boiled cows' milk.

Experiments on Kittens.-Comparatively little work has been carried out upon kittens. Although the kitten, when it reaches the age when it can leave its mother, appears to be able to utilise cows' milk very readily, it would seem that until this period" has been reached cows' milk, whether raw or boiled, is not a suitable food for kittens. Most of the animals upon which these experiments were carried out either died or apparently would have died, had the experiments been continued.

Experiments on Pigs.-Here also a good deal of work has been carried out. Speaking generally, the results are very similar to those obtained by experimentation on puppies. In every case the breast-fed pigs were superior to the artificially-fed ones, not only during the experiment, but also later, when the experiment had ceased for some considerable time. The milk used for the artificially-fed pigs was of the highest quality, but two pigs were fed on market milk, in one case raw and in the other boiled. It appeared that in the pigs fed on the best milk, a slight superiority was noticed in the raw milk as against the boiled milk. In the pigs fed on market milk, however, the reverse was the case.

Experiments on Goats.-Brüning and Brückler both fed kids upon raw and boiled cows' milk. The small number of animals available reduces somewhat the value of the experiment; as, however, they show the same general features as those just considered, they afford useful corroborative evidence.

General Summary.-Summarising the results of work upon animals, the superiority of breast-feeding may be regarded as the most striking feature. In regard to artificial feeding, very little difference, if any, appears to be detected between the different forms of milk - that is, raw or boiled. In some instances the boiled milk appears to be better utilised than the raw, while in one or two cases the reverse is found to be the case. Generally, however, no marked difference was shown. 


\section{CHAPTER X}

EXPERIMENTAL DATA UPON THE NUTRITIVE VALUE OF RAW AND BOILED MILK AS A FOOD FOR THE YOUNG OF A DIFFERENT SPECIES

DETAIIS of the numerous experiments which have been carried out upon animals in order to ascertain the relative nutritive values of raw and boiled cows' milk are given below. General criticisms on this class of work have already been made in the summary on this chapter and need not be repeated.

Experiments upon Guinea-pigs.-The first experiments carried out upon guinea-pigs were those of Bolle. Bolle (I903) was led to carry out his experiments as the result of seeing a case of Barlow's disease in a child, which he attributed to the sterilised milk upon which the child had been fed.

This observer fed young guinea-pigs upon cows' milk which had been boiled for five, ten, fifteen minutes, and longer. $\mathrm{He}$ found that only the guinea-pigs who were fed upon the milk which had been boiled for five minutes did well; all the others died in periods varying inversely with the length of time for which the milk had been boiled. These results were sharply criticised by Bartenstein, who, on the publication of Bolle's results, had commenced experiments upon the same lines.

Bartenstein (I905) fed numerous young guinea-pigs upon raw, boiled, and sterilised cows' milk. They all died. He then varied the diet by adding to it small quantities of sterilised hay, but the animals refused the hay, and all died. Bartenstein then applied to Bolle for details in regard to the feeding. Bolle replied that the feeding had been supervised by another observer, who was no longer available for information; that there had been a little difficulty in getting the animals to feed at first, but that it had been overcome by giving cream. No observer has confirmed Bolle's results, and not much stress can be laid upon them.

Brüning (3) (I906) fed guinea-pigs upon raw and boiled cows' milk, using breast-fed guinea-pigs as controls. Profiting by Bartenstein's experience, he allowed all the animals small quantities of hay every day. All the animals lived. The controls did best of all, next came the animal fed upon boiled cows' milk, and then the one fed upon raw cows' milk. The coats of the artificially-fed ones were not in good condition. Only one animal was used for each of the series, and the possibility of error is therefore very great.

Moro (1907) fed considerable numbers of guinea-pigs upon human milk, and on cows' milk, both raw and boiled. All the guinea-pigs died in a few days, with acute symptoms suggestive 
of alimentary intoxication. Post-mortem examination gave no evidence as to the cause of death. Later, Moro succeeded in keeping guinea-pigs alive who were taken away from their mother immediately after birth, but were given a low vegetable diet. $\mathrm{He}$ then allowed the young ones to have mother's milk for periods of $0, I, 3,5,7$ days, and so on. The young guinea-pigs were then isolated and given a vegetable diet. Of those taken away immediately after birth 80 per cent. died, of those left one day 30 per cent. died, of those left three days only Io per cent. died, and of those left for longer periods all lived.

The weight-curves of the animals which survived are given in

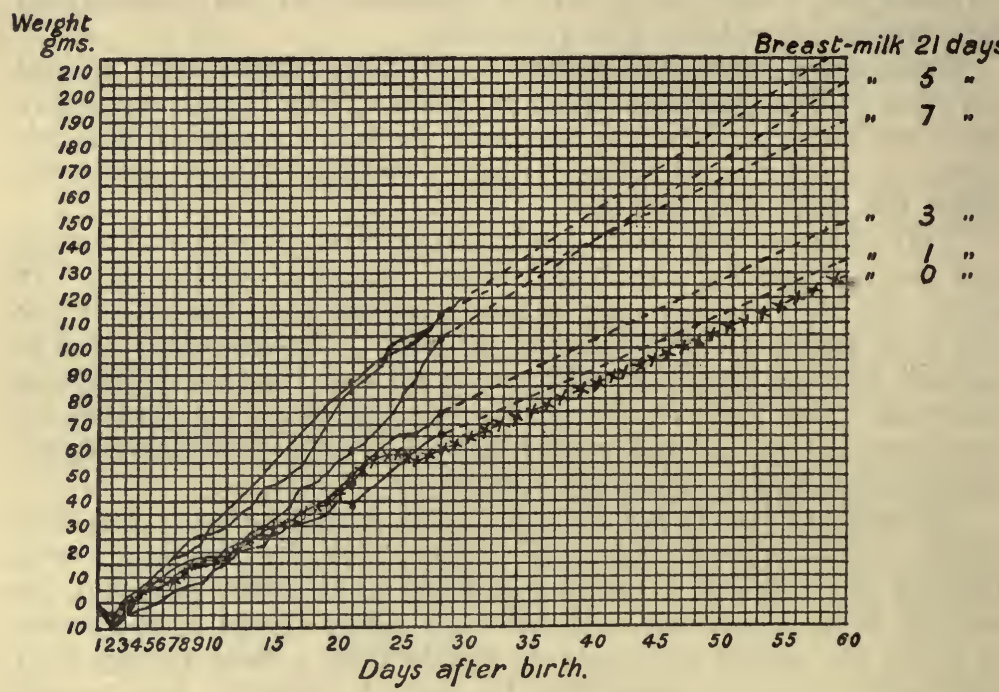

DIAGRAM 7- Showing the value of breast-feeding for young guinea-pigs.

The weight-curve of those deprived entirely of mothers' milk is represented by crosses.

Diagram 7. It should be noted that the result showed a progressive improvement with the length of time they were allowed to be with their mother, the superiority of the curve persisting up to the sixtieth day of life, when the experiment was discontinued.

These experiments show that guinea-pigs will not live upon a cows' milk diet alone, but that they must have vegetable food. I can also personally confirm this fact, from some experiments carried out by me at the Lister Institute in I908. (Unpublished.)

Some experiments were carried out by Schroeder on guineapigs bred under his own supervision. It was not possible to obtain a sufficient quantity of young guinea-pigs at the same date, and the experiments ranged over ten months, during which time some 
467 guinea-pigs were fed from birth onwards on various forms of cows' milk, and 156 were left with their mother and thus received their natural food. Guinea-pigs were selected for the purpose of experiment as being to some degree analogous with calves, that is to say, both species are herbivorous, and in both cases the young are dependent for a comparatively short period upon their mother's milk as sole food.

The guinea-pigs were not fed exclusively on milk but were allowed other forms of food, the nature of which is not specified.

As the litters of young pigs were born they were separated into various groups, being divided equally as far as possible. No weakly ones were placed in the groups used for artificial feeding, these being all left with their mothers and forming part of the series of pigs dealt with for the natural-feeding controls. The guinea-pigs on artificial food were divided into three groups: (a) Those fed on raw milk, (b) on pasteurised milk (heated to $140^{\circ} \mathrm{F}$. for twenty minutes and then rapidly cooled), and (c) on boiled milk. (The boiled milk was slowly heated to boiling-point, kept at that temperature for one minute and then rapidly cooled.) A special apparatus was devised by which I c.c. of milk was fed to each guinea-pig five times a day. After the twentieth day milk was accessible to the pigs for ten days longer, after which it was withdrawn from their diet. The milk used for the purpose was of the best quality, obtained from the experiment station and from tuberculin-tested cows, and in no case was it more than eight hours old when fed to the pigs.

The effect of feeding with the three kinds of milk was measured (a) by the mortality among the experimental animals and (b) by the average weight at different periods of the surviving animals. Schroeder gives the following table:

\section{Percentage Mortality among the Guinea-pigs}

\begin{tabular}{|c|c|c|c|c|}
\hline \multirow{2}{*}{ Mortality } & \multirow{2}{*}{$\begin{array}{l}\text { Young with } \\
\text { Mothers }\end{array}$} & \multicolumn{3}{|c|}{ Young fed artificially on Cows' Milk } \\
\hline & & Raw & Pasteurised & Boiled \\
\hline $\begin{array}{l}\text { First Io days } \\
\text { First } 20 \text { days } \\
\text { First } 30 \text { days } \\
\text { First year. }\end{array}$ & $\begin{array}{c}\text { Per cent. } \\
4^{\circ} \mathrm{O} \\
5^{\circ} \mathrm{O} \\
6.0 \\
\mathrm{r} 4^{\circ} \mathrm{O}\end{array}$ & $\begin{array}{c}\text { Per cent. } \\
27 \cdot 74 \\
40 \cdot 00 \\
44 \cdot 52 \\
52 \cdot 90\end{array}$ & $\begin{array}{c}\text { Per cent. } \\
30 \cdot 13 \\
46 \cdot 16 \\
51 \cdot 28 \\
53 \cdot 85\end{array}$ & $\begin{array}{c}\text { Per cent. } \\
27 \cdot 56 \\
39 \cdot 74 \\
42 \cdot 95 \\
46 \cdot 79\end{array}$ \\
\hline
\end{tabular}

Schroeder emphasises the great superiority of mother's milk over that of any form of cows' milk for the young guinea-pigs, more especially as the weakly ones were always left with their mothers. This last fact accentuates the marked difference between the two groups. As regards the artificially fed groups he points 
out that the results are in favour of the boiled milk. The mortality rate can be further gauged by comparing the number of animals used with those which died.

\begin{tabular}{|c|c|c|c|c|}
\hline & Mother's Milk & Raw Cows' Milk & Pasteurised Milk & Boiled Milk \\
\cline { 2 - 4 } & I56 & I55 & I56 & I56 \\
$\begin{array}{c}\text { Total number } \\
\text { Number surviving } \\
\text { at end of year }\end{array}$ & I34 & 74 & 72 & 83 \\
\hline
\end{tabular}

Schroeder points out that the favourable results obtained with the boiled milk were obtained with milk of a superlative quality. Those animals which died, died mainly from inflammation of the stomach and bowels, and of pneumonia. In some cases no lesions were discovered to account satisfactorily for death. The average weight of the guinea-pigs at different ages is also given and is here appended :

Average Weight in Grammes of Guinea-pigs at different Ages

\begin{tabular}{|c|c|c|c|c|}
\hline Time of Weighing & $\begin{array}{l}\text { Young with } \\
\text { Mothers }\end{array}$ & $\begin{array}{l}\text { Young fed Raw } \\
\text { Cows' Milk }\end{array}$ & $\begin{array}{c}\text { Young fed } \\
\text { Pasteurised Cows' } \\
\text { Milk }\end{array}$ & $\begin{array}{l}\text { Young fed Boiled } \\
\text { Cows' Milk }\end{array}$ \\
\hline At birth . & $75 \cdot 94$ & $75 \cdot 94$ & $76 \cdot 04$ & $76 \cdot 22$ \\
\hline roth day of life. & $127 \cdot 34$ & I $16 \cdot 27$ & I $18 \cdot 37$ & II9.35 \\
\hline 2oth ," ", . & 182.84 & $175 \cdot 19$ & I $76 \cdot 68$ & 180.57 \\
\hline 3oth ", & 234.65 & $228 \cdot 8 I$ & $230 \cdot 04$ & $233.7 I$ \\
\hline 5oth ", & $349 \cdot 15$ & $317 \cdot 25$ & $320 \cdot 23$ & $318 \cdot 36$ \\
\hline 8oth ," ," , & $502 \cdot 29$ & $422 \cdot 16$ & $427 \cdot 17$ & $430 \cdot 49$ \\
\hline I roth " " " & $597 \cdot 76$ & $528 \cdot 30$ & 523.84 & $53 I \cdot 88$ \\
\hline I40th " " , . & $67 x \cdot 76$ & $587 \cdot 8 I$ & $596 \cdot 72$ & $592 \cdot 43$ \\
\hline I 7oth ", & $732 \cdot 34$ & $645 \cdot 29$ & $655 \cdot 69$ & $646 \cdot 07$ \\
\hline 2ooth ", & $776 \cdot 63$ & $697 \cdot 12$ & $700 \cdot 15$ & $699 \cdot 14$ \\
\hline 23oth ," & $822 \cdot 00$ & $74 I \cdot I 4$ & $74 I \cdot 65$ & $750 \cdot 5^{8}$ \\
\hline 260th " " ", & $858 \cdot 84$ & $789 \cdot 48$ & $781 \cdot 6 I$ & $795 \cdot 42$ \\
\hline 29oth & 913.27 & $817 \cdot 87$ & 813.08 & $839 \cdot 46$ \\
\hline 320th ", " & 944.07 & $853.8 \mathrm{I}$ & $836 \cdot 15$ & $879 \cdot 7 x$ \\
\hline 350th " " " & $965 \cdot 23$ & 885.03 & 872.99 & $904 \cdot 86$ \\
\hline End of first year & $974 \cdot 29$ & $895 \cdot 5$ I & $888 \cdot 40$ & $920 \cdot 86$ \\
\hline
\end{tabular}

Here again in the artificially-fed groups the more favourable results were obtained with boiled milk.

Experiments on Mice.-In I9n4 Keller published some experiments on mice. Like those of Bartenstein on guinea-pigs, they were carried out as a result of Bolle's work, and were conducted by him personally or under his immediate supervision

The mice were fed upon raw milk, upon milk just boiled, and upon milk which had been boiled for two hours. He found no 
difference between the mice of the different batches. Some digestive disturbances were present, but these were obviated by preventing the contamination of the food by fæces.

Experiments on Rats.-Some experiments were carried out by myself on rats, but the animals, though young, were no longer of an age when suckling is necessary. The rats were fed in batches of one dozen upon raw, boiled, and dried milk, and a little bread. In one series those fed upon dried milk showed a slightly more rapid gain in weight than those fed upon boiled milk, and these again a rather more rapid gain than those fed upon raw milk. In two other series fed upon raw and boiled milk respectively, no difference could be detected between the rats of either series.

In making any deductions from these experiments bearing on the feeding of infants the sources of fallacy are, that the rats were no longer of suckling age, and that they received bread as well as milk. As, however, all the batches received the same percentage of milk and bread per kilo. of body-weight, it may reasonably be inferred from these experiments that rats just past the suckling age are able to utilise dried and boiled milk fully as well as raw milk.

Experiments on Rabbits.-It appears that rabbits are scarcely suitable animals for the purposes of such experiments, nor are they at all easy to use.

It is difficult to get young rabbits to drink out of a bottle; also rabbits' milk is much richer in fat than cows' milk and thus complications are introduced as to the amount of food required to supplement mother's milk.

Brüning (3) (1906) carried out some experiments on young rabbits five days old. One rabbit of the litter was left with its mother, another was given raw cows' milk with the addition of cream, and the other boiled cows' milk, also with the addition of cream. The rabbit fed upon raw milk died upon the eleventh day of the experiment, and the one fed upon boiled cows' milk was in a greatly inferior condition to the one left with its mother. No comparisons are possible between the effects of the raw and boiled cows' milk since one of the animals died.

Moro (1907) fed young rabbits upon both human and cows' milk, raw and boiled. Nearly all the animals died, in spite of the fact that they took the food well. If they were allowed mixed feeding of rabbits' milk and cows' milk they rarely showed any untoward symptoms, and if these occurred the attack was warded off by stopping the cows' milk and giving only mother's milk. The addition of cream and sugar to the cows' milk gave better results and the animals lived longer. It seems, therefore, that young rabbits do not thrive either on raw or boiled cows' milk or human milk, and hence are hardly suitable for making deductions as to the relative nutritive value of raw and boiled cows' milk as a food for infants.

Experiments on Dogs.-A considerable number of experiments 
have been carried out upon dogs, and cows' milk seems to be a suitable food for this species.

Rodet (I896) took six puppies-four of one litter (dogs I-4) aged from five to six weeks old, one of another litter of the same age $(\operatorname{dog} 5)$, and another rather older $(\operatorname{dog} 6)$.

Puppies I and 2 were fed upon raw cows' milk.

Puppies 3 and 4 were fed upon cows' milk, just boiled.

Puppy 5 was fed upon cows' milk subjected to prolonged boiling.

Puppy 6 was fed upon cows' milk just boiled, as for puppies 3 and 4 .

As regards weight, the balance was distinctly in favour of the boiled cows' milk, the increase in weight at the end of thirtyone days, when the experiment was terminated, being in the proportion of

638 for dogs $I$ and 2 ,

796 for dogs 3 and 4 ,

276 for $\operatorname{dog} 5$,

525 for $\operatorname{dog} 6$.

Dogs 5 and 6 were receiving rather less milk per kilo. of bodyweight than dogs I-4.

Taking the quotient $\frac{\text { increase of weight }}{\text { daily food }}$ he found the value to be .62 for dogs I and 2 , . 68 for dogs 3 and 4 ,

-6I for dog 5 ,

.62 for $\operatorname{dog} 6$.

Thus there was a better utilisation of the boiled cows' milk than of the raw.

Keller (I904) fed two young dogs upon sterilised and boiled cows' milk respectively and found no difference between the two dogs even after three months. dogs.

Brüning (I) (I904) carried out two sets of experiments upon

In the first series he had six puppies (hounds), of which two were left at the breast, one was fed upon raw cows' milk, and another upon boiled; the two remaining puppies received raw and boiled goats' milk respectively. The puppy fed upon raw cows' milk died on the fourth day of the experiment of inhalation pneumonia, providing another example of the drawback of an insufficient number of animals in an experimental series.

The breast-fed puppies did incomparably better than any of the others. Then came the one fed upon boiled cows' milk, and then those fed upon boiled and raw goats' milk respectively. 
The average gain for the breast-fed puppies was II3-I2I grammes per day; for the boiled cows' milk puppy 48.2 grammes per day; for the boiled goats' milk puppy $45^{\circ} 7$ grammes per day; and for the raw goats' milk puppy 38.4 grammes per day.

In the second series four puppies were taken from birth. Two were fed upon the breast, the third on raw, and the fourth on boiled, cows' milk.

Here again the breast-fed puppies did incomparably better than the others.

The experiment lasted seventy-five days, and during this time-

Puppy I on the breast had increased in weight from I65 to 2864 grammes; a gain of 2699 grammes.

Puppy 2 on the breast had increased in weight from 205 to 2215 grammes; a gain of 2010 grammes.

Puppy 3 on raw cows' milk increased in weight from 299 to II05 grammes; a gain of 806 grammes.

Puppy 4 on boiled cows' milk increased in weight from 238 to 1785 grammes; a gain of 1547 grammes.

Puppy 3 had the breast for six days and weighed 299 grammes when the raw milk was started. The puppy fed upon raw cows' milk showed what appeared to be evidence of rickets and was chloroformed and examined post-mortem. No evidence of rickets could, however, be found either macro- or microscopically.

The coats of the breast-fed dogs were on the whole smoother than those of the artificially fed dogs.

Feer's 'Quotient of Increase' 1 (which is represented by increase per kilo. of body-weight)

kilos. of milk taken ) was worked out for the artificially-fed dogs of this series, and was found to be II 8 for the dog fed upon raw cows' milk and IIg for the dog fed upon boiled cows' milk.

In both the series all the surviving animals developed into very good dogs.

It appears, therefore, that cows' milk can act as a substitute for mother's milk in dogs, and that the dogs thrive better if the milk is given boiled.

The breast-fed dogs remained, however, greatly superior to the artificially-fed ones.

Moro (I907) showed that dogs fed upon human milk remained alive but were in a very miserable condition, whereas dogs upon cows' milk did extremely well. These results, taken in conjunction with the results obtained by the same observer on rabbits, show that in deducing results from experiments it is very important to use a species of animal whose milk is suitable for the other species

1 For details see Jahrb. f. Kinderh. I902, lvi. 42 I. 
whose growth is being investigated. The milk of one species of mammal is by no means always suitable for the young of another species. This appears again in the experiments upon kittens, which will be described immediately.

Experiments on Kittens.-Chamouin (I892) took kittens thirty to forty days old, and fed them on raw and boiled cows' milk, three kittens on each kind of milk. There was also a control breast-fed kitten. The experiment lasted twelve days. The control kitten put on 560 grammes in weight. The kittens fed on raw cows' milk put on I72 grammes, and the kittens fed upon boiled cows' milk put on 349 grammes each. It seems, however, that the artificiallyfed kittens were not in a good state of health, and that not improbably had the experiment lasted much longer the artificiallyfed kittens would have died.

From some work carried out by Grünbaum for the Local Government Board (referred to in the Annual Report of the Medical Officer to the Board for I906), it seems fairly evident that cows' milk is not a suitable substitute for mother's milk for kittens, until they have reached an age when mother's milk is no longer necessary.

Vincent (IgII) has carried out some experiments upon kittens. These experiments as such do not come within the scope of this report ; but since he deduces from them that boiled milk is harmful for babies, brief mention must be made of them.

The kittens taken were of the age of two months, and the feeding was carried out by the animal attendant. Milk was brought from the Infants' Hospital, and after the milk had been raised to $200^{\circ} \mathrm{F}$. it was incubated for twenty-four hours at $85^{\circ} \mathrm{F}$. In most of the series the milk, after heating, was inoculated with special organisms, the action of which it was desired to study.

No kittens appear to have been fed upon raw milk to act as control animals to those fed upon this form of milk, but it is stated that the infants in the hospital who were fed upon raw milk acted as controls to the kittens fed on other forms of milk at the Lister Institute.

All the kittens fed upon these foods died. It is clear that no kitten was fed upon boiled milk as ordinarily meant by the term, since even where there had been no inoculation of the milk, it was incubated for twenty-four hours before administration and therefore not comparable with milk which, in accordance with usual practice, is boiled and used very shortly afterwards.

None of the experiments on kittens seem to have given results upon which any reasonable deductions can be based in regard to the relative nutritive value of raw and boiled cows' milk as a food for either infants or kittens.

Experiments on Pigs.-Brüning (3) carried out experiments upon young pigs.

The litter used consisted of seven pigs. Pigs A, B, C were 
left with their mother, but were only allowed to feed at stated intervals, and were weighed before and after each feed, so that the total quantity of milk taken was known. Pigs D and $E$ were fed upon boiled cows' milk, and pigs $F$ and G upon raw cows' milk.

The initial weights of the pigs varied from $912-1365$ grammes. The supply of mother's milk was poor, and the breast-fed pigs obtained a much smaller quantity of milk than the artificially fed pigs. All ate well and put on weight well.

No appreciable difference could be detected between the different pigs $D$ and $E$, and $F$ and $G$, but the artificially fed pigs doubled their weight rather sooner than the breast-fed ones, possibly owing to the shortage of food supply in the latter case.

Feer's quotient (increase per kilo. of body-weight $\div$ kilos. of milk taken) gave a value of 165 for the breast-fed pigs, of 65 for the pigs fed upon boiled cows' milk, and of 60 for those fed upon raw cows' milk.

Mother's milk is therefore very much better utilised by pigs than cows' milk, and boiled cows' milk rather better than raw.

Bamberg (Igro), realising that in all the experiments which had been carried out so far, ordinary impure market milk had been used, undertook some experiments upon pigs in which he used the purest milk obtainable in Berlin. The bacterial content of the milk was taken and the milk was found to be almost germ-free throughout the experiment.

The milk was obtained from the Viktoria Park Dairy.

A litter of eight pigs was taken immediately after birth.

Of these pigs-

$A$ and B were fed upon raw cows' milk from the Viktoria Park Dairy.

C and D were fed upon boiled cows' milk from the Viktoria Park Dairy.

E was fed upon raw cows' milk (market milk).

F was fed upon boiled cows' milk (market milk).

$G$ and $H$ were fed upon the breast.

Pigs $\mathrm{G}$ and $\mathrm{H}$ doubled their weight on the I4th day.

," A " B ." " , , I7th day.

Pig F doubled its" weight on the Igth day.

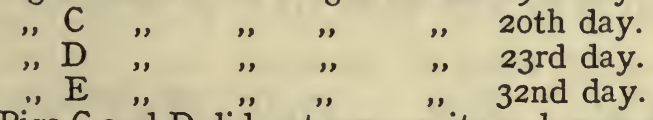

Pigs C and D did not seem quite so happy as A and B.

As regards weight, therefore, the pigs fed upon raw germ-free milk did rather better than those fed upon the same milk boiled. But the pig fed upon boiled market milk did very considerably better than the one fed upon raw market milk. 
Feer's quotient was worked out for the artificially fed pigs, and the following values were obtained:

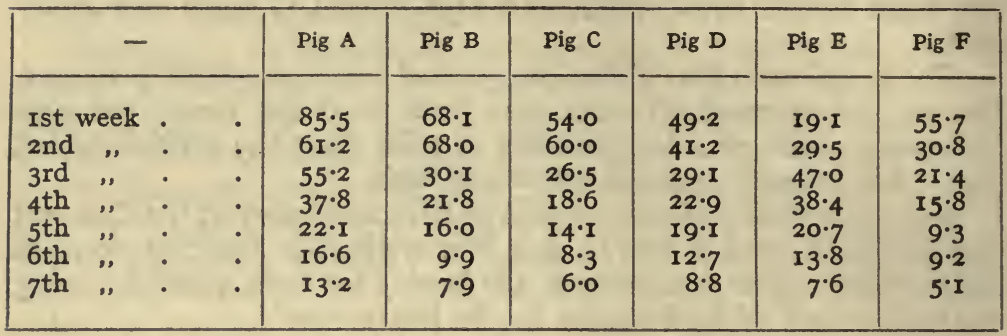

As a whole, therefore, pigs A and B utilised their food rather better than pigs $C$ and $D$. But pig $F$ utilised its food better than pig E.

After seven weeks the pigs were returned to their owner, who reported later on that the artificially fed pigs were all inferior to the breast-fed pigs, but that no difference could be detected between the different artificially-fed pigs.

Klein carried out feeding experiments upon fourteen little pigs about seven weeks old. The pigs were divided into three groups as follows :-

Group I.-Four pigs fed upon raw skim milk, potatoes, and barley-bran.

Group II.-Five pigs fed upon pasteurised skim milk, potatoes, and barley-bran.

Group III.-Five pigs fed upon raw skimmed milk, potatoes, barley-bran, and dried yeast.

The milk was gradually replaced by the yeast in Group III, but the animals refused it after a while, and did not do so well as in Group I.

No difference could be detected between Groups I and II except that there was a slight balance in favour of the group which had received the pasteurised milk.

The experiment lasted twelve weeks and the weights at the beginning and end of the experiment are given below :-

\begin{tabular}{|c|c|c|c|c|}
\hline & Group I & Group II & Group III & \\
\hline $\begin{array}{l}5 / 5 / 13 \\
7 / 8 / 13\end{array}$ & $\begin{array}{r}35.50 \\
163.50\end{array}$ & $\begin{array}{r}46 \cdot 75 \\
208 \cdot 75\end{array}$ & $\begin{array}{r}46 \cdot 00 \\
190 \cdot 50\end{array}$ & $\begin{array}{c}\text { Kg. total weight, } \\
", " ~\end{array}$ \\
\hline & $\begin{array}{r}I 28 \cdot 50 \\
0.38\end{array}$ & $\begin{array}{r}I 62 \cdot 00 \\
0.39\end{array}$ & $\begin{array}{r}\text { I } 44.50 \\
0.34\end{array}$ & $\begin{array}{l}\text { Kg. total gain, } \\
\text { Gain in kg. p } \\
\text { day per pig, }\end{array}$ \\
\hline
\end{tabular}

showing a slight advantage for the pasteurised milk. 
Experiments on Goats.-Brüning $(2,3)$ carried out two sets of experiments on goats, which are, however, really supplementary the one to the other and can be taken together. Each litter had consisted of three kids. These were fed as follows :-

First Litter-

Kid I. Breast-fed.

Kid 2. Boiled mother's milk.

Kid 3. Boiled cows' milk.

Second Litter-

Kid 4. Breast-fed.

Kid 5. Breast twice a day and other feeds raw cows' milk. Kid 6. Raw cows' milk.

Kid r. Doubled its weight on the fifteenth day. The value for Feer's quotient was $50 \cdot 2$.

Kid 4. Doubled its weight on the sixteenth day. The value for Feer's quotient was $53 \cdot I$.

Kid 2. Doubled its weight on the twenty-second day. The value for Feer's quotient was 28.4 .

Kid 5. Doubled its weight on the twenty-second day. The value for Feer's quotient was $25^{\circ} 0$.

Kid 3. Doubled its weight on the twentieth day. The value for Feer's quotient was $24^{\circ} 0$.

Kid 6. Doubled its weight on the twenty-fifth day. The value for Feer's quotient was $2 \mathrm{I} \cdot 0$.

The initial weights of the animals were very different, so that some of them had put on considerably more weight than the others. Feer's quotient shows the nutritional value of the food, although it does not show the caloric value of the food taken.

These experiments bring out the great superiority of mother's milk over that of cows' milk as a food for kids. They also show slight superiority of boiled cows' milk over raw.

Brückler (1907) carried out an experiment on goats on identical lines to those of Brüning. Two litters were used, and two goats, for each method of feeding. The milk given was collected with all possible precautions, and was as far as possible germ-free. Brückler obtained a rather more rapid increase in weight with the raw cows' milk than Brüning did, but Feer's quotient was higher with the boiled cows' milk than with the raw.

Goats seem therefore to do fairly well on cows' milk, but the results are very inferior to those obtained with mother's milk. boiled.

If cows' milk be given there is a slight advantage in giving it

Although experimentation upon animals in order to determine the nutritive properties of raw and boiled milk of foreign 
species cannot altogether be regarded as satisfactory, the results show :

(a) The great superiority of breast-feeding over any form of artificial feeding employed.

(b) That where series of animals were fed simultaneously over fairly prolonged periods on raw and boiled cows' milk respectively, no essential difference in nutritive value between the two forms of food could be detected. In some cases the boiled milk gave distinctly better results than raw milk, whereas in isolated cases the reverse was found.

(c) In considering the nutritive value it is not sufficient to consider merely the gain in weight, but the gain in relation to the amount of food taken should also be considered. This, however, does not alter the general trend of the remarks made above.

\section{REFerences in Chapter $X$}

\section{Experimental Data relating to Nutritive Value of Raw and Boiled Milk}

BAMBERG, 'Zur Frage der Rohmilch Ernährung,' Jahrb. f. Kinderh. Igro, 1xxi. 670.

BARTENsteIN, 'Beiträge zur Frage des künstlichen Morbus Barlow bei Tieren,' Jahrb. f. Kinderh. 1905, Ixi. 22.

Bolle, 'Zur Therapie der Barlow'schen Krankheit,' Zeit. f. Diät. Therapie, 1903, vi. 354 .

BRÜCKLER, 'Zwei Ziegenfütterungsversuche mit roher und gekochter Kuhmilch,' Jahrb. f. Kinderh. I907, lxvi. 373.

BRUNing. (r) 'Beiträge zur Lehre der natürlichen und künstlichen Säuglingsernährung,' Münch. med. Wochensch. 1903, lii. 369. (2) 'Vergleichende Studien über den Wert der natürlichen und künstlichen Säuglingsernährng bei Tieren,' Wiener klin. Rundschau. I904, xxvii. 48I, 503, 52 I, 539, 556. (3) Ibid. Zeitsch. f. Tiermed. I $906, \mathrm{x}$. Heft. 2 and 3.

Chamourn, 'Valeur et effets comparés du lait cru et du lait bouilli,' Rev. scientifique, 1892 , xxiv. 91 .

GrUNBAUM. See Annual Report of M.O. to the L.G.B. for 1906.

KELLER, 'Fütterungsversuche an Mäusen mit hochsterilisierter Milch,' Zeit. f. Diät. Therapie. 1904, vii. 90.

KLEIN, 'Schweinefütterungsversuche zum Vergleich von unerhitzter und erhitzter Magermilch und mit Trockenhefe bei Ferkeln,' Milchw. Zentralb. 1914, Heft 14, p. 381.

LANE-CIAYPON, 'Observations upon the Influence of Heating upon the Nutritive Value of Milk, etc.' Journ. of Hyg. I909, ix. 233.

Moro, ' Experimentelle Beiträge zur Frage der künstlichen Säuglingsernährung,' Münch. med. Wochensch. 1907, xlv.

RODET, 'Sur la Valeur nutritive du lait sterilisé,' Compt. Rend. de la Soc. de Biol. 1896, xlviii. 555 .

SCHROEDER, 'An Experiment with Raw and Heated Cows' Milk and its Lesson,' Amer. Journ. of Children's Dis. I91 3, vi. 334.

VINCENT, The Intestinal Toxamia of Infants, Lonclon, I9זx. 


\section{SUMMARY OF CHAPTER XI}

\section{CLINICAL DATA ON THE NUTRITIVE VALUE OF RAW AND BOILED}

COWS' MILK AS A FOOD FOR INFANTS

IT is difficult to obtain the necessary data for an accurate consideration of the subject of this chapter, from the records of hospitals for sick children. Until recently, however, this was the only means available. The hospital patient is hardly suitable for the purpose of investigating the nutritive properties of any special food. The sick child is liable to react, and probably does react, differently from the normal child to a large number of food-stuffs. Sick children are not here under consideration, but rather the average, reasonably healthy infant. If hospital cases alone are considered, therefore, there will be a tendency to error which cannot be regarded as negligible. Moreover, hospital cases are naturally unsuited for a prolonged investigation of the nutritive value of any kind of food. At the time of admission they are for the most part in a pathological state and require special measures in order to enable them to improve. As soon as such improvement has begun, it is more than probable that the physician considers it .desirable to alter the dietary of the child. This, although clearly necessary as a curative measure, cannot be regarded as other than an impairment of the data from the experimental point of view. In addition to the probability of the dietary being altered every few days, the child is sent back to its home, and away from skilled observation, at the earliest possible moment.

Consequently observations made in hospitals upon the nutritive value of raw and boiled milk for infants have for the most part been confined to pathological cases, and have extended over short periods only. It is not possible to deduce from them what the ultimate effect upon the child of either method of feeding may be.

One defect of observations carried out in hospitals has already been briefly alluded to in the preceding chapter. It was there pointed out that physicians tend to use one form of feeding for the majority of their cases who are in a reasonably healthy condition. This will vary according to the individual predilection of the 
physician. As a result, control observations in regard to other methods of feeding are usually absent.

The published investigations show that a good many children appear to improve rapidly upon raw milk, while an equal number appear to improve equally well upon boiled milk.

A few experiments have been carried out in other countries upon children in institutions, who could be observed for longer periods. The most comprehensive experiments were carried out by Finkelstein, who observed a number of children, both healthy and sick, over considerable periods. Children of both classes were fed upon raw and boiled milk. The milk used was of the best quality, and was used for all the children, whether fed upon raw or upon boiled milk. No definite superiority of one method of feeding was established, but there was perhaps a slight balance in favour of the boiled milk.

The work of Park and Holt in New York has shown that even when reasonable precautions are taken and when good milk is supplied, it is safer to heat the milk used for the infants. Their special investigations upon some ninety infants gave results which were distinctly unfavourable to raw milk.

In all work where the results likely to be obtained from feeding infants on any form of milk are analysed, it is necessary to consider not only the possible original contamination of the milk, but also the possibility (or rather, the probability) of contamination in the home of even an ideal milk supply.

The material which had been collected in one of the infant consultations in Berlin was kindly placed at my disposal in IgII ; and I was enabled to analyse the medical notes of 300 breast-fed babies, and of 204 infants fed on good milk, which was boiled in the homes. This does not give a comparison of the value of raw and boiled milk. The results obtained with the boiled milk were, however, so favourable as to render it unlikely that any form of artificial feeding would have produced more favourable results, especially in view of the experience derived from previous investigations on these lines.

Generally, it may be stated that no form of artificial feeding will produce results of as favourable a nature as are obtained by natural methods of feeding. Where artificial feeding must be employed, there is no evidence that milk loses any of its nutritive value by boiling. The work of numerous observers indicates that rather more satisfactory progress is made with boiled than with raw milk.

These remarks apply to the general infant population, and not to special infants in pathological conditions. In these latter cases idiosyncrasies for special forms of food are frequently exhibited. 


\section{CHAPTER XI}

\section{CLINICAL DATA ON THE NUTRITIVE VALUE OF RAW AND BOILED} COWS' MILK AS A FOOD FOR INFANTS

THE general considerations arising in regard to the value of the clinical data available as a result of the feeding of hospital infants is considered in the summary of this chapter. It is necessary, however, to give a somewhat detailed account of the individual observations which have been made by various investigators.

The earliest published work appears to be that of Uhlig, who in I89I quoted thirty-nine cases of children suffering from various degrees of mal-nutrition, who all did well on sterilised milk. No control cases were taken.

In the same year Leeds and Davis published an account of the results of feeding sick children-all apparently suffering from diarrhœa-on sterilised milk. The results were stated to be unsatisfactory, some of the children dying from apparent starvation. No improvement followed the peptonising of the milk. Marked improvement occurred in such children as received a few breastfeeds in the day, together with the sterilised milk. No controls seem to have been carried out with either raw or pasteurised milk. The milk used was sterilised for half an hour.

Much stress cannot be laid upon these results, since there were no controls, although Davis states that he has seen children who were not improving on sterilised milk do well upon raw.

Variot (1898) at a meeting in Paris quoted thirty cases of atrophic children who had attended his consultation at Belleville, and who had all done very well when fed upon sterilised milk. He gave no control cases.

Palmer (I900) described the satisfactory results which he had obtained in America with raw milk, and advocated its use. $\mathrm{He}$ gives no control cases fed upon boiled milk, and, moreover, had the great advantage of the large ice supply of American cities. No actual data are given.

Monrad (Ig02) published six cases of atrophic and dyspeptic children who had improved when fed upon raw milk. He considers that only certain cases need raw milk. No controls fed upon boiled milk are mentioned.

Czerny (I902) at the Breslauer Klinik fed atrophic children upon both raw and boiled goats' milk, the goats being kept upon the premises. He was unable to detect any appreciable difference between the children fed upon raw and boiled goats' milk, both sets were very constipated, those fed upon raw milk rather more so than those fed upon boiled milk. The improvement in all cases was very inferior to that which usually occurs when similar cases receive mother's milk. 
Halipré (I904) quotes the case of a child whose weight was increasing at the rate of 7 grammes per day while fed upon sterilised milk. When given raw milk the increase rose to a rate of 30 grammes per day. He states that he has seen other similar cases. The period of sterilisation of the milk is not given.

Hohlfield (I905) published eight cases of children suffering from various stages of mal-nutrition who were fed for the most part upon raw milk; some, however, received raw milk alternately with boiled milk over periods of about one month. All the children were ill, some of them severely so. Three had only raw milk, two vomited boiled milk, and another put on more weight on raw milk than on boiled milk. The remaining two were twins, of whom the sicklier child was put upon raw milk, and the healthier one had boiled milk. The sicklier one did better than the healthier one.

These data certainly seem to show that there are cases of sick children where raw milk gives better results than boiled milk : at the same time the evidence already given shows that many children who are suffering from mal-nutrition do extremely well upon boiled milk. It would not appear to be justifiable to draw conclusions in regard to the relative nutritive properties of raw and boiled milk in the treatment of healthy babies, as a result of Hohlfield's experiments, where only four babies were given boiled milk, and of those, two had an apparent idiosyncrasy against boiled milk and vomited it after administration.

Vincent (Ig06) has published twenty cases of markedly severe mal-nutrition in infants which were fed upon raw milk and did very well. These cases were fed upon the percentage method of feeding, under constant supervision, and often of change of the percentage of ingredients. No case was fed upon boiled milk of a similar percentage mixture.

Extensive observations were carried out by Finkelstein which are difficult to summarise, and the results are best seen by reproducing Finkelstein's tables. He classified the cases into three groups, as below, where the results obtained in each group are shown.

GrouP I.-(A) Healthy children, that is children with no apparent signs of disease; under eight weeks of age, and having an average weight of 3600 grammes.

\begin{tabular}{|c|c|c|}
\hline- & Raw Milk & Boiled Milk \\
\hline Number of children . & 29 & I9 \\
\hline Average number of days of observation & 34 & 27 \\
\hline Good result-good progress, no disturbance. & $\begin{array}{l}\text { Io }=34.4 \\
\text { per cent. }\end{array}$ & $\begin{array}{l}\text { Io }=52 \cdot 6 \\
\text { per cent. }\end{array}$ \\
\hline Daily increase in grammes & I 5.5 & 19.8 \\
\hline Fair result-progress not so good, no disturbance & $7=24 \cdot 1$ & $2=10.5$ \\
\hline Daily increase in grammes & $7 \cdot 6$ & 8.0 \\
\hline $\begin{array}{l}\text { Bad result-loss of weight, or appearance of } \\
\text { acute disturbance. }\end{array}$ & $\begin{array}{l}\mathrm{I} 2=4 \mathrm{I} \cdot 5 \\
\text { per cent. }\end{array}$ & $\begin{array}{l}7=37 \\
\text { per cent. }\end{array}$ \\
\hline
\end{tabular}


(B) Twelve children were fed periodically with raw and boiled milk. The results were :

\begin{tabular}{|c|c|c|c|c|}
\hline \multirow{2}{*}{ ) } & \multicolumn{2}{|c|}{ Average Length of Feeding } & \multicolumn{2}{|c|}{ Daily Increase } \\
\hline & Raw Milk & Boiled Milk & Raw Milk & Boiled Milk \\
\hline $\begin{array}{l}\text { Raw and boiled milk equally } \\
\text { good } 3=25 \text { per cent. }\end{array}$ & $\begin{array}{l}\text { Days } \\
33\end{array}$ & $\begin{array}{c}\text { Days } \\
\text { I } 7\end{array}$ & $\begin{array}{c}\text { Grammes } \\
16 \cdot 3\end{array}$ & $\begin{array}{l}\text { Grammes } \\
14.7\end{array}$ \\
\hline $\begin{array}{l}\text { Raw and boiled milk equally } \\
\text { bad, } 4=33 \text { per cent. }\end{array}$ & 32 & 22 & $-5 \cdot x$ & $-I I \cdot O$ \\
\hline $\begin{array}{l}\text { Raw milk better than boiled, } \\
3=25 \text { per cent. }\end{array}$ & 27 & 20 & 13.5 & -10.0 \\
\hline $\begin{array}{l}\text { Boiled milk better than raw, } \\
2=\text { I } 6 \text { per cent. }\end{array}$ & 25 & I9 & 3.5 & $15 \cdot 5$ \\
\hline
\end{tabular}

Group II.-Atrophic children, older than Group I, markedly below weight, but without other symptoms of disease. Raw and boiled milk given periodically.

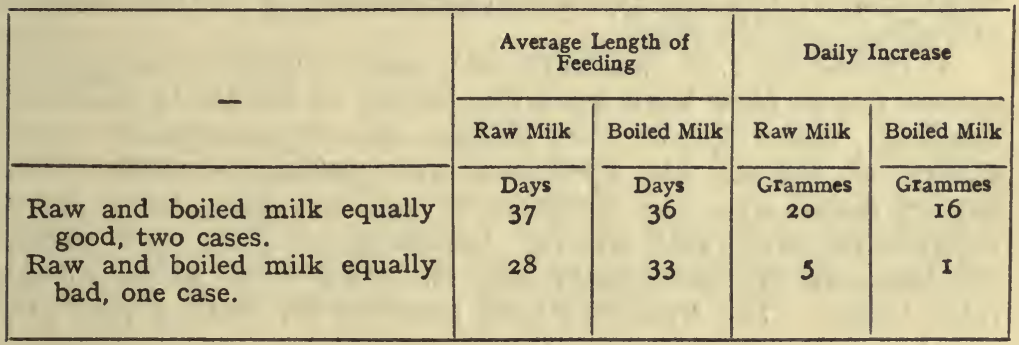

GROUP III.--(A) Children with digestive disturbances, showing strong local and, usually, general symptoms. The quantity, etc., of the food was the same in all cases.

\begin{tabular}{|c|c|c|}
\hline- & Raw Milk & Boiled Milk \\
\hline $\begin{array}{l}\text { Number of children } \\
\text { Average length of observation in days } \\
\text { Improved and did equally well } \\
\text { Did not improve }\end{array}$ & $\begin{array}{l}25 \\
3^{8} \\
\text { I } 5=60 \text { per cent. } \\
\text { Io }=40 \text { per cent. }\end{array}$ & $\begin{array}{c}16 \\
26 \\
16=68 \cdot 8 \text { per cent. } \\
5=31 \cdot 2 \text { per cent. }\end{array}$ \\
\hline
\end{tabular}



milk.

(B) Nine children were fed periodically with raw and boiled

\begin{tabular}{|c|c|c|c|c|}
\hline \multirow[t]{2}{*}{ t } & \multicolumn{2}{|c|}{$\begin{array}{l}\text { Average Length of } \\
\text { Feeding }\end{array}$} & \multicolumn{2}{|c|}{ Daily Increase } \\
\hline & Raw Milk & Boiled Milk & Raw Milk & Boiled Milk \\
\hline $\begin{array}{l}\text { Improved equally well with raw } \\
\text { and boiled milk, } 4=44 \text { per } \\
\text { cent. } \\
\text { No improvement with either ra } \\
\text { Improved on raw milk, after fai } \\
\text { Improved on boiled milk, after }\end{array}$ & $\begin{array}{l}\text { or boi } \\
\text { Ire on b } \\
\text { ilure on }\end{array}$ & $\begin{array}{l}\text { milk, } 3 \\
\text { ed milk, } \\
\text { w milk, }\end{array}$ & $\begin{array}{l}\text { Grammes } \\
\text { I9 }\end{array}$ & $\begin{array}{l}\text { Grammes } \\
\text { I9.3 }\end{array}$ \\
\hline
\end{tabular}

Finkelstein concludes that 'no definite distinction between the results obtained by feeding upon raw and boiled milk respectively, could be detected.' If these figures of Finkelstein's are examined a little further, it is seen that in Group I (A) there is a balance in favour of the boiled milk, whereas in the other groups there is a balance which is slightly in favour of the raw milk.

Plantenga (I9I0) treated children with digestive troubles with both raw and boiled milk, and from a study of the weight-curves was unable to find any evidence of the superiority of either method of feeding, over the other.

Park and Holt, in the course of a most valuable investigation, carried out in New York upon the feeding of infants in tenement dwellings, made special observations upon approximately equal groups of infants fed upon raw and pasteurised milk. The inquiry lasted over the summers of two successive years, being commenced each year at the beginning of June and lasting till the end of the summer, and the results are given in the table below. The milk was used modified for both groups and

\begin{tabular}{|c|c|c|c|c|c|c|c|}
\hline Kind of Milk & $\begin{array}{l}\text { No. of } \\
\text { Infants }\end{array}$ & $\begin{array}{l}\text { Remain- } \\
\text { ed well } \\
\text { for entire } \\
\text { Summer }\end{array}$ & $\begin{array}{l}\text { No. } \\
\text { having } \\
\text { Severe } \\
\text { or Mode- } \\
\text { rate Di- } \\
\text { arrhoea }\end{array}$ & $\begin{array}{l}\text { Average } \\
\text { Number } \\
\text { taken } \\
\text { off Milk } \\
\text { during } \\
\text { Summer }\end{array}$ & $\begin{array}{l}\text { Average } \\
\text { Weekly } \\
\text { Gain in } \\
\text { Weight }\end{array}$ & $\begin{array}{l}\text { Average } \\
\text { Number }\end{array}$ & Deaths \\
\hline $\begin{array}{l}\text { Pasteurised milk: } \\
\text { I000 to } 50,000 \text { bac. } \\
\text { teria per c.c. } \\
\text { Raw milk : } \\
\text { 1,200,000 to } 20,000,000 \\
\text { bacteria per c.c. }\end{array}$ & $4 I$ & $3 I$ & 33 & $5 \cdot 5$ & $\begin{array}{l}4 \mathrm{oz} . \\
3.5 \mathrm{oz} .\end{array}$ & $\begin{array}{r}3 \cdot 9 \\
\text { II } \cdot 5\end{array}$ & 2 \\
\hline
\end{tabular}

was of good quality when used. The average number of bacteria 
counted in the milk was 45,000 per c.c. and in the cream $30,000,000$. When prepared in the bottles the average number of bacteria in the raw milk was $1,200,000$ per c.c. and in the pasteurised about rooo. Investigations of the bacterial content carried out later in the same days from similar bottles showed counts respectively of $20,000,000$ and 50,000 per c.c. Of the fifty-one children who were fed on raw milk, thirteen had to be transferred before the end of the period of observation to pasteurised milk, on account of attacks of diarrhœa which supervened. The figures given are not favourable to raw milk, and the physicians who carried out the investigations believed that the comparative results would have been still less favourable had these thirteen children all been kept upon the raw milk.

The children were taken off milk when an attack of diarrhœa supervened.

Variot and Lorenz-Monod carried out some observations upon children fed upon raw milk. ${ }^{1}$ The milk was obtained from a large dairy and from tuberculin-tested cows. It was delivered packed in ice and saw-dust and was kept cold until use. Bacteriologically it was sterile, and was chemically of very good quality. Eighteen children were fed upon pure raw milk and of these cases five died. Three did well and remained well for the whole period. Several had serious intestinal trouble, when it was necessary to replace the raw milk by Lepelletier's milk or by condensed milk. The children were grouped under headings according to their ages.

\begin{tabular}{|l|c|c|c|}
\hline & Age & $\begin{array}{c}\text { No. of } \\
\text { Infants }\end{array}$ & \multicolumn{1}{|c|}{ Remarks } \\
\hline Group I. & I6 days to 2 months & 4 & I died, 2 did fairly well, I well \\
Group II. & $\begin{array}{c}\text { 3-4 months } \\
\text { Group III. }\end{array}$ & $\begin{array}{l}\text { I died, 2 did fairly well, I well } \\
\text { Group IV. }\end{array}$ & $\begin{array}{l}\text { I months } \\
\text { I9 died, 6 did fairly well, I did well }\end{array}$ \\
\hline
\end{tabular}

Variot noticed that the stools were particularly offensive in many of the cases, and bacteriological examination showed a preponderance of organisms of the coli type. The children did well when the diet was altered to other foods.

The experiments described above do not carry the observations over a sufficiently prolonged period, nor is the number of children sufficient for deductions to be made from them for the general infant population. In IgII I was commissioned by the Local Government Board to carry out investigations on a large scale, using healthy infants or reasonably healthy infants only.

Of late years the rise of infant consultations, where healthy

1 Their work, published in I9I4, is here out of its chronological position but it is more convenient to consider it before taking the Berlin material. 
children are kept at regular intervals under medical supervision, accompanied by home visitation by trained women visitors, has afforded opportunity for observations upon healthy children which had hitherto not existed.

The largest infant consultations existing at that time were to be found in Berlin. These consultations, which are maintained by the municipality, had been established for a number of years, and the amount of material accumulated in their archives was immense. So far, however, no results of the medical supervision had been published. The infants attending these consultations were for the most part breast-fed, this form of feeding being naturally encouraged as much as possible by the medical officers to the consultation. Children for whom artificial feeding was required were fed upon boiled cows' milk supplied in connection with the consultation. The milk was produced on the Berlin municipal farm with adequate precautions to ensure the cleanliness of the milk, and was delivered cooled at a number of centres in the city. Mothers attending the infant consultations were entitled to obtain the milk from these centres at a reduced rate, if this was necessary. They were instructed to bring the milk just up to the boil in their own houses, to set it aside in a cool place, and to prepare it for the infant as directed by the doctor of the consultation. In order to ensure that this method of procedure was carried out, a sufficient staff of trained health visitors was available from the centre, the homes being visited at least every ten days.

The drawback for this investigation was the absence of children fed upon raw cows' milk. Enquiry in a number of quarters showed that there was no infant consultation of sufficient size to afford the necessary material available from which to draw for data, in connection with the nutritive value of raw cows' milk. ${ }^{1}$

Material used for the Investigation.-For the purpose of comparing the progress made by infants when breast-fed or when fed upon cows' milk, it was determined to secure at least two hundred infants for each series, utilising as far as possible similar numbers of infants in the same year in order to eliminate as far as possible climatic influences. The mortality among the infants at the consultation was extremely low in the years from which the material was taken, and careful calculation showed that the mortality factor could be neglected altogether in the material investigated.

Children specifically stated in the notes to be suffering from some congenital defect or disease were not admitted into the series. No child who was older than four months at the time of its first attendance was considered, and the very great majority of cases in both

1 Raw cows' milk is used for the feeding of artificially fed infants in Belfast, but the material has not been worked up, and at the time the investigation here being considered was made, the material was not sufficient for the purpose. 
series attended the infant consultation from about the tenth day of life onwards, up to the end of the first year and even later.

Infants coming into the breast-fed series had all been breast-fed for at least four months after birth. Comparatively few had been fed for as short a period as this, and the great proportion of them had received natural food for from six to nine months. At this latter age weaning was carried out by the recommendation of the medical officer to the consultation. Three hundred such cases were taken for investigation.

Of the artificially fed babies the majority had been artificially fed from birth or from about the first week after birth, only a few having received the breast for some weeks; two hundred and four cases were taken. Detailed figures relating to both series are given in Appendix D.

These babies were brought up for weighing regularly, usually at intervals of ten days, sometimes at fortnightly intervals. The weight was recorded on each occasion, and the child was seen by the medical officer. The method of feeding was prescribed by the doctor, and noted on the medical record. Observations in regard to the child's progress, the presence of minor ailments, presence of teeth, etc., were also recorded.

In order to obtain comparable series, it was necessary to work up the actual age of the child in days on each of the occasions on which it was weighed: The weights of the infants in each series, i.e. breast-fed and artificially-fed, which had attained the same day of life, were then added together and divided by the number of observations available. For convenience it was necessary to group these into periods of eight days. The results of this grouping were then tabulated. They are given fully in the Appendix and shown graphically on the diagram, on the next page.

It will be necessary to consider this diagram in three divisions:

I. The early days of life.

2. The period from about six weeks to six months.

3. The period from six months onwards.

First Period.-A detailed investigation of the first period is somewhat beyond the scope of this present work. The number of observations was small compared with those of a later age, and hence somewhat less reliable. The divergence between the two groups was examined by statistical methods and was shown to be attributable in large measure to the difference in the methods of feeding. At this period of life special value attaches to breastfeeding, and the infant put upon artificial food from birth apparently suffers more markedly in the early days than later. The cause of this has already been investigated in previous chapters, and it is not necessary to deal with it any further here. Complications evidently arise in this period in regard to the loss of weight which occurs in all children during the early days after birth. 
Second Period.-In many ways this period is the most interesting

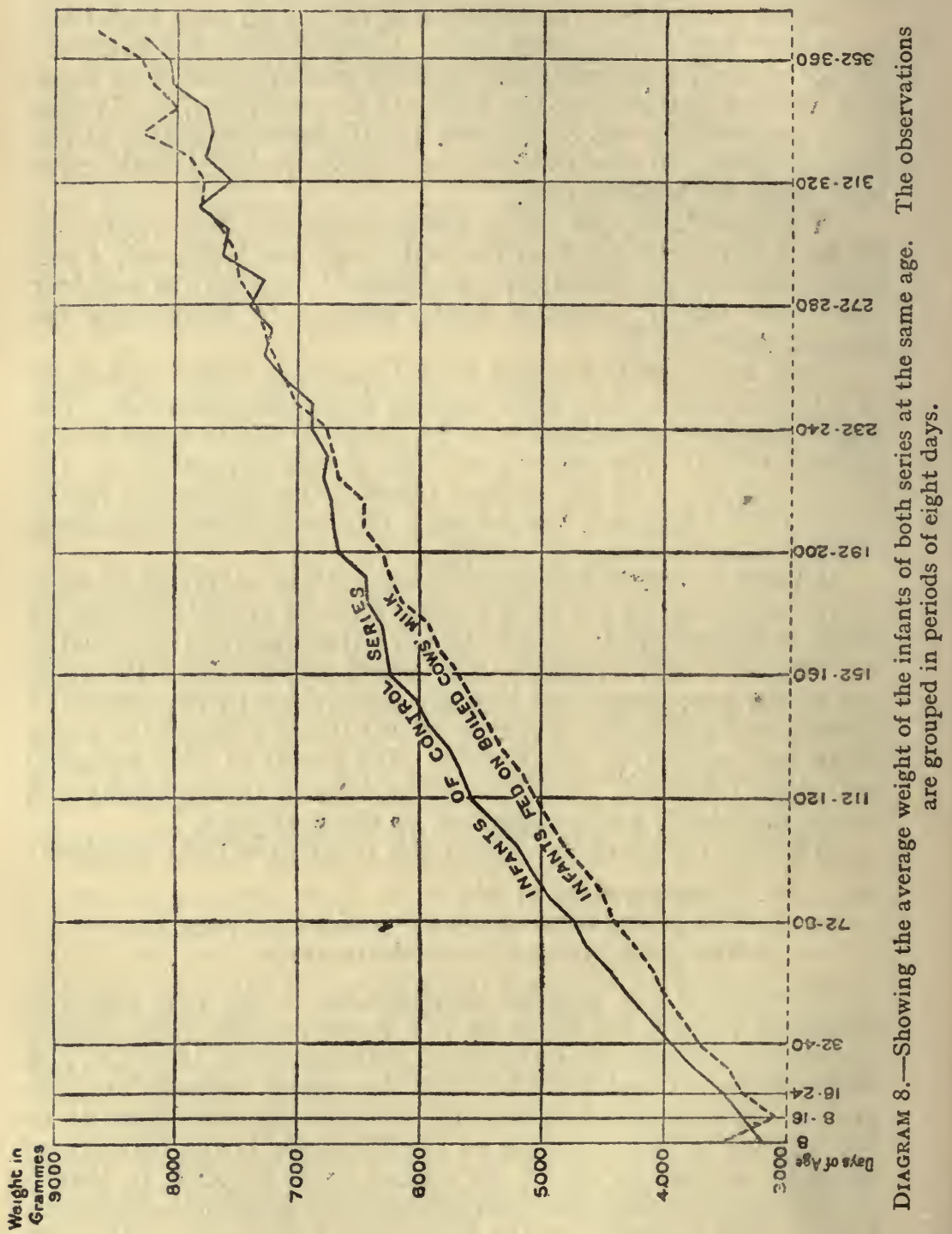

one for the subject under consideration. An examination of the curves from about the sixth week to the sixth month of life shows that at the beginning of this period there was already some 
divergence between the curves, becoming somewhat increased later and then diminishing fairly rapidly, until at a period rather later than the sixth month, this difference has altogether disappeared.

If reference be made to the tables given in Appendix D showing the number of observations and the weights of the infants on each day of life, it will be seen that the number of observations available became larger shortly after the sixth week, and remained at a high level during the whole period under consideration. The number of observations is such as to eliminate any reasonable source of error and to render the observations reliable.

The weight curves of the two series show that the artificially fed infant suffers from the disadvantage of its feeding for some weeks after birth, when it begins to regain some of the lost ground, and at about the sixth month it succeeds for the most part in catching up, in weight at any rate, its breast-fed fellows. Evidently, however, certain considerations must be borne in mind, and the matter is not quite so simple as above outlined.

In the first place it may be argued that the artificially-fed children may be children of weaker parents, since the mother was apparently unable to breast-feed her infant. Against this it may be borne in mind that, speaking generally, the artificially-fed infants are for the most part children of parents whose earnings are sufficient to enable them to provide better hygienic surroundings for the infant. This circumstance would probably to some extent mitigate the disadvantage under which the child might suffer if the health of its mother were unsatisfactory. In Berlin, if investigation of the home circumstances showed that the parents could not afford to buy milk, and it were necessary for any reason that the child should be artificially fed, arrangements were made to supply the milk either free or at a much reduced rate. In order to eliminate as far as possible any source of error which might arise from these considerations, a statistical investigation was undertaken of the relationship of the nature of the food with the wages earned by the father.

(Note.-The wages of the father were in all cases given on the record charts and were a vailable for use in these investigations, as well as the other information in regard to the progress of the infant.)

The result of the statistical investigation which is described fully in the original paper, showed that the nature of the food given, that is breast milk or boiled cows' milk, was more im. portant to the infant than the wages of its father. In this connection the reservation above mentioned as to the absence of shortage of milk supply for the children, owing to the action of the municipality, must be taken into consideration.

The rate of growth of the infants in the two series was studied. This was done in two ways. In the first place the percentage gain shown by each series during each eight-day period was calculated. Secondly, the rate at which growth progressed in each series 


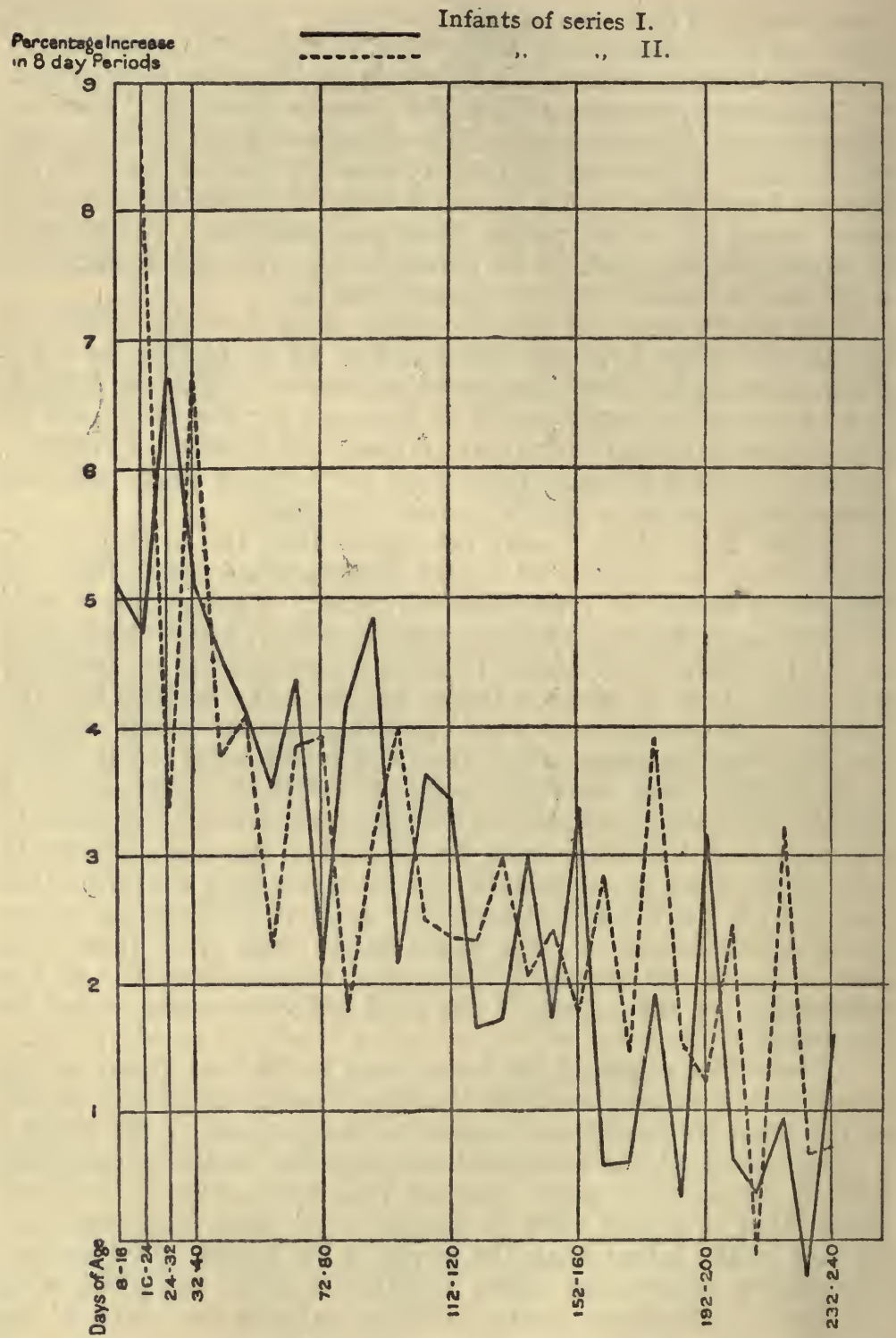

DIAGRAM 9.-Showing the percentage increase of weight in both series, between each eight-day period. 
was also worked out. In this latter case the calculations were based on the weights of each series on the sixteenth day, the data of earlier periods being regarded as unreliable. The percentages given by the first method have been charted in relation to the age of the infant, and are shown in Diagram 9 on the preceding page. This shows that the actual percentage increase in weight from one eightday period to another, of all the infants of each series considered in the aggregate, is extremely variable; even where infants of precisely the same age are considered in large numbers, as in this investigation, there appears to be no constant rate of growth from birth onwards. The figures showing the rate of growth are given in Appendix D. The percentages, although (except in two cases) positive, show an extraordinary variation, and differ in range between 0.6 and 0.8 per cent. in the breast-fed series, and between $I^{.} 4$ and 6.8 in the artificially fed series, during the life-period now under consideration. It is frequently believed by those concerned with the feeding of infants that the infant's weight should show a constant increase from day to day. Doubtless this does occur in a considerable number of children, although in most infants the amount of increase will vary very considerably not only from day to day but from week to week. The present investigations, however, seem to indicate sufficiently clearly that a large number of children who are reasonably healthy show much variety in relation to their progress from day to day. In many cases a slight loss occurs, to be followed at a succeeding period by a larger rise than that of the loss incurred.

The fluctuations appear to be slightly less marked in the artificially fed infants than in the breast-fed infants. In both series there is a tendency for the percentage increase between any two consecutive periods to become less as the age advances.

It has long been recognised that the infant gains weight more rapidiy in the first few months of life than it does later, the progress becoming slower after the first few months.

If, now, the results of the second method, showing the rate of increase of weight of the infants in the two series from the sixteenth day of life onwards, be considered, it is found that from the beginning of the period up to about the fifth month there is very little difference in the curves. This absence of difference is accounted for by the fact that the artificially-fed infants show for the most part a lower absolute weight. Hence a less increment is needed in order to show a similar percentage increase to that of the breast-fed series. This is shown on the diagram on p. 200. It may be observed that after approximately the fifth month, the artificially-fed infants gain at a slightly greater rate than the breast-fed infants. For figures see Appendix D.

The deficit in weight of the series of artificially-fed infants over that of the breast-fed infants was also investigated, and 
it was found that the maximum difference in the weight at any one six-day period between the two series did not at any time reach Io per cent. of the whole, and the percentage on the majority of the average weights was very greatly below this figure.

In order to eliminate any possible source of error owing to the

Percontage

Rate of Growth.

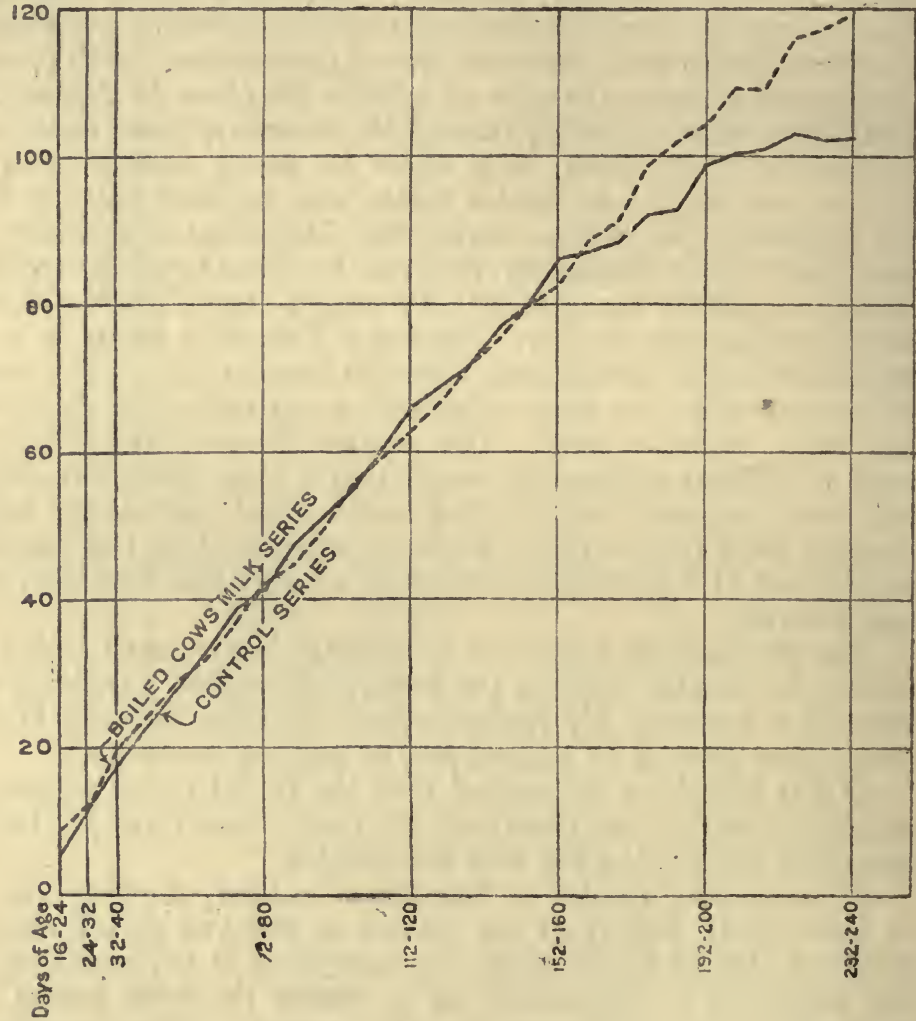

DIAGRAM 10.- Showing the percentage increase in weight in the infants of each series, commencing at the sixteenth day of life.

overlapping of feeding in the two series, i.e. either through a certain amount of mixed feeding in the breast-fed series or through commencing weaning towards the sixth month, it was decided to investigate in greater detail the curves of such children of the series as were entirely breast-fed up to at least the sixth month, and those who had been artificially fed from birth upwards. It was found that out of the 204 babies who were fed on boiled cows' 
milk, 78 had never received the breast and $4 \mathrm{I}$ had received it for periods which in no case exceeded eight days, and in many cases was considerably less. Among the breast-fed series I30 infants out of the 300 were taken, who had received only the breast up to the 20oth day of life or longer.

A comparison of these two subsidiary series $^{2}$ on the same lines as before showed a rather greater divergence of the curves during

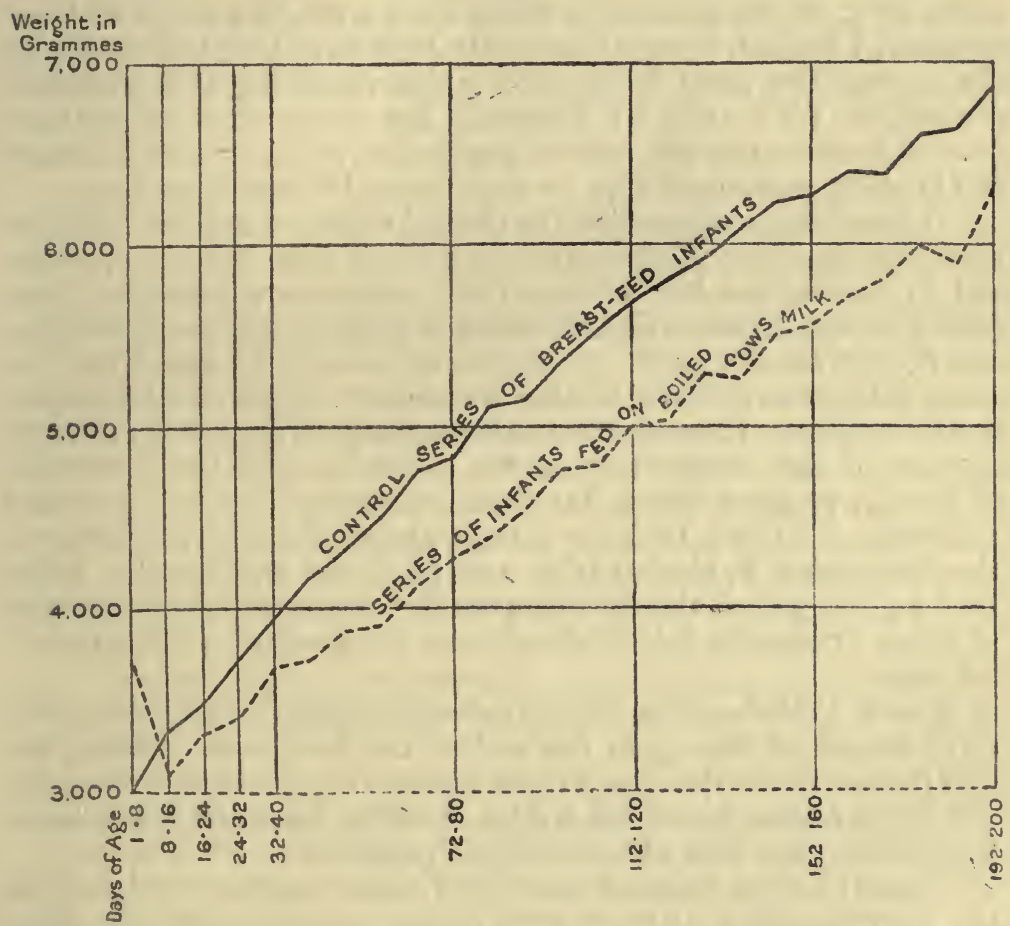

DIAGRAM II.-Showing the average weight of 139 infants exclusively breast-fed, and of 199 infants fed only on boiled cows' milk.

the period under consideration, but a tendency for the curves to approximate towards the end of the period. This is shown on Diagram II, which gives the weights up to the 200th day.

The rate of growth was also studied in a similar manner to that already explained in the two main series, and showed that although the percentage rate of growth was slightly less in the artificially-fed infants, here again the tendency was shown for

1 The figures relating to the subsidiary series are given in the original paper. 
the curves to approximate about the 200th day of life. It is possible, therefore, that slight overlapping is shown in the curves of the two main series, but against this possibility it must be remembered that the number of infants considered in these two subsidiary series is only approximately half the number contained in the main series, and hence the sources of error are considerably increased.

In view of the fact that the artificially-fed children undoubtedly suffer more in the early days of life than later, as a result of their method of feeding, it may reasonably be believed that these results are among the most favourable which could be anticipated in connection with artificial feeding. The cases were taken haphazard from among the poorer population, and in many instances the housing accommodation was known to be unsatisfactcry.

Taking into consideration the clinical evidence and the evidence contained in these Berlin investigations, where the infants were not in institutions but were in their own homes throughout the period of the investigation, it seems difficult to believe that there can be any disadvantage in using boiled cows' milk instead of raw cows' milk, when artificial feeding is necessary. The initial loss would hardly be less on the raw cows' milk and might conceivably be more in view of the composition of the colostrum and the absorption of foreign proteins which has been considered fully in previous chapters. The fact that the infants thus artificially fed catch up the breast-fed babies at the age of about six months, shows that at one period the rate of growth is more rapid on the part of those artificially-fed children, than on the part of the breastfed ones.

Third Period.-This period extends approximately from the sixth month of life up to the end of the first year. During the first part of the period the weight-curves are approximately equal, the curve of the breast-fed babies showing, however, rather more fluctuation than that of the artificially-fed ones.

Several causes arise at about the sixth month to account for the approximation of the curves of the two series at this period and for the fact that they remain parallel up to the end of the first year. In the first place many of the children were weaned at about the sixth month, and were placed upon the same food, that is, boiled cows' milk, as, the infants in the artificially-fed series. Hence the food of the two series tends to become more similar, and by about the ninth month it is probable that all the differences in the feeding were eliminated. Further, in the breast-fed series between the sixth and the ninth month it is probable that the milk supply of the mother was no longer as plentiful as in the earlier months, and it is not unlikely that the infant was receiving rather less food than the corresponding artificially-fed infant, whose food supply was regulated by the physician. The regulation of the food supply in the artificially-fed series probably accounts for the lesser fluctua- 
tion in percentage gains which has already been noted as occurring in this series as compared with the breast-fed series.

It must not be supposed that because the children who were artificially fed show at a later date an equal weight with the breast-fed children, that there is nothing advantageous in breastfeeding. Doubtless where the infants are under constant medical supervision, as was the case in the infants in the Berlin series, the results of artificial feeding are in great measure mitigated.

It is well known that the death-rate among artificially-fed infants during the first year of life is very much higher than that among the breast-fed infants. This alone emphatically condemns artificial feeding from the public health point of view.

Further, even when medical supervision is available, the medical records of the Berlin series showed that the artificiallyfed infants were more frequently indisposed and suffered from minor ailments to a much greater degree than the breast-fed infants. Many of the breast-fed babies appear to have been exempt from minor ailments throughout the greater part of their first year of life, whereas among the artificially-fed ones there are numerous records of dyspeptic conditions, mild bronchitis, and slight attacks of diarrhœa. The sickness incidence which is recorded on the artificially-fed series bears out what is already known, namely, that the mortality figures merely form a partial index of the general prevalence of whatever disease may be under consideration. For every infant that dies as a result of its feeding, a considerably greater number will show minor ailments which will possibly impair the constitution, but will probably not lead to death.

Of recent years a large amount of information has been obtained and recorded at the numerous infant consultation centres in this and other countries. In a few cases the presiding physician has worked up the figures of infants' weights and the medical notes, and has published the results obtained. In the majority of these cases, however, the number of infants which are under observation over a prolonged period and fed upon the same diet is not large. They all, however, confirm the facts already brought forward, and show the great superiority of breast-feeding over any other method of feeding, due regard being had to the social conditions of the infants.

One or two of the publications upon this matter deserve recording, but in the majority of cases the general trend, although supporting the above remarks, is not sufficiently precise to be utilised for the present purpose. Phillipson reports the results of observations upon twenty-three artificially-fed babies at the infant consultation at Frankfort. The children were about a month old when the observations were commenced and were all under observation for some weeks. The infants were fed on simple milk dilutions, the milk being heated. The children appear to have made satisfactory progress and no untoward after-effects were observed.

Krost, of Chicago, reports upon the feeding of 500 babies whose 
diet was supervised by him at the infant welfare station in that city. Some of the infants appear to have been fed upon raw and others upon boiled milk. Krost reports that he used boiled milk for six months for the babies so fed and found no ill-effects. The gain in weight from week to week was about the same in babies fed both on raw and boiled milk. After some months' feeding by these methods, however, the gain in weight was greater in the boiled milk babies than in those fed upon raw milk.

Reference might be made to several other papers where more or less details are given relating to small series of infants fed upon raw or boiled milk. These papers, however, do not add anything to the statements above made. Opinions are purposely not quoted, because these, as is well known, are liable to be formed without a full consideration of the actual facts available. It would be easy, however, to quote the opinions of many well-known physicians which support the information already given.

\section{REFERENCES IN Chapter XI}

\section{The Nutritive Value of Boiled Milk}

Czerny, 'Rohe Milch als Säuglingsnahrung,' Centralb. f. Stoffwechsel u. Verdaunngskrankheiten, 1902, iii. 93.

Davis. See Leeds and Davis.

FINKELsteIN, 'Die rohe Milch in der Säuglingsernährung,' Therap. Monatsch. October 1907.

HALIPRE, 'Le Lait cru dans l'Allaitement des Nourissons,' Rev. mens. des Mal. de l'Enfance, 1904, xxii. 405.

HoHLFIELD, 'Ueber rohe Milch als Säuglingsnahrung,' Jahrb. f. Kinderh. 1905, lxii. 22.

Holr. See Park and Holt.

Krost, 'The Feeding of Five Hundred Infant-welfare Babies in Chicago,' Journ. Amer. Med. Assoc. 1913, 1xi. 2187.

LANE-Claypon, Report to the L.G.B. upon the Available Data in Regard to the Value of Boiled Milk as a Food for Infants and Young Animals, I912, New Series, No. 63.

LeEds and Davis, 'On the Clinical Value of Sterilised Milk,' Amer. Journ. of Med. Science, r891, p. 560.

LORENZMONOD. See Variot and Lorenzmonod.

MONRAD, 'Ueber Benutzung von roher Milch bei Atrophie und chronischen Magen- und Darmkatarrh bei Säuglingen,' Jahrb. f. Kinderh. I902, lv. $6: 2$.

Palmer, 'Feeding the Infants of the Poor with Unsterilised Cows' Milk,' New York Med. Journ. 1900, lxxii. 404.

PARK AND HOLT, ' Report upon the Results of Feeding Infants upon different Kinds of Pure and Impure Milk, etc.' Arch. of Ped. I903.

Phillipson, "Ueber die Entwicklung junger Säuglinge bei künstlichen Ernährung,' Monatsch. f. Kinderh. 1913, xii. I57.

Plantenga, 'Ueber rohe Milch,' Gesell. $f$. Kinderh. February 1910; Meeting of the Netherlands Soc. for Pediatrics, Cologne, rgro. 
NUTRITIVE VALUE OF RAW AND BOILED MILK 205

UHLIG, 'Ueber Versuche einer Ernährung kranken Säuglinge mit Steri lisierter Milch,' Jahrb. f. Kinderh. 1891, xxx. 81, r05.

VARIOT, 'Sur le Traitement de l'Atrophie infantile par l'Emploi du Lait sterilisé,' Bull. de la Soc. des H6p. de Paris, I898, xv. 757.

VARIOT AND LORENZ-MONOD, 'Observations sur la valeur nutritive du lait cru et sur l'influence du sucre pour l'utilisation physiologique du lait cru par le nourrisson,' Bull. de la Soc. de Ped. de Paris, February I9I4, p. 98.

VINCENT, Clinical Studies on the Nutritional Disorders of Infancy, London, I906. 


\section{SUMMARY OF CHAPTER XII}

\section{ON DRIED MILK AS A FOOD FOR INFANTS}

THE use of dried milk as a food for infants is a development of the last few years. It seems likely, however, that it is a development which will continue.

A large variety of dried milks are on the market, but of these numerous varieties, three appear to be most commonly used for infant feeding. These are the Just-Hatmaker dried milk, Glaxo, and Trumilk. Glaxo is a modified milk which approximates in composition to human milk. The other two milks are merely dried without the addition of other substances.

A number of estimations of the composition of dried milks have been made and appear to be fairly uniform. The published figures give the following for the composition:

Fat, approximately . . . 25 to 28 per cent.

Protein, practically the same as fat.

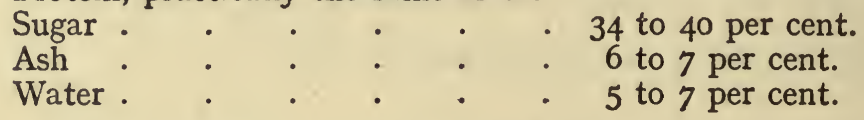

Roughly, the solids are present in eight times the strength of the original milk, although this figure must not be regarded as an absolute one.

The above figures refer to full milk which has been dried. Several manufacturers also produce a variety known as 'halfcream' milk, in which the fat is only present in about half the usual amount. This raises the proportion of the other constituents in relation to the fat, and also increases the percentage amount of the other constituents present in the milk.

Further, dried milk is also prepared in which there is only a small residue of fat, the milk having been previously passed through a separator, to remove the cream. In such milk the percentage figures for the other constituents will evidently be raised still higher in relation to the total dried substances.

In individual cases sugar (both lactose and cane sugar) has been 
added to the dried milk with a view to increasing its nutrient value for infants. But, speaking generally, these preparaticns are not on the market.

Dried milk for infants appears to have been used first in Bruges, Lille, and Lyons. I have been unable to obtain detailed information as to the use of the milk in the first two places, although reports of the work are quoted by some of the French authors. It is stated that the results obtained were very favourable. Details are, however, available of the results obtained in Lyons and in Paris. Dried milk is also used extensively in certain towns in this country.

France.-Some divergence of opinion has arisen among the French observers in regard to the value of dried milk as a routine method for the artificial feeding of infants.

In I9I2 Professor Porcher, of the Veterinary College at Lyons, published a book dealing with the methods of the desiccation of milk, and showing the results he had obtained upon a number of individual children. He showed that dried milk gave very satisfactory results when employed as a food for infants. Successful results have also been published by Bonnamour, of Lyons, who substantiates Porcher's work in regard to the suitability of dried milk as a food for infants. The half-cream variety appears to be very generally used in France, for infants fed on dried milk, at any rate up to the age of about six months.

England.-In this country dried milk is extensively used by certain municipalities and also in connection with the work for infant and child welfare which is carried out by a number of voluntary agencies.

It is unfortunate that up to the present no detailed work upon the results obtained by the use of dried milk for infants in this country have been published, but general statements have been made by Pritchard (St. Marylebone), Naish (Sheffield), and Killick Millard (Leicester).

\section{CHAPTER XII}

\section{ON DRIED MILK AS A FOOD FOR INFANTS}

The Chemical Composition of Dried Milk.-A considerable number of investigations have been carried out upon the composition of dried milk. The various preparations of dried milk which are manufactured from whole milk show a considerable similarity in chemical composition, as might have been anticipated from the nature of the case. The majority of the detailed investigations have been carried out in Germany, where the milk appears to be 
used mainly in the process of the manufacture of chocolate, rather than for feeding purposes.

Goy investigated the composition of dried milk obtained both from America and also prepared locally in Germany. He found that in samples of whole milk, fat and protein were present in almost equal proportions and amounted in each case to approximately 25 per cent. of the total substance, sugar being from 38-40 per cent. of the total content, ash from 6-8 per cent., with a small percentage of water, amounting to about 4 per cent. Evidently these proportions will not hold where the milk has been deprived of all or part of the cream, in which case the fat content will be reduced and the content of the other substances proportionally raised.

Figures were also obtained by Kühl, who gives-Fat, 22-26 per cent. ; protein, 25-26 per cent. ; sugar, 34-37 per cent.; ash, 5-6 per cent.

Utz gives somewhat similar figures, namely-Fat, 26-30 per cent.; protein, 24-26 per cent. ; sugar, 34-40 per cent.; ash, 5-7 per cent.

Such figures as are given incidentally in other work are all corroborative of the above.

Bonnamour (I) states that one litre of milk produces approximately I25 grammes of dried milk, and Goy estimates that I2 grammes of powder correspond to Ioo c.c. of milk, that is, the proportion is roughly $8: I$, or the powder represents eight times the strength of ordinary milk. This figure is agreed with by numerous other observers, commenting upon the composition of dried milk.

There is some difference of opinion in regard to the keeping qualities of dried milk, some authors stating that the samples keep for many months, while others do not consider that milk can safely be kept for so long a period. Goy, in his investigations, used some samples which were several months old and found that the material was quite fresh. He carried out experiments with a view to ascertaining some of the physical changes which were likely to have occurred as a result of the drying of the milk. He found that the fat globules had changed in form, and did not emulsify very readily, but on allowing the milk prepared from the powder to stand in a cylinder, the fat rose to the top in the usual manner. Several observers (Goy, Jacquet, and others) comment upon the low degree of acidity of milk prepared from the dried powder.

Investigations have also been carried out upon the bacterial content of dried milk. Kühl states that the bacteria are not all killed, and that the bacterial content does not permit of the milk being kept for prolonged periods. Goy appears to consider that bacteria are still present, but he states that the milk is too dry to allow of any bacterial growth. 
Delépine, who carried out investigations upon the bacterial content of milk, which had been subjected to the drying process, concludes that there is a very great reduction in the total number of bacteria present, but that the milk is not rendered sterile in the process.

The investigators above mentioned draw attention to the changes in relative composition which must be allowed for, when the fat is removed prior to desiccation.

Experimental Data on the Value of Dried Milk as a Food.A few investigations have been carried out with a view to ascertaining the nutritive value of dried milk as a food. Jacquet subjected himself to a diet of dried milk and rusks for a period of six days. He examined carefully the nitrogen taken in and the nitrogen eliminated, and found that nitrogenous equilibrium was maintained after the first two days of this diet, while in the later days there was a slight retention of nitrogen. Jacquet also carried out observations on the metabolism of a child of seven months who was fed on dried milk, with satisfactory results. The nitrogen content of the milk taken was estimated and also the nitrogen content of the fæces. A high rate of absorption of nitrogen was found, amounting to over 90 per cent.

Brezina and Lazar carried out metabolism experiments upon one adult and three children. The results showed a better utilisation of the milk by the children than by the adult. The children were aged four, seven, and eight years respectively, and other food was allowed during the course of the experiment. The diet included at first a given quantity of raw milk, the nitrogen metabolism being investigated. The raw milk was then changed to dried milk. The highest absorption of nitrogen took place in the youngest child, aged four, and reached 92-93 per cent. of the total. The percentage of nitrogen absorbed by the other children was 92 per cent. in the case of the child of seven and 86 per cent. in the case of the child of eight.

Seligmann fed dogs first upon raw and then upon dried milk, and found that the utilisation of the dried milk was apparently not quite so good as that of the raw milk. The dogs were young puppies of the same litter, and the experiment was carried out over a short period only.

Delépine conducted some feeding experiments on rabbits, using raw cows' milk, condensed milk and dried milk. In each series of animals four rabbits were used, and the amount of food and the weight of the rabbit on each day were noted. The rabbits were young and were kept under observation for two weeks before commencing the experiment, which lasted for approximately nine weeks. Oats were given in addition to the milk, but as this was arranged in a similar manner for all groups, it need not be considered in detail.

The dried milk was made up with sterilised water, at first in 
the proportion of one part of dried milk to four of water, and after eight days in the proportion of one to six. The condensed milk was prepared in the proportion of one part of milk to three of water. The fresh milk was received at the laboratory less than two hours after the afternoon milking. Each variety of milk was either kept in a refrigerator or incubated until it was used the following morning. Each group of rabbits was divided into two, two animals of each group being fed on refrigerated milk, and two on milk incubated at $22^{\circ} \mathrm{C}$, a temperature which was afterwards raised to $30^{\circ} \mathrm{C}$.

Delépine records that "the refrigerated milk diet seemed to agree with all the rabbits for about one month, after which the animals generally began to lose weight, but on replacing 30 c.c. of milk by 30 gms. of cabbage, they gradually regained the lost weight.' In this connection it is interesting to compare the experiments carried out upon young guinea-pigs in regard to raw and boiled milk, where it was shown that a vegetable dietary is a necessity for these animals.

The conclusions reached by Delépine are summed up by him as follows: "On comparing the groups of weights, it is clear that the animals fed on dried milk diluted seven times gained weight more rapidly than those fed on condensed milk diluted four times, or on undiluted normal milk. The superiority of dry milk over fresh milk observed in this set of experiments may be purely accidental, but with regard to the differences between dry milk and condensed milk the explanation is obvious, for even though the condensed milk was diluted only four times the reconstituted condensed milk was poorer in protein and fatty matter than the reconstituted dry milk, this being due to the fact that more than one-half of the solid constituents of condensed milk consists of cane sugar.'

All the rabbits did not survive to the end of the experiment. One fed on condensed, one on fresh refrigerated milk, and all the rabbits fed on incubated milk died before the end of the experiment, with the exception of one rabbit fed on fresh incubated milk. Two of these animals had suffered from acute gastro-enteritis, but there was some evidence that the milk had not been the source of the infection. The results obtained with the incubated milk are of interest when compared with the results obtained by Vincent, who used milk which had been heated and then incubated as a food for kittens. ${ }^{1}$

The experiments on rats conducted by myself, and referred to on p. I79, also showed the favourable results obtained with dried milk.

Clinical Data on the Value of Dried Milk as a Food for Infants. -The value of dried milk as a food is of considerable importance both clinically and economically.

If good results can be obtained by the use of dried milk for 1 see p. 182 . 
infants, many of the difficulties of the milk supply are obviated. It must be clearly stated, however, that no subsequent treatment of the milk, such as desiccation, should be allowed to provide an excuse for dirty methods, or for carelessness in milk production or in transit.

Much of the danger of contamination in the home is avoided by the use of dried milk, and there is no temptation to give the infant stale milk from motives of either economy or laziness. The milk supply is at hand and can be used as required.

Economically it avoids waste in the homes, and if carried out on a large scale should help to reduce waste in the general supply.

A good deal of discussion has arisen upon the nutritive value of dried milk for the routine feeding of infants. The first investigations were made in France and Belgium, and formed the cause of much discussion both in Lyons and Paris. The developments in dried milk feeding are of recent date, the book published by Prof. Porcher appearing in IgI2. Dried milk had been used in several places for infant feeding before this date, but the cases were comparatively few in number and the results had not been published.

Porcher and Bonnamour, in Lyons, have upheld the feeding of infants with dried milk, not necessarily to the exclusion of boiled milk obtained fresh, but as affording a safe food for infants, more especially perhaps in the summer-time and also as a supplementary food to breast-feeding.

Bonnamour $(I, 2)$ gives details of a number of cases fed by him at his infant consultation in Lyons. Out of 900 children which passed through his hands some 56 had to be artificially fed over prolonged periods, and these children were fed upon dried milk. Bonnamour groups them under four main headings:

Group I.-Nine infants who received mixed feeding for a short period. Dried milk was gradually increased as the breast milk failed.

Group $I I$.- Six infants only breast-fed for a few days.

Group III.-Seventeen infants fed exclusively on dried milk after a preliminary period of two or three months' breast-feeding.

Group IV.-Twenty-one sick children who were for the most part ' nurse' children in bad condition.

Bonnamour used half-cream milk up to six months of age with proportions of one teaspoonful of milk to three of water, rising gradually to three of milk to eight or nine of water. He obtained for the most part extremely good results, although the weight curves of some of the children remained somewhat low.

The accompanying diagram (see next page) shows the weight curve of a case taken from Group III.

Bonnamour states that he did not prescribe dried milk as a food for infants who were making satisfactory progress upon ordinary boiled or sterilised milk. He found, however, that it 
was extremely useful and especially valuable in cases of sickly children who, while unable to digest milk in other forms, could

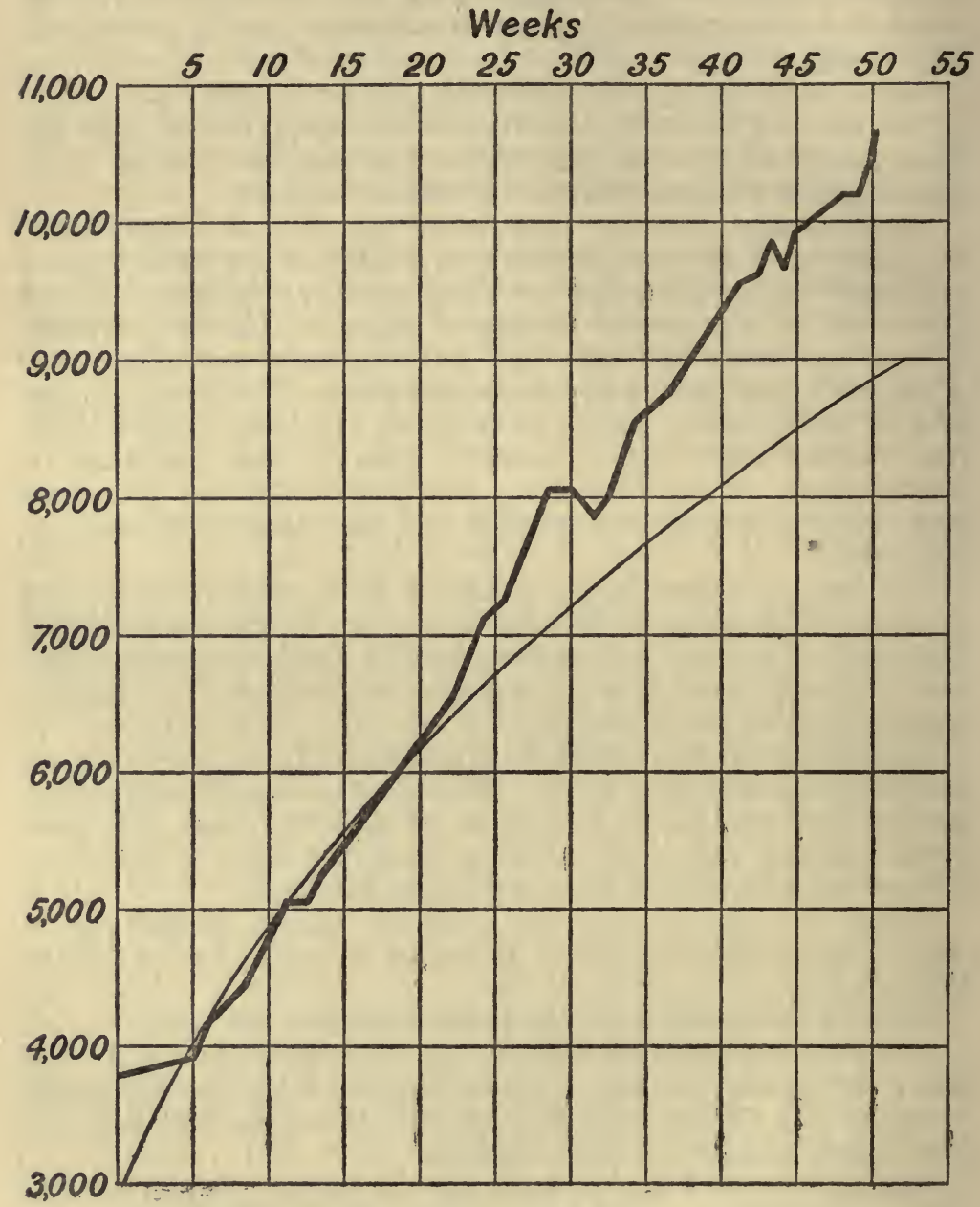

(After Bonnamour.)

DIAGRAM 12.-Weight-chart of a child in Group III fed on dried milk as whole diet after the second month of life.

Half-cream dried milk was used as the whole diet at the fifth week on this chart. Whole milk (dried) was commenced at the thirty-first week.

yet take dried milk readily and make good progress. Other physicians do not agree with Bonnamour in regard to his favourable 
estimate of the value of dried milk, although their observations did not extend over any large number of cases. Generally, it appears that they recognise the value of dried milk for sickly children who are unable to take ordinary milk, although in certain . cases as much intolerance is shown for dried milk as for other forms of milk.

Bonnamour, in a discussion upon this subject held by thephysicians of Lyons, states that he had only met five cases of intolerance to dried milk in the course of eight years' experience. In the course of the discussion Bouchoud gave details of cases treated by him with dried milk, and professed himself converted from a former stage of doubt as to the value of dried milk.

Favourable results on pathological cases (twenty-four children) were also given by Weill and Mouriquand, who, however, doubted the advisability of using it as a routine method of feeding.

Plauchu disagreed with Bonnamour and Porcher in the favourable results they claim to have obtained, but has not himself given any details of cases treated by him with dried milk.

Favourable results have also been obtained by Avriaguet, Bloch-Michel, and Dorlemcourt. These authors used dried milk for cases of mixed feeding and for dyspeptic children, and obtained very satisfactory results, although they state that doubtless satisfactory results could also have been obtained by using boiled milk. They believe that the results with dried milk are due to the increased digestibility of the casein and albumen as a result of the heating process.

Variot states that he used dried milk for some fourteen cases of sick children and considered that the results obtained were poor. The experiments do not appear to have extended over any length of period.

Nageotte-Wilbouchewitch believed that Variot's conclusions were hardly justified in view of the small number of cases treated by him with dried milk, and quotes figures from Ghent and Bruges in support of this statement.

(Detailed information as to the work on these lines in Bruges and Ghent are not available.)

Pouliot states that dried milk is especially valuable for use in intestinal disturbances.

Comby, reviewing the situation as a whole, considers that dried milk should be regarded as a useful form of food, owing to the dangers which arise from the use of ordinary milk.

At the English-speaking conference on Infant Mortality, held in London in I9I3, evidence was given as to the use of dried milk for infants.

Pritchard reported the use of dried milk, both as whole milk and as separated milk, with good results, and Naish gave information as to the use of dried milk among a large number of infants in Sheffield. In this town there are large municipal infant consulta- 
tions, and it has been the practice of the physicians at this institution for some years, to recommend dried milk for such cases as require artificial feeding, either entirely or as supplementary to breast-feeding. This milk has been used for several thousands of children, although the precise figures are not available. The infants are kept under medical supervision. Naish states that he has obtained very good results with the use of this form of milk, and that no disadvantages have been observed. Summing up the considerations advanced, he says: "We have in dried milk a food which contains the same substances as cows' milk and in the same proportions (except when humanised), which is adjustable to a wider range of infants, which has obvious advantages of storage and distribution, and which appears to have no danger of the later nutritional disorders.'

Generally favourable results have also been obtained in other places of which no published information is available. Further data as to the use of dried milk are given in Chapter XIII, dealing with the alleged production of scurvy and rickets, and also in Appendix E.

The manufacture of dried milk is described in Appendix F.

\section{References in Chapter XII}

\section{Dried Milk}

Avriaguer, Bloch-Michel, AND Dorlemcourt, 'Le lait sec dans l'alimentation des nourissons,' Arch. de Méd. des Enfants, I9I2, xv. 641 .

Bloch-Michel. See Avriaguet, Bloch-Michel, and Dorlemcourt.

Bonnamour. (I) 'Le lait desséché,' Bull. de la Soc. méd. des Hópitaux de Lyons, I9I3, xi. 95, and Lyons Méd. I913, cxx. 305. (2) 'Le lait desséché dans l'alimentation du nourisson bien portant et du nourisson malade,' Arch. de Méd. des Enfants, 1913, xvi. 321, 401.

Bouchoud, in Discussion, Lyons Méd. I9I3, Cxx. 305.

BREzINA AND LAzAR, 'Ueber die Ausnutzung der Justhatmakerschen Trockenmilch,' Wien. klin. Wochensch. I906, p. II 39.

Сомву, 'Le lait desséché,' Arch. de Méd. des Mal. de l'Enfance, r9r 3, xvi. 49.

DELEPINE, Report to the L.G.B. upon the Effects of certain Condensing and Drying Processes used in the Preservation of Milk upon its Bacterial Contents, New Series, No. 97, I9I4.

Dorlemcourt. See Avriaguet, Bloch-Michel, and Dorlemcourt.

Goy, 'Ueber einige amerikanische Milchpulver,' Zeit. f. Unters. Nahr- $u$. Genussm. I9I3, xxv. 445.

JACQUET, 'Ueber Trockenmilch und ihre Verwendung als Nahrungsmittel,' Korrespondenzblatt $f$. Schweizer Aerzte, 1904, p. 745.

KÜHL, 'Trockenmilch Präparate,' Hyg. Rund. I9I3, xxiii. 709.

LAzAR. See Brezina and Lazar.

Lane-Claypon, "Observations on the Influence of Heating upon the Nutri tive Value of Milk, etc.' Journ of Hyg. r909, ix. 233.

Mouriguand. See Weill and Mouriquand.

Nageotie-Wilbouchewitz, 'Le Lait en Poudre,' Bull, de la Soc. de Pediat. de Paris, rgr $3, \mathrm{xv} .20,4 \mathrm{r}$. 
NAIsH, 'The Use of Dried Milk' (a paper given at the English-speaking Conference on Infant Mortality held in London, August I9I3). Pediatrics, I9I4, xxvi. 247.

Prauchu. ( I) 'Le lait desséché,' Lyons Méd. I912, cxix. Iro6. (2) 'A propos du lait desséché,' Bull. de la Soc. méd. de Lyons, I9r3, xi. 90. Also Lyons MEd. I913, cxx. 321.

Porcher (I) Le lait desséché, Lyons, I9I2. (2)'Les qualités qui doit posseder un bon lait desséché au point de vue médical,' Arch. de Med. des Mal. de l'Enfance, r9r 3, xvi. 433.

Poulior, 'Le poudre de lait dans l'alimentation des nourissons,' Journ. de Med. de Paris, I9I4, xxvi. I 49.

Pritchard, 'Dried Milk in Infant Feeding,' Pediatrics, I914, xxvi. 300.

Seligmann. For account of work see under Hanne, 'Die Kochpasteurisierung von Kindermilch im Hamburger-Milchpasteur,' Gesundheitsingenieur, I 91 I, xxxiv. 489 .

UTz, 'Ueber Trockenmilch mit besonderer Berücksichtigung der Bestimmung des Fettgehaltes,' Milchw. Zentralb. I9I4, p. II3.

Variot. (I) 'Essai sur la valeur alibile du lait desséché,' Bull. de la Soc. de Ped. de Paris, I9I3, xv. 20. (2) La Clinique infantile, February rgr 3.

Weill and Mouriguand, ' Note sur le lait desséché,' Lyons Méd. Igra, cxix. 935 ; Bull. de la Soc. méd. des Hopitaux de Lyons, I9I2, x. 495. 


\section{SUMMARY OF CHAPTER XIII}

\section{ON THE ALLEGED PRODUCTION OF BARLOW'S DISEASE AND RICKETS}

BY THE USE OF HEATED MILK FOR INFANTS

CASES of Barlow's disease have always attracted, and will probably continue to attract, very considerable attention on the part of the medical profession. The acute symptoms, followed by their rapid subsidence under adequate treatment, compel attention, although the disease cannot be regarded as in any sense one of common occurrence.

It has been stated to be due to the use of heated milk, but the degree of heat and the method of heating employed have not in every case received that attention which they deserve, before the statement was made.

Most physicians appear now to have relinquished the general idea that this disease is produced by the heating of milk, but it cannot be said that an adequate explanation of its etiology has been reached.

The details of cases given in discussions upon Barlow's disease which took place in Berlin in I903, and in America in I898 and in I9I4, seem to show that there may be a close connection between the two-fold heating of milk and the production of Barlow's disease. It is not, however, clear whether such a connection may not be closely related to the length of time the milk has been kept. One of the great dangers of heated milk on a commercial scale, is the tendency for such milk to be kept longer than would have been the case had the milk not been heated. A false sense of security appears to be engend red by the heating of milk, which induces both the salesman and the consumer to delay unduly the consumption of the milk.

A large number of the cases of scurvy have been shown to be associated with the use of proprietary foods of different types, and occur mainly among the children of the well-to-do. Breastfed babies are not exempt from this disease. It would seem that a monotonous dietary may produce the disease, as also one which is remote in quality from the child's normal food.

The increasing attention which is now bestowed upon infant 
feeding shows that it is impossible to lay down hard and fast rules for the feeding of infants, although there can be little doubt that the most suitable food for infants is the natural food, that is, the milk of its mother.

There is no evidence to show that the use of heated milk is productive of rickets in young children.

\section{CHAPTER XIII}

ON THE ALLEGED PRODUCTION OF BARLOW'S DISEASE AND RICKETS BY THE USE OF HEATED MILK FOR INFANTS

THE literature upon the subject of Barlow's disease, its etiology, course, and treatment, is too great for any attempt to be made to consider it completely. It is merely proposed to give the more important papers and the discussions dealing with a large number of cases of this disease, which have been analysed by different authors.

The first cases in the literature were published by Cheadle in I878, but the cases quoted in the years following Cheadle's communication do not appear to have been very numerous.

In 1898 a full discussion on infantile scurvy took place in Boston, Mass., by the American Pediatric Society. This society sent out circular letters to numerous physicians, requesting them to fill in the details asked for on the papers sent. The papers contained questions on a comprehensive scale, dealing with the number of cases seen, the food which had been given prior to the onset of the disease, the treatment prescribed, and the results obtained. Records of 379 cases of the disease were thus obtained by the Pediatric Society. A committee was appointed to analyse the records, which consisted of Drs. Griffiths, Jennings, and Morse, and the results obtained were considered at a meeting of the Medical and Chirurgical Society. A few of the details thus collected may be given here.

The age at which the disease occurred was found to vary from three weeks to nine years, but the great majority of the cases occurred between the ages of seven and thirteen or fourteen months. The social circumstances of the children attacked were for the most part good. Eighty-three per cent. of the cases occurred in the private practice of the physicians supplying the information, and only I7 per cent. in their hospital practice. Out of the 379 cases, the information given showed that in 303 cases the circumstances were 'good,' and in only 40 cases were they described as 'bad.' The diet before the onset of the disease was found to vary very greatly, but in the majority of instances either sterilised milk or patent foods of one form or another had been given. Of the total 
number ro had been entirely breast-fed, 4 had received only raw milk, and I6 pasteurised milk. Recovery followed in a great many cases without any change of diet or merely on the addition of beef juice or fruit juice. In a fair number of cases recovery followed by merely changing the diet, which was sometimes accompanied by the addition of fruit juice, but this was not always found to be necessary.

The conclusions of the committee, after studying the analysis made, were to the effect that the disease appeared to be due to prolonged use of an unsuitable dietary, that the more remote this dietary from the natural food the more likely it appeared that scurvy would supervene. This was more especially the case with proprietary foods.

In I900, dealing with the occurrence of Barlow's disease and rickets, Escherich says: 'I have not once seen infantile scurvy among all the many thousands of children fed artificially and with sterilised milk which passed through my hands in München and Graz.'

In the year I902-3 a great increase in the number of cases of Barlow's disease appears to have been noticed in Berlin. About this date one of the large dairies of Berlin which collected the milk from a considerable distance and supplied it to a great many of the well-to-do families, adopted a method of pasteurisation. The pasteurisation appears to have been carried out on a very large scale, and the milk to have been sold in a large measure for special infants' milk. It is noted by several observers upon this subject that the milk was altered in character, having sometimes a brownish colour and appearing to have been heated to a considerable temperature.

In I902 Neumann (I) of Berlin, in a paper dealing with Barlow's disease, quotes twenty cases which had occurred in his own practice. He stated his belief that the disease was due to a double heating of the milk, which was already pasteurised before being sold to the custumer, and was then usually heated a second time in the house before being fed to the infant. He quotes especially two cases of scurvy. In one, a child aged twenty months, had always been given heated milk, which had been kept boiling for ten minutes in a Soxhlet apparatus. Some months previous to the outbreak of the disease the milk supply had been changed, and instead of being obtained raw had been obtained from this dairy in a pasteurised form and subsequently heated in the house.

In the other case the child had been breast-fed for six months, and for eight months subsequently had received the pasteurised milk, which was afterwards heated in the Soxhlet apparatus.

Neumann mentions that if careful observations are made it is usually noted that the children begin to refuse the food some months before the disease actually occurs. Usually, however, no attention is paid to this action on the part of the infant, 
continual suasion being applied to induce the child to take its nourishment.

In I903 a paper was given by Heubner, who points out that in his experience the number of cases of Barlow's disease had increased very greatly of recent years. He quoted sixty-five cases of the disease, details being given of fifty-five of these cases. The method of feeding was as follows:

Thirteen had received good milk from various sources, usually given raw.

Twclve cases had also received good milk which was subsequently heated in the Soxhlet apparatus for fifteen minutes.

Nineteen cases had been fed on pasteurised milk, subsequently boiled in the home.

Seven had received patent foods or condensed milk.

Four had received starchy foods.

An animated discussion followed Heubner's paper, in the course of which Neumann (2) stated his opinions, which have been already dealt with. Finkelstein quoted thirteen cases which had occurred in the previous eighteen months and gave details. $\mathrm{He}$ stated that of the thirteen cases five had received starchy food, but that the disease was cured even when the starchy food was continued, raw milk being given in addition. In seven cases milk had been given which was already pasteurised and then again heated in the home. In two of these cases it had only been boiled for five minutes in the home. In one case it was especially desired to avoid the occurrence of Barlow's disease in a child which had to be artificially fed, and the milk was given only just boiled, and fruit juice was added throughout the entire period of feeding. In spite of this precaution the child did develop scurvy, which, however, subsided under treatment, the details of which are not given.

Schultze stated that he had recently seen a good many cases, but in practically all of them the milk had been pasteurised by the dairy and subsequently again in the home in a Soxhlet apparatus.

Ritter stated that the increase in Barlow's disease in Berlin had begun since Igoo and was, he believed, due to the introduction of sterilisation. In the cases seen by him the length of heating varied from five to forty minutes, and out of twenty-two cases the milk had been heated for twenty minutes or more and other foods had also been given.

In the course of the discussion it was pointed out that the cases did not occur among the poorer population, but were mainly among the population whose social circumstances were good, and where every care was taken in the preparation of the infants' food.

Variot, in I904, issued a report of his infant consultation at Belleville, near Paris. At this consultation the artificially-fed children received milk which had been heated to $108^{\circ} \mathrm{C}$. Variot 
reviewed the work at his consultation and stated that in the 3000 cases included in this report, there had been no case of Barlow's disease.

Bresset, dealing with the results of similar work in another district in Paris, states that in over 2000 cases fed on sterilised milk no case suspicious of Barlow's disease was seen.

Budin says: "As for the so-called infantile scurvy which is alleged to follow the use of sterilised milk, I have heard a very great deal about it during the last few years, but I am still looking for my first case.'

In the year Ig08 the Medical Society of Geneva held an inquiry into the frequency of Barlow's disease in Switzerland. Papers of inquiry were sent to the medical men of the district, and seventyone answers were received from different physicians. Of the seventy-one physicians only five had seen cases of the disease, and only ten cases in all were reported, of which six had occurred in Geneva itself. Of these ten cases nine had been fed either upon special forms of milk or upon milk sterilised at high temperatures. The tenth child had been fed upon milk prepared in a Soxhlet apparatus.

An interesting case is quoted by Carel of a child who was taken away from home with a supply of sterilised milk sufficient to last for several weeks. The child appears to have shown peculiar symptoms, which disappeared on the arrival of a fresh supply of sterilised milk. As this fresh supply became stale, the same symptoms, previously noticed, reappeared, and the child was brought up for medical advice. The case was diagnosed as one of infantile scurvy. This case suggests that it is not advisable to employ sterilised milk which has been kept, as a food for infants.

Plantenga published an account of an outbreak of Barlow's disease which occurred among the children of his infant consultation in Igro. The milk, which was given out at his consultation, was at one period pasteurised overnight by heating at $70^{\circ} \mathrm{C}$. for half an hour, and in the morning was further heated by being boiled for five minutes in a Soxhlet apparatus. Twentythree cases of Barlow's disease developed among the infants of the consultation, which numbered 200 in all. As a result of this outbreak the routine of the milk preparation was altered, and the morning's milk was obtained and subjected only to pasteurisation before being given out. No case of Barlow's disease occurred with the adoption of this alteration. Plantenga attributed the occurrence of the trouble to the length of time the milk had been kept before being used, and he pointed out that the value of raw milk in certain cases may arise from the fact that it is given sooner after milking.

There is evidence that changes occur in milk, when it is allowed to stand, and in this connection reference may be made to Appendix $\mathrm{C}$, dealing with the preservation of human milk, and to the 
work of Ellenbeck mentioned on pp. 79 and II3 in connection with the keeping of milk in the cold.

Naish, dealing with the feeding of infants upon dried milk, says: 'With regard to scurvy, I believe the risk is non-existent. I did see one slight case two or three years ago, which was cured within three days, but the mother in this instance had been attending very irregularly, and I was never able to satisfy myself as to what the baby's diet really had been. Besides this I have seen no other, and I am not in the habit of ordering any orange juice or other anti-scorbutic.'

Morse $(x, 2)$, in IgI4, dealt with eighty-seven cases of Barlow's disease which had occurred in the out-patient department of the children's hospital at Boston, Mass. He stated that there had been a marked increase in the number of cases of Barlow's disease which had developed, the percentage having risen from - II per cent. in I904 to .87 per cent. in I9I3 of all the new cases seen at the hospital. The cases had been fed as follows:

Condensed milk .

Proprietary foods with water

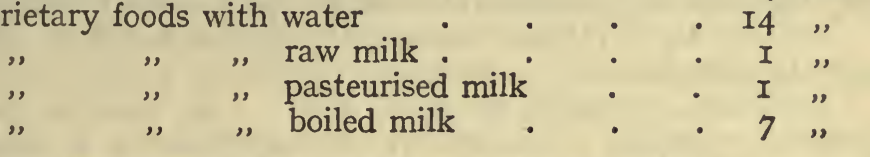

In seventeen cases no precise data were available.

Diluted milk had been given pasteurised in five cases.

" " boiled or scalded, in twenty-three cases.

" " without available details as to heating, in fourteen cases.

Three cases had been breast-fed.

In eleven cases which occurred in I905 one had been breastfed, two had received modified milk, and the others condensed milk or dried milk foods.

Following on Morse's paper a discussion took place by the Medical Society upon the occurrence of Barlow's disease.

Miller, of Atlantic City, believed that scurvy was increasing in this town, as he had himself seen twelve cases in the last two years in his own practice. In five of the cases there had been two pasteurisations carried out on the milk given to the infants. He believed that the production of scurvy might be due to a badly balanced diet.

Several physicians spoke upon the question, and there appeared to be a general opinion that Barlow's disease was increasing in several cities. The New York physicians, however, thought that scurvy was decreasing in New York City in spite of the commercial pasteurisation of the milk supply. One of them believed that scurvy was due to artificial foods.

Griffith, of Philadelphia, stated that a committee had 
investigated the question of scurvy and had reached the conclusion that changes of dietary were probably necessary. He reported the occurrence of ten cases in breast-fed babies.

The result of the discussion was summed up by Morse, who concluded that there appeared to be nothing which could really point to the production of scurvy by pasteurised milk.

Comby (2), in I9I5, quoted twenty-six cases of scurvy in children, some of which had been previously fed on sterilised milk or on proprietary foods, or other special preparations. He stated that scurvy can be cured by the use of boiled milk and pointed out the dangers of a too great similarity of diet.

Further information upon the literature of Barlow's disease can be obtained by consulting papers by Netter, Corlette, Schreiber and François, Comby (r), Heubner (2), Bolle, la Fetra, and others.

Rickets.-The production of rickets by the use of heated milk has been much discussed in recent years. The general experience, however, which has now been gained as a result of the large infant welfare centres in this and other countries, has tended to discredit any belief in the production of rickets by the use of boiled milk.

It may be of interest, however, to give a few facts connected with this matter.

Escherich, speaking in I900, says: 'As regards the much disputed question of rickets, in my experience it is hardly less frequent in breast-fed babies than in bottle-fed ones. The worst degrees of rickets are, however, only met with in the latter class.' It may be mentioned that in the artificially-fed class Escherich was dealing entirely with infants fed upon milk called by him 'sterilised,' but which had apparently been subjected to prolonged boiling and not strict sterilisation.

Bresset, in the work on his consultation already referred to, stated that rickets was extremely rare among the children attending the consultation.

Variot stated (in the work already referred to) that a few cases which had been overfed or had received farinaceous food while still too young had developed rickets. These cases occurred in a total of about 3000 .

In the Berlin babies investigated by myself, it was shown that out of the total number of infants (504) investigated there were sixtyone cases where rickets appeared to be definitely developed and ten doubtful cases. Of the sixty-one cases thirty occurred in the breast-fed series and thirty-one in the boiled milk series. Too much stress must not however be laid upon these figures, as the children were in many cases not seen after the age of one year. The incidence of rickets in Berlin is admittedly high among the general population.

Naish, in the work already referred to, says : 'I have followed up considerable numbers of those fed on dried milk, and noted the time at which independent walking commences; this I have 
found to be usually within fourteen months, except where the infant has been very far from the normal at the time of its first attendance or has suffered subsequently from measles, whoopingcough or other bacterial infection; in not a few cases the child has walked before the end of the first year, and in one case at nine months. I have also followed up as many as possible to the ages of three, four, and five years, and am personally convinced that there is no more risk of rickets with this diet than with a good quality raw cow's milk.' He also states that it is possible to cure rickets by changing a previously-given diet to a dried-milk diet.

It is a well-known fact that the incidence of rickets varies considerably in different countries and in different districts, and it is probable that although feeding cannot be entirely excluded, other factors are concerned in the production of rickets. Many French physicians believe that rickets can be induced as a result of over-feeding, and this view is also held by Pritchard.

Findlay, who has carried out experimental work upon the production of rickets, believes that bad sanitation and absence of proper ventilation must be regarded as largely responsible for the production of this disease.

It is impossible to discuss the question of rickets further in this work.

\section{ReFerences in Chapter XIII}

\section{Barlow's Disease and Rickets}

Bolle, 'Zur Therapie der Barlow'sche Krankheit,' Zeit.f. diätet. u. physik. Therapie, 1903 vi. 354 .

BRESSET. Rapport de la dispensaire gratuite de la caisse des écoles du septieme arrondissement. Statistique de r888-1905, pp. 25, 26.

Budin, The Nursling. Translated into English, Paris, 1907, p. 146.

CAREL, 'Un cas de scorbut imputable au lait sterilisé consumé trop longtemps après la sterilisation,' Bull. de la Soc. de Ped. de Paris, Igro, January.

CheAdle, "Three Cases of Scurvy supervening on Rickets in Young Children, Lancet, 1878, p. 685 .

Сомву. (I) 'Scurvy in Children,' La Tribune Médicale, October 1906. Quoted in New York Med. Journal, January 1907. (2) 'Le Scorbut infantile,' Arch. de Medd. des Enfants, 1915, xviii. 181.

CoRlette, 'An Explanation of the Cause of Infantile Scurvy, with Sugges. tions as to its Prevention,' British Med. Journ. I900, ii. 573.

ElLeNBeCK, 'Zur Haemolyse der Frauenmilch,' Verh. d. Gesell. f. Kinderh. Münster, 19r2, p. 63.

EsCHERICH, ' Zur Kenntnis der Unterscheide zwischen den natürlichen und kủnstlichen Ernährung des Säuglings,' Wiener klin. Wochensch. I900, xiii. II 85 .

Finduay, 'The Etiology of Rickets,' British Med. Journ. 1908, ii. 13; and Lancet, I91 5, clxxxviii. 956.

Finkelstein, in Discussion, Berl. klin. Wochensch, r903, p. 374. 
FrançoIs. See Schreiber and François.

Geneva, 'Rapport de la Commission de la Maladie de Barlow,' Rev. méd. de la Suisse Romande, January 1908.

Griffiths, Jennings, and MORSE, 'The American Pediatric Society's Collective Investigations on Infantile Scurvy in N. America,' Boston Med. and Chir. Journ. I898, xxxviii. 605; and xxxix. 3 .

Heubner. (I) 'Ueber die Barlow'sche Krankheit,' Berl. klin. Wochensch. I903, p. 285. (2) 'Ueber die scorbutartige Erkrankung rachitischer Säuglinge,' Jahrb. $f$. Kinderh. I892, xxxiv. 36r.

Jennings. See Griffiths, Jennings, and Morse.

LA Fetra, 'Infantile Scurvy,' Amer. Journ. of Med. Sciences, June 1907.

LANE-Claypon, Report to the L.G.B. upon the Available Data in Regard to the Value of Boiled Milk as a Food for Infants and Young Animals, New Series, No. 63 , I912, p. 35 .

MII,LER, in Discussion, A mer. Journ. of Obst. I9I4, xx. 316.

Morse. (I) 'Infantile Scorbutus and the Pasteurisation of Milk,' Amer. Journ. of Obst. I9I4, IXx. 3I6. (2) 'Infantile Scorbutus,' Boston Med. and Chir. Journal, April ror 4.

Morse. See Griffiths, Jennings, and Morse.

NAISH, 'The Use of Dried Milk' (a paper given at the English-speaking Conference on Infant Mortality held in London, August rgr3), Pediatrics, I914: xxvi. 247.

Netter, Rev. mens. des Maladies de l'Enfance, I902, xx.

Neumann. (I) 'Bemerkungen zur Barlow'sche Krankheit,' Deutsch. med. Wochensch. 1902, xxviii. 628, 647. (2) 'Ueber die Barlow'sche Krankheit,' Berl. klin. Wochensch. I903, xl. 308.

Plantenga, 'Ueber rohe Milch,' Gesell. $f$. Kinderh., February rgro; Meeting of the Netherlands Society for Pediatrics, Cologne, rgro.

PRITCHARD, 'The Over-feeding of Infants,' Meeting of the B.M.A. at Cheltenham, rgor.

Ritrer, in Discussion, 'Ueber die Barlow'sche Krankheit,' Berl. klin: Wochensch. 1903, p. 374 .

SCHREIBER AND FRANÇOIS, "Scorbut infantile chez un enfant de quatre ans nourri au lait homogénéisé,' Bull. de la Soc. de Ped. de Paris, I9I4, No. 4, p. 225.

Schultze, in Discussion, Berl. klin. Wochensch. 1903. p. 374.

VARIOT, 'Ueber den Wert hochgradiger erhitzter Milch für die Ernährung der Säuglinge,' Compt. Rend. I905, vol. cxxxix. 


\section{SUMMARY OF CHAPTER XIV}

\section{CHANGES OCCURRING IN MILK AS A RESULT OF THE APPLICATION OF HEAT}

WHEN the use of boiled milk first became at all general, certain observers believed that they noticed a detrimental influence upon the children who were fed with milk which had been subjected to heat. The chemical changes which undoubtedly occur as a result of heating at temperatures not exceeding $100^{\circ} \mathrm{C}$. were investigated by a considerable number of observers. Many of these investigators at once attributed the detrimental effects said to have been noticed, to the changes which they discovered in the milk, very frequently without any attempt to connect the statement with fact.

It was found that the application of heat produced a lowering of the calcium content of milk by throwing the calcium out of solution. The amount of calcium precipitated was found to be different by the different authors who investigated the subject. In any case only a portion of the calcium falls out, and the total calcium content of cows' milk appears, even after boiling, to be equal to, or higher than, that of human milk. The changes in acidity and the delay in clotting with rennet, which were found to occur as a result of heating, were studied in detail. It is probable that both these phenomena are connected either directly or indirectly with the calcium content of the milk, and the changes occurring therein as a result of heating.

Changes also occur in the protein on heating, but unless the temperature is allowed to reach considerably above $100^{\circ} \mathrm{C}$. these changes appear to be confined to the albumin fraction. Different observers have given different temperatures for the commencement of precipitation of the albumin. It seems probable that comparatively little change, if any, occurs below the temperature of $65^{\circ} \mathrm{C}$., but that after this temperature has been reached an increasing amount of albumin is precipitated, the amount depending not only upon the absolute temperature reached, but also upon the length of time of heating.

Changes of a more radical character do not take place in the milk unless the temperature is raised above $100^{\circ} \mathrm{C}$. In the process 
of desiccation, milk is exposed on rollers which are heated to a temperature of approximately $120^{\circ} \mathrm{C}$. This exposure, however, is for a very short period only, and it has been shown by Delépine ${ }^{2}$ that the maximum temperature probably does not at any time exceed $96^{\circ} \mathrm{C}$., and that the duration of the exposure to that temperature approximates to $3 \cdot 3$ seconds. It need not therefore be anticipated that any appreciable change takes place in the protein of milk on desiccation. The albumin is probably in part coagulated, but there is no loss, since the whole of the dried milk is utilised. The work given in Chap. XII bears out the above remarks.

Slight changes in viscosity occur in the fat when heat is employed, but no diminution in content appears to be noted below a temperature of $100^{\circ} \mathrm{C}$. or even somewhat above this temperature. The cream line is said to be affected at $150^{\circ} \mathrm{F}$. approximately, but this is probably related to the changes in viscosity already alluded to.

No change occurs in the lactose content unless the temperature be raised considerably above $100^{\circ} \mathrm{C}$., when a brownish colour may occur which indicates that some caramelisation has taken place.

The so-called 'biological properties' have been studied with a view to determining the effect upon them of heat. Ferments are destroyed by a temperature of $100^{\circ} \mathrm{C}$., or below, but as there is no reason to suppose that these, when present in milk, are of any value, the question of their destruction does not call for consideration.

The properties which are concerned in immunity have also been the subject of investigation, but it cannot be said as yet that the results are entirely harmonious. It seems probable that where any alteration has been observed as a result of the heating of milk, this can be referred to the coagulation of the albumin or perhaps to the reduction in the calcium content of the fluid. In a number of cases where the effect of heat upon the reactions for immunity has been studied, no change has been detected when the temperature has reached $100^{\circ} \mathrm{C}$. or even higher. It has been shown in Chap. VI that these properties are only of value to the suckling animal in the early days of life. In any case, therefore, the effect of heat after this period needs to be considered only in relation to the nutritive properties possessed by the proteins to which the properties are attached. This has already been done in the preceding chapters, where the satisfactory results obtained by the use of boiled milk have been dealt with in detail.

There is no evidence to show that the reduction in calcium content which occurs when milk is boiled, has any influence on the human infant when artificially fed. Such other acid or basic radicals which may be present in the milk and appear to be slightly, reduced by heating, are present in considerable excess in cows' 
milk when compared with human milk. It may therefore be reasonably assumed that, in relation to infant feeding, boiling produces no detrimental effect upon the ash of milk. Moreover, it may be mentioned that these substances only pass from the soluble to the insoluble state, and there is no reason for supposing that they are incapable of being assimilated by the infant in this latter form.

Generally speaking, the changes which occur on heating milk to a temperature of about $100^{\circ} \mathrm{C}$. for a short period cannot be regarded as having any detrimental influence from the nutritional standpoint. Above this temperature changes undoubtedly occur, but for the most part high temperatures are not employed to any extent in connection with the feeding of infants.

\section{CHAPTER XIV}

\section{CHANGES OCCURRING IN MILK AS A RESULT OF THE} APPLICATION OF HEAT

IT would not appear necessary to enter at any length into a discussion of the literature concerned with the chemical changes produced by the heating of milk. The evidence which has been brought forward in the preceding chapters, provides sufficient testimony to the value of heated milk as a food for infants. Any additional consideration of the chemical changes taking place on heating is therefore a matter of interest, rather than directly connected with the hygienic aspect of the milk question.

In view of the great discussion which has taken place during this century, and earlier, upon the changes due to heating, it is proposed to consider briefly the more important papers dealing with various aspects of this subject. There can be no question that changes do occur in connection with the heating of milk, but the degree of change is dependent upon the temperature and the length of time over which that temperature is maintained. The changes in the more important constituents alone will be considered here.

Changes occurring in the Protein Constituents of Milk as a Result of Heating.-The proteins of milk have been considered already in Chap. III, where reference was made to the different proteins occurring in milk and to their relative proportions in both human and cows' milk. It was there stated that caseinogen forms the major part of the protein of cows' milk, while in human milk the proportion of caseinogen to albumin is more equal.

Effect of Heat on Caseinogen.-Caseinogen is not coagulated 
by heat unless the temperature be raised above that usually employed for the milk of infants, but alterations apparently occur in the molecule which affect the action of digestive ferments upon this substance. The general trend of evidence shows that the digestibility of caseinogen is increased by heating, but one or two authors have believed the reverse. ${ }^{1}$

Netter (2) found that the digestion in the stomach of sterilised cows' milk was almost as good as that of human milk, but he is careful to point out that this does not imply that it is as good a food in all other respects.

Klemperer investigated in the laboratory the digestibility of raw and boiled cows' milk, and was unable to detect any appreciable difference between the two.

Gerber investigated the effect of caseases derived from plants, upon raw and boiled caseinogen. He found that these pancreatins did not produce any amino-acids, whatever amount of ferment was added. In heated milk, however, such action was obtained and varied with the amount of the ferment added and with the temperature to which the milk had been raised. No action occurred under a temperature of $67^{\circ} \mathrm{C}$., but heating for ten to fifteen minutes at this temperature produced a small amount of soluble nitrogen. From $75^{\circ} \mathrm{C}$. to $85^{\circ} \mathrm{C}$. there was considerable increase in the amount of amino-acids formed, and very little further increase was obtained when the milk was heated at $100^{\circ} \mathrm{C}$.

Brennemann worked on the clot formation of casein in the stomach. He utilised for his investigations a young adult who had the capacity of regurgitating food without experiencing any discomfort. These experiments showed that the curd obtained with raw milk was very tough and large, while with boiled or sterilised milk it was soft and much finer in character. In connection with the digestibility of caseinogen it may be remembered that Brennemann and others found that the so-called ' casein curds' in infants' stools, occur only when raw milk is given." This suggests that caseinogen is more readily digested when the milk has been heated. The increased ease in the digestibility of the caseinogen of dried milk has already been referred to.

It seems probable that the digestion of casein occurs for the most part in the small intestine. This conclusion was reached by Rotondi as a result of experiments on the digestion of both cows' and human caseinogen. He showed that cows' and human caseinogen were equally well digested by both pepsin and trypsin, but that the pancreatic ferments attack caseinogen rather more readily than fibrin, whereas the reverse occurred with the gastric ferments, and he concluded that the chief digestion of caseinogen probably occurred in the small intestine.

The work of Bayliss and Plimmer in relation to the breaking

$1 \mathrm{Cp}$. de Jaeger, Hougardi, and others.

2 Cp. p. 36. 
off of the phosphorus from the caseinogen as the result of alkalies and digestive enzymes is of interest in this connection.

The Effect of Heat on Albumin.-The albumin of both human and cows' milk is affected by heating and coagulates at temperatures below that of boiling-point.

Solomin stated that albumin begins to be coagulated and hence precipitated at $60^{\circ} \mathrm{C}$., but that it does not coagulate completely until the temperature reaches $130^{\circ}-140^{\circ} \mathrm{C}$.

Jensen and Plattner carried out elaborate investigations upon the temperature of the coagulation of albumin and the extent to which this occurred. The general trend of their investigations is shown in the following table:

Cows' Milk, showing Percentage Distribution of Nitrogen on Heating

\begin{tabular}{|c|c|c|c|c|c|c|}
\hline \multirow{2}{*}{ - } & & \multirow{2}{*}{$\begin{array}{c}\text { Not } \\
\text { Heated }\end{array}$} & \multicolumn{4}{|c|}{ No. of Minutes at } \\
\hline & & & $75^{\circ} \mathrm{C}$ & $80^{\circ} \mathrm{C}$ & $90^{\circ} \mathrm{C}$. & $99^{\circ} \mathrm{C}$. \\
\hline $\begin{array}{l}\text { Nitrogen of casein }+ \text { albumin } \\
\text { Nitrogen of soluble albumin } \\
\text { Nitrogen of filtrate }\end{array}$ & $\dot{\bullet}$ & $\begin{array}{c}\text { Per cent. } \\
80.54 \\
\text { I } 3.24 \\
6.22\end{array}$ & $\begin{array}{l}\text { Per cent. } \\
82 \cdot 0 \\
\text { I I } \cdot 0 \\
6 \cdot 22\end{array}$ & \begin{tabular}{|c} 
Per cent. \\
$85 \cdot 0$ \\
$8 \cdot 0$ \\
$6 \cdot 22$
\end{tabular} & $\begin{array}{c}\text { Per cent. } \\
89.0 \\
3.0 \\
6.22\end{array}$ & $\begin{array}{c}\text { Per cent. } \\
93.0 \\
0.5 \\
6.09\end{array}$ \\
\hline
\end{tabular}

The method employed was to heat the milk to the temperature required and subsequently collect the casein by the addition of acetic acid. The precipitate thus obtained consisted of all the casein plus the coagulated albumin. This gave the figure for the casein plus albumin. The figure for the remaining albumin in solution was obtained by estimating the protein in the filtrate, and the figure for nitrogen in the filtrate shows the residual nitrogen after the albumin had been removed.

In the experiments where the milk was not heated the caseinogen was precipitated alone in the cold and the albumin subsequently precipitated by heating. The degree of precipitation of albumin as a result of heating is shown to some extent in the preceding table, but in addition the authors show that the soluble albumin was-

Completely precipitated by 5 minutes at $90^{\circ} \mathrm{C}$.,
or 30 minutes at $80^{\circ} \mathrm{C}$.,
or 60 minutes at $77.5^{\circ} \mathrm{C}$.

When the temperature was raised above $100^{\circ} \mathrm{C}$. the nitrogen in the filtrate was found to be increased. This effect was produced by heating either at $110^{\circ} \mathrm{C}$. for half an hour or to $120^{\circ} \mathrm{C}$. for from five to fifteen minutes.

It has already been mentioned that the coagulation of caseinogen 
does not occur at temperatures below boiling-point, but Jensen and Plattner considered that such coagulation does occur when the milk is heated for half an hour at $130^{\circ} \mathrm{C}$. or for five minutes at $140^{\circ} \mathrm{C}$., and they believe that the brown colour which appears in milk when heated to these temperatures is due to a commencing disintegration of caseinogen.

Grosser estimated the total nitrogen content of both cows' milk and human milk at different temperatures. He removed the protein from the milk used by him by passing it through a Bechhold filter under pressure of six atmospheres of nitrogen.1

It seems certain that when milk is boiled some of the albumin is precipitated, but where the same vessel is used for storage and feeding purposes, there is no difficulty in maintaining the same amount of nitrogen in the food. There is no indication that there is any difficulty in the digestion of the coagulated albumin; in fact it is probably more readily digested than in the raw state.

Caseinogen is not coagulated, and such evidence as is available tends to show that it is more readily digested after heating than before. There would not appear, therefore, to be any disadvantage in the heating of milk in relation to the protein portion of this food.

Lactose.-There is abundant evidence to show that no alteration occurs in lactose unless the temperature be raised considerably above $100^{\circ} \mathrm{C}$, , or unless the boiling be carried out for a very prolonged period. ${ }^{2}$

Fat.-Changes in the fat as a result of heating have been investigated by several observers.

Jensen and Plattner showed that the fat does not undergo any hydrolysis as a result of boiling.

Woll heated the milk he was investigating in a steriliser for several successive days for a period of thirty to thirty-five minutes, and found practically no change in the size of the fat globules. $\mathrm{He}$ obtained, however, some slight decrease in the viscosity in the first period of sterilisation and also with pasteurisation for twenty minutes at $67^{\circ} \mathrm{C}$. When the sterilisation was repeated more than once, a slight rise in the viscosity was found to occur.

Purvis, Brihaut and McHattie found that there was some decrease in the fat content when milk was boiled, which amounted to approximately 60 per cent. of the total fat, which loss was replaced by a gain of 13 per cent. when the milk was sterilised at a temperature of $110^{\circ}-130^{\circ} \mathrm{C}$. They found that less loss occurred when the milk was boiled in closed vessels, but the figures obtained in the different experiments gave somewhat unequal results.

Calcium.-The calcium content of milk in its raw condition has already been considered in Chap. IV, and it is not proposed

1 See table on p: 232.

a $C p$. Splittgerber, Jensen and Plattner, and others. 
to deal at any length with the changes which occur in the calcium content on heating.

It is a well-established fact that a reduction in the calcium content occurs when milk is heated, and this reduction has been held responsible for the production of rickets in children who were fed upon boiled or otherwise heated milk. The work which has been dealt with in the preceding pages ${ }^{1}$ shows that there is no ground for supposing that rickets is produced by small alterations in the calcium content of the milk given.

The question of alteration in the calcium content is closely connected with that of the citric acid content and also with the coagulation of caseinogen by rennet.

It will be simplest first of all to consider the changes in calcium content which occur as a result of heating, and subsequently to give additional work upon the citric acid content and upon the coagulation of milk.

The work upon calcium belongs to a comparatively early period in the investigation of milk. Söldner, in I888, carried out extensive investigations upon the effect of heating milk, and in particular upon the effect on the calcium and phosphorus content. $\mathrm{He}$ found that when milk was just boiled the loss of calcium by precipitation amounted to from I3-I5 mgms. per roo c.c. of milk. Thus the amount of calcium present in Ioo c.c. of raw milk was-

In one case . 80 mgms., falling to 66 on boiling, a loss of I4 mgms.

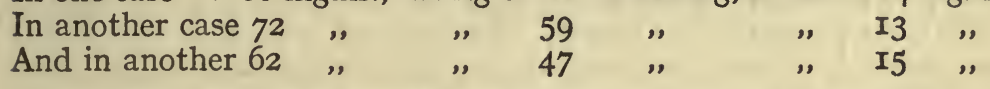

Söldner believed that the calcium was present combined with phosphorus as mono- and di-calcium phosphate, which on heating passed to the tri-phosphate and was precipitated. He showed further that the loss of phosphorus was on similar lines: thus in different Ioo c.c. samples:

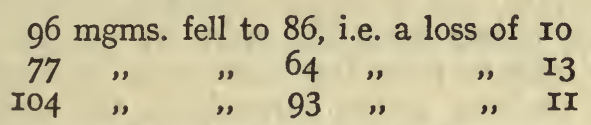

Boekhout and de Vries found that only from 3-5 mgms. of calcium were precipitated from Ioo c.c. of milk when the milk was just boiled. The variations in the results may perhaps be due to peculiarities in the different samples of milk, since these authors found that there are some Dutch milks which will not coagulate with rennet although they contain normal amounts of calcium. Such milks require the addition of a large amount of calcium chloride, much of which apparently becomes insoluble, in order to produce a coagulation with rennet.

Grosser has investigated more recently the effect of boiling 
upon the calcium and phosphorus content of both human and cows' milk. The method employed by him was somewhat different from the usual methods of previous observers. He used both cows' milk and human milk, but in the former case the cream was removed before the manipulations about to be described. In human milk this was found not to be necessary.

The milk was put through a Bechhold filter, working under 6 atmospheres' pressure of nitrogen. As a result of filtration the colloids remain behind and the crystalloids come through. Both varieties of milk were examined raw and after boiling for five, ten, and thirty minutes. He found, as shown by the following table, that greater loss occurred on boiling in human milk than in cows' milk, more especially in the case of calcium. The depression of the freezing-point, which was also investigated, showed no appreciable change, as shown in the following table:

\begin{tabular}{|c|c|c|c|c|c|c|}
\hline \multicolumn{4}{|c|}{ Cows' Milk } & \multicolumn{3}{|c|}{ Human Milk } \\
\hline \multirow{2}{*}{-} & \multirow{2}{*}{$\underset{\text { Milk }}{\text { Separated }}$} & \multicolumn{2}{|c|}{ Filtered } & \multirow{2}{*}{$\begin{array}{l}\text { Whole } \\
\text { Milk }\end{array}$} & \multicolumn{2}{|c|}{ Filtered } \\
\hline & & Raw & Boiled $15^{\prime}$ & & Raw & Boiled $15^{\prime}$ \\
\hline $\begin{array}{l}\Delta \\
\stackrel{N}{N} \\
\mathrm{P}_{2} \dot{\mathrm{O}}_{s}\end{array}$ & $\begin{array}{l}\text { Per cent. } \\
\text { IOO } \\
\text { IOO } \\
\text { IOO } \\
\text { IOO }\end{array}$ & $\begin{array}{c}\text { Per cent. } \\
76 \cdot 8 \\
8 \cdot 0 \\
36 \cdot 3 \\
23.4\end{array}$ & $\begin{array}{c}\text { Per cent. } \\
75 \cdot 4 \\
8.8 \\
35 \cdot 9 \\
\text { I } 8 \cdot 0\end{array}$ & $\begin{array}{l}\text { Per cent. } \\
\text { roo } \\
\text { I00 } \\
\text { 100 } \\
\text { I00 }\end{array}$ & $\begin{array}{c}\text { Per cent. } \\
83 \cdot 3 \\
38 \cdot 5 \\
74 \cdot 4 \\
44 \cdot 7\end{array}$ & $\begin{array}{c}\text { Per cent. } \\
85.0 \\
26 \cdot 1 \\
67 \cdot 4 \\
23.7\end{array}$ \\
\hline
\end{tabular}

The table shows that there is a greater loss in salt content, owing to precipitation by boiling, with human milk than with cows' milk.

Using butter milk he obtained no difference between the raw and the boiled filtrate, and he suggests that the acidity which has developed in the butter milk has split off practically all the phosphorus and calcium from the caseinogen. He also suggests that this action probaby occurs normally in the stomach.

It does not seem necessary to quote any further observations, as it is generally admitted that there is a loss of calcium on heating cows' milk, but in view of the higher percentage of this constituent in cows' milk than in human milk, it is probable that there is still an excess of calcium in cows' milk over human milk even after it has been boiled. Moreover, if the milk is boiled and the precipitate of calcium subsequently mixed up again in the milk, there need not be any loss in the total lime content, although the calcium may be present in a rather different form. When milk for infants is prepared in a special vessel, as should always be the case, there is no difficulty in obtaining the full calcium content in the milk even after it has been boiled. 
Phosphorus.-There is a slight loss of phosphorus when milk is heated, which appears to fall out of solution in the form of calcium phosphate.

Thus Solomin found that at $80^{\circ} \mathrm{C}$. a little phosphorus falls out, and at $130^{\circ}-\mathrm{I} 40^{\circ} \mathrm{C}$. about half the ash of the milk was precipitated, including all the calcium phosphate.

Purvis, Brihaut and McHattie obtained varying results, which were further affected by the method of heating. Less loss was found if the vessel used was closed. Among their experiments they found a loss of phosphorus amounting to II per cent. in milk kept at $100^{\circ} \mathrm{C}$. for half an hour and 6 per cent. of the total in sterilised milk. ${ }^{1}$

On the Question of Citric Acid in Milk, and its Reduction by Heating.-Many statements have been made in regard to the connection between the citric acid in milk, its diminution as a result of heating, and the consequent production of scurvy. A number of these statements have been entirely unsupported by facts, and the connection appears to have been hailed with some degree of satisfaction, as affording a possible solution of a difficult question. Recently, however, less has been heard of the reduction in the amount of citric acid as a result of heating milk, owing probably to the generally favourable results which are obtained by feeding infants upon boiled or dried cows' milk.

The discovery of citric acid in cows' milk appears to have been first made by Scheibe and Henkel, whose work was communicated to a medical society by Soxhlet. These investigators found that citric acid was present in cows' milk to the extent of about $0 \cdot I$ per cent. and that nine-tenths of this total amount appeared to be attached to calcium. They were unable to obtain any evidence of the presence of citric acid in several samples of human milk which were examined by them. They believed that the difference between the two milks can be accounted for by the fact that the cow is a herbivorous animal.

Netter (I) states that human milk contains $.5 \mathrm{mgm}$. of citrates per litre, while cows' milk contains from two to three times as much.

Obermaier studied the effect of boiling upon the citric acid content of cows' milk. He clarified the milk with a variety of earth until the filtrate was no longer opalescent. The filtrate was then acidified with sulphuric acid to remove the calcium from the citric acid. Excess of the sulphuric acid was then removed with baryta and the citric acid converted to the barium citrate. Evaporation was carried out and the citric acid freed with a fresh addition of sulphuric acid. After further methods of purification the citric acid was estimated. Obermaier found that there was a considerable difference in the amount of citric acid

$1 C p$. also the work just quoted by Söldner and Grosser. 
present in the different samples of milk, and that it varied from I. 2 to 2 gms. per litre in raw milk. The loss by heating was investigated when milk was boiled on the open fire for five, ten, and fifteen minutes respectively. The loss in citrates obtained by heating for five minutes varied from I2.29-3I.86 per cent. on the total, and from 5.0I-29.78 per cent. when heated for fifteen minutes. When heated for longer periods of half an hour an apparent gain occurs which he believed to be due to loss of water and increased concentration. The increase, however, shows such wide deviations, that it is somewhat difficult to believe that sufficient concentration would take place to account for a gain, instead of a loss of approximately 30 per cent. When milk was heated on the water-bath, the following approximate results were obtained :

Heated for $15 \mathrm{~min}$. at $75^{\circ} \mathrm{C}$. gave a loss of 4.13 per cent.

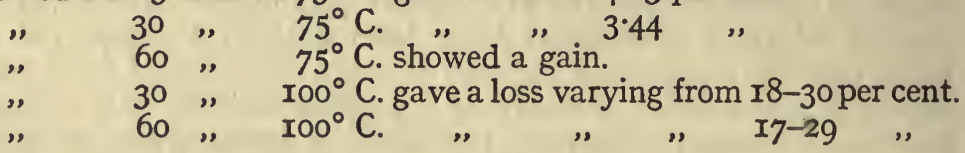

At higher temperatures, e.g. at $120^{\circ} \mathrm{C}$., there was a loss of 22 per cent.

Splittgerber investigated the effect of heat upon various substances in milk, notably on the citric acid. He took known solutions of mono-, bi-, and tri-calcium citrate, heated these to dryness, and then heated further for prolonged periods. He found that the tri-citrate heated by this method showed a slight loss of approximately I mgm. on I8I after five hours' drying. The monoand bi-citrates showed a slight increase in weight, which he believed might be accounted for by the holding of water of crystallisation. These results of Splittgerber's are of considerable interest when taken in conjunction with the work of several authors upon the effect of heating on the calcium content of milk dealt with on p. 23r. It was there mentioned that the diminution in calcium as a result of heating milk was believed to be due to a change from mono- or bi-calcium phosphate to the fully saturated form, which last becomes insoluble when heated. Splittgerber's work does not suggest the occurrence of this change in the form of the citrate, although this has been suggested by other writers. It is possible, however, that the effect of heating in a complex solution such as milk may be different from that which occurs when heated in aqueous solution.

Bosworth and Prucha showed that citric acid disappears from milk which has been allowed to go sour.

The work above described does not suggest that the citric acid content of cows' milk as a food for infants is of any great importance. Such evidence as there is seems to show that even after boiling the content is probably as high as in the infant's natural foodnamely, human milk. Further, the same remarks apply as for the 
calcium - that it is not lost, and if heated in a special vessel can be obtained by the infant if this is desired.

The Effect of Heating on the Coagulation by Rennet.-The effect of heating on the coagulation of caseinogen by rennet has been studied by numerous investigators, and it is not proposed to deal with many of the papers.

There is no doubt that the time of coagulation with rennet is prolonged by heating. This was mentioned by Söldner (I888) who believed that the delay in the coagulation was due to deficiency of calcium, the calcium having been thrown out of solution as a result of heating.

Ringer (I890) showed that coagulation of caseinogen can be brought about if calcium chloride is added to milk, and that the addition of lime salts hastens coagulation by rennet, while their reduction delays clotting.

This was confirmed by Conradi, who showed also that if the milk is heated to a temperature of $70^{\circ} \mathrm{C}$. before the addition of calcium chloride, it will coagulate at a temperature of from 8-I2 degrees lower than if the calcium is added before heating. The coagulation with rennet, he believed, was not affected by heating the milk for half an hour at $70^{\circ} \mathrm{C}$., and was very little delayed by a temperature of $75^{\circ} \mathrm{C}$. After this temperature the coagulation time gradually increases, but coagulation will still occur until the temperature has been raised to well above $100^{\circ} \mathrm{C}$. (about $I I 0^{\circ} \mathrm{C}$.). Milk which has been just boiled and then cooled coagulates just as well as raw milk. ${ }^{1}$

Kreidl and Lenk investigated the question of rennet coagulation in heated milk and dealt fully with the literature. These authors state that when the milk and all the apparatus concerned in the process are sterile, coagulation does not occur, but on the least contamination by any unsterilised material, even a finger on the top of the test-tube, coagulation occurs.

Rupp, working on the changes produced in milk as a result of heating, found that using low temperatures, i.e. from $55^{\circ} \mathrm{C}$. up to $65^{\circ} \mathrm{C}$., the coagulation with rennet takes place more rapidly than was the case with raw milk. Retardation commenced at $70^{\circ} \mathrm{C}$. and at $75^{\circ} \mathrm{C}$. The time of coagulation was approximately doubled, and the coagulation was of a flocculent character. Similar observations were made by Stassano and Talarico some years previously.

Sidler showed that human milk does not coagulate with rennet, and generally speaking this is the opinion of later investigators, although it appears that human milk does alter somewhat on the addition of rennet but does not form into a solid clot.

There is some evidence to show that the delay in clotting is connected both with the falling out of calcium and with the acidity

1 See Conradi's paper for the early literature: 
of the milk. It is generally believed by those who have investigated the question that the acidity of milk falls somewhat as a result of heating. This is believed to be due to the passing off of carbonic acid as a result of heating.

Jensen and Plattner found a decrease in the total acidity with the employment of moderate heat, and a rise of acidity when the temperature rose to $120^{\circ} \mathrm{C}$., or even when a temperature of $100^{\circ} \mathrm{C}$. is employed for a prolonged period. They believe that the fall of acidity, which is slow, is due to the giving off of carbon dioxide, and they point out that the calcium falls out from solution when the acidity has been reduced to the lowest point reached. They state, however, that the falling out of the calcium does not always occur, and they believe that this depends upon the amount of semicombined carbon dioxide present in the milk: the rise of acidity consequent on heating to a high temperature being due to a slight disintegration both of the lactose and of the caseinogen.

Splittgerber found that there was a fall of total acidity when the milk was heated for about two hours in a Soxhlet apparatus. He pointed out that lactic acid, when present, passes off very readily on the application of a low temperature, and appears to suggest that the reduction in acidity may be connected with small quantities of lactic acid in the milk. In the course of heating it is very likely that changes take place in the method of combination of the calcium with the phosphorus in the milk, and possibly with the carbon dioxide present. The possibility of similar changes has been mentioned in connection with the effect of heat upon calcium citrate. Any such changes, if they occur, would tend to reduce the acidity of the milk and at the same time cause the calcium salt to fall out of solution.

It has been shown above, and it is a well-known fact, that reduction in the calcium content of the milk delays the time of clotting. The degree of acidity appears also to exercise influence upon the time of clotting. Some difficulty has been experienced in the making of cheese with boiled or pasteurised milk, owing to the delay which occurs in the subsequent process of clotting with rennet. Sammis and Bruhny have shown in recent investigations upon this subject, that the difficulty can be readily overcome by the addition of a small quantity of hydrochloric acid to the milk after it has been heated. It seems likely, therefore, that milk, even when the coagulation has been indefinitely delayed as a result of heating to a high temperature, will undergo coagulation when it reaches the stomach. Moreover, there appears to be subtle differences between the rennets occurring in the stomachs of different animals. Fuld and Noeggerath found, for instance, that the rennet obtained from calves and goats showed a greater activity on the caseinogen of the same species. It is possible, therefore, that although human milk does not clot readily with cows' rennet, clotting may occur in the stomach of the human infant. 
In any case, it is difficult to attribute a high degree of importance to the delay in clotting of cows' milk produced as a result of heating. Many of the investigators have brought forward this fact as an argument to show the denaturisation of the protein as a result of heating, and have straightway deduced from this that some harmful effect was probably produced. If, however, it be the case that human milk does not form into a solid coagulum in the infant's stomach, it seems reasonable to suppose that the soft, flocculent coagulum formed in cows' milk which has been heated, will be more favourable for the digestion of the human infant than the solid clot formed with raw milk.

The Biological Properties of Milk. Ferments.-The work of numerous authors, already detailed in Chap. $\mathrm{V}$, shows the very small importance, if any, of the ferments which are normally present in milk. It is unnecessary, therefore, to deal with any possible loss of nutritive or biological properties which might occur in a milk as a result of the destruction of the enzyme content by heat. Where the initial value is negligible, a reduction in value cannot be regarded as occurring.

On the Effect of Heat upon the Properties concerned with the Production of Immunity.-The work which has been considered in Chap. VI has afforded evidence as to the direct absorption of native protein (with such properties as may be attached to the molecule), in the early days of life. Some absorption of ' foreign' protein seems also to occur, but only in small amounts; moreover, there is some reason to suppose that such absorption may not be beneficial to the suckling animal. There can be no doubt that the natural food is of the greatest importance in the early days of life, and such food would be subjected to heat, only in special circumstances, which have been considered in Chap. IX.

The clinical results obtained by the use of heated cows' milk ${ }^{1}$ for infants render a consideration of the effect of heat upon the so-called 'protective substances' of academic interest only; especially in view of the fact that such properties are destroyed by digestion. In spite of these practical considerations, there has been some amount of discussion in regard to the so-called 'denaturisation' of the milk protein by heat. It has been asserted that if the precise temperature at which such a process occurred could be ascertained, it might be permissible to heat the cows' milk used for artificially-fed children to just below that temperature. Such arguments have little weight, and have presumably been advanced without adequate consideration of the processes of digestion. It is a matter of common physiological knowledge that proteins are broken down to their simpler groupings before absorption. These groupings have no 'biological' properties, and have been shown to be capable, when given by the mouth, of supplying the needs 
of the body in the same manner as the protein molecules from which they were derived.

Such experimental work as has been carried out has, for the most part, been concerned with the forensic or legal side of the question. The object has been to determine a method either for differentiation of raw and boiled milk, or for the detection of proteins of different species. For this purpose the methods which have been considered in Chap. III have been employed, based upon the production of anti-sera by the injection of raw or heated milk.

There is some lack of uniformity in the results obtained, much of which can probably be explained by the different methods used. In the early investigations no differentiation of the antigens was made, the whole milk being injected. It was shown in Chap. III that such a method will produce a complex result since several different antigens are injected, each producing its own effect.

Further, in the preceding pages it has been shown that heat reduces the amount of soluble albumin. Hence when milk is heated before injection the amount of soluble antigen which will be injected will be reduced, and the degree of reduction will vary with the duration of the period of application of heat before injection.

Caseinogen is not so readily affected by heat, although this occurs when high temperatures are used.

A number of the investigations upon the effect of heat on the antigens of milk have been concerned with milk which had been boiled for prolonged periods-frequently for half an hour-or raised to temperatures above the boiling-point of water. In these circumstances there will be a decrease, or even perhaps an absence, of soluble albumin in the fluid injected.

No experiments appear to have been performed with heated albumin alone, and it is impossible to ascertain from the original papers whether the precipitated albumin was used in the injection or not. In view of the differences in the methods of heating, it is likely that in some cases the albumin remained in the vessel, and in others-where the milk was only just boiled - that the albumin was present in the injected fluid.

Some observers who have used the precipitin reaction, have concluded that the divergent results were attributable to the variation in the calcium content occasioned by heating the milk.

The results obtained by different observers are shown in the table on p. 239.

Bauer (I9IO) found that caseinogen as an antigen was not affected by being boiled, and regarded the effect of heat upon the antigens in milk as attributable to the effect on the albumin. This view is confirmed by the work of Rudicke and Sachs, who found that a lacto-serum produced by injecting milk which had been boiled for half an hour, did not react with the homologous serum although it did react with the homologous milk. It will be 


\begin{tabular}{|c|c|c|c|c|}
\hline 密 & 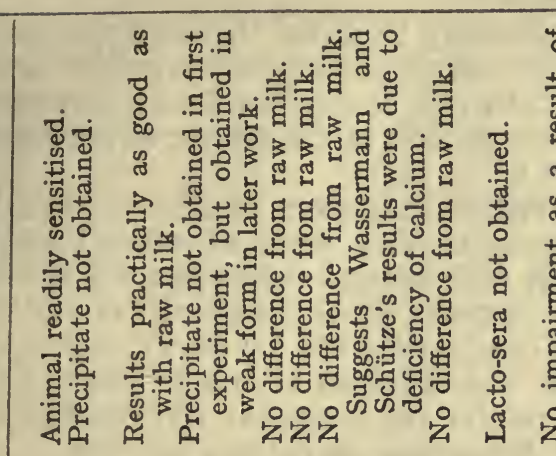 & 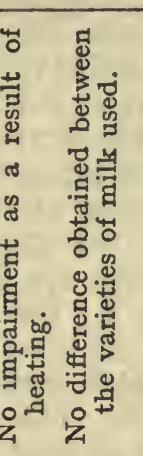 & 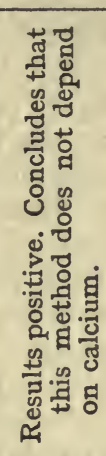 & 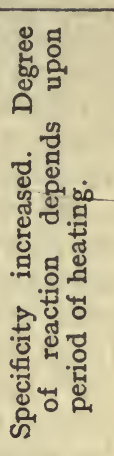 \\
\hline 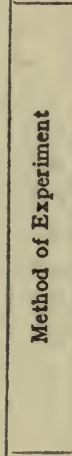 & 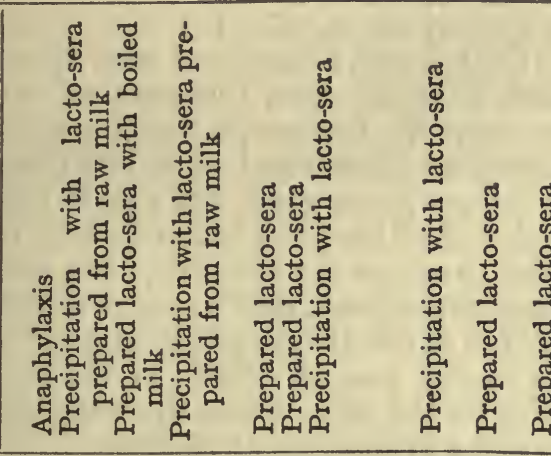 & 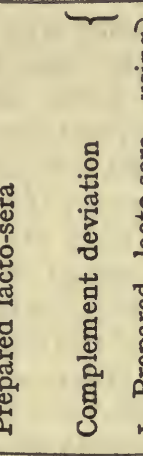 & 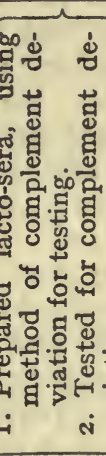 & 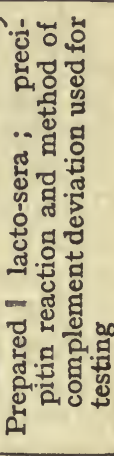 \\
\hline 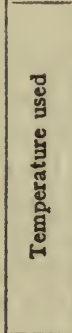 & 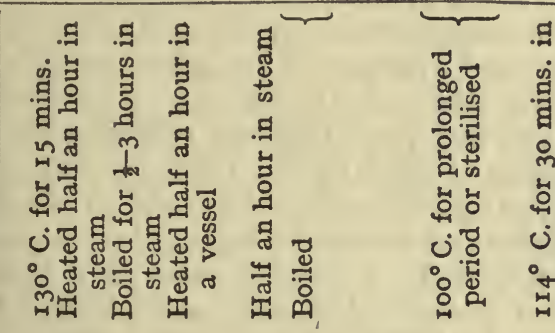 & 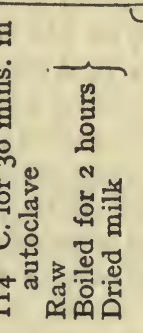 & 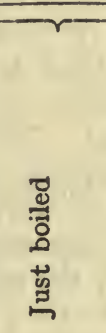 & 离 \\
\hline 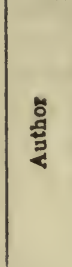 & 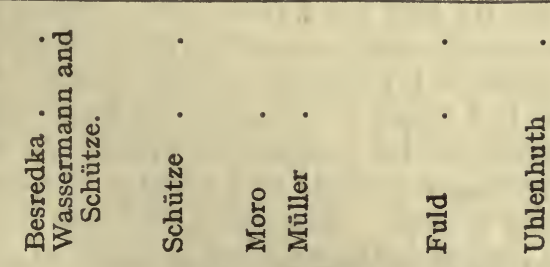 & 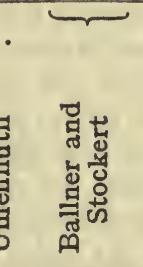 & 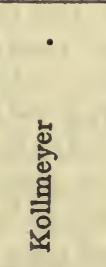 & \\
\hline
\end{tabular}


remembered that caseinogen has been shown to be a substance apart from the blood-proteins. ${ }^{1}$

As a general conclusion it may be stated that antigens are not affected by just boiling milk, but that some effect is produced when the heating is prolonged. In this connection the observations of Delépine on the temperature reached in the process of drying milk are of considerable interest. ${ }^{2}$

On the Presence of further Substances in Milk concerned in the Nutrition of the Organism.-The work of several authors indicates that there are in milk several substances which are of great importance for the adequate development of the organism. These investigations have been carried out for the most part upon adult animals which have been deprived of one or other of their normal food-stuffs. The results are somewhat fragmentary from the present point of view, but cannot be entirely omitted.

The earliest work was that of Stepp, who fed mice upon food which had been previously treated with alcohol and ether to remove the lipoids. He found that mice fed upon this food as the sole diet did not survive very long. If, however, a small quantity of milk was added to the dietary no detrimental effect was observed. The minimum amount of milk was given which was able to keep the animals alive. Stepp found that rather more boiled milk had to be given than raw milk in order to ensure the survival of the animals.

The work of Hopkins upon rats showed that where an insufficient dietary was given, the addition of minute quantities of milk caused a most striking difference in the rate of growth of the animals. No work was carried out with heated milk, so that these experiments are somewhat outside the scope of the present chapter.

Funk $(x, 2,4)$ in his investigations upon the deficiency diseases believed that he had obtained evidence of the presence of a nonphosphorus-containing compound which was necessary for the life of the animal. This substance was termed by him vitamine, and was isolated by him from samples of dried milk. Funk (3) alleged that this substance was destroyed by boiling, but the evidence in support of this statement is indefinite and cannot be regarded as conclusive. Moreover, the substance prepared by Funk is now very generally believed to be a mixture of several substances, so that much stress cannot at the present time be laid upon this work. There seems little doubt that milk does contain substances of (at present) unknown composition which are essential for the life of the animal where milk is the sole dietary, but there is no evidence to show that these substances are destroyed by boiling, especially when the heat is not applied for prolonged periods and when a temperature not exceeding boiling-point is used. The work of Stepp suggests that there may be some loss of 'vitamine' as a result of boiling milk. This loss, however, if it occurs, is evidently not sufficient to affect the nutritive value of milk for infants, as has been abundantly shown in the preceding chapters.

$$
{ }^{1} C p \text {. Chap. III. } \quad{ }^{2} C p \text {. Appendix F. }
$$


If a reduction in ' vitamine' does occur, it would only be detected clinically when the amount fell below the minimal physiological needs of the infant, and it is unlikely, either that the average infant receives the minimal amount of milk or that the "vitamine" content of milk is minimal. The content of the other constituents of milk varies within fairly wide limits, and there is no reason to suppose the 'vitamine' would occupy any different position in this respect. Hence, experiments such as those just quoted, although of great interest, have only an indirect bearing upon the hygienic and nutritional aspects of infant feeding, even where milk is the sole diet.

\section{REFERENCES IN ChapteR XIV}

\section{Heated Milk}

Ballner and Stockert, 'Einige Bemerkungen über Trockenmilch,' Zeit. f. Unters. Nahr- u. Genussm. I9I I, xxii. 648; Ref. Milchw. Zentralb. I9II, p. 437.

BAUER, 'Ueber den Artcharakter der Milcheiweisskörper,' Berl. klin. Wochensch. I9I0, i. 830 .

BAyliss AND Plimmer, "The Separation of Phosphorus from Caseinogen by the Action of Enzymes and Alkali,' Journ. of Physiol. I906, xxxiii. 439. BesReDKA, 'De l'anaphylaxie lactique (sixième mémoire),'Ann. de. l'Inst. Pasteur, I909, xxiii. I66.

BOEKHOUT AND DE VRIES, 'Beitrag zur Kenntnis der Labgerinnung,' Landw. Versuchs. IgOI, p. $22 \mathrm{I}$.

Bosworth AND PRUChA, 'Die Gärung der Citronensäure in Milch,' Geneva Bulletin, New York, No. I4 ; Ref. Zeit.f. Nahr-u. Genussm. I912, xxiii. I56.

Brennemann, 'Boiled versus raw Milk,' Journ. of Amer. Med. Assoc. I9I3, lx. 575 .

Brifiaut. See Purvis, Brihaut, and McHattie.

BRUHNY. See Sammis and Bruhny.

CONRADI, 'Ueber den Einfluss erhöhter Temperaturen auf das Casein der Milch,' Münch. med. Wochensch. I90I, xlviii. I75.

Furd, 'Ueber das Bordet'sche Lactoserum,' Hofmeister's Beiträge, 1902, ii. 425.

Fuld and NoEgGerath, 'Ueber die Bedeutung der Artspezifität für die Funktion des Verdauungsferments, insonderheit des Magenlabs,' Verh; d. Gesell. f. Kinderh. I9r I, p. I32.

Funk. (I) 'The Etiology of the Deficiency Diseases,' Journ. of State Med. June 1912. (2) 'The Preparation from Yeast and Certain Food-stuffs of the Substance the Deficiency of which causes Polyneuritis in Birds,' Journ. of Physiol. I9I2-13, xlv. 75. (3) "An Attempt to Estimate the Vitamine Fraction in Milk,' Biochem. Journ. I9I3, vii. 2 II: (4) 'Rice and Vitamine,' Journ. of Physiol. I9I4, xlviii. 228 and 232.

Gerber, 'Digestion du lait par les caséases,' Compt. Rend. de la Soc. de Biol. I9I 3 , lxxiv. IIII.

Grosser, 'Ueber den Einfluss des Kochens auf das physikalisch-chemische Verhalten von Frauenmilch, Kuhmilch und Buttermilch,' Biochem. Zeit. I913, xlviii. 427.

HENKEL. See Scheibe and Henkel. 
Hopkins, 'Factors in Diet,' Journ. of Physiol. I912, xliv. 425.

Hougard, 'Versuche über die Verdaulichkeit der Milch,' Jahresb. d. Tierch. I905, xxxv. 285.

DE JÄGER, 'Ueber die beim Kochen der Milch eintretenden Veränderungen,' Nederl. Tijdsch. v. Geneesk. I896; Zentralb. f. med. Wissensch. I896, p. 145 .

Jensen and Plattner, 'De l'action du chauffage sur le lait de vache,' Rev. gen. du Lait, 1904-5, iv. 36I, 388, 4I9.

KLEMPERER, quoted in the Discussion 'Ueber die Barlow'sche Krankheit,' Berl. klin. Wochensch. 1903, xl. 307.

KOLLMEYER, "Ueber die biologische Differenzierung von Milch und Milcheiweisskörper,' Zeit. f. Biol. I9ro, liv. p. 64.

KREIDL AND LENK, 'Das Verhalten steriler und gekochter Milch zu Lab und Säure,' Biochem. Zeit. I9I I, xxxvi. 357.

LENK. See Kreidl and Lenk.

McHatrie. See Purvis, Brihaut, and McHattie.

Moro, 'Biologische Beziehungen zwischen Milch und Serum,' Wiener klin. Wochensch. I901, p. 1073.

MÜLlER, 'Vergleichende Studien über die Gerinnung des Kaseins durch Lab und Laktoserum,' Arch. f. Hyg. I902, xliv. I26.

NetTer, ' 'Scorbut infantile et lait sterilisé,' Rev. mens. d. Mal.de l'Enfance, I903, xxviii. I73. (2) 'Chimisme gastrique chez les nourrissons nourris au lait sterilisé,' Progrès méd. 1899.

Noeggerath. See Fuld and Noeggerath.

OBERMAIER, "Ueber die Abnahme des Zitronensäuregehaltes der Milch beim Kochen,' Arch. f. Hyg. 1904, 1. 52 ; Zeit. f. Unters. Nahr-u. Genussm. I905, ix. 33.

Plattner. See Jensen and Plattner.

Plimmer. See Bayliss and Plimmer.

Prucha. See Bosworth and Prucha.

Purvis, Brihaut, ANd McHattie, 'Some Chemical Changes produced in Boiled and Sterilised Milk,' Journ. of Roy. San. Inst. I912, xxxiii. I54.

RINGER, 'Regarding the Action of Lime Salts on Caseine and on Milk,' Journ of Physiol. 18yo, xi. 464 .

Rotond, "Ueber gastrische und pankreatische Verdauung von Frauenund Kuhmilch Caseinogen,' Arch. f. Kinderh. 1902, xxxiii. 461.

RUDICKE AND SACHS, 'Ueber das biologische Verhalten roher und gekochter Milch,' Zeit. f. Immunitätsf. I913, xx. 316.

RUPP,' Chemical Changes produced in Cows' Milk by Pasteurisation,' Bureau of Animal Ind., Bull. 166, 1913.

Sachs. See Rudicke and Sachs.

SAMMIS AND BRUHNy, "The Manufacture of Cheddar Cheese from Pasteurised Milk,' Bureau of Animal Ind., Bull. 165, I913.

Scheibe AND HENKEL, 'Citronensäuregehalt der Kuhmilch,' Münch. med: Wochensch. $1888, \mathrm{xxxv} .328$.

ScHÜTZE, ' Ueber ein biologisches Verfahren zur Differenzierung der Eiweissstoffe verschiedener Milcharten,' Zeit. f. Hyg. I90I, xxxvi. 5, and ibid. I9CI, Xxxviii. 487 .

ScHÜTZE. See Wassermann and Schütze.

SIDLER, 'Untersuchungen über die gebräuchlichsten in der Schweiz Fabrikmässig-hergestellter Milchpräparate, etc.' Arch. f. Hyg. I903, xlvii. 327.

SöLDNER, 'Die Salze der Milch und ihre Beziehungen zu dem Verhalten des Kaseins,' Landw. Versuchs. 1888, p. 351.

Solomin, 'Ueber die beim Erhitzen der Milch ausfallenden Eiweissmengen,' Arch. f. Hyg. I897, xxviii. 43-48.

SPlitTGerber, 'Studien über die Trochensubstanz der Milch,' Zeit. $f$. Unters. Nahrm u. Genussm. I912, xxiv. 493.

Stassano and Talarico, 'De l'influence de la cuissance sur la caséification du lait par le lab-ferment' Compt. Rend. de la Soc. de Biol. Igro, lxix. 254. 
STEPP, ' Experimentelle Untersuchungen über die Bedeutung der Lipoide fürr die Ernährung,' Zeit.f. Biol. I9I I, lvii. I35.

STOCKERT. See Ballner and Stockert.

TALARICo, See Stassano and Talarico.

Uhlenhuth, Praktische Anleitung zur Ausführung des biologischen Eiweissdifferenzierungsverfahrens, Jena, I909, P. 24.

DE VRIES. See Boekhout and de Vries.

Wassermann and SchUtze, Deutsch. med. Wochensch. 1900, Vereinsbeilage, p. 178.

Wor., "The Effect of Pasteurisation and Sterilisation on the Viscosity and Fat Globules of Milk,' Agric. Exp. Stat. Wisconsin, 1895, p. 164. 


\section{SUMMARY OF CHAPTER XV}

ON THE PRESENCE IN MILK OF CERTAIN ORGANISMS LIABLE TO CAUSE DISEASE, WITH NOTES ON MILK-BORNE EPIDEMICS

IT is not intended here to accord any general consideration to microbial diseases of the udder, but certain affections of this organ, which can be classified together under the term mastitis or inflammatory conditions of the udder, are sufficiently common to call for a short consideration.

Mastitis may be either chronic or acute. It may be caused by the presence of streptococci or of tubercle bacilli in the udder. It has been shown in Chap. VII that the presence of streptococci in milk cannot necessarily be regarded as pathological even when present in milk obtained direct from the udder. Streptococci can be found nearly everywhere, and have been shown to be present on the outside of the udder and on the skin of the cow and to gain access to the milk directly from this position. It is also possible that they may find their way some distance up the teat and thus be passed out with the first portions of milk.

There is no doubt that a large number of cases of mastitis are due to infection by streptococci. How far such strains of streptococci may be pathogenic for the human species has not as yet been accurately determined, and it is likely that such a determination is hardly possible. Much time and labour have been expended by numerous observers in the endeavour to classify streptoccoci into pathogenic and non-pathogenic strains. These efforts cannot, however, be regarded as having been crowned with success. There is evidence to show that a strain of streptococcus, which may be apparently harmless, may become virulent as a result of being grown upon different media, more especially by passage through the animal organism. ${ }^{1}$

Examination of the general milk supply in a number of towns has shown the wide prevalence of streptococci in samples of market milk. In several cases where pathogenicity of these organisms was tested on the lower animals a number of such strains were found 
to be non-pathogenic, while others were found to be virulent. No cultural characteristics appear to afford a definite distinction between the virulent and the non-virulent strains.

It is probable that a number of the strains of these bacteria give rise to no symptoms when taken into the animal organism by the mouth. There is, however, abundant evidence to show that some strains have a high degree of virulence for human beings, and that many epidemics, generally of sore throats, have been produced by drinking milk containing such streptococci. The history of the epidemics which occurred in America, and were fully investigated, in the years IgII-I2, leaves no doubt on this matter, and the epidemics recorded in our own country afford evidence in support of these facts.

Tubercle Bacilli.-There is no need at the present day to bring forward evidence in regard to the presence of bovine tubercle bacilli in milk. Its occurrence in a large number of samples of the general milk supply has been demonstrated beyond doubt both in this and in other countries. Further, there can be no reasonable doubt that such bacilli-of bovine origin-are pathogenic to young children. The findings both of the Royal Commission on Tuberculosis and of other observers show that children suffer from disease caused by the tubercle bacillus obtained from cattle, and that the percentage of tubercular disease in children which is caused by the bovine tubercle bacillus is high. On the other hand, the percentage of this disease caused by the bovine tubercle bacillus in adults is very low.

Investigations have shown that the bacilli, when taken in with food, can pass through the walls of the alimentary canal and reach the neighbouring glands, where they develop and spread to further parts of the glandular system and to other organs, ultimately causing generalised tuberculosis. It has been shown that the main source of infection by bovine tubercle bacilli must be by means of milk which contains these organisms. The argument that if these organisms are harmless, or comparatively so, to adults, they are not harmful to children, cannot be regarded as having any weight. It is well known that children are susceptible to pathogenic influences which leave an adult unaffected.

Other Organisms.-Other organisms occur in milk when the cow or other animal supplying the milk is suffering from disease caused by such organisms. Thus, cows which have been infected by the Bacillus abortus continue to excrete these organisms for prolonged periods after such infection has occurred. The organisms are also passed out in the milk, in many cases before evidence of the infection by this organism has been demonstrated clinically.

A consideration of the presence of the organism of Malta fever in the milk of goats is beyond the scope of this work, but is interesting in view of the analogy which it presents to the conditions here under review. 


\section{CHAPTER XV}

ON THE PRESENCE IN MILK OF CERTAIN ORGANISMS LIABLE TO CAUSE DISEASE, WITH NOTES ON MILK-BORNE EPIDEMICS

A. On the Presence of Streptococci in Milk.-The occurrence of streptococci in milk has been already mentioned in Chap. VII, when their possible connection with a high cell count was discussed. It is necessary here to consider the prevalence of these organisms, and to determine, if possible, whether, when present, they must be regarded as harmful or if their presence may be neglected.

Prevalence of Streptococci.-Numerous investigators have examined large numbers of samples of milk in different towns for the presence of streptococci. Speaking generally, it may be said that wherever such systematic examination has been carried out, a high percentage of the samples examined have been shown to contain streptococci.

Bergey found that 80 per cent. of the samples of market milk investigated by him contained streptococci. In milk obtained from four of the best dairies streptococci were absent in all the samples examined from two of the farms, and present in 6.25 per cent. and 28.57 per cent. respectively of the samples from the remaining farms.

Brüning examined the market milk in Leipzig, and showed that 93 per cent. of all the samples taken showed streptococci. These streptococci did not present the same characteristics, but could be roughly classed under two headings:

r. Those which were gram-positive, thick in appearance, and formed in short chains ; order.

2. Those which were gram-negative and arranged in diplococcic

Kaiser examined the milk in Gratz, and found that in the period from November 22, I904, to June 27, I905, 76.6 per cent. of all the samples examined contained streptococci.

Campbell, working in Philadelphia in I909 in connection with the enumeration of leucocytes, found streptococci present in all the samples of market milk examined (twenty).

Ernst, working in Munich, stated in I909 that in I840 samples examined by him, all contained streptococci.

Savage demonstrated the presence of streptococci in 47 per cent. of the samples of milk examined by him, when the centrifugalised deposit was brushed over agar plates. In eleven samples 
of milk obtained fresh from the farm and examined within three hours, streptococci were found in all.

It is not necessary to adduce further evidence to show that streptococci are widely distributed in the milk supply of most countries.

The sources of the organism have been studied by numerous observers, and it has been shown that streptococci can be obtained from the udder, mouth, fæces, and milk of the cow, ${ }^{1}$ and that they are found on the human body ${ }^{2}$ and in numerous other localities. Roger found that most of the varieties of streptococci present in the milk were derived from the udder of the cow.

It has long been known that there are many different varieties of streptococci, and numerous efforts have been made to classify them as pathogenic or non-pathogenic, according to the appearance and cultural properties of the different strains.

Streptococci are responsible for a number of diseases or affections in man, and for a large proportion of the cases of mastitis, or inflammation of the udder, in cows. It is clearly important to determine whether the streptococci found so generally in milk, are liable to produce disease in those who consume the milk.

With this object prolonged investigations have been carried out upon the pathogenicity or otherwise of the strain of streptococci found in milk, and also those obtained from the sufferers in milkborne epidemics of sore throat.

The classification of streptococci found in milk in relation to their cultural properties cannot be regarded as having been very successful.

Savage endeavoured to classify them according to the lines suggested by Gordon, but without success.

Müller, who investigated the streptococci found by Kaiser in his investigations in Gratz, believed that there was a close relationship between the streptococci found in milk and those which are pathogenic to animals. Of the strains examined, three appeared to be identical with the pathogenic varieties, and produced hæmolysis of red corpuscles when cultured.

Ruediger considers it possible to differentiate the Streptococcus commonly found in milk from the Streptococcus pyogenes, by means of blood agar plates. He believes that the Streptococcus lacticus has no sanitary significance. The Streptococcus pyogenes does not occur commonly in milk, but when found it denotes an inflammatory condition of the cow's udder. Thirty-five strains were examined.

Heinemann (I), however, considers that the Bacillus acidi lactici is in reality the Streptococcus lacticus, and that it agrees in cultural and coagulative properties with the prthogenic streptococci obtained from sewage and fæces. The Streptococcus lacticus was found by 
him in all the samples examined and in all stages of handling of the milk.

Heinemann (2) also found that Streptococcus lacticus becomes more virulent by passage through rabbits, and after five passages may become equal in virulence to Streptococcus pyogenes. The same culture, after it had been increased in virulence by passage, proved fatal to an animal, which showed no symptoms on being inoculated with a dose of the same strain before passage.

More definite results have been obtained by studying the appearance of the organisms.

The chain formation has been shown to have variable characteristics. Some samples have long chains, others short chains, and in some cases an ill-defined capsule is present. The long and short chain varieties are shown in the accompanying plate. (See Plate II.)

Ernst believes that with experience it is possible to determine the presence of the pathogenic varieties of streptococci with a high degree of certainty. He says: "The streptococcus acquires a diplococcic formation, the cocci appear to press one another, become disc-shaped, and appear linear in profile. They lie on a different axis from that of the chain. A more or less pronounced capsule is formed around the streptococci of "animal " origin, which may expand to a broad mucin capsule.' The presence of this variety is regarded by Ernst as denoting mastitis. ( $C p$. Plate III.)

Trommsdorff agrees with Ernst, and thinks that in the early stages of mastitis the short diplococcic forms are found in the sediment, passing to the long chain formation in later stages.

Gminder also showed that the streptococci appearing in milk when mastitis is present appear rather to have the form of flattened diplococci than of the usual chain. These characteristics may, however, also be shown by saprophytic strains outside the organism. Saprophytic forms, when injected into the udder, tend to become pathogenic. No precise morphological characteristics in the two varieties were determined, but Gminder considers that where a milk sediment is found to contain streptococci showing the peculiar form above mentioned, further investigations should be carried out. He considered that there was no connection between the virulence of the strain and the production of hæmolysis.

Similar appearances in the streptococcic formations were found by Rosenow and Davis, in connection with a milk-borne epidemic in Chicago, and by Hamburger in Baltimore.

Rosenow and Davis found that the streptococci which were isolated from this epidemic showed a weak capsular substance surrounding the streptococci. The capsule was not indented and was lost on culturing. The strains were pathogenic to mice and rabbits, killing them within twelve to twenty-four hours. Virulence was increased by passage, as was also the definition of the capsular substances. 



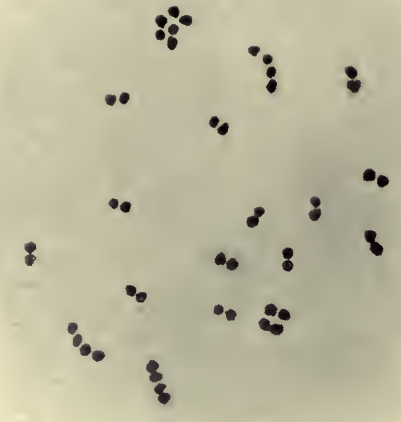

I.-Short Chains of Streptococci.

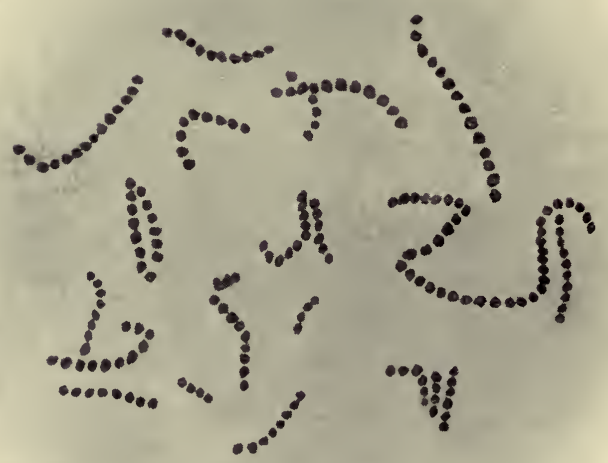

2.-Long Chains of Streptococci. 
PLATE III.

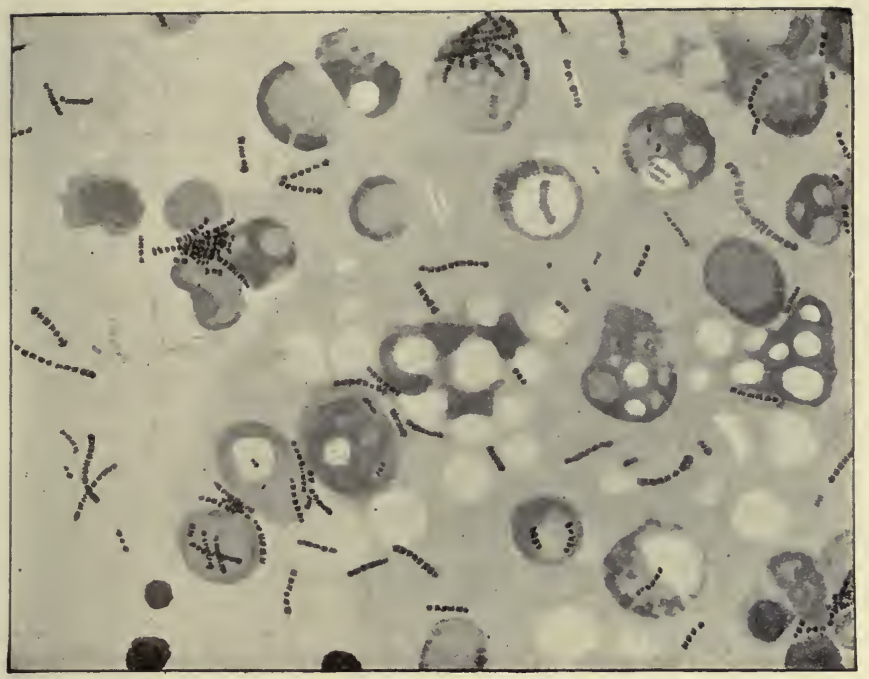

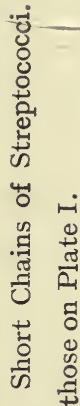

㐘

गั

๑

苍 交

คั ธั

ฮี

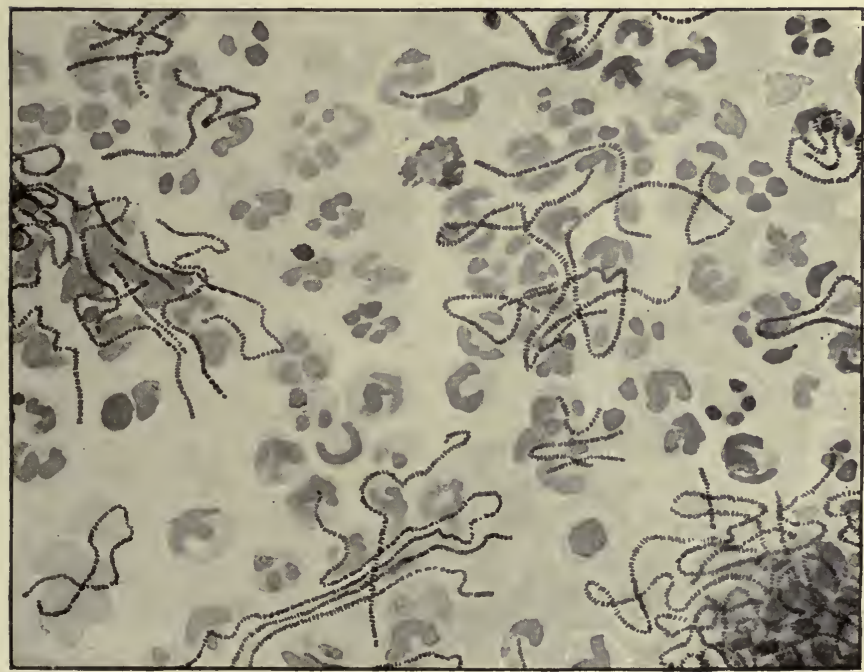

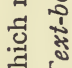

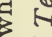

. क ले

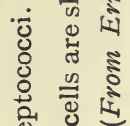

언 0

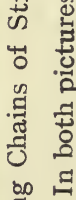

듐 

Hamburger found that the organisms were arranged in the form of diplococci with a sort of halo, which did not however stain with any of the capsular stains. The diplococci were placed end to end, and when grown on milk these organisms showed chain formation.

Further work on similar lines has been carried out by Hölling, Puppel, Stowell and Hilliard, and others. ${ }^{1}$

There seems little doubt that streptococci are present in the milk of cows which cannot be regarded as other than healthy. Moreover, these organisms occur when the milk is collected with the strictest aseptic precautions, as is the case with 'certified's milk, as given below.

Heinemann obtained ' certified' milk and allowed it to stand for eight days to become sour. He then investigated the milk for streptococci and found these organisms present in all dilutions used, both at room temperature and at $37^{\circ} \mathrm{C}$. He then took ro litres of this milk and divided it equally into forty-two flasks. Of the forty-two flasks thirty-eight were heated in a steam steriliser for three successive days. All except one of the flasks which had been heated were then inoculated with streptococci obtained from numerous sources, namely, human fæces, cow fæces, milk, separator slime, sewage, etc. He found that all these strains when grown in milk tended to develop the characteristic diplococci and their chain formation.

Rosenow obtained milk with a milking-tube from twelve apparently healthy cows. Five of the samples were sterile. Of the other seven, three showed large numbers of streptococci after incubation, and of these two varieties were found to be virulent on injection. He found that streptococci, when grown in milk, take on the characteristics of those found in epidemic sore-throats. The greatest effect is produced when the organisms are grown in unheated milk, less being produced when grown in pasteurised milk, and little or none when the milk has been heated in the autoclave. $\mathrm{He}$ also investigated a large number of streptococci obtained from milk and from epidemic sore-throats. Slime was obtained from the milk of known farms, and was subjected to a process of cleansing in a special clarifying machine. He also used the sediment obtained from a cream separator. Immense numbers of streptococci and other bacteria, also of leucocytes and foreign matter, were found in the material obtained from both sources. Emulsions of the organisms which were made and injected into animals were found to be highly pathogenic, the animals dying within three days. Virulent cultures of streptococci were obtained from the exudate or from the blood in thirteen out of fifteen animals examined. A pseudodiphtheria bacillus was the next commonest organism found in the investigation.

${ }^{1} C p$. also work by Rosenow and Moon, and by Krumwiede and Valentine, published since the above was written.

2 For explanation of the term 'certified,' see p. 27r. 
The investigation of samples of cream obtained in the open market showed the presence of virulent streptococci. The cream used was stated to have been pasteurised by the 'flash method.' 1

B. Tubercle Bacilli in Milk.-The literature upon tuberculosis in cattle, and in milk, and its relationship to disease can only be described as voluminous, and any detailed consideration of the subject would be outside the scope of the present work. It is proposed to present only such aspects of the question as appear to be inseparably connected with any consideration of the hygienic aspect of milk. The literature dealing with the regulations for controlling tuberculosis in cattle, and with the clinical signs of tuberculosis in cows will be entirely omitted. The points which will be considered are (I) the presence of tubercle bacilli in milk, with an attempt to show their relative prevalence in milk samples and in milking cows, and (2) the connection between the presence of the bacilli in milk and the health of children.

I. The General Prevalence of Tubercle Bacilli in Milk Samples in certain Large Cities.-The incidence of tubercle bacilli in milk samples has now been investigated in the milk supply of a number of cities, and the results have been published. It is not necessary to examine a large number of the results obtained in the course of such enquiries, since the prevalence of bovine tuberculosis in one country does not afford any guide as to the prevalence of tuberculosis in another. Only a few enquiries will therefore be considered.

The Medical Officer of Health of the London County Council has reported upon the presence of tubercle bacilli in milk samples which had been examined under the auspices of this Council. $\mathrm{He}$ states that between the date of the coming into force of the L.C.C. General Powers Act of 1907 and December I9I3, I3,32I samples of milk forwarded from places outside the county had been examined for the presence of tubercle bacilli. Of these, I323 samples, or 9.9 per cent., had been found to contain tubercle bacilli, as shown by the inoculation of guinea-pigs. During the year I9I3, 2900 samples had been examined. Of these the examination of 2682 was complete at the time of writing his report, of which 25 , or 9.3 per cent., had been shown to contain tubercle bacilli.

The presence of tubercle bacilli has been investigated on several occasions in the market milk of New York. In I909 Hess found the incidence of tubercle bacilli to be about 16 per cent. of all the samples examined by him, and in I9I2-13 Grund and Wilcox found that 9 out of 78 samples of milk examined, or II'5 per cent., were positive.

Eastwood, in his investigations on the American milk supply, obtained figures relating to the number of infected cows in North Wisconsin in the years I905-8. Out of 23,35 I cows tested with tuberculin, $78 \mathrm{I}$, or 3.5 per cent. of all investigated, showed a positive reaction. These cows belonged to 1586 different herds, of which

2 For explanation see p. 229. 
number 88 , or 17 per cent. of all the herds, contained infected cows. In the southern part of Wisconsin State, which had been settled for a longer period than the other parts and which has a denser population, 43, I76 cows had been examined. Of these animals 4570, or 10.5 per cent., gave a positive reaction. The cows belonged to 2 I64 different herds, of which $94 \mathrm{I}$, or 43.4 per cent. of all the herds, contained infected animals.

The difference in the rate of incidence of tuberculosis in the cattle of the two portions of the state is very striking.

Campbell, in I909, investigated the presence of tubercle bacilli in the general milk supply of Philadelphia. He took I30 samples of market milk and found that I8 contained tubercle bacilli. Seven of the inoculated guinea-pigs died before they could be examined for tuberculosis, but excluding these the precentage of positive samples was $13 \cdot 8$. Samples of milk sold as pasteurised milk were also examined, and of these 8.3 per cent. gave positive results. This fact shows the unreliability of pasteurisation in procuring a safe milk supply. This point is considered further in Chap. XIX.

Delépine, dealing with the milk supply of Manchester between the years I897 and I9I3, examined 768I samples of milk, of which 67 I were found to contain tubercle bacilli, or 8.7 per cent. of the total. The figures given show that there had been a considerable fall in the percentage of positive samples since the commencement of the investigation, the percentage for the first two years having been $I 7 \cdot 2$ per cent.

These figures apply only to milk samples and do not give any indication of the number of individual cows giving tuberculous milk. Delépine points out that one cow giving tuberculous milk can infect a much greater quantity of milk than her own, when the milk from several cows is mixed together. In one experiment he took some milk from a cow whose udder was in a state of advanced tuberculous mastitis, and diluted it with various quantities of cows' milk which contained no tubercle bacilli. The mixed milk of various dilutions was inoculated into different guinea-pigs, and the results showed that one part of the tuberculous milk was capable of infecting I00,000 parts of non-tuberculous milk. Delépine adds that had the dilution been pushed further it is probable that the milk would have been found capable of infecting $1,000,000$ parts of non-tuberculous milk. Evidently, therefore, the samples of tuberculous milk give no indication of the absolute number of infected cows.

Delépine gives figures for the number of farms upon which tuberculous cows were found, and from which milk was supplied to Manchester during the years I896 to I9I3. The average number of farms containing infected cows for the whole period was found to be 10.4 per cent., the figures varying from 16.8 per cent. in the first four years to 6.3 per cent. in one of the later years. The figures showed a marked tendency to fall up to the year IgIo, since when 
there seems to have been a rise in the percentage of farms from which infected milk was obtained.

Delépine traced the source of tubercle bacilli in a large number of samples of milk and obtained the following results:

I. Tuberculous udders the cause of infection in

Per cent:

2. Tuberculous udders probably the cause of infection in

3. Nothing definite to connect infection with the state of the cow in . . . . $5 \cdot 2$

These figures were obtained after investigating the milk from 276 farms.

Tubercle bacilli have been shown to occur in milk from cows in whose udder no tuberculous lesion could be detected. This fact is now very generally recognised, but an interesting case is quoted by Delépine as showing the difficulty of detecting early tuberculous lesions of the udder by inspection and palpation alone. This was a case where mixed milk from three farms was found to be tuberculous. All three farms were inspected, but no cow having a tuberculous udder could be detected. Mixed milk of the three farms was again tested and still found to be tuberculous. The veterinary surgeon again inspected the farms, and after lengthy examination discovered in each a cow showing slight signs of disease of the udder, but in none were the symptoms at all typical of tuberculosis. Samples of milk taken from each of these cows all produced tuberculosis in experimental animals. Further cases on the same lines are also quoted by him.

Mitchell ( $\mathrm{I}$ ) investigated the presence of tubercle bacilli in mixed milk obtained from milk shops in Edinburgh between November I9I3 and May I9I4. Four hundred and six samples were tested, of which 82 , or 20 per cent., were found to be capable of producing tuberculosis when inoculated into guinea-pigs.

Mitchell gives a table showing the occurrence of tuberculosis among the Edinburgh dairy cows, compiled from the medical officer's reports from I900-I3. These figures afford sufficient evidence to show that tuberculosis is widespread among cows generally.

The source of the bacilli in milk need not necessarily be the cow. Evidently they can also be derived from milkers suffering from tuberculosis, who, as a result of dirty or careless milking, contaminate the milk with the tubercle bacilli in their own saliva. It seems, however, that in the majority of instances the tubercle bacilli found in milk are derived from the cow herself, a conclusion which is confirmed by the figures obtained by Delépine, and quoted above. ${ }^{1}$

1 Tubercle bacilli cannot be entirely excluded even from milk of the high quality of 'certified' milk. Helmholtz states that where the precautions required for the production of this grade of milk have been fulfilled, virulent tubercle bacilli have been found in the milk. $C p$ : also the work of Heinemann quoted above in relation to pathogenic streptococci in 'certified ' milk, 
The Royal Commission on Tuberculosis, as a result of the evidence obtained by them, state: 'Bovine tubercle bacilli are apt to be abundantly present in milk as sold to the public when there is tuberculous disease of the udder of the cow from which it was obtained ... but these bacilli may also be present in the milk of tuberculous cows presenting no evidence whatever of disease of the udder, even when examined post-mortem. Further, the milk of tuberculous cows not containing bacilli as it leaves the udder may, and frequently does, become contaminated with the fæces or uterine discharges of such diseased animals.'

2. On the Infectivity of Tuberculous Milk-The importance of ascertaining the presence of tubercle bacilli in milk is essentially bound up with the question of whether such bacilli can produce tuberculous lesions in the human species. Here again the literature is voluminous and highly controversial, and it is not proposed to deal with it in this work. It will suffice to quote some of the results obtained by the extended investigations which have been carried out by competent authorities.

It has been known for a number of years that certain differences exist between the tubercle bacilli found in cattle and those found in the human species. These have been fully investigated, and for further details any one interested is referred to the report of the Royal Commission on Tuberculosis. The essential point is the presence of bovine tubercle bacilli in lesions in the human subject. The most extensive observations have been carried out by the workers for the Royal Commission, and it will be of interest to quote sentences from the report made by the Commissioners. After dealing with the investigations which were conducted upon I08 cases of human tuberculosis in persons of various ages, the Commissioners say: "Of the total 108 cases of human tuberculosis investigated, 84 yielded human tubercle bacilli, only I9 yielded bovine tubercle bacilli, and 5 both bovine and human tubercle bacilli. Although the bovine tubercle bacilli may, as it appears, be solely responsible for certain cases of pulmonary tuberculosis (consumption), and though it may be present with the human tubercle bacillus in the bronchial glands, it is evident from the data recorded that the majority of cases in which the bovine tubercle bacillus is the infective agent in the human being are cases of alimentary tuberculosis. Such are cases of cervical gland and primary abdominal tuberculosis. In the latter class of cases at least the tubercle bacillus has unquestionably been swallowed. . . . The percentage of these cases of alimentary tuberculosis due to the bovine tubercle bacillus is very large.' (The percentage appears to be about 50 per cent.)

It is not necessary to bring forward evidence to show that bovine tubercle bacilli affect young children rather than adults. The prevalence of gland infection in children and of pulmonary infection in adults is a matter of common medical knowledge. 
Experiments were conducted by the Commission in which large numbers of animals were fed upon bovine tubercle bacilli. The animals thus fed showed infection of the mesenteric glands in nearly every case, and in several cases also of other glands more distant from the alimentary canal, and also infection of some of the organs, especially the liver and spleen. In one or two cases the lungs were also infected. Evidently the bacilli had found entrance through the alimentary canal by passing through the mucous membrane and then to the glands.

Dealing further with this subject, the Commissioners state: - Of young children dying from primary abdominal tuberculosis, the fatal lesions could in nearly one-half of the cases be referred to the bovine bacillus, and to that type alone. In children, too, and often also in adolescents, suffering from cervical gland tuberculosis, a large proportion of the cases examined by us could be referred to the bovine tubercle bacillus. .... Whatever, therefore, may be the animal source of tuberculosis in adolescents and in adult man, there can be no doubt that a considerable proportion of the tuberculosis affecting children is of bovine origin, more particularly that which affects primarily the abdominal organs and the cervical glands. And further, there can be no doubt that primary abdominal tuberculosis, as well as tuberculosis of the cervical glands, is commonly due to ingestion of tuberculous infective material. Judging by our feeding experiments, there would appear to be strong presumption that as regards most animals, comparatively large doses, given either singly or by frequent repetition, are necessary to produce by ingestion acute progressive generalised tuberculosis, though we have recorded instances in which a very small dose administered but once has produced this result. Applying a like presumption to man (and our observations on the monkey and chimpanzee in this connection afford warrant for so doing), it may be asked in what way are children, the members of the human family who are especially liable to exhibit acute fatal tuberculosis commencing as an abdominal affection, most likely to obtain a large and fatally infective dose of tubercle bacilli ? 'As already indicated by us, to this question there can be but one answer-namely, that the evidence which we have accumulated goes to demonstrate that a considerable amount of the tuberculosis of childhood is to be ascribed to infection with bacilli of the bovine type transmitted to children in meals consisting largely of the milk of the cow.

In many cases of abdominal tuberculosis and in tuberculosis of the cervical glands, however, it must be recollected that the child may be injured by the ingestion of bovine tubercle bacilli in milk without a fatal result occurring. The cases of abdominal tuberculosis examined by us had all been fatal, that is, death occurred from a generalised tuberculosis or from some local condition resulting, with possibly two exceptions, from tuberculosis of the abdomen. 
But many cases of abdcminal tuberculosis in children recover, though what proportion of these is due to the bovine bacillus and what to the human, we have no means of knowing at present. The cases of cervical gland tuberculosis investigated by us were all cases that recovered or were recovering after operation, and a large proportion of them were bovine in origin. ... We are convinced that measures for securing the prevention of ingestion of living bovine tubercle bacilli with milk would greatly reduce the number of cases of abdominal and cervical gland tuberculosis in children, and that such measures should include the exclusion from the food supply of the milk of the recognisably tuberculous cow, irrespective of the site of the disease, whether in the udder or in the internal organs.'

Investigations together with summaries of other cases investigated by different authors have been prepared by Park and Krumwiede. These authors have worked up, the percentage of bovine infections occurring in children who were found to be affected with tubercle, causing their death, or who had died from other causes, and were found post-mortem to contain also tuberculous lesions. The table given below is taken from their paper and gives the incidence of infection only.

Percentage Incidence of Bovine Infection

\begin{tabular}{|c|c|c|c|}
\hline Diagnosis & $\begin{array}{l}\text { Adults } 6 \text { Years } \\
\text { and over }\end{array}$ & $\begin{array}{l}\text { Children 5-16 } \\
\text { Years }\end{array}$ & $\begin{array}{l}\text { Children under } \\
5 \text { Years }\end{array}$ \\
\hline Pulmonary tuberculosis . & 0.4 & 0.0 & $2 \cdot 8$ \\
\hline Tuberculous adenitis, cervical . & $2 \cdot 7$ & $38 \cdot 0$ & $6 \mathrm{r} \cdot 0$ \\
\hline Abdominal tuberculosis & $20 \cdot 0$ & $53 \cdot 0$ & $58 \cdot 0$ \\
\hline $\begin{array}{l}\text { Generalised tuberculosis, ali- } \\
\text { mentary origin }\end{array}$ & $14 \cdot 0$ & $57 \cdot 0$ & $47 \cdot 0$ \\
\hline Generalised tuberculosis . & 0.0 & r6.0 & $8 \cdot 6$ \\
\hline $\begin{array}{l}\text { Generalised tuberculosis, includ- } \\
\text { ing meninges, alimentaryorigin }\end{array}$ & 0.0 & $0 \cdot 0$ & $66 \cdot 0$ \\
\hline $\begin{array}{l}\text { Tubercular meningitis (with or } \\
\text { without generalised lesions } \\
\text { other than preceding) }\end{array}$ & 0.0 & $0 \cdot 0$ & $4 \cdot 6$ \\
\hline Tuberculosis of bones and joints & $3 \cdot 3 ?$ & 6.8 & 0.0 \\
\hline Tuberculosis of skin & $23^{\circ} 0^{:}$ & $60 \cdot 0$ & 0.0 \\
\hline
\end{tabular}

The authors state: 'In our own series of non-selected fatal cases under five years of age bovine infection constituted $12 \frac{1}{2}$ per cent. We had nine cases under six years of age, who were exclusively cow's milk fed, from a foundling asylum. Of these, five were bovine infections. If the fatal cases in this series are deducted from the total cases, the bovine infections comprise about Io per cent. In a non-selected series of fatal cases from the Babies Hospital $6 \frac{1}{8}$ per cent. were due to bovine infection. 
- Where other investigators have reported non-selected cases the percentages come close to these figures.

'On the whole, bovine infection causes somewhat less than Io per cent. of the total deaths in young children.'

Mitchell (2) examined eighty consecutive cases of tuberculous cervical glands in children. Of these eighty children forty-two resided in Edinburgh and thirty-eight came from the neighbouring country districts. The bovine bacillus was present in 88 per cent. of the cases and the human bacillus in I2 per cent. Mitchell states that " without exception the cases were those of children twelve years of age and under. The maximum incidence occurred during the second year of life. This is not surprising when it is recalled that the large majority of children of this age are nourished in whole or in part on cows' milk. I found that in my series of cases 84 per cent. of the children of two years and under had been fed with unsterilised cows' milk since birth. Whatever may be the case in other countries the mode of feeding children in Britain, especially Scotland, is such as to favour bovine infection.'

The method of feeding of children showing lesions due to bovine tubercle bacilli, has been investigated by Fraser. Out of seventy cases of tuberculosis of bones or joints thirty-eight cases had a clear history of feeding on cows' milk, and the bacteriological results suggested infection by bacilli of bovine origin. In nineteen of the cases the children were breast-fed, and the evidence was in favour of infection with bacilli of human origin. In thirteen cases the evidence was either incomplete or showed apparent contradiction between the bacteriological findings and the history.

The question of infection in children by the ingestion of bovine tubercle bacilli in milk was thoroughly discussed at the conference on tuberculosis which took place in Edinburgh in I9I4, at which conference some of the results above described were given by the authors concerned.

Stiles, in dealing with the question, reviewed some of the work of the observers already mentioned, and urged the necessity for attention being directed towards the stamping out of bovine tuberculosis. He considers that if measures were energetically carried through, the amount of surgical tuberculosis in children would rapidly diminish. $\mathrm{He}$ adds: "I maintain, however, that until such legislation has been in force for some time it is the duty of the medical profession to insist on the boiling of all milk given to children. Professor von Pirquet, one of the greatest authorities on tuberculosis in Vienna, states that practically all the surgical tuberculosis which is met with in children in that city is due to the human bacillus. This statement would at first sight appear to throw doubt upon the reliability of the Edinburgh investigations, but when Professor von Pirquet assures us that the whole of the milk of Vienna is boiled we can quite understand why surgical tuberculosis in that city is never of bovine origin.' 
The work above recorded affords indubitable evidence as to the infection of children by the bovine tubercle bacillus through the alimentary canal.

C. On the Presence of Bacillus Abortus in Milk.-A fair number of investigations have been carried out on the presence of Bacillus Abortus in the milk obtained from cows who had aborted in previous pregnancies. The disease is well known, and when it attacks a herd produces serious financial loss.

It has been shown by numerous observers that the Bacillus abortus is present in the milk of cows both before they have shown any symptoms of abortion and also for a considerable period after the abortion has occurred. The disease, its prevalence, method of infection, etc., was investigated by a special committee appointed by the Board of Agriculture and Fisheries. In connection with this committee special investigations were carried out by MacFadyean and Stockman.

Abortion is produced when the bacillus attacks the uterus, and the investigations were directed towards ascertaining how the disease reached this organ, and infection was found to take place readily by ingestion of the bacillus. In four experiments where the bacillus was given by the mouth three results were positive and one negative, and the committee states: 'With regard to infection by the mouth it is a natural source of infection which until recently did not enter into anybody's calculations regarding the spread of abortion, and knowing, as we do, that the food including the bacillus, and even the feeding-trough, may more or less easily be contaminated on an infected establishment, it seems highly probable that infection by ingestion often takes place. In fact we are inclined to believe that the disease is more frequently contracted in this way than in any other. Presumably the bacilli are absorbed from the intestine and gain the blood stream whereby they reach the uterus. In the case of ewe 77 the microbe of cattle abortion was found in the cotyledons six days after infection by the mouth.'

The committee further showed that a large number of animals are susceptible to the disease arising from the Bacillus Abortus, and they produced abortion experimentally in cows, ewes, goats, bitches, and guinea-pigs, and state that Bang also was successful in producing abortion in a mare.

The committee say: "Although it is hardly germane to the present enquiry we think it advisable to point out that since the bacillus of cattle abortion is pathogenic for so many species, the possibility of the human female being infected should not be lost sight of.'

The prevalence of the disease in this country was also investigated by the committee, who found it impossible to ascertain the precise prevalence in the absence of any order requiring the disease to be reported. Information given voluntarily by stock-owners 
having infected herds showed that the disease was found in fiftyfive farms which were situated in no less than thirty-six different counties.

The presence of the bacillus in milk was investigated by Schroeder and Cotton. They found that the milk from apparently healthy cows which did not react to tuberculin, might contain Bacillus Abortus, and that these bacilli when injected into guinea-pigs produced lesions similar to, but not identical with, those produced by tubercle bacilli. They found that the abortus bacillus could be detected in the udder when no trace of disease could be found on examining the carcase. Further, they found that the excretion of this organism in the milk is extremely persistent, having been traced in one case for a period of eleven months after the abortion. They confirm the work of MacFadyean and Stockman in regard to the infection of other animals, and produced characteristic lesions by feeding, in cattle, sheep, goats, mares, guinea-pigs, rabbits.

Schroeder and Cotton investigated the milk from cows on two farms and also from individual cows. On one farm there were I 40 cows tested with the tuberculin and found to be free from this disease; nineteen cows, however, showed a positive reaction for the abortus bacillus. On the second farm of thirty-six cows, eleven gave positive reaction, and in the total number of cows investigated I4 per cent. were found to contain the Bacillus Abortus.

Smith and Fabyan showed that the fœtus obtained from a guinea-pig infected with Bacillus Abortus when injected into another guinea-pig gave rise to lesions simulating tubercle but in reality due to the Bacillus Abortus. These lesions could be reproduced at will in a series of animals. The authors believe that tuberculous lesions are sometimes stated to occur which are in reality due to the Bacillus Abortus. The organism was found to grow readily in milk.

Zurick and Krage investigated the milk from three cows which had respectively aborted fourteen days, six months, and thirteen months previously. The abortus bacillus was found in all cases, but no pathological changes could be detected either in the udder or in the milk. They found that if the bacilli were injected into one side of the goat's udder they were excreted from the injected side four or five days after the injection but not from the other side. The blood of the goat showed agglutinating power for the Bacillus Abortus. In other experiments the bacilli were introduced intravenously or subcutaneously. Two of the animals injected showed Bacillus Abortus in the milk within twenty-four hours, a third in forty-eight hours, and the organism persisted in the milk for a period of about three weeks.

Schroeder (r), in the course of work carried out upon the nutritive properties of boiled milk for guinea-pigs, found lesions in some of the guinea-pigs examined, which caused him to investigate the 
milk which had been used. All the milk was obtained from tuberculin-tested cows kept at the experiment station and was of superlative quality.

At the time of the experiment it was not known that one cow in the herd from which the milk was obtained was infected with the Bacillus Abortus, and it appears that there was at that time on evidence whatever of the cow being thus infected. Working in conjunction with Cotton, Schroeder had previously discovered that milk cuntaining this bacillus, if injected into guinea-pigs, gave rise to this disease in guinea-pigs.

In another paper Schroeder (2) showed that many if not most cows that become infected with the Bacillus Abortus remain chronic carriers for long periods of time, possibly permanent carriers, and that the bacillus is of common occurrence in the milk of rows that have ceased to abort and have produced several healthy calves in succession. Among aborting cows the bacillus appears in the milk before an abortion occurs, and in one instance was discovered in the milk of a cow that did not abort until 255 days later. These facts afford strong testimony to the impossibility of securing milk, from even the most carefully supervised cows, that can be guaranteed free from the germs of disease.

Although somewhat beyond the immediate scope of this work, it may be mentioned that Teacher and Burton found that abortion in guinea pigs was apparently produced both by streptococci and by a diphtheroid bacillus. In two cases the changes in the placenta resembled the white infarctions found in human placentæ: no bacteria could be found, but the authors believed that the lesion was probably of streptococcal origin.

D. On Milk-borne Epidemics. - It is not proposed to enter into any detail as to the epidemics which have been attributed to milk-borne organisms. For the most part these epidemics have been of the nature of sore throats varying greatly in intensity. Some diphtheria epidemics have also occurred. Three outbreaks, which will not be dealt with, are stated to have been of the nature of gastro-enteritis. In some cases the symptoms have been of an extremely severe type, and although the sore throat was the primary symptom, this has been succeeded by serious secondary troubles, leading in many cases to death.

In IgI2 Savage summarised the epidemics which have been regarded as being due to milk in this country.

Out of nineteen epidemics investigated, the source of infection, although most certainly due to milk, could not be precisely traced, but the remainder of the epidemics were traceable in most cases quite definitely to a diseased cow.

Of the last the following is a brief summary :

Rugby

Dover
I880 Apparently due to a cow suffering from mastitis. I884 Believed to be due to cows among whom some had suffered from foot-and-mouth disease. 
Finchley 1894 Three cows whose milk had been mixed with the general supply showed ulcerated teats and one had a chronic abscess of the udder.

Anglesea I897 Streptococci found in the milk of one cow of the dairy concerned.

Guildford 1903 Streptococci found in the milk of a variety which was virulent to mice. It seemed doubtful whether the farmer or the cows on the farm had first shown symptoms of trouble, but the epidemic appears to have been transmitted to the milk.

Finchley 1904 Streptococcal outbreak attributed by Prof. Kenwood to two cows in unsatisfactory condition of health.

Glasgow I904 An epidemic of mild tonsillitis believed to be due to an eruption of the teat of a new cow introduced into the herd which had spread to other cows. The hands of four out of eight of the milkers became affected with similar eruptions. The epidemic stopped when the milk from this farm was sterilised before use.

Colchester 1905 An epidemic of at least 600 cases. This epidemic was traced to infection from one cow which had mastitis. The milk from this cow, which was known to be sick, had been added to the common milk supply for some time. Cessation of the epidemic corresponded with the exclusion of the milk from this cow.

Leith I904 Epidemic of diphtheria. Several cows were found with pustules which had practically dried upon the teats. The Klebs-Loeffler bacillus was not found in the pustules. It was suggested that the pustules had been cow-pox.

Christiania 1908 At least 504 cases of sore throat occurred. The cause was traced to a cow with a diseased udder giving milk containing streptococci which were pathogenic to mice.

A similar survey of the epidemics in America has been prepared by Trask, and should be consulted for further information.

Serious epidemics of sore throats due to streptococci in the milk occurred in America in the year IgII-I2.

Hamburger describes an epidemic in Baltimore. The milk concerned in the production of the epidemic all came from one dairy which collected milk from many farms. The milk had been pasteurised at the dairy by the flash method, i.e. just raised to $160^{\circ} \mathrm{F}$. Subsequently it was held at a temperature of $145^{\circ} \mathrm{F}$. for from twenty minutes to half an hour. When the dairy raised the temperature of the pasteurisation and the customers were advised to boil the milk, the epidemic subsided, although a few stray cases occurred, apparently by infection from one person to another. Investigation showed that in the few days preceding the outbreak of the epidemic pasteurisation had been omitted. 
A very severe epidemic of streptococcal sore throats occurred in Cambridge, Mass., in the winter of $\mathrm{IgII}-\mathrm{I} 2$, and was dealt with by several authors ( $c p$. Winslow and Darling). It was known that 730 cases occurred, but the real number was probably considerably above this. Twenty-seven deaths occurred among the persons attacked, of whom the majority were over forty years of age. Children appeared to be comparatively immune. The bacterial content of the milk supplied from the dairy was fairly low, being approximately 300,000 per c.c. Two-thirds of the samples examined gave a count below 50,000 and half of the samples below 10,000.

Capps and Miller investigated an outbreak of sore throats in Chicago due to streptococcal infection of the milk supply. The epidemic presented features of considerable interest and involved about I0,000 cases, which is considered to be a conservative estimate. A number of deaths occurred as a result of the infection. The outbreak was divided into two parts : the first occurred about September $2 \mathrm{I}$, rising in intensity to the $25^{\text {th }}$, when it rapidly subsided. The second outbreak of cases, which was not so numerous, occurred on January I and 2, with a slight interruption from the Ioth to the I7th of this month. The epidemic was worse in some parts of the city than others, and was bad in the village of Batavia, which lies just outside Chicago. The source of infection was traced to a dairy whose pasteurising plant was in Batavia. It was found that a few days before each of the outbreaks there had been serious defects in the pasteurisation, which had been especially bad on December I7 and December I9. The milk appears to have been consumed two or three days after pasteurisation and the incubation period to have been about four days. An interesting point arises in the fact that at one children's hospital which was supplied with milk from this dairy the children did not suffer at all, although the nursing and medical staff suffered severely. Investigation showed that the milk supply for the children was delivered raw and pasteurised in the hospital before being given to the children, while the milk supplied for the staff was obtained direct from the dairy, where it was supposed to have been pasteurised and did not undergo any further heating. Investigation on the farms which supplied milk to the dairy showed that there had been an unusual number of cases both of mastitis in the cows and of sore throats in several of the persons on the farms supplying the milk to the dairy. Samples of milk supplied from the farms were found to contain pus and streptococci.

Outbreaks due to milk infection were reported upon by Fletcher in Woodbridge in I9I3-I4, and by Macewen in South London. In the latter case the epidemic appears to have been due to infection from the teats of the cows, which was also found on the milkers' hands. At the time of the investigation the Klebs-Loeffler bacillus was isolated from the hands of two of the milkers; The pustules on the cows' teats had however become dry and the organisms 
were not obtained from them. The epidemic ceased when the milk from this cow was pasteurised.

Epidemics of scarlet fever and typhoid fever have been traced to infection from the milk supply in a number of cases. Such infection usually occurs from the presence of the organisms in one of the milkers, or in one of the inhabitants at the farm. Cases are given both by Savage and Trask, and others have occurred in recent years. Thus Meader reports an outbreak of I39 cases of scarlet fever, and 282 cases of sore throat, which may have been a mild form of the disease. The source of infection was traced to one of the milkers, and the large number of cases arose from the fact that the contaminated milk was mixed with a large volume of other milk.

These epidemics occur in spite of all observance of apparently adequate precautions. Pathogenic streptococci have been shown above to occur in ' certified' milk. Winslow, in describing the severe epidemic of tonsillitis which occurred in Boston, Mass., in IgII-I2, says: "I am at a loss to suggest any other precautions that could have been taken to guard against infection with human germs of disease that were not taken in this instance. "Excellent regulations were drawn up for the exclusion of contagion, the milkers and the cattle carefully inspected, the dairy was admirably arranged, and the whole process controlled by laboratory examinations under the direction of bacteriologists and sanitarians of the highest standard. If in spite of such precautions the milk becomes infected, any raw milk supply may at any time become infected; and this I believe to be the lesson not only of this outbreak, but of many that have preceded it in all parts of the world. It is practically impossible to exclude mild and unrecognised cases of disease of the process of milk production. The larger the supply the greater, of course, is the danger, but even a small supply must meet it at some time. Thus a cough over the pail, a finger inside the can as it is lifted, and the danger is imminent. There is in my judgment but one safeguard against such outbreaks-proper pasteurisation.'

There is little to add to this summary of the position : owing to the risks of subsequent contamination, however, pasteurisation is safest when carried out in the home.

\section{References in Chapter XV}

\section{A. Streptococci}

Bergey, 'The Prevalence of Streptococci in Cows' Milk,' Amer. Med. IgOI, i. 122.

BRÜNING, 'Untersuchungen der Leipziger Marktmilch,' Jahrb. f. Kinderh. I905, 1xii. I.

CAMpBeiL, 'Leucocytes in Milk,' Bureau of Animal Ind., Bull. II 7, I909.

Davis. See Rosenow and Davis. 
ERNST, 'Ueber Milchstreptokokken und Streptokokkenmastitis,' Monats. f. Tierheilk. I909, xx. $4 \mathrm{I} 4$; and I9I0, xxi. 55 .

GMINDER, 'Untersuchungen über Mastitisstreptokokken und ihre Differenzierung von saprophytischen Streptokokken,' Cent. f. Bakt. Orig. I9I2, lxiii. I 52.

GoRDon, 'Report by Dr. Gordon on an Investigation of the Fermentative Characters of Streptococci on the Fauces during Scarlet Fever,' Rept. of M.O. to L.G.B. I9IO-II.

Hamburger, 'An Epidemic of Septic Sore Throat in Baltimore, and its Relation to a Milk Supply,' Journ. of Amer. Med. Assoc. I912, lviii. I Io9:

Heinemann. (I) 'The Pathogenicity of Streptococcus Lacticus,' Journ. of Inf. Diseases, I907, iv. 87: (2) 'The Significance of Streptococci in Milk,' Journ. of Inf. Diseases, 1906, iii. 173.

HilliaRD. See Stowell and Hilliard.

Hölling, Inaug. Dissert., Bonn., I904. (Quoted by Heinemann.)

KAISER, 'Ueber die Häufigheit des Streptokokkenbefundes in der Milch," Arch. f. Hyg. I906, lvi. 51.

Krumwiede AND VAlEntine, 'A Bacteriological Study of an Epidemic of Septic Sore Throat,' Journ. Med. Res. I9I5, xxiii. 231.

Muller, 'Ueber die Streptokokken der Milch,' Arch. f. Hyg. 1906, lvi. 90.

PUPPEL, ' Ueber Streptokokken in der Milch und im Säuglingsstühle,' Zeit.f. Hyg. I9I 2, 1xx. 3.

Roger, 'The Origin of Some of the Streptococci found in Milk,' Journ. of Agric. Res. I9I 4, i. 49I.

Rosenow, 'A Study of Streptococci from Milk, \&c.,' Journ. of Inf. Diseases, I $912-13$, xi. 338 .

Rosenow and Davis, 'An Epidemic of Sore Throat due to a peculiar Streptococcus,' Journ. of Amer. Med. Assoc. r912, lviii. 773.

Rosenow AND Moon, 'An Epidemic of Septic Sore Throat, \&c,' Journ. Inf. Diseases, I9I 5, xvii. 69.

RuEdiger, 'A Study of Thirty-four Strains of Streptococci isolated from Samples of Milk,' Science, I9I2, xxxv. 223.

Savage. (I) 'Streptococci and Leucocytes in Milk', Journ. of Hyg. I906, vi. 123; (2) 'Report on Bacterial Studies of Milk from Healthy and Diseased Cows,' Report of M.O. to L.G.B. 1906-7.

Stowell and Hilliard, A Comparison of Streptococci from Milk and from the Human Throat,' Science I9I2, xxxy. 223.

TROMMSDORFF, 'Ueber den gegenwärtigen Stand der Mastitisfrage in ihrer Beziehung zur Milchhygiene,' Cent. f. Bakt. Abt. I, I9I2, lxvi. $505 ;$ Ref. Milchw. Zentralb. I9I2, p. 741 .

ZaNGmeister, 'Ueber die Verbreitung der Streptokokken,' Münch. med. Wochensch. 1910, lvii. 1268.

\section{B. Tubercle Bacillus}

Campbell, 'Tubercle Bacilli in Market Milk in Philadelphia,' Report of Bureau of Animal Industry, r909, p. I62.

Delépine, 'Report upon the Prevalence and Sources of Tubercle Bacilli in Cows' Milk,' Report of the M.O. to the L.G.B. I908-9.

Eastwood, Report to the L.G.B. on American Methods for the Control and Improvement of the Milk Supply, rgog, New Series, No. I.

FrASER, 'The Relative Prevalence of Human and Bovine Types of Tubercle Bacilli in Bone and Joint Tuberculosis occurring in Children,' Journ. of Exp. Medicine, 1912, xvi. 433.

GRUND AND WILcox, "The Frequency of B. Tuberculosis in the Market Milk of New York City,' Dept. of Public Health in City of New York, 1912-13.

Helmholtz, 'Pasteurisation, Sterilisation, and Boiling of Milk,' Annual Meeting of the Amer. Assoc. for the Prevention of Infant Mortality, r913, iii. 206. 
Hess, 'The Incidence of Tubercle Bacillus in the New York City Milk,' Journ. of Amer. Med. Assoc. 1909, lii. ror I.

KRUMWIEDE. See Park and Krumwiede.

London County Council, Report of the M.O. to the L.C.C. I913, p. 227.

Mrtchell. (I) "The Prevalence of Tubercle Bacilli in the Edinburgh Milk Supply,' Journ. of State Med. I9I5, xxiii. 44: (2) 'A Bacteriological Study of Tuberculosis of the Lymph Glands in Children,' Journ. of State Med. I9I 5, xxiii. I.

Park and KRUMwiede, The Relative Importance of the Bovine and Human Types of Tubercle Bacilli in the Different Forms of Tuberculosis,' Journ. of Med. Research, 1912-13, xxvii. III.

Strles, 'Surgical Tuberculosis,' Journ. of State Med. I914, xxii. 7I 4.

Tuberculosis, Final Report of the Royal Commission on Tuberculosis.

Wricox. See Grund and Wilcox.

\section{Bacillus Abortus}

Burton. See Teacher and Burton.

Cotron. See Schroeder and Cotton.

FABYAN. See Smith and Fabyan.

KRAGE. See Kürick and Krage.

McFadyean and Stockman, Report by Departmental Committee appointed by Board of Agriculture and Fisheries to Inquire into Epizootic Abortion, Appendix to $\mathrm{Pt}$. I. London, Igo9.

Schroeder. (I) 'An Experiment with Raw and Heated Cows' Milk and its Lesson,' Amer. Journ. of Children's Diseases, I9r3, vi. 334. (2) 'Pure Milk Production and the Abortion Bacillus,' Amer. Vet. Review, I9r3-r4, xliv. 467 .

Schroeder and CotTon, 'Infectious Abortion of Cattle and the Occurrence of its Bacteria in Milk,' Bureau of Animal Industry, 28th Rept. I9I I, p. I 37.

Smith aNd Fabyan, 'Ueber die pathogene Wirkung des Bacillus abortus Bang,' Centralb. f. Bakt. Abt. I, I912, lxi. 549.

Stockman. See McFadyean and Stockman.

TEACHER AND BURTON, 'Infective Abortion in Guinea-pigs,' Journ. of Path. and Bact. I9I $5, \mathbf{x x}$. I4.

ZÜRICK AND KRAGE, "Ueber die Ausscheidung von Abortusbazillen mit der Milch infizierter Tiere,' Berl. Tievärzt. Wochensch. I913, No. 3; Ref. Milchw. Zentralb. I9r3, p. 268.

\section{On Milk-borne Epidemics}

Capps and Mrller, 'The Chicago Epidemic of Streptococcus Sore Throat and its Relation to the Milk Supply,' Journ. of Amer. Med. Assoc. I9I2, lviii. 1848 .

DARLING, "Clinical Aspects of the Epidemic Sore Throat in Cambridge in May I9II,' Boston Med. and Chir. Journ. I9II, clxv. 904.

Fletcher, 'Outbreak of Sore Throat in the Woodbridge Rural District,' Rept. of M.O. to L.G.B. I9I3-I4, Appendix, p. 6.

HAMBURGer, 'An Epidemic of Septic Sore Throat in Baltimore and its Relation to a Milk Supply,' Journ. of Amer. Med. Assoc. I912, lviii. I Iog.

MACEWEN, ' Report on a Diphtheria Outbreak in South London,' Rept. of M.O. to L.G.B. I9r 3-14, Appendix, p. 30.

Meader, 'Milk-borne Epidemic of Scarlet Fever,' Health News, New York State Dept., September I9I5.

Miller. See Capps and Miller.

SAVAGE, Milk and the Public Health, ror2.

TRASK, "Milk as a Cause of Epidemics of Typhoid Fever, Scarlet Fever, and Diphtheria,' Dept. of Hyg. Washington, Bull. 56, I9r2.

Winsiow, 'An Outbreak of Tonsilitis or Septic Sore Throat in Eastern Massachusetts and its Relation to an Infected Milk Supply,' Boston Med. and Chir. Journ. I9I I, clxv. 899. 


\section{CHAPTER XVI}

NOTES ON THE SOURCES OF THE CONTAMINATION OF MILK

THE contamination of milk is brought about by the addition to it of bacteria, and is liable to occur at all stages of its production, and of its transit to the consumer.

The class of bacteria will evidently differ very greatly, and will depend upon the source of the contamination. These following sources may be regarded as the more common:

I. From the cow herself, either from the udder or from other parts of the animal.

2. From the milker.

3. From the cow-shed, either from the air, the walls, floor, bedding, or the food.

4. From the milk-pails.

5. In the process of filtering and cooling.

6. From churns or bottles.

7. In the process of transit from the farm to the dairy and from the dairy to the customer.

8. In the course of manipulation at the dairy.

9. In the home of the customer.

These sources may now be considered individually:

I. From the Cow herself.-It seems hardly possible, even when full precautions are taken, to obtain milk by the ordinary process of milking which has a lower count than a few hundred bacteria per cubic centimetre. Seibold, using antiseptics for washing the teats, and after discarding a considerable amount of first milk, was able in a few instances to obtain sterile milk by milking directly into sterile tubes. Ordinarily, however, sterile milk can only be obtained by the use of a milking-tube passed up the teat into the space which occurs in the cow's udder between the gland tissue and the teat, and by collecting the milk thus obtained, all the apparatus used having been previously sterilised. The counts obtained by Seibold, and later by Rullmann, using all precautions, wcre found to vary from 0 to about 400 bacteria per c.c.

In cases where there is disease of the udder the organisms pro- 
ducing the disease will be passed out into the milk, which will be contaminated at its site of production. This subject has already been dealt with in Chap. XV.

It has also been noted in Chap. VII that streptococci, and hence presumably other organisms, may gain entrance to the teats from the outside of the udder and teats.

The first jets of milk which leave the udder on milking are known to contain a larger number of bacteria than the later portions, and it is usual in producing milk of a high quality to reject the first portion of milk.

Further, the cows, unless cleaned, usually have their hindquarters contaminated by fæces and urine. Fæcal matter is replete with organisms, of which the most characteristic and the best known are those of the coli group. The presence of Bacillus coli is usually regarded as diagnostic of fæcal contamination. When present in milk it is probable that its main source of origin is from the fæces of the cow. The fæces are allowed to dry on the hindquarters of the animal and tend in the process of friction of the milker against the cow to fall or be wafted by air currents into the milking pail. The greater part of the dirt, i.e. sediment, which is found in milk is well known to be mainly composed of fæcal material. A small amount of such material in the milk provides a rich supply of coli organisms. ${ }^{1}$

It is not necessary to consider at length the literature upon this subject, but it may be mentioned in passing that Hewlett and Barton, examining milk as it came into London from a very large number of English counties, found that in 46 per cent. of the samples, Bacillus coli was present in I c.c. of milk. It is probable that had larger quantities of milk been taken, the percentage would have been still higher.

Other organisms will be attached to the hair of the cow and, together with the hairs rubbed off in the process of milking, will fall into the milk. On farms where milk with a low bacterial count is produced, it is not unusual for the cows' udders to be clipped in order to remove the main growth of hair. Such clipping is probably especially valuable in certain cases where the hairs grow almost on to the teats and will be rubbed in the process of milling. Where the milker leans his head against the side of the cow, hair from the cow's flanks will alsn fall-probanly into the milk.

2. From the Milker. - The milker's hands are a potent source of origin for bacteria in milk. In the course of milking any dirt which is on the hands will gradually be rubbed off and find its way into the milk. A practice exists among dirty milkers of milking with their hands moistened by means of their own saliva. This revolting practice, which is known as 'wet' milking, clearly adds to the bacterial contamination of the milk. In the first place

1 The remarks of the Royal Commission on tuberculosis, quoted on p. 253 , may also be referred to. 
the organisms present in the milker's mouth or throat will be transferred to the milker's hands. In the process of milking there will be an accumulation of bacteria, epithelial débris and dirt, both from the hands of the milker and from the teats of the cow. A large proportion of this material will fall into the milk-pail.

Some of the epidemics which have arisen as a result of contaminated milk, have been traced directly to disease in the milkers. A milker with a sore throat will be liable to infect the milk with the organisms present in his throat. One suffering from pulmonary tubercle will transfer tubercle bacilli to the milk with the greatest ease, either by a cough or by the saliva if the hands are moistened with it. Epidemics of scarlet fever have been traced to infection from a member of the dairy staff through the milk. Further, epidemics of typhoid fever have been traced to the fact that one of the milkers was a carrier of these germs. ${ }^{1}$

3. From the Cow-shed.-It is not necessary to dwell upon this subject, since the presence of large numbers of organisms in straw, etc., is a matter of universal knowledge. These organisms cannot fail to be present in the air of the cow-shed where bedding or fodder is present, and a certain number will inevitably find their way into the milk-pail. Where it is desired to obtain a milk of low bacterial content, it is usual either to milk the cows in a shed where no bedding is allowed, or to use sawdust for bedding instead of straw or similar substance. The bacteria which gain access from these sources are probably harmless.

4. From the Milk-pails.-A dirty milk-pail will contaminate the milk which is milked into it, and it is to be feared that there is frequently a lack of cleanliness, especially in the smaller farms, in regard to this matter. A good deal of the contamination referred to above could evidently be prevented if the contaminating matter were not allowed to fall into the pail. The reduction of the bacterial count by using (I) a properly shaped milk-can and (2) care in cleanliness of the milk-pails will be dealt with later.

5. Conveyance from the Farm to the Customer.-The sources of contamination under headings 5, 6, 7, and 8 (see above, p. 265) resolve themselves into a consideration of the conveyance of milk from the milking-shed to the customer, and will evidently depend upon the method of transit employed. So much has already been written, and so many investigations carried out, upon the various phases of contamination of the general milk supply in the course of its transit, that no further remarks will be made here. Those interested will find much information in the work of Houston and of Savage, and of the authors quoted by them.

6. Contamination in the Home of the Customer. - This source of contamination, which is outside the purview of investigations 
dealing with the general milk supply; is too frequently overlooked when the milk for infants is under consideration. A milk of the greatest purity introduced into a dirty home or placed in the hands of careless persons may become seriously contaminated before it reaches the child for whom it was intended. Perhaps one of the most serious difficulties encountered in the preservation of milk in the poorer class of homes arises from the absence of any satisfactory place for storage of milk. In this country there are no regulations requiring the delivery of milk at a low temperature, and it is probable that the bulk of the milk supplied by dairymen in this country is delivered at a temperature at which bacterial growth is proceeding with considerable rapidity. In many homes the only safe storage place is in a cupboard adjacent to the fire, separated only from the chimney by one layer of bricks. Here the milk, already warm, becomes still warmer, and the bacteria grow at an increasing rate of speed. A small degree of contamination in the original milk may therefore produce a highly contaminated milk before such milk is taken as food. Further, contamination may arise from the use of dirty vessels and from manipulation with dirty hands, or from leaving the milk uncovered and exposed to aerial contamination. It is hardly necessary to elaborate these sources of contamination any further, as everyone will be able to supply additional personal data.

The bacterial content of raw milk, when it reaches the consumer in the course of the daily milk round, will usually have reached at least one million organisms per c.c. (a cubic centimetre is about eighteen minims), and will often be many times that figure. The high degree of bacterial contamination is not realised owing to the opacity of milk.

Houston, summing up the results of his investigations upon bacterial examinations of milk, says: "The whole history of milk from start to finish, from secretion by the cow to ingestion by the human being, is fraught with "potential " risk to the consumer. The influence of time and temperature on the microbial qualities of milk is most important. Milk is not generally consumed fresh, and commonly many hours elapse between the time of milking and the time when the milk reaches the consumer. During this period bacteria multiply in the milk at a rate which is governed chiefly by the temperature. It follows that a comparatively clean milk to start with, after a lapse of some time and under the influence of a high temperature, will yield worse results as judged by the ordinary bacteriological tests than a milk containing initially an excess of filth but which is maintained at a low temperature or which has been examined shortly after milking.' 


\section{References in Chapter XVI}

\section{The Sources of Milk Contamination}

BArton. See Hewlett and Barton.

HEWLETT AND BARTON, 'Examination of Samples of London Milk,' Journ. of Hyg. 1907, vii. 22.

Houston, Report to the L.C.C. on the Bacteriological Examination of Milk, 1905. RullmanN, "Ueber den Enzym- und Streptokokkengehalt aseptischgewonnener Milch,' Arch.f. Hyg. I9I I, lxxiii. 8I.

SavaGE, Milk and the Public Health, Igr2.

SEIBOLD, 'Ueber den Keimgehalt unter aseptischen Kautelen gewonnener Milch, und dessen Bedeutung für die Praxis,' Centralb. $f$. Bakt. Abt. I, tis I910, lv. 301. 


\section{SUMMARY OF CHAPTER XVII}

\section{ON THE PRODUCTION OF MILK AS FAR AS POSSIBLE FREE FROM CONTAMINATION}

Ir is difficult to summarise the very wide question of milk production, and it is hoped that any one interested may read the chapter dealing with this subject.

It is clearly of the greatest importance that an adequate and satisfactory milk supply should be provided for infants and young children. While it seems hardly necessary that the standard of ' certified ' milk should be reached, an improved standard on that at present prevailing is very necessary.

It has been shown in the preceding chapters that milk which has been boiled may safely be used as a food for infants, and that no disadvantage over raw milk can be traced for this purpose. On the other hand, the heating of milk should not be regarded as a means for removing micro-organisms, which have collected in large numbers in the milk, as a result of entirely unnecessary carelessness at various stages of the milk production. 


\section{CHAPTER XVII}

\section{ON THE PRODUCTION OF MILK AS FAR AS POSSIBLE FREE FROM CONTAMINATION}

DIFFERENT views are taken as to the desirability of using milk in the raw condition as a food for infants. Whatever view, however, be taken upon this subject there can be no difference of opinion as to the desirability of obtaining milk for infants in as pure a condition as is possible.

Of recent years, investigations which have been carried out both by hygienists and by agriculturists have shown the methods which it is desirable to adopt in order to secure a good milk supply for infants. The way was largely shown by the American Medical Milk Commissions, which commenced their work some thirty years ago. It is not possible in this work to enter into a detailed account of the work of these commissions, but a few notes may be made.

Primarily these commissions set out to provide milk known as 'certified ' milk, that is, it was certified by the commission as being of a prescribed standard. Certain conditions were formulated by the commissions which had to be complied with by any farmer, who was desirous of putting on sale milk of a quality which could be certified.

The main conditions required are comprised in a bacterial standard of not more than I0,000 per c.c. when delivered to the consumer, the milk to be obtained from tuberculin-tested cows, with due precautions in regard to the possible infection of the milk either by disease in the cows or in the employees on the farm. The premises were subjected to frequent inspection by officers employed by the commissions, and the milk was examined not less often than once a week for bacteria content and for chemical composition.

The chemical standards which are required by the commissioners vary slightly in the different districts of the United States. The fat content required varies fom 3.5 to 4.5 per cent., the most usual figure for the non-fatty solids being 8.5 per cent. The production of a milk of the bacterial standard required in 'certified' milk 
carries with it the necessary attention to the condition of the cows, of the sheds, etc. ; also the need for great care and cleanliness both in the milkers and in the methods of milking.

Numerous precautions must be adopted in order to obtain a milk having a bacterial content of not more than I0,000 per c.c. when delivered to the customer. This figure, although it appears to be so low as to be almost unattainable to the average farmer, has been exceeded for prolonged periods by a number of farms in the States. These farms have produced a milk, which, when tested under circumstances corresponding as closely as possible to those which would obtain at the time of the actual consumption of the milk, showed a bacterial count of 2000 per c.c. or even occasionally less. Only the main items requiring attention in order to produce milk of this quality will be dealt with.

The Milking-shed.-A separate shed should be employed for milking, or, if the cows are milked in the same shed as that in which they are kept during the rest of the day, the bedding must not be of straw or other dried herb: sawdust is preferable. Suitable sheds are required, great cleanliness is necessary, and the sheds should, as far as possible, be washed down a little while before milking. Various arrangements are in use in regard to the position occupied by the cows in the shed. It is perhaps more usual nowadays for the cows to be arranged in two rows with their heads facing one another, with space to admit of feeding between the two rows of cows, as shown in the accompanying plate. The floor slopes slightly both ways towards the trough, into which the dirty water, fæces, etc., fall or are swept and pass along it out of the shed.

The cows themselves must be free from disease, and for this purpose should be tested every six months with tuberculin and should be subjected at frequent intervals to careful veterinary examination. The frequency of such examinations varies in practice from once a week to once a month. The presence of disease cannot however be absolutely excluded even under these conditions. A cow which is tested with tuberculin in January will not react to a fresh injection within the next six months, although there is no protection whatever against the contraction of tubercle within that period should the cow be in contact with any source of this disease. During the six months' interval she may for a long period easily excrete tubercle bacilli in the milk which will pass undetected and be capable of giving rise to tubercular disease. ${ }^{1}$

The cleanliness of the cows is also a most important point, and the cow's hindquarters and udder should be cleansed before each milking. There is some divergence of practice in regard to the 


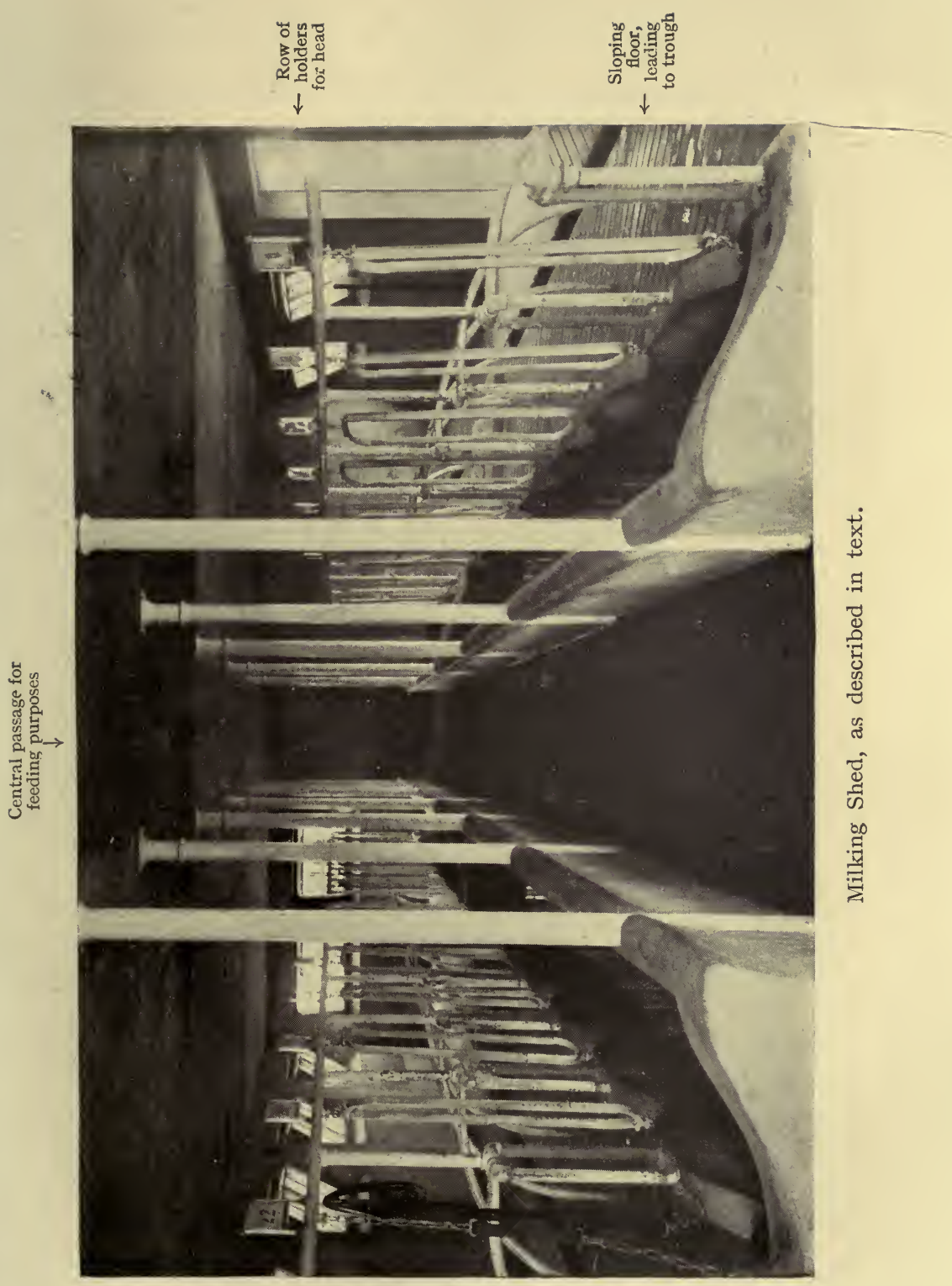



details of the method pursued. In some farms warm water is used, in others cold water. It is usual, however, not to leave any part of the cow actually wet, more especially the udder. The hindquarters should be dried down with a cloth after washing, and it is a frequent practice only to rub the udder over with a damp cloth.

The effect of the method of cleaning the udder upon the number of moulds and fungi alone was investigated by Leufven by the following means. He prepared sterile flasks, of which the bottom was covered with a medium suitable for the growth of bacteria. Three cows were used. The udder of cow No. I was washed before milking and was then dried; the udder of cow No. 2 was rubbed over before milking with a dry cloth; the udder of cow No. 3 was left untouched. The milking was then commenced, and the flasks were exposed for one second by removing the plug and holding the flasks just over the edge of the milking-bucket, both at the beginning and at the end of milking, separate flasks being used. Only the moulds and fungi, which grew upon the media were counted, and the following figures were obtained from I square centimetre of the nutrient medium:

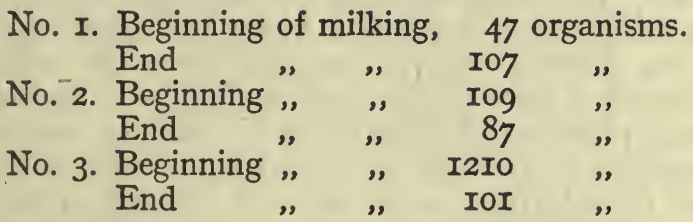

Evidently in the third case the number decreased at the end of milking owing to the major part of those present having already been passed out into the milk in the earlier phases of milking.

The milkers must be themselves free from disease, and in order to secure this condition they should be examined at relatively frequent intervals by a doctor. Any case of suspected illness in a milker should lead to his prompt exclusion from milking until either the disease is cured or the danger has been eliminated. Many epidemics which have been traced to the milk supply have been found to arise from the presence of the organisms of disease, in one of the milkers or of those handling the milk. ${ }^{1}$ The milkers should wash their hands carefully, and the nails should be kept short and clean. They should wear white overalls and caps and should not be allowed to lean their heads against the side of the cow. Their hands should be dry when milking. They must not handle the milking-pail or other 
unsterilised article after having washed their hands prior to milking. The hands should be washed between the milking of each cow. On some farms the overalls and caps worn are sterilised in steam; in others they are merely kept clean by frequent washing.

Milking machines have been invented with a view to the economy of labour and also from a desire to obviate some of the possible contamination of milk from an unclean or diseased milker. At first these milking machines were not found very satisfactory, because they did not milk the cow completely, but left behind much of the strippings, which have been shown on p. 22 to contain the highest fat content. As a result of this unsatisfactory emptying of the gland, the cows tended to go 'dry.' More recently, milking machines have been invented which are stated to milk the cows more completely, although it seems that certain cows can never be milked completely with the machine but must be stripped by hand afterwards. So long as stripping is accomplished the use of the milking machine does not appear to have any injurious effects upon the cows, nor to reduce the yield of milk. ${ }^{2}$

The milking machines are said to economise labour, as several cows can be milked at the same time, but the discussions of dairymen reported from America hardly suggests complete uniformity of opinion. Regarded from the hygienic aspect in relation to the milk supply, it seems difficult to believe that the milking machine is not a step backwards. The rubber tubes are known to be very difficult to cleanse, and flexible tubes must be used in view of the probable movement of the cows. Unless these machines are used with a care and cleanliness which can hardly be expected of anyone without a bacteriological training, it is greatly to be feared that they will prove an insidious variety of the old long-tubed feeding-bottles, now justly condemned as a death-trap for infants. A milking machine is shown in the accompanying plate. The tubes are applied to the several teats, and a reduction of pressure in the can is produced. By this means the milk is sucked into the can.

The pail used is a matter of very considerable importance. The old-fashioned open pail should not be used. A hooded pail, or one with a side aperture, gives greatly superior results, and the pail which has a side aperture only, is said to be superior to the hooded variety. These pails, which are shown in the figure, p. 275, prevent the contamination of the milk, by bacteria from the cow or from the air, which may, and usually do, fall into the milk-pail from above.

The following figures, which were obtained as a result of bacteriological experiments recently made at Birmingham at four good 
PLATE V

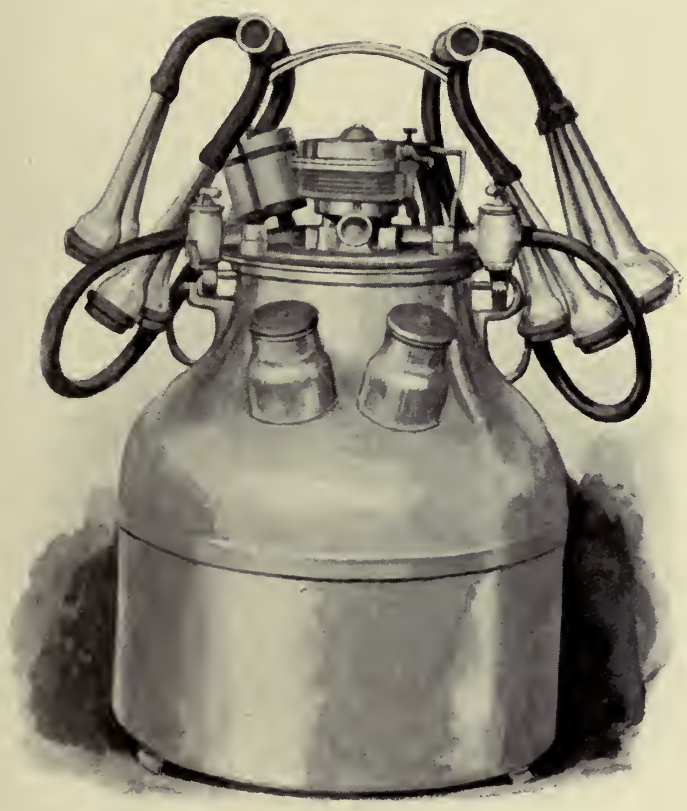

Milking Machine.

From Dr. W. G. Savage's 'Milk and the Public Health. (Macmillan \& Co., Ltd.) 

dairy farms, with the use of the ordinary open pail and of the protected pail, are of great interest.

Number of Germs in I Cubic Centimetre of Milk Samples taken by

Ordinary Milking Methods, and by Special Milking Methods.

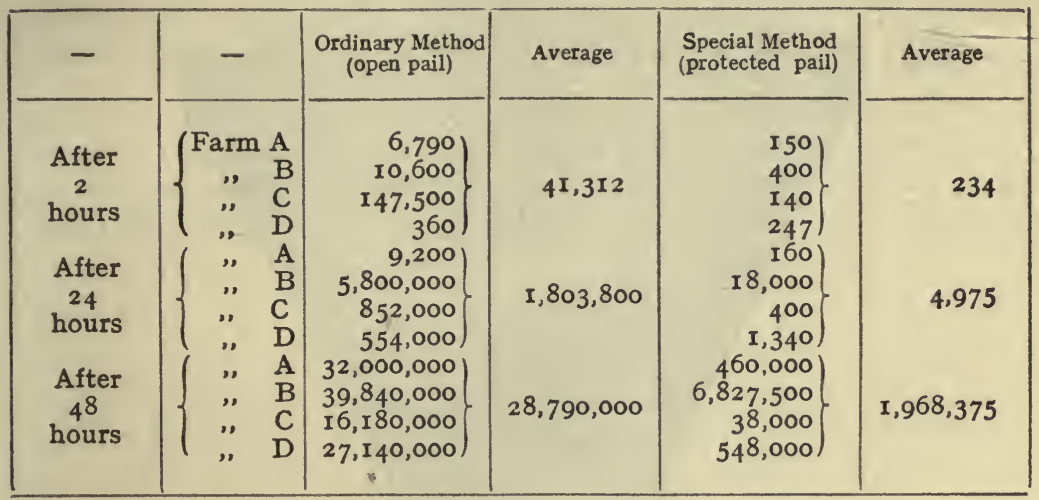

Similar data have been obtained by other experimenters.

The pails used should be sterilised, and, prior to use, should be kept covered or in such a position as not to admit of the entrance of micro-organisms from the air.
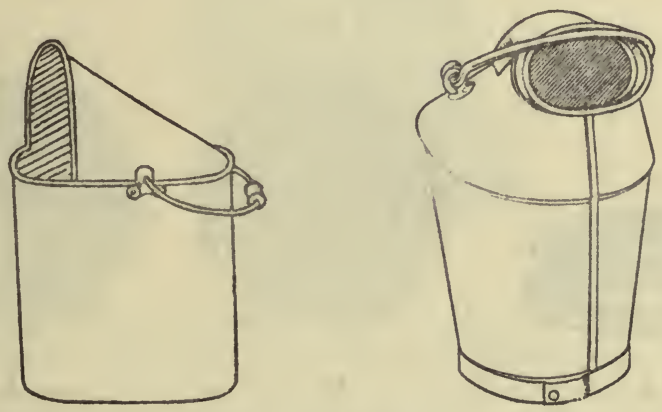

Protected Pails.

As each cow is finished milking, the milk should be removed at once to the dairy, and when it is required to maintain a low bacterial count, should be passed straight through the necessary manipulations for bottling.

The first phase in such manipulations is usu lly that of filtration. The value of this procedure appears, however, to have been considerably overrated. It is true that the gross particles of dirt 
are kept back, but these gross particles should not be present. They are usually portions of dried fæcal material which have become detached from the cow, and should be absent.

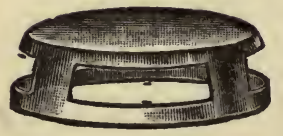

2.

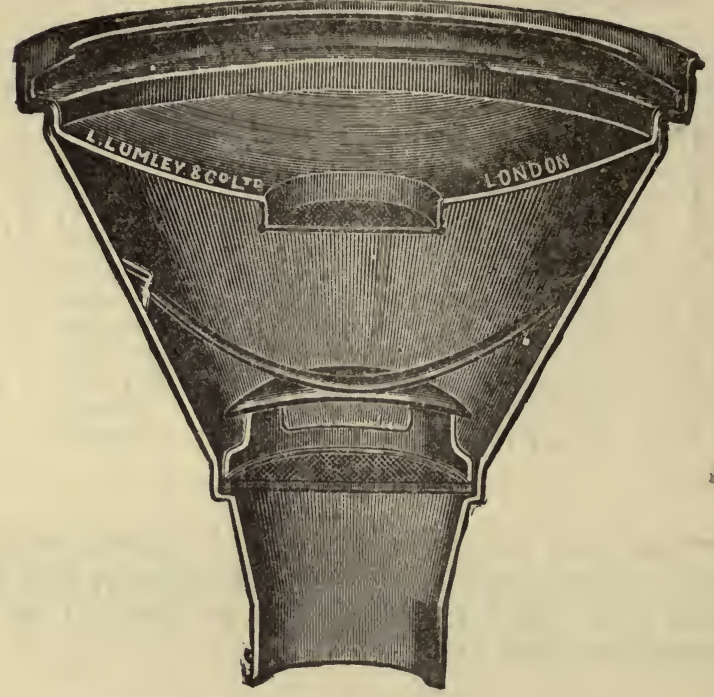

I.

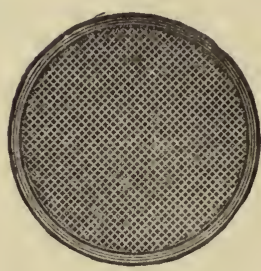

3.

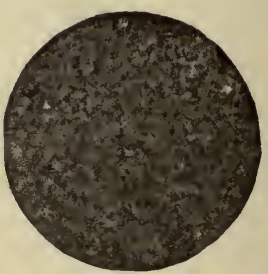

$4 \cdot$

Ulax filter. (r) Shows a section of the filter! The milk is poured on to the top part, and is filtered through a layer of woolly substance (4), which is held in position between wire-discs (3), and the piece (2), which is secured by a metal spring:

Savage gives data upon the bacterial content of milk which had been filtered and of similar samples which were not filtered. He quotes two sets of experiments, one set in which the Ulax filter was used (see figure), and another in which a different strainer was used.

The milk is said to have been collected in the ordinary way 
for purposes of general sale. In the case of the experiments with the Ulax filter, he obtained the follow ng figures:

\begin{tabular}{|c|c|c|c|c|}
\hline- & $\begin{array}{l}\text { No. of Organ- } \\
\text { isms in Unfiltered } \\
\text { Sample }\end{array}$ & $\begin{array}{l}\text { Amount of Sedi- } \\
\text { ment per roo c.c. }\end{array}$ & $\begin{array}{l}\text { No. of Organisms } \\
\text { in filtered Sample }\end{array}$ & $\begin{array}{l}\text { Amount of Sedi- } \\
\text { ment per roo c.c. }\end{array}$ \\
\hline $\begin{array}{cc}\text { Experiment } & \text { r. } \\
\text { ", } & 3 .\end{array}$ & $\begin{array}{l}242,000 \\
408,000 \\
600,000\end{array}$ & $\begin{array}{l}0.022 \\
0.06 \\
0.048\end{array}$ & $\begin{array}{l}230,000 \\
139,000 \\
760,000\end{array}$ & $\begin{array}{l}0.022 \\
0.025 \\
0.03\end{array}$ \\
\hline
\end{tabular}

Commenting on the results, Savage says: ' . . On the whole the experiments showed no bacterial advantage from filtration

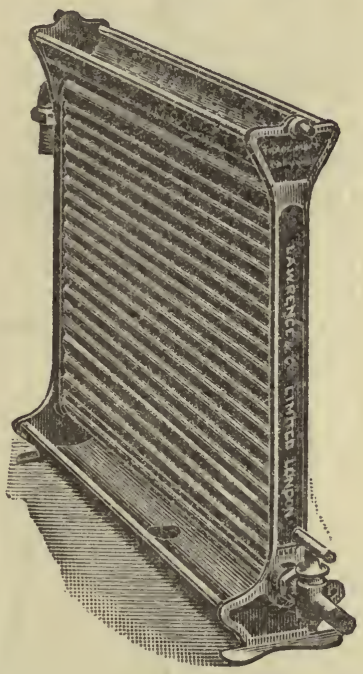

Cooler,

of the milk, and this although one of the supposed best strainers was employed, the apparatus steamed before each experiment, and the wool used for the filtration of only half a gallon of milk.'

In the case of the other filter, he says: "The strainer in this experiment consisted of wire gauze and a layer of loose flannellike material. It rapidly strained the milk. It was fixed in a shed near the cow-sheds, and the farmer had unbounded faith in its filtration properties, rather to the neglect of ordinary cleanliness in milking.' In these samples the number of bacteria in the unstrained sample was 5980 and in the strained sample 43,300. Savage says: 'In this experiment the straining added a large number of bacteria to the milk, no doubt partly from the strainer being dirty, causing a breaking down of the manure or other particles, and a better distribution of the bacteria.' 
After milking, the milk should be at once cooled. The most usual apparatus is shown in some detail in the figure on p. 277, and on a smaller scale in plate facing p. 280.

The milk is usually conducted straight from the filter to the trough on the top of the cooler. It then passes through the small holes on to the outer aspect of the cooler, passing down in a thin stream over the corrugated surface to the lower trough, whence it is

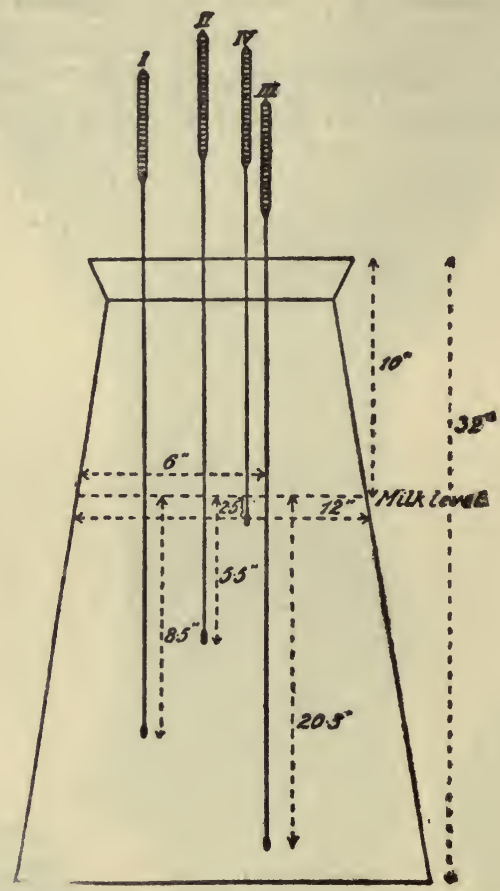

Section of churn illustrating experiments on p. 279. The position of the four thermometers is seen in the diagram.

conveyed to bottles, churns, or a pasteurising plant, as desired. The corrugated surface is formed by the outside of pipes, which contain water, the entering and exit pipes for which are shown in the figure. Except in the summer-time it is usually sufficient to employ a full stream of ordinary water, but in hot weather artificial cooling of the water by ice or the use of carbon dioxide or ammonia may be necessary.

In some dairies the cooler is covered during use so as to avoid aerial contamination during the process. When the cooling is carried out in a clean room it is probable that there is very little contamination from this source. When, however, such cooling is 
carried out in the open, this danger cannot be neglected and greatly reduces the value of the cooling. Cleanliness of the cooler is of course essential.

The object of cooling is to prevent the multiplication of bacteria, and, when properly carried out with carefully collected milk, is of great importance. The temperature of milk appears to alter slowly when in bulk, whether in the direction of a rise or fall in temperature. An effectual preliminary cooling secures a low temperature for some time afterwards. This point is well shown by the experiments carried out by Savage. A large churn containing I7 gallons of milk was employed, and four thermometers were used, the bulbs being placed at different levels in the milk, as shown in the figure on p. 278.

In one case the milk was cooled in a cool chamber to about $4.0^{\circ} \mathrm{C}$. It was then allowed to warm up gradually by being kept at room temperature. The resulting temperatures are shown below.

\begin{tabular}{|c|c|c|c|c|c|c|c|}
\hline & \multirow{2}{*}{ Time } & & \multirow{2}{*}{$\begin{array}{l}\text { Air Tempera- } \\
\text { ture (Centi- } \\
\text { grade) }\end{array}$} & \multicolumn{4}{|c|}{ Milk Temperature (Centigrade) } \\
\hline & & & & Thermometer & $\begin{array}{c}\text { Thermometer } \\
\text { II }\end{array}$ & $\begin{array}{c}\text { Thermometer } \\
\text { III }\end{array}$ & $\underset{\text { IV }}{\text { Thermometer }}$ \\
\hline 12.0 & noon & . & $19 \cdot 0$ & 4.5 & 5.0 & $3^{\circ} 0$ & $6 \cdot 0$ \\
\hline I.0 & P.M. & . & 19.0 & $6 \cdot 7$ & $7 \cdot 7$ & $3 \cdot 5$ & $9 \cdot 4$ \\
\hline I.30 & , & . & $2 I \cdot I$ & $7 \cdot 7$ & $9 \cdot 0$ & $4 \cdot 5$ & $9 \cdot 4$ \\
\hline 2.30 & ," & . & $2 I \cdot I$ & $8 \cdot 6$ & $9 \cdot 4$ & 6.0 & 10.6 \\
\hline 3.0 & $"$ & - & $20 \cdot 0$ & $10 \cdot 6$ & $10 \cdot 0^{\top}$ & $6 \cdot 4$ & $10 \cdot 6$ \\
\hline $4 \cdot 0$ & ", & - & $19 \cdot 4$ & II $\cdot 7$ & II $\cdot 9$ & $7 \cdot 7$ & II $\cdot 0$ \\
\hline 5.0 & ", & . & 19.43 & II 9 & $12 \cdot 5$ & $8 \cdot 3$ & II $\cdot 7$ \\
\hline 6.30 & & - & 19.4 & $13 \cdot 1$ & 13.6 & $9 \cdot 4$ & $12 \cdot 8$ \\
\hline
\end{tabular}

In another case the milk, instead of being cooled, was warmed to about $55^{\circ} \mathrm{C}$. The following table shows the temperatures recorded :

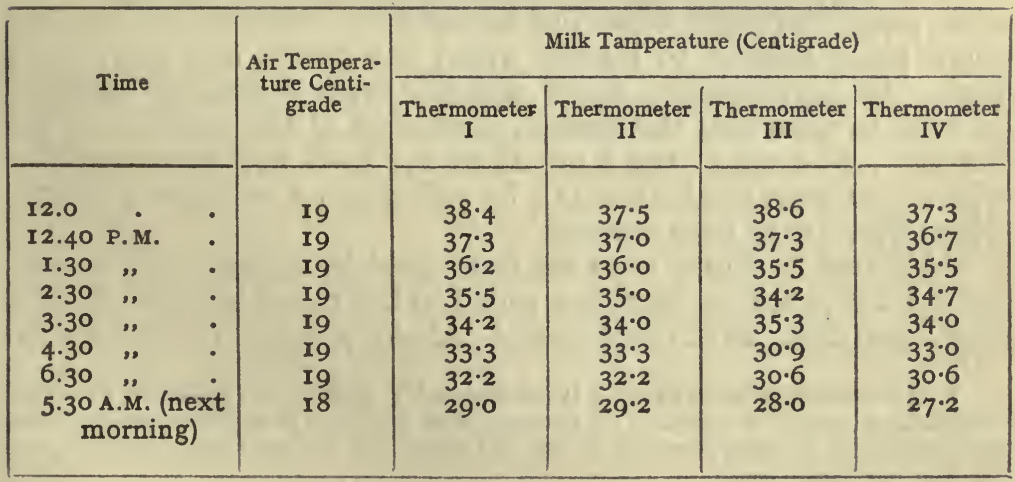


Savage gives some interesting experiments upon the temperature of milk in churns on its way to the customer. These experiments demonstrate the importance of a thorough cooling on the farm in view more especially of the absence of cooling facilities later on.

In the first experiment the milk in the churn was warmed until the temperature after stirring reached $37^{\circ} 6^{\circ} \mathrm{C}$. The milk was then sent out in the milk cart, covered with an ordinary canvas churn cover to protect it from the direct rays of the sun, and was driven all over London. It left the dairy at II.3O A.M., the temperature of the air being $I 9^{\circ} \mathrm{C}$. It returned to the dairy at 4 P.M., the air temperature being then $2 \mathrm{I}^{\circ} \mathrm{C}$. The temperature of the milk, however, had only fallen to $30.8^{\circ} \mathrm{C}$.

In the next experiment the initial average temperature of the milk was reduced to $6.4^{\circ} \mathrm{C}$. It left the dairy at II.40 A.M. under similar conditions to the above. The initial air temperature was then $18.6^{\circ} \mathrm{C}$. The milk was brought back to the dairy at 4 P.M., the air temperature being then $2 \mathrm{I}^{\circ} 6^{\circ} \mathrm{C}$. The temperature of the milk, however, was only $10.8^{\circ} \mathrm{C}$., that is to say, in four and a half hours the temperature of the milk had only been increased by $4.4^{\circ} \mathrm{C}$., although the air temperature throughout was much higher.

Evidently the alterations in the temperature of milk take place very slowly, owing no doubt to slowness of convection.

The milk, after cooling, should be at once run into sterile receptacles. If into bottles, these should have been washed in hot water and soda, and after satisfactory rinsing should be exposed to the action of steam, and be kept mouth downwards until required for the next service. These bottles should be sealed on the farm at once, after filling, by means of a cap, and if considered desirable by means of some apparatus which will show whether the bottle has been kept intact or whether it has been opened after filling. This last is insisted on by the American Medical Milk Commissions.

After the milk has been bottled it should be transported cool to the dairyman and delivered cool to the customer.

The apparatus used for bottling is shown in Plate V. The milk passes straight from the cooler to a tank, with numerous small pipes leading to bottles which are placed one below each pipe. An arrangement exists which allows a definite quantity of milk to pass into the bottles, according to the capacity of the bottles. As soon as the e are filled the milk flow stops and the whole tray with the bottles can be pulled to an adjacent platform, where they are at once covered.

Milk sent in churns from the farm must be subsequently bottled by the dairyman, or be taken round in the churn and delivered in small quantitie to the customers. ${ }^{1}$ At every stage of its manipula-

1 The contamination arising from the entry of dust through the so-called ventilation holes in the lids of churns, and the risk of contamination from manipulation on the journey or at the dairy are too well known to require further mention here. 
PLATE VI.

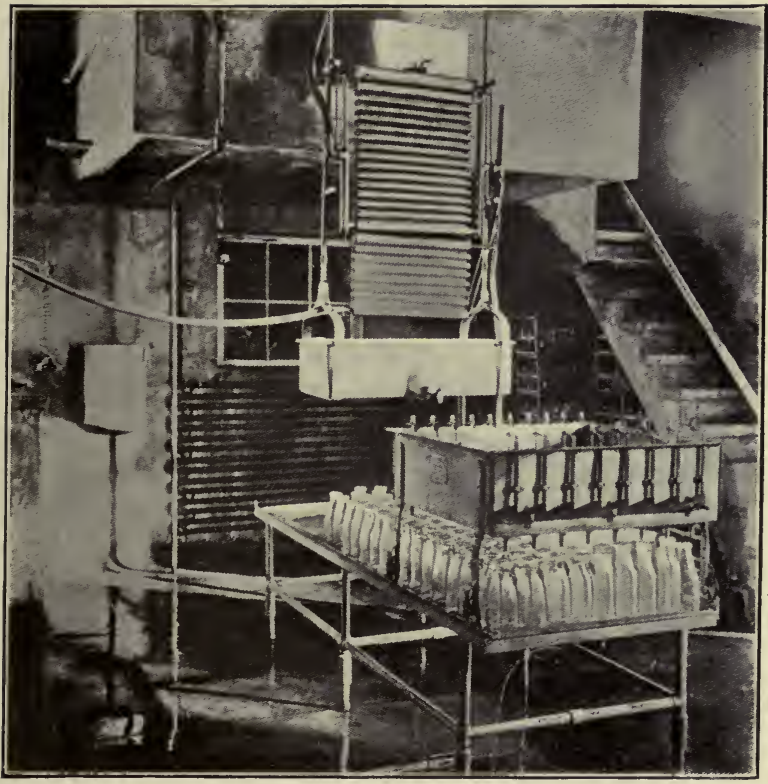

Bottling Plant. The cooler is shown above the apparatus for bottling. The milk passes straight from the cooler to the tank placed above the bottles. 

tion it will receive a fresh supply of micro-organisms, many of them doubtless from the air, and a certain number will be added owing to the difficulty of using strict cleanliness in every detail when so many processes are involved. Moreover, it is almost impossible for the temperature to be kept low throughout.

In this country the transit of milk by bottles is extremely expensive, and is in fact prohibitive for the general milk supply at the present time. There are no means for keeping milk (sent on a large scale) cool during transit, and there can be no doubt that the temperature is often fairly high for a considerable period before the milk reaches the dairy, especially when delivered to large towns.

Although it is not possible for all the precautions enumerated above to be adopted for the general milk supply without raising the cost of production to so high a figure as to be prohibitive for the general population, much improvement in the bacterial content of the general milk supply could be effected without any appreciable increase in cost. For instance, the cleanliness of the milkers, and in many respects of the cows and of the sheds in which the cows are kept, would not entail any appreciable additional labour when once the practice was started. The provision of satisfactory pails, which have been shown to exercise a great effect upon the bacterial content of the milk, is a very small item in the total cost of milk production. Churns have been manufactured having an air chamber round the milk, which aids very greatly in keeping the milk at a low temperature during transit, if the milk has been properly cooled before being put on the rail. These are perhaps a somewhat expensive item, but doubtless could be supplied for at least a part of the milk supplied by a number of farms even where the total cost of production cannot be raised, and yet allow a sufficient margin of profit to the farmer.

A bacterial standard of I0,000 per c.c. is impracticable for the general milk supply, but there is no doubt that a standard of some tens of thousands only per c.c. could easily be attained if reasonable precautions were taken. It is of course possible to kill the bacteria by various methods, and it is advisable that all milk used should be heated before use, but this in no way alters the need for obtaining a reasonably low initial bacterial standard. So long, however, as the public continues to be satisfied with a milk containing an immense number of micro-organisms, so long, presumably, will the dairy farmer continue his out-of-date and dirty methods. If the public realised that the number of bacteria present in the average sample of market milk is so great that, were the milk transparent, it would be cloudy as the result of the presence of these organisms, more efforts might be directed towards the production of a milk having a low bacterial standard. The heating of milk, which kills this vast number of organisms, does not remove the dead bodies of the bacteria which have been present, nor does it destroy any harmful chemical sub- 
stances which may have been formed by them. Any actual decomposition of the constituents of the milk which may occur as the result of bacterial action is probably negligible and need not be seriously considered.

\section{References in Chapter XVII}

On the Production of Milk as far as possible free from Contamination

American Medical Milk Commissions, Reports of.

DÉLÉPINE, ' Report upon the Prevalence and Sources of Tubercle Bacilli in Cows' Milk,' Report of Medical Officer to L.G.B. I908-9.

LEUFVEN, 'The Effect of a Clean Udder on the Bacteria in the Milk.' Quoted without reference in Milchw. Zentralb. I9I4, p. 302.

MaIrs, 'Test of a Mechanical Cow Milker,' Penn. State College Agric. Exp. Stat. Bull. 85, 1908.

Savage, ' Report upon the Bacterial Measurement of Milk-pollution,' Report of Medical Officer to L.G.B. I909-IO. 


\section{CHAPTER XVIII}

\section{ON THE TYPES OF BACTERIA COMMONLY FOUND IN MILK AND THEIR THERMAL DEATH-POINTS}

THE varieties of bacteria present in milk will occur in innumerable combinations, which will evidently depend upon the source from which they are derived, i.e. air, cow, milker, vessels, etc. Roughly, however, they can be classified into several main groupings according to the action they display upon certain substances. The most usual groupings are as follows : (I) Acid-forming bacteria,

(2) those forming acid and gas with coagulation of milk protein,

(3) peptonising bacteria, and (4) inert bacteria.

Milk is a good medium for the growth of the majority of bacteria except where the growth of one organism is antagonised by that of another variety.

In the early hours after milk has been collected there is an apparent decrease in the total number of organisms found. This has already been referred to on pp. II4-20 in connection with the alleged bactericidal properties of milk. It was there shown that this decrease is probably apparent rather than real, and due to the agglutination of the bacteria by the action of the agglutinins, which are found in milk. When milk, examined in the early hours after milking, is violently shaken so as to break up the clumps of bacteria, the number of colonies found on plating out samples of the milk does not suggest that there has been any actual decrease in the number of bacteria present. Some six hours after milking an increase in the bacterial content commences. The predominating growth appears usually, if not always, in the acidforming organisms. The acid thus produced renders the medium an unsuitable one for the growth of certain other organisms, which become gradually reduced in numbers. The rate of this reduction will depend upon the relative proportion of the bacteria present and the temperature at which the milk is kept.

The increase in the number of acid-forming bacteria has been investigated by a number of workers, but is well shown in the following table, taken from the work of Conn and Stocking. Similar results were obtained by Conn and Esten. 


\begin{tabular}{|c|c|c|c|c|}
\hline Time after Milking & $\begin{array}{c}\text { Total Bacteria } \\
\text { per c.c. }\end{array}$ & $\begin{array}{l}\text { Acid-forming } \\
\text { per c.c. }\end{array}$ & $\begin{array}{l}\text { Liquefying } \\
\text { per c.c. }\end{array}$ & $\begin{array}{l}\text { Per cent. of } \\
\text { Acid-forming }\end{array}$ \\
\hline Fresh & 12,550 & 1,250 & 200 & Io \\
\hline Three hours & 12,250 & 2,000 & 200 & I6 \\
\hline Six hours . & 19,650 & 2,250 & 800 & 23 \\
\hline Nine hours. & 56,900 & 20,250 & $55^{\circ}$ & 36 \\
\hline Twelve hours & I I 4,250 & $\begin{array}{c}68,400 \\
\text { (Practically } \\
\text { all B.A.Lact.) }\end{array}$ & 1,900 & 60 \\
\hline
\end{tabular}

It is so well known that bacteria multiply more readily in a warm atmosphere than in a cold as to render it unnecessary to lay stress upon this point. A certain amount of work has been carried out in regard to the optimum temperature of the multiplication of different strains of bacteria, and there is some reason to believe that this temperature varies slightly for different organisms. There is no doubt that until the optimum temperature is reached the rate of growth becomes increasingly rapid. Some figures prepared by myself in relation to the growth of $\mathrm{B}$. coli at different temperatures are illustrative of this fact and are given below: ${ }^{1}$

Growth of $B$. coli at Temperatures $20-42^{\circ} \mathrm{C}$.

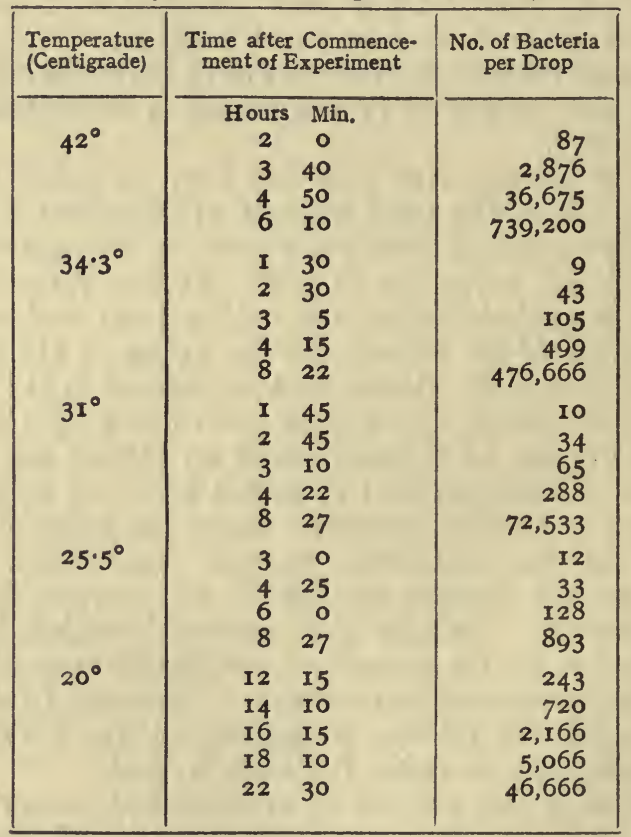

1 Since writing the above, figures have been published by Slator for Bacillus Acidi Lactici. 
Bacterial growth does not, however, entirely cease even at a temperature of $0^{\circ} \mathrm{C}$, as has been shown by the work of Pennington and others.

The work of St. John and Pennington shows also that bacteria multiply more readily in milk after it has been heated than before. This fact has been shown by a number of authors, reference to which will be found in the paper mentioned.

The rate of development of bacteria in milk will depend upon the temperature at which the milk is kept on its transit from the farm to the consumer. Moreover, where milk is pasteurised on a large scale, any subsequent contamination will tend to produce a rapid rise in the bacterial content of the milk which has been thus treated.

There is no direct evidence as to the effect upon infants of feeding them with milk containing a high bacterial content, but the risk of pathogenic organisms is clearly increased when the total number is great. Moreover, it is well known that deleterious results are produced by feeding animals on large numbers of organisms even though these are of harmless types. Milk having a high bacterial content must be regarded as contaminated food, and general experience shows the risk of using such material.

The investigations published by Park and Holt, and referred to in detail on pp. I92-3, illustrate this point.

The remedy for existing contamination in a food material, lies in heating it before it becomes harmful, and this is the usual method employed with milk. The possibility of the presence of toxic substances formed by the bacteria must be considered, but there is comparatively little evidence available on this subject. The only work in regard to the progress of children in relation to the bacterial content of milk appears to be another section of the work of Park and Holt. The work formed a part of the comprehensive investigation undertaken in New York City in the summers of IgOI and I902. The children were visited in their homes by physicians appointed for the purpose, the method of feeding being noted, together with the progress of the children and the general home conditions. In cases where it was desired to study the effect of certain forms of milk, as in the work about to be described, arrangements were made for the supply of that milk to the people. The experiments are of sufficient interest to quote them somewhat freely.

Efforts were made to secure comparable conditions in the various groups of children, but the difficulties connected with delivery of milk, etc., rendered it necessary to keep the groupings in different parts of the city. It happened that the children fed on the cheap store milk lived under worse home conditions than those fed on pure bottled milk. The table on the next page shows the figures obtained.

The authors summarise the results as follows: "There is nothing in the observations to show that fairly fresh milk from healthy 
cows, living under good hygienic conditions, and containing, on some days, when delivered, as many as 200,000 bacteria per c.c.,

Table showing the results of feeding during July and August, Igor, in tenement houses, of III bottle-fed iufants under one year of age, and of 47 bottle-fed infants between one and two years of age with milk from different sources, and the number of bacteria present in the milk.

\begin{tabular}{|c|c|c|c|c|c|c|c|c|c|c|}
\hline \multirow{3}{*}{ Character of Milk } & \multicolumn{5}{|c|}{ Infants under One Year } & \multicolumn{5}{|c|}{ Infants over One Year } \\
\hline & \multirow{2}{*}{ 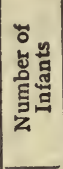 } & \multirow{2}{*}{ 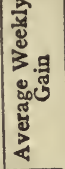 } & \multicolumn{2}{|c|}{ Diarrhcea } & \multirow{2}{*}{ 芭 } & \multirow{2}{*}{ 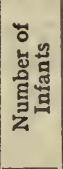 } & \multirow{2}{*}{ 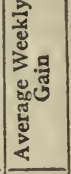 } & \multicolumn{2}{|c|}{ Diarrhœe } & \multirow{2}{*}{$\begin{array}{l}\text { 营 } \\
\text { مू }\end{array}$} \\
\hline & & & 苛 & 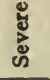 & & & & 苛 & 岕 & \\
\hline $\begin{array}{l}\text { I. Pure milk boiled and } \\
\text { modified at dispensary } \\
\text { or stations; given outin } \\
\text { small bottles. Milk be- } \\
\text { fore boiling averaged } \\
20,000 \text { bacteria per c.c. } \\
\text { after boiling } 2 \text { per c.c. }\end{array}$ & $4 \mathrm{I}$ & $\begin{array}{c}\text { Ozs. } \\
3\end{array}$ & IO & & $\mathrm{I}^{1}$ & 一 & Ozs. & - & - & - \\
\hline $\begin{array}{l}\text { 2. Pure milk, } 24 \text { hours old, } \\
\text { sent in quart bottles to } \\
\text { tenements, heated and } \\
\text { modified at home, } \\
20,000-200,000 \text { bacteria } \\
\text { per c.c. when delivered. }\end{array}$ & 23 & $4 \frac{1}{6}$ & 8 & 5 & 0 & 24 & $4 \frac{1}{2}$ & 8 & 2 & 0 \\
\hline $\begin{array}{l}\text { 3. Ordinary milk, } 36 \text { hours } \\
\text { old, from a selected } \\
\text { group of farms, kept } \\
\text { cool in cans during } \\
\text { transport; I,000,000- } \\
25,000,000 \text { bacteria per } \\
\text { c.c., heated and modi- } \\
\text { fied at home before } \\
\text { using. }\end{array}$ & 18 & 4 & 6 & 6 & $I^{2}$ & 12 & 4 & $\mathbf{I}$ & 2 & 0 \\
\hline $\begin{array}{l}\text { 4. Cheap milk, } 36-60 \text { hours } \\
\text { old, from various small } \\
\text { stores, derived from } \\
\text { various farms, some } \\
\text { fairly clean, some } \\
\text { very dirty; } 400,000- \\
\text { I75,000,000 bacteria } \\
\text { per c.c. }\end{array}$ & $2 I$ & $t$ & 4 & 13 & $4^{8}$ & 7 & $\frac{1}{3}$ & I & 3 & 0 \\
\hline
\end{tabular}

had any bacteria or any products due to bacteria that remained deleterious after the milk was heated to near the boiling-point.

1 This infant died from enteritis and toxemia.

2 This infant died of pneumonia. There had been no severe intestinal disorder noted.

3 One of the four had pertussis, the remaining three died from uncomplicated enteritis. 
'On the other hand, it is possible that certain varieties of bacteria may, under conditions that are unsanitary, find entrance to milk and survive moderate heat or may develop poisonous products resistant to heat in sufficient amount to be harmful, even when they have accumulated to less than 200,000 per c.c.

'Turning now to the results of feeding with milk which has been heated and which before sterilisation contained from I,000,000 to $25,000,000$ bacteria per c.c., averaging about I5,000,000, though obtained from healthy cows living under fairly decent conditions and kept moderately cool in transit, we find a distinct increase in the amount of diarrheal diseases. Though it is probable that the excessive amount of diarrhœa in this group of children was due to bacterial changes which were not neutralised by heat or to living bacteria which were not killed, yet it is only fair to consider that the difference was not very great, and that the infants of this group were under surroundings not quite as good as those on the purer milk.

' Finally, we come in this comparison to the infants who received the cheap store milk pasteurised. This milk had frequently to be returned because it curdled when boiled, and contained, according to the weather, from $4,000,000$ to $200,000,000$ bacteria per c.c. In these infants the worst results were seen. This is shown not only by the death-rate, but by the amount and the severity of the diarrheal diseases, and the general appearance of the children as noted by the physicians. Although the average number of bacteria in the milk received by this group is higher than that received by the previous group, the difference in results between this group and the previous one can hardly be explained by the difference in the number of bacteria. The varieties of bacteria met with in this milk were more numerous than in the better milk, but we were unable to prove that they were more dangerous. Probably the higher temperature at which the milk was kept in transit and the longer interval between milking and its use allowed more toxic bacterial products to accumulate.'

It has been shown in preceding chapters that it is practically impossible to obtain milk which can be guaranteed free from germs of disease. The conditions under which 'certified' milk is produced could hardly be made stricter, and yet virulent streptococci and tubercle bacilli have been found in this milk. ${ }^{1}$ The remedy can only be found in heating milk before use, and it becomes important to consider the temperature at which the more important organisms liable to be present in milk are destroyed.

On the Thermal Death-points of Micro-organisms in Milk.Under this heading it will be necessary to consider the temperature at which special organisms of pathogenic type are destroyed, and also the general effect of different temperatures upon the large bacterial

${ }^{1}$ Cp. p. 249 and footnote p. 252. 
flora of comparatively harmless organisms, which have gained access to the milk in the process of its manipulation.

The Thermal Death-point of Tubercle Bacilli.-Much work has been done upon the temperature to which milk must be raised in order to destroy tubercle bacilli when they are present, and considerable diversity of results has been obtained.

Rosenau has summarised the results of investigations of numerous observers, and the table on p. 289 is taken from his work. ${ }^{1}$

It seems hardly possible, from a consideration of the results shown in that table, to arrve at a definite temperature at which tubercle bacilli are killed, but it appears reasonable to suppose that a temperature of $60^{\circ} \mathrm{C}$. for twenty minutes may be sufficient, or a

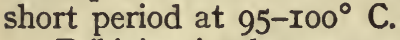

Délépine in the course of his investigations found that tubercle bacilli were still living in milk which had been dried by passing over cylinders heated to $138-140^{\circ} \mathrm{C}$. He points out, however, that this temperature is not reached by the milk as it passes between the rollers, and he ascertained by experiment, that the greater part of the milk must have remained at a temperature below $100^{\circ} \mathrm{C}$., and he says that in all probability the maximum temperature reached by every part of the milk did not exceed $96^{\circ} \mathrm{C}$., and that the duration of the exposure to that temperature probably never exceeded $3 \cdot 3$ seconds.

The Thermal Death-point of Streptococci and other Organisms.Ayers and Johnson (I) investigated the temperature necessary to kill various strains of streptococci. They found that the streptococci normally occurring in milk showed a greater resistance to temperature than those obtained from the udder or from the mouth or fæces of the cow. After examining the death-point of I39 strains they found that-

89 or $64^{\circ} 03$ per cent. survived 30 minutes heating at $140^{\circ} \mathrm{F}$.,

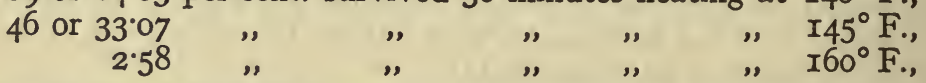

while all were killed at a temperature of $165^{\circ} \mathrm{F}$. for the same period.

Rosenow found that the virulent streptococci obtained from an epidemic of sore throats were killed by a temperature of $45^{\circ} \mathrm{C}$. or approximately $\operatorname{II} 3^{\circ} \mathrm{F}$. The non-virulent ones, however, survived a temperature of $60^{\circ} \mathrm{C}$. or $140^{\circ} \mathrm{F}$. His experiments were carried out in milk.

The thermal death-points of numerous other pathogenic organisms, e.g. B. typhosus, B. diphtherae, B. cholorae, B. dysenterae, and Micrococcus melitensis, were investigated by Rosenau with a view to determining the temperature to which milk must be raised in order to render it safe. The general conclusion reached by him was that ' milk heated to $60^{\circ} \mathrm{C}$. and maintained at that

1 For reference to the authors quoted in this table, see Rosenau's paper. 


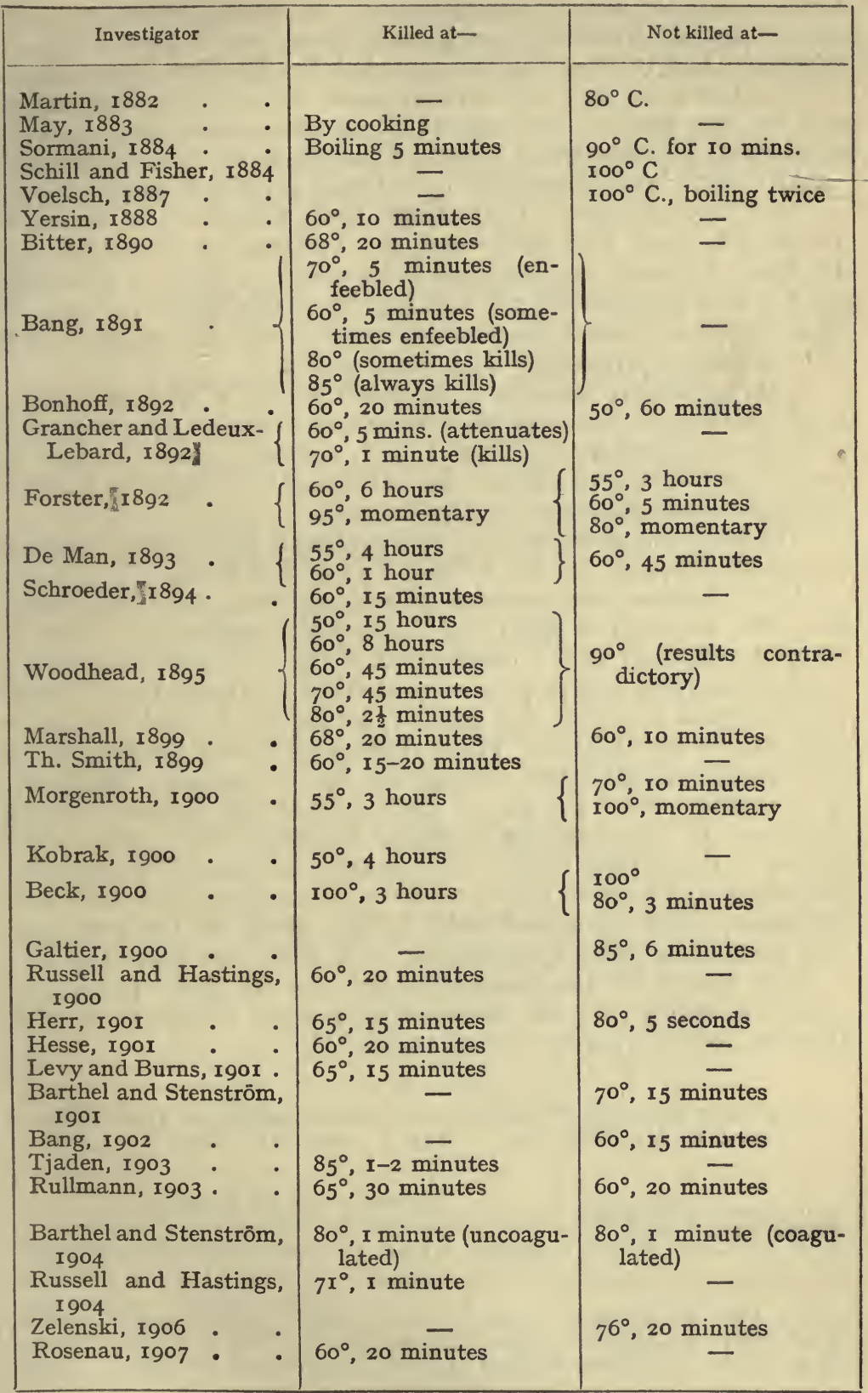


temperature for twenty minutes may be considered safe so far as conveying infection from the micro-organisms tested is concerned.' The micro-organisms included the Bacillus Tuberculosis.

For the most part the investigations which have been carried out on the thermal death-point of bacteria in milk have been conducted entirely with a view to determining the lowest temperature to which it was necessary to heat milk in order to render it safe.

The investigations, which have been described in detail in Chap. XI, show that milk used for the feeding of infants may be raised without disadvantage for a short, or even a prolonged period, to a temperature which is approximately $100^{\circ} \mathrm{C}$., or $212^{\circ} \mathrm{F}$. It is shown on p. 295 that this temperature is not reached when milk is heated surrounded by a water-jacket.

The conclusion which may be fairly made, is that milk when used as a food in the home may be heated to $100^{\circ} \mathrm{C}$. approximately without any detrimental effect. Such heating, moreover, acts as an efficient safeguard against the causation of disease by harmful organisms accidentally present in the milk.

The destruction of bacteria in the general milk supply assumes a slightly different character from that in the home.

In the former case economy of fuel, appearance of the creamline, etc., all tend to keep the temperature employed, as low as may be consistent with a destruction of the main mass of bacteria.

The bacteria which survive pasteurisation have been studied in great detail by Ayers and Johnson (2) for the United States Department of Agriculture. These authors show that the majority of organisms are killed within the first half-hour of heating. Reduction does continue when the milk is heated for longer periods, but this reduction is proportionately small compared with that which occurs in the earlier period. The greater number of bacteria are destroyed in the first half-hour even at comparatively low temperatures. This is shown both in the figure on the next page and also in the tables appertaining to it, which are given below.

The figures for the number of bacteria are given below, and show the efficacy of the comparatively small difference of temperature existing between $57.2^{\circ}$ and $60^{\circ} \mathrm{C}$.

Table showing Bacterial Reduction during Pasteurisation for Three Hours at

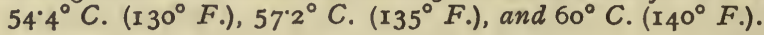

\begin{tabular}{|c|c|c|c|c|c|c|c|c|}
\hline \multirow{2}{*}{\multicolumn{2}{|c|}{$\begin{array}{l}\text { Temperature of } \\
\text { Pasteurisation }\end{array}$}} & \multirow{2}{*}{$\begin{array}{l}\text { Bacteria per } \\
\text { c.c. in Raw } \\
\text { [Milk }\end{array}$} & \multicolumn{6}{|c|}{ Bacteria per c.c. in Milk Pasteurised for } \\
\hline & & & t hour & I hour & I hours & 2 hours & $2 \frac{1}{2}$ hours & 3 hours \\
\hline $\begin{array}{c}\text { C. } \\
54^{\circ} 4^{\circ} \\
57^{\circ} 2^{\circ} \\
60 \cdot 0^{\circ}\end{array}$ & $\begin{array}{l}\text { F. } \\
130^{\circ} \\
135^{\circ} \\
140^{\circ}\end{array}$ & $\begin{array}{l}2,530,000 \\
2,530,000 \\
2,330,000\end{array}$ & $\begin{array}{l}75,000 \\
63,000 \\
20,800\end{array}$ & $\begin{array}{l}27,600 \\
15,400 \\
19,400\end{array}$ & $\begin{array}{l}19,400 \\
12,600 \\
14,100\end{array}$ & $\begin{array}{r}13,200 \\
8,400 \\
12,400\end{array}$ & $\begin{array}{r}12,300 \\
7,900 \\
10,300\end{array}$ & $\begin{array}{l}9,200 \\
5,600 \\
8,700\end{array}$ \\
\hline
\end{tabular}


Ayers and Johnson also studied the rate of destruction of different groups of organisms-acid-forming, peptonising, inert, and alkaliforming-and showed that the effect produced upon these by heat differs very considerably.

The nature of the organisms surviving pasteurisation is shown in Plate $\mathrm{V}$, the total numbers of bacteria at different times in the same experiment being given in the table on p. 292.

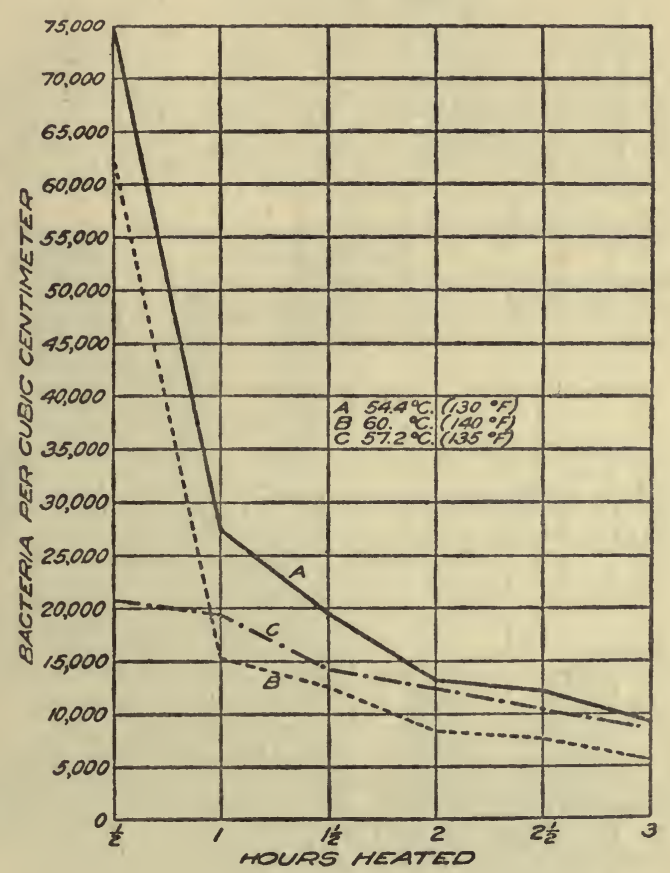

Figure showing the Bacterial Reduction during Pasteurisation for Three Hours at $54^{\circ} 4^{\circ} \mathrm{C}$. $\left(130^{\circ} \mathrm{F}.\right), 57^{\circ} 2^{\circ}$ C. $\left(135^{\circ}\right.$ F. $)$, and $60^{\circ} \mathrm{C}$. (I $40^{\circ} \mathrm{F}$.).

The figure shows that the acid-forming organisms survive in greater number than any of the other types. The same result was obtained in a large number of experiments to which it is impossible to refer here.

The authors remark that the change in the group percentages which is shown between three and a half and four hours is undoubtedly due to experimental error. 
This table shows the reduction in the total number of bacteria in the experiment shown in Plate V.

Table showing Bacterial Reductions during Pasteurisation for Six Hours at $62 \cdot 8^{\circ}$

C. $\left(\mathrm{I} 45^{\circ} \mathrm{F}\right.$.), the estimations being made every half-hour.

\begin{tabular}{|c|c|c|c|}
\hline $\begin{array}{c}\text { I. } \\
\text { Iength of } \\
\text { Pasteurisation } \\
\text { (hours) }\end{array}$ & $\begin{array}{c}\text { II. } \\
\text { Bacteria per cubic } \\
\text { centimetre }\end{array}$ & $\begin{array}{c}\text { I-contd. } \\
\text { Length of } \\
\text { Pasteurisation } \\
\text { (hours) }\end{array}$ & $\begin{array}{c}\text { II-contd. } \\
\text { Bacteria per cubic } \\
\text { centimetre }\end{array}$ \\
\hline 0 & $27,000,000$ (Raw) & & \\
\hline I & 46,000 & $3 \frac{1}{2}$ & 32,900 \\
I & 46,000 & 4 & 31,200 \\
I $\frac{1}{2}$ & 45,000 & $4 \frac{1}{2}$ & 44,000 \\
2 & 65,000 & 5 & 35,700 \\
$2 \frac{1}{2}$ & 62,000 & $5 \frac{1}{2}$ & 39,000 \\
3 & 54,000 & 6 & 34,500 \\
\hline
\end{tabular}

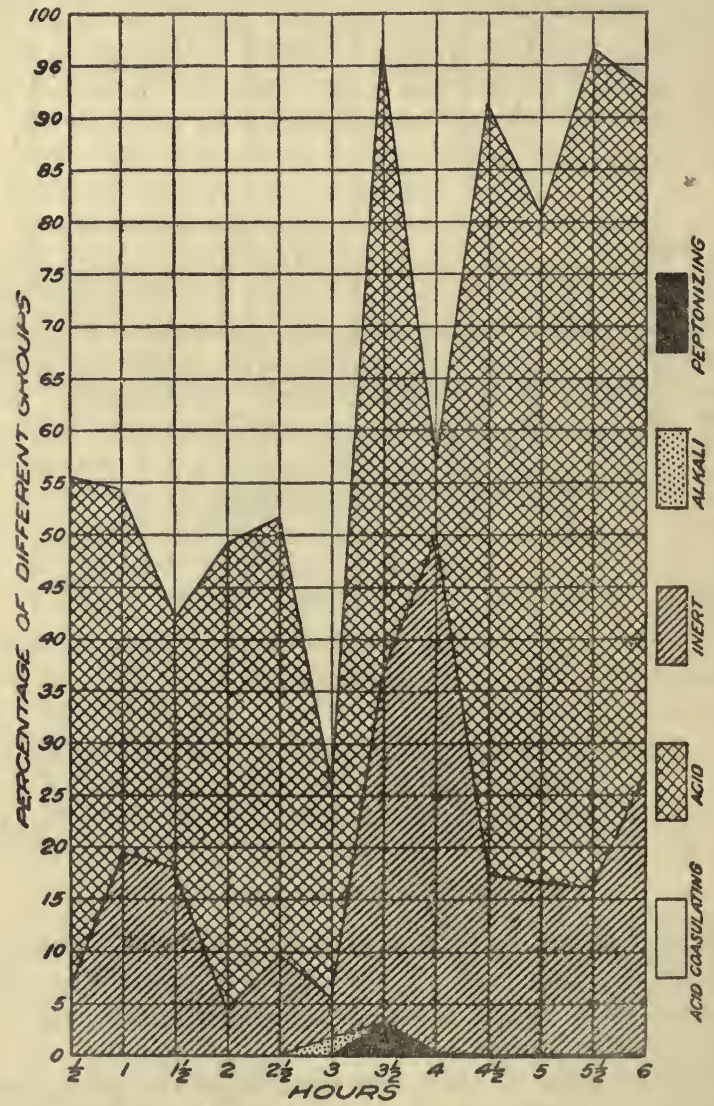

Showing the relative percentages of the different groups of organisms and the changes which occur in them on pasteurisation. (By per. mission of the Department of Agriculture, Washington.) 
Numerous other observations upon the effect of heat on the bacterial content of milk have been published, but a detailed consideration appears to be somewhat beyond the scope of the present work, and references will be found in the works mentioned.

\section{REFERENCES IN CHAPTER XVIII}

\section{Bacteria in Milk}

Ayers and Johnson. (r) 'Ability of Streptococci to Survive Pasteurisation;' Journ. of Agric. Res. I9I 4, ii. 32I. (2) 'A Study of the Bacteria which Survive Pasteurisation,' Bureau of Animal Ind., Bull. 16r, I9r3.

Conn AND Esten. (I) 'Qualitative Analysis of Bacteria in Market Milk,' and (2) 'Growth of Bacteria in Normal Milk,' Rockefeller Inst. Reprints, I904, vol. i.

Conn AND Stocking, 'Studies on the so-called Germicidal Action of Milk,' Rev. gén. du Lait, I $902-3$, ii. 265 and 298.

DELÉPINE, Report to L.G.B. upon the Effects of certain Condensing and Drying Processes used in the Preservation of Milk upon its Bacterial Contents, New Series, No. 97, I914.

Esten. See Conn and Esten.

Holr. See Park and Holt.

Johnson. See Ayers and Johnson.

LANE-Claypon, ' Multiplication of Bacteria and the Influence of Temperature and some other Conditions thereon,' Journ. of Hyg. I909, ix. 239.

PARK AND HOLT, ' Report upon the Results with Different Kinds of Pure and Impure Milk in Infant Feeding in Tenement Houses and Institutions of New York City,' Arch. of Ped., December I 903.

Pennington and Others, 'Bacterial and Enzymic Changes in Milk and Cream at $0^{\circ}$ C.,' Journ. of Biol. Chem. 1913, xvi. 33 I.

Pennington. See St. John and Pennington.

RosENAU, 'The Thermal Death-points of Pathogenic Micro-organisms in Milk,' Dept. of Hyg., Washington, I908, Bull. 4I and 42.

Rosenow, 'A Study of Streptococci from Milk,' Journ. of Inf. Diseases, I912-13, xi. 338 .

ST. John and PENnington, 'The Relative Rate of Growth of Milk Bacteria in Raw and Pasteurised Clean Milk,' Journ. of Inf. Diseases, I907, vii. 647. StatoR, 'The Rate of Growth of Bacteria,' Trans. Chem: Soc. I9I6, STOckING. See Conn and Stocking. 


\section{CHAPTER XIX}

ON THE METHODS COMMONLY USED IN THE HEATING OF MILK

THE use of cows' milk as a food for children has involved much discussion as to the best method of heating the milk. Different methods have been used in several countries, and there has been not only considerable difference of opinion as to the best method to employ, but also some confusion has arisen from the casual use of the same term to denote different methods of dealing with the food. It would not seem to be of any particular interest to endeavour to trace the origin of the divergence either in the practice or the use of terms, and it will be simpler here to explain briefly the present position and the practices which are very generally employed.

It will be possible to consider the main forms of heated milk which are used under the terms, pasteurised, boiled, sterilised, and dried milk.

Milk is heated for two purposes : (a) In order to destroy harmful bacteria, and $(b)$ in order to preserve the milk for a longer period than would be the case if heat were not employed. In both cases the use of heat is connected with the presence of bacteria, since in the second case the milk is in danger of going sour owing to the presence of these organisms.

\section{PASTEURISED MILK}

Pasteurisation of milk appears to have been introduced by Soxhlet. The original term was used to denote a milk which had been heated to a temperature below that of boiling-point and which had been subsequently rapidly cooled. This general meaning is for the most part still preserved. Great differences, however, exist in regard to the method of carrying out the pasteurisation. Some pasteurisation is carried out at a temperature of only $60^{\circ} \mathrm{C}$. $\left(I 40^{\circ} \mathrm{F}\right.$.), and, on the other hand, it is not uncommon for the process to be designated as pasteurisation when the milk is in effect raised to a temperature approximately equal to the boiling-point of water - $100^{\circ} \mathrm{C} .\left(212^{\circ} \mathrm{F}\right.$.). Moreover, the length of time which is occupied 
both in attaining the maximum temperature and the period over which the milk is maintained at this temperature vary within wide limits. But the term 'pasteurisation' appears to be applied very generally to them all, and at the present day appears merely to imply that the milk has been heated to a temperature which probably has not reached that of the boiling-point of water and that it has been subsequently rapidly cooled.

The use of the lower temperatures $\left(\mathrm{I} 40-\mathrm{I} 70^{\circ} \mathrm{F}\right.$.) is mainly commercial and hardly employed in the preparation of infants' food in the home.

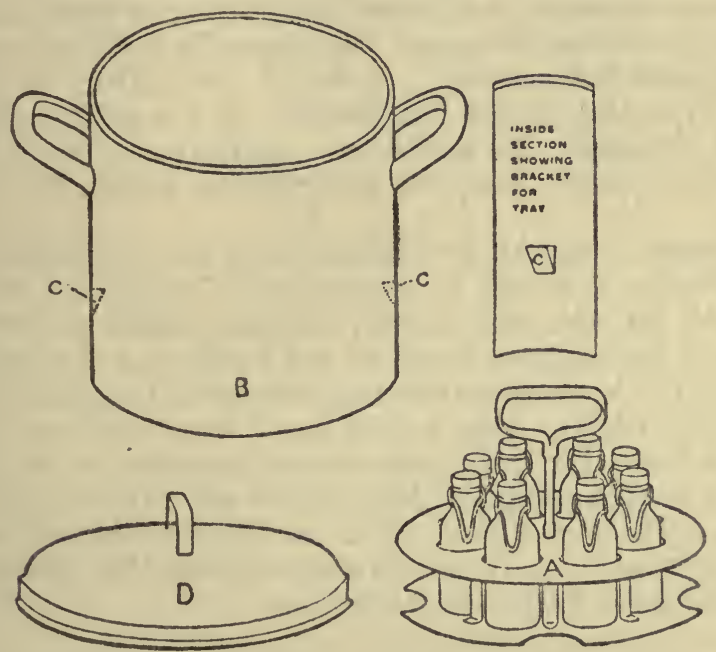

Apparatus for home pasteurisation. The carrier with bottles, when in position, rests with the upper disc of the carrier on the supports $\mathrm{C}$ in the vessel.

The term is, however, frequently applied to the domestic preparation of food for infants.

Where pasteurisation is concerned two points should be mentioned: (a) The maximum temperature to which the milk is raised, and $(b)$ the length of time the maximum temperature is maintained. It is rare, however, except in the literature dealing with the commercial pasteurisation of milk, to find any mention of these items, although the maximum temperature reached is sometimes given.

Home Pasteurisation.-It is usual in home pasteurisation to employ some form of apparatus of the type shown in the figure above. Modifications will evidently be found in the number of bottles and in the shape of the bottle, the form of the carrier holding the bottles, 
etc. They all, however, agree in the main principles. These consist of a vessel which contains water and is of a sufficient depth for the bottles to be immersed in the water up to the neck. After heating to the required temperature, the bottles can be removed together in the carrier, and plunged into cold water.

Some form of stopper or cap for the bottles is usually provided. In some cases the teat is put on the bottle before the heating is commenced, but it is not unusual for a plug of cotton wool to be placed in the neck of the bottle, this plug being subsequently removed and the teat placed on the bottle at the time of feeding. Where the milk has to be diluted or modified in any way, this modification is carried out before the heating is commenced. In practice it is not easy to ensure that the milk shall be heated only up to a definite temperature. A rise of temperature in the water does not show the precise temperature of the milk. Further, it would be necessary to watch the apparatus the whole time, otherwise it is likely that the temperature would frequently be exceeded.

The figures obtained by Freudenreich and by Rosenau show that in practice it would be impossible to determine the precise temperature for the milk in the bottles. There is considerable difference in temperature between the water and the milk in the bottles, and further between the temperature of the milk in different parts of the bottles. Hence it is usual in practice to allow the water in the vessel to boil, and in some cases the water is allowed to boil for a few minutes. The figures given by Rosenau show that the temperature of the milk is much below that of the water, even when the water has been allowed to boil for over three minutes.

Freudenreich's figures are as follows:

\begin{tabular}{|c|c|c|}
\hline Time of Day & Temperature of Water & Temperature of Milk \\
\hline $\begin{array}{c}2.32 \text { P.M. } \\
3.17 \text { " } \\
3.22 \text { ", } \\
\text { Heat stopped } \\
3.29 \text { P.M. } \\
3.38 \text { " } \\
3.44 \text { " } \\
3.52 \quad "\end{array}$ & $\begin{array}{l}12^{\circ} \mathrm{C} . \\
65^{\circ} \mathrm{C} . \\
70^{\circ} \mathrm{C} . \\
70^{\circ} \mathrm{C} . \\
69^{\circ} \mathrm{C} . \\
68 \cdot 5^{\circ} \mathrm{C} . \\
67 \cdot 5^{\circ} \mathrm{C} .\end{array}$ & $\begin{array}{l}\mathrm{I} 5 \cdot 0^{\circ} \mathrm{C} . \\
60 \cdot 0^{\circ} \mathrm{C} . \\
65 \cdot 0^{\circ} \mathrm{C} . \\
69 \cdot 0^{\circ} \mathrm{C} . \\
69 \cdot 5^{\circ} \mathrm{C} . \\
69 \cdot 0^{\circ} \mathrm{C} . \\
69 \cdot 0^{\circ} \mathrm{C} .\end{array}$ \\
\hline
\end{tabular}

The following figures afford an illustration of the results of numerous experiments performed by Rosenau.

Experiment-

Quart mixed market milk.

Bottle immersed in water to lip.

Distinct cream-line from standing at least five hours. 


\begin{tabular}{|c|c|c|c|c|c|}
\hline \multirow{2}{*}{$\begin{array}{l}\text { Water Tempera- } \\
\text { ture }\end{array}$} & \multicolumn{2}{|c|}{ Milk Temperatnre } & \multirow{2}{*}{ Time in Mins. } & \multirow{2}{*}{$\begin{array}{l}\text { Colonies per } \\
\text { Loop in Agar }\end{array}$} & \multirow{2}{*}{ Remarks } \\
\hline & Top & Bottom & & & \\
\hline${ }^{\circ} \mathrm{C}$. & ${ }^{\circ} \mathrm{C}$. & ${ }^{\circ} \mathrm{C}$. & {[} & 150000 & \\
\hline $\begin{array}{l}24 \\
30\end{array}$ & $\begin{array}{l}25 \\
25\end{array}$ & 24 & $\overline{21}$ & $\stackrel{450,000}{-}$ & \\
\hline 40 & 26 & 25 & 5 & - & \\
\hline 50 & 28 & 30 & 81 & - & \\
\hline 60 & 35 & 32 & 12 & 550,000 & \\
\hline 70 & 45 & $43 \cdot 5$ & I5 & 550,000 & \\
\hline 80 & 52 & $52 \cdot 5$ & $18 \frac{1}{2}$ & - & \\
\hline 82 & 55 & 57 & $19 \frac{1}{2}$ & 550,000 & \\
\hline 84 & $5^{8}$ & $57 \cdot 5$ & $2 \mathrm{I}$ & 550,000 & \\
\hline 85 & 60 & $57 \cdot 5$ & $2 I \frac{3}{4}$ & 550,000 & Simmered \\
\hline $\begin{array}{l}87 \\
88\end{array}$ & 63 & 62 & $\overline{223}$ & 425,000 & \\
\hline 90 & 65 & 64 & 23 & I 75,000 & \\
\hline 97 & $69 \cdot 5$ & $7 x \cdot 2$ & 25 & I 3,000 & Boiling \\
\hline IOO & 75 & $79 \cdot 5$ & $28 \frac{1}{2}$ & 33 & \\
\hline
\end{tabular}

Commercial Pasteurisation. A. The Pasteurisation of Milk for Infants on a Large Scale.-The pasteurisation of milk for infants is carried out by a considerable number of dairies and also in connection with the milk depots, which are described in detail in Appendix E. In general principles it resembles the methods above described for home pasteurisation. In this case, however, the bottles are not removed from the pasteuriser, but cold water is passed in at once as soon as the temperature has reached the required figure, and the milk cooled as rapidly as possible by this means. In some cases the milk may be of high quality, as is the case in certain of the continental dairies and in a few of the dairies in this country. Milk for infants which has been pasteurised is ready for consumption, and should not be again heated to a higher temperature than that of the body before being given to the infant. In order to avoid contamination it is usually prepared in the required modification and the required quantity for each feed. It may happen, however, that the whole milk is pasteurised and bottled without modification. In this case there is some danger from contamination in the home, as the milk is there subjected to further manipulation.

The employment of pasteurisation for milk of good quality, which is used for infant feeding, has for its object the destruction of any germs of disease which may have gained entrance from the cow, or from other sources in the course of milking and transit. The object is not to lengthen the period over which the milk will keep, but to ensure that disease is not contracted by the infant through its food.

B. Commercial Pasteurisation of Milk in Bulk.-Many persons 
who possess a wide knowledge of the conditions of the general milk supply, consider that all milk should be pasteurised before being placed on sale, with the possible exception of milk of a high quality which may be specially produced for infants or invalids. Others, again, consider that it is more advisable for the general milk supply to be sold without being heated, unless a statement is made to the effect that heat has been applied to the milk before sale. More discussion appears to have arisen in connection with the pasteurisation of the general milk supply in America, than in any other country. The advances which have been made in the United States in the production of 'certified' milk have led to a close investigation of the general milk supply. ${ }^{1}$ Where the general milk supply is under consideration it is contemplated that pasteurisation shall take place as soon as possible after milking. The object of pasteurisation is, first, to remove any possible pathogenic bacteria which may be present, and, secondly, to preserve the milk for a longer period than would be the case if it were not heated. The preservation of the milk is perhaps more necessary in America than in this country. The milk has frequently to travel very long distances before it reaches the city in which it will be distributed. In the summer-time the heat is greater than in this country, although this adverse condition for the preservation of milk is to some extent, if not entirely, modified by the use of refrigerating wagons by the railway companies. Hence the milk, if it is placed on the train cool, does not become heated on the journey. The approximate duration of time which must elapse between milking and the distribution of the milk is known to be considerable, and the milk is pasteurised in order to preserve it for this period.

In many districts in America large pasteurising plants have been established, and the milk is brought to the pasteurising station from a number of farms in the surrounding district. The milk is then subjected to pasteurisation on a vast scale, being subsequently despatched from the centre to the train, and to the town for which it is destined. Milk which has been pasteurised under this system must be sold as pasteurised milk, and may be further sold in grades of milk. ${ }^{2}$ In America the lower grades of milk are not usually regarded as being suitable for infants' food, but for ordinary household or cooking purposes only.

In this country pasteurisation, when used by dairymen, appears for the most part to be carried out on a relatively small scale by the individual dairyman, and to be used for the purpose of preserving milk which has not been sold on one day until the next day. That is to say, the milk is already somewhat stale and is heated in order to prevent it going sour before it can be sold.

Two main processes are employed for the pasteurisation of milk and are known respectively as the 'holder process' and the

1 Notes upon the standards set by New York City will be found in Appendix G.

2 Cp. Appendix G. 


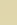




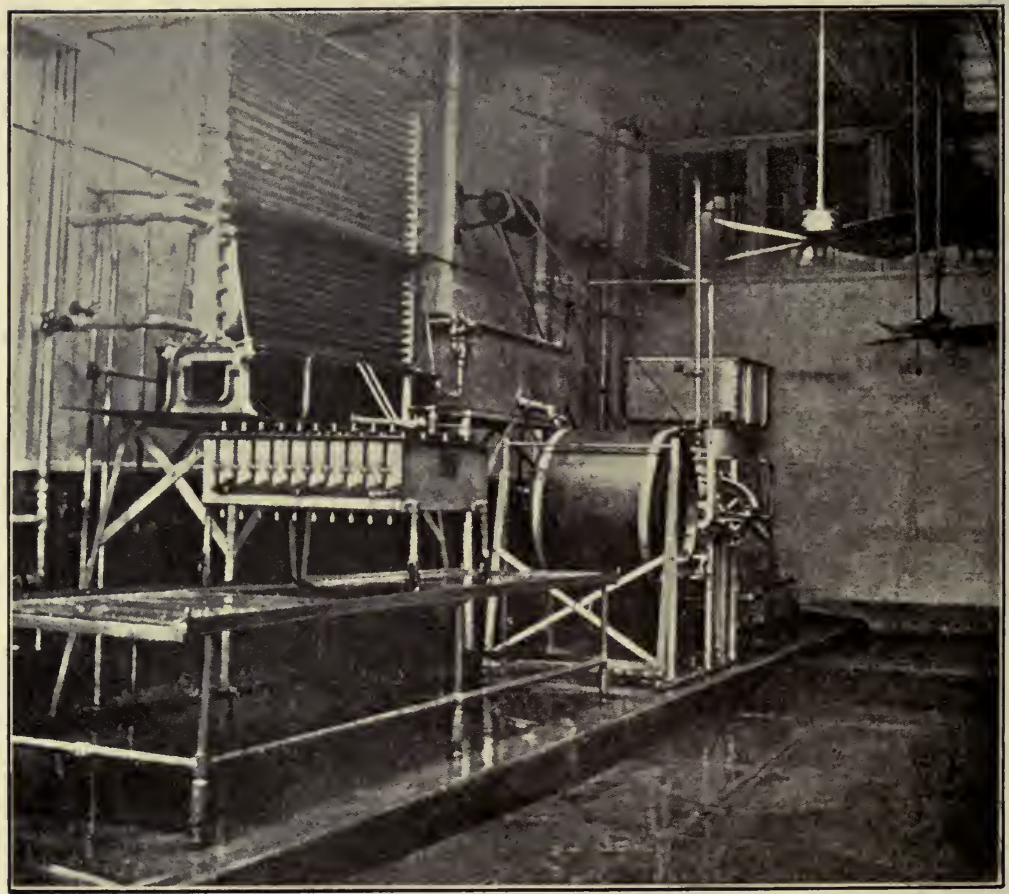

A Pasteurising Plant, showing supply tank and heating apparatus to the right, with cooler above; also. bottling arrangements. 
' flash process.' Both systems are used in the United States, but in this country the 'flash' process appears to be more generally used.

I. The 'Holder Process.'-In this process the milk is gradually brought up to the temperature which is intended to be the maximum temperature to which it shall be exposed, and is held at that temperature for a given time. There is no definite temperature to which the milk is raised in this process, different dairies employing various temperatures.

Ayers and Johnson, in their investigations carried out for the Department of Agriculture in Washington, made enquiries of the pasteurising firms in nearly all the American cities having populations of over 25,000 . The replies showed that the average temperature with this process was $62.8^{\circ} \mathrm{C}$. ( $145^{\circ} \mathrm{F}$.). The actual temperatures used, however, varied very considerably. Out of 219 plants, 75 used the holder process, and 62 of these employed a temperature of from $60^{\circ}-655^{\circ} \mathrm{C}$. $\left(140^{\circ}-150^{\circ} \mathrm{F}\right.$.). One used a temperature somewhat below this, and I2 employed temperatures ranging from $66.7^{\circ}-76 \cdot 7^{\circ} \mathrm{C}$. $\left(152^{\circ}-170^{\circ} \mathrm{F}\right.$.).

2. The 'Flash Process.'-This process consists in heating the milk up to a particular temperature for one minute and then rapidly cooling it. Out of the 219 milk plants concerning which information was obtained, I44 used the flash process, the average temperature being $7 \mathrm{r} \cdot \mathrm{I}^{\circ} \mathrm{C}$., or $\mathrm{I} 60^{\circ} \mathrm{F}$. Of the $\mathrm{I} 44$ plants, $6 \mathrm{I}$ used the average temperature, $6 \mathrm{r}$ used temperatures below the average (being in some cases as low as $140^{\circ} \mathrm{F}$.), and 22 used temperatures above the average, in some cases as high as $82.2^{\circ} \mathrm{C}$, , or $180^{\circ} \mathrm{F}$. No reasons appear to be given for these great divergences in practice. It is probable that the lower temperatures are in some of the cases too low to be of any appreciable value, since they hardly touch the thermal death-point of a considerable number of organisms.

The cream-line is said to be affected when the temperature is raised above $150^{\circ} \mathrm{F}$. Hence the object of many of the pasteurising firms is to keep the temperature about this point.

The cost of pasteurising must be borne in mind, and the holder process will involve a longer heating and hence be more expensive than the flash process.

Some authorities consider that the holder process is a safer method than the flash process, but this probably depends very largely upon care exercised by the individual dairyman.

A pasteurising apparatus is of necessity a somewhat complicated one, and the problem of keeping it clean cannot be regarded as a simple matter. Plate VII shows the exterior of a pasteurising plant. The milk after heating is conducted to the cooler, over which it passes on its way to the tank, and thence to the bottles The figures which have been already given show the differences of temperature which obtain in different parts of even a small amount of milk when it is being heated. In order to ensure that 
milk in bulk shall reach the average temperature aimed at, some form of stirring must be resorted to in order to keep the milk heated evenly as it passes up to the required temperature. It will of necessity have to pass through various pieces of apparatus, and a number of forms of such apparatus involve a coil of somewhat narrow dimensions through which the milk is made to circulate. The purpose of this coil is to cool the milk either by means of cold or iced water, or sometimes by running the milk which is to be pasteurised, and is cool, through the coil, thus saving some heat. If the object of pasteurisation is to be attained, absolute cleanliness, and if possible sterility, must be secured in the apparatus used, otherwise there is a danger that the milk may acquire as many bacteria from the pasteurising plant as it loses in the process of heating. The net result, therefore, is that little or no advantage has been gained by the pasteurisation.

The figures of Pennington and McClintock (given below) are of considerable interest in this connection, and show the recontamina. tion of milk as a result of an unclean pasteurising plant.

I

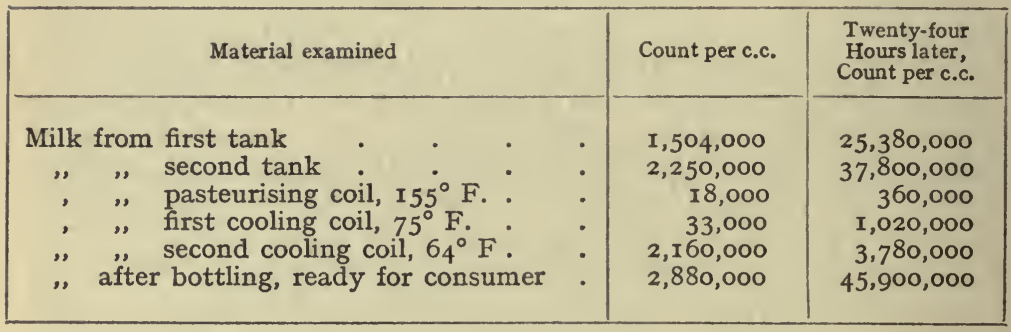

II

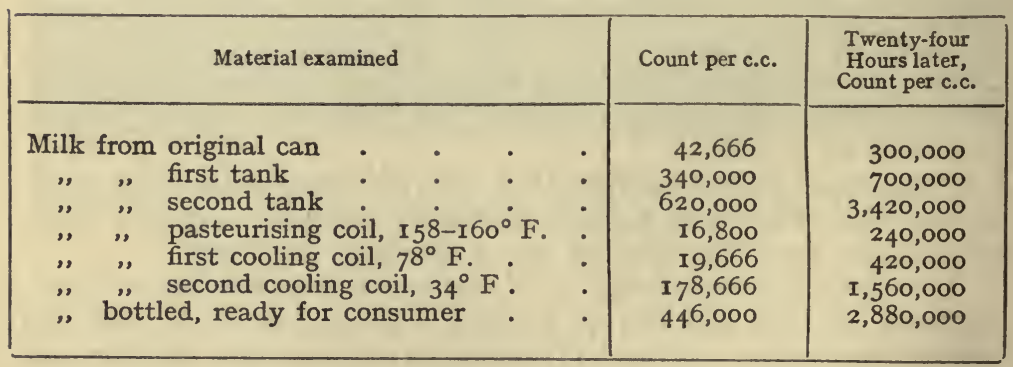

These figures afford excellent examples of contamination by dirty machinery.

Another example of contamination in the process of condensation is given by Delépine in the course of his investigations upon 
the fate of bacteria added to a sample of milk which was to be condensed. He shows that a considerable increase in the number of bacteria-the increase being chiefly due to moulds-occurred in the course of the process, and he states that this may be attributed to the presence of some bacteria and moulds in the delivery pipe used to empty the vacuum pan. The conditions under which the milk was manipulated were stated to have been excellent.

The temperatures to which milk should be heated in order to destroy certain forms of bacteria, both pathogenic and otherwise, are considered in Chap. XVIII. But it may be stated that the dangers of dirty apparatus or of ineffectual pasteurisation should not be minimised. They have been shown to be real. In this connection Chap. $\mathrm{XV}$, section $\mathrm{D}$, dealing with milk epidemics, may be compared.

These difficulties, and the dangers connected with commercial pasteurisation, are dwelt upon by many authors who have written upon the subject. Thus Savage points out that one of the objections arises from the sale of milk which, owing to pasteurisation, is prevented from souring, and ' in practice probably often is kept over a number of days. Old, stale milk may be sold as fresh owing to the removal of most of the lactic acid bacilli. Such milk will appear normal to sight and taste, but may be bacterially highly dangerous. If used without statutory control, there can be little doubt that the extensive use of pasteurisation would lead to neglect of general sanitary conditions even more than is the case to-day, under the belief that the pasteurisation would be an efficient substitute for cleanliness. . . . It is probable that much commercial pasteurisation is inefficiently done. It is a procedure involving an accurate adjustment of time and temperature, and frequently being left to be performed by careless and unskilled persons (the so-called " practical man"), it is very unequally and inefficiently done. If pasteurisation is to be allowed at all, it should be controlled both as regards methods and apparatus. In the writer's opinion, summing up the matter, pasteurisation is an efficient and useful procedure which may be very valuable pending satisfactory and radical improvement in the milk business as a whole, but it is likely to be more harmful than beneficial unless the practice is rigidly supervised, and the conditions under which it may be employed regulated.' Rosenau, in his work upon pasteurisation undertaken for the Hygienic Laboratory in Washington, says: "One of the chief objections to pasteurisation is that it promotes carelessness and discourages the efforts to produce clean milk. It is believed that the general adoption of pasteurisation will set back improvements at the source of supply and encourage dirty habits. It will cause the farmers and those who handle the milk to believe that it is unnecessary to be quite so particular, as the dirt that gets into the milk is going to be cooked and made harmless.' 
A well-known dairyman in this country, dealing with the organisation of a safe milk supply, says: "The process of pasteurisation, though apparently so simple, is in grave danger of being discredited by the careless and inefficient methods of some of its exponents. It is a most serious fact that the process, as almost universally conducted in this country, fails to exclude with certainty the germs of tubercle, and thus loses its main raison d'être. . . . Subsequent dirty methods also render nugatory whatever benefit is conferred by the process. Such sham pasteurisation is a delusion and a snare, against which it behoves the public to be on their guard. Numerous instances are known where such milk contained more germs after the process than before. This is not the fault of the process, but the fault of the operator, his methods, equipment, and the use of originally inferior milk. . . The ordinary method of pasteurisation is to heat any old milk available, for a single instant, and immediately to cool it by running it over a refrigerator in a thin film, and whereon every drop is exposed afresh to all the impurities of the atmosphere. It is not surprising that milk so treated is often worse rather than the better for it.'

The inefficacy of careless pasteurisation is brought out by the following facts quoted in a short article in the Medical Officer for October 9, I9I5, headed 'Pasteurisation-so-called.' The article says: 'In dealing with milks, samples of which have proved to be tuberculous or have been found to contain an undue proportion of organisms associated with excremental pollution, the Medical Officer of Health for Newcastle-upon-Tyne is occasionally met with the statement that the whole of the milk from a supply in question is now pasteurised and cooled at a city dairy before distribution.' Tests made in connection with an inspection at one of the largest and best equipped dairies gave the following results: - Sample I: Original milk as received from the farm-B. Coli present in $0.0000 I$ c.c., the lowest degree to which the test was carried. Sample 2, after " pasteurisation " at $160^{\circ} \mathrm{F}$., gave identical results, as also did sample 3 , which had been "pasteurised" at I $80^{\circ}$ C. Sample 4 was " pasteurised " at $200^{\circ}$ F., and B. Coli was found in quantities down to $0.000 \mathrm{I}$ c.c. It is usual to classify as " unsatisfactory" any milk in which B. Coli is detectable in less quantities than 0.01 c.c. In the above cases the milk merely passed through the apparatus, and proceeded direct to the cooler, so that the highest temperature reached was probably only maintained for a matter of moments. The plant in question is an elaborate and costly one, and absolute confidence has been felt by the owners in its efficiency, a confidence which would be entirely justifiable if the operator had known how to use it.' Further comment on the above appears unnecessary.

The general trend of discussions which have taken place in various American cities has been to show that if milk is pasteurised it must be carried out under supervision and must be carefully 
conducted. The feeling of safety engendered by the belief in pasteurisation is very unsatisfactory if the farmer regards it as enabling him to use dirty methods in collecting the milk. The remarks in connection with the preliminary filtration which are given on pp. $275-7$ show that this tendency cannot be neglected in considering the conditions of the public milk supply.

\section{BOILED MILK}

The border-line between pasteurised and boiled milk may become so fine as to be almost absent. Strictly speaking, a milk which is boiled must be supposed to have reached the temperature corresponding to the boiling-point of milk, which for the present purpose may be considered to be that of water. Where milk is heated in a water bath without pressure, the temperature of the milk will not reach that of the surrounding water. Where the water is only just raised to the boiling-point, the temperature of the milk is probably several degrees lower than that of the water, but where the water is kept at the boiling-point for some minutes, the temperature of the two fluids will approximate more closely, although the temperature of the milk will remain below that of the boiling water. ${ }^{1}$ For all practical purposes, however, the milk may be regarded as having been boiled.

Milk is frequently boiled without a surrounding water-jacket, in which case the temperature will evidently reach $100^{\circ} \mathrm{C}$. and will fulfil the technical requirement for using the term boiled. Domestically, it is probable that if this method is used the temperature is not maintained at boiling-point for any length of time, owing to the physical fact that the milk will boil over and tends to burn. Usually, therefore, the temperature will only be kept at this level for one or two minutes, and the milk subsequently cooled. Commercially, however, or on a large scale, the temperature could be maintained at this height for any desired length of time by using steam under pressure, although actually it is not attempted. Here also, as in the case of pasteurised milk, the length of time at which the temperature is maintained should be mentioned.

\section{STERILISED MilK}

Strictly speaking, milk thus designated should be free from all bacteria and from their spores. In actual fact such milk is very difficult to obtain. The early work of Flügge showed many years ago that the spores found in milk are extremely resistant to heat, and that there is considerable difficulty in obtaining a really sterile milk. Spores are not killed by a temperature of $100^{\circ} \mathrm{C}$, , and in order to destroy them it is necessary to heat the milk considerably over $100^{\circ} \mathrm{C}$. on successive days. Very little milk thus treated is used for infant feeding. 
The term sterilised is more frequently used to denote a milk which has been subjected to a somewhat prolonged boiling either at a temperature of $100^{\circ} \mathrm{C}$. or as much below it as occurs when the milk is merely surrounded by boiling water. Prolonged boiling at this temperature does not, however, destroy spores nor certain of the living organisms found in milk. Only a relative degree of sterility is reached, although the term " sterilised 'is very frequently employed. It is often impossible to determine from the literature when the term 'sterilised ' is used whether a prolonged heating has occurred, or whether it is used loosely to denote a pasteurisation in which the temperature has been allowed to approach that of boiling-point.

The French literature deals very frequently with milk to which the term 'sterilisé' is applied. This usually, however, does not imply that the milk is absolutely sterile, i.e. that it has been superheated, but that it has been kept at a high temperature, although perhaps below boiling-point, for a considerable period. Used in American literature, however, it appears usually to denote a superheated milk which will presumably keep for some days at least, if not longer.

In Germany the term is variously used, but appears more usually to denote merely boiled milk.

In this country it is difficult to suppose that there is any rule at all as to terminology, and in determining the process which has really been used it is necessary to ascertain the method employed and the length of time of heating.

\section{DRIED MILK}

Of recent years a further method of heating milk has been used as a result of which the solids in the milk are obtained in the form of a powder. Several methods are used, two of which are described in Appendix $\mathrm{F}$.

\section{REFERENCES IN Chapter XIX}

Ayers AND Johnson, 'A Study of the Bacteria which Survive Pasteurisation,' U.S. Dept. of Agriculture, Bull. I6r, 19r3.

Delepine, "Report to the L.B.G. upon the Effects of certain Drying and Condensing Processes used in the Preservation of Milk upon its Bacterial Contents,' L.G.B. Reports, New Series, No. 97, r914.

FLÜGGE, 'Die Aufgaben und Leistungen der Milchsterilisierung.' Zeit. $f$. Hyg. x 894, xvii. 272.

V. FreudenReich, "Sur la pasteurisation du lait dans l'alimentation de l'enfance,' Rev. gén du Lait, 1904-5, iv. 433.

Johnson. See Ayers and Johnson.

McCintock And Pennington. Quoted by Eastwood, Report to the L.G.B. New Series, No. I, I909.

MEDICAL OFFICER-Article, 'Pasteurisation, So-called,' gth Oct. I9I 5.

Rosenau, 'Pasteurisation,' Dept. of Hygiene, Washington, Bull. 56, 1912.

SaVAGE, Milk and the Public Health, 1912, p. 383 . 


\section{CHAPTER XX}

ON THE PRESENCE OF PATHOGENIC BACTERIA IN BUTTER AND

CHEESE

THE utilisation of milk, which is infected with pathogenic germs, for the purpose of manufacturing butter or cheese has perhaps hardly received the attention which it deserves. There is abundant evidence to show that cream contains a very large percentage of the total bacteria which are present in milk, as the organisms rise to the surface with the cream. This has been shown by Anderson, who in the course of numerous experiments showed that the cream contained many times more bacteria per c.c. than did the rest of the fluid. In one case the figure was 500 times as great for the bacterial content of the cream as for that of the milk below it. It will be sufficient to quote one set of the figures obtained by him :

Gravity Method: Centrifuged Milk.

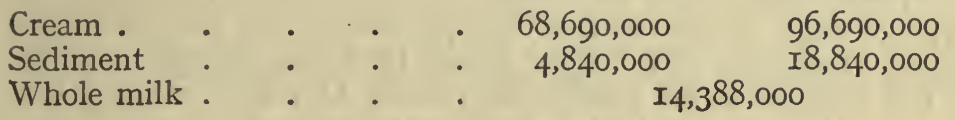

These figures demonstrate forcibly the high bacterial content of cream whether obtained by gravity or by centrifugalising. The effect of centrifugalising is to send more bacteria up into the cream ; only a small percentage of the total number are found in the sediment.

Niederstadt, as quoted by Anderson, has found 75 per cent. of all the bacteria present in the cream. ${ }^{1}$

Considerable evidence has already been given in the preceding pages upon this well-known point.

Butter.-Evidently butter is likely to contain more bacteria than fresh milk when made from fresh cream. If the cream is allowed to go sour before utilising, it may reasonably be supposed that certain strains of bacteria will die out, leaving others in possession of the

$1 C p$. also Scheurlen and others. 
field. There is no doubt as to the presence of tubercle bacilli in butter which has been made from tuberculous milk, and much work has been done upon this subject.

A list of the authors who have investigated the presence of tubercle bacilli in butter is given by Newman and Swithinbank, and the matter has been carefully investigated by Schroeder and Schroeder and Cotton.

Schroeder and Cotton state that since bacteria, and especially tubercle bacilli, are present in greater quantity in butter than milk, milk should be pasteurised before being used for butter-making Complete references are given by these authors.

Objections have been raised to the pasteurisation of milk for the making of butter, it being stated that such milk will not work up satisfactorily. Babcock and Russell investigated this and believe that the difficulty arises from loss of viscosity of the cream. They found that this viscosity is much reduced by pasteurisation at a temperature of $140^{\circ} \mathrm{F}$. or more for ten minutes. These observers found that the viscosity lost by the heating can be restored by the addition of a small amount of sucrate of lime (four parts to a litre).

Roger, Berg, and Brook I. Davis investigated the temperature at which pasteurisation should take place in order to obtain the best effects for butter-making. They found that if a temperature below $I 70^{\circ} \mathrm{F}$. was used, some factor appeared to remain which tended to cause deterioration in the quality of the butter. They considered that no disadvantage was incurred by raising the temperature above $170^{\circ} \mathrm{F}$., though above $180^{\circ} \mathrm{F}$. there was a slight alteration in the flavour.

Investigations have also been carried out to determine the length of time during which tubercle bacilli will live in butter. Mohler, Washburn and Rogers found that cold storage does not kill the bacillus when present in butter, and they showed that this organism when present is usually unequally distributed in the same piece of butter. They considered that cream should be pasteurised either by heating at $140^{\circ} \mathrm{F}$. for twenty minutes or at $176^{\circ} \mathrm{F}$. for a moment.

Rosenow investigated two samples of butter for streptococcione of the samples was found to contain a virulent strain.

Cheese.-The presence of pathogenic micro-organisms in cheese has also been demonstrated, and a number of observations have been made showing that tubercle bacilli occur in this food.

Thus Horman and Morgenroth, in I898, found that in fifteen samples of cottage cheese, tubercle bacilli were present in three. Rabinowitch obtained tubercle bacilli in three out of five similar samples. Harrison, who investigated this question, endeavoured to ascertain the length of time during which tubercle bacilli will remain alive in cheese. He found that at the end of ten days they 
were still virulent, but it seemed possible, judging from the gradual decrease in virulence, that they might have died out by the end of four months.

Heim believed that tubercle bacilli died after about four weeks in cheese. Galtier, however, found that they were still virulent after about seventy days.

Mohler, Washburn, and Rogers, investigating the presence of tubercle bacilli which had been added to milk and subsequently made into cheese, considered that there was some reason to suppose that tubercle bacilli might die out after four months, but possibly a longer period might be required.

Evidently the longevity of tubercle bacilli in cheese becomes important if the cheese is to be consumed within the period over which they are known to be virulent. Some cheeses take several months to ripen, but many are eaten considerably within four months after their manufacture has commenced.

Difficulties have been experienced in manufacturing cheese from milk which has been pasteurised, but these appear to have been now largely overcome. Thus Liska, dealing with the manufacture of cheese from pasteurised milk, used milk which had been heated to $65^{\circ} 68^{\circ} \mathrm{C}$. He commenced using heated milk on account of an outbreak of foot-and-mouth disease in the district, and also apparently because the fodder given to the cattle in that district (and utilised both for economy and for general convenience) appeared to produce a milk containing many organisms and having a peculiar taste. (Note.-The methods of collecting the milk are not given, but it seems probable that the bacteria were derived from the fæces of the cow. The fodder used was a particular waste from breweries which is well known to produce very liquid fæces, and unless the strictest cleanliness is exercised the fæcal material which clings to the cow will almost certainly fall into the milk.)

Liska kept the temperature at the above-mentioned point for from twenty-five to thirty minutes; the milk was then cooled to the proper temperature for the addition of rennet. The results obtained appear to have been successful, and Liska notes that killing the B. Coli before utilising the milk for cheese produces a firmer cheese with fewer holes than that produced when B. Coli is present.

Sammis and Bruhny, working in America, found that the addition of hydrochloric acid up to 0.25 per cent. restores the property of clotting to pasteurised milk and improves the flavour. They experimented for many years in the making of cheese with milk which had been pasteurised at a temperature of $I 60-165^{\circ} \mathrm{F}$. If the temperature is raised much above this point, the quality of the cheese is stated to be affected. The authors found that clotting was more readily produced in the pasteurised milk by the addition of acid, than by the addition of a calcium salt, which, as 
has been shown in Chap. XIV, restores the property of clotting to heated milk. The flavour of the cheese made after this manner is said to be excellent, and the authors recount the prizes taken by such cheeses at numerous shows for dairy produce.

\section{References in Chapter XX}

\section{Pathogenic Bacteria in Butter and Cheese}

Anderson, 'The Proportion of Bacteria in Top and Bottom Milk,' Journ. of Inf. Dis. 1909, vi. 392.

BABCOCX AND RUSSELL, "Conditions affecting the Consistency of Milk: Means of Restoring Consistency of Pasteurised Cream,'Rept. of Agric. Exp. Stat., Wisconsin, 1903, p. I83.

Berg. See Roger, Berg, and Brook I. Davis.

BRUHNY. See Sammis and Bruhny.

Cotron. See Schroeder and Cotton.

Davis. See Roger, Berg, and Brook I. Davis.

Galtier, 'Dangers de l'utilisation des produits tel que le petit lait et le fromage obtenu avec le lait des vaches tuberculeuses,' Compt. Rend. de l'Acad. de Science, I 887 , civ. I 333 .

Harrison, 'La durée de la vie du bacille de la tuberculose dans le fromage,' quoted in Bureau of Animal Ind., I9th Annual Report, I902, p. 2 I 7.

Heim, 'Ueber das Verhalten der Krankheitserreger der Cholera u. Tuberkulose in Milch, Butter, Molke u. Käse,' Avb. a.d. Kaiserl. Gesundheitsamt, I 889, v. 294.

HoRMaN AND MORGENROTH, 'Weitere Mitteilungen über Tuberkel-bazillenbefunde in Butter und Käse,' Hyg. Rund. I 898, viii. I08I-88.

Liska, 'Käse-fabrikation aus pasteurisierter Milch,' Milchw. Zentralb, I9I2, p. $4^{82}$.

MOHLER, Washburn, and Rogers. (I) 'The Viability of Tubercle Bacilli in Butter,' 26th Rept. of Bureau of Animal Ind. I909, p. I79. (2) 'The Viability of 'Tubercle Bacilli in Cheese,' 26th Rept. of Bureau of Animal Ind. I909, p. I87.

MORGENROTH. See Horman and Morgenroth.

NewMan AND Swithinbank, The Bacteriology of Milk, I903, p. 221.

Niederstadt. Quoted by Anderson, as Koch's Jahresb. I893, iv. 201.

Rabinowitch, 'Verbreitung der Tubercle Bazilli durch Milch und Fleisch,' in Cornel's Die Tuberculose, I900, i. I23.

Roger, BERG, AND BROOK I. DAvis, 'The Temperature of Pasteurisation for Butter-making,' Bureau of Animal Ind. Circ. I89, I912.

Rogers. See Mohler, Washburn, and Rogers.

Rosenow, 'A Study of Streptococci from Milk,' Journ. of Inf. Dis. I9I2-I3, xi. 333 .

RusSEll. See Babcock and Russell.

Sammis and BRUHny, "The Manufacture of Cheese of the Cheddar Type from Pasteurised Milk,' Bureau of Animal Ind. I9I3, Bull. I65.

Scheurlen, "Ueber die Wirkung des Centrifugirens auf Bakterien-suspensionen,' Arb. a. d. Kaiserl. Gesundheitsaint, I891, vii. 269.

SCHROEDER. (I) 'Medical Milk Commissions and Bovine Tuberculosis,' 26th Rept. of Bureau of Animal Ind. I909, p. I93. (2) 'Milk and its Products as Carriers of Tuberculous Infection,' Bureau of Animal Ind. I909, Circular I 43.

Schroeder AND CotTon, 'Tubercle Bacilli in Butter,' Bureau of Animal Ind. I908, Circular 127.

SwITHINBANK. See Newmann and Swithinbank.

Washburn. See Mohler, Washburn, and Rogers. 


\section{APPENDICES}

\section{APPENDIX_A}

AS TO THE DEVELOPMENT OF THE MAMMARY FUNCTION

THIS subject has been considered in Chap. VIII, and the figures are supplementary to that chapter.

Schlossman (r) in r 900 published full figures upon this matter, and those relating to two women are given below.

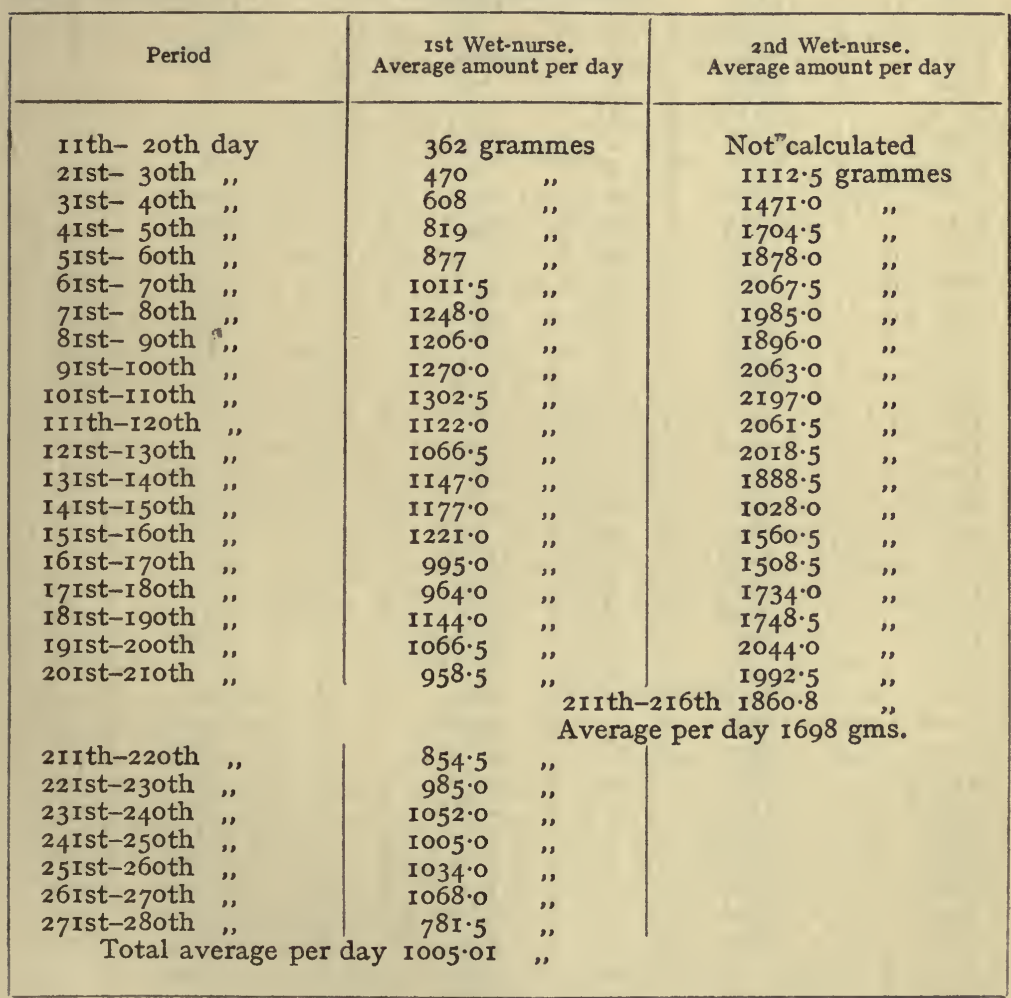




\begin{tabular}{|c|c|c|c|c|c|c|c|}
\hline \multirow{2}{*}{\multicolumn{2}{|c|}{$\begin{array}{l}\text { Date after } \\
\text { Parturition }\end{array}$}} & \multicolumn{2}{|c|}{ Ist Wet-nurse } & \multicolumn{2}{|c|}{ and Wet-nurse } & \multicolumn{2}{|c|}{ 3rd Wet-nurse } \\
\hline & & $\begin{array}{l}\text { Milk given } \\
\text { in } 24 \text { hours } \\
\text { Grammes }\end{array}$ & $\begin{array}{l}\text { No. of } \\
\text { Children } \\
\text { fed }\end{array}$ & $\begin{array}{l}\text { Milk given in } \\
24 \text { hours } \\
\text { Grammes }\end{array}$ & $\begin{array}{c}\text { No. of } \\
\text { Children } \\
\text { fed }\end{array}$ & $\begin{array}{l}\text { Milk given in } \\
24 \text { hours } \\
\text { Grammes }\end{array}$ & $\begin{array}{l}\text { No. of } \\
\text { Children } \\
\text { fed }\end{array}$ \\
\hline 8th w & week & - & - & 910 & 3 & - & - \\
\hline 9th & , & I990 & 4 & - & - & - & - \\
\hline roth & $"$ & - & - & - & - & 1280 & 3 \\
\hline IIth & " & - & 一 & 1450 & 3 & - & - \\
\hline I2th & " & I $74^{\circ}$ & 4 & - & - & $\overline{0}$ & 一 \\
\hline I 3 th & $"$ & - & - & $\overline{6}$ & 一 & I380 & 4 \\
\hline I $4^{\text {th }}$ & $"$ & $\overline{7700}$ & $\overline{4}$ & I640 & 4 & $\overline{850}$ & $\overline{-}$ \\
\hline I6th & 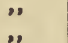 & 1700 & $\underline{4}$ & E & - & 1850 & $\underline{4}$ \\
\hline I 7 th & $"$ & 1810 & 4 & 1900 & 4 & - & - \\
\hline I 8th & $"$ & I 700 & 4 & - & - & I 830 & 4 \\
\hline I9th & $"$ & $\overline{180}$ & $\overline{2}$ & $\overline{720}$ & $\bar{c}$ & 1420 & 3 \\
\hline $\begin{array}{l}\text { 2oth } \\
\text { 2rst }\end{array}$ & : & $\begin{array}{l}\text { I I 80 } \\
1720\end{array}$ & $\begin{array}{l}2 \\
3\end{array}$ & I720 & $\underline{4}$ & $\overline{180}$ & $\overline{3}$ \\
\hline $\begin{array}{l}\text { 2Ist } \\
\text { 22nd }\end{array}$ & $"$ & $\begin{array}{l}\text { I } 720 \\
1570\end{array}$ & 2 & - & - & $\begin{array}{l}1400 \\
1250\end{array}$ & $\begin{array}{l}3 \\
2\end{array}$ \\
\hline $23 r d$ & $"$ & $\begin{array}{l}1570 \\
1470\end{array}$ & 3 & I630 & 4 & II 40 & 2 \\
\hline $24^{\text {th }}$ & , & 1700 & 3 & - & 工 & 1280 & 3 \\
\hline $25^{\text {th }}$ & $\because$ & I5IO & 3 & - & 一 & 710 & 2 \\
\hline 26th & $"$ & 1220 & 2 & I 470 & 4 & 1290 & 3 \\
\hline $27^{\text {th }}$ & ", & I 700 & 3 & 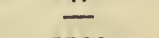 & - & I I 20 & 2 \\
\hline 28 th & " & 1620 & 3 & II90 & 3 & rogo & 3 \\
\hline 29th & ", & I 730 & 3 & - & 一 & - & 一 \\
\hline 3oth & ". & 1940 & 4 & - & - & - & - \\
\hline 3 Ist & " & I 750 & 3 & 1650 & 4 & 1275 & 4 \\
\hline 32 nd & $"$ & 2080 & 4 & - & - & I 545 & 4 \\
\hline 33rd, & " & 2030 & 4 & 1970 & 4 & 1270 & $\begin{array}{l}3 \\
4\end{array}$ \\
\hline $\begin{array}{l}34^{\text {th }} \\
35_{\text {th }}\end{array}$ & ", & $\begin{array}{l}2235 \\
1860\end{array}$ & $\begin{array}{l}4 \\
4\end{array}$ & I $55^{\circ}$ & $\underline{4}$ & $\begin{array}{l}1630 \\
1630\end{array}$ & $\begin{array}{l}4 \\
3\end{array}$ \\
\hline 36 th & " & 1840 & 3 & I I 80 & 3 & 2120 & 4 \\
\hline $37^{\text {th }}$ & " & I990 & 4 & roro & 2 & r9oo & 4 \\
\hline $3^{8 \text { th }}$ & ", & I990 & 4 & I 220 & 3 & I 5 IO & 4 \\
\hline 39th & ", & 2080 & 4 & $I_{4} 10$ & 3 & I610 & 4 \\
\hline 4oth & ", & 2160 & 4 & I IOO & 2 & I680 & 4 \\
\hline 4Ist & ", & 2280 & 4 & 960 & 2 & I920 & 4 \\
\hline 42nd & " & 2070 & 4 & 1070 & 3 & I 820 & 4 \\
\hline $43 r d$ & " & 1660 & 3 & 570 & 2 & I730 & 4 \\
\hline 44th & ", & I940 & 4 & 510 & 2 & I8Io & 4 \\
\hline $45^{\text {th }}$ & ", & I 840 & 4 & 9ro & 3 & I 450 & 4 \\
\hline 46th & ", & 2030 & 4 & 1230 & 4 & I4 IO & 3 \\
\hline $47^{\text {th }}$ & " & 196̆о & 3 & 770 & 3 & I68o & 4 \\
\hline $4^{8 \text { th }}$ & ", & 2020 & 4 & 1620 & 4 & I960 & 4 \\
\hline 49th & , & 2030 & 4 & I 690 & 4 & 1460 & 3 \\
\hline 5oth & " & 2030 & 4 & 1600 & 4 & I 540 & 4 \\
\hline 5Ist & ", & I950 & 4 & I 540 & 4 & I670 & 4 \\
\hline 52nd & " & I850 & 4 & I 400 & 4 & I 370 & 4 \\
\hline 53 rd & " & I 890 & 4 & 1840 & 4 & I 500 & 4 \\
\hline 54th & " & 1820 & 4 & I 780 & 5 & I 560 & 4 \\
\hline $55^{\text {th }}$ & ", & 2120 & 4 & I 580 & 4 & I 590 & 4 \\
\hline 56 th & " & 1640 & 4 & I 300 & 3 & I 710 & 4 \\
\hline 57 th & ", & 2080 & 4 & 1520 & 3 & I650 & 4 \\
\hline $5^{8 \text { th }}$ & ," & I 620 & 3 & I 740 & 4 & I 740 & 4 \\
\hline 59th & ", & I700 & 3 & I 720 & 4 & I $37^{\circ}$ & 3 \\
\hline 6oth & ", & I 880 & 3 & I 190 & 3 & I 390 & 3 \\
\hline 6 rst & " & - & - & 850 & 2 & I 360 & 3 \\
\hline 62nd & ", & - & - & - & - & I 560 & 4 \\
\hline 63rd & ", & - & - & - & - & I6̧9o & 4 \\
\hline 64 th & " & - & - & - & - & 2180 & 4 \\
\hline
\end{tabular}


Figures have also been published by Finkelstein and others: further abundant material is available in the numerous institutions in foreign countries where wet-nurses are employed. All however show the same point, and this need not be further expanded.

2. Budin gives, in the table on the preceding page, the quantities of milk given by a wet-nurse feeding varying numbers of children.

\section{REFERENCES}

Budis, The Nursling, Appendices II and III, pp. 166-172, English translation.

Finkelstein, Die Waisensäuglinge Berlins. Berlin I904.

SchrossmanN, 'Zur Frage der natürlichen Sauglingsernährung,' Arch. $f$. Kinderh. 1900, $\mathbf{x x x} .324$.

\section{APPENDIX B}

ON THE SUBSEQUENT DEVELOPMENT OF THE ORGANISM IN RELATION TO THE METHOD OF FEEDING IN EARLY LIFE

THE high infant mortality rate occurring among artificially-fed children as compared with breast-fed children has been referred to in Chap. VIII. This investigation reaches only up to the second year of life. Recently it has been forcibly realised that it is not sufficient to study the infant and its well-being up to the second year of life only, but that the future fate must be followed equally closely. It is important that the condition of the children should be known not only up to and during school age, but it would be of great interest to ascertain the effect of the method of feeding (natural or artificial) upon the next generation. The study of actual mortality figures would not suffice. It would be necessary to determine what effect the method of feeding might have upon general well-being in later life. Such an investigation is complicated by a number of factors which render any complete work one of great difficulty For example, it must be supposed that the general environment will greatly affect the well-being of the child. The advantages of breast-feeding in the early months may, it must be supposed, be completely counteracted by disadvantageous home conditions, such as insufficient food, lack of air-space, general absence of cleanliness, \&c., while the artificially-fed child, placed in good surroundings, is probably to a great extent compensated for the disadvantages of its feeding. Unless these factors were taken into consideration, the results which might be obtained by ascertaining the early method of feeding and the general condition of health of the individual in later life would almost certainly be mis. leading. Certain very general statements have been made by observers in different countries upon the capacity for breast-feeding among certain tribes or sections of the community in different parts of Europe, but none of these investigations appear to have been supported by any definite evidence. The observations appear to have been made from 
general knowledge obtained during a residence in these parts. This information, although interesting, is of little value for the present purpose.

The present arrangements in this country for the medical inspection of school-children will no doubt facilitate the making of such observations, but the school medical officer is hampered in the first place by lack of time for original work, and further by the difficulty of ascertaining the home conditions and general surroundings of the child between its birth and the time it comes under medical inspection at school. Attempts at such investigation have doubtless been made by a number of these medical officers, but it would appear that only in one case has the investigation been recorded.

The observations referred to have been made by Dr. Norman of the London County Council. A reference to this work is made in the report by the medical officer of the London County Council for I9I3, but the reference is somewhat brief, and I am indebted to Dr. Norman for kindly allowing me to use his MS. copy, which gives a considerably more detailed account than that in the report referred to. The conditions of the home life were not available to Dr. Norman, although he made an effort to obtain such information but found it to be impossible.

The investigation was made among infants of non-selected schools in St. Pancras and Holborn during the summer of 1913. Children were reckoned as having been breast-fed when this method of feeding alone was used for at least six months after birth. The ages of the children investigated ranged from three to eight years, most of them being from four to six years of age. The method of feeding during infancy of 355 children was investigated, of whom 176 were boys and I 79 girls. Dr. Norman points out the great preponderance numerically of the breast-fed over the bottle-fed babies, the numbers being 70.7 per cent. and 29.3 per cent. respectively. It was noticed that the poorer type of children were those who had most usually been breastfed. It is a matter of common knowledge that artificial feeding prevails among the better-to-do to a greater degree than among the very poor. Hence the artificially-fed child will usually have better surroundings than many breast-fed children. The table on p. 315 has been prepared from Dr. Norman's figures and shows fairly fully the condition of all the children investigated. It may be noted that without an exception the range both of height and weight in the groups o. breastfed children is greater than that among the bottle-fed children. This may indicate that the poorer specimens among the breast-fed children survived while those in a corresponding condition among the bottlefed ones did not do so. This inference, however, cannot be pressed too far. The weeding out of the sickly bottle-fed babies is referred to by Dr. Norman in his conclusions, which are as follows :

'The superiority of breast-fed children as compared with bottlefed ones is not so well marked at school age as one would be led to expect. It is during the early years of life, prior to school age, that the great advantage of breast-feeding over bottle-feeding is so apparent. The bottle-fed children of the poor that survive, appear to overtake their disadvantages, and by the time we find them in school, show no inferiority physically to their breast-fed fellows.'

The investigation is of interest as being the only one of which 


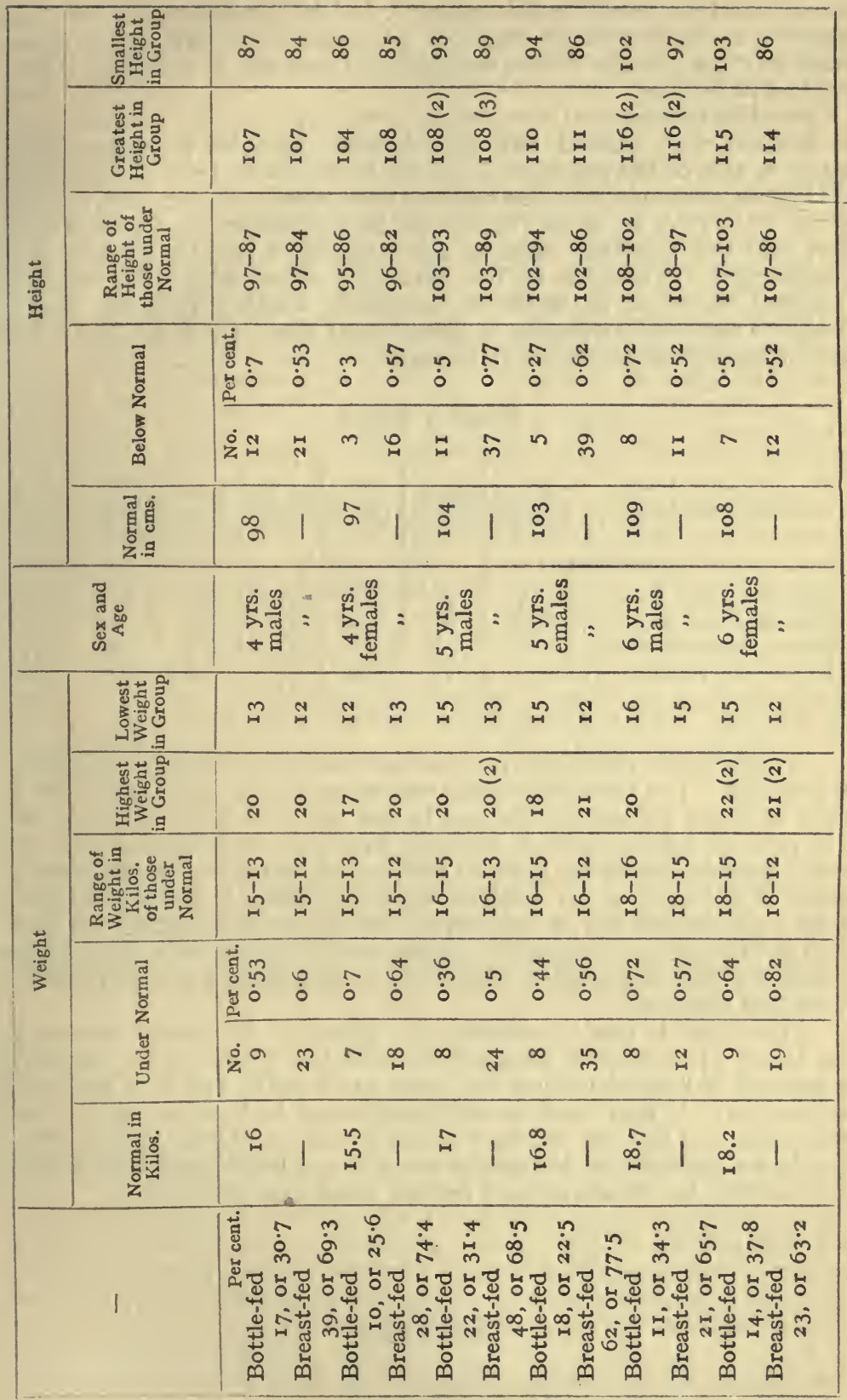


record has been made in this country; but in the absence of the data referred to, it cannot be regarded as establishing any very definite facts in regard to the future well-being of children in relation to their method of feeding.

Breeding Experiments from Artificially-fed Guinea-pigs.-Experiments of interest were carried out by Schroeder in order to ascertain the effect, if any, of the methods of feeding in the early days of life, upon fertility in guinea-pigs. The animals used were those already referred to on pp. I77-8 as having been used by Schroeder for the investigation into the nutritive value of raw and boiled cows' milk for young guinea-pigs. A number of the surviving guinea-pigs were used for breeding purposes in order to ascertain whether artificial feeding could be regarded as having a detrimental effect upon fertility. The accompanying table shows the results.

\section{Breeding Record}

\begin{tabular}{|c|c|c|c|c|c|c|c|}
\hline Guinea-pigs raised on & $\begin{array}{l}\text { No. of } \\
\text { Males }\end{array}$ & $\begin{array}{l}\text { No. of } \\
\text { Females }\end{array}$ & $\begin{array}{l}\text { No. of } \\
\text { Litters }\end{array}$ & $\begin{array}{l}\text { No. of } \\
\text { Young }\end{array}$ & $\begin{array}{l}\text { Young } \\
\text { born } \\
\text { dead }\end{array}$ & $\begin{array}{l}\text { Young } \\
\text { living } \\
\text { less than } \\
30 \text { days }\end{array}$ & $\begin{array}{l}\text { Young } \\
\text { alive at } \\
\text { end of } \\
30 \text { days }\end{array}$ \\
\hline Mother's milk & 5 & I 5 & 62 & 210 & I2 & II & I 87 \\
\hline Raw cow's milk. & 5 & I 5 & 37 & 120 & I5 & 6 & 99 \\
\hline Pasteurised cow's milk. & 5 & I5 & 52 & I 70 & I5 & 8 & I 47 \\
\hline Boiled cow's milk & 5 & I5 & 52 & I77 & II & ro & I 56 \\
\hline
\end{tabular}

It seems clear that there is a decreased fertility in all the artificiallyfed groups. The more favourable results appear to be obtained in the case of those guinea-pigs fed on boiled milk. Schroeder points out, however, that some caution must be exercised in accepting the very unfavourable results on the raw milk series, owing to the presence in some of the milk of the Bacillus abortus. There is reason to believe that this bacillus has a prejudicial effect upon the fertility of cows, and it is therefore reasonable to assume that some such effect is also possible in the case of these pigs which may likewise have been infected with this organism.

This table is one of considerable interest. It cannot necessarily be taken as absolutely comparable with the effects which might be produced in human infants fed upon cow's milk, but it is extremely suggestive. It also receives additional value in that, as far as I can ascertain, it is the only attempt which has hitherto been made to trace the fate of animals fed artificially for so long a period, and to endeavour to ascertain the effects of such feeding upon their progeny.

\section{REFERENCE}

Schroeder, ' An Experiment with Raw and Heated Cows' Milk, and its Lesśon,' Amer. Journ. Dis. Child. 1913, vi. 334. 


\section{APPENDIX C}

\section{THE PRESERVATION OF HUMAN MILK}

EFFORTS have been made in Germany and Austria to provide human milk for sickly babies where wet-nurses were either not available or not available in sufficient number. For this purpose women having more milk than is required for their own babies have been persuaded to express as much milk as possible and to bring it up to the hospital, where it is preserved in the cold room. In order to increase the length of time during which this milk can be kept, hydrogen peroxide has been added. It appears from the work of Knape and of Mayerhofer and Pribram that the milk can be preserved for at least twenty-four hours, and possibly longer. On keeping it tends to develop a musty odour which is rather disagreeable. Knape states, however, that the children fed on this milk under his care did very well. The same result also appeared to have been obtained by Mayerhofer and Pribram, but very much larger quantities of hydrogen peroxide are necessary to preserve the milk than in the case of cows' milk. In some cases calcodat (calcium peroxide) was used as a preservative. They also used this milk dried with varying results; in some cases it appears to have been quite satisfactory. Davidsohn gives cases of children fed upon human milk which had been kept for twenty-four hours and mentions, as do also the above authors, that the milk develops a musty smell, rendering it less agreeable to the older children, although the younger ones did not appear to dislike it.

\section{REFERENCES}

Davidsorn, 'Neue Methode zur Unterscheidung von Frauenmilch und Kuhmilch,' Zeit.f. Kinderh: I9I3, viii. I4.

KNAPE, 'Ueber Konservierung von Frauenmilch,' Monats. $f$. Kinderh. Orig: I $9 I I, X .28 I$.

MAyerhofer AND Pribram, 'Praktische Erfolge der Ernährung mit konservierter Frauenmilch,' Zeit. f. Kinderh. I9I3, iii. 525.

\section{APPENDIX D}

TABLES AND ADDITIONAL DATA RELATING TO THE BERLIN MATERIAL

Results obtained by Working up the Material.-In working up the material which had been obtained from the Berlin consultation the first point was to add the weights of all the babies of each series at the same day of life, and then divide by the number of babies weighed, thus obtaining the average weight of the babies under consideration at the same day of life.

The average weights so obtained showed considerable inequalities, and the number of them was unwieldy and cumbersome. It was 


\section{TABLE I.}

Showing the average weights of the babies of the control or breast-fed series, grouped in periods of eight days, and the number of observations made.

\begin{tabular}{|c|c|c|c|}
\hline Age in Days. & $\begin{array}{l}\text { II. } \\
\text { No. of Observations on Each Day }\end{array}$ & $\begin{array}{l}\text { III. } \\
\text { Total No. }\end{array}$ & $\begin{array}{l}\text { IV. } \\
\text { Average } \\
\text { Weight }\end{array}$ \\
\hline $\begin{array}{l}\text { I-8 } \\
9-16 \\
\text { I7-24 } \\
25-32 \\
33-40 \\
41-48 \\
49-56 \\
57-64 \\
65-72 \\
73-80 \\
81-88 \\
89-96 \\
97-104 \\
105-112 \\
113-120 \\
121-128 \\
129-136 \\
137-144 \\
145-152 \\
153-160 \\
161-168 \\
169-176 \\
177-184 \\
185-192 \\
193-200 \\
201-208 \\
209-216 \\
217-224 \\
225-232 \\
233-240 \\
241-248 \\
249-256 \\
257-264 \\
265-272 \\
273-280 \\
281-288 \\
289-296 \\
297-304 \\
305-312 \\
313-320 \\
321-328 \\
329-336 \\
337-344 \\
345-352 \\
353-360 \\
361-368\end{array}$ & 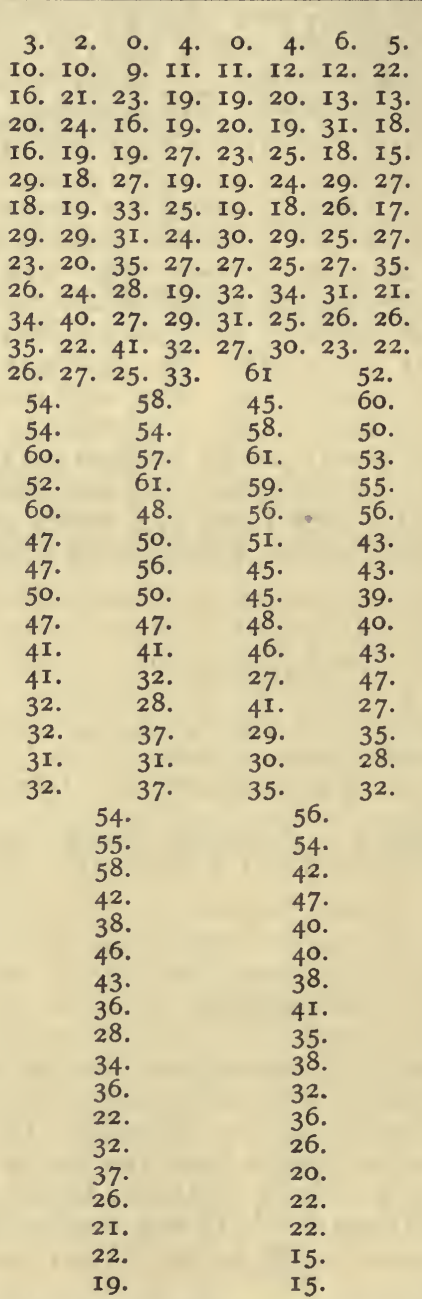 & $\begin{array}{r}24 \\
97 \\
144 \\
167 \\
162 \\
192 \\
175 \\
224 \\
219 \\
215 \\
238 \\
232 \\
224 \\
217 \\
216 \\
231 \\
227 \\
220 \\
191 \\
191 \\
184 \\
182 \\
171 \\
147 \\
128 \\
133 \\
120 \\
136 \\
110 \\
109 \\
100 \\
89 \\
78 \\
86 \\
81 \\
77 \\
63 \\
72 \\
68 \\
58 \\
58 \\
57 \\
48 \\
43 \\
37 \\
34\end{array}$ & 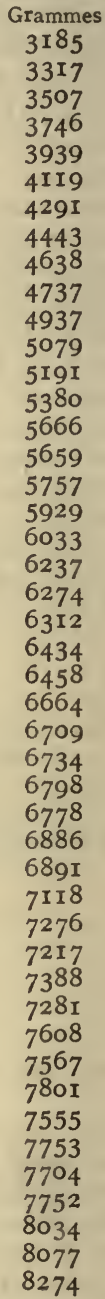 \\
\hline
\end{tabular}


therefore decided to take the unit of age as eight days, and to group together all the weights of the babies from I-8, 9-I 6 days of age and so on up to 368 days of age.

The total weights of all the babies which were weighed in each eightday period of life were divided by the total number of babies weighed. Thus the average weight of all the babies of each series for consecutive periods of eight days of life up to one year of age was obtained, the inequalities of the averages for each day being thus smoothed out and the number of average weights reduced to a convenient number for plotting on a curve.

No serious overlapping of weighings was produced by this method, since the babies were usually brought up at intervals of eight or ten days, so that it was only in exceptional cases that the weight of the same baby was recorded twice in any period of eight days.

Appended are subsidiary tables and curves which deal more fully with the material used and which may be regarded as supplementary to the information given in Chap. XI.

Table I shows the results obtained by thus working up the babies of the control or breast-fed series, and Table II the corresponding results for the babies of the boiled cows' milk series.

In these tables

Column I. shows the age in periods of eight days of the babies considered.

Column II. gives the number of observations, i.e. the number of babies which were weighed upon each of the consecutive days of each period of eight days; the figures being given in chronological order.

Column III. gives the total number of observations (weighings) in each period of eight days, as given in Column I.

Column IV. gives the average weight of the babies of each series for each period of eight days corresponding to the period of Column I.

NotE.-As regards Column II., in collecting the weights of the babies the weights were worked up for each day separately up to Ioo days of age, from 100-224 days of age they were worked up in two-day periods, and from 224-368 days the weights were worked up in four-day periods. This is shown in the tables.

The average weights found, and shown in Tables I and II, are plotted on Diagrams, p. 196.

The total number of observations worked up for the cases in Series I. amount to 6297 and for Series II. to 5444 .

The percentage rate of growth of babies of both series. - It seemed desirable to study the rate of growth of the babies of the two series dealt with in this report.

This was done in the following ways:-

(I) By estimating the percentage increase per kilo. of bodyweight during each period of eight days, each series being taken separately.

(2) The rate at which growth took place as measured by the time required by the babies of each series for the doubling of the initial average weight, the values of the first eight-day period being omitted on account of the small 
TABLE II.

Showing the average weights of the babies of the boiled cows' milk series, grouped in periods of eight days, and the number of observations made.

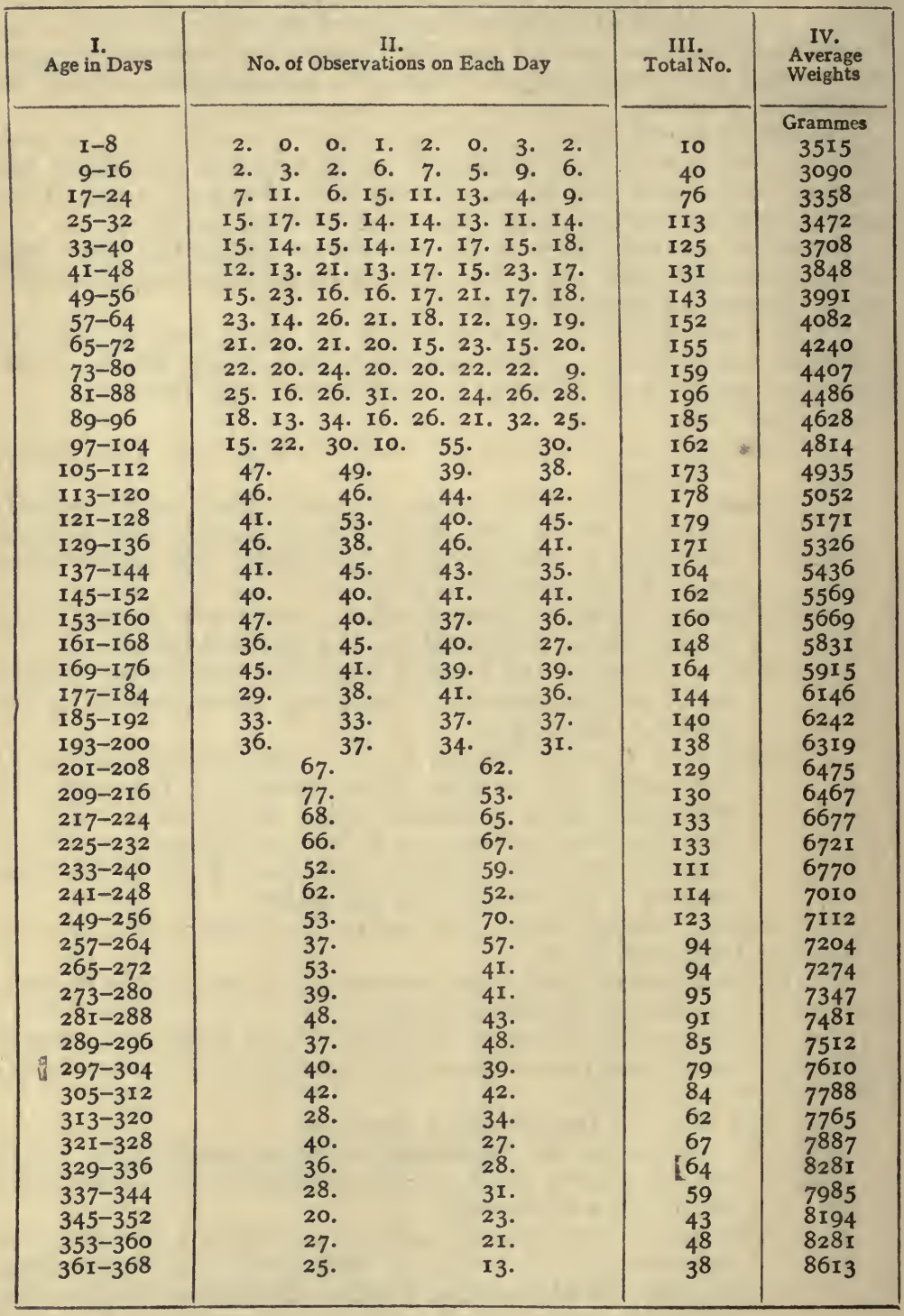


number of observations available in the series of babies fed upon boiled cows' milk.

(3) By estimating the percentage deficit of the average weight of babies fed upon boiled cows' milk as compared with the weights of the breast-fed babies. The weights of the breast-fed babies being taken as Ioo.

The results of the first method are given in Table III and are plotted on Diagram 9, p. I98. Both series show an extreme irregularity in the rate at which the weight increases, but after the first two estimations it would be difficult to point out any marked difference between the values of the two series.

\section{TABLE III}

Showing percentage rate of increase for each period of eight days, of the babies of both series, up to the age of eight months.

\begin{tabular}{|c|c|c|c|c|c|c|}
\hline \multirow{3}{*}{ Age in Days } & \multicolumn{3}{|c|}{ Breast-fed Series } & \multicolumn{3}{|c|}{ Boiled Cows' Milk Series } \\
\hline & $\begin{array}{l}\text { Average } \\
\text { Weight }\end{array}$ & \multicolumn{2}{|c|}{ Increase } & $\begin{array}{l}\text { Average } \\
\text { Weight }\end{array}$ & \multicolumn{2}{|c|}{ Increase } \\
\hline & $\begin{array}{c}\text { In grammes } \\
3185\end{array}$ & In grammes & Per cent. & $\begin{array}{c}\text { In grammes } \\
3515\end{array}$ & In grammes & Per cent. \\
\hline 9-I6 & 3348 & 163 & $5 \cdot \mathrm{I}$ & 3090 & -425 & $-12 \cdot 0$ \\
\hline I $7-24$ & 3507 & I59 & $4 \cdot 7$ & 3358 & 268 & $8 \cdot 7$ \\
\hline $25-32$ & 3746 & 239 & $6 \cdot 8$ & 3472 & I 4 & $3 \cdot 4$ \\
\hline $33-40$ & 3939 & I93 & $5 \cdot I$ & 3708 & 236 & 6.8 \\
\hline $4^{I}-4^{8}$ & 4 II 9 & I 80 & $4 \cdot 6$ & 3848 & 140 & $3 \cdot 8$ \\
\hline $49-56$ & 4291 & I 72 & $4 \cdot 2$ & 3991 & 143 & $4 \cdot I$ \\
\hline $57-64$ & 4443 & I 52 & $3 \cdot 5$ & 4082 & 9 I & $2 \cdot 9$ \\
\hline $65-72$ & 4638 & 195 & $4 \cdot 4$ & 4240 & 158 & $3 \cdot 9$ \\
\hline $73-80$ & 4737 & 99 & $2 \cdot I$ & 4407 & 167 & $3 \cdot 9$ \\
\hline $8 \mathrm{r}-88$ & 4937 & 200 & $4^{\cdot 2}$ & 4486 & 79 & $1 \cdot 8$ \\
\hline $89-96$ & 5079 & 142 & $4 \cdot 9$ & 4628 & I 42 & $3 \cdot 2$ \\
\hline 97-ro4 & $5 I 9 I$ & II2 & $2 \cdot 2$ & $4^{8} \mathrm{I}_{4}$ & I86 & $4 \cdot 0$ \\
\hline $105-112$ & 5380 & I 89 & $3 \cdot 6$ & 4935 & I2I & $2 \cdot 5$ \\
\hline II 3 - I 20 & 5566 & 183 & $3 \cdot 6$ & 5052 & II 7 & 2.8 \\
\hline $12 I-128$ & 5659 & 93 & I.7 & 517 I & II9 & $2 \cdot 4$ \\
\hline I29-136 & 5757 & 98 & $1 \cdot 7$ & 5326 & I 55 & $3 \cdot 0$ \\
\hline I $37-144$ & 5929 & 172 & $3 \cdot 0$ & 5436 & I IO & $2 \cdot 0$ \\
\hline $145^{-1} 5^{2}$ & 6033 & 104 & I. 8 & 5569 & I33 & $2 \cdot 4$ \\
\hline I 53-16o & 6237 & 204 & 3.4 & 5669 & 100 & $I \cdot 8$ \\
\hline $16 I-168$ & 6274 & 37 & $\cdot 6$ & $5^{8} 31$ & 162 & 2.9 \\
\hline $169-176$ & 6312 & 38 & $\cdot 6$ & 59 I 5 & 84 & $I \cdot 4$ \\
\hline $177-184$ & 6434 & 122 & I.9 & $61_{4} 6$ & $23 I$ & $3 \cdot 9$ \\
\hline $185-192$ & $645^{8}$ & 24 & $\cdot 4$ & 6242 & 96 & $1 \cdot 6$ \\
\hline I93-200 & 6664 & 206 & $3 \cdot 2$ & 6319 & 77 & $I \cdot 2$ \\
\hline $201-208$ & 6709 & 45 & $\cdot 7$ & 6475 & I 56 & $2 \cdot 5$ \\
\hline $209-216$ & 6734 & 25 & $\cdot 4$ & 6467 & -8 & $-\cdot I$ \\
\hline $217-224$ & 6798 & 64 & $I \cdot O$ & 6677 & 210 & $3 \cdot 2$ \\
\hline $225^{-232}$ & 6778 & -20 & -3 & 6721 & 44 & $\cdot 7$ \\
\hline $233^{-240}$ & 6886 & 108 & $x \cdot 6$ & 6770 & 49 & 7 \\
\hline
\end{tabular}

After this age the increase becomes very variable. 
The results of the second method are shown in Table IV, and have been plotted on Diagram Io, p. 200, which shows that as regards rate of growth there is little to choose between the two series. The babies fed upon boiled cow's milk doubled their weight at the 185-192nd day, or a fortnight earlier than the breast-fed babies, but they started with an initially lower weight, since the first value was omitted, on account of the small number of observations.

\section{TABLE IV.}

Showing the percentage rate of growth of the babies of both series starting from the second eight-day period of life. Control series being the breast-fed babies and the other series being babies which were fed upon boiled cows' milk.

\begin{tabular}{|c|c|c|c|c|c|c|}
\hline \multirow{3}{*}{$\frac{\text { Age in Days }}{8-16}$} & \multicolumn{3}{|c|}{ Control Series } & \multicolumn{3}{|c|}{ Boiled Milk Series } \\
\hline & \multirow{2}{*}{$\begin{array}{c}\begin{array}{c}\text { Average } \\
\text { Weight }\end{array} \\
\text { In grammes } \\
334^{8}\end{array}$} & \multicolumn{2}{|c|}{ Increase } & \multirow{2}{*}{$\begin{array}{c}\begin{array}{c}\text { Average } \\
\text { Weight }\end{array} \\
\begin{array}{c}\text { In grammes } \\
3090\end{array}\end{array}$} & \multicolumn{2}{|c|}{ Increase } \\
\hline & & In grammes & Per cent. & & In grammes & Per cent. \\
\hline I 7-24 & 3507 & I 59 & $4 \cdot 7$ & $335^{8}$ & $268=$ & $8 \cdot 6$ \\
\hline $25-32$ & 3746 & 398 & II 8 & 3472 & 382 & $12 \cdot 3$ \\
\hline $33-40$ & 3939 & 591 & I $7 \cdot 6$ & 3708 & 618 & $20 \cdot 0$ \\
\hline $4 I-48$ & 4 II 9 & $77 \mathrm{I}$ & $23 \cdot 0$ & 3848 & $75^{8}$ & $24 \cdot 5$ \\
\hline $49-56$ & $429 I$ & 943 & $28 \cdot I$ & 3991 & 901 & $29 \cdot I$ \\
\hline $57-64$ & 4443 & 1095 & $32 \cdot 7$ & 4082 & 992 & $32 \cdot 1$ \\
\hline $65-72$ & 4638 & 1290 & $38 \cdot 5$ & 4240 & II 50 & $37 \cdot 2$ \\
\hline $73-80$ & 4737 & I 389 & $4 I \cdot 4$ & 4407 & I3I7 & $42 \cdot 6$ \\
\hline $8 I-88$ & 4937 & I 589 & $47 \cdot 4$ & 4486 & I 396 & $45 \cdot I$ \\
\hline $89-96$ & 5079 & I73I & $5 I \cdot 7$ & 4628 & I $53^{8}$ & $49 \cdot 7$ \\
\hline $97-104$ & 5 I9I & I 843 & $55^{\circ} \circ$ & $48 I_{4}$ & I 724 & $55 \cdot 7$ \\
\hline $105^{-112}$ & 5380 & 2032 & $60 \cdot 6$ & 4935 & I 845 & $59 \cdot 7$ \\
\hline II $3-I 20$ & 5566 & 2218 & $66 \cdot 2$ & 5052 & 1962 & $63 \cdot 4$ \\
\hline I $2 I-I 28$ & 5659 & 23 II & $69 \cdot 0$ & $5 I 7 I$ & $208 I$ & $67 \cdot 3$ \\
\hline $129-136$ & 5757 & 2409 & $71 \cdot 9$ & 5326 & 2236 & $72 \cdot 3$ \\
\hline I $37^{-I} 44$ & 5929 & $258 \mathrm{I}$ & $77^{\circ} 0$ & 5436 & 2346 & $75 \cdot 9$ \\
\hline $145^{-1} 5^{2}$ & 6033 & 2685 & $80 \cdot 1$ & 5569 & 2479 & $80 \cdot 2$ \\
\hline $153-160$ & 6237 & 2889 & $86 \cdot 2$ & 5669 & 2579 & $83 \cdot 4$ \\
\hline $16 I-I 68$ & 6274 & 2926 & $87 \cdot 3$ & $5^{8} 31$ & $274 I$ & $88 \cdot 7$ \\
\hline I69-I 76 & 6312 & 2964 & $88 \cdot 5$ & 5915 & 2825 & $9 \mathrm{I} \cdot 4$ \\
\hline I $77-184$ & 6434 & 3086 & $92 \cdot I$ & 6146 & 3056 & $98 \cdot 8$ \\
\hline $185-192$ & $645^{8}$ & 3IIO & $92 \cdot 8$ & 6242 & 3152 & $102 \cdot 0$ \\
\hline I93-200 & 6664 & $33 I 6$ & $99 \cdot 0$ & 6319 & 3229 & $104 \div 4$ \\
\hline $20 I-208$ & 6709 & $336 I$ & $100 \cdot 3$ & 6475 & 3385 & 109.5 \\
\hline $209-216$ & 6734 & 3386 & IOI·I & 6467 & 3377 & $109 \cdot 2$ \\
\hline $217-224$ & 6798 & 3450 & $103 \cdot 0$ & 6677 & 3587 & II $6 \cdot 0$ \\
\hline $225-232$ & $677^{8}$ & 3430 & 102.4 & 6721 & 3631 & II 7.5 \\
\hline $233-240$ & 6886 & $353^{8}$ & $102 \cdot 6$ & 6770 & 3680 & II $9^{\circ} 0$ \\
\hline
\end{tabular}

The third method, giving the percentage deficit of the average weights of the babies fed upon boiled cows' milk as compared with the breast-fed babies, showed that at no period of life does the deficit exceed Io per cent., and that during the greater part of the period under observation the deficit is much less. 


\section{APPENDIX E}

\section{THE MILK DEPOTS OF ENGLAND}

Ir seemed advisable to add a short note upon the existing milk depots in this country. It is not necessary to enter into any detail of the history of milk depots in general, which has been already dealt with by numerous authors. ${ }^{1}$

A list of the milk depots and their condition in I9I3 was given by the Medical Officer to the Local Government Board in his second report on Infant and Child Mortality. It was then shown that there had been in England thirteen depots, the first established being at St. Helens, opened in I899. Of these milk depots three had been closed before 1913, the remainder being still open. Of the remaining ten, two were conducted by voluntary agencies and eight by municipal authorities. Since that date a voluntary milk depot has been established in Sydenham and arrangements for supplying milk in various forms are now in existence in connection with certain municipalities and with a number of voluntary agencies.

Until the introduction of dried milk, the milk supplied from milk depots was almost universally prepared from raw milk. This milk was obtained as far as possible from a farm where the methods of collection were believed to be satisfactory, and was delivered once a day at the milk depot. Here it was prepared in several set modifications for children of different ages, and in bottles considered to be of suitable size for the ages of children for whom the milk formulae were prepared. The bottles were then subjected to heat in a steam steriliser, the temperature usually being kept somewhat below that of boiling water. After heating, the milk was rapidly cooled by passing cold water through the apparatus, and the milk given out in a small crate capable of holding a number of bottles corresponding to the number of feeds prescribed for the infant.

This method of dealing with milk still obtains in six milk depots in this country. Apart from these, in one case the milk is not subjected to heat but is given raw, and in the remaining three dried milk is now exclusively used.

In addition, as has been already indicated in several chapters, a large amount of dried milk is utilised in connection with the infant consulta. tions in Sheffield and elsewhere.

Cost of the Milk Depot.-The method of preparing boiled or pasteurised milk in small bottles is a very expensive one. The cost of the $m$ inipulation and establishment charges for the milk depot far exceed the actual cost of the material. It is usual to obtain, as far as possible, a payment from the mothers for whose children the milk is available, which would cover the actual cost of the milk, the difference between the total cost and the sum obtained being borne by the rates. The cost per head does not appear to diminish appreciably with the increased number of children for whom the milk is prepared. The actual cost 
to the rates was given in the annual report of the Medical Officer to the Local Government Board already referred to.

The use of dried milk for infants removes any difficulty connected with the cost of preparation. The dried milk is usually bought wholesale and sold at a price that will just cover any incidental expenditure connected with its provision and sale. As a whole this form of milk appears to approximate closely in cost to that of ordinary milk obtained from a dairy and no expenditure need be incurred. In Leicester a profit is even made by the sale of the dried milk at the municipal depot.

Apart from the relative and nutritive values of either boiled or dried milk, the provision of dried milk removes some of the drawbacks of the milk depot, where the milk is prepared in bottles. The milk depot where the milk is either boiled or pasteurised is not as popular with the mothers as is the dried milk depot. In the one case the milk must be fetched daily and in the other a sufficient amount can be obtained to last a week or more if necessary. Moreover the mother learns nothing as to the methods of infant feeding when the milk is provided for her ready prepared in bottles for each feed. Where dried milk is used she has to prepare the milk according to the directions given her at the depot.

Neither form of milk depot should be regarded as providing a generally satisfactory method for the feeding of infants apart from medical supervision. The provision of a good milk supply is not a panacea for infant mortality, and a mother's natural intelligence does not teach her how to feed a child artificially nor even naturally. She requires instruction, more especially when artificial feeding has to be resorted to. In Sheffield, dried milk is only provided for those mothers who attend the infant consultation and for whom the presiding doctor prescribes the method of feeding. No form of artificial feeding, whet er by dried milk or from a milk depot, should be resorted to for children of tender age unless it is clearly established that the mother cannot feed the child naturally. Unless proper medical supervision is intimately connected with the supply of milk from a municipal milk depot, a tendency to artificial feeding is almost unavoidable, although it may be difficult to establish any definite cessation of breast-feeding on account of the facility with which the mother can obtain milk, which is regarded in a sense an official hall-mark of quality.

\section{APPENDIX F}

\section{ON THE METHODS EMPLOYED IN THE DESICCATION OF MILK}

THE methods of desiccation of milk have been described by several authors, but the notes below are taken from the work of Prof. Delépine (Report to the L.G.B., New Series, No. 97).

Two methods are described.

First Method.-The accompanying diagram represents the stages in the process. 
The drying apparatus consists of two cylinders placed side by side, the space between them not exceeding 2 millimetres. They rotate in opposite directions at a speed of six to fourteen revolutions per minute. They are heated by steam under pressure at a temperature of $139^{\circ}-\mathrm{I} 4 \mathrm{I}^{\circ} \mathrm{C}$. for whole milk or rather lower for separated milk. The steam enters through pipe $V$. The milk enters through pipe $L$, the outflow through $d$ being regulated. It falls into the gutter $a$ when it passes into a state of ebullition. The temperature of the milk during the short time it was in the gutter was found to remain below $100^{\circ} \mathrm{C}$.

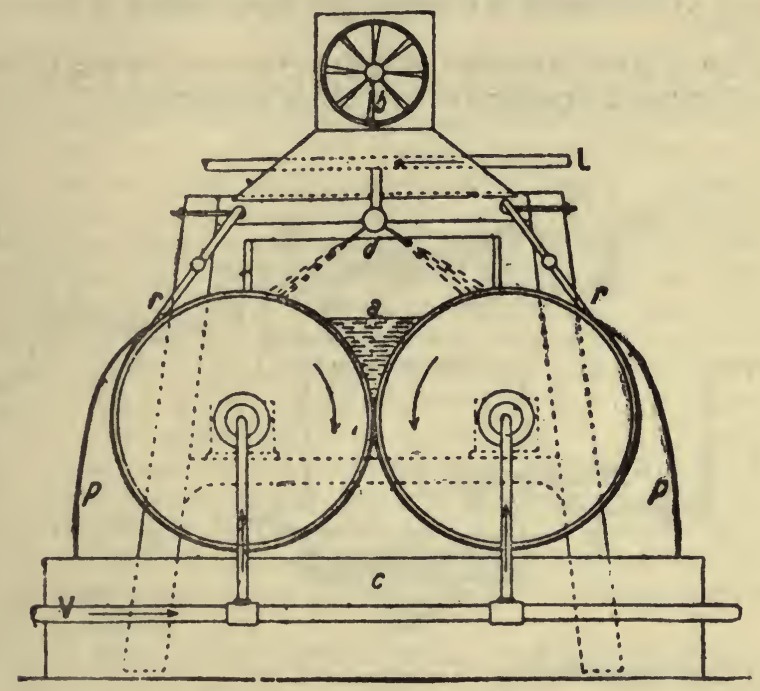

Figure showing the first method of desiccation:

The milk passes out from the gutter in a thin layer which rapidly dries in a pellicle on the surface of the rotating cylinder. By the time that two-thirds (approximately) of a revolution has been accomplished the milk is sufficiently dry to be separated in a continuous ribbon by means of the long straight blades at $r$. The ribbon falls into the chamber $C$, whence it is removed, powdered, and packed in tins.

Second Method.-This method is described by Prof. Delépine as follows (see diagram on next page) :

' $I$. The milk on arriving from the farm is poured into a large vessel, the outlet of which is provided with a strainer; this vessel is also used to weigh the milk.

' 2 . The strained milk is allowed to mix in a large tank from which it is admitted to

3. A heater, where it is warmed before passing to

${ }^{1}$ Cp. also pp. 225-6. 
' 4. The separator. The separated milk may be dried separately, in which case the cream is removed. When dried whole milk is wanted the separated milk and cream are brought together again in a common channel which carries the milk to

'5. A pasteurising apparatus where the temperature of the fluid is raised from $70^{\circ} \mathrm{C}$. to $75^{\circ} \mathrm{C}$. When separated milk is treated the temperature is raised slightly above $75^{\circ} \mathrm{C}$.

' 6 . The pasteurised milk is collected in a large vacuum pan, where it is heated by steam to a temperature of about $58^{\circ} \mathrm{C}$. and is reduced to a little less than one-half of its original bulk. When the milk has reached a suitable consistency its temperature is rapidly raised to $95^{\circ} \mathrm{C}$., and as soon as this point is reached the temperature is brought down again to $58^{\circ} \mathrm{C}$.

'7. According tothe amount of milk in the vacuum pan the condensng process occupies from two to two and a half hours.

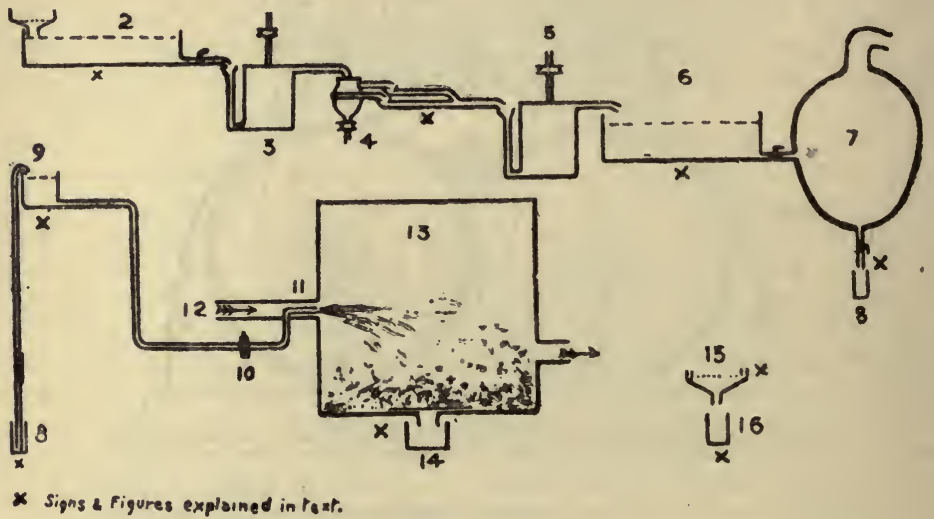

Figure illustrating the and method of desiccation.

' 8. The condensed milk is drawn into metal cylinders from which it is immediately pumped into

'9. A small tank, from which the fluid passes into

- 10. A powerful pump, which forces it under a pressure of 2000 to $3000 \mathrm{lbs}$. through the

'II. Spraying apparatus, by which a cone of finely sprayed milk is produced. This takes place in the middle of an opening to which a current of dry air heated to $115^{\circ} \mathrm{C}$. is brought by

' I2. A large pipe. Both the hot air and the spray are projected into

' 13. A tin-lined chamber, the internal temperature of which is $76-$ $8 \mathrm{I}^{\circ} \mathrm{C}$. The droplets of milk dry as they fall to the floor, upon which they rapidly form a layer of granules of dry milk.

- The current of hot air passes out of this first room into a second room, where the particles which have not fallen in the first room are collected.

' When the desired amount of milk has been dried, the drying-room 
is emptied through an opening in the floor, and the milk powder is collected in

I4. Metal cylinders.

- I5. It is afterwards sifted through a fine gauze screen. The milk is then packed in suitable receptacles.'

\section{APPENDIX G}

\section{NOTES ON THE GRADING OF MILK}

THE efforts which have been made in various countries to improve the general milk supply, have led those concerned to endeavour to establish a standard for milk in order to obtain and maintain a satisfactory milk supply. The American Medical Milk Commissions have perhaps done more than other bodies in the investigation of the regulations which should be laid down in order to obtain satisfactory grades of milk.

The Commissions of the various States of America have adopted their own standards, in some measure, but there are some points upon which there is very general agreement, and for which similar standards have been adopted by the majority of the commissions.

Fundamentally, the standards are based upon the bacterial count of the milk. In addition, standards are laid down for the fat content, and for the total solids, which must be found in any sample of milk. Attempts have been made also to obtain a test for the amount of dirt present, which would enable some sort of standardisation to be made. The standardisation of the leucocyte count has also been contemplated, but does not appear as yet to have reached a definite issue. Recent investigations appear rather to show the difficulty of establishing any such standard.

Grades of Milk. - The highest grade of milk produced in America is very generally known as 'certified' milk. Numerous regulations have been drawn up for the production of this milk, and the Commissions, after due investigation of the conditions under which the milk is produced, pass certain farms which conform to the required standards, permitting them to state that the milk is of this quality for a certain period. The bacterial count and the chemical composition of the milk are regularly investigated. If the result of these examinations is satisfactory, the permission is renewed: if unsatisfactory, it is withdrawn.

It is impossible for the general milk supply to reach this standard. The cost of production is considerably higher than can be met by the farmer for the prices of ordinary market milk. It has been necessary therefore to introduce lower grades of milk which can be sold at a cheaper rate than ' certified' milk, but over which some control is aiso exercised. The different States and cities have issued their own regulations for grading, and it is not proposed to deal with these individually. It seemed, however, of interest to give some brief notes showing the nature of the standards laid down. The State of New York issued regulations which came into force in November I9I4 and which described explicitly the nature of the grades in milk. Briefly they amount to the following : 
Grade A. Raw.-This milk must not at any time previous to the delivery to the consumer contain more than 60,000 bacteria per c.c. and such cream not more than 300,000 bacteria per c.c. It must be delivered within thirty-six hours from the time of milking, unless a shorter time shall be prescribed by the local authorities. It must be delivered to customers only in containers sealed at the dairy, and must show its grade and the name and address of the dealer.

Grade A. Pasteurised.-Such cream or milk before pasteurisation must not contain more than 200,000 bacteria per c.c. After pasteurisation and previous to the delivery to the consumer it must not contain more than 30,000 per c.c. in the milk and 150,000 per c.c. in the cream. It must be delivered in sealed containers and labelled 'Grade A. Pasteurised.'

Grade B. Raw.-Such milk must not at any time previous to delivery to the consumer contain more than 200,000 bacteria per c.c. and such cream not more than 750,000 bacteria per c.c. Regulations as to delivery as for Grade A.

Grade B. Pasteurised.-Such cream or milk before pasteurisation must not contain more than 300,000 bacteria per c.c. After pasteurisation such milk must not at any time contain more than I00,00o bacteria per c.c. and such cream not more than 500,000 per c.c. The milk must be delivered within thirty-six hours after pasteurisation and such cream within forty-eight hours after pasteurisation. It must be labelled 'Grade B.'

Grade C. Raw and Pasteurised.-This grade has no prescribed bacterial standard, but must be delivered within forty-eight hours from the time of milking in the case of the raw milk or within fortyeight hours after pasteurisation.

The cows from which the milk of Grade A is obtained must have been tested at least once in the previous year with tuberculin, and any tuberculous cow must be excluded from the herd.

For Grade B the cows must be healthy, as disclosed by an annual physical examination.

The farms producing all these classes of milk are subjected to inspection and are themselves graded by a system of score cards. By this method marks are allowed for the various items concerned in the production of milk, and farms supplying Grade A milk must reach a higher percentage of marks than those supplying milk of Grade $B$, and these again a higher percentage than those supplying milk of Grade $\mathrm{C}$.

The regulations issued by the Department of Health for the city of New York define milk of Grade A as being suitable for infants and children, Grade B suitable for adults, and Grade C for cooking and manufacturing purposes only.

The regulations of New York City for the farms and dairies connected with the milk supply are extremely detailed.

In this country individual investigators have examined the most suitable standards for improving the general milk supply. Regulations as to the fat content of milk have been in force for some years, but no regulations as to bacterial or other standards exist at the present time.

Savage, reporting upon the measurement of milk pollution based upon a bacterial standard, did not come to very definite conclusions, but it seems probable from his work and from that of Houston, com- 
bined with the experience obtained in other countries, that a bacterial standard affords more control over the care which has been exercised in the collection of the milk, than any other method.

\section{REFERENCES}

SAVAGE, ' Report to the L.G.B. upon the Bacterial Measurement of Milk Pollution,' r909-10.

Houston, 'Report to the L.C.C. on the Bacteriological Examination of Milk,' 1905.

\section{APPENDIX $\mathrm{H}$}

\section{ON METHODS USED FOR THE DESTRUCTION OF BACTERIA IN MILK WITHOUT THE APPLICATION OF HEAT}

AT different times methods have been brought forward which should destroy the bacteria in milk without the application of heat. It may be said at once that none of them has been widely used. All have drawbacks or difficulties, and the excellent results obtained in the feeding of infants, by using milk which has been heated in the home, or (at the present time) dried, render it unlikely that any other known method will receive wide acceptance.

One of the main difficulties arises in preventing the re-contamination of the milk after treatment, and the further danger that it shouldas commercial pasteurisation may also do-tend to encourage carelessness or uncleanliness in the course of production.

Towards the end of last century Buddé suggested the addition of hydrogen peroxide to milk in order to preserve it, and to destroy the bacteria. This method gained some little vogue on the Continent, especially in Germany, but it appears to have been almost, if not completely, abandoned at the present time. It was claimed that the milk remained in effect ' $r a w^{\text {' }}$ milk, and that the 'vital' properties were not destroyed. At that time the investigations which have been dealt with in the preceding chapters had not been made, and scientific knowledge as to the artificial feeding of infants was in a rudimentary state. Hydrogen peroxide is split up by catalase, whether this ferment is present in the milk as such or due to subsequent bacterial action. Where sufficient of the reagent is added bacterial growth is inhibited. Difficulty arises in determining how much should be added to milk when the total bacterial content is unknown. Hydrogen peroxide has a very disagreeable taste, so that it is necessary to add only as much as may be required for the purpose of an antiseptic.

As the physicians of Germany gained experience in the feeding of infants and found the excellent results which are obtained by the use of milk which is heated in the homes, attention was diverted from the need for Buddisation, and the recent literature contains no mention of this method. 
In this country there is still a section of people who cling to the belief in the 'vital ' properties of milk (said to be destroyed by heat) as essential elements in the successful feeding of infants. The results obtained all around them by the use of pasteurised, boiled, or dried milk fail to convince them of the absence of such properties.

Doubtless much of this attitude of mind arises from the fact that the scientific literature dealing with the subject is for the most part in foreign periodicals, and the pressure of daily life does not encourage acquaintance with the results obtained by other methods.

This sentiment has recently found expression in an experiment conducted by the Liverpool Corporation to sterilise milk used at their infant milk depôts by electricity. The work was carried out by Prof. Beattie and his assistants, and the results investigated from various standpoints.

There seems no doubt that the method is entirely satisfactory in destroying as high a percentage of bacteria as is effected by pasteurisation. The report made to the City of Liverpool in I914 showed, that over a period of fifteen days the percentage of bacteria destroyed reached an average of $99^{\circ} 93$ per cent. Special mention is made of the destruction of the acid-forming organisms; and tubercle bacilli were destroyed in some experiments in which the organisms added to he milk. The milk is said to keep extremely well after the treatment, and it is further "claimed that the 'enzymes are not destroyed.' The nature of [the enzymes is not stated, but in view of the experiences already recorded in the previous pages, the whole question is immaterial.

The more important features of the method are shown in Plate VIII.

The milk is poured into a large tank and is passed gradually into the 'lethal' tube. The rate of passage is regulated to ensure a sufficient duration of the treatment. After passing through the tube the milk is at once bottled.

The re-contamination of the milk must be avoided as in the case of pasteurised milk, and the bottles must be cleaned and sterilised as in the case of pasteurisation. There is however the added risk of contamination during manipulation, which risk has been found to be a very real one, and has led to the abandonment of the method at the milk depôts.

It is possible that this method might be of value for commercial purposes. As, however, the plant is expensive, and must be worked by a competent engineer (owing to the high electric potential of the currents used and to the complicated apparatus), it is unlikely, in view also of the cost of the electric current, that this would be found cheaper than the use of heat.

Another method has recently been introduced in Germany, and has proved a source of much discussion. The apparatus, which is known as the 'Biorisator,' consists of a double-walled chamber, the milk being heated by means of steam at $75^{\circ} \mathrm{C}$. The milk is passed in, in a fine jet in the form of a spray and is said to retain all the properties of raw milk. The discussion arose between various investigators who were unable to find much reduction in the bacterial content in the milk stated to have been purified by this method. It seemed probable that here also a difficulty had arisen in regard to 
PLATE VIII.

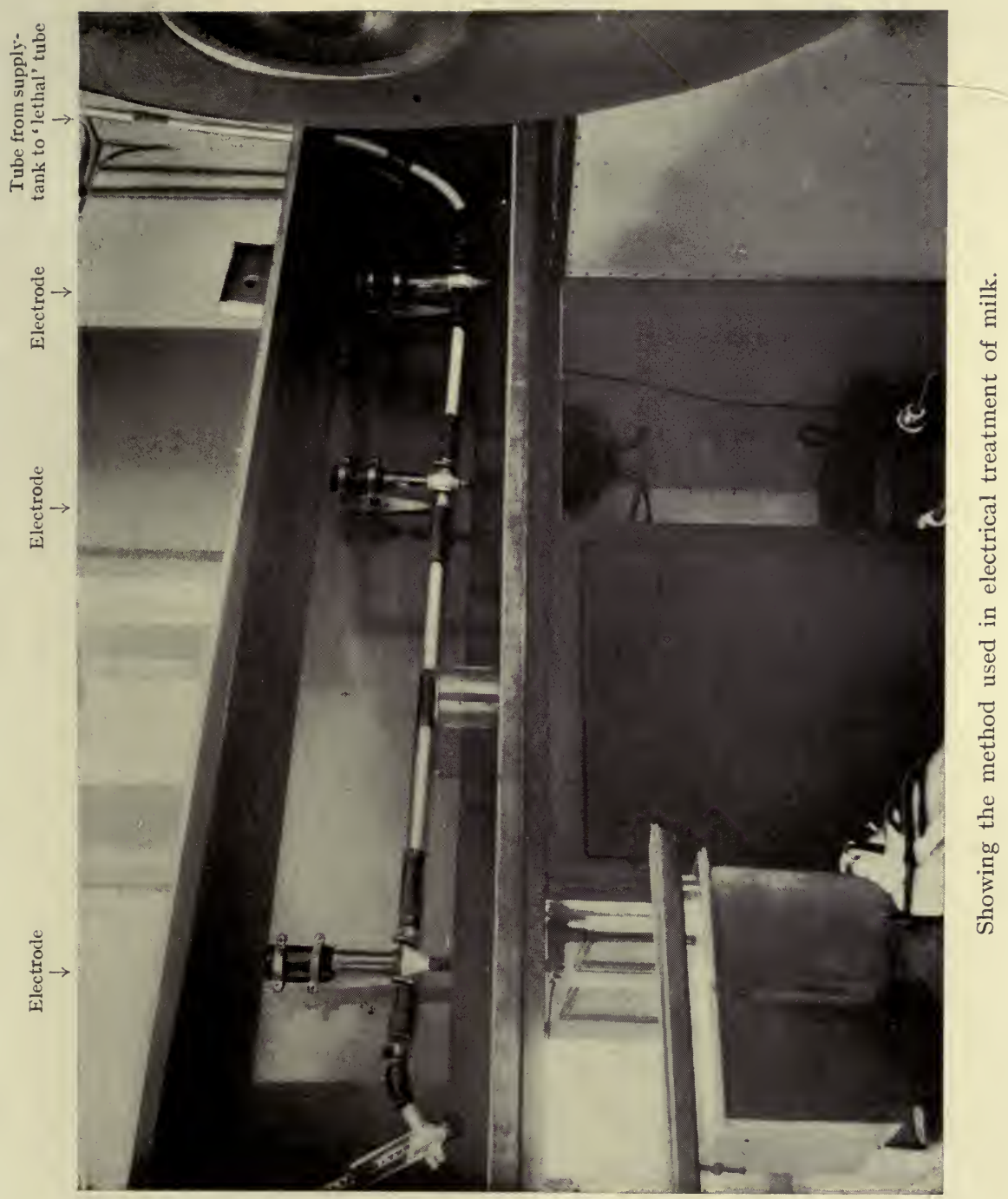

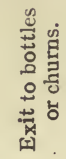



re-contamination of the milk, partly perhaps by certain parts of the apparatus and partly in the process of bottling. ${ }^{1}$

\section{REFERENCES}

BeATtre, "The Utilisation of Electricity in the Continuous Sterilisation of Milk,' Journ. of Path. and Bact. 1913, xviii. I20.

For discussion on Biorisator see Lobeck, Deutsch. med. Wochensch. 1912, p. 2082, and other papers in Milchw. Zent. 1913 and r914.

1 Details as to other less used methods are given by Ernst, Milk Hygiene, translated by Mohler and Eichhorn (London, 19I4), pp. 199-202. 



\section{NDEX}

ABORTION, experimental production in animals, 259; in cows, 257; possible spread to human female through cows' milk, 257

Absorption by suckling, production of immunity by, 120

Acid-forming bacteria increased by time after milking, II 5

Acidity of milk, 236

Agglutinating substances, presence of, II 4

Agglutination of bacteria, I I 7, I I 9

Albumin, 40, 4I ; coagulated, in milk, digestion of, $230 ;-$, temperature of, 229; content, of colostrum, I6 ; - of blood and milk, 39 ; effect of heat on, 229 ; percentage composition of samples, 1o ; precipitation, 229, 230 ; soluble, 238

Alcohol and ether-treated food, effect upon mice, 240

Aldehyde-catalase, 86

Aldehyde-reductase, 86

Alkalinity, reaction due to, 70

Allemans, influence of diet on milk, 2I

Amboceptor, presence of, III, II2

American Medical Milk Commissions, regulations for satisfactory grades of milk, 325 ; work of, 270,271

Amylase, in cows' milk, 74, 97; in human milk, 74, 98 ; presence of, 97

Anaphylactic methods, in relationship of milk-proteins, 31

ANDERSON, pathogenic bacteria in milk, 305

ANDERSON and RosenaU, on organic constituents of milk, 38

Animals, experiments with boiled milk as to nutritive value, I7I, I75; immunity experiments on,
I20, I23; young of different species, value of boiled milk as food, I7I, I75. See also under names of animals

Antigen, soluble, 238

Antigens, 38

Anti-sera, hæmolysis obtained by, 40 ; potency of globulin in producing, 40; production by raw or heated milk, 238

Anti-serum for ox-blood, 38

Antiseptics, catalase inhibited by, 94

Antitoxin, absorption of, by suckling, I2I, I 23

ARNOST, on oxidising ferments in milk, 8I

Artificial feeding, clinical data, I87, r89; death-rate comparatively high in first year, 203; weight statistics in, I95

ASCHENHEIM, on calcium content of milk, 57

Ash, in colostrum, 6 ; in human and cows' milk compared, 8

Ash content, of colostrum, I6, I7, I8; of human and cows' milk compared, 5 ; total cf, 49; variation due to period after parturition, 23

Ash, percentage composition of samples, IO, I 5

AURNHAMMER, fat content of milk, 42 ; period of lactation, 154

Austria, preservation of human milk in, 315

AUTENRIETH and FUNK, on sugar in milk, 44

Auto-digestion of milk, 77

AYERS and JoHnson, bacteria in milk, 288, 290 : pasteurisation of milk, 299 
BABCOCK and RUSSELL, oxidising ferments in milk, 80; pathogenic bacteria in butter, 306; proteolytic ferments in cows' milk, 76 ; proteolytic ferments in milk, 66

BABCOCK, VIVIAN, and RUSSELI, on proteolytic ferments in cows' milk, 76

BABICK, on the nutritive value of boiled cows' milk, I68

ВАсCHI, on organic constituents of milk, 37

$\mathrm{BACH}$, indirect reductase reaction, 9I; reducing ferments in milk, 86

BACr and CHODAT, on catalase, 93 ; oxidising ferments in milk, $8 \mathrm{I}$

Bacillus abortus, agglutinating power of goat's blood for, 258 ; effect on fertility of cows, 314 ; experimental infection with, 259; in cows, percentage, 258 ; in cows' milk, 257

Bacillus acidi lactici, identity with streptococcus lacticus, 247

Bacillus coli, amount in milk estimated dangerous, 302 ; growth of, at different temperatures, 285 ; in cows' milk, 266

Bacteria, agglutination of, II7, II9 ; formation of catalase by, 94 ; killed in milk, products of, $28 \mathrm{r}$, 282 ; in milk, $66,68,72,76,95$; -, acid forming, $283,284,291$; - comparison between raw and pasteurised milk, I93; -, destruction at low temperatures of heating, 290, 29I ; -, destruction without application of heat methods, $327 ;-$, influence on cell count, $131 ;-$, multiplication after heating, 285 ; - , reductions during pasteurisation, 292 ; -, surviving pasteurisation, fate of, 290 ; thermal death-point, 287-290; types of, 283 ; multiplication in milk, 268; pathogenic, in butter, 305,306 ; - in cheese, 306, 307; -, in cream, 305 ; reduction of methylene blue by, 87 ; relationship between catalase and, 95

Bacterial content of unfiltered and filtered milk, 276, 277

Bacterial standard for milk supply, $28 \mathrm{I}$

Bactericidal substances, presence of, II 4

BAHRd and Edelstein, calcium content of milk, 54,55

BAILEY and MURLIN, nitrogen and ash in early human colostrum, I7
BAMBERa, calcium content of milk, 56 ; composition of milk, 24 ; constituents of human milk, 9, I2; nutritive value of milk in the feeding of pigs, 183 ; period of lactation, 158

BANG, on the nutritive value of boiled cows' milk, r66

Barlow's disease, age incidence, 217 ; connection with pasteurisation of milk, 2 I8; -, use of Soxhlet apparatus, 218,220 ; diet in infants before onset of, 218 ; following feeding on proprietary foods, $22 \mathrm{I}$; in Switzerland, 220 ; in U.S.A., 22I; increase in Berlin (I902-3), 218; non-prevalence in poorer classes, 219 ; production by heated milk, 2I6, 2I 7

BARTELII, on bactericidal and agglutinating substances, II 7

BARTENSTEIN, nutritive value of milk in feeding of guinea-pigs, 175

BARTHEL, catalase in cows milk, 94; direct and indirect reductase, 88 ; peroxidase reaction, 84

BAUER, biological relationship of milk-proteins, 33 ; effect of heat upon the properties concerned with the production of immunity, 238 ; organic constituents of milk, $35,36,37,39$; substances concerned in hæmolysis, II2; substances concerned in hæmolysis in human milk, II 3

BAUER and Davidsohn, lipase in human milk, 79

BAUER and ENGel, biological relationship of milk-proteins, 33; organic constituents of milk, 39 , $4 \mathrm{I}, 42$

BAUEREISEN, organic constituents of milk, 35, 39, 4I ; proteins of colostrum, 32

Beattie, destruction of bacteria in milk, 327

BERGEY, presence of disease in milk, I 44; prevalence of streptococci, 246

BERKA, on cellular elements in milk, 135

Berlin, infant consultations in, I94; streptococci in milk in, 246; weights of breast-fed and artificially fed infants, 3I5-320

BERTARELle, on direct absorption of protein, I25

Bertin-Sans and Ganjoux, direct and indirect reductase, 89 ; variations in catalase content, 97 
BESREDKA, organic constituents of milk, 4I

Bibliography, 3 ; bacillus abortus in milk, 264; bacteria in milk, 293 ; Barlow's disease, 223 ; boiled milk of the same species, 169; breastfeeding, r59; cellular content, 145: composition of milk, 27; destruction of bacteria in milk, 329; development of the mammary function, 3II ; dried milk, 214 ; enzymes of milk, 100 ; experimental data relating to nutritive value of raw and boiled milk, I 86 ; grading of milk, 327 ; heated milk, 24I, 304 ; immunity, 125 ; inorganic constituents of milk, 60 ; methods commonly used in heating milk, 304; milk-borne epidemics, 264 ; nutritive value of boiled milk, 204 ; organic constituents of milk, 44; pathogenic bacteria in butter and cheese, 308 ; preservation of human milk, 315 ; production of milk as far as possible free from contamination, 282 ; rickets, 223 ; sources of milk contamination, 269; streptococci in milk, 262; tubercle bacillus in milk, 263

BIER, on variations in catalase content, 97

BIOLCHINI and LuzzaTr, on lipolytic ferments in cows' milk, 78

Biological properties of milk, 63

Biorisator for destruction of bacteria in milk, 328

BIRK, ash of human colostrum, 18, 19: period of lactation, 154,158

Blood, interrelationship of milkproteins and proteins of, 37 ; lipase present in, 79; ox, anti-serum for, 38

Blood-proteins, 37, 240

BOCKHOUT and DE VRIES, calcium content of milk, 231 ; proteolytic ferments in cows' milk, 76

Boiled milk, 303; clinical data as to value in infant feeding, 190, 192 ; experiments on animals as to nutritive value of, $177,178,180$, 183,185 ; nutritive value of, $16 \mathrm{r}$, 162 ; - , as food for infants, 187 , 189 ; - , for young of different species, I7I, I 75 ; of same species, nutritive value of, 16r; Schardinger's test for, 89

Boiling, effect on growth of bacteria in milk, Ir6

BOLLE, nutritive value of milk in feeding of guinea-pigs, I75
BORDAs and TOUPlaIN, on peroxidase reaction, 84

BORDET, on organic constituents of milk, 38

BosworTH and PRUCHA, citric acid in milk, 234

Bottle-feeding with boiled human milk, I63

Bottling, sterile, of milk, 280

BRAND, on constituents of milk concerned in F.M.B. reaction, 9I

Breast. See Mammary gland

Breast-feeding, 2, I47; advantages of, factors counteracting, 3II ; death-rate comparatively low in, 203; in guinea-pigs, value of, I76 ; later effects of, I59 ; natural immunity conferred by, 125 ; nutritive value of, 163 ; weight statistics in, I64. See also Lactation

BREDIG and SOMMER, on indirect reductase reaction, 9 I

Breed. See Cows

BRENNEMANN, casein curds in infants' stools, 228 ; organic constituents of milk, 36

BRODSKY, on the period of lactation, 154

BRÜCKLER, nutritive value of milk in feeding of goats, 174,185

BRUNING, hydrogenase in cows' milk, 92 ; nutritive value of boiled goats' milk, 168 ; nutritive value of milk, in the feeding of dogs, 180 ; -, in the feeding of goats, 174, 185 ; - in the feeding of guineapigs, I75; - in the feeding of pigs, 182 ; - ; in the feeding of rabbits, I 78 ; prevalence of streptococci, 246

BuDDE's method for destruction of bacteria in milk, 327

BUDIN, capacity for lactation, $\mathbf{I}_{4} 8$; development of the mammary function, 3II; infantile scurvy, 220; period of lactation, I54, 158

BUNGE, ash content of milk, 49 ; capacity for lactation, 148 ; iron content of milk, 50; phosphorus content of milk, 59

BURRI and KURSTEINER, Schardinger's reaction, 90

BURRI and SCHMID, Schardinger's reaction, 90

BURRI and Staub, method of estimation of catalase, 93

Butter, pathogenic bacteria in, 305 , 306: tubercle bacilli in, 306

Butter-fat in cows' milk, 43 
Butter-making, pasteurisation of milk for, 306

Butter-milk, raw and boiled, chemical analysis of, 232

CALCIUM chloride, coagulation of caseinogen effected by, 235

Calcium content, of human and cows' milk, 54, 232; of infants' milk, how obtainable, 232; of milk, 37,48 , $54 ;-$, changes after heating, 231 ; -, in relation to rickets, $23 \mathrm{I}$; -, reduction, delays, clotting, 236

Calcium in food, effect on milk, 2I, 55

Calories. See Heat value

Calves, value of boiled and raw milk as food for, 166

CAMERER, iron content of milk, 50 ; organic constituents of milk, 36

CAMERER and SöldNER, ash content of milk, 49; differences between colostrum and average milk, 6 ; iron content of milk, 51 ; values of colostrum, I 7

CAMPBELL, estimating the cellular content of milk, I39, I40, I4I ; presence of streptococci, 246; tubercle bacilli in milk, $25 \mathrm{I}$

Capobianco, osmotic pressure of colostrum in the cow, 16

CAPPS and Miller, milk-borne epidemics, 26I

Carbohydrate percentage in human colostrum, I7

CAREL, case of infantile scurvy connected with stale milk, 220

Carlyle and Woll, influence of diet, 20

Caseases derived from plants, effect upon caseinogen, 228

Casein, curd of infants' stools, 36 ; digestion of, situation in body, 228

Caseinogen, 30, 32, 34, 40, 4I, 240; amount of, 34 ; as antigen unaffected by boiling, 238 ; chemical composition of, 36 ; coagulation of, 229,$230 ;-$, effected by addition of calcium chloride, 235 ; - by rennet, 235 ; content, of colostrum, I6; - , in milk, digestion after heating, 230; digestibility of, 36 ; effect of heat upon, 227 ; percentage, $37 ;-$, amount in human and cows' milk, 35 ; - composition of samples, Io; raw and boiled, effect of caseases on, 228 ; separation of, 39 ; - phosphorus from, 229
Catalase, 65 ; amount of, as determining quality of milk, 96 ; content, variations in, 97 ; estimation of, method, 93 ; in cows' milk, 72,93 ; -, sources of, $94^{\prime}$; in human milk, 73,96 ; inhibited by antiseptics, 94; presence of, 72

CATHCART and HAHN, reducing ferments in milk, 87

Cathcart and Paton, source of lactose in milk, 2I; sugar in milk, 44

Cattaneo, on substances concerned in hæmolysis in human milk, $\operatorname{Ir} 3$

Cell activity in mammary gland, 136

Cell count, influence of disease on, I32; methods of obtaining, I30, I 40

Cells in human milk, I35; main classes of, I33, I35

Cellular content of milk, 130, 134; methods of estimating, 137 ; presence of disease in, $143 ;-$, in relation to certain other factors, 142

Cellular elements, nature of, I33, I34

Centrifugalised milk, cellular content of, 130,138

Cervical glands, tuberculosis of, due to bovine tubercle bacilli, 254 , 255,256

Chamouin, nutritive value of milk in feeding of kittens, 182

Cheadle, W. B., Barlow's disease, 217

Cheese, manufacture from pasteurised milk, 307; pathogenic bacteria in, 306,307

Cheese-making, with boiled or pasteurised milk, 236

CHICk, on catalase, 93

Children, artificially fed, high mortality, 3II; young, chiefly affected by bovine tubercle bacilli, 253, 254

Children. See also Infants

Churns, hygienic improvement in, $28 \mathrm{r}$; temperature of milk in, 280

Citric acid content of cows' and human milk, 233; disappearance from milk turned sour, 234

ClaUS, on the period of lactation, I 57

Clot formation of casein in stomach, 228

Coagulation by rennet, effect of heating on, 235

Coagulum, soft, digestibility of, 237

Coloration of milk, 69

Colostrum, agglutinating power of, II9; bactericidal power in, II7; complement in, II2 ; composition 
of, 6 , I 5 ; cows', percentage composition, I6; essential differences between milk and, 6 ; food value of, 18 ; heat value of, 19 ; human, ash content of, 18 ; - percentage composition, I7; immune substances in, IIo; proteins of, 32, $4 \mathrm{I}$

Cомву, cases of infantile scurvy in children, 222

Complement deviation, 39 ; in relationship of milk-proteins, 3I ; normally present in cows' milk, II 2

Composition of dried milk, chemical, 207 ; of colostrum, 6,15

Composition of milk, at different stages of emptying the gland, 22; average, cows' and human, 4,8 ; breed of cow affecting, Io; changes occurring at different stages of lactation, 5, I I ; chemical, 26; diseases of gland affecting, 26; in early days after parturition, I5; in relation to amount of milk produced, 24 ; influence of diet, 20 ; percentage of samples, ro; variations due to period of lactation, II

CONN and EsTEN, bacteria in milk, 283

CoNN and STocking, bacteria in milk, 283 ; bactericidal and agglutinating substances, II 5

ConRaDI, effect of heating on the coagulation by rennet, 235

Coplans, on bactericidal and agglutinating substances, I 16

Cow, method of obtaining milk sterile from, 265 ; one, variation in yield and composition of milk, I4; tuberculous, milk of, $25 \mathrm{I}$

Cow-sheds, source of contamination of milk, 267

Cows, abortion in, 257: breed of, composition affected by, ro: diseased, milk-borne epidemics due to, 259, 260; diseases of, effect on ferment content of milk, 99; fertility of, effect of bacillus abortus on, 314; hind-quarters, contamination of, 266 ; mastitis in, cause of, 247; teats of, infection from, 261, 262; testing with tuberculin, 272; with no recognisable tuberculous lesion of udder, tubercle bacilli in milk from, 252. See also Holsteins, Jerseys, Shorthorns, \&c.

Cows' milk, amount given on consecutive days, 26; amylase in,
74, 97 ; as food for infants, clinical data, 187,189 ; bacillus abortus in, 257; bacterial content, 276, 277 ; boiled, nutritive value of, I6I, I65; calcium content of, 54 ; catalase in, 72,93 ; -, sources of, 94 ; certified, 325 ; -, bacteria in, 287 ; -, pathogenic streptococci in, 262 ; -, provision of, 271 ; citric acid in, 233; complement present in, II 2; composition of average, 4,8 ; contamination, sources of, 265 , 268,269 ; cooling of, 278,279 ; desiccation of, methods of, 322, 323, 324; dried, advantages of, 322 ; experiments on, 68 ; fæcal contamination, 266 ; fat content of, 43 ; filtration of, 275,276 ; grading of, 325,326 ; hairs in, 266 ; heated, nitrogen in, 229; heating before bacterial invasion, 285 ; hydrogenase in, 92 ; iron content of, 50,51 ; lipase in, 78 ; maximum heating - point non-detrimental to food, 290; pasteurised, clotting of, 307; -, manufacture of cheese from, 307; presence of peroxidase in, 8r; proteolytic ferments in, 76 ; raw and boiled, digestibility compared, 228 ; salolsplitting ferment in, 98 ; stale, sale.of, 301 ; sterilisation by electricity, 328 ; sterilised, digestion of, 228 ; sugar content of, 44 ; total protein in, 35 ; transference to sterile receptacles, 280 ; transit by bottles, $28 \mathrm{I}$; variations in composition due to period after parturition, I2

Cows' and human milk, calcium content of, 232; phosphorus content of, 232; salt content of, 232 ; total nitrogen content, 230

Cozzolino, on bactericidal and agglutinating substances, II 5

Cream, pathogenic bacteria in, 305 : virulent streptococci in, 250

Csonka and EDelstein, on iron content of milk, $5 \mathrm{I}$

CURD, casein, in infants' stools, 36

Czerny, cellular elements in milk, I35; nutritive value of raw and boiled cows' milk as food for infants, 189

DAIRY cows of Edinburgh, tuberculosis among, 252

Dammans, on the nutritive value of raw and boiled cows' milk, I68 
DARLING, milk-borne epidemics, 26I

DAVIDSOHN, fat-splitting ferments in milk, 67, 68; lipase in human milk, 78; preservation of human milk, 3I5; substances concerned in hæmolysis, II 4

DEAN, nutritive value of boiled cows' milk, I66

Death-rate, comparison between breast-feeding and artificial feeding, 203

DELEPINE, bacteria in milk, 288 ; pasteurisation of milk, 300 ; tubercle bacilli in milk, 25I

DENNEMARK and ENGEL, colostrum of the cow, 16

Diarrhœa, causes of, I64, I66 ; infantile, in relation to quality of milk, 287

DIBBELT, on calcium content of milk, 56, 57

DIENES, metabolism of pregnancy and lactation in dogs, I5

Diet, influence on composition of milk, 20; milk in relation to, 7

Digestion, infantile, chemistry of, 36 ; of milk, 77

Diphtheria, milk-borne epidemic of, 260

Diphtheroid bacillus, experimental production of abortion by, 259

Diplococcic formation, streptococci in milk acquiring, 248,249

Disease, presence of, effect on cellular content, I43

DOANE and BUCKLEY, on estimating the cellular content of milk, 137

DOANE and PRICE, on the nutritive value of boiled cows' milk, I 66

Dogs, experiments on, nutritive value of milk, I74, I79

DOBRR and NOTTBOHM, on iron content of milk, $5 \mathbf{I}$

Dried milk, 304; as food, clinical data, 2 10 ; - experimental data, 209 ; - , for infants, 206 ; chemical composition of, 207

Dutch milks not coagulating with rennet, 231

EAsTwOoD, tubercle bacilli in milk, 250

ECKLES, variations of fat in cows' milk, I I

ECkles and Plaut, fat content of milk, 43

Eckles and Shaw, differences in composition of milk, 22, 24; effect of stage of lactation upon the milk of cows, I2 ; fat content of milk, 43 ; influence of breed of cows on composition of milk, ro; variations in the fat content of milk, 25

EDELSTEIN and BAHRDT, calcium content of milk, 54, 55

EDELSTEIN and CsonkA, iron content of milk, 5I

Edelstein and Langstein, iron content of milk, 53; organic constituents of milk, 37

Edelstein, LANGstein, and Rotr, human colostrum, 17, 19

Edinburgh, tubercle bacilli in mixed milk from milk-shops in, 252

EHRLICH, passive immunity by suckling, I 20

'Eisenzucker,' 53

Electricity, sterilisation of cows' milk by, 328

ElLENBECK, on lipase in human milk, 78

End-milk, 7, I7

ENGEL, constituents of milk, 22 ; fat content of milk, 43 ; period of lactation, I 59

ENGEL and BAUER, organic constituents of milk, 39

ENGEL and DENNEMARK, colostrum of the cow, 16

ENGEL and MURSCHHAUSER, organic constituents of milk, 42

ENGEL and PLAUT, influence of diet on human colostrum, 2 I

England, dried milk as food for infants in, 207 ; pasteurisation of milk in, 298

Enzymes in milk, 63, 75, 328

Epidemics, milk-borne, 259, 26r, 262, 267 ; - , spread by milkers, 273 ; - , streptococci isolated from cases of, 248

ERNST, estimating the cellular content of milk, I38; prevalence of streptococci, 246, 248

EsCHERICH, Barlow's disease and rickets, 218 ; rickets in breast-fed and bottle-fed babies, 222

EUGLING, on organic constituents of milk, 38

Experiments as to value of boiled milk for young animals, I 7 , I75

FAecal contamination of cows' milk, 266

FAMUlener, passive immunity by suckling, 122 
Farms containing infected cows supplying milk to Manchester, average number (1896-19r3), 25 r

Fat, in colostrum, 6; in human and cows' milk compared, 8 ; in milk, 4

Fat content, of colostrum, 16,17 ; of human and cows' milk compared, 5 ; of milk, 42 ; - changes after heating, 230 ; towards end of milking, 22, $15 \mathrm{I}$; variations in, 7 ; -, at different periods of milking, 25 ; - , due to period after parturition, II, I2, I3, 23

Fat globules, action of cells on, 136

Fat percentage composition of samples, ro

Fat-splitting ferments of milk, 67

Fats in milk, 33

Feeding, artificial, detrimental element in, 36; experiments, 55 ; methods in early life, $3 \mathrm{rx}$. See also Breast-feeding and Food

Ferment content of milk in abnormal conditions, increase in, 99

Ferments, 75 ; acting on sugar, 68 ; fat-splitting, 67; glycolytic, in milk, 79 ; in milk, 63,75 ; lactase, in milk, 79 ; lipolytic, 67,78 ; oxidising, in milk, 80; - presence of, 68 ; present in milk, 237 ; proteolytic, acting on proteins, 66 ; - in cows' milk, 76 ; - in human milk, 77 ; reducing, in milk, 85 ; reductase, $7 \mathrm{I}$; reduction of methylene blue by, 87 ; salol-splitting, in cows' milk, 98 ; - in human milk, 98 ; tests for, 69 ; value to infants of, 66

Filter. See Ulax filter

Filtration of milk, 275,276

FindLAy, factors in causation of rickets, 223

Fingerling, goats' milk, 7 ; influence of diet on the milk of goats, 2 I ; phosphorus content of milk, 59

Finkelstein, development of the mammary function, 3 II ; nutritive value, of boiled human milk, 165 ; -, of raw and boiled cows' milk as food for infants, 190, 192; organic constituents of milk, 36 ; period of lactation, $\mathbf{x}_{59}$

First milk, bacteria and catalase relationship in, 95 ; constituents concerned in F.M.B. reaction, $9 \mathrm{I}$; fat content of, 22

Flash process for pasteurisation of milk, 299

Fletcher, milk-borne epidemics, 26 I
FLÜGGE, sterilised milk, 303

F.M.B. reaction, 72 ; constituents of milk concerned in, 91 ; reduction of, 88

Food, for infants, dried milk as, 206, 209: influence on composition of milk, 20; quantity of taken, effect on milk, 7 ; special substances added to, effect of, 7,55 ; value of colostrum, I 8

Foot-and-mouth disease, effect on ferment content, roo

Fore-milk, cellular content, 139

Formaldehydase, 86, 90

Formalin - methylene - blue. See F.M.B.

ForsyTH, on the period of lactation, I 53

France, dried milk as food for infants in, 207 ; sterilised milk in, 304

Frank and Schloss, on calcium content of milk, 57

Fraser, tubercle bacilli in milk, 256

FRED, on direct and indirect reductase, 88

FREUDENREICH, pasteurisation of milk, 296; proteolytic ferments in cows' milk, 76

FrICK, cellular content in relation to stages of lactation, 142 ; presence of disease in milk, 144

FrIEdJUNG and Hecht, catalase in human milk, 96; lipase in human milk, 78 ; peroxidase in human milk, 71, 82; proteolytic ferments in human milk, 77

Fuld and NoEggerath, effect o heating on the coagulation by rennet, 236

Funk, presence of further substances in milk concerned in the nutrition of the organism, 240

FUNK and AUTENRIETH, sugar in milk, 44

GaltieR, pathogenic bacteria in cheese, 307

GANGHOFNER and LANGER, direct absorption of protein, 124 ; passive immunity by suckling, 123

GERBER, effect of caseases upon raw and boiled caseinogen, 228

Gerber and OTTIKER, amount of catalase as determining the quality of milk, 96; method of estimation of catalase, 94 ; variations in catalase content, 97 
GERLACH, on the nutritive value of boiled cows' milk, I65

Germany, biorisator for destruction of bacteria in milk used in, 328 ; preservation of human milk in, 315 ; sterilised milk in, 304

GewiN, on direct absorption of protein, 125

GIFFHORN, amylase in cows' milk, 74, 97; variations in catalase content, 97

GILLET, reductases in human milk, 92

GiLlet and Marfan, peroxidase in human milk, 7I

GIORDANI, iron content of milk, 53

GitTINGS and GrIFFITH, weight of breast-fed infants, 20

GrIKIN, on phosphorus content of milk, 59

Globulin, 40, 4I ; content of colostrum, 16

Glycolytic ferments in milk, 79

GMINDER, presence of disease in milk, 144; presence of streptococci, 248

Goats, experiments on, nutritive value of milk, 174, 185

Goats' blood, agglutinating power for bacillus abortus, $25^{8}$

Goats' milk, 90

GRATZ, streptococci in milk at, 246

Gratz and MARAY, cellular content in relation to stages of lactation, 142; cellular elements in milk, I36; ferment content of milk in abnormal conditions, Ioo

GRIFFITH, change of diet necessary for infantile scurvy, 221, 222

GRIFFITH and GitTings, weight of breast-fed infants, 20

GrImMER, peroxidase reaction, 83 , 84 ; proteolytic ferments in milk, $67,77,78$; salol-splitting ferment in cows' and human milk, 99

GROSSER, calcium content of milk when boiled, 23x; nutritive value of boiled cows' milk, I69; total nitrogen of cows' and human milk, 230

Guaiacum tincture, use of, 69, 8I

Guinea-pigs, artificially fed, 3I4; average weight at different ages, I78; breast-feeding of, value of, I76; experimental production of abortion in, 259 ; experiments on, nutritive value of milk, I73, I75: percentage mortality among, I 77
HFMolysis, obtained by anti-sera, 40 ; substances concerned in, presence of, II2; surface tension connected with, I I 4

HAHN, on direct absorption of protein, 124

Hairs in cows' milk, 266

Halban, direct absorption of protein, 125

HALBAN and LANDSTEINER, direct absorption of protein, 125

HALIPRE, nutritive value of raw and boiled cows' milk as food for infants, 190

HALLIBURTON, organic constituents of milk, 34

HAMBURGER, milk-borne epidemics, 260 ; organic constituents of milk, 38 ; passive immunity by suckling, I20, I21, I23; prevalence of streptococci, 248

HammaRsten, organic constituents of milk, 34

HARDEN and LANE-ClAYPON, catalase in cows' milk, 73, 95; method of estimation of catalase, 94; peroxidase in cows' milk, $8 \mathrm{I}$

HARRISON, pathogenic bacteria in cheese, 306

Heat, effect of, upon albumin, 229; -, upon caseinogen, 227 ; - upon cellular content, 140 ; - , upon peroxidase reaction, 84 ; reduction of soluble albumin and antigen by, 238,240 ; value of colostrum, I9

Heating, changes in protein of milk from, 225, 227; effect of, on coagulation by rennet, 235; of milk, methods employed for, 294

HЕсHт, reductases in human milk, 92 HECHT and FRIEDJUNG, peroxidase in human milk, $7 \mathrm{I}$

HEIM, pathogenic bacteria in cheese, 307

Heineman, prevalence of streptococci, 247, 249

HELBICH, analysis of mixed samples of human milk, 25; constituents of milk, 22; effect of different intervals of milking (human), 24 ; effect of the intervals of feeding on the amount of milk, 155, 156 ; fat content of milk, 43 ; period of lactation, I 54

Hess, tubercle bacilli in milk, 250

HESSE and KOOPER, on peroxidase reaction, 83

HEUBNER, Barlow's disease, 219

HEUNER, organic constituents of milk, 4I 
Hewlett, cellular content in relation to stages of lactation, I42 ; presence of disease in milk, I44

HEWLETT and BARTON, sources of milk contamination, 266

Hewlett and Revis, substances concerned in hæmolysis, $\mathrm{I}_{3} 3$

Hewlett, Revis, and Villar, cellular content of milk, 26 ; cellular elements in milk, I35, I36, I42

HEYGENDORFF and MEURER, on amount of catalase as determining the quality of milk, 96

HippIUS, on lipase in human milk, 78

Hittcher, experiments with raw and boiled cows' milk, 167 ; nutritive value of boiled cows' milk, I 65, I66, I68

HOEFFTER, hydrogenase in cows' milk, 92

HOHLFIELD, nutritive value of raw and boiled cows' milk as food for infants, 190

Holborn, breast-fed and bottle-fed children in, 312,313

Holder process for pasteurisation of milk, 298, 299

HölLING, prevalence of streptococci, 249

Holstein cows, composition of milk of, ro

Holstein cows' milk, composition variations in, 13

HOOBLER, calcium content of milk, 57

Hopkins, presence of further substances in milk concerned in the nutrition of the organism, 240

HoRMAN and MORGENROTH, pathogenic bacteria in cheese, 306

Houses, contamination of milk in, 267,268

Houston, grades of milk, 326 ; sources of milk contamination, 267,268

Human milk, amylase in, 74, 98 ; boiled nutritive value of, 161,162 ; calcium content of, 54 ; catalase in, 73,96 ; cells in, I35; complement present in, Ir 3 ; composition of, average, 4,8 ; constituents of, average, 9 ; experiments on, 67 ; iron content of, $50,5 \mathrm{I}$; lipase in, 78 ; presence of peroxidase in, 70 , $8 \mathrm{I}$; preservation of, 315 ; proteolytic ferments in, 77 ; reductase in, presence of, 92 ; salol-splitting ferment in, 98 ; total protein in, 35 ; variations in composition due to period after parturition, II
Hunnaeus, calcium content of milk, 54 ; fat content of milk, 42

Hydrochloric acid, addition to milk, 236

Hydrogen peroxide, action of amylase increased by, 98; addition to milk, 327 ; for preservation of milk, 93

Hydrogenase, 86 ; in cows' milk, 92

Hygiene, milk in relation to, I

IMMUNITY, acquired, production of, 33, I09; natural, 109; passive, I09; -, by suckling, $120 ;-$, substances concerned in, I08, II2; transferred by suckling, $\mathrm{x} 20$; transmission of, from parent to offspring, 120

Infants, artificial feeding of, 317,318 , 322 ; - boiled milk in, clinical data, 190, I92; -, detrimental element in, $36 ;-$, methods of, $2 ;-$, nutritive value of boiled milk in, $\mathrm{x} 62$; -, raw milk in, clinical data, 190, 192; Barlow's disease in, alleged production by heated milk, 216,217 ; breast-fed and artificially ed, I 48, 319; breast-fed and bottlefed, state of health in, 312,313 ; feeding of, dried milk in, 206, 209; feeding with milk with high bacterial content, 285 ; frequent feeding not necessary, I $5 \mathrm{I}$, I 55 ; iron metabolism in, with different milks, 53; loss of weight in, 19 ; nutritive value of boiled and raw cows' milk for, $x 87, \quad 189$; results of feeding with milk from different sources, 286,287 ; value of ferments to, 66 Inorganic constituents of milk, 48 Intestine, small, digestion of casein in, 228

Iron, presence in colloidal form, 70

Iron content, total of, 49

Iron metabolism in infants according to the milk feed, 52

JENSEN, catalase in cows' milk, 95; constituents of milk concerned in F.M.B. reaction, 9I ; differences in composition of milk, 22 ; hydrogenase in cows' milk, 92 ; peroxidase reaction, 84

Jensen and PlatTNer, effect of heating on the coagulation by rennet, 236 ; fat content of milk on boiling, 230; temperature of coagulation of albumin, 229 
Jersey cows, composition of milk of, ro ; milk composition, variations in, 13

JOLlEs, on peroxidase in human milk, 82

KaISER, prevalence of streptococci, 246

KAMINER and MAYERHOFER, on phosphorus content of milk, 60

KASTLE and PORCH, on peroxidase in human milk, 83

KELLER, nutritive value of milk in the feeding, of dogs, 180 ; - of mice, $178 ;-$, of rats and mice, $x 73$

KIRCHNER, average composition of cows' and human milk, 5

Kittens, experiments on, nutritive value of milk, I74, I 82

KLEBS, oxidising ferments in milk, 69,80 ; peroxidase reaction, 84

KLEIN, nutritive value of milk in the feeding of pigs, 184

KLIMMER, bactericidal and agglutinating substances, II 5

KNAPE, preservation of human milk, 315

KNOX and TRACY, on phosphorus content of milk, 60

KOBELE, on substances concerned in hæmolysis, II 3

KoHN, influence of diet on the milk of goats, 2I

KOLLE, bactericidal and agglutinating substances, II 5

KOLLMEYER, organic constituents of milk, 39, 4I, 42

KöNIG, percentage composition of cows' colostrum, I 6

KoNING, amylase in cows' milk, 97 ; bactericidal and agglutinating substances, II 5 ; influence of diet on the milk supply of cows, 21 ; method of estimation of catalase, 93; reductases in human milk, 92; variations in catalase content, 97

KOOPER, catalase in cows' milk, 94 ; method of estimation of catalase, 94; peroxidase reaction, 83,84 ; variations in catalase content, 97

KOPF, substances concerned in hæmolysis, II 2

KöSTLER, ferment content of milk in abnormal conditions, 99

KOWALEWSKY, oxidising ferments in milk, $8 \mathrm{I}$

KRASNOGORSKY, iron content of milk, 52
KRAUS, bactericidal and agglutinating substances, II 9

KREIDL and LENK, effect of heating on the coagulation by rennet, 235

KRost, nutritive value of raw and boiled cows' milk as food for infants, 203

LACT-ALBUMIN, 30 ; amount of, 34 ; anti-sera, 39; chemical composition of, 36 ; percentage of, 37 ; -, amount in human and cows' milk, 35

Lactase, 75 ; ferment, 68 ; ferments in milk, 79

Lactation, capacity for, I 48 ; changes in composition of milk at different stages of, 5, II ; iron content of milk in, $5 \mathrm{I}$; metabolism. of, 15 ; periods of, 150 ; variations in composition due to, II ; stages of, 142

Lacto-globulin, 30, 32, 34 ; percentage amount in human and cows' milk, 35

Lacto-protein percentage composition of samples, ro

Lacto-serum, action of, 38 ; production of, 239

Lactose, 68 ; in milk, source of, 21 ; content of colostrum, I6; percentage composition of samples, ro; reduction of methylene blue by, 87

LAGANE, amylase in human milk, 98 ; Schardinger's reaction, 90

LAM, amount of catalase as determining the quality of milk, 96

LANE-Claypon, amylase in cows' milk, 98; nutritive value of raw and boiled cows' milk as food for infants, 193

LANE-CLAYPON and HARDEN, catalase in cows' milk, 73, 95; method of estimation of catalase, 94 ; peroxidase in cows' milk, 81

LANGER, bactericidal and agglutinating substances, II9; organic constituents of milk, 42

LANGSTEIN, iron content of milk, $5 \mathrm{I}, 52,53$

LANGSTEIN and EDELstein, iron content of milk, 53 ; organic constituents of milk, 37

LANGSTEIN and MEYER, nutritive value of boiled human milk, I63

LANGSTEIN, ROTT, and EDELSTEIN, human colostrum, I7, 19 
Later milk, ash content of, I8 ; bactericidal power in, II 7

LEEDS and DAvIS, on the nutritive value of raw and boiled cows' milk as food for infants, I 89

LENZEN, on substances concerned in hæmolysis, II3

LEPERRE, on lipolytic ferments in cows' milk, 78

Leucocytes, action of, 135 ; dead and living, I33; estimation of, I3I ; polymorphic, 134, I35

LEUFVEN, production of milk as far as possible free from contamination, 273

LEVEN and BARRATT, on the period of lactation, $5 \mathrm{I}$

LEWIS, on the presence of disease in milk, I44

Life, early days of, absorption of protein after, 124

Lime content of human milk, 56

Lipase, 75 ; in cows' milk, 78 ; in human milk, 78

Lipolytic ferments, 78 ; of milk, 67

LIsKA, pathogenic bacteria in cheese, 307

Literature. See Bibliography

Liverpool Corporation, sterilisation of milk by electricity, 328

Lobeck's apparatus, 94

LOEW, on oxidising ferments in milk, 80

London County Council, tubercle bacilli in milk samples examined under, 250

LUST, direct absorption of protein, I24; sugar in milk, 44

MACEWEN, milk-borne epidemics, 261

MACFADYEAN and STOCKMAN, bacillus abortus in milk, 257

MaI, on iron content of milk, 53

Mal-nutrition, clinical data on, r89

Mammary function, development of, 309-II

Mammary gland, cell activity in, 136 ; disease of, composition of milk in, 26 (see also Mastitis); emptying necessary, I50 ; opposite, variations in composition of milk, I2 ; stages of emptying, composition of milk at, 22 ; stimulus of, 154

Manchester, farms containing infected cows supplying milk to, 25I ; milk supply of, tabercle bacilli in, 251
MARFAN and Gillet, lipolytic ferments in cows' milk, 78 ; peroxidase in human milk, 71,82

MARSH and MEIGS, average composition of cows' and human milk, 5, 9; organic constituents of milk, 42

Mastitis, complement present in cases of, II2 ; diagnosis of, I44; effect on ferment content of milk, 99 ; in cows, cause of, 247 ; milk analysis in, 27 ; tests for, I 38

MAYERHOFER and KAMINER, phosphorus content of milk, 60

MAYERHOFER and PRIBRAM, direct absorption of protein, I24; preservation of human milk, 3I 5

MEIGs and MARSH, average composition of cows' and human milk, 5, 9; organic constituents of milk, 42

Mellanby, metabolism of pregnancy and lactation, I5

MenozzI and Musso, on organic constituents of mill, $3^{8}$

Methylene blue, deduction of, 87

MEYER, on the nutritive value of boiled human milk, I63

Mice, experiments on, nutritive value of milk, I73, I 78

Micro-organisms in milk. See Bacteria

Middle milk, bacteria and catalase relationship in, 95 ; cellular content of, I 39 ; constituents concerned in F.M.B. reaction, $9 \mathrm{r}$; fat content of, 22

Milk, amount of, during lactation, I5I : 'biological properties' (socalled), 63,75 , I08, II2; cellular content of, I30, I34, I37; certified, inoculation with streptococci, 249 ; clinical data of nutritive value of raw and boiled cows' milk, I87; composition of, $2,4,8$; dried as, food for infants, 206; experimental data upon nutritive value of boiled milk, I7I, I75; fat content of, 42 ; ferments or enzymes, 63,75 ; foreign research on, I ; heated, alleged production of Barlow's disease and rickets by use of, $216 ;-$, changes occurring in, $225 ;-$, and rickets, 217,222 ; human, breast feeding, I 47 ; - composition of, $2,4,8 ;-$, nutritive value of, I6I; hygienic relations, I : immunity, production of, substances concerned in, I08, II2; in. organic constituents of, 48 ; nutri- 
tive value; of boiled milk, $16 r, x 7 x$, I 75 ; - of human milk, I6I ; - of raw and boiled cows' milk, 187 : organic constituents of, 30,33 ; organisms in, liable to cause disease, 244; peroxidase in, summary of, 71 ; production of, 2 ; -, in relation to hygiene, $I$; sterilised, in relation to Barlow's disease, 220 ; - , stale, ill effects of, 220 ; sugar content of, 44 ; value in supplementing insufficient diet, 240. See also First Milk, Middle Milk, Strippings

Milk-cooler, 277, 278, 279

Milk depots of England, 32 I

Milk-pails, contamination of cows' milk from, 267

Milk-proteins, biological relationship of, 31

Milk supply, bacterial standard for, $28 \mathrm{I}$

Milkers, infection transmitted by, $26 r, 262,266$; personal hygiene of, 273; spread of milk-borne epidemics by, 273: tubercle bacilli in milk conveyed by, 252

Milking, bacteria decrease by time after, II5; effect of different intervals of, 24; fat content, towards end of, $22 ;-$, variations at different periods, 25; frequent, necessary, I50; table showing number of colonies at different intervals after, 118

Milking machines, 274

Milking methods, 275

Milking-pails, 274 ; protected, 275

MILLER, increase of infantile scurvy at Atlantic City, 22I

Mitchell, tubercle bacilli in milk, 252,256

MOHLER, WASHBURN, and ROGERS, pathogenic bacteria, in butter, 306: -, in cheese, 307

Monobutyrin, 67

MonRad, on the nutritive value of raw and boiled cows' milk as food for infants, 189

MoNtius, on ferment content of milk in abnormal conditions, roo

MOORE and WHITLEY, oxidising ferments in milk, 8I

MORo, amylase in human milk, 98 ; direct absorption of protein, 124, 125: lipolytic ferments in cows' milk, 78 ; nutritive value of boiled human milk, I62; nutritive value of milk in the feeding, of dogs, $18 \mathrm{r}$; of guinea-pigs, $175 ;-$, of rabbits,
I79; peroxidise in human milk, 82 ; proteolytic ferments, in cows' milk, 76 ; - in human milk, 77 ; salol-splitting ferment in cows' and human milk, 99

MORO and Schlossmann, organic constituents of milk, 39

MORSE, percentage of Barlow's disease at children's hospital, Boston, U.S.A., 22 I

MOSER, on substances concerned in hæmolysis, $\mathrm{Ir} 3$

$\mathrm{MUCH}$ and HAPPICH, passive immunity by suckling, I22, 123

MUCH and RöMER, passive immunity by suckling, I22

MÜLLER, nutritive value of boiled human milk, I64; presence of streptococci, 247

MÚLLER and JochMANN, proteolytic ferments in human milk, 77

MURLIN, metabolism of pregnancy and lactation in dogs, I 5

MURSCHHAUSER and ENGEL, organic constituents of milk, 42

Musso and MeNozzi, on organic constituents of milk, 38

NAISH, dried milk in relation to rickets, 223; risk of scurvy to infants fed on dried milk, 22I

NeIsSER and WechSBERG, on reducing ferments in milk, 86

NeTTER, citric acid in milk, 233; digestion of sterilised cows' milk, 228

NeUberg and REICHert, on lipase in human milk, 79

Neumann, Barlow's disease, 218

NeUMANN-Wender, catalase, 93 ; oxidising ferments in milk, 80

New York, tubercle bacilli in market milk of, 250

NEWMAN and SwITHINBank, pathogenic bacteria in butter, 306

Nitrogen, in colostrum, 6 ; distribution in colostrum, 16,19 ; in heated cows' milk, 229; in human milk, 9 ; non-protein, 42

Nitrogen-containing substances, 33

Nitrogen content, of cows' and human milk, 230; variations due to period after parturition, 12, 13, 23

NOBECOURT and MERKLEN, on salolsplitting ferment in cows' and human milk, 98

NoEggerath and KolfF, on substances concerned in hæmolysis in human'milk, II3 
NORDMANN, on peroxidase in human milk, 82

NOTTBOHM and DôRR, on iron content of milk, 5 I

Nutritive value, of boiled milk of same species, I6I ; of boiled human milk, I6I ; of boiled and raw cows' milk for infants, 187,189

OBERMAIER, oitric acid in milk, when boiled, 233

Opalism, 42

Opsonic power of milk, II9

Oxidising ferments, in milk, 80 ; presence of, 68

Oxygen, estimations of, 73,95

PAAL and Gerum, on indirect reductase reaction, 9 r

PALMER, on the nutritive value of raw and boiled cows' milk as food for infants, 189

Parent, transmission of immunity from, to offspring, I 20

PARK and HoLT, bacteria in milk, 285 ; nutritive value of raw and boiled cows' milk as food for infants, 192

PARK and KRUMWIEDE, tubercle bacilli in milk, 255

Parturition, colostral characteristics after, 5 ; composition of milk in early days after, 15 ; period after, variations in composition of milk due to, II, I3, 23

Pasteurisation of milk, 294, 295, 295, 298; commercial, in bulk, 297,298 ; - dangers of, 3 or, 302 ; connection of Barlow's disease with, 2 I 8 ; defective, cause of milkborne epidemic, 260, 26I ; fate of bacteria in milk surviving, 290 , 292 ; for butter-making, 306 ; temperature of milk after, 296, 297

Pasteurised milk, bacterial content of, I93 ; experiments on animals as to nutritive value of, I77, I78, I $80, I 83, I 85$

Pasteurising apparatus, cleanliness and sterility essential, 299, 300

PATON and CATHCART, source of lactose in milk, 2I; sugar in milk, 44

Pennington and McCintock, pasteurisation of milk, 300

Peroxidase, 65 ; in milk, summary of, $7 \mathrm{I}$; presence of, in cows' milk, $69,8 \mathrm{I} ;-$, in human milk, $70,8 \mathrm{I}$
Peroxidase reaction, 82 ; effect of heat on, 84 ; inactivation point, table, 85 ; mechanism of, 83

PFAUNDLER and MORO, substances concerned in hæmolysis, II2 etc.

Pfeiffer, alterations in human milk during period of lactation, I I differences between colostrum and áverage milk, 6

Philadelphia, milk supply of, tubercle bacilli in, 25I; streptococci in milk in, 246

Phillipson, on the nutritive value of raw and boiled cows' milk as food for infants, 203

Phosphates excreted in urine, 60

Phosphorus content, of caseinogen, 37; of human and cows' milk, 232 ; of milk, 58 ; -, when heated, 233

Phosphorus, in food, effect on milk, 2I; loss in milk upon heating, 23I ; separation from caseinogen, 229

Pigs, experiments on, nutritive value of milk, I 74,182

PINARD, on the capacity for lactation, 149

Plantenga, nutritive value of raw and boiled cows' milk as food for infants, I92; outbreak of Barlow's disease, 220

PlaUt and ECKLES, fat content of milk, 43 ; influence of diet on human colostrum, 2 I

Plimmer, on lactase and glycolytic ferments in milk, 80

Polypeptides, 67

PORCHER, on sugar in milk, 44

PotPESChNIG, on the nutritive value of boiled human milk, I6 3

Precipitin method, 39 ; in relationship of milk-proteins, 3 I

Pregnancy, metabolism of, 15 ; weaning during, I5

PRESCOTT and BREed, on estimating the cellular content of milk, I4I

PRICE, on the nutritive value of boiled cows' milk, I66

Proprietary foods, Barlow's disease in cases of feeding with, 22 I

Proscher, milk of species, 4

Protein, absorption of, after early days of life, I22, I24; 一, without digestion, 120 ; in human and cows' milk compared, 8 ; in milk, 4; total in human and cows' milk, 35

Protein content, of human and cows' 
milk compared, 5 ; of milk, 237 ; variations due to period after parturition, II

Protein percentage in human colostrum, 17

Protein substances, 30, 33

Proteins, biological relationship of, 31 ; broken down to simple groupings, 237; 'foreign' to one another, 38 , 122, 124; interrelationship of blood and milk, 37 ; of colostrum, 7, 32, 4I ; of milk, differentiation of, 38 ; - changes in, as result of heating, 225, 227; percentage of, 35 ; proteolytic ferments acting on, 66; relation of the three, 40

Proteolytic ferments, acting on proteins, 66; in cows' milk, 76 ; in human milk, 77

PUPPEL, prevalence of streptococci; 249

Purvis, Brihaut, and Mchattie, fat content in milk when boiled, 230; phosphorus content of milk when heated, 233

QUALITY of milk, amount of catalase as determining, 96

RABBITs, experiments on, nutritive value of milk, I74, I79

RABINowITCH; pathogenic bacteria in cheese, 306

Rats, experiments on, nutritive value of milk, r73, I79

RAUDNITZ; amount of catalase as determining the quality of milk, 96 ; calcium content of milk, 58 ; hydrogenase in cows' milk, 92 ; organic constituents of milk, 37 ; oxidising ferments in milk, 80; peroxidase in human milk, $8 \mathrm{I}$; peroxidase reaction, 84 ; phosphorus content of milk, 59

Raw milk, clinical data as to value in infant feeding, I90, I92; experiments on animals as to nutritive value of, 177,178, r 80 , 183,185 ; nutritive value as food for infants, 187,189 ; Schardinger's test for, 89

Reaction, F.M.B., constituents of milk concerned in, $9 \mathrm{I}$; peroxidase, effect of heat on, $84 ;-$, mechanism of, 83 ; reductase, indirect, mechanism of, 9I ; Schardinger's, 89
Reducing ferments in milk, 85

Reductase, direct and indirect, $7 I$, $72,86,87$; ferments of milk, 71 ; in human milk, presence of, 92

Reductase reaction, $7 \mathrm{I}$; indirect mechanism of, $9 \mathrm{r}$

References. See Bibliography

Rennet, clotting action of, 34 ; coagulation of caseinogen by, 235; Dutch milks not coagulating with, 23I; effect of heating on the coagulation by, 235; human milk not coagulated by, 235

Rennets in stomachs of different animals, 236

REvis, on estimating the cellular content of milk, $\mathrm{r}_{3} 8$

Rickets, early stages of, 57 ; incidence varies in different countries, 223; production by heated milk not proved, 217,222 ; reduction of calcium content in milk and, 231

RIETSCHEL, on organic constituents of milk, 42

RINGER, effect of heating on the coagulation by rennet, 235

RITTER, cause of Barlow's disease in Berlin, 219

RODET, on the nutritive value of milk in the feeding of dogs, 180

ROGER, presence of streptococci, 247

ROGER, BERG, and DAvis, pathogenic bacteria in butter, 306

Rohman and Shmamine, on peroxidase reaction, 83

RöMER, passive immunity by suckling, I2I, I23

ROMER and SAMES, passive immunity by suckling, I23 ; Schardinger's reaction, 89

RONA and MICHAELIS; on lipase in human milk, 79

ROSENAU, bacteria in milk, 288 ; pasteurisation of milk, 296, 30r ; pathogenic bacteria in butter, 306 ; presence of disease in milk, I44; prevalence of streptococci, 249

ROSENAU and ANDERSON, organic constituents of milk, 38

ROSENAU and McCOY, bactericidal and agglutinating substances, i 6

Rosenow and Davis, prevalence of streptococci, 248

RठsING; hydrogenase in cows' milk, 92

Ross, cellular content in relation to stages of lactation, I42; estimating the cellular content of milk, I42 
ROTHENFÜSSER, on oxidising ferments in milk, $8 I$

ROTONDI, digestion of cows' and human caseinogen, 228

RotT, EDELSTEIN, and LANGSTEIN, human colostrum, I7, I9

RUEDIGER, prevalence of streptococci, 247

RUHM, on estimating the cellular content of milk, 138

RULLMAN, catalase in cows' milk, 73, 95; hydrogenase in cows' milk, 93; peroxidase in cows' milk, 8I; reductases in human milk, 92 ; salol-splitting ferment in cows' and human milk, 99; Schardinger's reaction, 89,90 ; sources of milk contamination, 265

RULLMANN and TROMMSDORFF, bactericidal and agglutinating substances, II 6

RUPP, effect of heating on the coagulation by rennet, 235

RUSSELL and BABCOCK, proteolytic ferments in milk, 66

RUSSELI and HOFFMANN, estimating the cellular content of milk, 139 , I4I

St. John and Pennington, bacteria in milk, 285

St. Pancras, breast-fed and bottlefed infants in, 312,313

SALGE, direct absorption of protein, 125; passive immunity by suckling, I24

Salol-splitting ferment, in cows' milk, 98 ; in human milk, 98

Salolase in milk, 74

Salt content, of human and cows' milk, 232; of milk, I68

Saltpetre, traces in milk, 2I

Salts in milk, 48 ; variations due to period after parturition, II

Salts percentage in colostrum, I9

SAMELSOHN, on lipase in human milk, $7 \mathrm{~S}$

SAMMIS and BRUHNY, effect of heating on the coagulation by rennet, 236; pathogenic bacteria in cheese, 307

SARTHOU, catalase in cows' milk, 94 ; peroxidase reaction, 83

SASSENHAGEN, bactericidal and agglutinating substances, II 7 ; fat content of colostrum of the cow, 16 ; reductases in human milk, 92 ; substances concerned in hæmolysis, II 2
Savage, cellular content in relation to stages of lactation, 142 ; cellular elements in milk, 136,138 ; grades of milk, 326; milk-borne epidemics, 259,262 ; pasteurisation of milk, 301 ; prevalence of streptococci, 246 ; production of milk as far as possible free from contamination, 276 ; sources of milk contamination, 267

Scarlet fever, milk-borne epidemics, 262

ScHABAD, calcium content of milk, 56

SCHARDINGER, reducing ferments in milk, 86,87 ; reductases in milk, 7 I

Schardinger's reaction, 86,89

SCHEIBE and HENKEL, citric acid in milk, 233

ScHloss, calcium content of milk, 56; constituents of human milk, 9 ; constituents of milk, 22

Schloss and FraNK, calcium content of milk, 57

SchlossmanN, alterations in human milk during period of lactation, II, I2; composition of human milk at different stages after parturition, 24; development of the mammary function, 309 ; organic constituents of milk, 35 ; period of lactation, I 54, I 57, I 59

SchlossmanN and MORO, organic constituents of milk, 39

Schmid, on substances concerned in hæmolysis, II2, II 4

SCHROEDER, bacillus abortus in milk, 258, 259; breeding experiments from artificially fed guineapigs, 3I4; nutritive value of milk in the feeding of guinea-pigs, 176 , I 77

SchroEder and CotTon, bacillus abortus in milk, 258 ; pathogenic bacteria in butter, 306

SCHROETER, amount of catalase as determining the quality of milk, 96; direct and indirect reductase, 88

SchulTZE, milk and Barlow's disease, 219

ScHuppius, estimating the cellular content of milk, I38

SEBELIEN, organic constituents of milk, 34

Sediment,' smeared,' method, I30

SEEL, analysis of cows' milk during inflammation of the udder, 27

SEIbold, presence of disease in milk, I44 
Seligmann, catalase in cows' milk, 94; constituents of milk concerned in F.M.B. reaction, 9I ; direct and indirect reductase, 88 Serum, action of, 38

SHAw and ECKLES, differences in composition of milk, 22, 24; effect of stage of lactation upon the milk of cows, 12 ; fat content of milk, 43 ; influence of breed of cows on composition of milk, ro; variations in the fat content of milk, 25

Shorthorn cows, composition of milk of, 10 ; -, variations, 13

SIDLER, effect of heating on the coagulation by rennet, 235 ; organic constituents of milk, 35

SiEBOLD, sources of milk contamination, 265

SIEGFELD; oxidising ferments in milk, 8I ; Schardinger's reaction, 89

SIEGFRIED, phosphorus content of milk, 58

SmIDT, catalase in cows' milk, 94 ; constituents of milk concerned in F.M.B. reaction, 9I ; direct and indirect reductase, 87 ; reductases in human milk, 92

Smith and FABYAN, bacillus abortus in milk, $25^{8}$

SNYDER; on proteolytic ferments in cows' milk, 77

SöLDNER, calcium content of milk, 231 ; composition of human milk at different stages after parturition, 23 ; effect of heating on the coagulation by rennet, 235

SöLDNER and CAMERER, ash content of milk, 49 ; differences between colostrum and average milk, 6 ; iron content of milk, $5 \mathrm{I}$; values of colostrum, I7

Solids, total, variations due to period after parturition, I I, I3

Solomin, effect of heat on albumin, 229: phosphorus content of milk, when heated, 233

SOMMERFELD, bactericidal and agglutinating substances, II5; direct and indirect reductase, 88

Sore throat, epidemic of, due to infection of milk, 260, 261 ; streptococci from cases of, 249

SOXHLET, introduction of pasteurisation of milk by, 294 ; iron content of milk, 49, 50, 5I, 53

Soxhlet apparatus, connection with Barlow's disease, 218, 219, 220; effect on acidity, 236
SPINDLER, on variations in catalase content, 97

SPLITTGERBER, citric acid in milk when heated, 234 ; effect of heating on the coagulation by rennet, 236

SPolverini, amylase in cows' milk, 97 ; lactase and glycolytic ferments in milk, 79 ; lipolytic ferments in cows' milk, 78 ; peroxidase in human milk, 7I, 82; proteolytic ferments in cows' milk, 77 ; - in human milk, 77 ; salolsplitting ferment in cows' and human milk, 99

Starch, action of amylase on, 97

STEPP; presence of further substances in milk concerned in the nutrition of the organism, 240

Sterilisation of cows' milk, r 66

Sterilised milk, 303

Stern's reaction, I65

STETTER; on ferment content of milk in abnormal conditions, roo

Stewart, on estimating the cellular content of milk, 137

StILES, tubercle bacilli in milk, 256

STOcklasA, lactase and glycolytic ferments in milk, 79; lecithin in milk, 44

STokes, on estimating the cellular content of milk, 137

Stomach; clot formation of casein in, 228 ; coagulation of milk in, 236

Stomachs of different animals, rennets in, 236

Stools, offensive, 193

STORCH, oxidising ferments in milk, $8 \mathrm{I}$; peroxidase ferment in milk, 65

Storch's reagent, $65,8 \mathrm{I}$

Store milk, cheap pasteurised, effects on infants, 287

STOWELL and HILLARD," prevalence of streptococci, 249

Streptococcal infection causing epidemics of sore throat, $260,26 \mathrm{I}$

Streptococci, cause of mastitis in cows, 247; effect on cellular content, I43 : experimental production of abortion by, 259; in cream, 250 ; in healthy cows' milk, 249; in milk, 246; - acquiring diplococcic formation, 248, 249; - influence on cell count, I3r ; - pathogenic varieties, $248 ;-$, sources of origin, 247 ; infection by milk-borne, 260 ; inoculation of certified milk with, 249 ; isolated from cases in milkborne epidemics, 248 ; pathogenic, in certified milk, 262; sapro- 
phytic strains injected into udder, 248 ; virulent, in certified milk, 287

Streptococcus lacticus, identity of bacillus acidi lactici with, 247; relation to streptococcus pyogenes, 247 ; virulence increased experimentally, 248

Streptococcus pyogenes, relation to streptococcus lacticus, 247

Strippings, 7 ; bacteria and catalase relationship in, 95 ; cellular content, 139; constituents concerned in F.M.B. reaction, 9I ; fat content of, 22

Suckling, immunity transferred by, I20 ; production of passive immunity by, 122; syphilis transmitted by, I6r; transference of immunity by, I IO

Sugar, ferments acting on, 68 ; in colostrum, 6 ; in milk, 33

Sugar content, of human and cows' milk compared, 5; of milk, 44; variations due to period after parturition, II, I2, I3, 23

Sulphur content of caseinogen, 37

Syphilis transmitted by suckling, I6I

TEACHER and BUrton, bacillus abortus in milk, 259

Test, for boiled milk, 89 ; for raw milk, 89 ; Schardinger's, 86

Tests for ferments, 65,69

Thermal death-point of bacteria, 287-90

THIEMICH, capacity for lactation, I49; peroxidase in human milk, 82

THомas, on cellular elements in milk, $\mathbf{1}_{36}$

TOBLER and BOGEN, intervals of feeding, $I_{5} \mathrm{I}$

TORDAYS, on catalase in human milk, 96

TRACY and KNox, on phosphorus content of milk, 60

TRASK, milk-borne epidemics, 26o, 262

Tributyrin, 67

TROMMSDORFF, estimating the cellular content of milk, 137; ferment content of milk in abnormal conditions, 99; presence of streptococci, 248

TRUNZ, ash content of cows' milk, 15 ; calcium content of milk, 58 ; phosphorus content of milk, 59
Tubercle bacilli, cause of cervical gland tuberculosis, $254,255,256$; in butter, 306 ; in certified milk, 252,287

Tubercle bacilli, bovine, affects young children principally, 253 , 254 ; - experimental work as to infection by, 253 ; - in lesions in human subject, 253; - mainly cause of abdominal tuberculosis, 253,254 ; - percentage of infection by, 255

Tubercle bacilli, in milk, 250; derived from milkers, 252 ; findings of Royal Commission on Tuberculosis as to, 253; infectivity of, 253 ; in mixed milk from milkshops in Edinburgh, 252; in samples of milk, source of, 252 ; spread from one milk to other milks, 25 I

Tubercle bacilli in milk supply, of Manchester, 25I ; of Philadelphia, 25I

Tuberculin, presence of bacillus abortus in cows tested by, 258 ; testing cows with, 272

Tuberculosis, abdominal, bovine tubercle bacilli mainly cause of, 253, 254; generalised acute, progressive, experimental production, 254 ; in cows, I66; Royal Commission on, findings as to bovine tubercle bacilli, 253; surgical, prevention of, 256

TUNNICLIFFE, on bactericidal and agglutinating substances, 1 I 9

Typhoid fever, carriers of, 267 ; milk-borne epidemics, 262

UDDER, cleansing of, important, 272 273; diseases of, catalase content increased by, 73; -, contaminating milk, 265,266 ; - , effects on ferment content, $99 ;-$, influence on cell count, 132 ; inflammation of, milk analysis in, 27; saprophytic strains of streptococci injected into, 248

UHLENHUTH, on direct absorption of protein, I 24

UHLIG, on the nutritive value of raw and boiled cows' milk as food for infants, 189

Ulax filter, 276

UlLMANN, ferment content of milk in abnormal conditions, roo

United States, pasteurisation of milk in, 298 
USENER, on salol-splitting ferment in cows' and human milk, 99

UTz, hydrogenase in cows' milk, 92 ; Schardinger's reaction, 89

Van Alstyne and Grant, on direct absorption of protein, 124

VANDEVELDE, lactase and glycolytic ferments in milk, 79; lipolytic ferments in cows' milk, 78 ; proteolytic ferments in cows' milk, 76 ; salol-splitting ferment in cows' and human milk, 99

VAN ECK, on effect of heat upon peroxidase reaction, 84

VARIOT, nutritive value of raw and boiled cows' milk as food for infants, 189

VARIOT and LORENZ-MONOD, on the nutritive value of raw and boiled cows' milk as food for infants, I93

VAUDIN, on reducing ferments in milk, 86

VELDEN, on catalase in human milk, 96

VINCENT, nutritive value, of milk in the feeding of kittens, 182 ; -, of raw and boiled cows' milk as food for infants, 190

Vitamine, 240

VOLLRATH, on ferment content of milk in abnormal conditions, 99

WAENTIG, effect of heat upon peroxidase reaction, 84 ; oxidising ferments in milk, $8 \mathrm{I}$

WALLER, intervals between feeding, I 56

Wassermann's reaction, 165

Water content of colostrum, I6

Water, in human and cows' milk compared, 8 ; percentage composition of milk samples, ro

Weaning during pregnancy, I5

WEDEMAN, on Schardinger's reaction, 90
Weight, average, of guinea-pigs at different ages, 178 ; fluctuation in, 199; increase of, according to groups and periods, $195 ;-$, in breast-fed infants, $195 ;-$, comparison of results of feeding with raw and boiled milk, 190, 192, I 95

Weight of infants, increased by use of boiled milk, I63; loss of, 18

WELLMANN, differences in composition of milk, 22

- Wet' milking, risks of, 266

Wet-nursing, 161,164

Whey, 40, 4I ; human, boiled, I6 4

Whey-proteins, 30, 32, 34 ; absorption of, 39

WrNKLER, on cellular elements in milk, I 35

WinsLow, milk-borne epidemics, 26r, 262

Wisconsin, U.S.A., cattle of, tuberculosis among, 25I

WOHLGEMUTH and STRICH, amylase in cows' milk, 98 ; proteolytic ferments in milk, 78

WOLL, fat content of milk, 43 ; -, when boiled, 230 ; influence of diet on the milk supply of cows, 20 ; relation of food to the produce tion of milk in cows, 7

Woll and CARLYLE, influence of diet, 20

WROBLEWSKI, organic constituents of milk, 42

ZaItscheK, Tamylase in cows' milk, 97 ; lactase and glycolytic ferments in milk, 79; proteolytic ferments, in cows' milk, 76 ; - in human milk, 77

ZUBRZYCKI and WOLFSGRUBER, bactericidal and agglutinating substances, II9

ZUCKMAYER, calcium content of milk, 56 ; nitrogen and ash in early human colostrum, I7 ; phosphorus content of milk, 59

ZURICK and KRAGE; bacillus abortus in milk, $25^{8}$ 


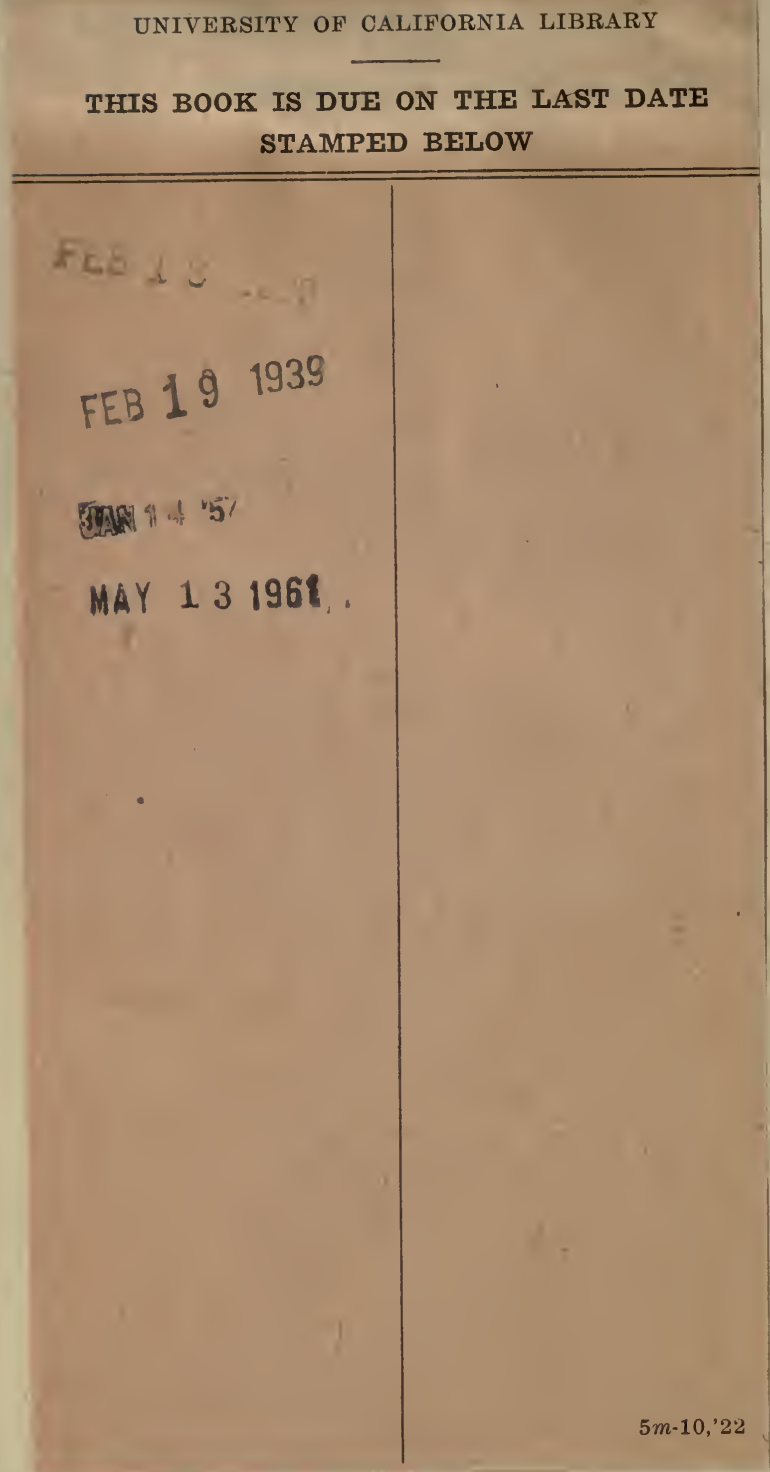




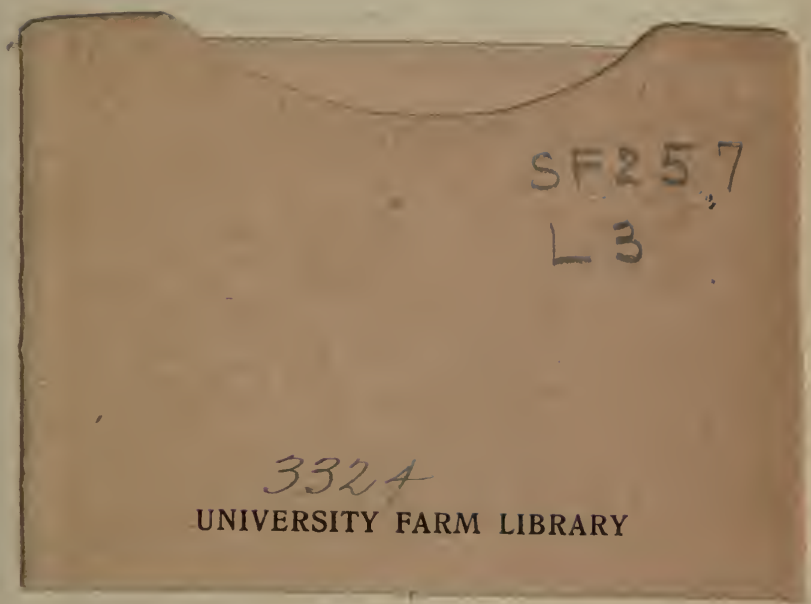




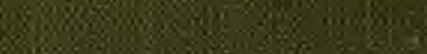

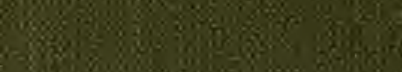

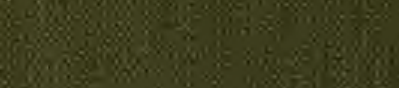

4.

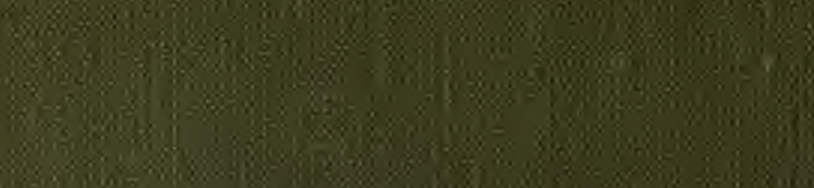

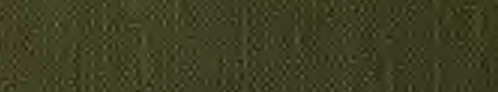

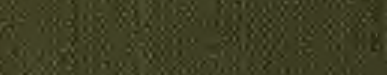

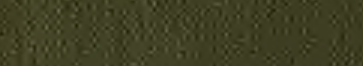

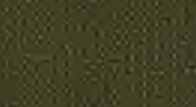

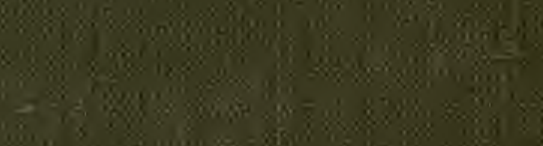

$-\frac{5}{5-20}$

820

20.6

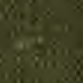

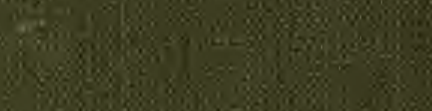

$\sqrt{x-1}$ 